\title{
Semi-detail reconnaissance of the Western Brooks Range, northern Alaska, 1971
}

De Benedetti, J.J., Rose, Robert, Abrahamson, D.W., and Amoco Oil Co.

GMC DATA REPORT 457

This GMC data report from the Amoco Heritage collection has been made available through funding from the FY2018 USGS National Geological and Geophysical Data Preservation Program, Grant Number G18AP00054. This project report is presented in its original format and has not been reviewed for technical content or for conformity to the editorial standards of DGGS. It should not be used or cited as reviewed data.

2019

State of Alaska

Department of Natural Resources

Division of Geological \& Geophysical Surveys

GEOLOGIC MATERIALS CENTER
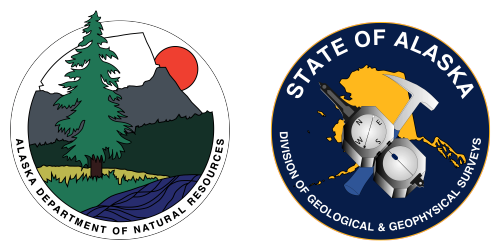
SEMI-DETAIL RECONNAISSANCE OF THE WESTERN BROOKS RANGE

NORTHERN ALASKA

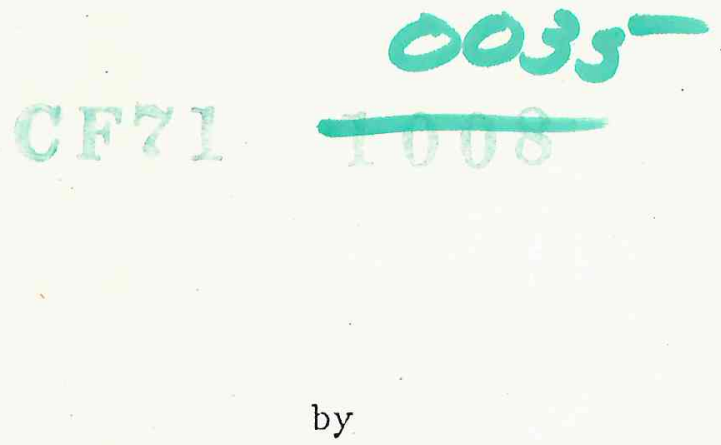

JOHN J . DE BENEDETTI

ROBERT ROSE'

DAVID W. ABRAHAMSON

1971

UNION OIL COMPANY OF CALIFORNIA

and

AMOCO PRODUCTION COMPANY 


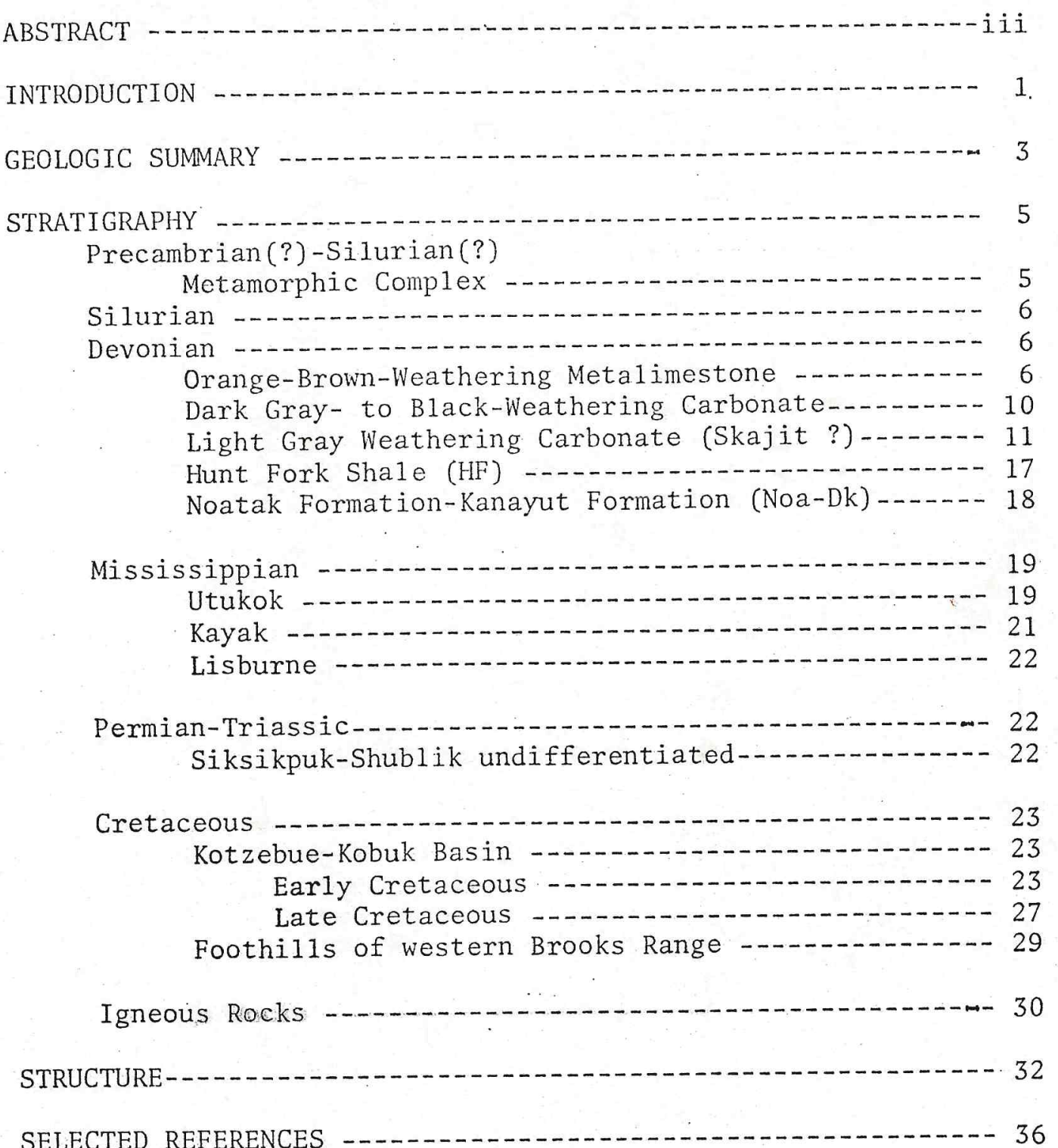

\section{APPENDICES}

APPENDIX A

Symbols Used in Stratigraphic Sections

Trail Creek Stratigraphic Columnar Section

Geologic Time Scale

APPENDIX B

Laboratory Data from Collected Samples 


\author{
APPENDIX C \\ Sample Register \\ APPENDIX D \\ Field Notebooks $1-4$
}

\title{
ILLUSTRATIONS
}

FIGURE 1 Index Map showing 1970 and 1971 Field Study areas...Page 2 FIGURE 2 Correlation Chart of the Western Brooks Range .....Page 4 FIGURE $3-10$ Geological Color Photographs .................. Text PLATE 12 Schematic Stratigraphic Cross Section ........... Pocket

\section{GEOLOGIC MAPS}

PLATE 1. Point Hope Quadrangle $\ldots \ldots \ldots \ldots \ldots \ldots \ldots$. . . . . . . . . . .

PLATE 2 De Long Mountains Quadrangle ................ Pocket

PLATE 3 Misheguk Mountain Quadrangle ............... Pocket

PLATE $4 \quad$ Howard Pass Quadrangle .................. Pocket

PLATE $5 \quad$ Noatak Quadrangle $\ldots \ldots \ldots \ldots \ldots \ldots \ldots$ Pocket

PLATE $6 \quad$ Baird Mountains Quadrangle ............... Pocket

PLATE $7 \quad$ Ambler River Quadrangle.................. Pocket

PLATE 8 Survey Pass Quadrangle $\ldots \ldots \ldots \ldots \ldots \ldots \ldots$ Pocket

PLATE $9 \quad$ Selawik Quadrangle $\ldots \ldots \ldots \ldots \ldots \ldots \ldots$. . . . . . . . . . . .

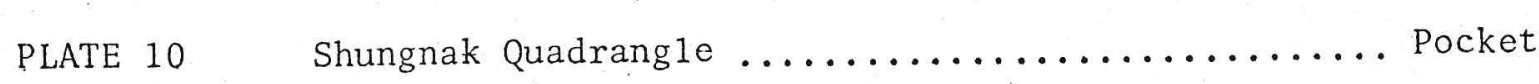

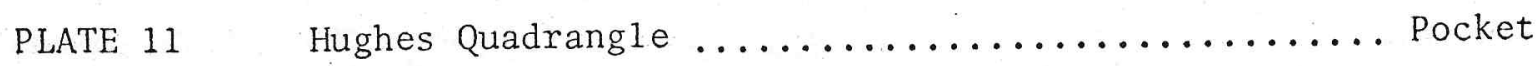




\section{ABSTRACT}

The oldest rocks in the study area are the Precambrian(?) to Silurian(?) metamorphic units of the Basement Complex. These rocks are unconformably overlain by various Devonian carbonate units or the Hunt Fork Shale. Gradationally overlying the Hunt Fork Shale is the marine Noatak Formation or its continental correlative, the Kanayut Formation, both of Devonian age. The Early Mississippian Utukok Formation probably gradationally overlies the Noatak Formation. The Kayak Formation is a lateral correlative of the Utukok Formation and gradationally underlies the Lisburne Carbonate as does the Utukok Formation. Undifferentiated Permian Siksikpuk-Triassic Shublik Formations disconformably overlie the Lisburne. Along the north flank of the Brooks Range, the Lower Cretaceous rocks unconformably overlie the undifferentiated Permian-Triassic Formations.

The lower contact of the Lower Cretaceous rocks is not exposed along the southern flank of the Brooks Range. The Upper Cretaceous rocks li.e upon Lower Cretaceous rocks with unknown relationship south of the Brooks Range and unconformably upon the Basement Complex along the south flank of the Brooks Range. 
SEMI-DETAIL RECONNAISSANCE OF THE WESTERN BROOKS RANGE, NORTHERN ALASKA

\section{INTRODUCTION}

The 1971 geological field work was carried out in the western Brooks Range by Union Oi1 Company of California (operator) and Amoco Production Company. Field personnel included Lloyd Furer and Robert Fehlmann of Amoco; John De Benedetti (party chief), Dave Abrahamson, Robert Rosé, and Chuck Bitgood of Union Oil. The area studied is shown on Figure 1.

The purpose of the field work was (1) to define the vertical and lateral extension of Paleozoic carbonate units, (2) to study the depositional environments of these units, (3) to delineate strand lines of the Paleozoic and Cretaceous rocks, (4) to evaluate petroleum source rock and reservoir rock potential in the sedimentary column, and (5) to study the geologic structure in relationship to the accumulation of hydrocarbons.

Seven weeks were spent in the western Brooks Range mapping 38,000 square miles and three days in the Sagwon area checking and sampling Cretaceous rocks. The objectives for the western Brooks Range study area were accomplished in 44 days including 14 days lost due to camp moves, bad weather, and loss of a helicopter in the Noatak River (no injuries). There were three base camps: one at Kiana, 75 miles east of Kotzebue; the second on the Noatak River six miles east of the Nimiuktuk River's confluence with the Noatak; and at Ambler, about 100 miles east of Kiana. The field parties were supported by a Jet Ranger Helicopter. 


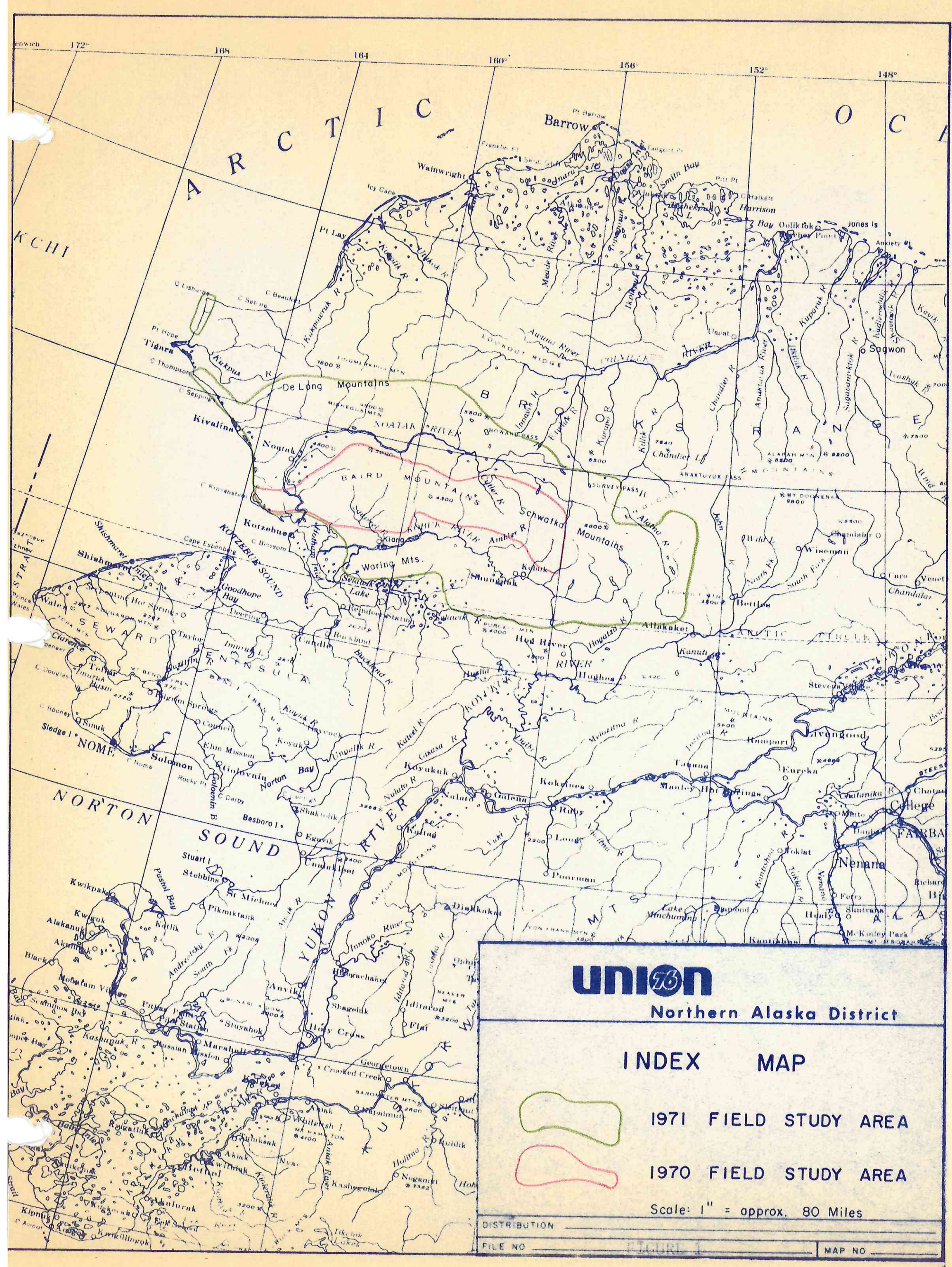


Geologic mapping was done on 1:250,000 topographic quadrangles and acrial photographs. The eleven plates accompanying this report cover the reconnaissance geologic mapping done in 1970 and 1971. Formation and/or rock unit contacts on plates are a result of field observation and aerial photographic interpretation. The geology mapped in the Cosmos Hills (north central Plate 10) was taken from Fritts (1970) and Patton et al (1968).

\section{GEOLOGIC SUMMARY}

In the study area, metamorphic rocks making up the Basement Complex possibly range in age from Precambrian to perhaps Silurian. The overlying sedimentary sequence ranges in age from Devonian through Cretaceous. Pennsylvanian and Jurassic rocks were not recognized and may be missing.

The metamorphic rocks of the basement consist of phyllite, schist, marble, and quartzite. These rocks are not petroleum source rocks but some of the recrystallized carbonates may prove to be reservoir rocks. The Basement Complex is overlain unconformably by an unnamed Devonian carbonate sequence and the Hunt Fork Shale. Locally, the carbonate is reefal and contains petroleum residues. In some localities the Hunt Fork Shale oyerlies carbonate of Devonian(?) age. Gradationally overlying the Hunt Fork Shale are the marine Noatak Formation and its continental equivalent, the Kanayut Formation, which consist mainly of sandstone with minor conglomerate.

The Early Mississippian Kayak Formation and Utukok Formation probably gradationally overlie the Noatak Formation. These two formations in turn are gradationally overlain by the Lisburre Carbonate of Mississippian age. 
The Permian-Triassic rocks are grouped together for this study because of the difficulty of separating in the field the Permian Siksikpuk Formation from the Triassic Shublik Formation. Early Cretaceous shale, sandstone, and conglomerate crop out on the north and south sides of the western Brooks Range. In the mapped area, upper Cretaceous conglomerate and sandstone crop out on the south flank and south of the Brooks Range. A Tertiary outcrop in the Kivalina Village area, northwest of Kotzebue, was not located and will not be mentioned further.

\section{STRATIGRAPHY}

Precambrian(?) to Silurian(?)

Basement Complex

The Basement Complex is composed of phylite, slate, marble, quartzite, and schist. These rocks are schistose to gneissic near the contact with the Schwatka Mountain igneous intrusion. Locally abundant white quartz veins, which could be as old as or younger than the metamorphic rocks, intrude the complex throughout the outcrop area.

In the northwestern part of the Schwatka Mountains, a thick unit of schistose carbonate crops out... This unit is estimated to be several thousand feet thick. The lower portion of the carbonate unit is interbedded with phyllite and schist whereas the upper part appears to overlie the phyllite-schist-carbonate sequence. The degree of metamorphism of the upper sequence appears to be the same as in the lower part. The upper part of this carbonate unit may have one of two age relationships: 1) it may be part of the pre-Middle Devonian Basement Complex, or 2) it may be correlative to the Middle and Late(?) Devonian carbonate units but has been metamorphosed more than other Devonian carbonate by extensive faulting and shearing of the 
rocks in the fault zone north of the outcrops (P1ate 7).

No recognizeable fossil material was found in samples collected from the Basement Complex. The age of the Complex is pre-Middle Devonian based on the oldest date available from Devonian outcrops known to be stratigraphically above the Complex.

Silurian

Silurian rocks are assumed to be present in the Baird Mountain area based upon the identification of Silurian megafossils from carbonate float collected by Amoco in 1970 (Fehlmann, 1971). The exact location from which these Silurian fossils were collected is in question and Union, in 1971, could not find additional Silurian rocks. Further field work is necessary to prove whether the Silurian is present in the Baird Mountains. Devonian Carbonate Units

Orange-Brown Weathering Metalimestone

An orange-brown weathering metalimestone is exposed in the west central Baird Mountains. Good outcrops were studied in the western half of T23N, R13W, and $T 21 N$, R15W, KRPM, but this unit was not delineated on the geologic maps. The unit is predominantly schistose, medium to coarsely crystalline, and weathers into "klinkly" plates. Locally, the limestone contains calcite and quartz veins, mica along foliation planes, wavy foliation planes and dolomite.

Depositional structures and fossils have not been preserved in the metalimestone; therefore, little inference can be made as to the environment of deposition. The lack of interbedded detrital sediments indicates a 
A

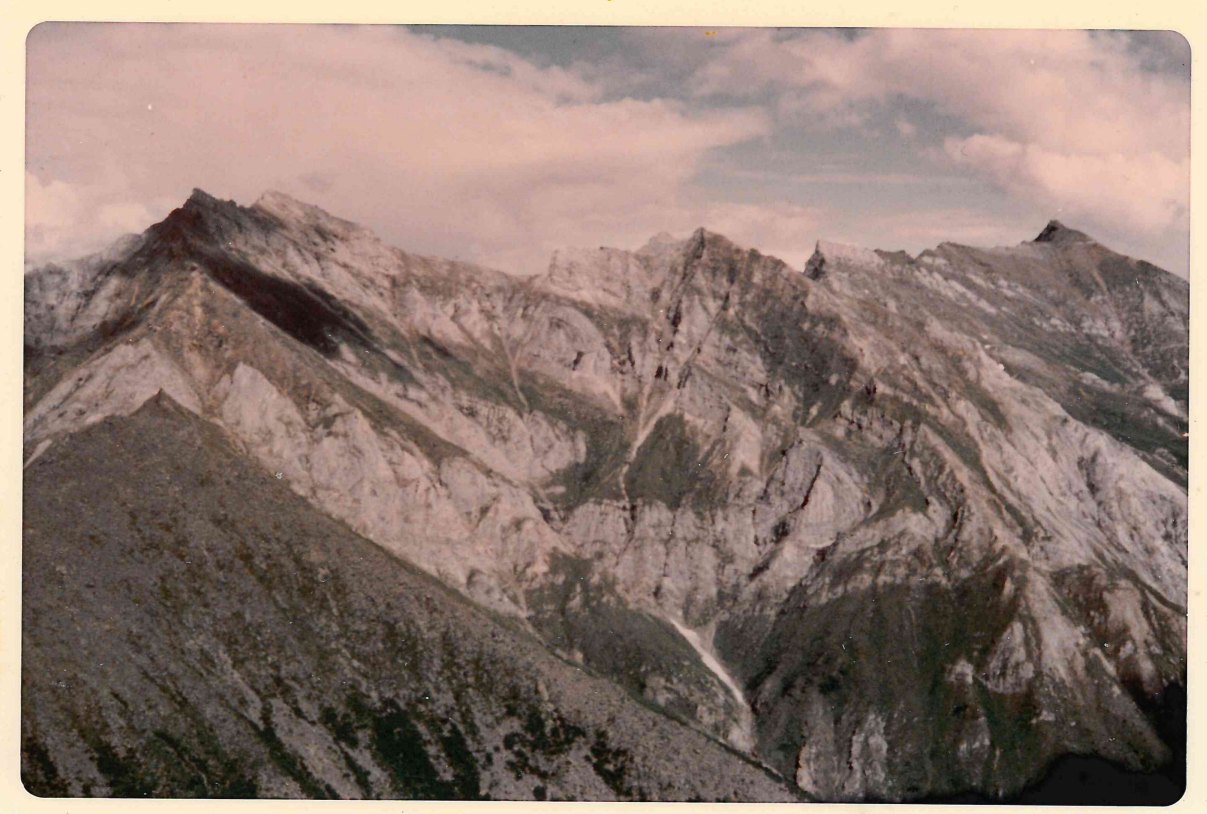

Structure in the Metamorphic Basement

Complex-Central Schwatka Mountains looking north

B

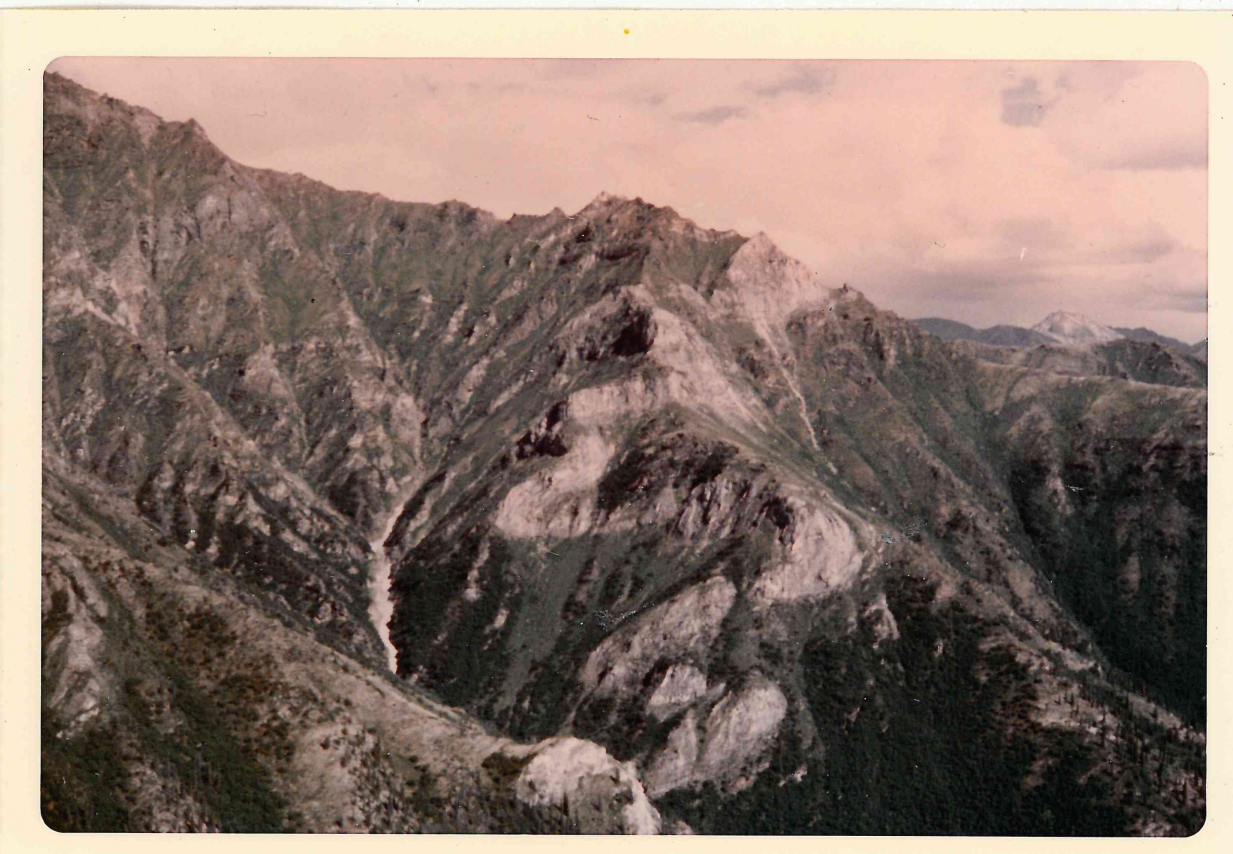

Strongly contorted marble in Metamorphic Basement Complex-Central Schwatka Mountains looking north 
A

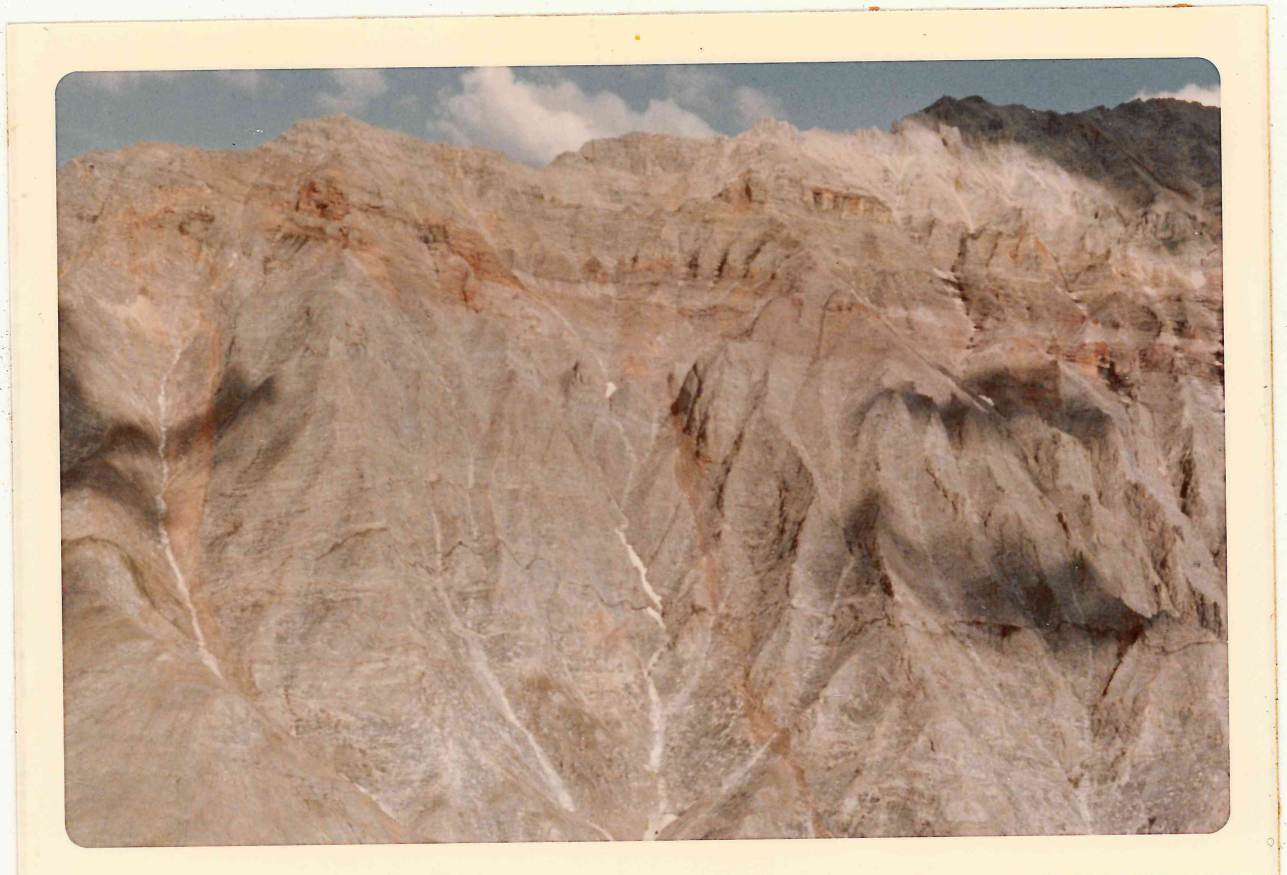

Part of upper unit of the massive carbonate sequence within the Metamorphic Basement ComplexNorthwestern Schwatka Mts. Iooking east

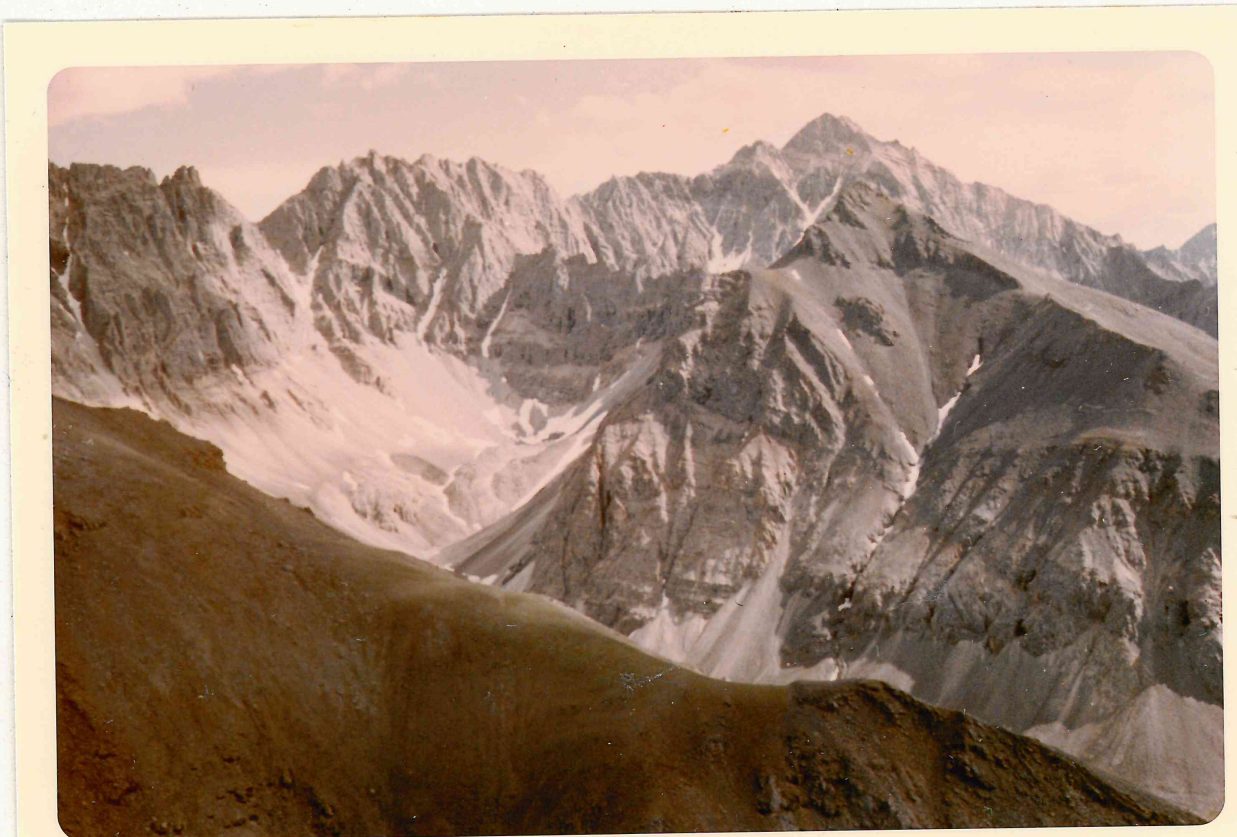

Faulted, massive carbonates of the Metamorphic Basement Complex in the Western Schwatka Mountains looking southwest 


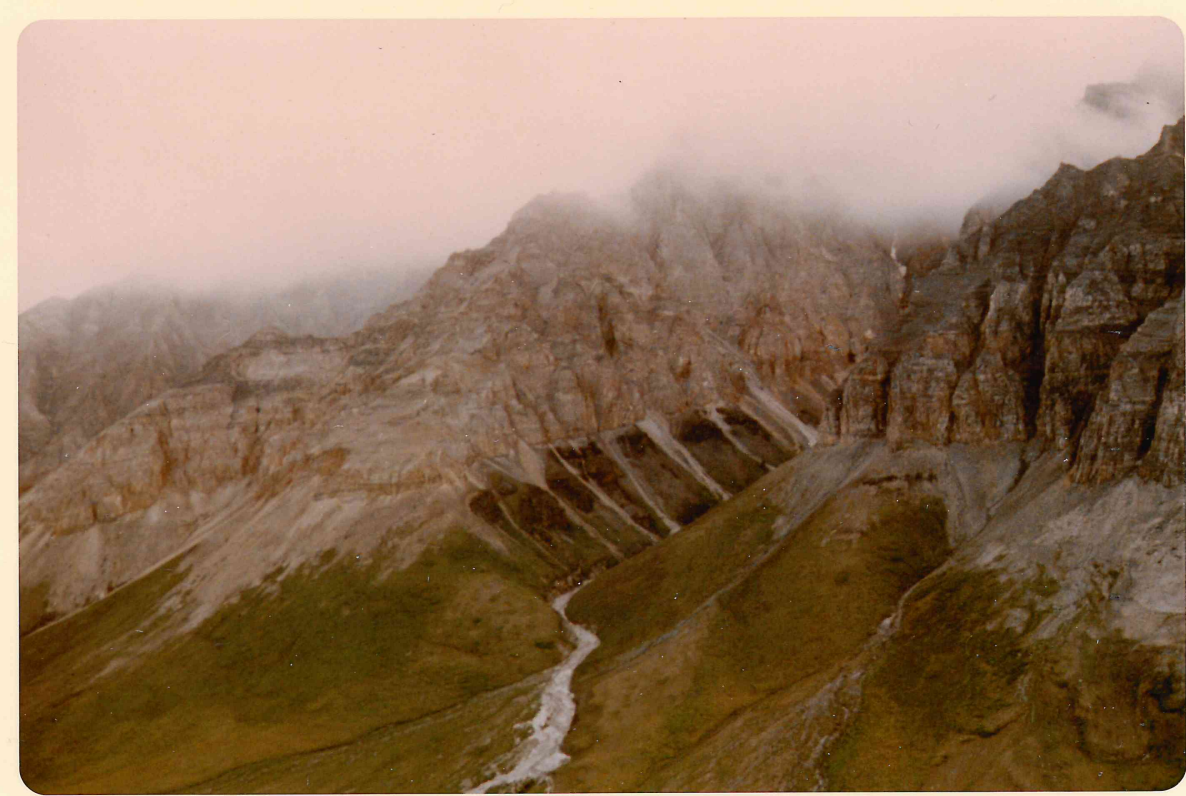

Metacarbonates on Black Phyllite as seen

in 14t, R25 Survey Pass Quadrangle F 25 N RI 14 Fooking northeast

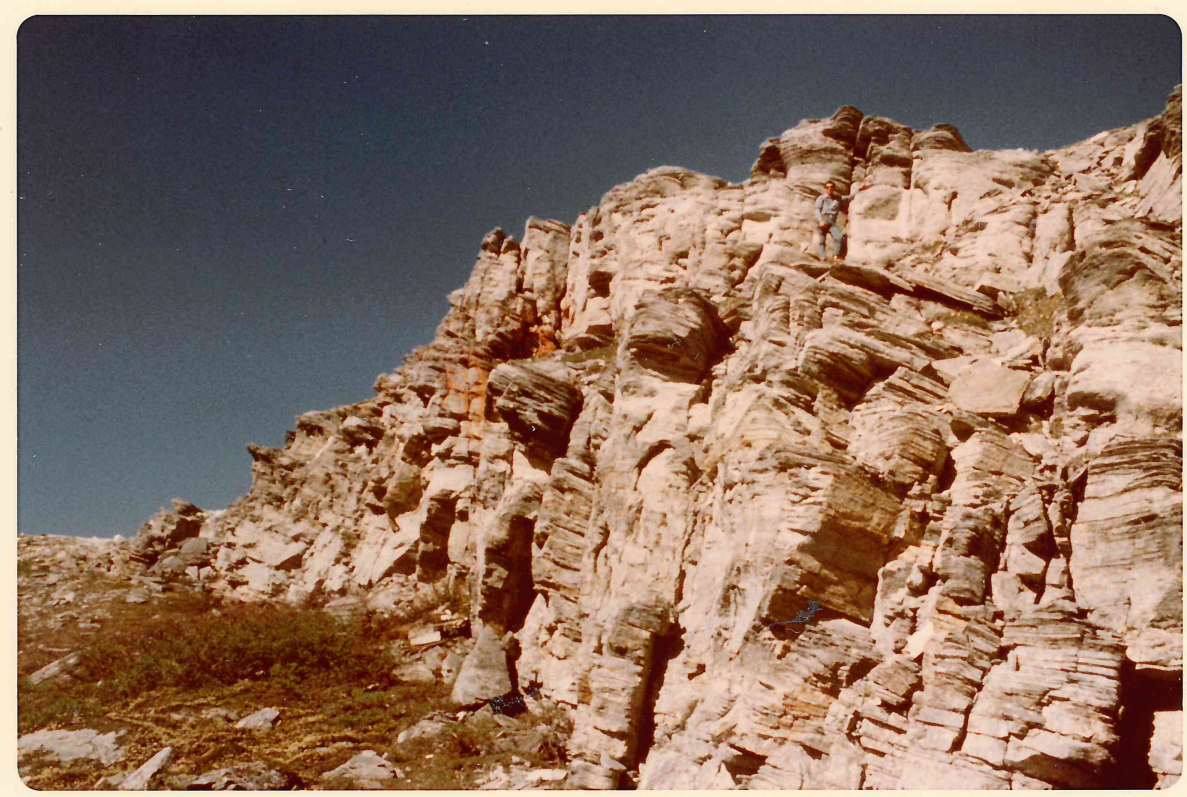

Marble and Schist interbeds as seen in the Kiana Hills (June 21, stop 3). Man at upper right for scale. looking northwest 
depositional environment common in a carbonate platform or shelf which was free of terrigenous influxes.

This carbonate is stratigraphically fixed between underlying metamorphics and overlying light or dark gray-weathering carbonates. The orange-weathering unit rests unconformably above darker schists and phyllites of the Basement Complex. The unit was never seen interbedded with the underlying metamorphics. Depending upon the location, either a light gray-weathering carbonate (possibly Middle to Upper Devonian Skajit Formation) as in the NW 1/4, T22N, R9W, KRPM or a dark gray-weathering carbonate (in part Middle Devonian) as in the western half of T23N, R13W, KRPM unconformably overlies the formation. The paleontological information from these overlying units indicates that the metalimestone can be no younger than Middle Devonian and quite probably is older. The stratigraphically higher carbonate units, although locally recrystallized, do not exhibit the marked metamorphic textures of the orange-weathering metalimestone. This metacarbonate is thought to have poor reservoir potential.

Dark Gray-to Black-Weathering Carbonate

A dark gray-to black-weathering carbonate unit crops out in the Baird Mountains in the Squirrel Creek and in the Kanaktok Creek drainages. Good outcrops were studied in the western half of $T 23 N, R 13 W$, and $N E 1 / 4 T 27 N$, R4W, KRPM, but this unit was not outlined on the geologic maps. The fresh, dark gray-to black-colored dolomite and limestone is predominantly dense, fine to medium crystalline, and has low visible porosity and permeability. Nodules, bands, and discontinuous beds of gray chert are found 1ocally as 
are thin interbeds of light gray dolomite with fetid odors. Fossils

include large brachiopods, stromatoporoids(?), tetracorals, small

unidentified fauna, and algal mats. Some outcrops are stromatoporoid(?) bioherms and biostromes.

The carbonate probably was deposited on a shallow-marine platform which at times was subaerially exposed. The stromatoporoid(?) biostromes and bioherms indicate a shallow, wave-agitated, oceanic platform. The algal mats are indicative of very shallow-marine sedimentation and possibly subaerial exposure.

The unmetamorphosed, dark carbonate unconformably overlies the orange-brown, schistose carbonate at several locations in the western half of T23N, R13W, KRPM, and field relationships in the western half of $T 27 \mathrm{~N}$, R4W, KRPM indicate that it may be overlain by a light gray-weathering limestone unit. Megafossil determinations indicate the dark carbonate unit to be Middle Devonian, Givetian, and thus equivalent to the lower(?) part of the light gray-weathering carbonate unit. The dark carbonate unit is possibly a facies of the light gray carbonate unit; subsequently, the black carbonate and the equivalent gray carbonate were overlain gradationally by younger carbonate deposits of the light gray unit. The formation is not thought to be a potential oil reservoir.

Light Gray-Weathering Carbonate (Skajit?)

A predominantly light gray-weathering, massive-appearing carbonate unit (Skajit?) is aerially extensive in the Baird and Schwatka Mountains (most CRB, GCRB, and BCRB on the geologic maps). Characteristically, the unit contains more limestone than dolomite, has a medium to dark gray fresh 
color, is micro- to coarsely recrystalline, and contains numerous recrystallized small limestone mounds and large organic buildups. In some localities, the formation is bedded, has a strong fetid odor, is fossiliferous, contains minor chert, is argillaceous, and gives a brownish "cut" with acid. Fossils include brachiopods, coelenterates, stromatoporoids, crinoidal debris, and unidentified microfauna.

This unit was deposited on a shallow-marine platform, a large portion of which (the larger organic buildups) was deposited at the high-energy margin. The large buildups, some hundreds of feet thick, are usually completely recrystallized, but locally large stromatoporoid masses and colonial corals are found to form the massive reefal cores. The smaller stromatoporoid and colonial coral lime mounds and biostromes may have grown on the platform lagoonward of the larger buildups. Algal mats and stromatolites in the carbonate are indicative of shallow subtidal, intertidal, and possibly even supratidal sedimentation.

In the central Baird Mountains and Kiana Hills, the light grayweathering carbonate is underlain unconformably by metasediments as in the SE $1 / 4, T 26 \mathrm{~N}, \mathrm{R} 10 \mathrm{~W}$, and $\mathrm{SE} 1 / 4, \mathrm{~T} 20 \mathrm{~N}, \mathrm{R} 12 \mathrm{~W}$, KRPM or the orange-brown weathering metacarbonate as in the NW 1/4, T22N, R9W, KRPM. Field relationships as in the western half of $T 27 N, R 4 W, K R P M$ indicate the unit may also overlie the dark gray-to black-carbonate unit in the central and northeastern Baird Mountains. In the western Baird Mountains and Igichuk Hills, the light gray unit overlies the metasediments and appears to change facies laterally to an interbedded, light brown and gray carbonate as in $\mathrm{T} 21 \mathrm{~N}$, R16W, KRPM. This banded unit is a1so present in the central Baird Mountains 
as in the NW 1/4, T23N, R12W, KRPM and again is thought to be a facies of the light gray, massive appearing carbonate.

The Hunt Fork Formation was found overlying the light gray carbonate in the northeastern Baird Mountains in the center of T28N, R3E, KRPM. In the northern Schwatka Mountains, the carbonate is overlain by dark shales of the Hunt Fork Formation in T26N, R16E, KRPM and may interfinger with the Hunt Fork in this area. Nowhere else were younger rocks found overlying the light gray carbonate.

The light gray-weathering carbonate is thought to be equivalent and correlative to the Skajit Formation. Two Skajit stratigraphic sections, Lower Eli River, located in the SW 1/4, T28N, R14W, KRPM and Upper Agashashak River, located in the SE 1/4, T26N, R12W, KRPM, measured by Amoco in 1970 (Amoco Memo \#152) are Middle and Late Devonian, Givetian, and Frasnian. Paleontological work on grab samples from the Baird Mountains, collected by Union's 1971 field party, indicate the light gray unit to be Devonian, much of it Middle Devonian.

In the De Long Mountains, the light gray-weathering carbonate may be represented by the lower part of the Kugururok Formation found in the Mount Bastille area in the SW 1/4, T1IS, R38W, UPM, and by an unnamed carbonate unit measured at the Trail Creek section in the SE 1/4, T34N, R10W, KRPM, Misheguk Mt. Quad. The Kugururok is 1ithologically similar to the light gray-weathering carbonate found in the Baird Mountains. The light gray-weathering lower portion of the Kugururok Formation at Mount Bastille overlies the Hunt Fork Shale(?) and is probably Frasnian or older in a section measured by Pan American in 1969 (Pan American Memo \#127) and from grab samples collected by Amoco in 1970 . 
The unnamed unit at the Trail Creek Section is Iimestone and dolomite, dominantly weathered light gray to gray, thinly to massively bedded, and contains beds with high to low carbonate mud content. Fossils in the section include brachiopods, stromatoporids, colonial corals, and unidentified fauna. Carbonate deposits represented by the rocks in the section include shallow platform-edge stromatoporoid and coral(?) buildups, intertidal to supratidal algal mats, and probable shallow lagoonal to platform sediments.

The age of the Trail Creek Section, on the basis of smaller foraminifera, is Late Devonian-Early Mississippian, Kinderhookian or older. Megafauna from this section, however, are Middle Devonian in the basal and middle part to Late Devonian in the upper part of the section. The authors consider the megafossil dates to be the more accurate. The unnamed carbonate in the Trail Creek Section is thus equivalent to the Skajit Formation measured by Amoco in 1970 at the Lower Eli River and Upper Agashashak River sections and to the lower portion of the Kugururok Formation at Mount Bastille.

In addition, in the SE $1 / 4, \mathrm{~T} 33 \mathrm{~N}, \mathrm{R} 4 \mathrm{~W}, \mathrm{KRPM}$ in the De Long Mountains, the light gray-weathering unit overlies the Hunt Fork Shale(?) and is Middle Devonjan, Eifelian, on the basis of megafossils. The light gray-weathering unit, therefore, ranges from at least Middle Devonian, Eifelian, to Upper Devonian, Frasnian, in the Baird-De Long Mountains area. 
A

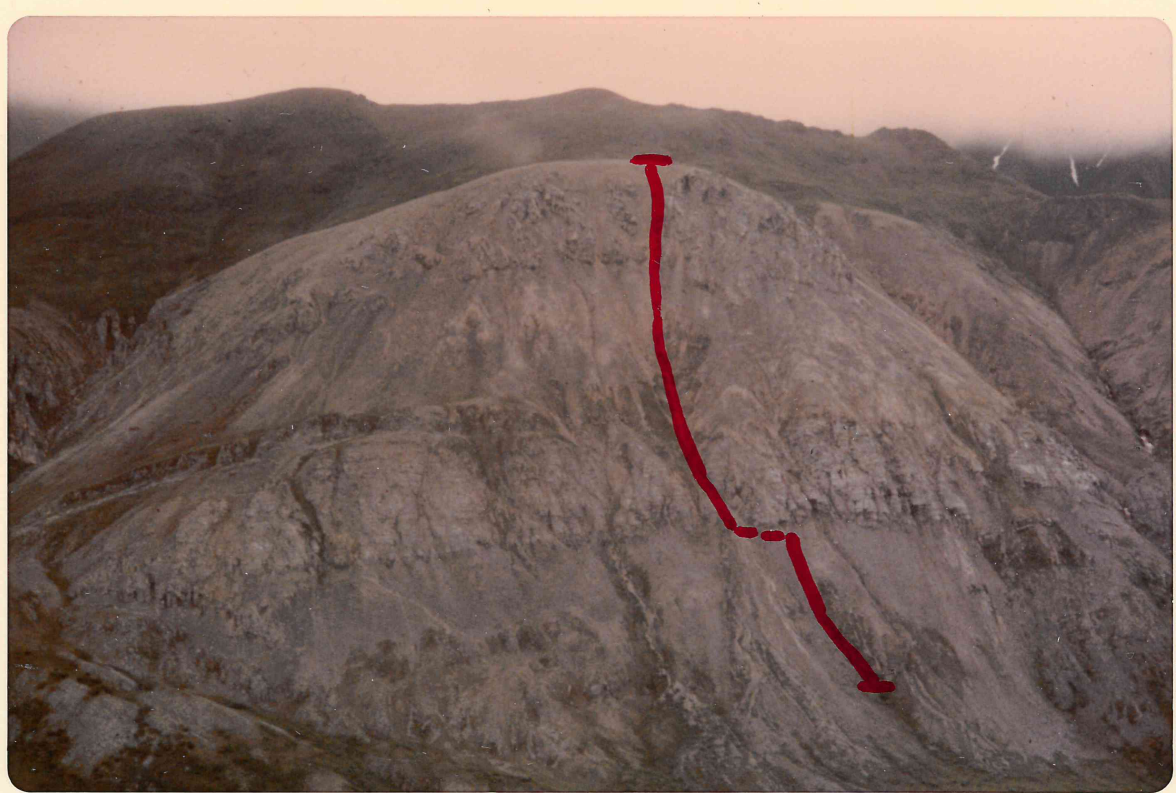

Middle to Upper Devonian. carbonate rock of Trail Creek Section looking south

$\cdot B$

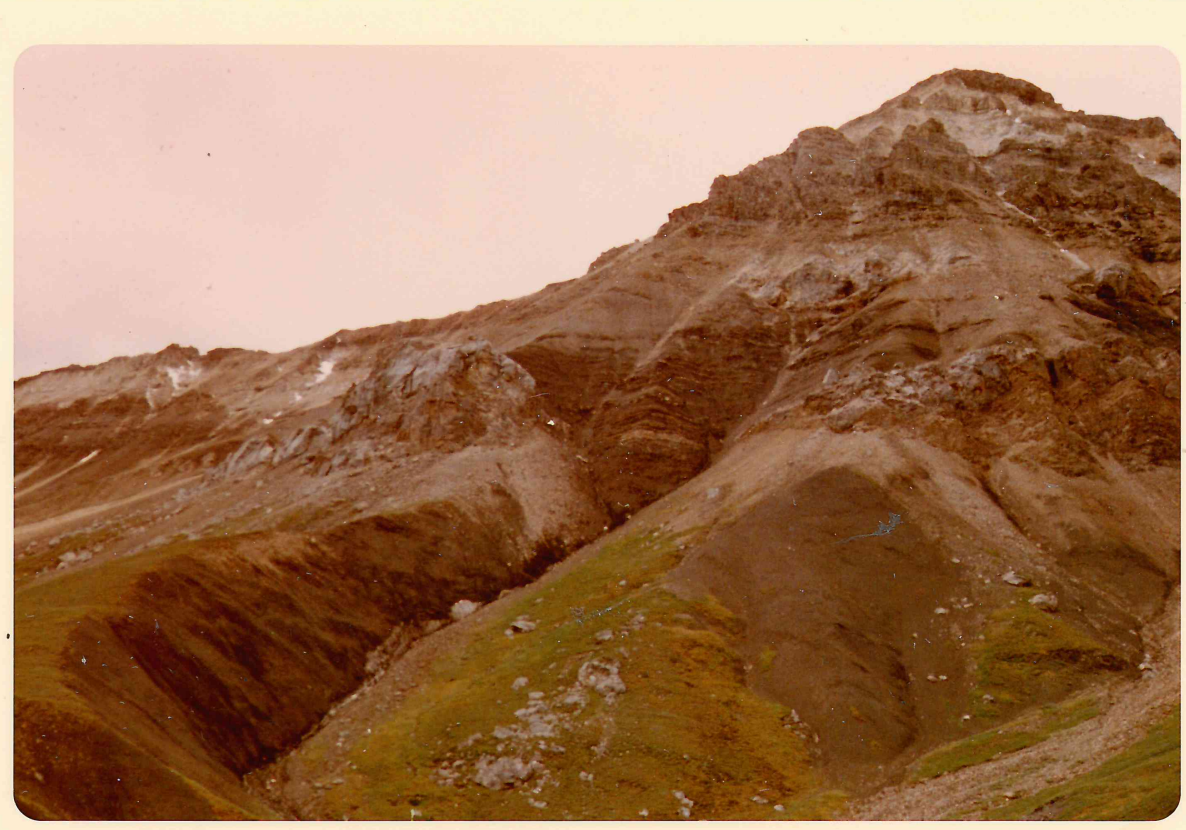

North face of Mt. Bastille with Hunt Fork Shale at base and Kugururok Fm. above it, all Late Devonian. 


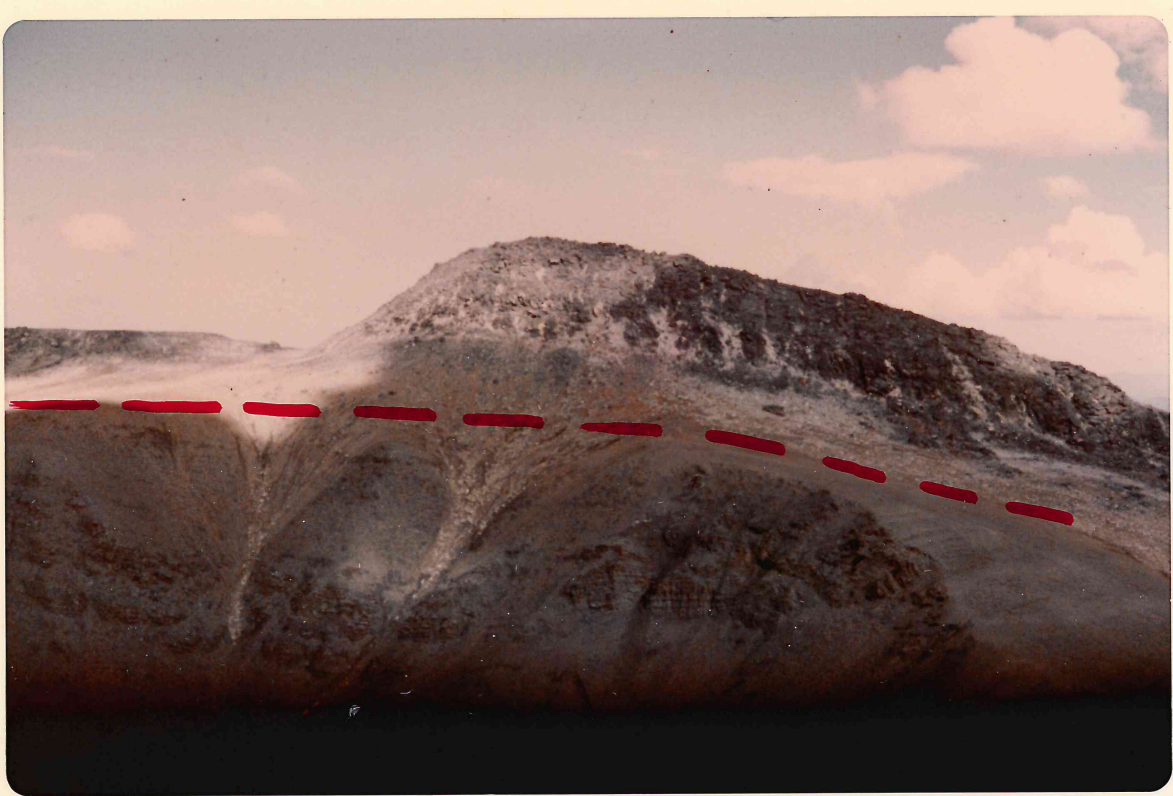

Kanayut and Hunt Fork overlying marble of Metamorphic Basement Complex with fault contact. Located at $156^{\circ} 52^{\prime} 30^{\prime \prime} \mathrm{E}$ and $67^{\circ} 46^{\prime} \mathrm{N}$ looking north

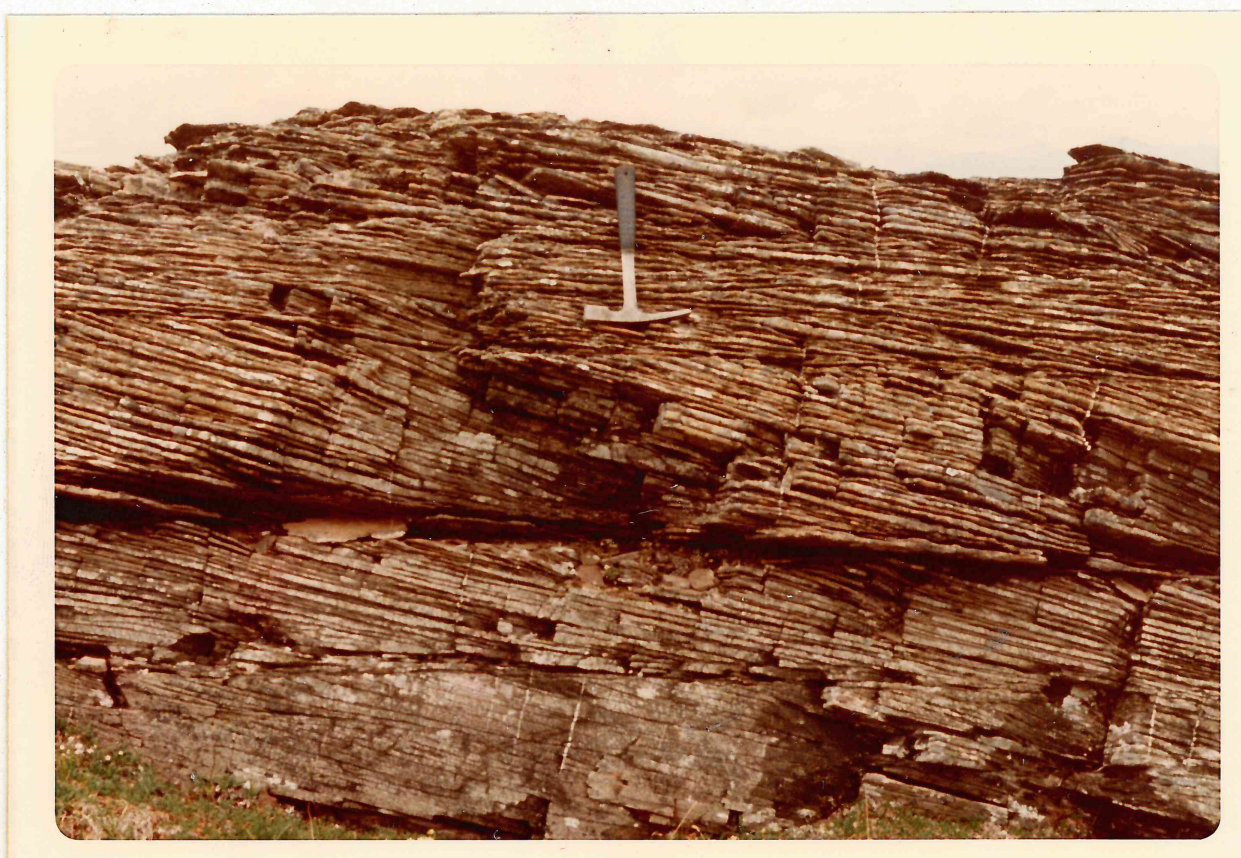

Cross-bedding in Noatak Formation sandstone [near the Noatak River] southwest of the type section looking north

FIGURE 7 
Hunt Fork Shale (HF)

The Hunt Fork Shale that crops out throughout the map area consists of shale and siltstone with fewer interbeds of silty limestone and sandstone. The areal distribution of this unit generally is within the northwestern Baird Mountains, eastern De Long Mountains, Howard Pass area, and north of the Schwatka Mountains (Plates 3, 4, 6-8). It is not known if the Hunt Fork Shale was even deposited in the southern part of the area mapped.

The Hunt Fork Shale appears to overlie the Basement Complex

unconformably south of the Noatak River (Plates 6 \& 7). In a few localities, it overlies (T28N, R3E of the Ambler River Quadrangle) Middle Devonian carbonate, but with an unknown relationship. The upper contact of the Shale is gradational into the Noatak Formation and also appears to grade into the Kanayut Formation (T27N, R9E of the Ambler River Quadrangle and the south central area of the Misheguk Mountain Quad.). The gradational sequence ranges in thickness from less than one hundred feet to several hundred feet. The change from Hunt Fork Shale to the Noatak occurs upwards by a gradual increase of sandstone accompanied by a decrease in shale interbeds until the sandstone becomes the predominate rock type. This contact is more abrupt into the Kanayut Formation where conglomerate or conglomeratic sandstone predominates.

The age of the Hunt Fork Shale is Middle to Late Devonian. The Middle Devonian (Eifelian) date comes from a carbonate unit sampled this season which overlies concordantly the shale considered Hunt Fork. Assuming this sequence is not overturned, the underlying shale unit is Eifelian and/or older. Fossils from the base of the Noatak Formation (Dutro, 1953) indicate a Late Devonian Age, which would be a minimum age for the Hunt Fork Shale. 
Most of the Hunt Fork Shale encountered is probably Upper Devonian. Fossils and primary sedimentary structures found in the shale and limestone indicate a shallow water marine environment of deposition.

Noatak Formation-Kanayut Formation (Noa-Dk)

In the area of study the Kanayut Formation is primarily a continental unit and the Noatak Formation primarily a marine unit. The separation of these two units is very arbitrary at this time due to the geologic reconnaissance type of survey done during the 1971 field season. More detailed work probably would resolve the interrelation of the Noatak and Kanayut formations. As mapped, the Noatak Formation is restricted to the northwestern portion of the mapped area (Plates 2, 3, 5, and 6) while the Kanayut Formation is confined to the northeastern portion of the mapped area (Plates 4,7 , and 8 ).

The Kanayut Formation consists of quartz-rich conglomerate and silty quartzose sandstone. Shale with plant remains is present as thin interbeds in the sandstone sequence. The sporadic outcropping of conglomerate is believed controlled primarily by local deposition rather than erosion.

The Noatak Formation consists primarily of quartzose sandstone with minor shale and siltstone interbeds. According to Dutro (1953) at the type section, about five miles north-northwest of the Nimiuktuk River mouth, the Noatak sandstone is mainly very fine-grained, siliceous, ferruginous, and rarely conglomeratic. Commonly, it is cross-bedded, rippled, and occasionally channeled. In the field, it was observed that the grain size increases westward from the type section to fine- to mediumgrained with numerous conglomerate beds (Knapp and Dalness, 1970). Thin 
beds of shale-pebble conglomerate are present sporadically in sandstone throughout the Noatak Formation.

The upper contact of the Noatak Formation with the Kayak Formation or Utukok Formation and the Kanayut Formation with the Kayak Shale was not observed during the 1971 field season. Dutro (1953) states that the Noatak Formation is gradational with the Utukok Formation, and the data obtained during the 1971 field mapping also indicates a gradational contact. The upper contact of the Kanayut was not observed, but according to Bowsher and Dutro (1957), at the type section east of the mapped area near Shainin Lake, the Kanayut Formation is overlain disconformably by the Kayak Formation.

Dutro (1953) states that the Noatak Formation contains a few Late Devonian plant genera and a diagnostic brachiopod species of Late Devonian age. No fossils have been dated so far from samples collected during the 1971 field expedition.

Mississippian

Utukok Formation (Utu)

The Utukok Formation consists of sandy and silty limestone, limy siltstone, and calcareous to siliceous sandstone interbeds. The limestone is commonly a fossil hash and it contains abundant quartz sand and silt and tiny iron specks. The limestone is ripple cross-bedded where clean and burrowed where argillaceous. The interbedded sandstone is very finegrained, silty, ferruginous, and usually limy. The quartz silt and sand appear to have the same source as the Noatak Formation. The carbonate was provided 


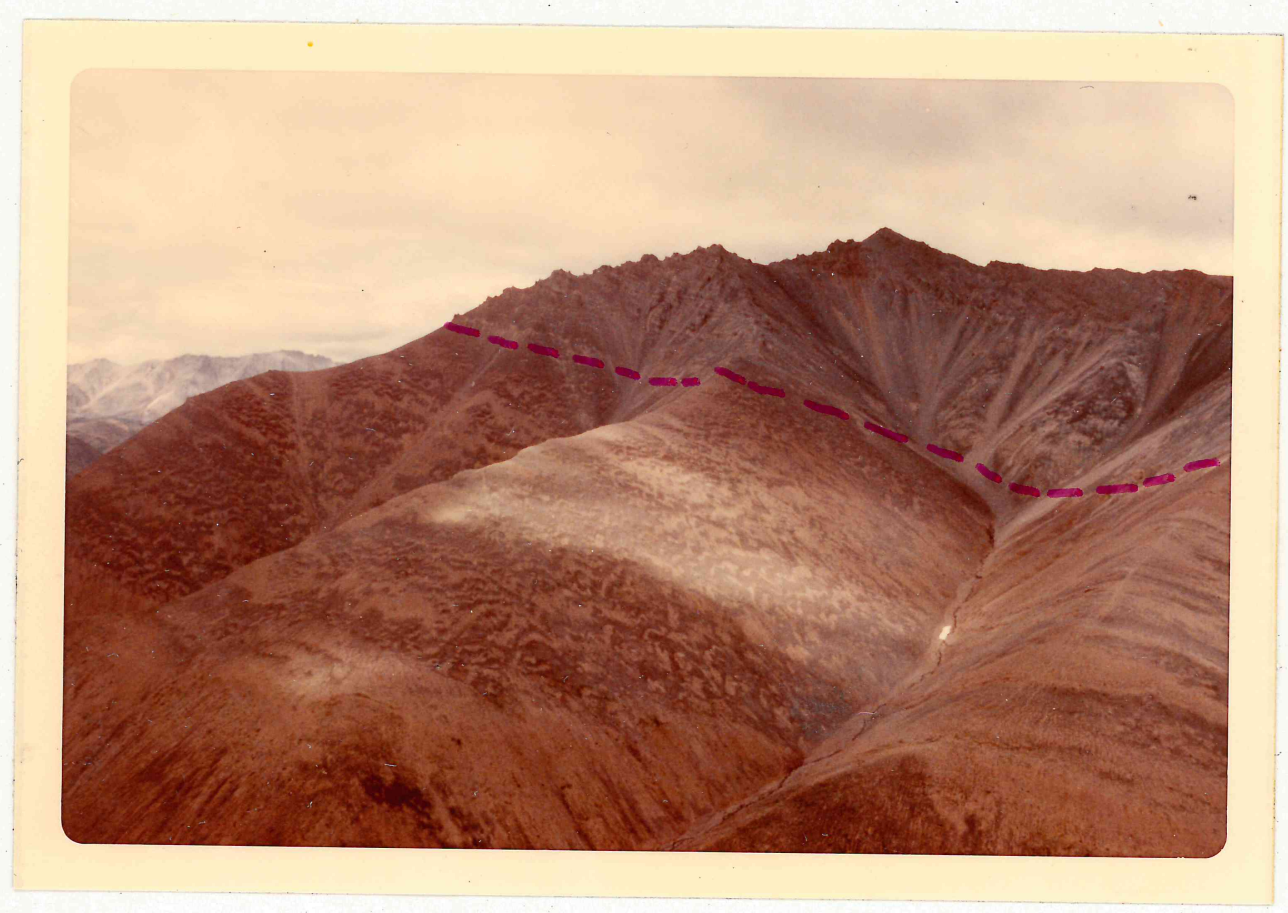

Gradational contact between the Utukok Formation below and the Lisburne Formation above. Line indicates approximate position of contact. Looking north. Location: T12S R13W (north central part) Misheguk Mountain Quadrangle. 
by marine organisms. This formation is a shallow water marine shelf edge deposit.

The lower contact of the Utukok Formation was not observed, but according to Dutro (1953), it is gradational with the Noatak Formation. The boundary between the Utukok and Noatak Formations occurs where the rocks are predominantly calcareous. The upper contact is gradational with the Lisburne Carbonate. The change between the two formations is a decrease of terrigenous clastic rocks upward, replaced by fossiliferous carbonate grainstones of the Lisburne Carbonate.

The age of the Utukok Formation, according to Dutro (1953), is upper Kinderhookian to lower Osagean. This unit laterally, at least in part, grades into the Kayak Formation.

Kayak Formation (Mk)

The Kayak Formation crops out mainly along a narrow belt in the northern flank of the De Long Mountains (Plate 2 and 3). It consists mainly of dark gray shale with thin laminae of white siliceous(?) rock and thin limestone interbeds toward the top. Dark gray chert beds are commoniy interbedded with the shale. In places, sequences of black silicified fossiliferous limestone and black chert are present near the base of the Lisburne Carbonate, or these beds could be considered as being the upper portion of the Kayak Formation. The upper contact between the Kayak and Lisburne Formations was not studied but is considered to be gradational. The Kayak Formation interfingers laterally with the Utukok Formation and represents a basinward facies of that unit. Due to the lateral interfingering with the Utukok Formation, the Kayak Formation is considered to be Early Mississippian in age. 
Lisburne (M1)

The Lisburne Carbonate, aerially extensive in the De Long Mountains and locally present in the northwestern Baird Mountains, was not primarily studied this field season. The gray-colored unit is a sequence of Mississippian limestone, dolomite, and chert. The Lisburne Carbonate is composed of a wide variety of carbonate rock types which were deposited on an open marine platform.

Conformably underlying the Lisburne in the De Long Mountains are the Kayak Shale, or the Utukok Formation. The carbonate unit is unconformably overlain by the undifferentiated Siksikpuk-Shublik Formations.

The Lisburne Carbonate is thought to be a potential hydrocarbon reservoir offshore of Cape Lisburne and the Lisburne Hills area and possibly in the foothills belt north of the Brooks Range. For more details about the Lisburne Carbonate, refer to Union 0il Company's report on the Western Brooks Range by Chauve1, 1969; Pan American's Geological Memorandum No. 127, 1970; and Amoco's Denver Division Memorandum No. 152, 1971.

Permian-Triassic ( $\mathrm{R}$ sh)

\section{Siksikpuk Formation-Shublik Formation}

These formations are discussed under one heading because in the field, often it was not possible to separate them due to their similar lithotypes, lack of diagnostic fossils, tectonic complexity, and poor outcrops. The usual lack of fossils in both formations restricts the determination of the range of the Siksikpuk Formation in the Permian and the range of the Shublik Formation in the Triassic. 
The two formations consist of gray to black fractured chert, gray siliceous shale and associated siliceous claystone, and greenish-gray to gray siliceous siltstone. Minor lithotypes include sooty black shale, shaly sandstone, siliceous coquina, and manganese(?) rich sandstone. The chert and siliceous shale usually weather brownish-red to rusty-brown. The diversified lithotypes indicate that part of the Shublik was deposited in locally restricted marine water with little influx of coarse-grained terrigenous clastic sediments.

The areal extent of the Siksikpuk and Shublik Formations is confined to the northern one-half of the mapped area. The rocks are generally contorted and sheared and crop out in valleys between fault-block mountains of Lisburne, Utukok, and Noatak Formations. Along the northern flank of the Brooks Range, they are, at least in part, deformed by gravity sliding.

\section{Cretaceous}

The Cretaceous studied during the 1971 field season will be discussed in two separate sections because of the differing geologic histories of the areas. The areas are: the Kotzebue-Kobuk Basin and the foothills region of the western Brooks Range. The Cretaceous outcrops studied in the Sagwon area will be discussed in a preliminary report and will later be integrated into the 1972 field report of that area.

\section{Kotzebue-Kobuk Basin \\ Early Cretaceous}

The lower Cretaceous rocks cropping out in the Waring Mountains consist of mudstone, conglomerate, siltstone, and sandstone. The conglomerate and sandstone form prominent mountains and bluffs while valleys and low 
subdued hills are formed of mudstone and siltstone. The highest mountains are located where concentrations of conglomerate are most abundant.

The western part of the Waring Mountains (Hockley Hills and Hotham Peak) contain the greatest percentage of conglomerate. The conglomerate and sandstone are composed primarily of cobbles, pebbles, and grains derived from igneous rocks. Other minor but significant framework constituents include limestone, chert, acid volcanics, sandstone (quartzite), siltstone, and vein quartz (Appendix B, pebble counts). The matrix of the sandstone is clay, silt, carbonate, and iron oxide. Matrix constituents of the conglomerate are sandstone, carbonate silt, iron, and clay.

Above and below the conglomerate-sandstone interval there are mudstone and sandstone with occasional conglomerate interbeds. This lithology is the most widespread and appears to have been deposited in a marine environment below wave base.

In the central and eastern Waring Mountains, the lithology is sandstone, siltstone, mudstone, and conglomerate. The conglomerate framework is primarily igneous clasts $(64-100 \%)$ with minor chert, quartzite, and silicified shale. The igneous clasts include acid volcanic, granite, basalt, dark igneous and intermediate igneous. The matrix is sand, silt, and mud intermixed or separated, with silica and iron cement. Scattered sandstone beds have calcareous cement. The conglomerate of the central Waring Mountains appear as lensing pods and are interpreted as being discrete channel deposits as opposed to outcrops in the west and east end of the Mountains where they appear more massive and probably represent coalescing channel deposits.

Siltstone and mudstone are abundant above and below the sandstoneconglomerate interval and common within it. They appear to be marine with the siltstone commonly containing carbonized plant fragments. Along the 
southern margin of the Waring Mountains, it is common to find pebbly to conglomeratic mudstone and siltstone. These units are thin and grade vertically into mudstone, siltstone, and sandstone.

The source terrane for the Early Cretaceous of the Waring Mountains is thought to be portions of the Baird and western Schwatka Mountains and possibly parts of the southern De Long Mountains. Extrusive volcanic rocks probably covered much of the northwestern Baird Mountains and provided much of the detritus for the sediments. A few cobbles of Lisburne limestone were collected from the conglomerate in the central Waring Mountains (sample locality RRR 215, Plate 9). These cobbles probably came from the Lisburne Carbonate cropping out in the northwestern Baird Mountains (Plate 6) and possibly the southern De Long Mountains. Minor clastic constituents probably came from the Metamorphic Complex in the Baird Mountains and the overlying Devonian carbonate in the Baird and western Schwatka Mountains.

The lower Cretaceous rocks of the Sheklukshuk Range and Lockwood Hills (Plates 10 and 11) area differ from the rocks described above. They consist mainly of sandstone, siltstone, and mudstone with a lesser amount of conglomerate and volcanic rocks mixed with mudstone and sandstone. In this area, Cretaceous igneous extrusive rocks are closely associated with the sedimentary rocks and probably were a significant source of sediments. The volcanic rocks consist of porphyritic basalt with phenocrysts of olivine, feldspar, and unknown minerals. The associated sandstone and siltstone consist of volcanic grains, and because of grain size and closeness to the source, they are difficult to. distinguish from the volcanic rocks. Conglomerate is most abundant in the central Lockwood Hills and decreases in abundance eastward; they were not found in the western portion of the Hills. The framework consists of granules to medium sized cobbles of 
intermediate and basic igneous rocks $(90 \%)$; the remainder of the detritus is acidic igneous, siliceous claystone, and quartz. The matrix is sandstone as described above, and it is highly cemented by iron and silica. Igneous derived "dirty" sandstone of all grain sizes are abundant in the Hills and are usually cemented by silica and iron. The framework of the sands is made of abundant feldspar, pyroxene, and/or amphibole, and rock grains, with minor red grains and quartz. Mudstone occurs interbedded with the sandstone and siltstone and is usually silty and hard with probably silica and iron

- cement. Carbonaceous fragments are common, and locally, oyster shells are present (Patton et al, 1968).

The lower Cretaceous of the western end of the Alatna Hills (NE Plate 11) is different from those rocks previously described. The bottommost beds of the section examined are part of a sequence of graded units. Many units have coarse sand at the base and grade upward to silty shale before the next graded unit occurs. There are occasional graded limestone beds. The section is probably several thousand feet thick. Stratigraphically above the graded beds are interbedded conglomerate and shale beds overlain by massive conglomerate with interbedded sandstone. The predominant framework constituents for the conglomerate and sandstone are basic igneous rocks and their mineral grains plus minor dark and light chert and quartz.

The age of all the lower Cretaceous rocks discussed is based on U. S. G. S. fossil collections and radiometric dates and two radiometric dates obtained from samples collected during the 1971 field party. Buchia sublaevis found by the U.S. G. S. (Patton et al, 1968) indicate an early Neocomian age while radiometric dating indicates a range from $87.8 \pm 3.9$ m. y. to $125 \pm 3.3 \mathrm{~m}$. y. (top of the Turonian down to the middle of the Neocomian). The older radiometric dates agree fairly, well with 
the paleontology but the younger dates are in large error. This error may be due to surface weathering of the sample or remobilization of the rock during later Cretaceous igneous activity. Additional fossil collections throughout the area are needed to provide a better understanding of the stratigraphic relationships of the Kotzebue-Kobuk Basin lower Cretaceous.

Late Cretaceous

The upper Cretaceous rocks crop out along most of the northern flank of the Waring Mountains, on the Kobuk River, around the Cosmos Hills, and in a narrow band in the Helpmejack Hills area (northern part of Plates 9, 10, and 11 and southern part of Plates 6 and 7). The rocks comprising the upper Cretaceous are primarily sandstone, and conglomerate with minor amounts of siltstone, mudstone, and coal. These coarser grained rocks are easily distinguished from the Early Cretaceous rocks because of the abundance of white vein quartz as a dominant framework constituent.

The conglomerate is abundant in outcrop and consists primarily of granules to medium-sized cobbles of vein quartz, schist, phyllite, and limestone with minor dark volcanics, quartzite, chert, and sideritic siltstone. Locally, the sideritic siltstone clasts are abundant. The matrix is medium- to coarse-sand that is medium- to well-sorted and cemented with silica, carbonate, and iron in order of decreasing abundance. The conglomerate observed along the Kobuk River was cross-bedded and appeared in most places to be fluvial in origin. Sandstone occurs as thin lenses within the conglomerate beds and above them as upward gradational units laid down during primary deposition. The sandstone in turn grades upward into siltstone and ranges from very fine- to coarse-grained with matrix content 


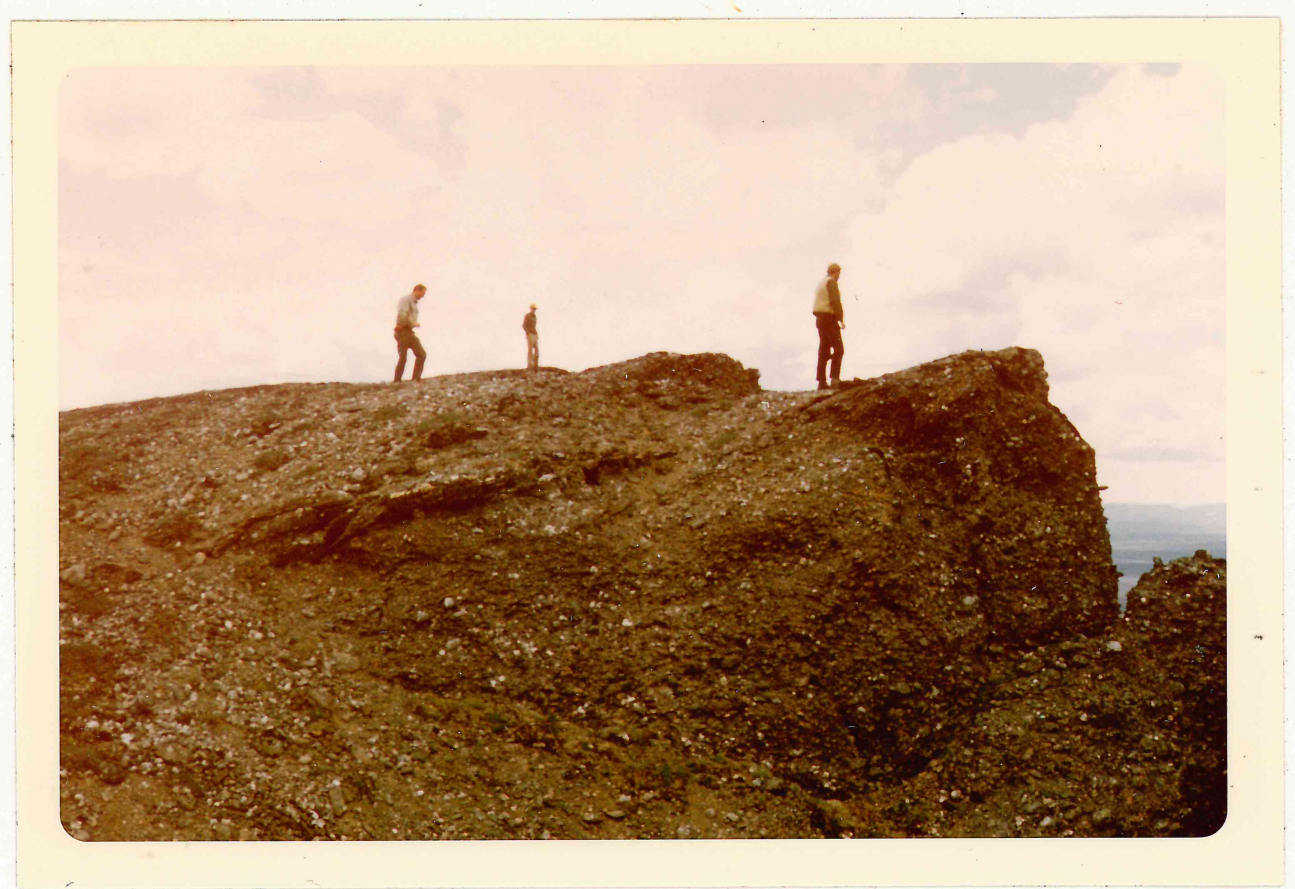

Upper Cretaceous conglomerate in Kobuk basin near contact with the Metamorphic Basement complex.

White cobbles are veinqtz. Taken July 24 a Stop 11. Looking south [Sec. 29 T18N R19E]

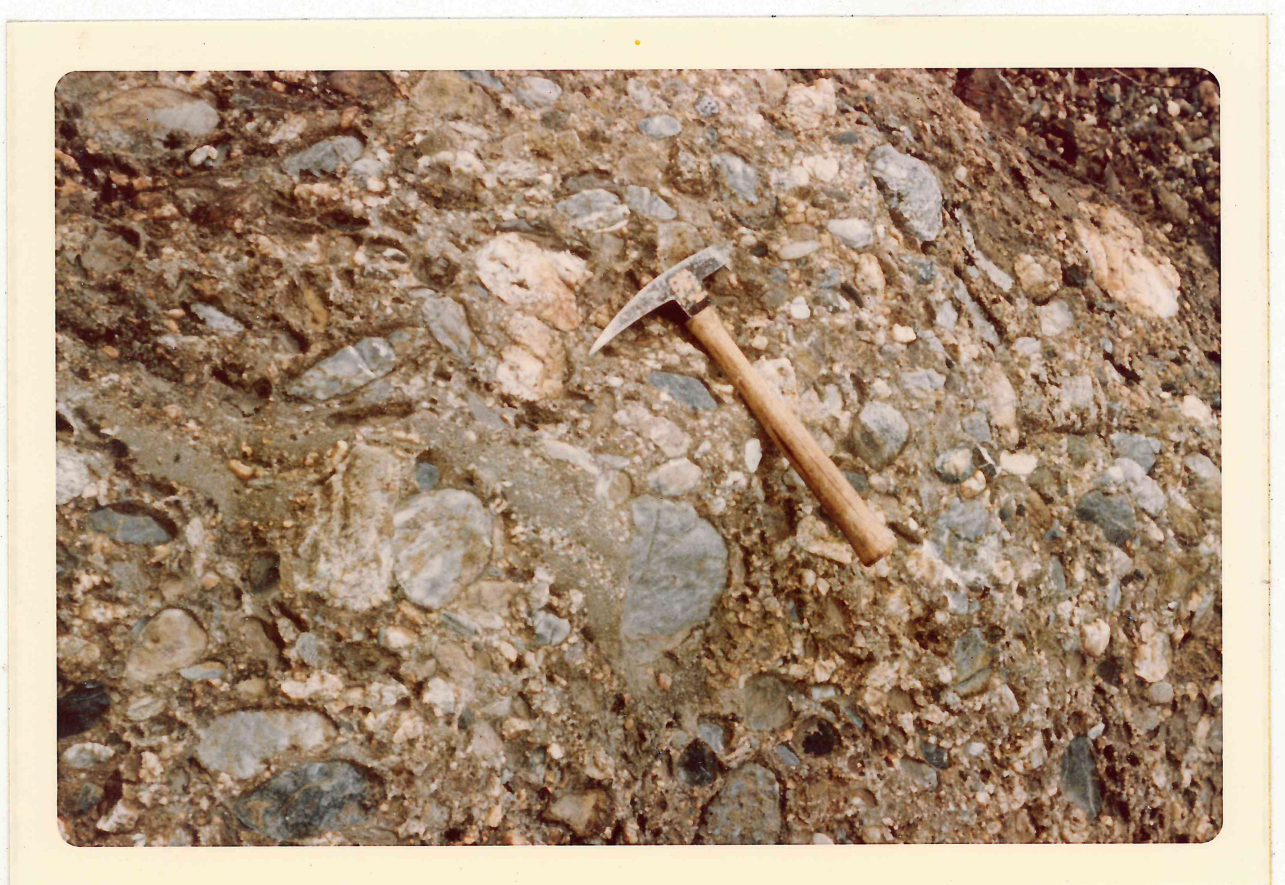

Upper Cretaceous conglomerate consisting of gray carbonate, white vein quartz, and very dark metamorphic cobbles \& pebbles. Outcrop on Kobuk River. (June 22, stop 5) Baird Mountain Quad. 
increasing with decreasing grain size. The cement is carbonate, silica, and iron. The siltstone varies in color from red to gray depending upon the carbonaceous content and degree of oxidation. It crops out only rarely, but it seems to cap the channel deposit sequence of conglomerate and sandstone. Coal was found in two localities as float and possibly it overlies very fine-grained sediments.

The lower contact of the upper Cretaceous rocks was not observed in outcrop, but reconnaissance mapping indicates that it is angular in the Helpmejack Hills area where Cretaceous rests on the Metamorphic Complex. At Hotham Peak ( $\mathrm{T} 16 \mathrm{~N}, \mathrm{R}$ 9W, Plate 9) the upper Cretaceous rests on the lower Cretaceous with unconformity, but of an unknown type (Patton and Mil1er, 1968).

The primary source terrane for the upper Cretaceous sequence was the Metamorphic Complex of the Baird and Schwatka Mountains. Additional detritals came from the Devonian carbonate and lower Cretaceous igneous rocks. These sources were north of the depositional area.

The age of the Cretaceous sequence based upon palynology is Late Cretaceous, Campanian-Maestrichtian. A radiometric age date from a tuff indicates middle Late Cretaceous deposition (Patton and Miller, 1968). Plant fossils have been collected by Union Oil Company geologists in 1971 and U. S. G. S. geologists, but they are not good index fossils (Patton and Miller, 1968 and 1966).

Foothills of western Brooks Range

The Cretaceous rocks in this area were observed only in a few outcrops and, therefore, a detailed description is not possible. The 
1ithotypes are mainly siltstone, shale, and sandstone with minor conglomerate. The siltstone and shale lithotypes are poorly exposed and form rounded hills and valleys in the northern foothills of the Brooks Range. These rocks are usually dark gray to black and contain scattered carbonaceous plant debris. The sandstone usually is a dark wacke ( $>10 \%$ matrix) with calcareous to siliceous cement. The grain size ranges from very fine to coarse but the majority are fine-grained. The framework constituents were not studied in detail but include rock, quartz of various types and chert grains. The sandstone is laminated to thin-bedded, rippled, and locally graded. It is often interbedded with shale and locally contains shale pebbles. The conglomerate is associated with the sandstone and in several places, it grades upward into it. The clasts are granules to small pebbles of varied undocumented lithotypes.

The lower contact of these Cretaceous rocks is unconformable. It overlies Triassic Shublik and the Lisburne Carbonate within and along the north flank of the De Long Mountains. The upper contact was not observed. Foraminiferal assembledges found in several samples collected by members of this survey were not diagnostic enough to give a reliable date. An Early Cretaceous age is given as a best guess. This agrees with the age as inferred by the U. S. G. S. (Sable, Dutro, Morris, 1951).

Igneous Rocks

Plates $2-6,8,10$, and 11 of this report illustrate the widespread occurrence of igneous rocks in the western Brooks Range. The great majority of these igneous rocks are fine to coarsely crystalline mafic sills, dikes, and stocks. The cores of the larger intrusive bodies are 


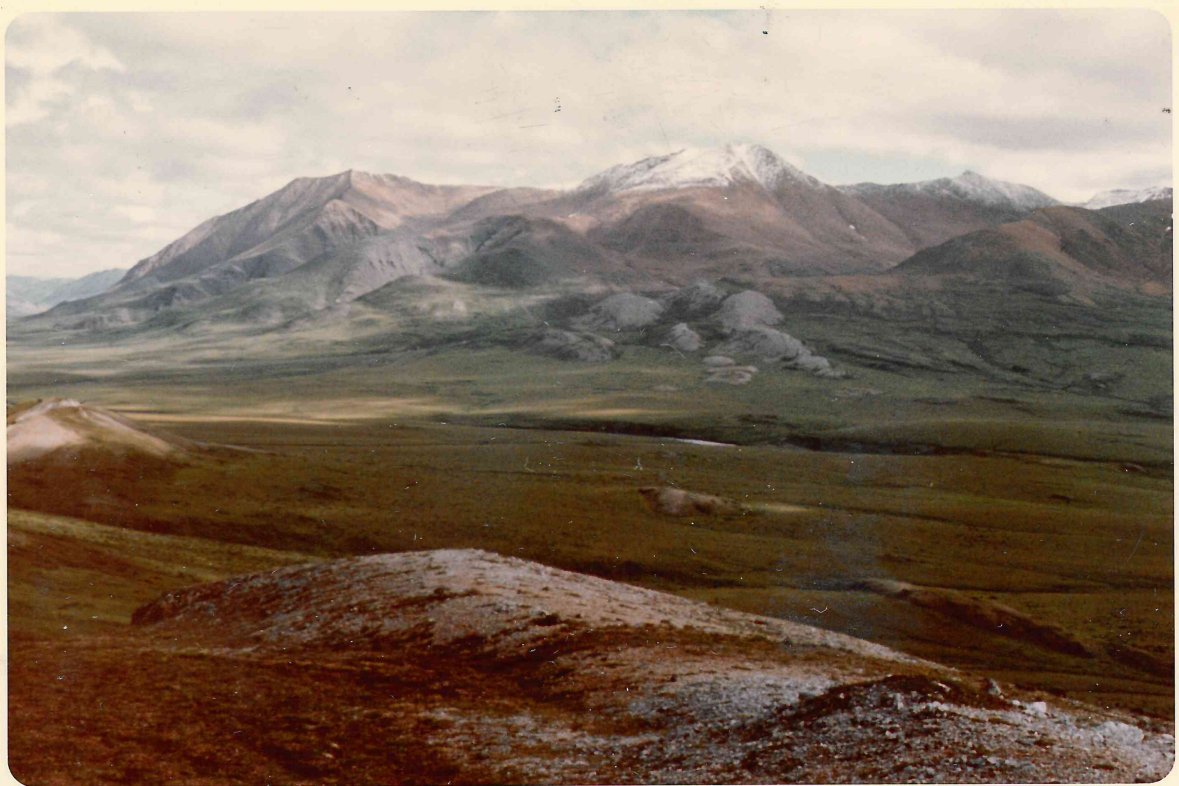

Light orange, snow capped Cretaceous igneous instrusive in central De Long Mountains (southcentra1, Plate 3)

Intruded sediments form the flanks of the mountains, looking northwest. 
composed of very dark and heavy ultramafic igneous rocks. Granitic rocks occur locally in small outcrops and are not widespread except in the Survey Pass Quadrangle where they form the core of the Schwatka Mountains (Fritts, 1970). Gneissic rocks occur at the periphery of this large intrusive.

The exposed igneous rocks suggest emplacement as stocks, batholiths, dikes, and sills with some subaerial and submarine basic flows. In the map area, igneous rocks are associated with Devonian carbonate and clastic rocks, Mississippian carbonate and shale, Permian and Triassic chert and clastic rocks, and Cretaceous clastic rocks. Several places in the De Long Mountains, Devonian carbonate blocks occur as large xenoliths. In the Sheklukshuk Range, about 135 miles east of Kotzebue (Plate 10), it appears as though submarine igneous flows are mixed with volcanic breccia and sandstone of Early(?) Cretaceous age.

The igneous rocks were intruded along faults and shear zones throughout the mapped area. These intrusive rocks are commonly aligned along and near normal faults bounding the grabens of the western Brooks Range area. Repeated igneous intrusions since Paleozoic time are suggested by scattered radiometric dating (Fehlmann, 1971). Radiometric dating and field observations indicate major igneous activity during the Cretaceous Period.

\section{STRUCTURE}

The structural deformation undergone by rocks making up the Baird Mountains probably is the result of orogenic movements that possibly began in the Precambrian and later recurred at the close of Silurian time and continued intermittently into Early Tertiary. 
Orogenic movements caused the regional dynamic metamorphism of the Lower Paleozoic and possibly Precambrian sediments. Evidence of dynamic metamorphism also can be observed locally in the carbonate and shale of Middle and Upper Devonian age. The metamorphism undergone by the Devonian sediments, however, is not as intense as the metamorphism of the underlying metamorphic complex.

The sequence making up the metamorphic complex that crops out in the Baird Mountains, at least in part, is considered in this report the probable age equivalent of the Neurokpuk Formation observed on the eastern portion of the Brooks Range.

It is postulated that the area occupied by the Baird Mountains underwent at least two major orogenies during lower Paleozoic time. It should. be pointed out that the writers believe a milder orogeny also occurred near the close of the Devonian. This milder orogeny, which affected principally the Baird Mountains, caused the regional metamorphism of the Hunt Fork Shale observed in those mountains. In most areas visited on the north flank of the Baird Mountains south of the Noatak River, the Hunt Fork Shale has been altered to a sericitic phyllite which at some localities is almost a schist. North of the Noatak River, however, the metamorphism gradually diminishes, becoming nearly absent. In the central and eastern Brooks Range, where the Hunt Fork crops out, the same relation can be observed; the metamorphism of the shale on the south flank of the range is greater than it is to the north where it is very mild or not present. This metamorphism of the shale was caused by the gliding of overlying sediments over the Hunt Fork Shale which served as the plane of detachment.

It is postulated that during the Early Paleozoic orogenies, block faulting, intense folding, and thrusting occurred in the Baird Mountains. 
These orogenies created more intense metamorphism than that undergone by the Middle and Upper Devonian rocks.

The regional dynamic metamorphism undergone by the Precambrian(?) and early Paleozoic sediments. and the age of the overlying sedimentary rocks and their relation to the metamorphic complex indicate that the Baird and western Schwatka Mountains are the oldest mountains of the western Brooks Range. The age of the rocks and the structures making up the De Long Mountains indicate that together with most of the northern flank of the Brooks Range, they are the youngest; possibly they are Late Cretaceous-Early Tertiary in age. The structural features observed across most of the northern flank of the Brooks. Range probably were caused by gravity sliding that took place during the Late Cretaceous uplift of the southern part of the range.

Gravity sliding, however, is not the solution that explains all the structural complications observed in the De Long Mountains. Other stresses, or the combination of differential stresses and gravity sliding may be closer to a solution than any single answer. For instance, the large graben present to the west and south of Feniak Lake (Plate 3 and 4), a tension feature, cannot be accounted for by gravity sliding. The same reasoning applies for another tensional feature making up the wide valley of the lower Noatak River near its mouth (Plate 5). These two features are the result of tension, but possibly they were not caused by one and the same stress. This stress differential possibly is indicated by the orientation of each graben. The presence of tensional structures definitely indicates some type of differential block faulting, at least in the vicinity of the grabens. It can, therefore, be postulated that in all probability the Baird Mountains, or a portion of them, are made up of up-thrown blocks. 
The movements along the boundaries of the blocks appear, at least in some cases, to have been not only vertical but also considerably lateral as postulated in Plate 6 .

It should be noted that if block faulting and lateral displacements did occur in the Baird Mountains, they were contemporaneous with the development of the Noatak River Graben but ended before the development of the Feniak Lake Graben.

The De Long Mountains, therefore, are believed to have formed after the differential block faulting took place in the Baird Mountains. The uplift of the blocks making up the Baird Mountains caused the gravity sliding responsible for the structural complications observed in the De Long Mountains. It is postulated that stresses of probable Early Tertiary age produced the arcuate shape of the De Long Mountains as well as wrench type faulting, additional thrusting and gliding, and fracturing resembling block faulting in the mountains.

It should be emphasized that the structural review just made of the Baird and De Long Mountains is very schematic. To be able to understand the complicated structure of the area being described, additional field work, stratigraphic in nature, must be done before a reasonable answer to the problem can be reached. 


\section{SELECTED REFERENCES}

Bowsher, Arthur, L., and J. Thomas Dutro, Jr., 1957, The Paleozoic section in the Shainin Lake Area, Central Brooks Range, Alaska, in Exploration of Naval Petroleum Reserve \#4 and adjacent areas, northern Alaska, 1944-53, Part 3, Areal Geology: U. S. Geo1. Survey Prof. Paper 303-A.

Dutro, John, Jr., 1953, Stratigraphy and paleontology of the Noatak and associated formations, Brooks Range, Alaska, Yale University, Ph.D, p. $1-53$.

Fehlmann, R. H., 1971, Data compilation 1970 Amoco field party, western and central Brooks Range, Alaska: Amoco Production Company geological memorandum No. 152 .

Fritts, Crawford, E., 1970, Geology and Geochemistry of the Cosmos Hi11s, Ambler River, and Shungnak Quadrangles, Alaska, Geological Report No. 39, Division of Mines and Geology, Department of Natural Resources, State of Alaska, p. 1-38.

Knapp, W. D., and W. M. Dalness, 1970, Progress report on the surface geology of the western Brooks Range, Alaska, Pan American Petroleum geologic memorandum 127.

Patton, W. W., Jr., and T. P. Miller, 1966, Regional Geologic Map of the Hughes Quadrangle, Alaska: U. S. Geol. Survey Misc. Geol. Inv. Map I-459, scale $1: 250,000$.

Patton, W. W., Jr., and T. P. Miller, 1968, Regional Geologic Map of the Selawik and southeastern Baird Mountains Quadrangles, Alaska: U. S. Geo1. Survey Misc. Geo1. Inv. Map I-530, scale 1:250,000.

Patton, W. W., Jr., T. P. Miller, and I. L. Tailleur, 1968, Regional Geologic Map of the Shungnak and southern part of the Ambler River Quadrangles, Alaska: U. S. Geol. Survey Misc. Geol. Inv. Map I-554, scale 1:250,000.

Sable, E. G., J. T. Dutro, and R. H. Morris, 1951, Stratigraphy and structure of the Driftwood-Noluk Area, Alaska, U. S. Geo1. Survey Geol. Inv., Naval Petr. Reserve \#4 Alaska, Preliminary Report \#39, p. 27. 


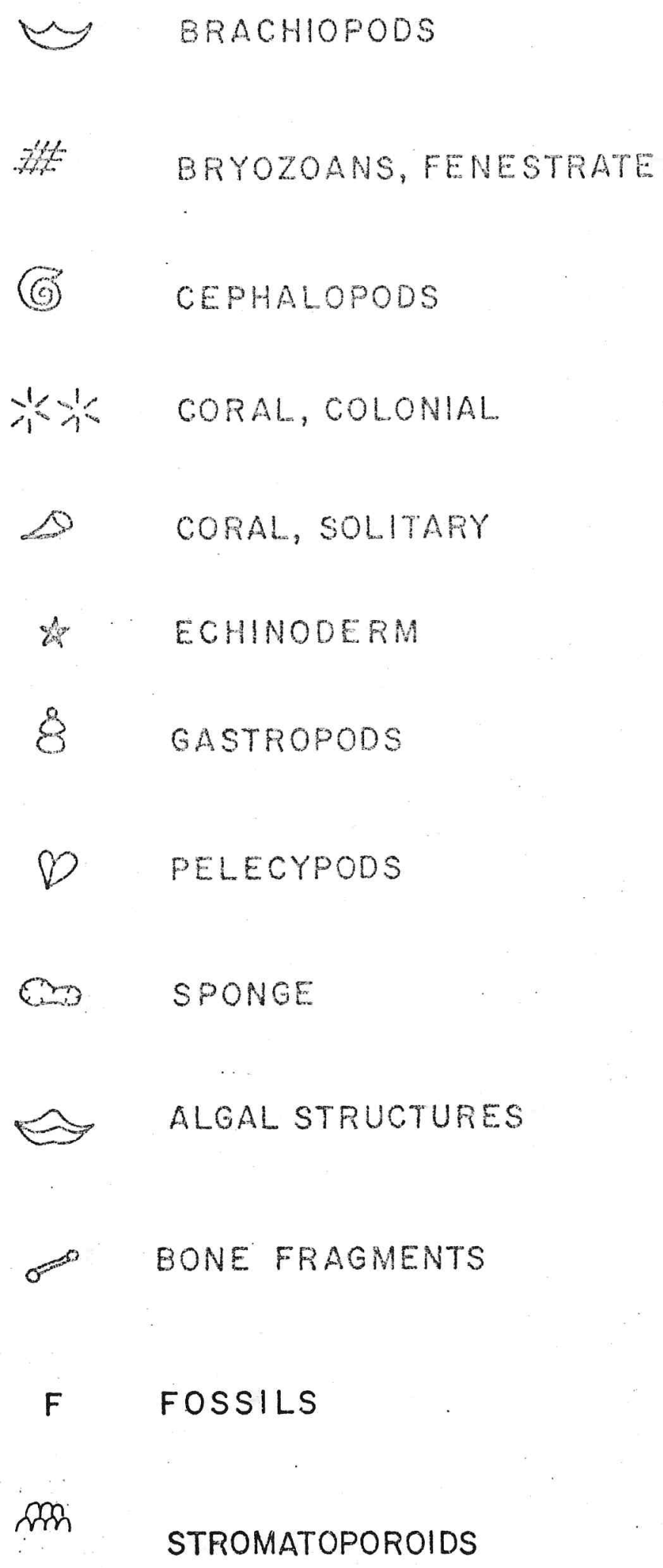




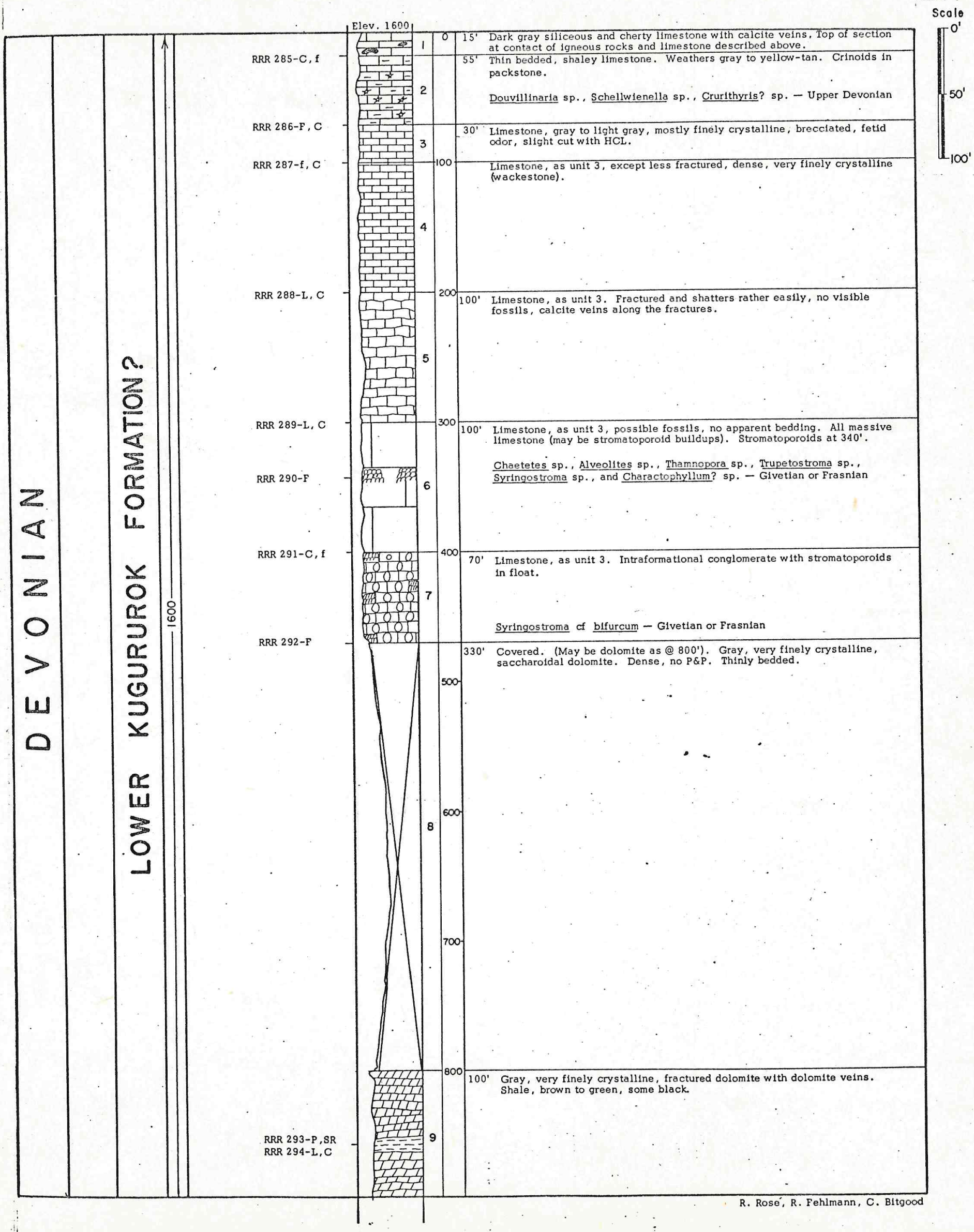




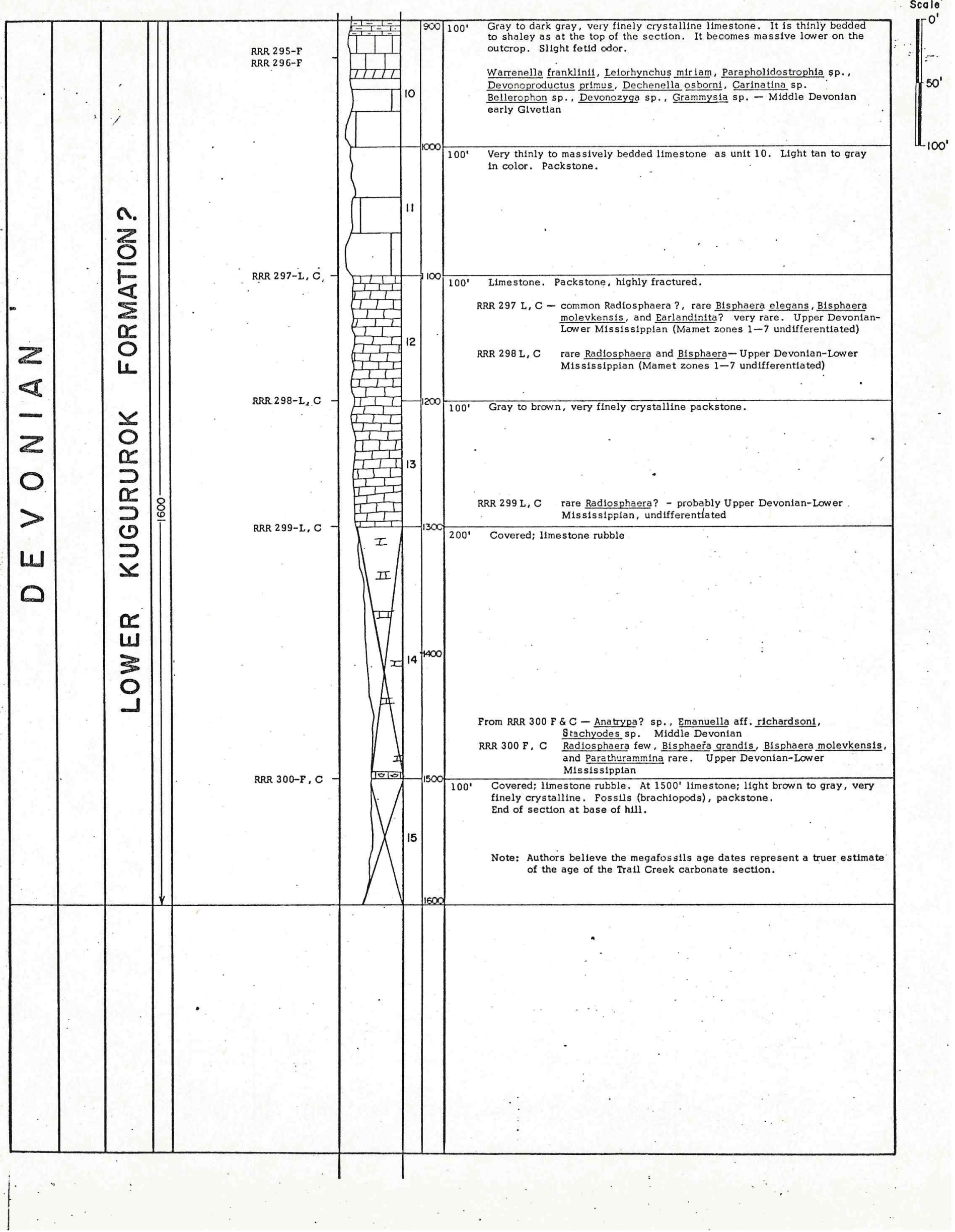




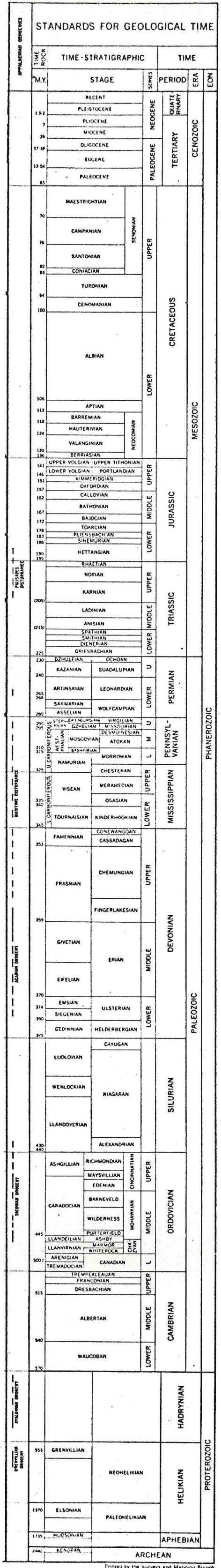




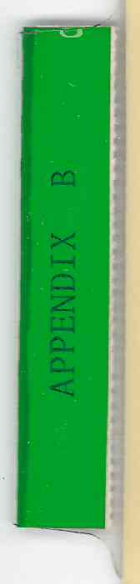





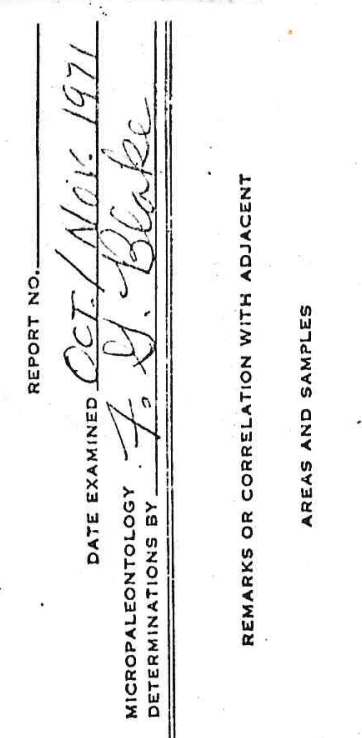

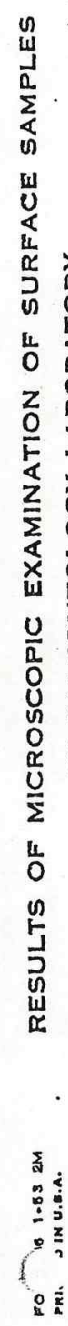

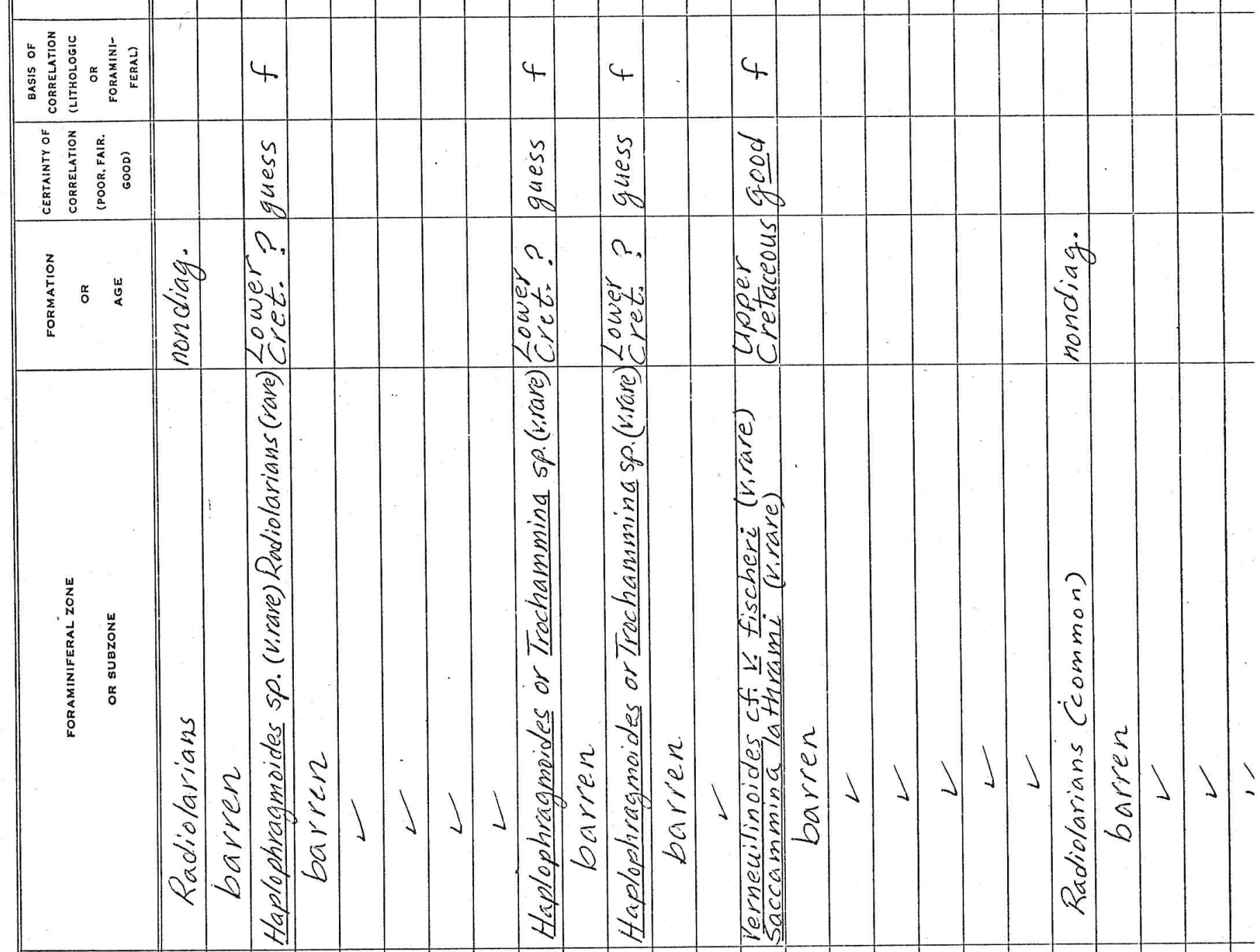

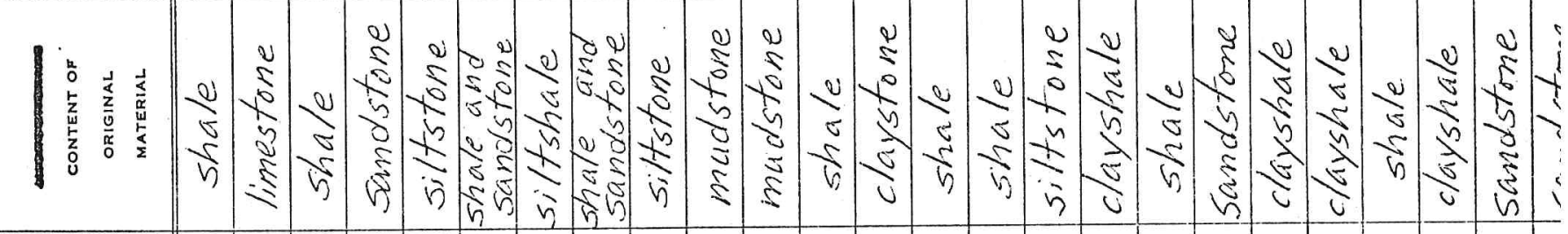

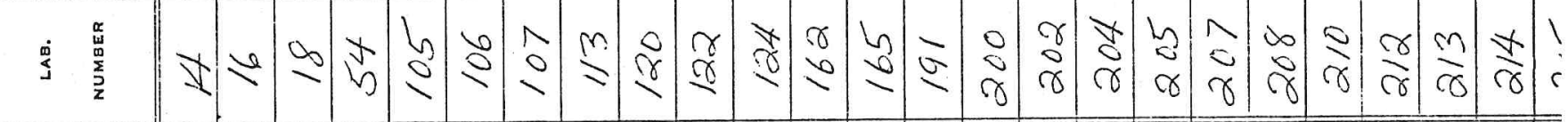

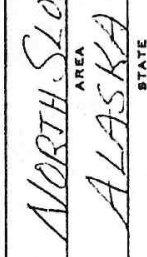

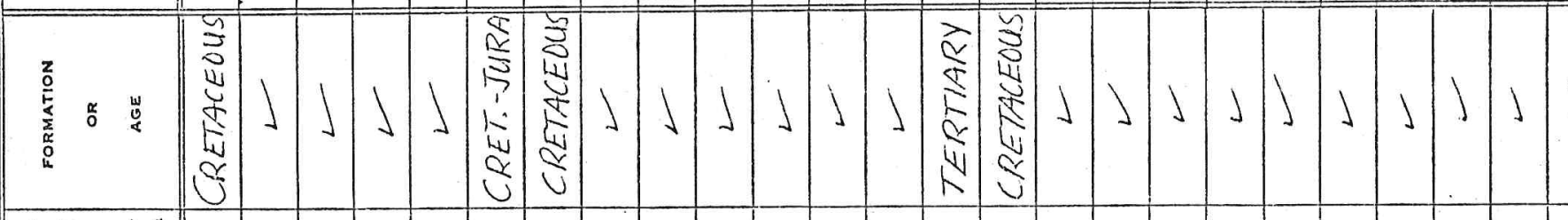

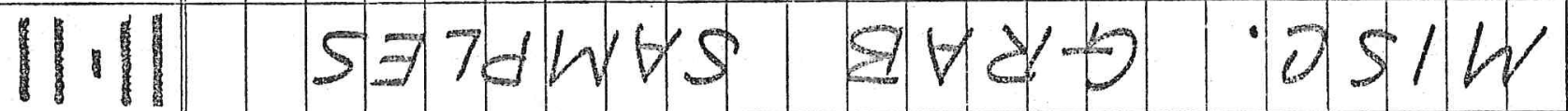

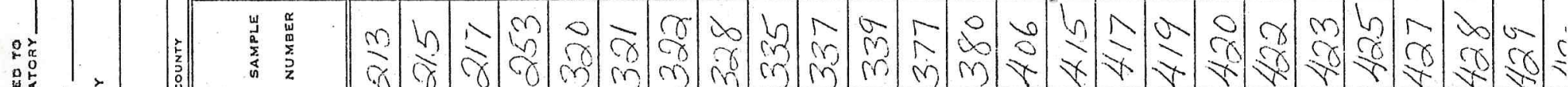




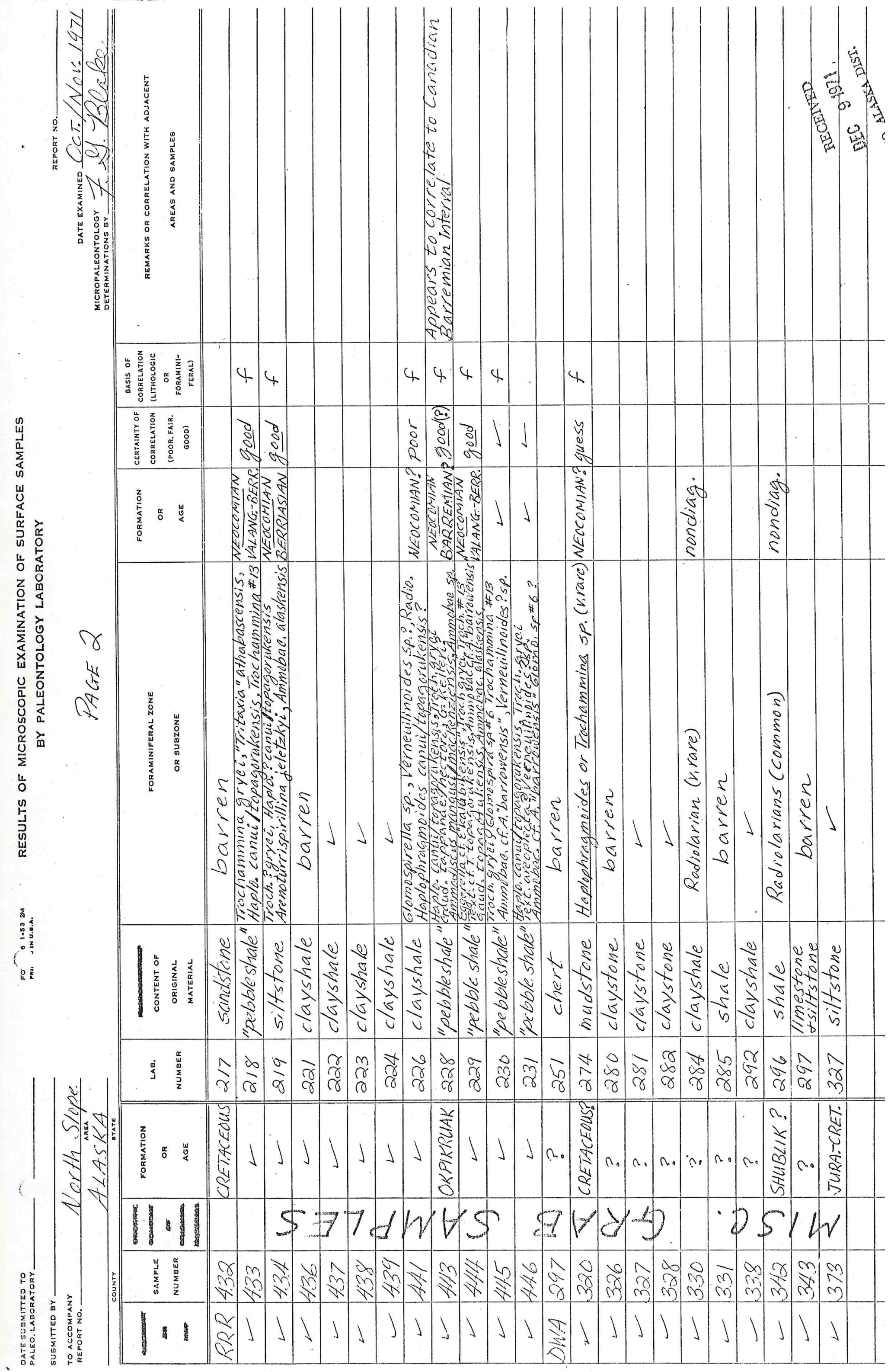




\section{Memorandum \\ Union Oil Company of California

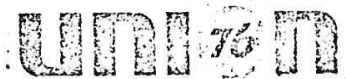

$\operatorname{May} 16,2972$

TO: D. W. Abrahamson, Anchorage, Alaska

FROM: A. A. Almgref, Faieo. Lab, Santa Fe springs

SUBJECT: 1971 Field Farty Semole RRR-215

As per. your memo request dated Nay 9, 1972, four carbonate pebbles from the subject gample have been processed. The age of the carbonate is Mississiopian no olcer than Zone 20 of Wamet, probably Meramec in age. Smaller foraminifera present include species of Endothyra, Gioboendothyra?, ietrataxis, Farlandia, and Fotuberitina. The carbonate rock is lime packstone/grainstone vith abundant crinoid and bryozoa fragments. AAA:go 


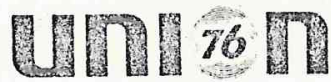

Decunber 8, 297

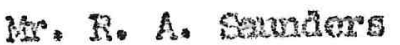

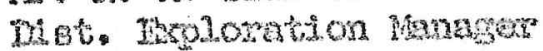

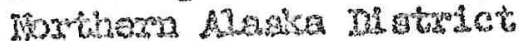

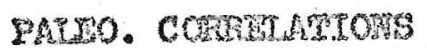

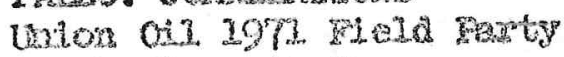

Nowta glope ansaces

Goctuon $\mathrm{Em} 108$

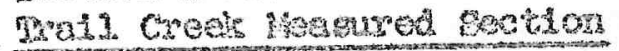

The polloring pelentologic conelationa are bused on a sudy of maller

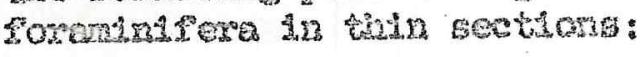

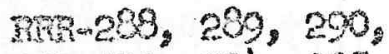

WR-29, 294, 295,

KRT 296

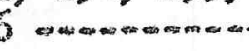

fte: Indroterand nete.

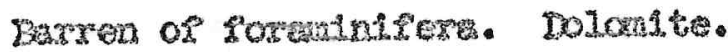

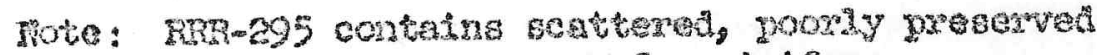
Porvs that may be aremseocus comanind are.

มีเ 297

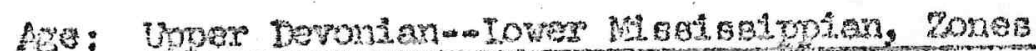

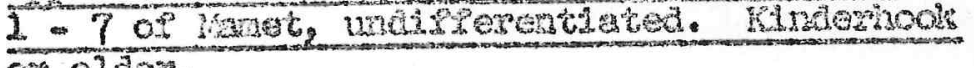
$00^{\circ} 03 \mathrm{des}$

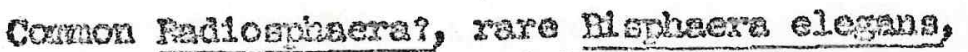

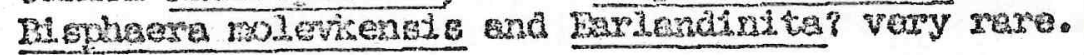

Itre mudstone. 
Iecenber 8,197

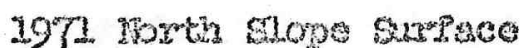

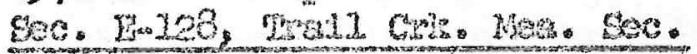

IFR- 298

Rus -29

9

Ace:

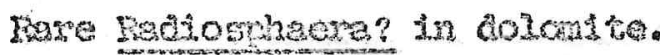

FRER 300

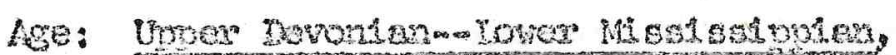

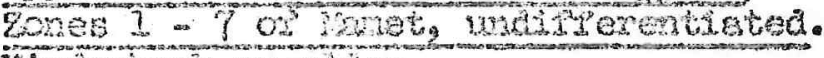
Mindestor or older.

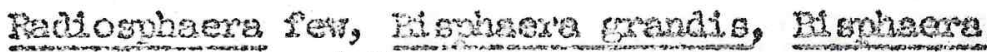
molevensis, and rarewnutrins nare.

Iine ruactone.

ORIGINAL SIGNDD BY

A. A. ALUGREN

A. A. ARORORT

D. Inleontologint

AAA:CO

ce: Co Heister

I. XDEe" 


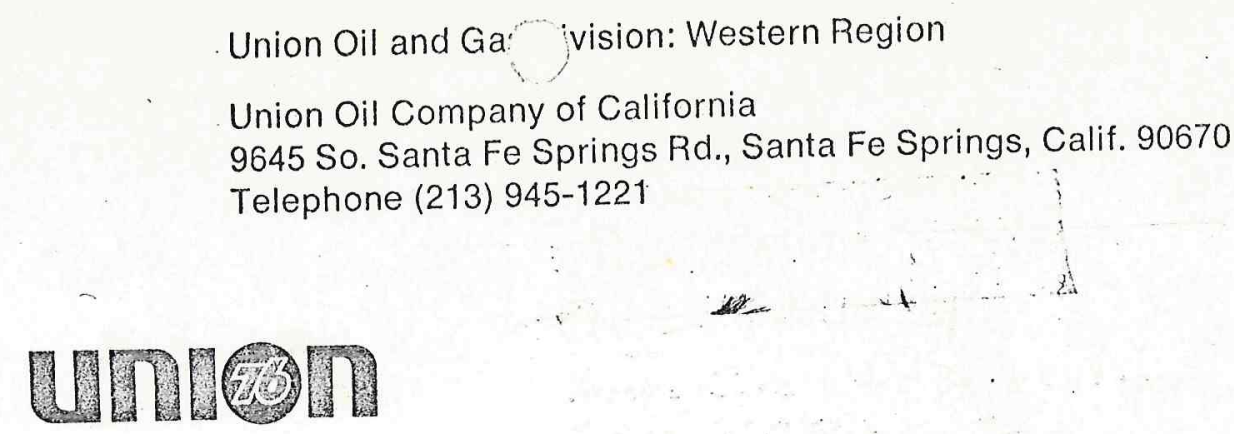

'aleontology Laboratory

Apxil 5, 2972

Mr. Robert A. Saunders

pist. Fxploretion Manager

Noxthern Alaska District

Anchorage

PAIEO. CORRELATIONS

North slope - 1971.

Western Party Grab Samples

Lab Acc. No. EII27

The following paleontologic determinations are based on the examination of thin sections of samples for which foraminiferal study was reguested:

RRR-235 -.....-Age: Upper Devonian-Mississippian, pre-Zone 18 of Mamet.

Scattered Radiosphaera in lime mudstone.

Similar to RRR-300 - Trail Creek Section.

RRR-237

Age: Upper Devonian-Mississippian, pre-Zone 18 and probably pre-zone 8 of Mamet.

Scattered Parathurammina and rare Bisphaera (?).

Buff lime muastone, in part, with fine ?spicules.

RRR-262 -....- Age: Indeterminate.

Barren of foraminifera. Dolomite, gray-black.

RECETVED

Apr $719 / 2$

MO. NIASEA DIST. 


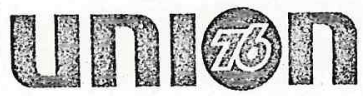

Aprill 5, 1972

North Slope - 1971

Western Party Grab Samples

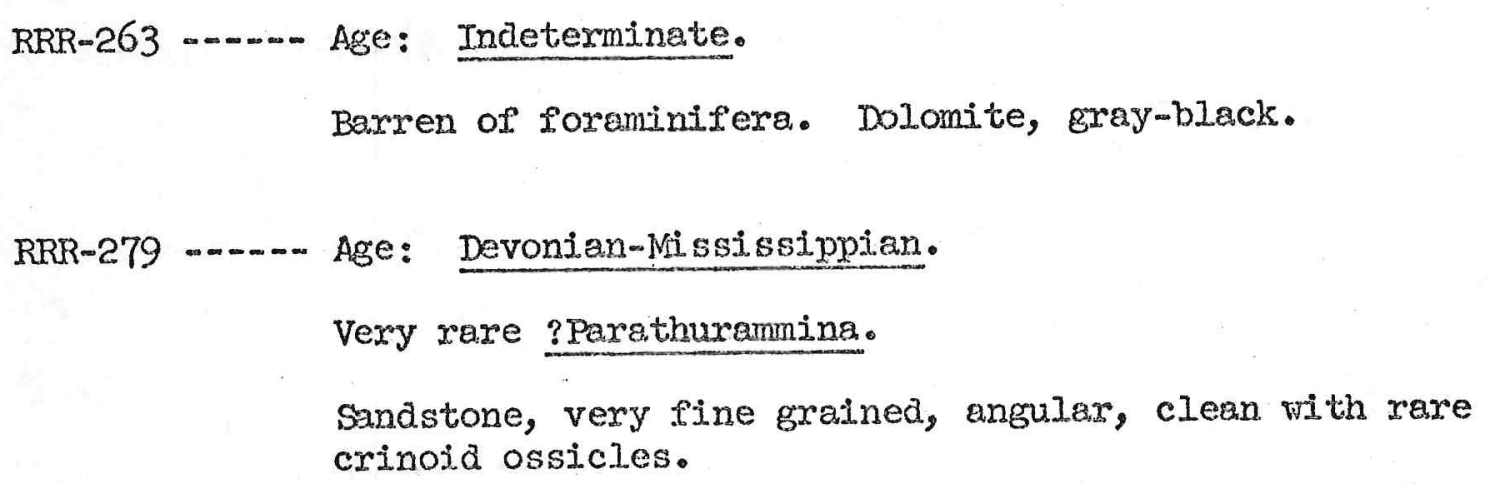

RRR -281

Age: Devonian-Mississippian, pre-Zone 18 of Mamet.

Radiosphaera few, Calcisphaera few, ?Vicinisphaera very raxe. Assemblage is, in part, similar to RRR-324.

Ifime muastone, buff.

RRR-301

Age: Indeterminate.

Barren of foraminifexa. Dolomite, gray-black with small ghosts of crinoid ossicles.

RRR-303

Age: Indeterminate.

Baxren of foraminifera. Sandstone, angulax.

RRR- 306 Age: Indeterminate.

Barren of foraminifera. Iime mudstone, buff, fractured. 


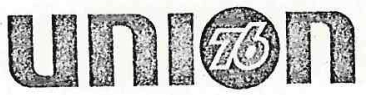

\author{
Apri1 5, 1972 \\ North Slope - 1971 \\ Western Party Grab samples
}

RRR -308

Age: Indeterminate.

Baxren of foraminifera.

Iime packstone, with common small fragnents of megafossils

including pelecypods, gastropods and crinoids, plus ostracods and rare elgae.

Sandstone, fine grained, angular with abundant crinoid ossicles.

RRR 311 ....... Age: Indeterminate.

Barxen of foraminifera. Sandstone.

RRR-315 ....... Age: Mississippian, probably Zones 13-15 of Mamet, or younger.

RRR-317 ...... Age: Indeterminate.

Barren of foraminifera.

Dolomite, medium brown with small ghosts of crinoid ossicles.

RRR-324 -..... Age: Upper Devonian-Mississippian, pre-Zone 18 of Mamet.

Rare Calcisphaera and other uncertain forms similar, in part, to $R R R-28 I$

Ifme packstone, skeletal, pelletoidal. 


\section{บำเำ}

April 5, 1972

Noxth Slope - 1971

Western Party Grsb Samples

RRR-353 ...... Age: Indeterminate.

Barren of foraminifera. Dolomite, burf, vexy fine grained.

RRR- 365

Age: Indeterminate.

Barren of forminifera. Dolomite, highly fractured.

RRR-366 ...... Age: Indeterminate.

Baxren of foraminifexa. Dolomite, gray-black, silty.

JDB-5 -......- Age: Indeterminate.

Barren of foraminifera.

All samples collected for megafossils and conodonts vere thin sectioned to check for presence of smaller foraminifera.

The following foux samples contained foraminifera:

RRR-369 ...... Age: Mississippian, Zones 14-15, within "Brunsia facies."

Brunsia and Archaediscus of the group Archaediscus krestovnikovi common, Fndothyra, Iuberitina and Calcisphaera few, Farlandia elegans very rare.

This assemblage is similar to Shainin Lake Section samples $\mathrm{FCH}-113$ and $\mathrm{FCH}-115$. 


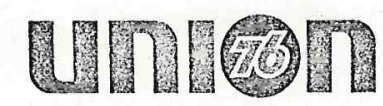

\author{
April. 5, 1972 \\ North Slope - 1971 \\ Westem Party Grab Samples
}

RRR-370 -..... Age: Mississippian, Zones 14-15, within Zones 14-15.

Ihe assemblage in this sample is similar to RRR-369.

RRR-371.

Age: Mississippian, probably Zone 14-15, "Brunsia facies."

Brunsia few, Endothyra few, and Calcisphere rare, similar to those in RRR-369 and RRR-370. No Archaediscus are present.

RRR-372 …......Age: Mississippian, Zones 14-17 of Mamet, undifferentiated; in "Brunsia feries."

Brunsia comon, Endothyra few, Farlandia elegans, Eaxlandia clavatula and Globoendothyra sp. raxe.

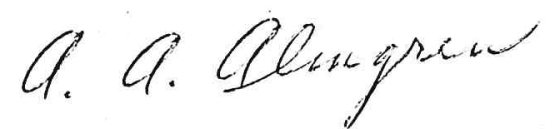
A. A. AIMGREN
Six. Paleontologist

AAA: go

cc: G. Feister

R. Rose' 



\section{4กำก}

\section{Dear Bob:}

The accompanying two-paxt report summarizes the results of palynologic dating and carbonization analysis of the 1971 North Slope, Brooks Range surface samples, selected for oux examination by Bob Rosé.

For convenience, the samples are listed in numericel order under the priority catagories set forth in the requesting letter (R. R. Rose' to R. E. Malloy, February 4, 1972). Detailed lists of species identified. in the fossiliferous samples are not included in this report, but are recorded on sample study cards on file here.

A majority of the samples are only slightly to moderately altered (i.e. carbonized); however, a large number show the effects of surface weathexing, either as "rust" stains on fractures or in their degraded palynologic residues. In some cases thermal alterations ratings are tentative or undeterminable for this reason.

If there are questions concerning any of this work, please do not hesitate to write me at any time.

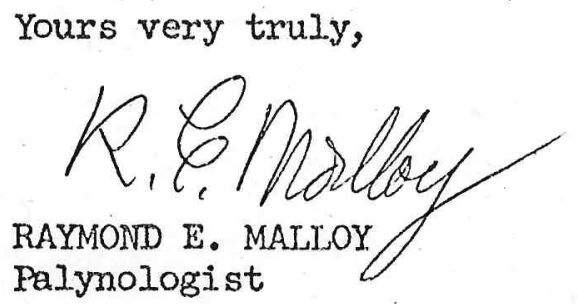

REM:go

cc: G. H. Feister

R. D. Mclennan, Atten: F. G. Blake 
PALYNOLOGIC AGE DETERMINATIONS

1971 NORTH SLOPE ALASKAN SURFACE SAMPLEES

\section{SAMPIE NO. \\ PRIORITY I}

AGE AIND PALYNOZONE *

RRR-405

" 407

" 408

1409

" 411

1412

" 415

" 427

" 419

" 420
Upper Cretaceous, Aquilapolienites-Azonia

Upperi Cretaceous,

Chlamydophorella sp. 1, Diplotesta anglica Zone (Iower)

Uppex Cretaceous, Aquilapollenites-Aronia

Upper Cretaceous, probable AquilapollenitesAzonia Zone

Upper Cretaceous, Aquilapolienites-Azonia

Upper Cretaceous, Aquilapollenites-Azonia

Upper Cretaceous, Aquilapolienjtes-Azonia

Upper Cretaceous, Cenomanian--Lower Senonian, Chlamydophorel].a sp. 1, Diplotesta anglica Zone

Upper Cretaceous,
undifferentiated
Upper Cretaceous, probable
ChIamydophorella sp. I,
Diplotesta anglica Zone

DEPOSTTIONAT ENVIRONMENI

COMMENTS

Open marine, shelf or slope

Rich sample, probable Maestrichtian

Open maxine, shelf or slope Reworked Mississippian present Open marine,
shelf

Open marine, shelf or slope

open marine

Nonmarine (?)

Open masine

open maxine

Open marine

Open Marine, shelf or slope
Minor rewoxking

(Cretaceous), probable Maestrichtian

Specific markers absent, poor preservation

Dinoflagelzates sparse; Campanian on negative evidence

Preservation poor; Campanian on negative evidence

Dinoflagellates sparse; Campanian on negative evidence

Preservation poor

Very poor presexvation

Dinoflagellates abundant

\footnotetext{
* = As defined in H. Ieffingwell's Project Report \#72-3I
} 
SAMPIEE NO.

$R R R-422$

" 423

" 425

" 427

" 428

". 429

" 430

" 432

" 447

" 434

PRIORIIY_II

$\mathrm{RRR}-202$

" 204

" 205

" 206
AGE AND PALYNOZONE *

Upper Cretaceous, undifferentiated

cretaceous, undift.

Upper Cretaceous, probable ChIamydophore1la sp. 1, Diplotesta anglica Zone

\section{Upper Cretaceous, Aquilapollenites-Azonia Zone (?)}

Upper Cretaceous, Aquilapollenites-Azonia Zone

Upper Cretaceous, Aquilapolienites Azonia Zone

Upper Cretaceous, Aquilapollenites-Azonia Zone

Upper Cretaceous, Aquilapollenites-Azonia Zone

Paleocene, "Unamed" Zone

Cretaceous, Neocomian
DEPOSTTIONAL

ENVTRONMENNT

Open marine

Very sparse microflora

Open marine

Open marine, shelf or slope

Open maxine, shelf or slope

Open marine, shelf or slope

Open maxine

Open marine

Open marine, shelf or slope

Nonmarine

Open marine

As above

Poor preservation

Poor preservation, much reworking

Rich assemblage

As above

Preservation poor

Probable Upper

Paleocene (H.A.I.)

Sparse assemblage,
Abundant dinoflageljates carbonized

Palynomorphs sparse, preservation poor

Indeterminate

Marine

Indeterminate
Barren of palynomorphs

Weathered sample

Barren of palynomorphs, veathered

* = As defined in H. Leffingwell's Project Report \#72-3I 
SAMPIEE NO.

RRR-207

" 208

" 209

" 210

". 211

" 212

213

" 214

" 215

" 216

" 217

" 218

" 219

11 22$]$

1 225

" 226
AGE AND PAIYNOZONE *

Cretaceous, probable Neocomian

Lower Cretaceous, probable Marine Neocomian

Indeterminate

Upper Cretaceous, Chlamydophorella sp. I, Diplotesta anglica Zone, (Probable Cenomanian)

Indeterminate

Cretaceous, Albian-Cenomanian

Indeterminate

Indetexminate

Indetexminate

Cretaceous, undiff.

Indeterainate

Indeterminate

Indeterminate

Indeterminate

Upper Mississippian to Lower Pennsylvanian

Indeterminate
DEPOSTTIONAI

ENVTRONMEINI

Marine

Indeteminate

Open marine, shelf or slope

Indeterminate

Marine

Indetexminate

Indeterminate

Indeterminate

Indeterminatie

Indeterminate

Indeterminate

Indeterminate

Indetexminate

Indeterminate

Indeterminate
COMMENTS

Mixed assemblage of poor preservation

Very poor preservation, weathered sample

Barren of palynomorphs, weathered

Very poor preservation, weathered sample

Barren of palymomorphs

Sparse fossils, weathered sample

Very rare, nondiagnostic palynomorphs, weathered sample

Barren of palynomorphs, weathered

Barren of palymomorphs, weathered

Very poor preservation, weathered sample

Vexy rare, poorly preserved palynomorphs

Barren of palynomorphs

Barren of palynomorphs

Completely carbonized sample

Sample altered, fossils rare

Baxren of palynomorphs and strongly pyritized

* = As defined in H. Leffingwell's Project Report \#72-31 
SAMPLE NO.

AGE AND PALYNOZONE *

RRR--227

" $\quad 228$

" 265

266

267

268

269

270

271

272

273

" 274

$" 284$

293

" 328
Indeterminate

Probable Jurassic (Upper?)

Indeterminate

Indeterminate

Upper Cretaceous,

Aqui lapollenites-Azonia

\section{Zone}

Upper Cretaceous,

Aquilapolienites-Azonia

Zone

Upper Cretaceous,

Aquilapollenites-Azonia

Zone

Upper Cretaceous,
Aquilapoljenites Azonia
Zone

Indeterminate

Upper Cretaceous, probable Cenomanian to Lowex

Senonian

Indeterminate

Upper Cretaceous, Chlamydophorella sp. I; Diplotesta anglica Zone

Indeterminate

Paleozoic, undiff.

Indeterminate
DEPOSTTTONAL ENVIRONMENT

Indeterminate

Near shore maxine

Indeterminate

Indeterminate

Nonmaxine or near shore marine

Nonmaxine, possibly near shore maxine

Nonmarine possibly near shore marine

Nonmarine possibly near. shore marine

Indeterminate

Nonmaxine, possibly near shore marine

Indeterminate

Maxine

Indeterminate

Nonmarine (?)

Indeterminate

\section{COMMENTS}

Barren of palynomorphs

Dinoflagel.lates very rare

"Redbed" Iithology- barren

Barren of palynomorphs, weathered

Foor preservatjon

Poor preservation

Poor preservation

Poor preservation, weathered

Baxren of palynomorphs

Sparse palynomorphs

Barren of palynomorphs

Sparse, poorly preserved assemblage, weathered

Rare, carbonized spores only

Carbonized spores only, weathered

Barren of palynomorphs-carbonized, weathered

* = As defined in H. Ieffingwell's Project Report \#72-31 


\section{SAMPIE NO.}

$R R R-330$

" 331

" 332

" 335

" 336

" $\quad 337$

" 338

" 339

" 361

" 362

" 363

$" 364$

" 367

" 374

" 377

" 380

" 400
AGE AND PALYNOZONE *

Upper Paleozoic, undiff.

Indeterminate

Indeterminate

Indeterminate

Indeterminate

Indeterminate

Indeterminate

Indeterminate

Indeterminate

Indeterminate

Indetexminate

Indeterminate

Indeterminate

Indeterminate

Indeterminate

Mesozoic, Jurassic-Cretaceous

Indeterminate
DEPOSITIONAT

ENVIRONMENT?

COMMENTS

Nonmarine (?) Rare, carbonized palynomorphs

Indeterminate

Rare, carbonized palynomorphs only

Indeterminate

Rare, carbonized pa.lynomorphs only, weathered

Indeterminate

Rare, carbonized palynomorphs only, weathered

Indeterminate

Rare, carbonized palynomorphs only, weathered

Indeterminate Barren of palynomorphs

Indeterminate Barren of palynomoxphs

Indeterminate

Raxe, caxbonized palynomorphs only

Indeterminate

Barren of pa.lynomorphs

Indeterminate

Barren of palynomorphs

Indeterminate

Rere, carbonized palynomorphs only

Indeterminate

Barren of palynomorphs

Indetexminate

Barxen of palynomorphs

Indeterminate

Barren of palynomorphs

Indeterminate

Berren of palynomorphs, weathered

Indeterminate

Indeterminate
Rare, poorly preserved palynomorphs

Barren of palynomorphs, weathered

* = As defined in H. Leffingwell's Project Report \#72-3I 


\section{SAMPLE NO.}

AGE AND PAJ_YNOZONE *

DWA-285

291

Indeterminate

Indeterminate

Indeterminate

Indeterminate

Indeterminate

Indeterminate

Indeterrninate

Indeterminate

Indeterminate

Indeterminate

Cretaceous, undiff.

Indeterminate

Indeterminate

Indeterminate

Paleozoic, probable Lower Mississippian
Indeterminate

Paleozoic, Lower

Mississippian (?)

Upper Triassic, Lower Jurassic
DEPOSITIONAL EIVTRONMENT

Indeterminate

Indeterminate

Indeterminate

Indeterminate

Indeterminate

Indeteminate

Indeterminate

Indeterminate

Indeterminate

Indeterminate

Nonmarine (?)

Indeterminate

Indeterminate

Indeterminate

Nommarine (?)

Indeterminate

Indeterminate

Nonmarine (?)

\section{COMMENTS}

No identifiable plant material

Barren of palynomuxphs, weathered

Palynomorphs rare and carbonized

Barren of palynomorphs, carbonized

Palynomorphs zare and poorly preserved

Rare, carbonized palynomorphs only

Rare, carbonized palynomorphs only

Rare, caxbonized palynomorphs only

Vexy rare, poorly perserved palynomorphs

Barren of palynomorphs

Sparse, caxbonized palynomorphs

Vexy rare, carbonized palynomorphs

Rare, carbonized palynomorphs only

Rare, carbonized palynomorphs only

Sparse, pooxly perserved palynomorphs

Barren of palynomorphs

Rare, carbonized palynomorphs, weathered

Dinoflagellates absent, acritarchs present, weathered

* = As defined in H. Leffingwell's Pxoject Report \#72-31 


\section{SAMPIE NO.}

AGE AND PALYNOZONE *

\section{PRIORITY III}

$R R R-230$

Permo--Triassic (?)

Jurassic-.cretaceous, undifferentiated

" 236

" 248

" 249

253

1. 254

" 255

" 256

" 302

" 304

" 312

314

" 316

" 320

" 321

" 322

Indetermingte

Indeterminate

Indeterminate

Indeterminate

Indeterminate

Indeterminate

Indetexminate

Indeterminate

Indeterminate

Probably Cretaceous

Indeterminate

Indeterminate

Indeterminate
DEPOSITIONAI

ENVIRONMENTI

COMMENTS

$\begin{array}{lll}\text { Indeterminate } & \text { Indeterminate } & \text { Essentially barren } \\ \text { Indeterminate } & \text { Indeterminate } & \begin{array}{l}\text { Barren of palynomorphs, } \\ \text { weathered }\end{array} \\ \text { Indeterminate } & \text { Indeterminate } & \begin{array}{l}\text { Rare, carbonized } \\ \text { palynomorphs }\end{array}\end{array}$

Indeterminate
Indeterminate

Indeterminate

Indetexminate

Indeterminate

Indeterminate

Indeterminate

Indeterminate

Indeterminate

Indeterminate

Indetexminate

Indeterminate

Indeterminate

Indeterminate

Indetexminate

Indeterminate

Indeterminate
Barren of palynomorphs

Essentially barren

Sparse, carbonized palynomorphs only

Rare, carbonized palynomorphs

Barren of palynomorophs Barren of palynomorohs Barren of palynomoxphs Barren of palynomorphs Rare, poorly preserved palynomorphs

Rare, pooxly preserved. palymomorphs

Barren of palynomorphs

Very raxe, poorly preserved palynomorphs

Essentially baxren

Rare, pooxly preserved palynomorphs

Rare, poorly preserved palynomomphs

Essentially barren, weathered

* = As defined in H. LeffingwelI's Project Report \#72-3I. 


\begin{tabular}{|c|c|c|c|c|}
\hline \multicolumn{2}{|c|}{ SAMPLE NO. } & AGE AND PALYNNOZONE * & ENVTRONMENT & COMMENTS \\
\hline & -396 & Indeterminate & Indeterminate & $\begin{array}{l}\text { Rare, poorly preserved } \\
\text { palynomorphs, weathered }\end{array}$ \\
\hline & 398 & Indeterminate & Indeterminate & $\begin{array}{l}\text { Rare, poorly preserved } \\
\text { palynomorphs, weathered }\end{array}$ \\
\hline & -298 & $\begin{array}{l}\text { Uppex Cretaceous, } \\
\text { Cenomanian, } \\
\text { Chlamydophorella sp. I, } \\
\text { Dlplotesta anglica Zone }\end{array}$ & $\begin{array}{l}\text { Open marine, } \\
\text { shelf or slope }\end{array}$ & $\begin{array}{l}\text { Preservation relatively } \\
\text { poor, weathered }\end{array}$ \\
\hline & 300 & Uppex Cretaceous (?) & Indeterminate & $\begin{array}{l}\text { Rare, poorly preserved } \\
\text { palynonorphs, weathered }\end{array}$ \\
\hline 81 & 301 & Upper Cretaceous (?) & Indeterminate & $\begin{array}{l}\text { Rare, poorly preserved } \\
\text { palynomorphs, weathered }\end{array}$ \\
\hline 81 & 302 & Paleozoic (?) & Indeterminate & $\begin{array}{l}\text { Rare, carbonized } \\
\text { palynomorphs }\end{array}$ \\
\hline (1) & 303 & Indeterminate & Indeterminate & $\begin{array}{l}\text { Raxe, carbonized } \\
\text { palynomorphs }\end{array}$ \\
\hline$"$ & 304 & Indeterminate & Indeterminate & $\begin{array}{l}\text { Rare, caxbonized } \\
\text { palynomorphs }\end{array}$ \\
\hline " & 314 & Indeterminate & Indeterminate & $\begin{array}{l}\text { Rare, carbonized } \\
\text { palynomorphs, } \\
\text { weathered }\end{array}$ \\
\hline 8 & 318 & Indeterminate & Indeterminate & $\begin{array}{l}\text { Rare, carbonized } \\
\text { palynomorphs }\end{array}$ \\
\hline " & 338 & Indeterminate & Indeterminate & Barren of palynomorphs \\
\hline " & 342 & Indeterminate & Indeterminate & $\begin{array}{l}\text { Barren of palynomorphs, } \\
\text { weathered }\end{array}$ \\
\hline & 344 & $\begin{array}{l}\text { Paleozoic, Upper } \\
\text { Mississippian--Iower } \\
\text { Pennsylvanian }\end{array}$ & Nonmarine (?) & Sparse palynomorphs \\
\hline & 345 & $\begin{array}{l}\text { Upper Paleozoic, } \\
\text { Carbonfferous (?) }\end{array}$ & Indeterminate & Rare palynomorphs \\
\hline & 357 & Indeterminate & Indeterminate & Barren of palynomorphs \\
\hline
\end{tabular}

* = As defined in H. Leffingwell's Project Report \#F2-3I

$-8-$ 
SAMPLE NO.

DWA-359

" 369

" 371

" 382
AGE AND PALYNOZONE *

Paleozoic (?)

Indeterminate

Indeterminate

Indeterminate
DEPOSITIONAL

ENVIRONMENT

Indetexminate

Indetexminate

Indeterminate

Indeterminate
COMMEINTS

Rare, carbonized palynomorphs

Rare, poorly preserved palynomorphs

Baxxen of palynomoxphs, weathered

Rare, carbonized palynomorphs, weathered

* = As defined in H. Leffingwell's Project Report \#72-31 


\section{CARBONTZATION (THERMAL ALTTERATION) ANALYSTS \\ OF 1971 NORTH SLOPE SURFACE SAMPIES}

Examination of separate residue slides, treated chemically only to remove mineral material and not to isolate palynomorphs, was carxied out for each of the previously discussed palynologic samples.

Kerogen (dispersed oxganic material) residues examined for evidence of thermal alteration consist predominantly of plant matexials identifiable as cuticle, spores, pollen, woody tissue, and algal remains. Othex elements often present in kerogen samples are amorphous (structureless) material, coaly fragments, and disseminated, very fine nonmineral particles. These last are probably of plant origin, but cannot be positively identified with any specific plant entity.

From laboratory experiments, performed by hesting fossil kerogen residues through a range of temperatures up to $700^{\circ} \mathrm{F}$, it is known that these plant residues originally unaltered, will undergo color changes and selective destruction of certain elements until a totally black residue is obtained. This carbonized residue may often contain only rare identifiable plant entities. A similar "alteration series" can be observed by field sampling fossil materials (from shales) at varying distances from igneous aikes or sills and observing the color changes in residues taken from the contact zone with the igneous body and outward to areas where no igneous intrusions are present. Such a progression of samples obviously furnishes an approximate declining paleotemperature scale; in this case beginning with temperatures in excess of those known, from laboratory experiments, to alter plant matexials.

A systematic study of these organic residues has resulted in a semi-quantitative ranking system similar to those now in use by several major oil companies. This ranking system, expressed in alteration indices from 1. through 5, is based in part on that proposed by F. L. Staplin. (Bull. of Canadian Fetroleum Geology, March 1969) and in part on a scale described by J. D. Burgess. As used in this report, the scale is based entirely on inspection of a sample's plant residues and does not rely on mineralogic evidence of metamorphism, as does the staplin method.

The outline of the alteration "sexies" below and its suggested relationship to world-wide hydrocarbon occurrences is based on the work of F. L. Staplin, J. D. Burgess, and other geologists and geochemists formerly with the Esso Production Research Company and, to a lessex degree, the experience of the writer. 
Thermal

Alteration Index

1. (No Alteration)

2. (Slight Alteration)

3. (Moderate Alteration)

4. (Strong Alteration)

5. (Severe Alteration)
Organic Residue,

Color and

Composition

Color yellow-green, woody tissue cuticle, palynomorphs, amorphous vegetable matter, coaly fragments

Color light brown to bright orange-brown; organic components as above

Colox deep brown; organic matter as in 1, but with amorphous matter sparse or absent

Color very dark brown to black with brown translucent bordexs; cuticle and amor. pho'ls matter normally absent palynomorphs often unidentifiable

Black color, particles' surfaces often reflective; pa.lynomorphs, if present, opaque; amorphous material absent
Commexcia.1

Hydrocarbon

occurrences

Pxincipally oil and wet gas

Oil, wet and dry gas

Oil, wet and dry gas

Minor wet ges to dry gas only

Dry gas or no fluid hydrocarbons

In reporting on carbonization analysis the form used here is a simplified version of a work sheet used in recording the raw data. Some or the hesaings on these sheets (pages 13 to 16) require explanation ox clarification. Under "Alteration Index" the decimal point figures (.5) are added to indicate intermediate alteration stages on the horizontal 1 through 5 scale; and do not necessarily imply greater degrees of numerical precision. "Residue Type," for the purpose of our analysis is characterized as either "amorphous" or "structured." Amorphous material, most abundant in relatively unaltered samples, is fluffy, wispy, light colored, irregularly fibrous matter, sometimes mixed with gel-like masses-all with no organized structure. It can occur in both marine and nonmarine paleoenvironments, but for the Alaskan 
North slope is most abundant in and characteristic of the marine seabee formation. Geochemical analysis made at Brea Research indicates that the seabee amorphous material contains petroleum-related hydrocarbons and analysis of other amorphous material from rocks of world-wide distribution, made both at Brea Reseaxch and at the Esso Production Research Laboratories, show similar, general results.

"Structured" material, present in nearly all samples in one form ox another, is that which shows identifiable organic structures and includes woody tissue, cuticle, spores, pollen, microplankton, acritarchs, and, raxely, algal filaments. It is this group of residue components, parttcularly the palynomorphs (spores, polien, etc.) which is most useful in determining the alteration stage of the organic residues. A high proportion of structured material, in Upper Paleozoic and younger samples, is woody tissue which, by its known chemical composition, would not be expected to have furnished abundant petroleum-related hydrocarbons in the geologic recoxd.

The balance of dispersed organic matter observed in a majority of samples can be described either as "covly fragments" or "finely disseminated organic matter." The former are black particles showing no organized structure and are composed of more or less pure carbon of biochemical origin or that resulting from natura. combustion processes. The latter, "finely disseminated material," is simply small (1. or less) particles of a nommineral (i.e. biologic) oxigin.

The above discussion is necessaxily oversimplified and the presence or absence of a particulax type of organic material should not be interpreted as relating directly to the petroleum source potential of a rock unit.

The following data sheets, among other things, denonstrate the effects of suxface weathering, past and present, on dispersed organic material in sediments (see "indeterminate!" samples). Chemical and biochemical processes can destroy the fractions which axe most useful in determining degrees of thermal alteration, and the last components to be destroyed in the weathering process are the "coaly fragments."

REM: go

$9-5-72$ 


\begin{tabular}{|c|c|c|c|c|c|c|c|c|c|c|}
\hline \multicolumn{5}{|c|}{ IDENTIFICATION } & \multicolumn{5}{|c|}{ 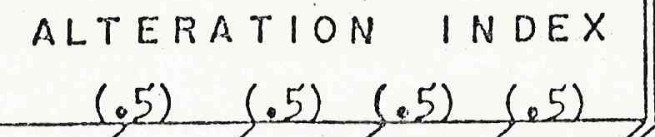 } & $\begin{array}{l}\text { RESIDUE } \\
\text { TYPE }\end{array}$ \\
\hline \multicolumn{11}{|c|}{ 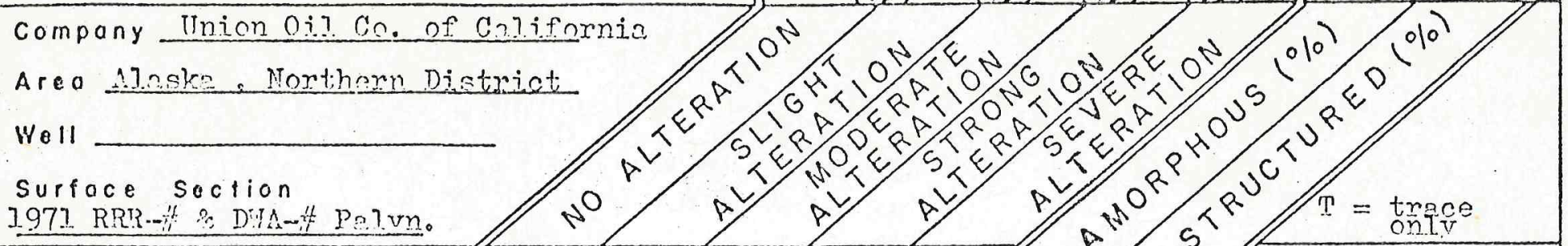 } \\
\hline \multicolumn{11}{|c|}{ Sample No. I Depth } \\
\hline \multicolumn{11}{|l|}{ Priority I } \\
\hline $\mathrm{RRR}-4.05$ & & + & & & & & 20 & 70. & & \\
\hline " -407 & & 4 & & & & & 10 & 60 & & \\
\hline$"-408$ & & 3 & & & & & 90 & $70^{\circ}$ & & \\
\hline$"-409$ & & $x$ & & & & & $\mathrm{~T}$ & 50 & & \\
\hline$"-4.77$ & & $x$ & & & & & $T$ & 70 & & \\
\hline$"-4 I ?$ & & 4 & & & & & 20 & 60 & & \\
\hline$\|-1.75$ & & x & & & & & $\mathrm{T}$ & 60 & & \\
\hline $1 "-417$ & & $x$ & & & & & $\underline{\underline{m}}$ & 70 & & \\
\hline$"-4.79$ & & $x$ & & & & & 60 & 20 & & \\
\hline$"-4.20$ & & x. & & & & & $\underline{T}$ & 70 & & \\
\hline$"-422$ & & $x$ & & & & & $T$ & 60 & & \\
\hline $1-4.23$ & & 卒 & & & & & T & 60 & & \\
\hline $11-425$ & & 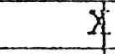 & & & & & 50 & 20 & & \\
\hline 11 -4.27 & & से & & & & & 60 & 30 & & \\
\hline $1-428$ & & 1 & & & & & 30 & 60 & & \\
\hline $11-429$ & & $\sqrt{4}$ & & & $\cdot$ & & $\underline{T}$ & 70 & & \\
\hline$=-4.30$ & & $x$ & & & & & 70 & 70 & & \\
\hline$=-432$ & & I & $\bar{E}$ & & & & $T$ & 70 & & \\
\hline $11-4.34$ & & & 1 & $x$ & & & $\mathrm{I}$ & 70 & & \\
\hline $1-417$ & & x & I & & & & 10 & 60 & & \\
\hline \multicolumn{11}{|l|}{ Prinrity II } \\
\hline RRR $-20 ?$ & & 1 & 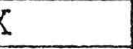 & & & & $T$ & 70 & & \\
\hline$" \quad-204$ & & t & & & & & $\mathrm{T}$ & 70 & & \\
\hline$"-205$ & & 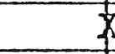 & L & & & & $T$ & 70 & & \\
\hline " -206 & & t & E & & & & $T$ & 60 & & \\
\hline$" \quad-207$ & & 1 & & & & & 10 & 60 & & \\
\hline$"-20.8$ & & $y$ & $E$ & & & & $\underline{m}$ & 4.0 & & \\
\hline " -209 & & 3 & & & & & 5 & $\ldots$ & vary & snarse resit. \\
\hline " -210 & & 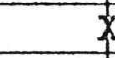 & $E$ & & & & 0 & 40 & & \\
\hline " - -211 & & & $x$ & & & & $T$ & 60 & & \\
\hline " -212 & & $x$ & & & & & T & 60 & & \\
\hline $18 \quad-273$ & & 7 & 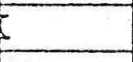 & & & & 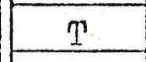 & 60 & & \\
\hline$" 1 \quad-214$ & & ind & tjermi: & ate & & & 0 & 0 & $\cos 3 \pi$ & frackents onlur \\
\hline $11-275$ & & 1 & $2 \quad$ & & & & $n$ & 40 & & \\
\hline $1 \quad-276$ & & & $\mathrm{x}$ & & & & $T$ & 60 & & \\
\hline " -27.7 & & & $y$ & 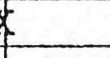 & & & 0 & 40 & & \\
\hline$"-27.8$ & - & ind & termin & ate & & & 0 & 0 & $\cos a 1 \mathrm{v}$ & Aragnents only \\
\hline " $\quad-219$ & & & 11 & & & & 0 & 0 & "1 & $11 \quad " 1$ \\
\hline$n-227$ & & & & & & $x$ & 0 & 50 & & \\
\hline " -2.25 & & & $\mathrm{X}$ & & & & $\theta$ & 60 & & \\
\hline $11-226$ & & int & letermi & nate & & - & 0 & $n$ & conly & fragments $n$ n $7 y$ \\
\hline $11 \quad-227$ & & & & & & & 0 & 0 & $1 "$ & $" 1 "$ \\
\hline " -228 & & & & & $x$ & & 0 & 40 & & \\
\hline
\end{tabular}




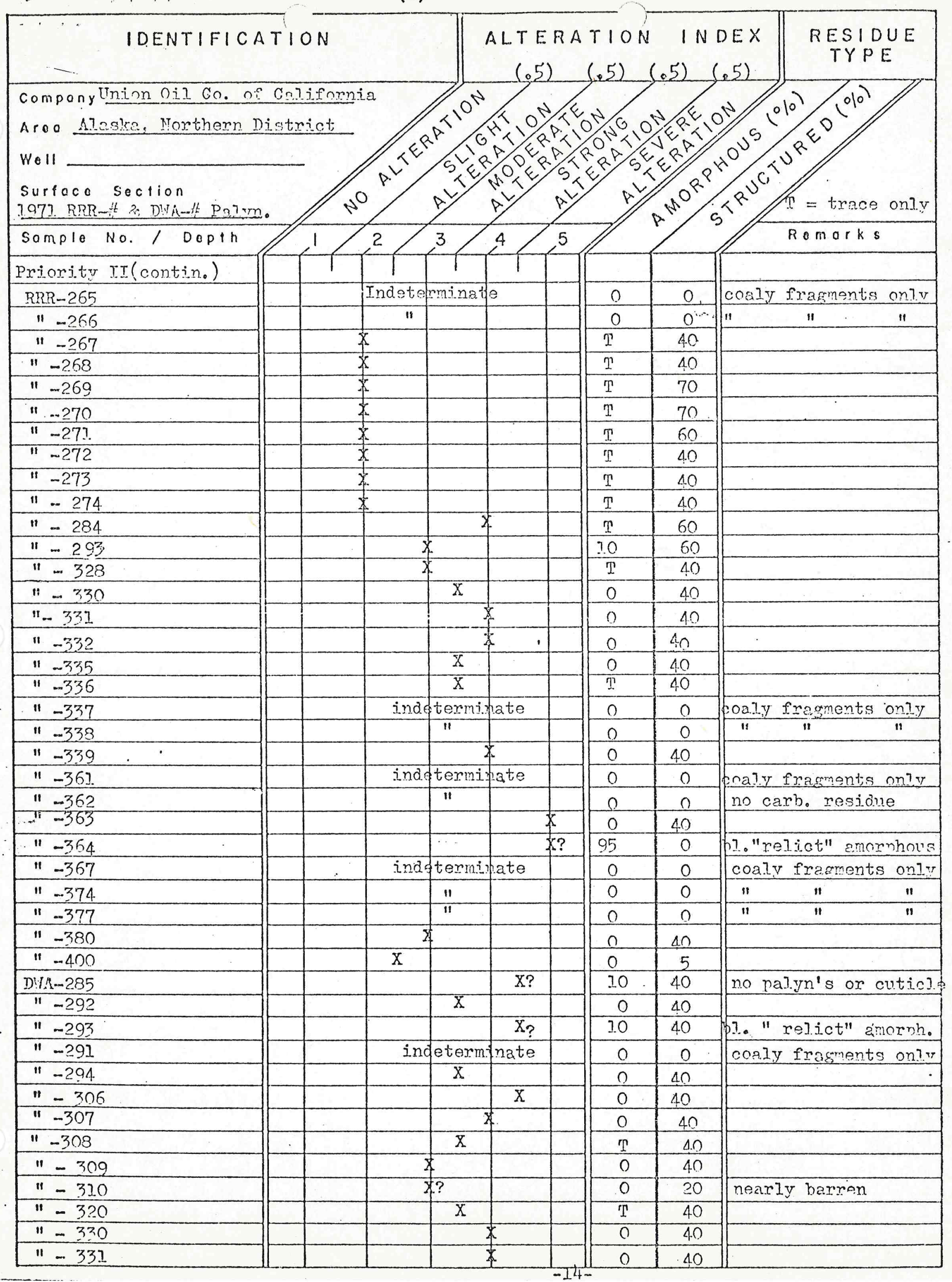




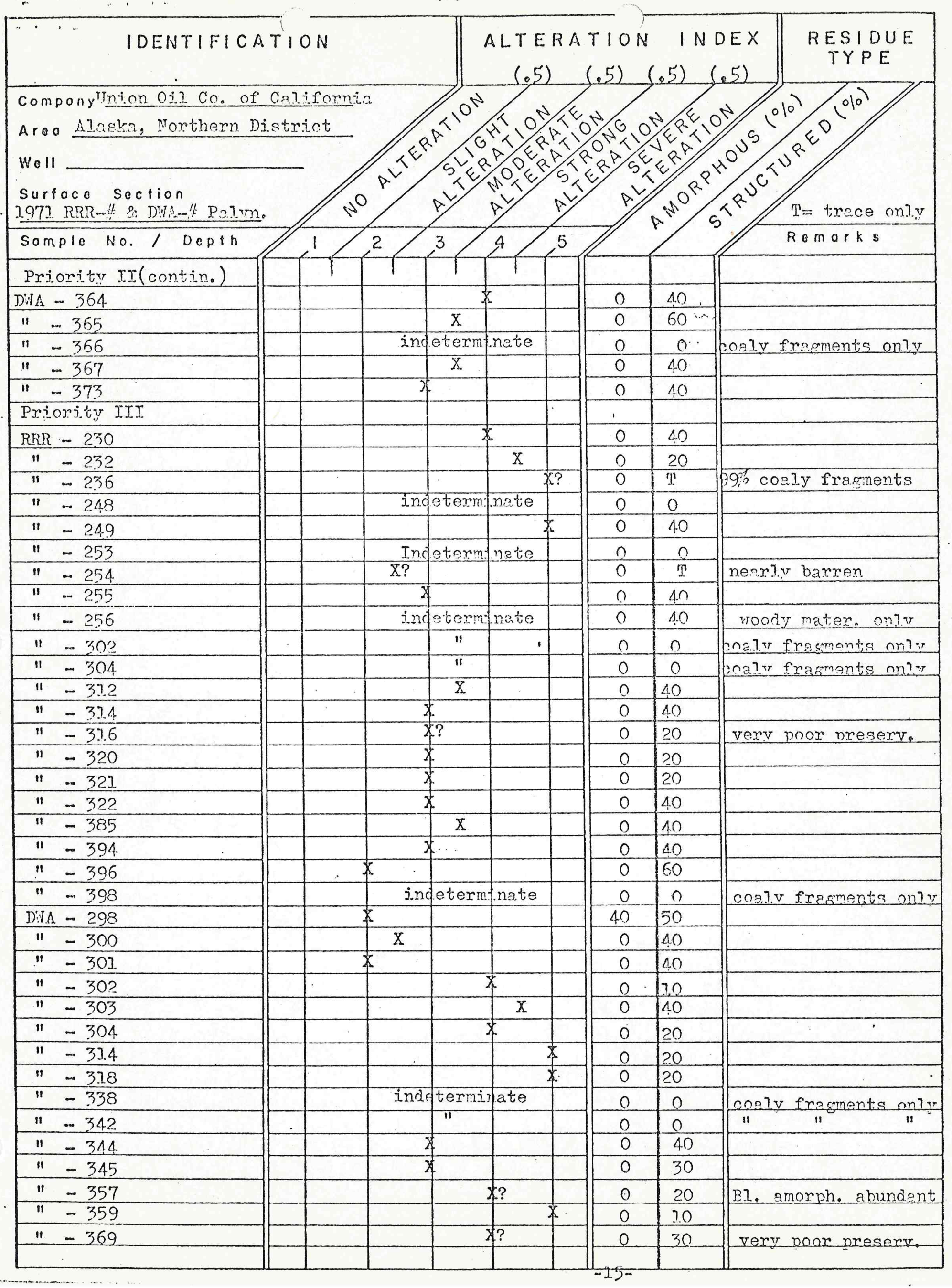




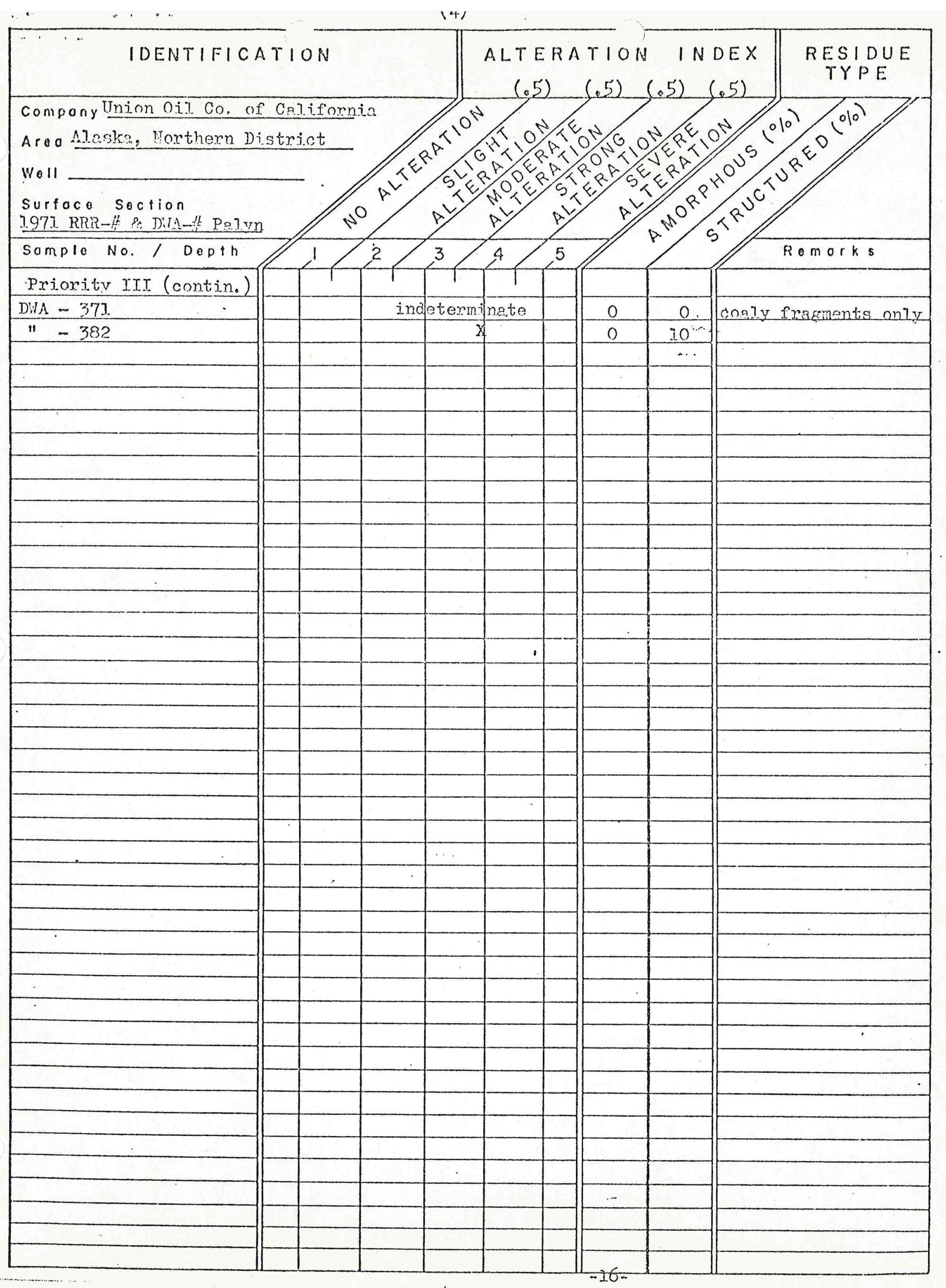



Shror to Rose

Tulsa, Oklahoma

October 20, 1971

Re: Megafossils from three Union 0i1 1971 grab samples, Baird and Delong Mtns., Alask.a

File: Technical Service No. 5719IR Locality No. 61.86

MEMORANDUM

Early examination of the following Union 1971 gxab samples was specifically requested by the Denver Division: $R R R-262, R R R-263$, JDB -4 . The following taxa have been identified:

Field No.

$R R R=262$

$R R R-263$

$\mathrm{JDB}=4$
Taxa

Stringocephalus sp. planar stromatolites

Stringocephalus affo axius indet. tetracorals

Syringopora sp. indet. tetracorals barren of conodonts
Age

Middle Devonian Givetian

Middle Devonian Givetian

Paleozoic Silurian to Mississippian

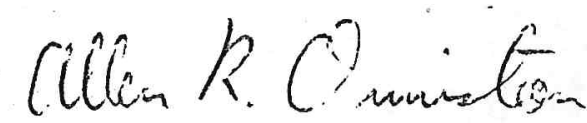

Allen R. Ormiston 


\section{Amoco Production Company}

Research Department Tulsa, Oklahoma

June 23, 1972

Re: Union 1971 megafossil collections, DeLong and Baird Mountains, Western Alaska

File: Technical Service 5719IR

Locality 6186

\section{MEMORANDUM}

Following priorities established in C. L. Conrad's letter of February 10 , 1972, work has begun on selected megafossil samples from Union's 1971 collections. Eleven samples have been completed and are reported here. Work on the remainder of the forty priority I samples is in progress.

Field No. Sample iNo. Taxa

$\begin{array}{lll}\text { DWA 287F } & 6186-4 & \text { Siphonodendron? sp } \\ \text { DWA 281F } & 6186-5 & \frac{\text { Ekvasophyllum sp. }}{\text { Amplexizaphrentis }} \\ & & \frac{\text { Amphipora? sp }}{\text { Bembexia sp. }} \\ \text { DWA 288F } & 6186-6 & \text { crinoid columnals } \\ \text { DWA 282F } & 6186-7 & \text { crinoid columnals } \\ \text { DWA 284F } & 6186-8 & \frac{\text { Inoceramus sp. }}{\text { Buchia sp. }} \\ \text { RRR.442F } & 6186-9 & \frac{\text { Mytilus sp }}{\text { Mya cf. producta }} \\ \text { RRR 410 } & 6186-10 & \frac{\text { Macoma }}{\text { Polinices? }}\end{array}$

Age

RRR 349

$6186-11$

Disphyllum cf. elongatum Psuedoactinodictyon sp. Thamnopora sp. crinoid columnals

Mississippian?

Mississippian Meramec

Devonian?

Paleozoic

Paleozoic

Late Jurassic or early Cretaceous

Oligocene to Recent

Middle Devonian 
Age

RRR 244

$6186-17$

Desquamatia sp.

Devonian

Squameofavosites sp.

probably

Stringocephalus? sp.

Givetian

Thamnopora sp.

Chaetetid indet.

RRR 326

$6186-18$

Homalophyllites cf. calceolus crinoid columnals

Lower

Mississippian

Alim R. Oniatam

Allen R. Ormiston

ARO: cme 
June 30,1972

Re: Megafossils from Union's 1971 Trail Creek Section, NE SE T34iN, R39W, Mi.sheguk Mtn. uuad., Alaska

File: Technical Service $571 \dot{9}$ IR Locality 6623

\section{MEMORANDUM}

Megafossils recovered from the subject section demonstrate it is all Devonian and that at least the lower half is of Middle Devonian age.

\begin{tabular}{|c|c|c|}
\hline Field iNo. & Sample iNo. & Taxa \\
\hline$R R R-286$ & $6623-15$ & $\begin{array}{l}\text { Douvillinaria sp. } \\
\text { Schellwienella sp. } \\
\text { Crurithyris? sp } \\
\text { crinoid columnals }\end{array}$ \\
\hline$R R R-290$ & $6623-11$ & $\begin{array}{l}\text { Chaetetes sp. } \\
\text { Alveolites sp. } \\
\text { Thamnopora sp. } \\
\text { Trupetostroma sp. } \\
\text { Syringostroma sp. } \\
\text { Charactophyllum? sp: }\end{array}$ \\
\hline$R R R-292$ & $6623-9$ & Syringostroma cf. bifurcum \\
\hline$R R R-295$ & $6623-6$ & $\begin{array}{l}\frac{\text { Warrenella franklinii }}{\text { Leiorhynchus miriam }} \\
\frac{\text { Parapholidostrophia }}{\text { Devonoproductus primus }} \\
\frac{\text { Dechenella }}{\text { indet. nautiloid }}\end{array}$ \\
\hline$R R R-296$ & $6623-5$ & $\begin{array}{l}\text { Warrenella franklinii } \\
\text { Devonoproductus primus } \\
\text { Carinatina sp. } \\
\text { Parapholidostrophia sp. } \\
\text { indet rhynchonellid } \\
\text { Bellerophon sp. } \\
\text { Devonozyga sp. } \\
\text { Grammysia sp. } \\
\text { pterioid clams } \\
\text { Dechenella osborni }\end{array}$ \\
\hline
\end{tabular}

Age

Upper Devonian

Givetian or Frasnian

Givetian or Frasnian

Middle Devonian early Givetian

Middle Devonian early Givetian 
Age

RRR-300 6623-1

Anatrypa? sp.

Emanuelia aff. richardsoni

Stachyodes sp.

indet. rhynchoneliid

\section{Discussion}

The early Givetian assemblage of samples RRR-295 and RRR-296 contains elements indicating correlation with the Pine Point Limestone of the Northwest Territories. The presence of Dechenella osborni permits correlation with the Bird Fiord Formation of Bathurst Island and indicates the existence of Givetian marine connection between western Alaska and the Canadian Arctic Islands.

Sample RRR-290 is a stromatoporoid boundstone, presumably part of a reefoid buildup.

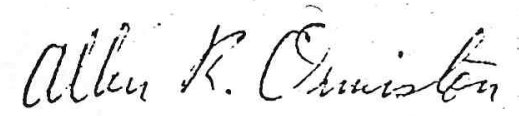

Allen R. Ormiston

\section{ARO: cme}




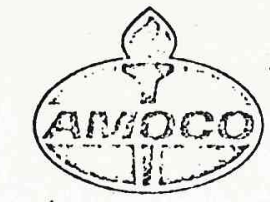

Amoco Production Company Research Center Tulsa, Oklahoma

July 3, 1972

Re: Megafossils from Union 1971 grab samples, Baird and Delong Mts., Alaska

File: Technical Service 5719IR Locality 6186

MEMORANDUII

Further samples from the priority I group of Union's 1971 collections are reported. Original textures of fossils in many of these samples have been so altered that positive identifications are difficult.

Field No. Sample ỉo. Taxa Age

RRR 352 6186-13: $\frac{\text { Thamnopora sp. }}{\text { indet. brachiopod }}$

ge

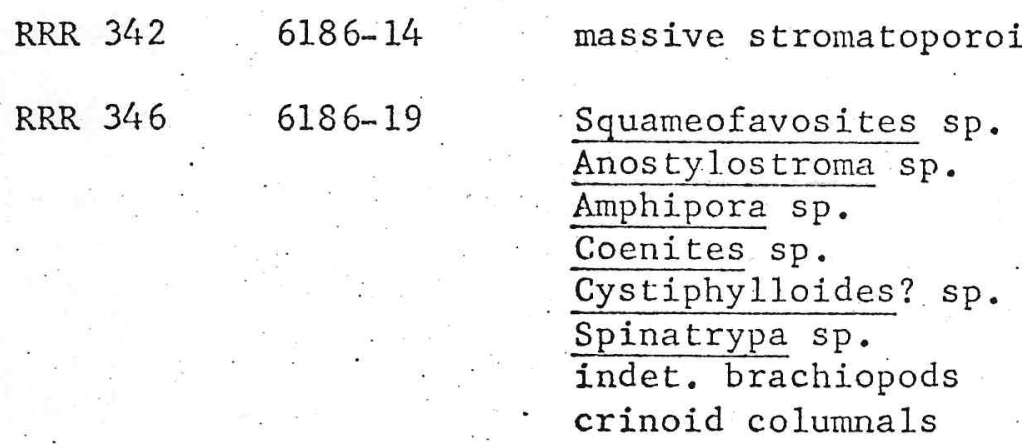

DWA 319 6186-20 barren of megafossils

RRR 245 6186-21 Squarneofavosites $\mathrm{sp}$. Thamnopora sp.

Devonian Givetian

RRR $240 \quad 6186-22$

Thamnopora? sp.

Devonian?

indet. tetracoral

crinoid columnals

RRR $241 \quad 6186-23$

Thamnopora? sp.

Devonian

RRR $203 \quad 6186-24$

Crassatelites sp.

Cretaceous or Tertiar

RRR 243 6186-25

Alveolites sp.

Parachaetetes sp.

Devonian

indet. tetracoral 


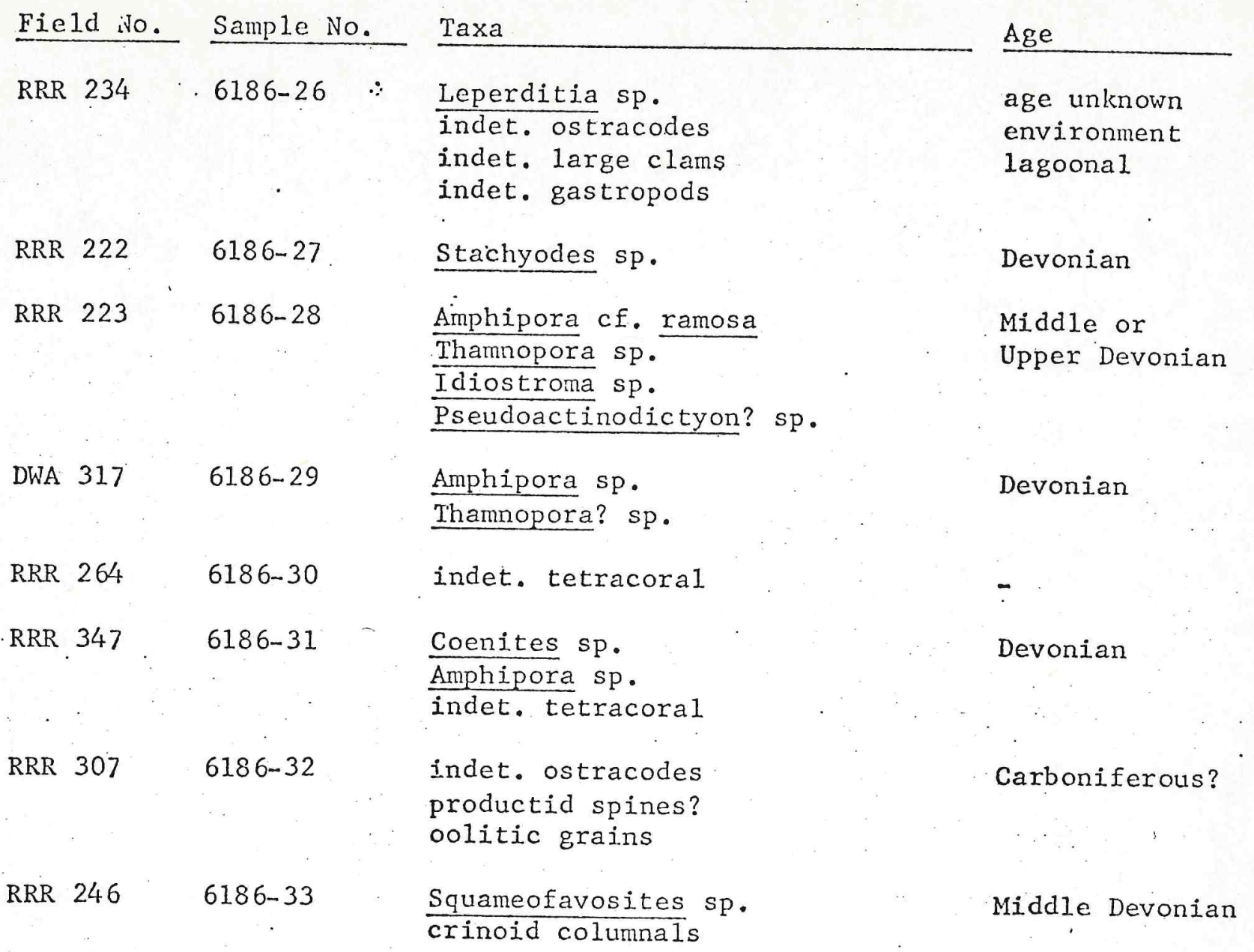
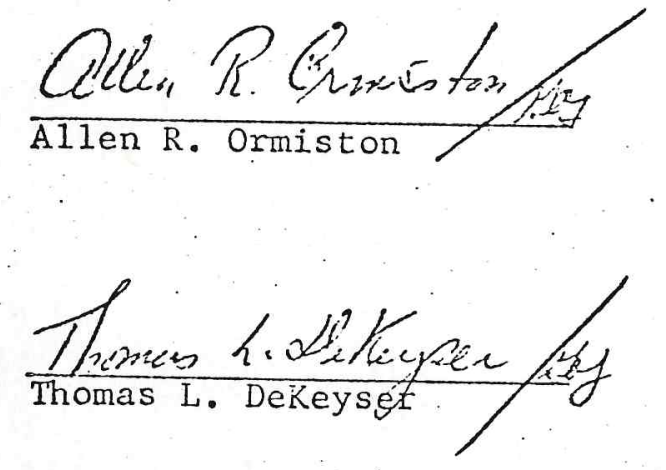

ARO/TLD: cme 


\section{Amoco Production Company}

Research Center

Tulsa, Oklahoma

July 5,1972

Re: Union 1971 megafossil grab samples from NE SE T33N, R33W, Misheguk Mtn. Quad., Alaska

File: Technical Service 5719IR

Locality 6186

MEMORANDUM

Field No.

$R R R-282$

$6186-15$

$R R R-283$

Discussion: These samp northwestern Alaska.

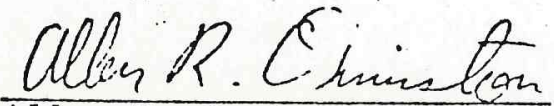

Allen R. Ormiston

ARO: cme

Hysterolites cf. SP. A. Johnson Carinatina cf. lowtherensis

Atrypa aff. devoniana

Leptostrophia sp.

Plicodevonaria sp.

Gypidula sp.

Spinatrypa cf. spinosaeformis

Cyrtina sp.

Eostrophalosia sp.

Leptagonia cf. boueii

Heliolites cf. porosa

Heliophyllum sp。

Alveolites sp.

indet. disphyllids

Parallelopora sp.

Hysterolites cf. sp. A. Johnson Plicodevonaria sp.

Barrandella sp.

Gypidula sp.

Spinatrypa cf. spinosaeformis

Eostrophalosia sp.

Leptostrophia sp.

Reticulariopsis sp.

Heliolites cf. porosa

Heliophyllum sp.

Thamnopora sp.

stromatoporoids

indet. clams

Dechenella sp. indet.

Leptagonia cf. boueii
Age

Middle Devonian Eifelian

Middle Devonian Eifelian 

Amoco Production Company

4502 East 41 st Street

P.O. Box 591

Tulsa, Oklahoma 74102

Research Center

September 29, 1972

Re: Conodonts from the Union Oil 1971 Grab Samples, Baird and Delong Mtns., Alaska

File: Technical Service 5719IR

Job No. 9704

Locality No. 6186

\section{MEMORANDUM}

Sample

No.

Footage

IBM No.

Identification

Count

15

RRR-282F

2901

Belode11a sp.

3

The specimens in sample 15 appear to be Lower or Middle Devonian representatives of the genus Belodella.

18

$\begin{array}{rr}R R R-326 F & 2831 \\ & 2620 \\ & 2618\end{array}$

Siphonode11a 2831

Siphonode11a sp.

Indet. conodonts

The fauna in sample 18 is Kinderhookian (Lower Mississippian) in age.

$\begin{array}{llll}34 & \text { RRR-220 } & 0501 & \text { Barren of conodonts } \\ 35 & \text { RRR-238 } & 0501 & \text { Barren of conodonts } \\ 36 & \text { RRR-242 } & 0501 & \text { Barren of conodonts } \\ 37 & \text { RRR-247 } & 1370 & \text { Polygnathus } 1370 \\ & 2618 & \text { Indet. conodonts } \\ \text { Polygnathus } 1370 \text { occurs in lower to middle Famennian } \\ 38 & \text { RRR-258 } & 0501 & \text { Barren of conodonts } \\ 39 & \text { RRR-259 } & 0501 & \text { Barren of conodonts } \\ 40 & \text { RRR-260 } & 0501 & \text { Barren of conodonts } \\ 41 & \text { RRR-261 } & 0501 & \text { Barren of conodonts }\end{array}$




\begin{tabular}{clll}
$\begin{array}{c}\text { Sample } \\
\text { No. }\end{array}$ & Footage & IBM No. & Identification \\
\hline 42 & RRR-327C & 0501 & Barren of conodonts \\
43 & RRR-340 & 0501 & Barren of conodonts \\
44 & RRR-343 & 0501 & Barren of conodonts \\
45 & RRR-344 & 0501 & Barren of conodonts \\
46 & RRR-345 & 0501 & Barren of conodonts \\
47 & RRR-355 & 0501 & Barren of conodonts \\
48 & RRR-356 & 0501 & Barren of conodonts \\
49 & RRR-358 & 0501 & Barren of conodonts \\
50 & DWA-280 & 2717 & Polygnathus 2717
\end{tabular}

The fauna in sample 50 indicates a Kinderhookian (Lower Mississippian) age.
51 DWA-286
2865
Panderodus sp.
2

The specimens in sample 51 suggest an Ordovician age; however, it is possible that they are as young as Middle Devonian.

$\begin{array}{llllr}52 & \text { DWA-296 } & 0501 & \text { Barren of conodonts } & \\ 53 & \text { DWA-305 } & 2831 & \text { Siphonode1la } 2831 & 1 \\ & 2620 & \text { Siphonode11a sp. } & 3 \\ & 2618 & \text { Indet. conodonts } & 6\end{array}$

The fauna in sample 53 is Kinderhookian (Lower Mississippian) in age and approximately correlates with the faunas in samples 18 and 50.

$\begin{array}{lccl}55 & \text { DWA }-337 & 2712 & \text { Polygnathus } 2712 \\ & & 2618 & \text { Indet. conodonts } \\ \text { The fauna in sample } 55 \text { is Middle Devonian in age. } \\ 56 & \text { DWA-339 } & 0501 & \text { Barren of conodonts } \\ 57 & \text { DWA-340 } & 0501 & \text { Barren of conodonts } \\ 59 & \text { DWA-361 } & 0501 & \text { Barren of conodonts }\end{array}$




\section{$-3-$}

Sample

\begin{tabular}{ccclc} 
No. & Footage & IBM No. & Identification & Count \\
\hline 60 & DWA-375 & 0501 & Barren of conodonts & \\
61 & JDB-2 & 0501 & Barren of conodonts & \\
62 & JDB-3 & 2618 & Indet. conodonts &
\end{tabular}

The fragments in sample 62 suggest an Ordovician age.

$\begin{array}{lllll}63 & \text { RRR-224C } & 0501 & \text { Barren of conodonts } \\ 64 & \text { RRR-257C } & 0501 & \text { Barren of conodonts } \\ 65 & \text { RRR-309C } & 0501 & \text { Barren of conodonts } & \\ 66 & \text { RRR-313CL } & 0501 & \text { Barren of conodonts } & 1 \\ 67 & \text { RRR-325C } & 2620 & \text { Siphonode1la sp. } & 1 \\ & & 2700 & \text { Polygnathus sp. } & 11\end{array}$

The conodonts in sample 67 are Kinderhookian (L. Mississippian) in age and approximately correlate with the faunas in samples 18, 50 and 53.

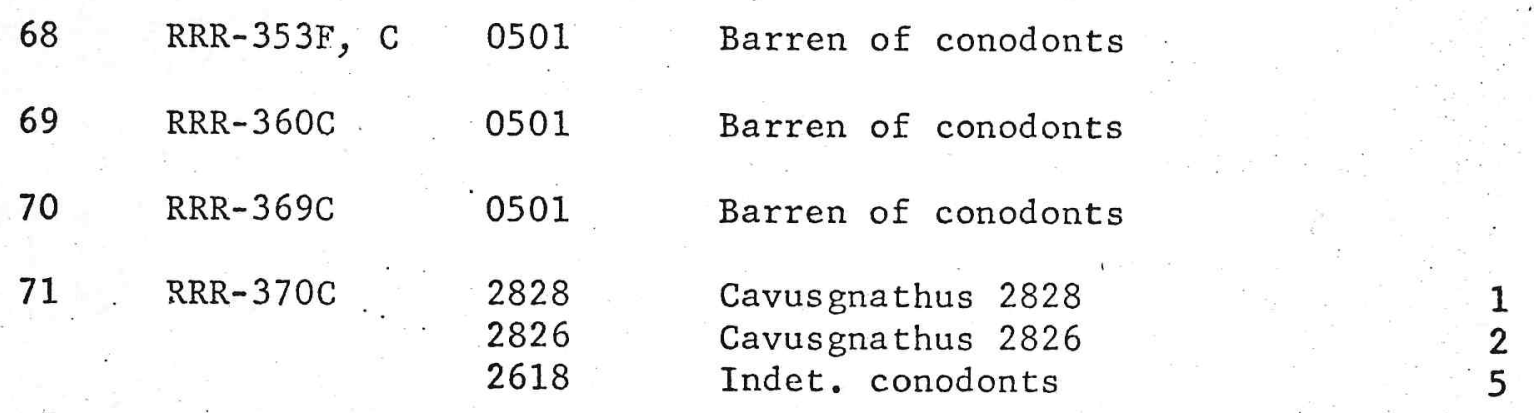

The fauna in sample 71 is upper Meramec or Chester (Upper Mississippian) in age.

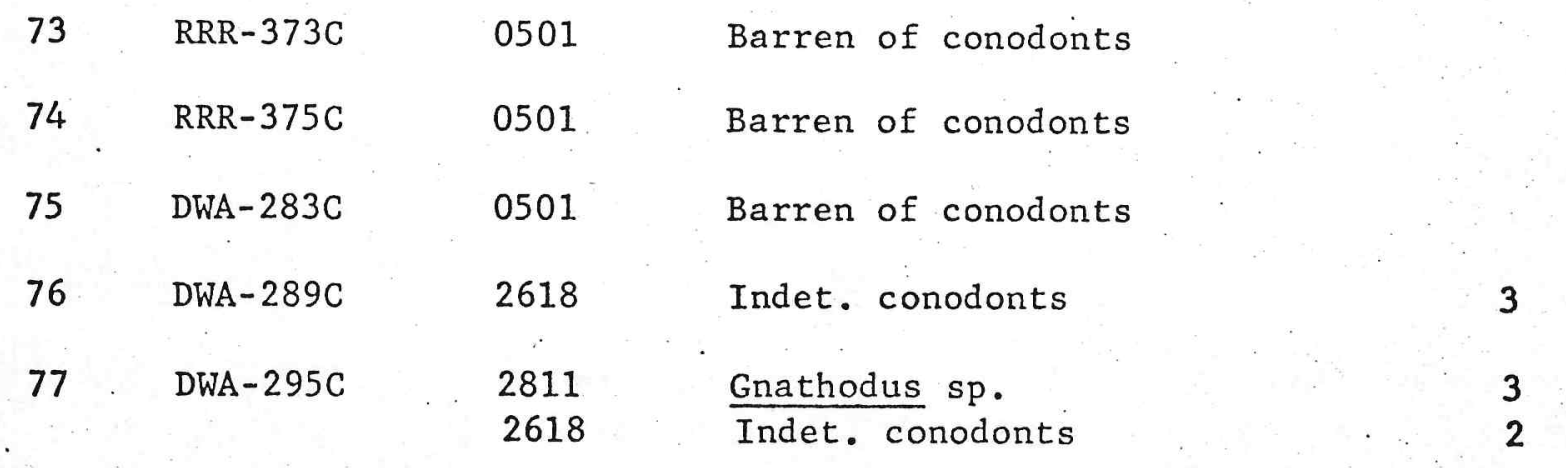


Sample

$\therefore$

The conodonts in sample 77 are Mississippian in age.

78

$\begin{array}{ll}\text { DWA-313C } & 2717 \\ 2736 \\ 2831 \\ 2718 \\ 2726 \\ 2618\end{array}$

Polygnathus 2717

Spathognathodus 2736

Siphonode11a 2831

Polygnathus 2718

Spathognathodus sp.

Indet. conodonts

2618

The fauna in sample 78 is Kinderhookian (L. Mississippian) in age and approximately correlates with the faunas in samples 18, 50, 53, and 67 .

$\begin{array}{llll}79 & \text { DWA-323C } & 0501 & \text { Barren of conodonts } \\ 80 & \text { DWA-358C } & 0501 & \text { Barren of conodonts } \\ 81 & \text { DWA-363C } & 2811 & \text { Gnathodus sp. } \\ & & 2858 & \frac{\text { Neoprioniodus sp. }}{\text { Indet. conodonts }} \\ \text { The fauna in sample } 81 \text { suggests } & \text { a Mississippian age. } \\ 82 & \text { DWA-381C } & 0501 & \text { Barren of conodonts } \\ 83 & \text { RRR-281 C \& F } 0501 & \text { Barren of conodonts } \\ 84 & \text { RRR-301 F,f,C } 0501 & \text { Barren of conodonts }\end{array}$

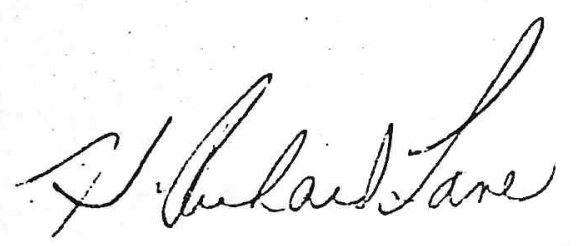

H. Richard Lane

HRL : vm 


\section{Amoco Production Company \\ Tulsa, Oklahoma \\ Research Center}

September 19, 1972

Re: Conodonts from the Union Trail Creek Section, NE 1/4, SE 1/4, T34N,

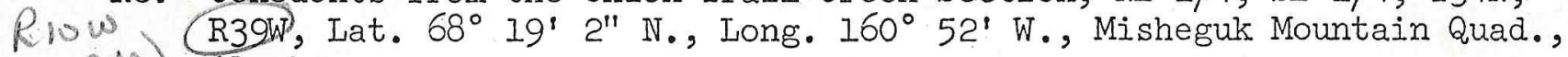
(KRM Alaska

File: Technical Service No. 5719IR

Job No. 9704

Locality No. 6623

\section{MEMORANDUM}

\begin{tabular}{cllll}
$\begin{array}{c}\text { Sample } \\
\text { No. }\end{array}$ & Footage & IBM No & Identification & Count \\
\hline 1 & RRR 300 & 0501 & Barren of conodonts & \\
2 & RRR 299 & 0501 & Barren of conodonts & \\
3 & RRR 298 & 0501 & Barren of conodonts & \\
4 & RRR 297 & 0501 & Barren of conodonts & 1 \\
6 & $R R R 295$ & 2705 & Polygnathus 2705 & 7 \\
& & 2712 & $\frac{\text { Polygnathus } 2712}{\text { Indet. conodonts }}$
\end{tabular}

The conodonts in sample 6 suggest an upper Eifelian age (Middle Devonian).

$\begin{array}{rrrll}7 & \text { RRR 294 } & 0501 & \text { Barren of conodonts } \\ 12 & \text { RRR 289 } & 0501 & \text { Barren of conodonts } & \\ 13 & \text { RRR 288 } & 0501 & \text { Barren of conodonts } & \\ 15 & \text { RRR 286 } & 20314 & \text { Polygnathus 20314 } & 1 \\ & & 2779 & \text { Palmatolepis } 2779 & 2 \\ & & 2618 & \text { Indet. conodonts } & 8\end{array}$

The fauna in sample 15 is lower Famennian (Upper Devonian) in age.

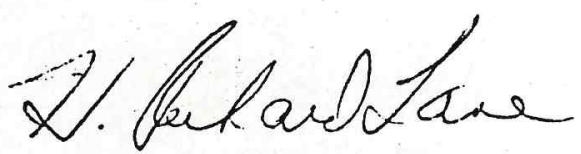

H. Richard Lane

HRI : skW 



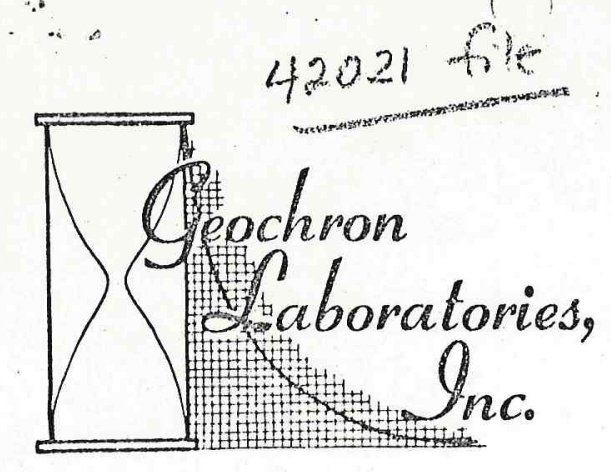

24 Blackstone Street, Cambridge, Mass. 02139

Telephone TRowbridge 6-3691

$$
\begin{aligned}
& \text { lcopysenty } \\
& \text { Amora }
\end{aligned}
$$

18 January 1972

Roderick D. McLennan

Union Oil Co. of Calif.

9645 So. Santa Fe Springs Road

Santa Fe Springs, Calif. 90670

Dear Mr. McLennan:

Enclosed are the analytical reports of the $K-A r$ age determinations on five (5) of the six (6) rock samples described in your letter of 23 INovember 1971.

We were unable to make a satisfactory mineral concentrate from your sample $\mathrm{JDB}-1$ and the sample is not really suitable for a whole-rock analysis, consequently there is no report for this sample. The other five samples gave ages ranging from about 75 to 217 million years. As you gave no indication of the magnitude of the ages you expected for these samples I cannot comment too much about them.

The age of sample JDB-6 should be considered to be a minimum age and may closely approximate the time of shearing and alteration of the rock. The age of RRR-275 should be a good metamorphic age for the rock. I would expect the ages of the other three samples to be rather reliable ages of formation of the individual rock units.

If you should have any questions about these analyses, please do not hesitate to contact me. In the meantime, I am enclosing our invoice for this work. I hope that we may be able to serve you again in the near future.

Sincerely, GEOCHRON LABORATORIES DIV.

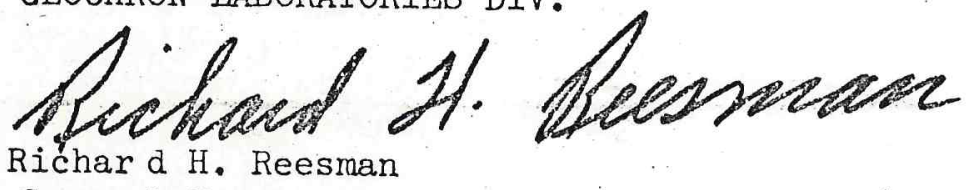

General Manager

$\mathrm{RHR} / \mathrm{dm}$ 
Our Sample NoR- 2172

Date Received: 30 November 1971

Your Reference: JDB-6

Date Reported: 18 Januaxy 1972

Submitted by: Roderick D. McLennan Union Oil Co. of Calif. 9645 So. Santa Fe Springs Road Santa Fe Springs, Calif. 90670

Sample Description \& Locality: Sheared and altered basalt (?) Alaska

Material Analyzed: Whole rock, crushed to $-40 /+100$ mesh.

$\operatorname{Ar}^{40 * / K^{40}}=.006212$

$\mathrm{AGE}=$

$103 \pm 4$

M.Y.

Argon Analyses:

$\begin{array}{cc}\operatorname{Ar}^{40 *}, \mathrm{ppm} . & \mathrm{Ar}^{40 *} / \text { Total }^{4} \mathrm{Ar}^{40} \\ .04376 & .814 \\ .04286 & .927\end{array}$

Ave. $\operatorname{Ar}^{40 *}, \mathrm{ppm}$.

.04331

Potassium Analyses:

$\% \mathrm{~K}$

5.691

5.739

Ave. \%K

5.715

$\mathrm{K}^{40}, \mathrm{ppm}$

6.972

\section{Constants Used:}

$\lambda_{\beta}=4.72 \times 10^{-10} /$ year

$\lambda_{e}=0.585 \times 10^{-10} /$ year

$$
A G E=\frac{1}{\lambda_{e}+\lambda_{\beta}} \ln \left[\frac{\lambda_{\beta}+\lambda_{e}}{\lambda_{e}} \times \frac{A r^{40 *}}{K^{40}}+1\right]
$$

$\mathrm{K}^{40} / \mathrm{K}=1.22 \times 10^{-4} \mathrm{~g} . / \mathrm{g}$.

Note: $\mathrm{Ar}^{40 *}$ refers to radiogenic $\mathrm{Ar}^{40}$.

$M . Y$. refers to millions of years. 
Our Sample No.R- 2173

Your Reference: - RRR-275

Submitted by: Roderick D. McLennan Union Oil Co. of Calif.

9645 So. Santa Fe Springs Road Santa Fe Springs, Calif. 90670

Sample Description \& Locality: Slate

$$
\text { Alaska }
$$

Material Analyzed: Whole rock, crushed to $-40 /+100$ mesh.

$\operatorname{Ar}^{40 * / K^{40}}=.01347 \quad$ AGE $=217 \pm 8 \quad$ M.Y.

Argon Analyses:

$\begin{array}{ccc}\operatorname{Ar}^{40 *}, \mathrm{ppm} . & \mathrm{Ar}^{40 *} / \operatorname{Total}^{4 \mathrm{Ar}^{40}} & \text { Ave. Ar }^{40 *}, \mathrm{ppm} . \\ .03924 & .836 & .03946 \\ .03968 & .817 & \end{array}$

Potassium Analyses:

$\begin{array}{rcr}\% K & \text { Ave. \%K } & K^{40}, \mathrm{ppm} \\ 2.407 & 2.401 & 2.929 \\ 2.396 & & \end{array}$

\section{Constants Used:}

$\lambda_{\beta}=4.72 \times 10^{-10} /$ year

$\lambda_{e}=0.585 \times 10^{-10} /$ year

$A G E=\frac{1}{\lambda_{e}+\lambda_{\beta}} \ln \left[\frac{\lambda_{\beta}+\lambda_{e}}{\lambda_{e}} \times \frac{A r^{40 *}}{K^{40}}+1\right]$

$\mathrm{K}^{40} / \mathrm{K}=1.22 \times 10^{-4} \mathrm{~g} . \mathrm{g}$.

Note: $A r^{40 *}$ refers to radiogenic $\mathrm{Ar}^{40}$.

M.Y. refers to millions of years. 
Submitted by: Roderick D. McLennan

Union Oil Co. of California

9645 So. Santa Fe Springs Road

Santa Fe Springs, California 90670

Sample Description \& Locality: Gneiss (Coarser-grained sample used) Alaska

Material Analyzed: Muscovite concentrate, $-100 /+200$ mesh.

$\operatorname{Ar}^{40 * / K^{40}}=.006478 \quad$ AGE $=108 \pm 4 \quad$ M.Y.

Argon Arralyses:

$\begin{array}{ccc}\mathrm{Ar}^{40 *}, \mathrm{ppm} . & \mathrm{Ar}^{40 *} / \operatorname{Total~Ar}^{40} & \text { Ave. Ar } \\ .05613 & .703 & .050647 \\ .05680 & \ldots .666 & .0564\end{array}$

Potassium Analyses:

$\% \mathrm{~K}$

7.141

7.149
Ave. \%K

7.145

$$
\mathrm{K}^{40}, \mathrm{ppm}
$$$$
8.716
$$

\section{Constants Used:}

$\lambda_{\beta}=4.72 \times 10^{-10} /$ year

$\lambda_{e}=0.585 \times 10^{-10} /$ year

$\mathrm{AGE}=\frac{1}{\lambda_{\mathrm{e}}+\lambda_{\beta}} \ln \left[\frac{\lambda_{\beta}+\lambda_{\mathrm{e}}}{\lambda_{\mathrm{e}}} \times \frac{\mathrm{Ar}^{40 *}}{\mathrm{~K}^{40}}+1\right]$

$K^{40} / K=1.22 \times 10^{-4} \mathrm{~g} . / \mathrm{g}$.

Note: $\mathrm{Ar}^{40 *}$ refers to radiogenic $\mathrm{Ar}^{40}$. $M . Y$. refers to millions of years. 
Your Reference: . RRR-386

Submitted by: Roderick D. McLennan Union Oil Co. of Calif.

9645 So. Santa Fe Springs Road

Santa Fe Springs, Calif. 90670

Sample Description \& Locality: 01ivine basalt

$$
\text { Alaska }
$$

Material Analyzed: Whole rock, crushed to $-40 /+100$ mesh.

$\operatorname{Ar}^{40 * / K^{40}}=.004436$

$A G E=74.3 \pm 4.2 \quad M . Y$.

Argon Analyses:

$\begin{array}{ccr}\operatorname{Ar}^{40 *}, \mathrm{ppm} . & \operatorname{Ar}^{40 *} / \text { Total Ar }^{40} & \text { Ave. Ar }{ }^{40 *}, \mathrm{ppm} \\ .003080 & .427 & .002771 \\ .002585 & .193 & \\ .002647 & \cdots .267 & \end{array}$

Potassium Analyses:

$\% K$

.521

.503
Ave. \%K

.512

$$
\mathrm{K}^{40}, \mathrm{ppm}
$$$$
.624
$$

\section{Constants Used:}

$\lambda_{\beta}=4.72 \times 10^{-10} /$ year

$\lambda_{e}=0.585 \times 10^{-10} /$ year

$A G E=\frac{1}{\lambda_{e}+\lambda_{\beta}} \ln \left[\frac{\lambda_{\beta}+\lambda_{e}}{\lambda_{e}} \times \frac{A^{40 *}}{K^{40}}+1\right]$

$\mathrm{K}^{40} / \mathrm{K}=1.22 \times 10^{-4} \mathrm{~g} . \mathrm{g}$.

Note: $\mathrm{Ar}^{40 *}$ refers to radiogenic $\mathrm{Ar}^{40}$.

M.Y. refers to millions of years. 
Our Sample NoR- 2176

Date Received: 30 November 1971

Your Reference: RRR-390

Date Reported: 18 January 1972

Submitted by: Roderick D. McLennan Union Oil Co. ef Calif.

9645 So. Santa Fe Springs Road Santa Fe Springs, Calif. 90670

Sample Description \& Locality: Basalt

Alaska

Material Analyzed:Whole rock, crushed to $-40 /+100$ mesh.

$\operatorname{Ar}^{40 * / K^{40}}=.005258$

$87.8 \pm 3.9$ M.Y.

\section{Argon Analyses:}

$\begin{array}{ccr}\mathrm{Ar}^{40 *}, \mathrm{ppm} . & \mathrm{Ar}^{40 *} / \text { Total Ar }^{40} & \text { Ave. Ar }{ }^{40 *}, \mathrm{ppm} \\ .003468 & .536 & .008279 \\ .008090 & .499 & \end{array}$

Potassium Analyses:

$\% \mathrm{~K}$

1.279

1.302
Ave: $\% \mathrm{~K}$

1.290
$\mathrm{K}^{40}, \mathrm{ppm}$

1.574

\section{Constants Used:}

$\lambda_{\beta}=4.72 \times 10^{-10} /$ year

$\lambda_{e}=0.585 \times 10^{-10} /$ year

$$
A G E=\frac{1}{\lambda_{e}+\lambda_{\beta}} \ln \left[\frac{\lambda_{\beta}+\lambda_{e}}{\lambda_{e}} \times \frac{\operatorname{Ar}^{40 *}}{K^{40}}+1\right]
$$

Note: $\operatorname{Ar}^{40 *}$ refers to radiogenic $\mathrm{Ar}^{40}$. M.Y. refers to millions of years. 



\section{AMOCO PRODUCTION COMPANY$$
\text { RESEARCH CENTER }
$$

SOURCE ROCK EVALUATION

- 5 outcrop samples from North Slope, Alaska -

\section{Geochemistry Group}

$$
\begin{aligned}
& \text { R. M. Byington } \\
& \text { J. A. Williams }
\end{aligned}
$$

Distribution: B. F. Baldwin, Attn G.F. Stansberry$$
\text { R. K. Taylor }
$$

B. G. Newton

W. R. Walton

J. A. Momper
Technical Service $8308 \mathrm{CR}$ Denver, Northwest District

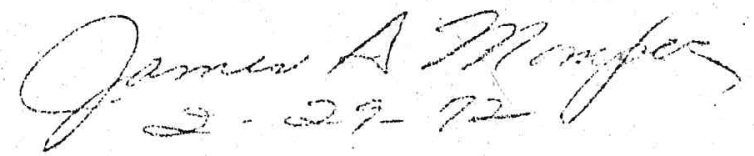

$\infty$

को

- $x$

18 रे

7.150 RECETV क 
T.S. $8308 \mathrm{CR}$

Denver, Northwest District

North Slope, Alaska

\section{INTRODUCTION}

Five outcrop samples collected by Union Oil Company of California in the extreme western portion of the Brooks Range, Alaska, were analysed for source rock quality. The samples were of Cretaceous, Jurassic and Mississippian age.

\section{OBSERVATIONS AND CONCLUSTONS}

1. The samples have source rock quality ratings ranging from NONSOURCE (1) to GOOD (2) - (Table 1).

2. There were very small amounts of mature hydrocarbon extracts from all the samples (Figs. 1 and 2), which is suggestive of gas sources. However, the possibility of oil generation cannot be ruled out on the basis of the present data.

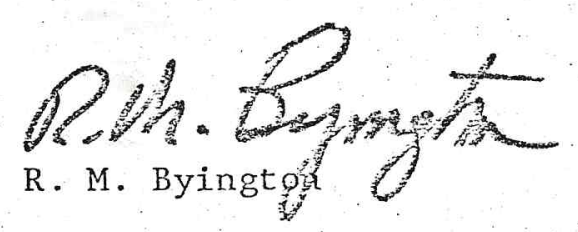

RMB : $g 1 j$ 
QFFICE Denver Division

AUTHOPIZEO BY D. R. Hembre

TECHACAL SERUICE NUMBER

STATE (PROVMCE) Alaska

\begin{tabular}{|c|c|c|c|}
\hline \multicolumn{3}{|c|}{ SAMPLE } & \multirow{2}{*}{ FORRAATION } \\
\hline NUMEER & TYPE & OUALITY & \\
\hline ANS -71 & $\begin{array}{l}\text { Out- } \\
\text { crop }\end{array}$ & RRP229 & $\begin{array}{l}\text { Ogotoruk } \\
\text { Jur.-Early Cret }\end{array}$ \\
\hline-72 & " & $|R(2) 23|$ & $\begin{array}{l}\text { Telavirak } \\
\text { Jur.-Early Cret }\end{array}$ \\
\hline-73 & $"$ & RRR233 & $"$ \\
\hline-74 & " & FR 281 & Cretaceous? \\
\hline-75 & $"$ & DWA 321 & $\begin{array}{l}\text { Kayak } \\
\text { Mississippian }\end{array}$ \\
\hline & & & \\
\hline & & & \\
\hline & & & \\
\hline & & & \\
\hline & & & \\
\hline & & & \\
\hline & & & \\
\hline & & & \\
\hline & & & \\
\hline
\end{tabular}

RERARKS:
AR:A North Slope, Alaska DATE $11-22-71$

$8308 \mathrm{CR}$

COUNTY

HELL LOCATIO

\begin{tabular}{|c|c|c|c|c|c|c|c|c|}
\hline LITHOLOGY & DEPTH & $\begin{array}{l}\text { IASOLUBLE } \\
\text { RESIDUE \% }\end{array}$ & $\begin{array}{l}\text { ORGANIC } \\
\text { CABBON } \\
\text { WT. \% } \\
\end{array}$ & $\begin{array}{l}\text { EXTRACTAELE } \\
\text { ORGANIC } \\
\text { BUI/ACRE FT. }\end{array}$ & $\begin{array}{l}\text { EXTRACT. } \\
\text { MYOROCAREON } \\
\text { BDI/ACREST. }\end{array}$ & $\begin{array}{c}\text { EXTRACT. } \\
\text { ORG. } \\
\text { ORTAL } \\
\text { OROL }\end{array}$ & RATIUG & C Isotope \\
\hline silty sh. & $\mathrm{NE}, 31 \mathrm{~N}-60 \mathrm{~W}$ & 87.6 & 0.5 & 1.4 & 0.5 & 0.01 & poor & -25.4 \\
\hline shale & $\begin{array}{l}\text { SW NE, } \\
31 \mathrm{~N}-59 \mathrm{~W}\end{array}$ & 84.5 & 1.3 & 0.7 & 0.2 & 0.00 & good & -25.9 \\
\hline shale & $\mathrm{C}, 31 \mathrm{~N}-59 \mathrm{~W}$ & 84.0 & 0.8 & 1.3 & 0.5 & 0.01 & fair & -- \\
\hline shale & $\begin{array}{l}66^{\circ} 40^{\prime} \mathrm{N} \\
156^{\circ} 13^{\prime} \mathrm{W}\end{array}$ & 73.8 & 0.3 & 1.0 & 0.3 & 0.02 & non-source & -26.2 \\
\hline shale & $\begin{array}{l}\mathrm{NE} N \mathrm{NE}, \\
12 \mathrm{~S}-44 \mathrm{~W}\end{array}$ & 63.6 & 1.1 & 0.7 & 0.1 & 0.00 & good & -26.2 \\
\hline & & & & & & & & \\
\hline & & & & & & & & \\
\hline & & & & & & & & \\
\hline & & & & & & & & \\
\hline & . & & & & & & & \\
\hline & & & & : & . & & & \\
\hline & & & & & . & & & \\
\hline & . & & & & & & & \\
\hline & & . & & & & & & \\
\hline & & & & & & & & \\
\hline
\end{tabular}

ANALYST
- moco Productor compan RESEARCS CENTEA

SOURCE ROCK EVALUATIONS 


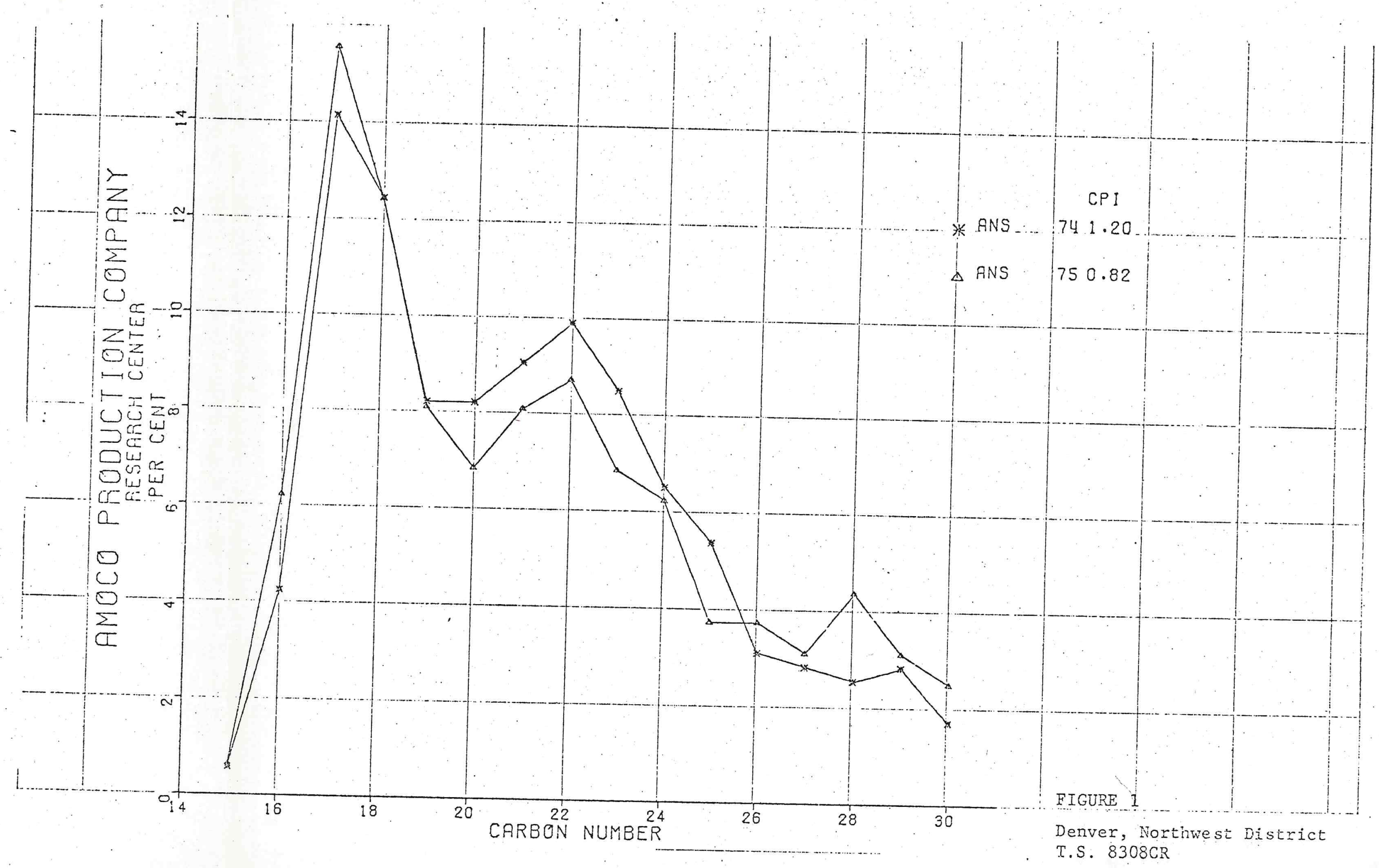




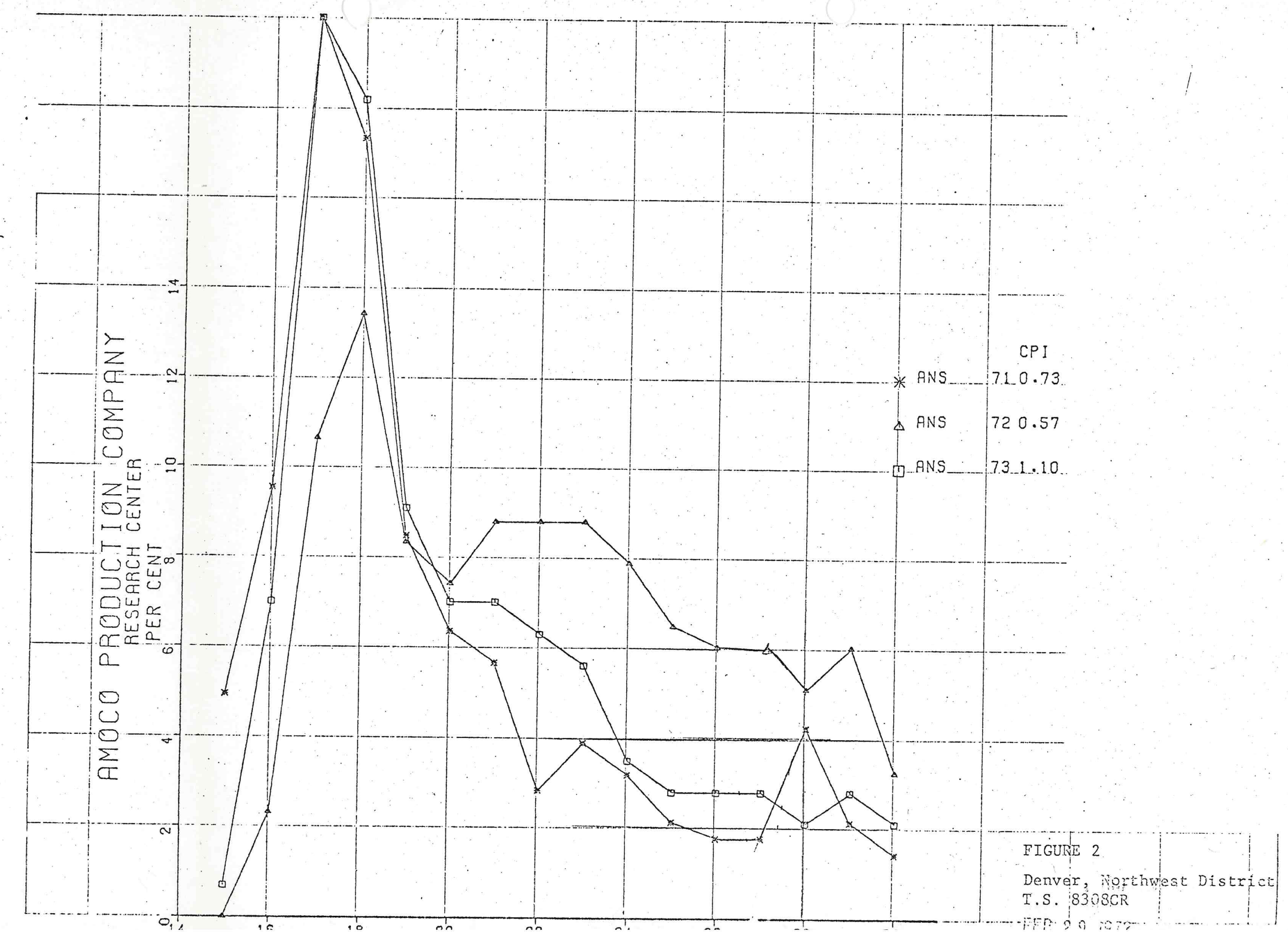




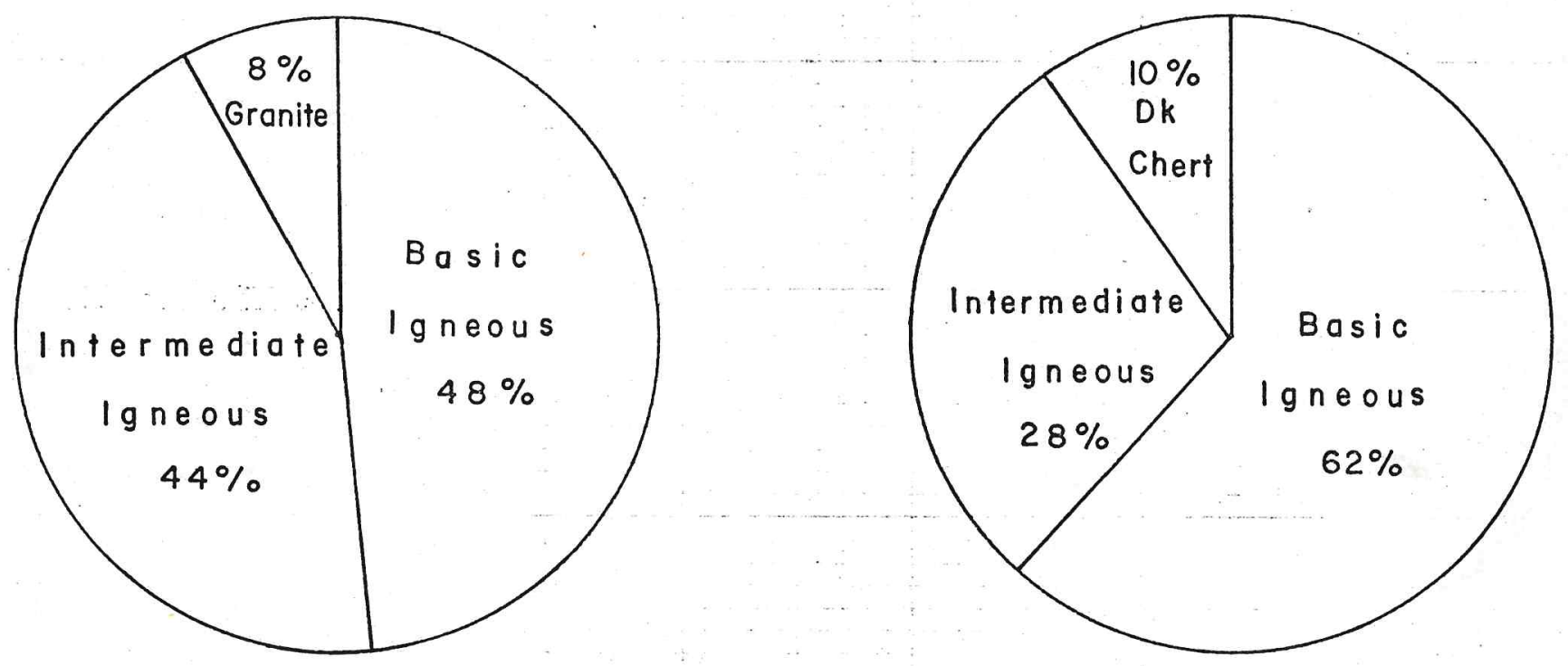

Pbl. Count From 7-6-26

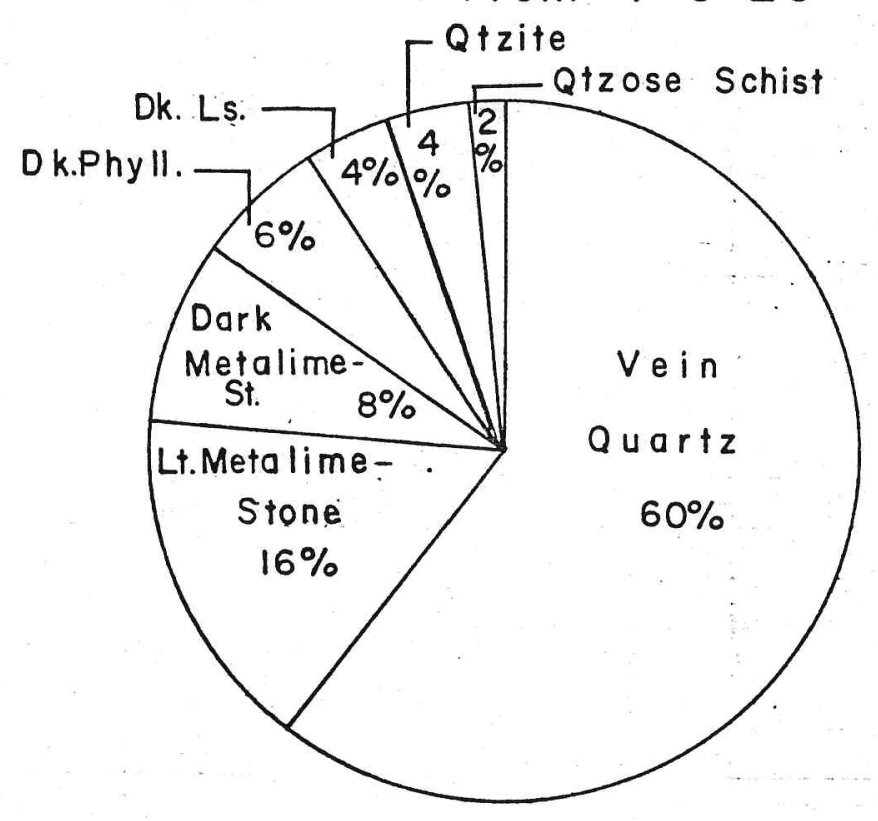

Pbl. Count From 5-6-24

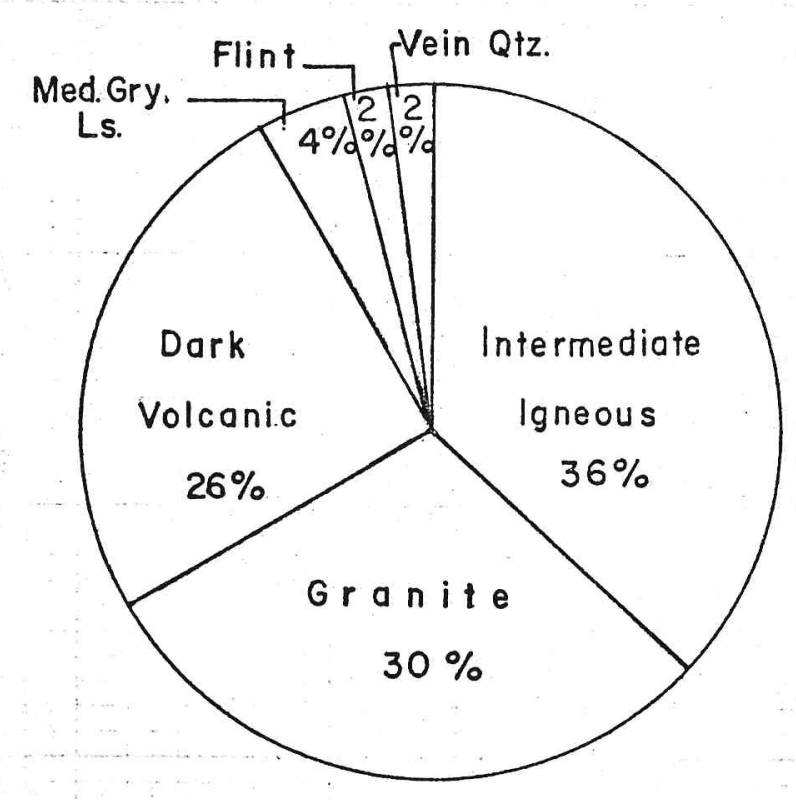


Pbl. Count From 7-6-24

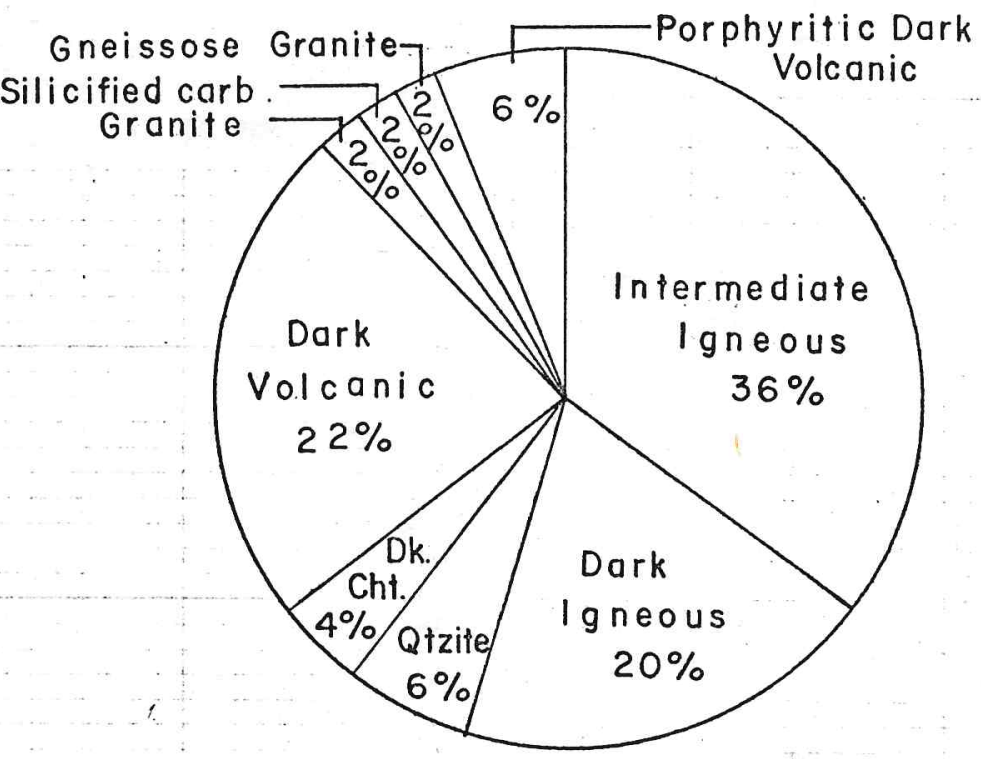

Pbl. Count From 15-6-24 Intermediate lg_Crinoidal Chert

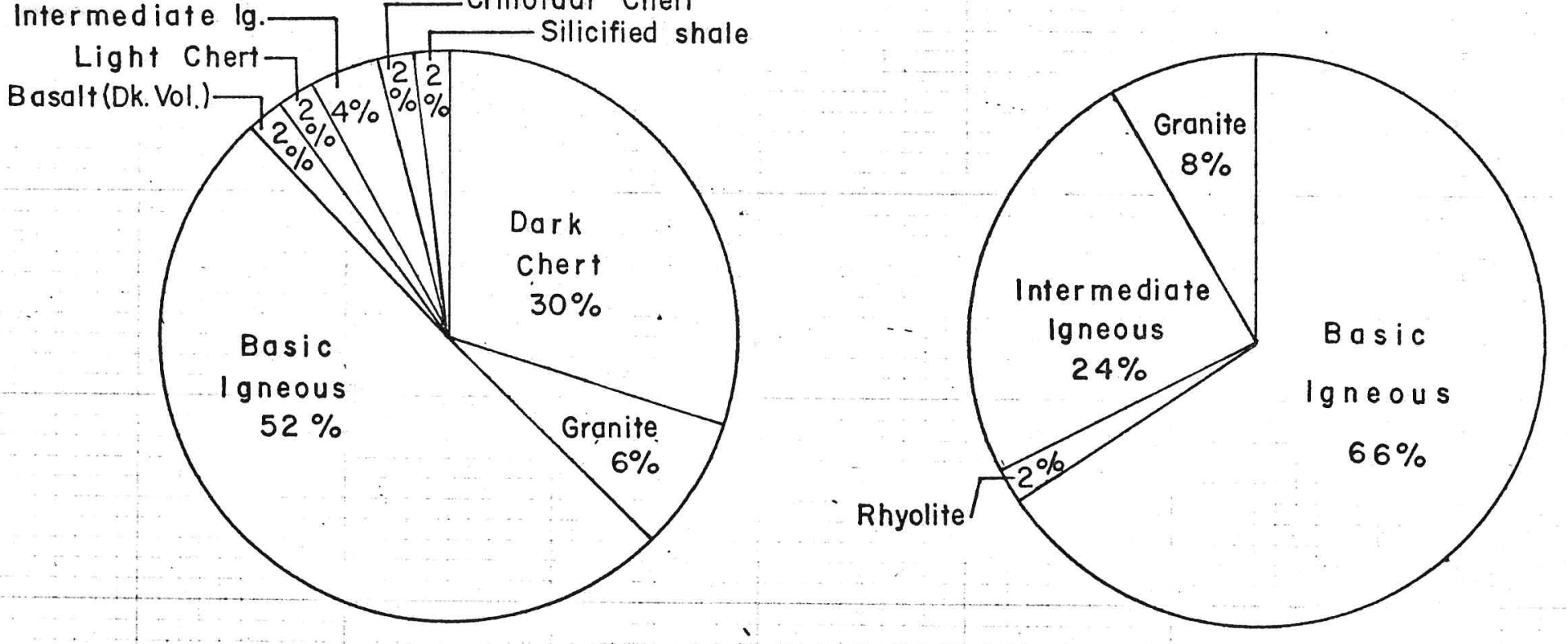

Pbl. Count From 14-6-24 Dk. Gray Cherf

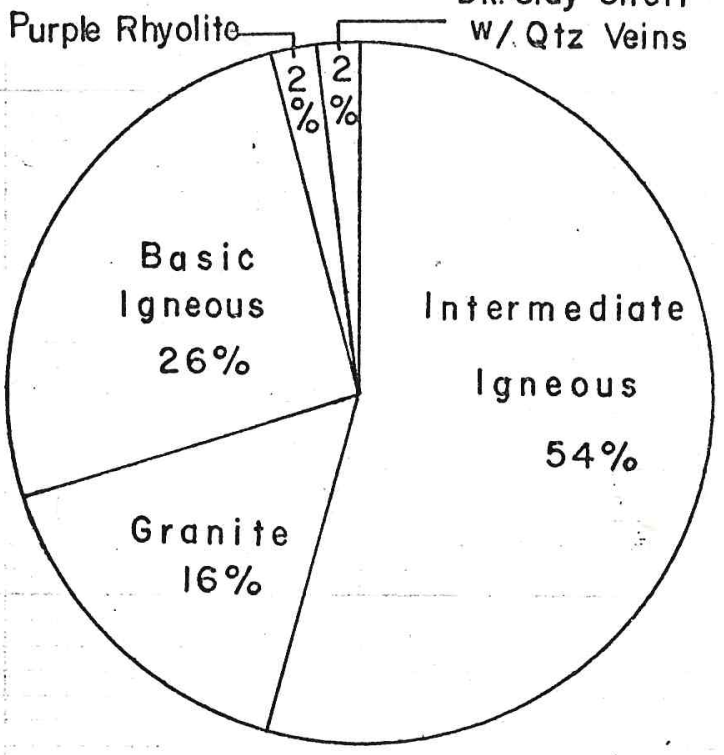

Pḅl. Count From 25-6-24 


\section{Pebble Count \# 1}

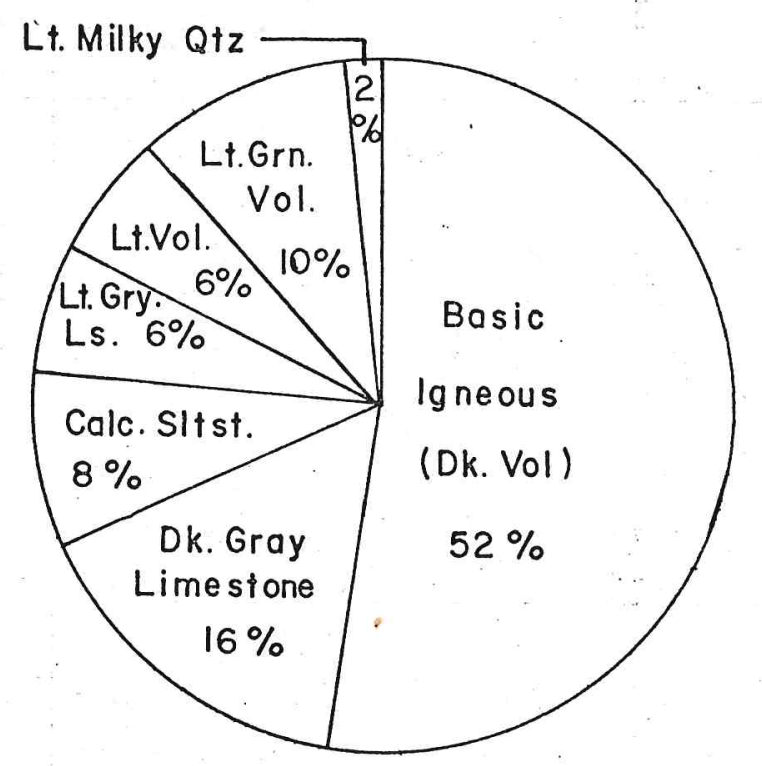

Pebble Count \#3

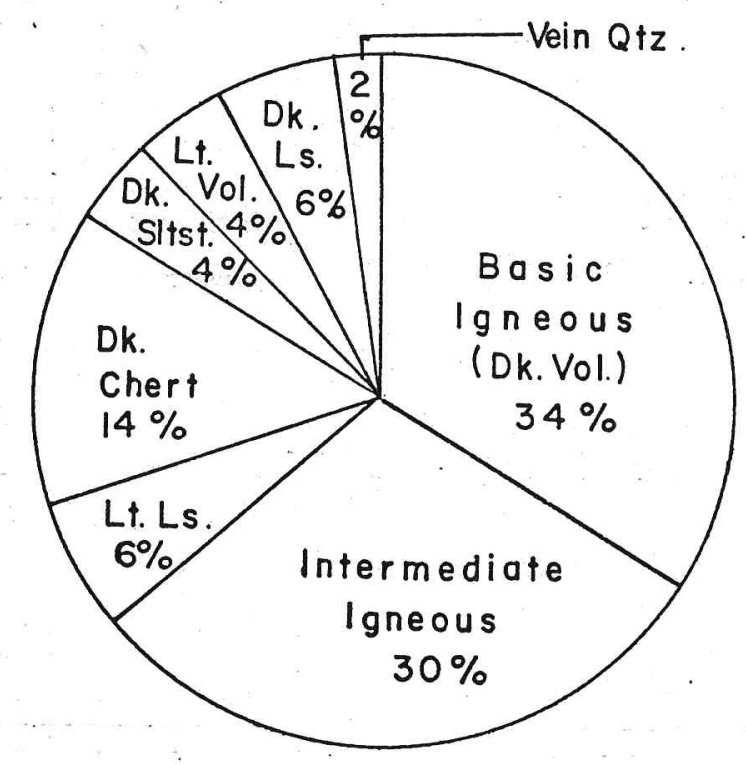

\section{Pebble Count \#2}

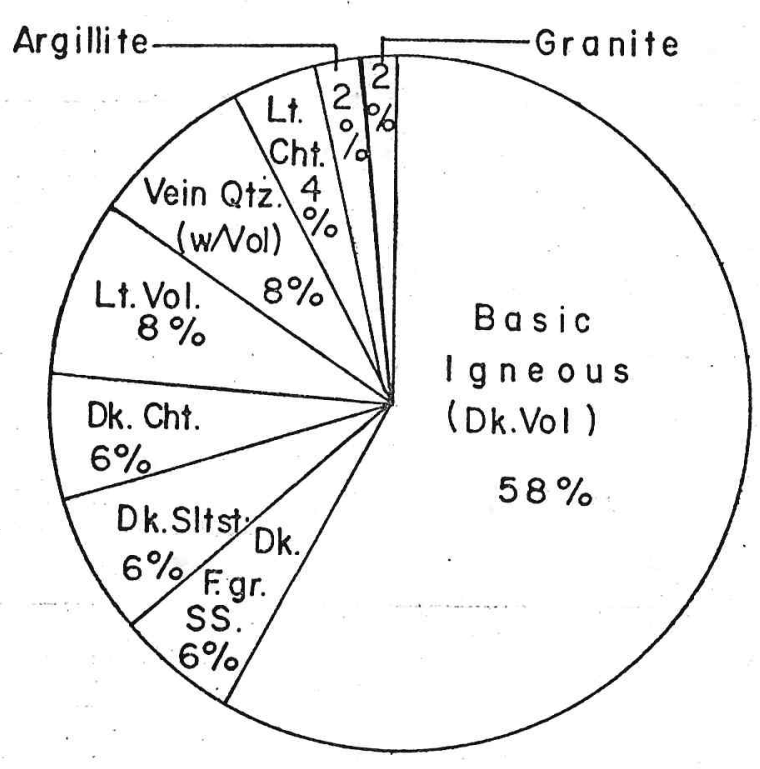

Pebble Count \#4

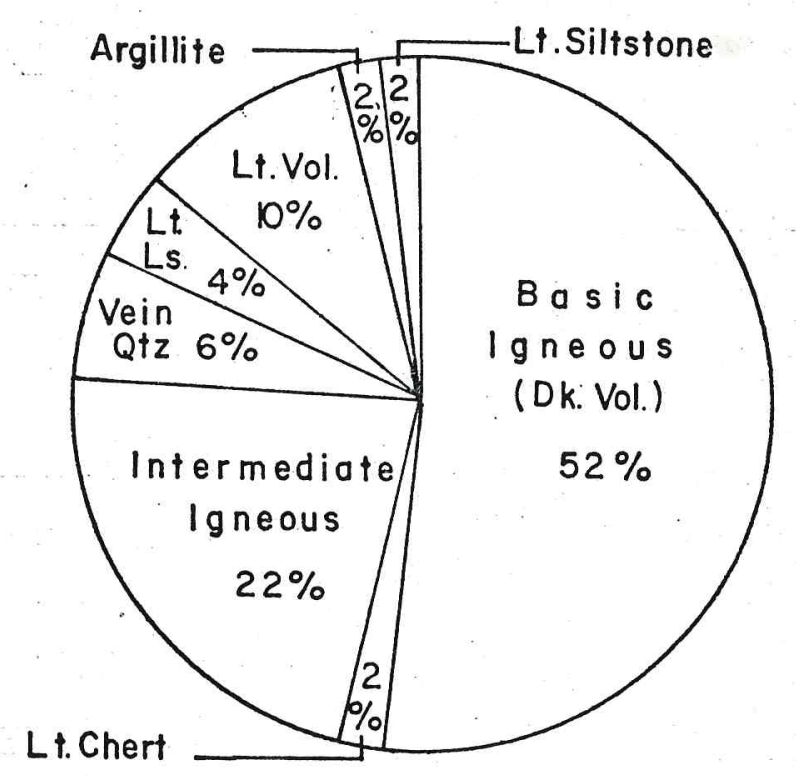


Pbl. Coun $\uparrow$ From 8-6-22

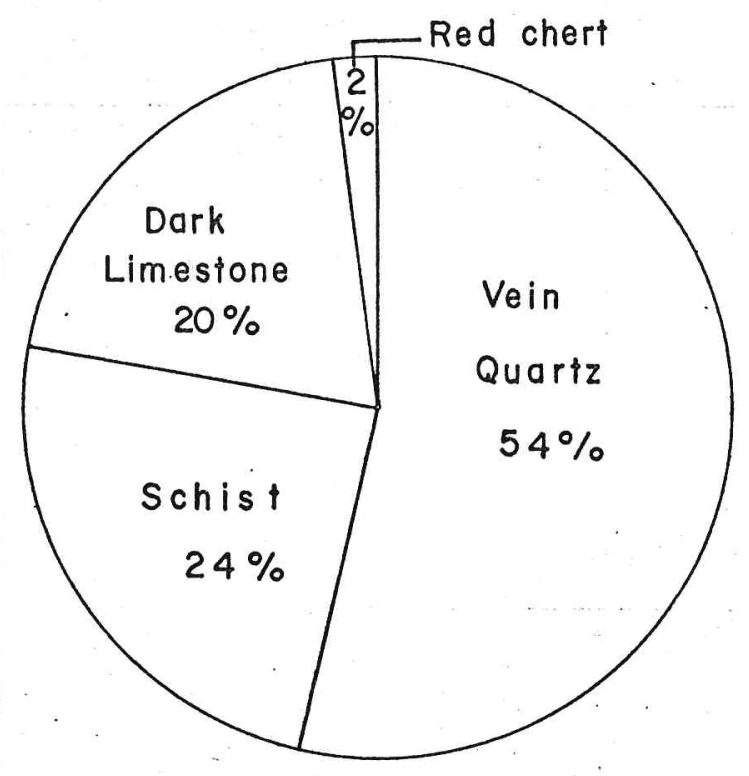

Pbl. Count From 12-6-22

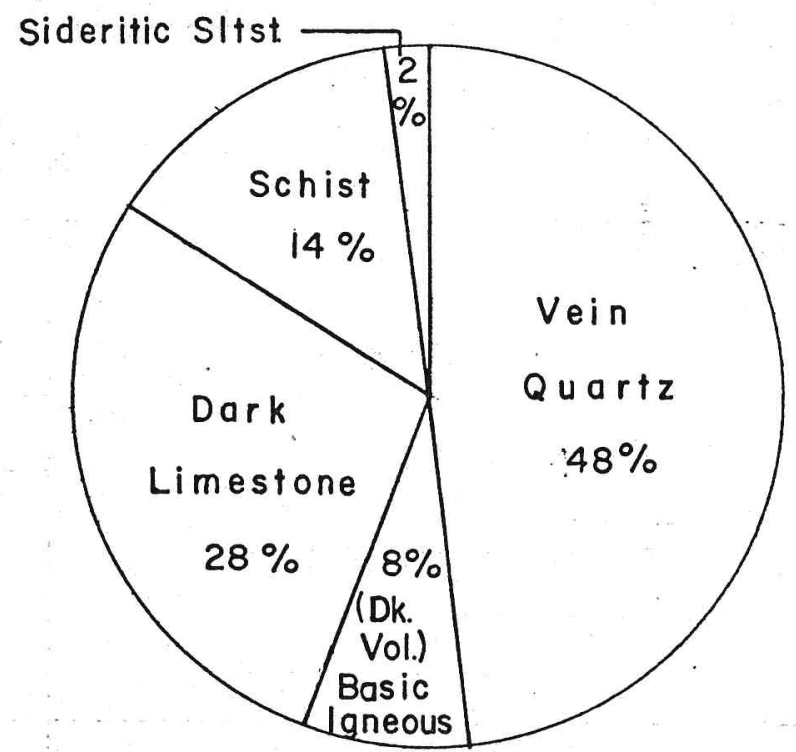

Pbl. Count From II-6-22

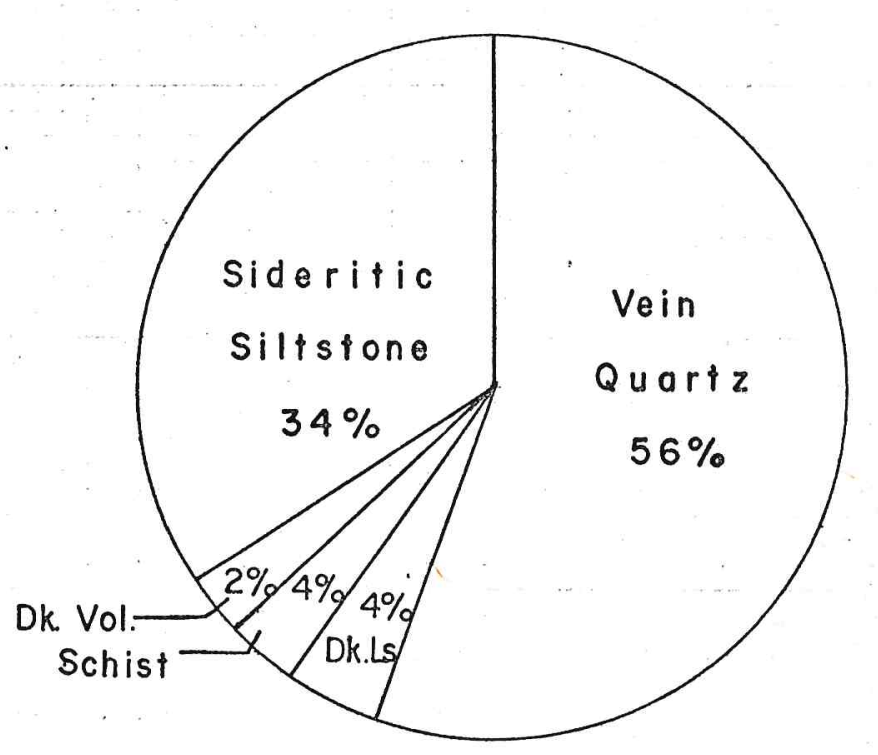

Pbl. Count From 13-6-22

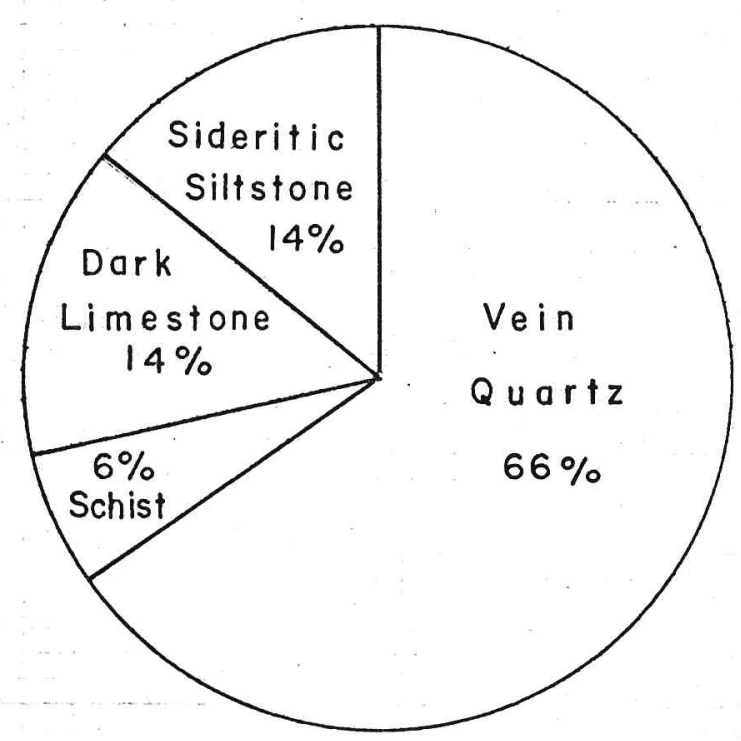


Pbl. Count From 6-7-24

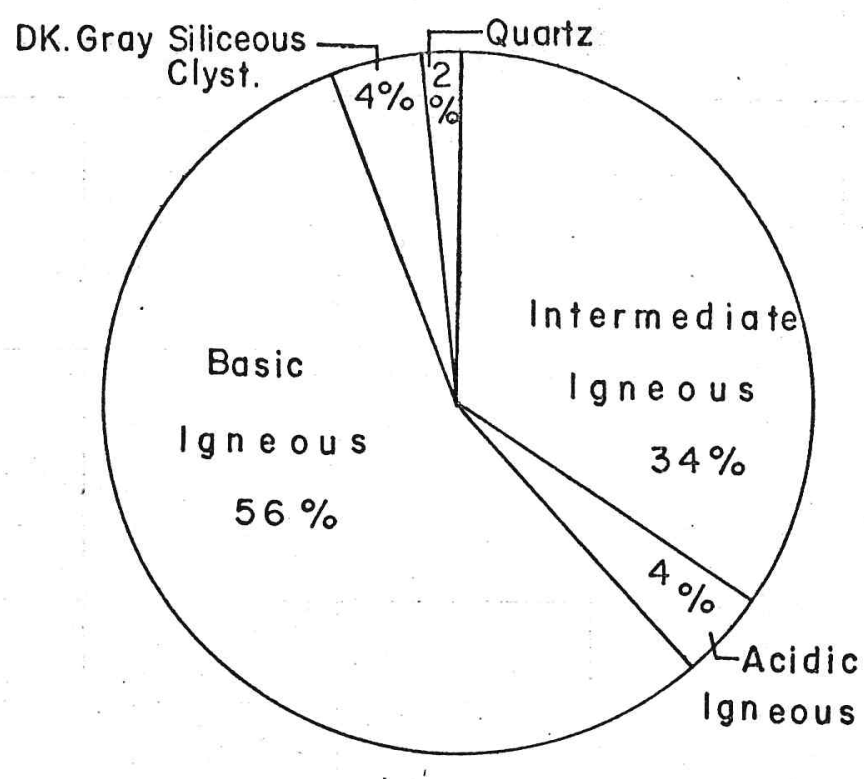

Pbl. Count From II-7-24

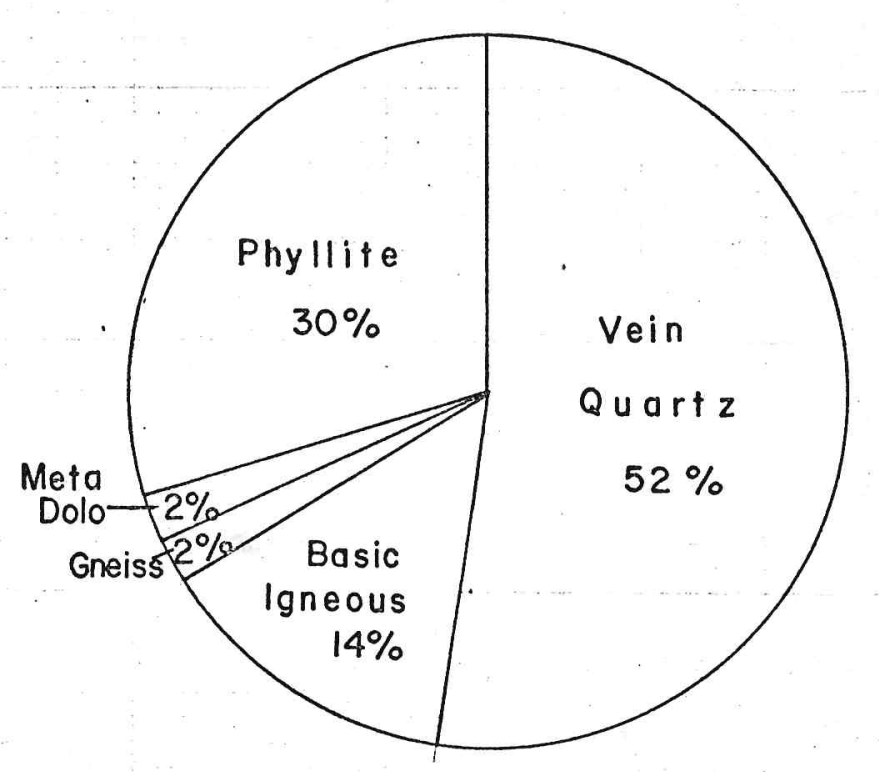




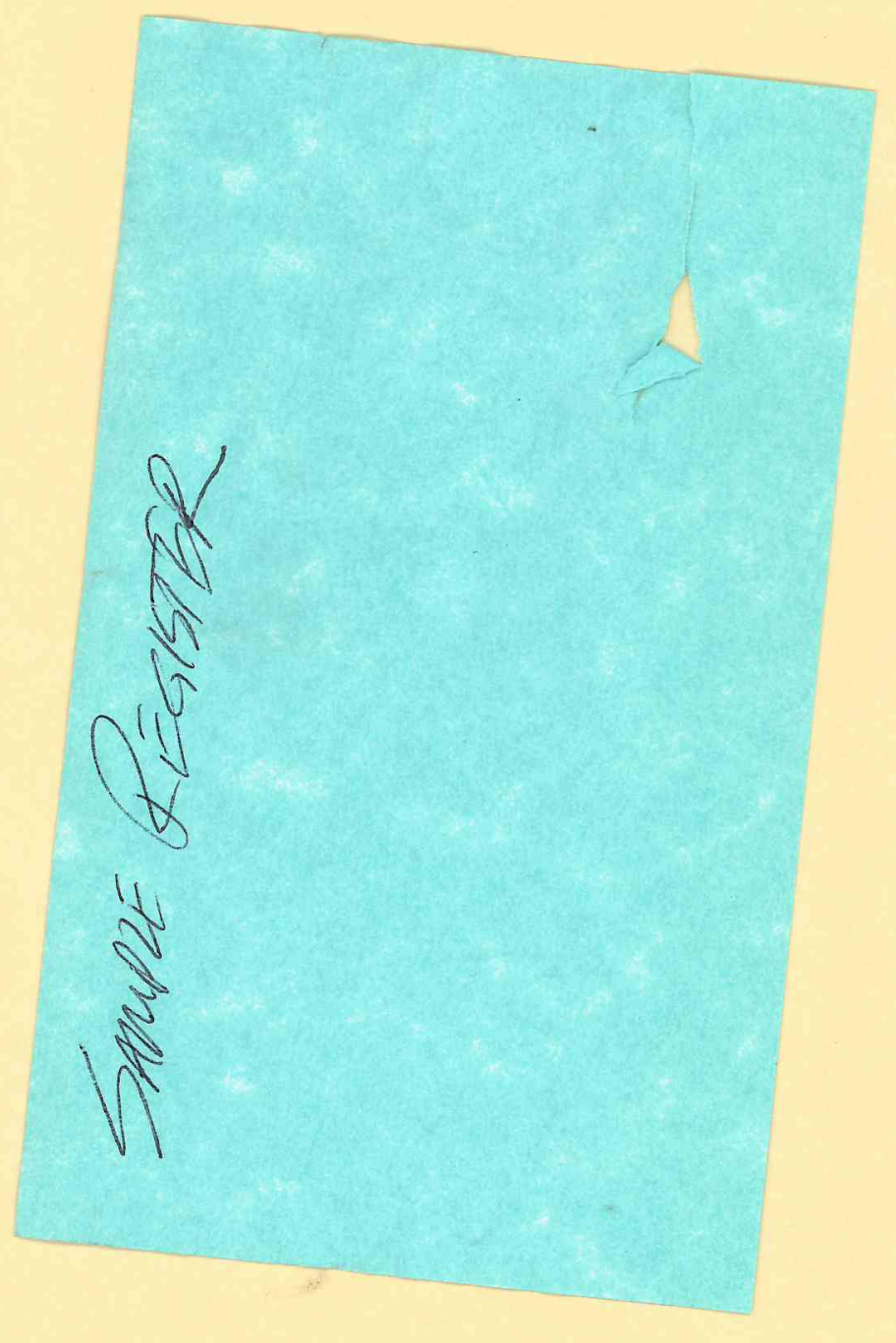


SAMPLE REGISTER

\begin{tabular}{|c|c|c|c|c|c|c|c|}
\hline $\begin{array}{l}\text { Sample No } \\
\text { (1) }\end{array}$ & $\begin{array}{l}\text { Type } \\
(2)\end{array}$ & $\begin{array}{l}\text { Field Book } \\
\text { (3) }\end{array}$ & $\begin{array}{l}\text { Formation } \\
\text { or Age } \\
\text { (4) }\end{array}$ & $\begin{array}{l}\text { Unit } \\
(5)\end{array}$ & $\begin{array}{l}\text { Footage } \\
(6)\end{array}$ & $\begin{array}{l}\text { Purpose } \\
\text { (7) }\end{array}$ & $\begin{array}{l}\text { Location } \\
\text { (Quad) } \\
\text { (8) }\end{array}$ \\
\hline DWA 280 & Grab & 2 & Mississippian & & & $\mathrm{C}$ & North-central Noatak \\
\hline DWA 281 & $"$ & 2 & Mississippian & & & $\mathrm{F}$ & " \\
\hline DWA 282 & $"$ & 2 & Skajit (?) & " & & F & $"$ \\
\hline DWA 283 & $"$ & 2 & Kayak? & $\cdot$ & & $\mathrm{C}$ & S.Central DeLong Mtns. \\
\hline DWA 284 & $"$ & 2 & $"$ & & & $\because F$ & $"$ \\
\hline DWA 285 & $"$ & 2 & $"$ & & & Paly & $"$ \\
\hline DWA 286 & $"$ & 2 & Utukok? . & & & C & Central Baird Mtns. \\
\hline DWA 287 & $"$ & 2 & Devonian or older & & & $F$ & W.Central Baird Mtns. \\
\hline DWA 288 & $"$ & 2 & & & & $\mathrm{~F}$ & $"$ \\
\hline DWA 289 & $"$ & 2 & Lisburne? & & & $\mathrm{C}^{-}$ & Southedge DeLong Mtns- \\
\hline DWA 290 & $"$ & 2 & Lisburne? & & & F & $" \quad:$ \\
\hline DWA 291 & $"$ & 2 & Kayak? & & & Paly & $"$ \\
\hline DWA 292 . & $"$ & 2 & Kayak? & r & & Paly & $"$ \\
\hline DWA 293 & $"$ & 2 & & & & Paly & $"$ \\
\hline DWA 294 &. & 2 & & & & Paly. & SW DeLong Mtns. \\
\hline
\end{tabular}




\section{Continued}

\begin{tabular}{ccccccc}
$\begin{array}{c}\text { Sample No } \\
(1)\end{array}$ & $\begin{array}{c}\text { Type } \\
(2)\end{array}$ & $\begin{array}{c}\text { Field Book } \\
(3)\end{array}$ & $\begin{array}{c}\text { Formation } \\
\text { or Age } \\
(4)\end{array}$ & $\begin{array}{c}\text { Unit } \\
(5)\end{array}$ & $\begin{array}{c}\text { Footage } \\
(6)\end{array}$ & $\begin{array}{c}\text { Purpose } \\
\text { (7) }\end{array}$ \\
\hline
\end{tabular}

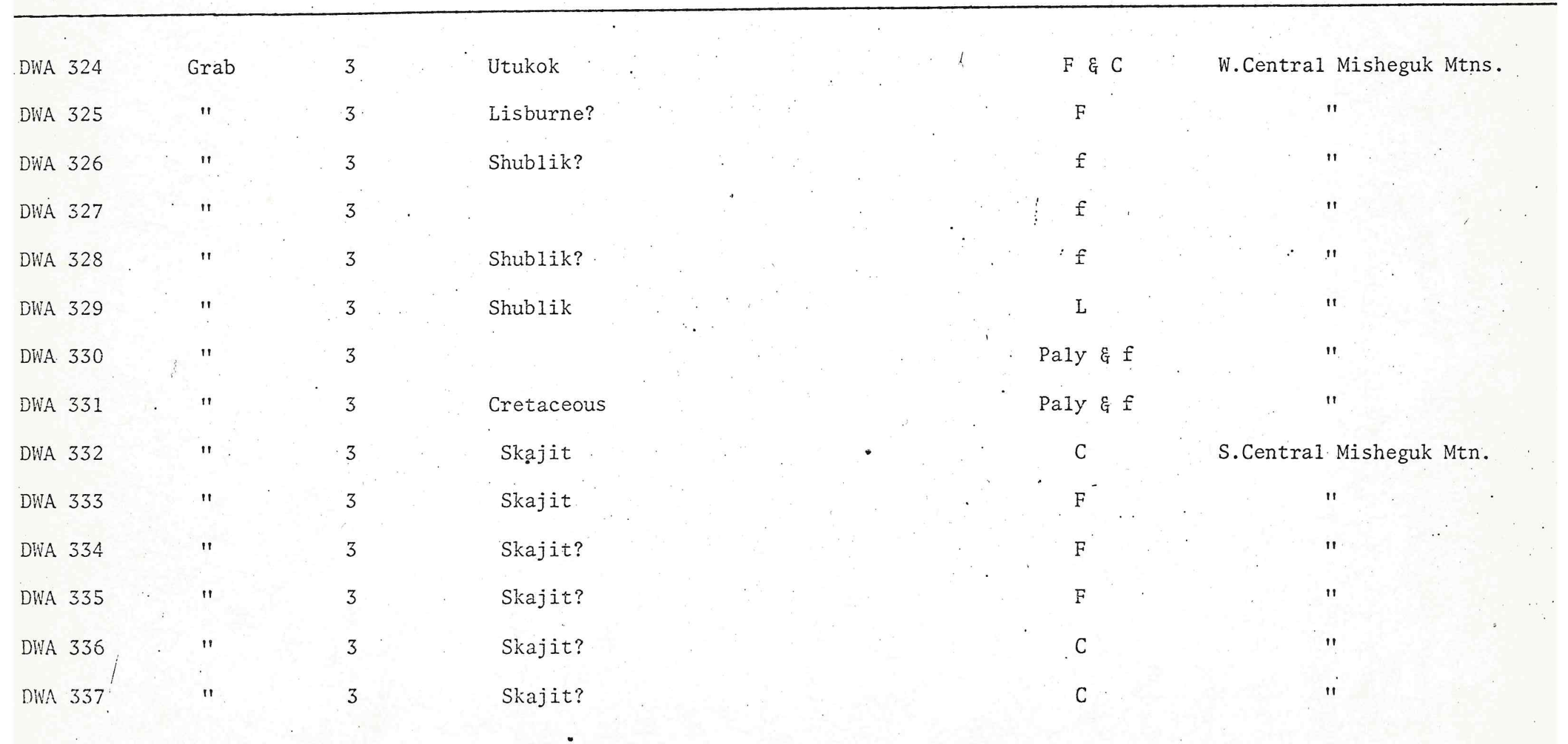


Continued

\begin{tabular}{|c|c|c|c|c|c|c|c|}
\hline $\begin{array}{l}\text { Sample No } \\
\text { (1) }\end{array}$ & $\begin{array}{l}\text { Type } \\
(2)\end{array}$ & $\begin{array}{l}\text { Field Book } \\
\text { (3) }\end{array}$ & $\begin{array}{l}\text { Formation } \\
\text { or Age } \\
\text { (4) }\end{array}$ & $\begin{array}{l}\text { Unit } \\
(5)\end{array}$ & $\begin{array}{c}\text { Footage } \\
\quad(6)\end{array}$ & $\begin{array}{l}\text { Purpose } \\
\text { (7) }\end{array}$ & $\begin{array}{l}\text { Location } \\
\text { (Quad) } \\
\text { (8) }\end{array}$ \\
\hline DWA 338 & Grab & $2 \& 3$ & Unknown & & & Paly \& $f$ & NW Baird Mtns. \\
\hline DWA 339 & $"$ & $"$ & $"$ & & & $\mathrm{C}$ & $"$ \\
\hline DWA 340 & $"$. & $"$ & $"$ & & & C & $"$ \\
\hline DWA 341 & $"$ & $"$ & Lisburne & & & $\mathrm{F}$ & SE DeLong Mtns. \\
\hline DWA 342 & $"$ & $"$ & Shublik? & & & Paly \& $f$ & .. " " \\
\hline DWA 343 & $"$ & 2 & & & & $f$ & NW Baird Mtns. \\
\hline DWA 344 & $"$ & 2 & Kayak & & & Paly & SE DeLong Mitns. \\
\hline DWA 345 & $"$ & 2 & Utukok? & & & PaIy. & $"$ \\
\hline DWA 346 & $"$ & 2 & Utukok? & & & F & $"$ \\
\hline DWA 347 & $"$ & 2 & Noatak & & & $\mathrm{F}^{-}$ & $"$ \\
\hline DWA 348 & $"$ & 3 & Noatak & & & F & N.Central Baird Mtns. \\
\hline DWA 349 & $"$ & 3 & Noatak & & & F & $"$ \\
\hline DWA 350 & $"$ & 3 & Noataḱ & & & $\mathrm{F}$ & $"$ \\
\hline DWA 351 & $"$ & 3 & Noatak & & & $F \& C$ & $"$ \\
\hline
\end{tabular}


Continued

\begin{tabular}{|c|c|c|c|c|c|c|c|}
\hline $\begin{array}{l}\text { Sample No } \\
\text { (1) }\end{array}$ & $\begin{array}{l}\text { Type } \\
(2)\end{array}$ & $\begin{array}{l}\text { Field Book } \\
\text { (3) }\end{array}$ & $\begin{array}{l}\text { Formation } \\
\text { or Age } \\
\text { (4) }\end{array}$ & $\begin{array}{l}\text { Unit } \\
(5)\end{array}$ & $\begin{array}{c}\text { Footage } \\
\text { (6) }\end{array}$ & $\begin{array}{c}\text { Purpose } \\
(7)\end{array}$ & $\begin{array}{l}\text { Location } \\
\text { (Quad) } \\
\text { (8) }\end{array}$ \\
\hline DWA 352 & Grab & 3 & Huntfork? & & & $F \& C$ & NW Baird Mtns. \\
\hline DWA 353 & $"$ & 3 & Huntfork? & & & F & " \\
\hline DWA 354 & $"$ & 3 & Lisburne & 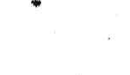 & & F & $"$ \\
\hline DWA 355 & $"$ & 3 & Lisburne & - & & $\vdots F$ & $"$ \\
\hline DWA 356 & $\because$ & 3 & Lisburne & & & $\cdot \mathrm{F}$ & $"$ \\
\hline DWA 357 & $"$ & 3 & Kayak & & & Paly & $"$ \\
\hline DWA 358 & $"$ & 3 & Lisburne & & & C & $"$ \\
\hline DWA 359 & $"$ & 3 & Noatak-Huntfork & & & Paly & $"$ \\
\hline DWA 360 & $"$ & 3 & Shublik & & & $\mathrm{F}$ & SE DeLong Mountains \\
\hline DWA 361. & $"$ & 3 & & & . & $\therefore \mathrm{C}^{-}$ & NW Baird Mtns. \\
\hline DWA 362 & $"$ & 3 & Utukok? & & & $L \& F$ & Central Misheguk Mtn. \\
\hline DWA 363 & $"$ & 3 & Utukok? & & & $\mathrm{C}$ & $"$ \\
\hline DWA 364 & $"$ & 3 & Utukok? & & & Paly \& SR & $"$ \\
\hline DWA 355 & $"$ & 3 & $\begin{array}{l}\text { Probable lower } \\
\text { Mississippian }\end{array}$ & & & Paly \& SR. & $"$ \\
\hline
\end{tabular}




\section{Continued}

\begin{tabular}{|c|c|c|c|c|c|c|c|}
\hline $\begin{array}{l}\text { Sample No } \\
\text { (1) }\end{array}$ & $\begin{array}{l}\text { Type } \\
\text { (2) }\end{array}$ & $\begin{array}{l}\text { Field Book } \\
\text { (3) }\end{array}$ & $\begin{array}{l}\text { Formation } \\
\text { or Age } \\
\text { (4) }\end{array}$ & $\begin{array}{l}\text { Unit } \\
\text { (5) }\end{array}$ & $\begin{array}{c}\text { Footage } \\
\text { (5) }\end{array}$ & $\begin{array}{l}\text { Purpose } \\
\text { (7) }\end{array}$ & $\begin{array}{l}\text { Location } \\
\text { (Quad) } \\
\text { (8) }\end{array}$ \\
\hline
\end{tabular}

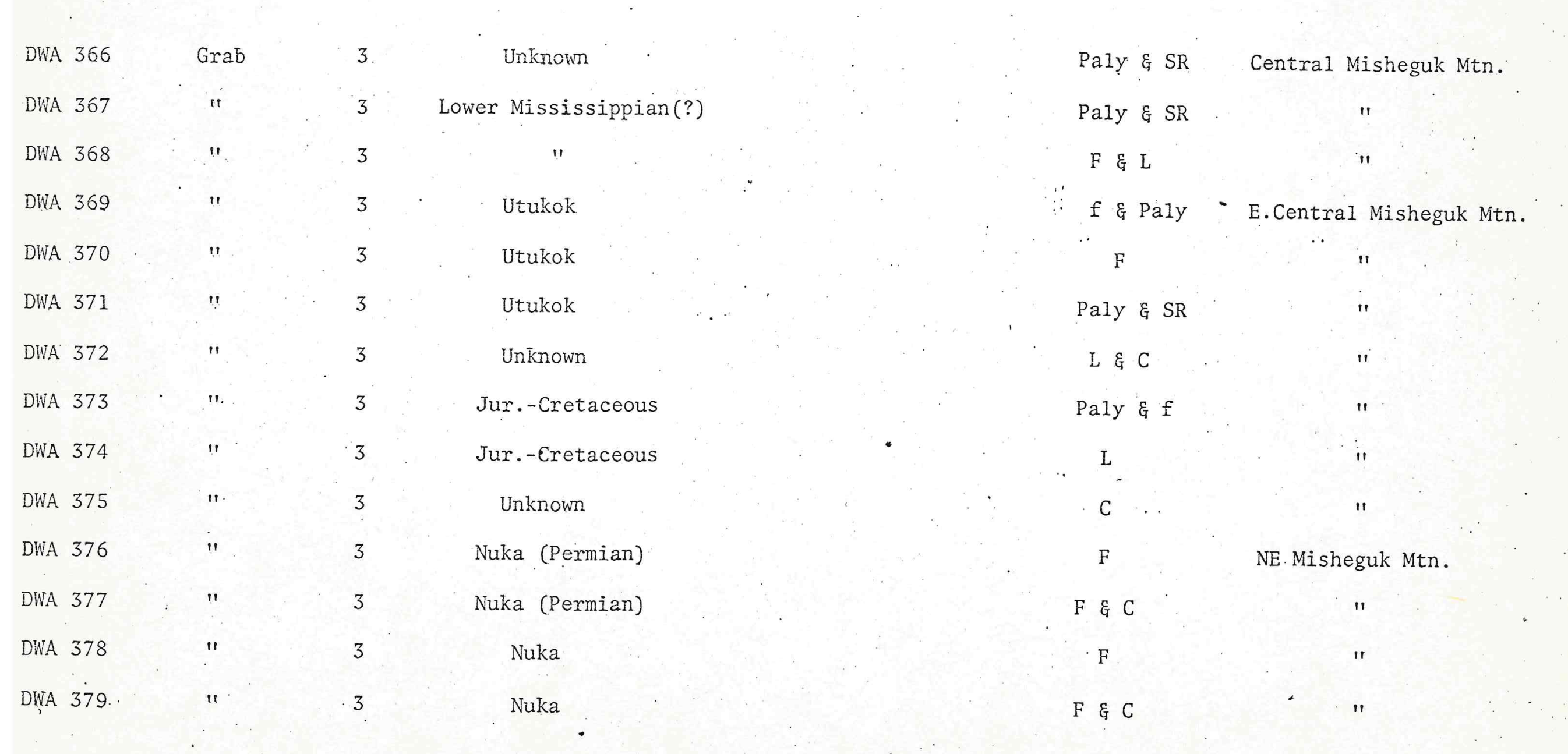


SAMPLE REGISTER

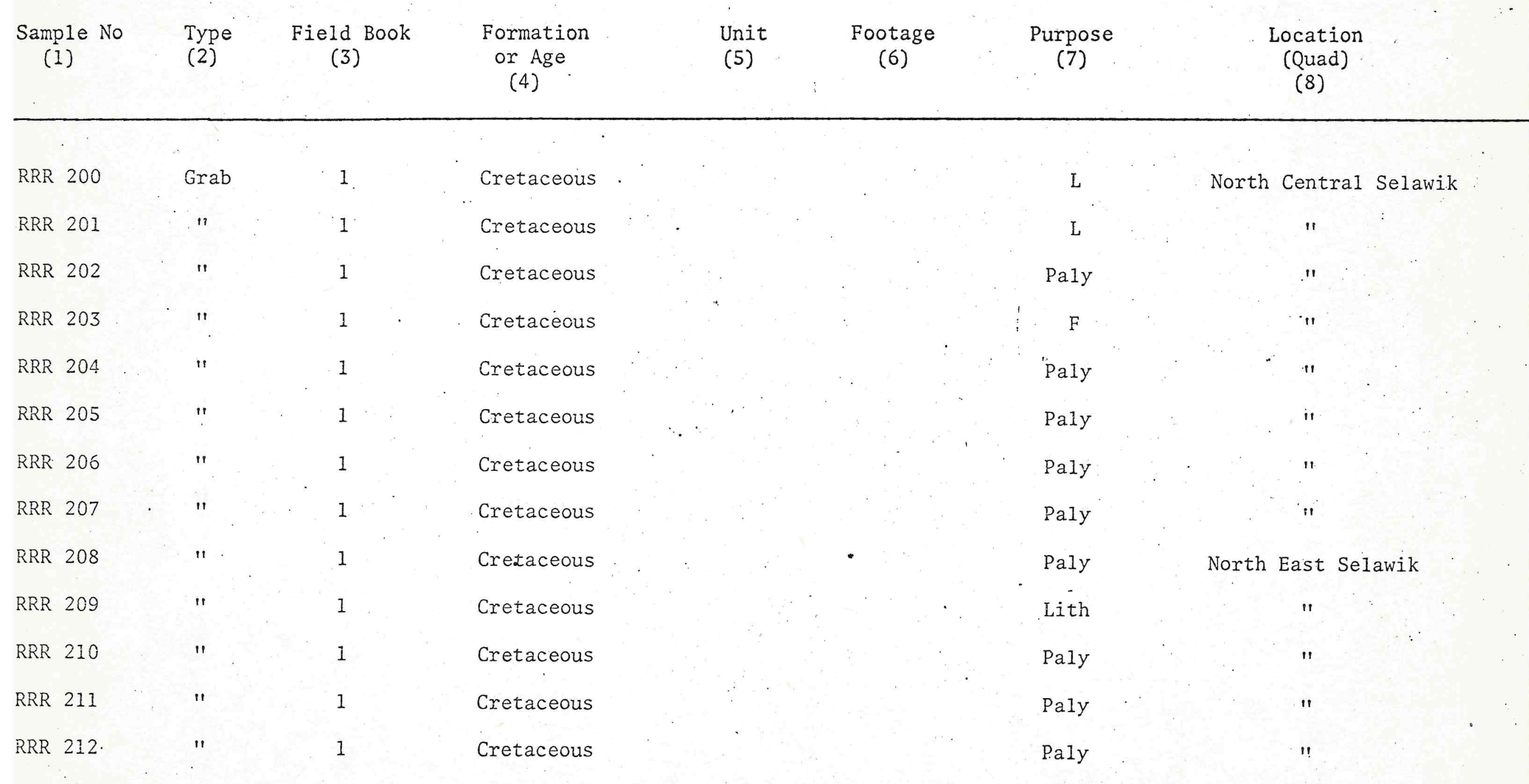




\begin{tabular}{|c|c|c|c|c|c|c|c|}
\hline $\begin{array}{l}\text { Sample No } \\
\text { (I) }\end{array}$ & $\begin{array}{l}\text { Type } \\
\text { (2) }\end{array}$ & $\begin{array}{l}\text { Field Book } \\
\text { (3) }\end{array}$ & $\begin{array}{l}\text { Formation } \\
\text { or Age } \\
\text { (4) }\end{array}$ & $\begin{array}{l}\text { Unit } \\
\text { (5) }\end{array}$ & $\begin{array}{c}\text { Footage } \\
(6)\end{array}$ & $\begin{array}{l}\text { Purpose } \\
\text { (7) }\end{array}$ & $\begin{array}{l}\text { Location } \\
\text { (Quad) } \\
\text { (8) }\end{array}$ \\
\hline RRR 227 & Grab & 1 & Unknown & & & Paly & Central Point Hope \\
\hline RRR 228 & $"$ & 1 & Jur.-Cret. & & & Paly & SE Point Hope \\
\hline RRR 229 & $"$ & 1 & Jur.-Cret. & & & $\mathrm{SR}$ & $\ldots$ \\
\hline RRR 230 & $"$ & 1 & Jur.-Cret. & $"$ & . & Paly & $" 1$ \\
\hline RRR 231 & $"$ & 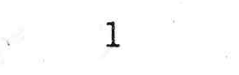 & Jur.-Cret. & & & $\therefore \mathrm{SR}$ &.$\quad .1$ \\
\hline RRR 232 & $"$ & 1 & Jur.-Cret. & $\cdot \cdots$ & & Paly & 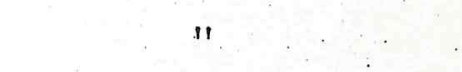 \\
\hline RRR 233 & $"$ & 1 & Jur.-Cret. & $\therefore$ & & SR & $"$ \\
\hline RRR 234 & $"$ & 1 & Skajit & & & $\mathrm{F}$ & NW Noatak \\
\hline RRR 235 & $" 1$ & 1 & Skajit & & . & f & $\because$ \\
\hline RRR 236 & $"$ & 1 & Huntfork & & & Paily & NW Survey Pass \\
\hline RRR 237 & $"$ & 1 & Unknown & & & $f$ & SE Howard Pass \\
\hline RRR 238 & $" 1$ & 1 & & $\because$ & & $\mathrm{C}$ & S.Central Baird Mtns. \\
\hline RRR 239. & $"$ & 1 & Meta Sediments & & & $\mathrm{L}$ & $"$ \\
\hline RRR 240! & " & 1 & Skajit & & & F & Central Baird Mtns. \\
\hline
\end{tabular}




\begin{tabular}{|c|c|c|c|c|c|c|c|}
\hline $\begin{array}{l}\text { Sample No } \\
\text { (I) }\end{array}$ & $\begin{array}{l}\text { Type } \\
\text { (2) }\end{array}$ & $\begin{array}{l}\text { Field Book } \\
\text { (3) }\end{array}$ & $\begin{array}{l}\text { Formation } \\
\text { or Age } \\
\text { (4) }\end{array}$ & $\begin{array}{l}\text { Unit } \\
\text { (5) }\end{array}$ & $\begin{array}{l}\text { Footage } \\
\text { (6) }\end{array}$ & $\begin{array}{l}\text { Purpose } \\
\text { (7) }\end{array}$ & $\begin{array}{l}\text { Location } \\
\text { (Quad) } \\
\text { (8) }\end{array}$ \\
\hline
\end{tabular}

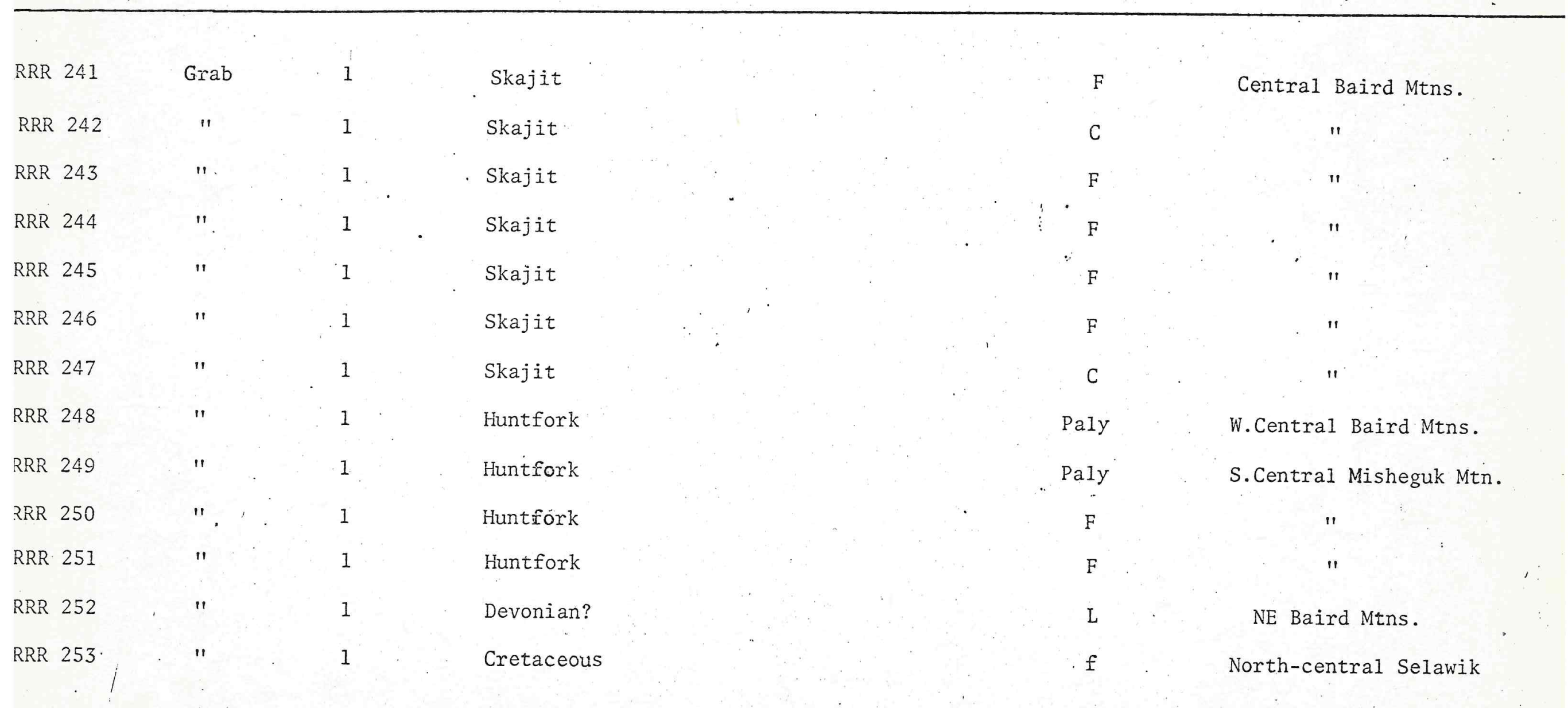




\section{Continued}

$\begin{array}{cccccccc}\text { Sample No } & \text { Type } & \text { Field Book } & \text { Formation } & \text { Unit } & \text { Footage } & \text { Purpose } & \text { Location } \\ \text { (1) } & (2) & (3) & \text { or Age } & (5) & (6) & (7) & \text { (Quad) } \\ & & & (4) & & & & \end{array}$

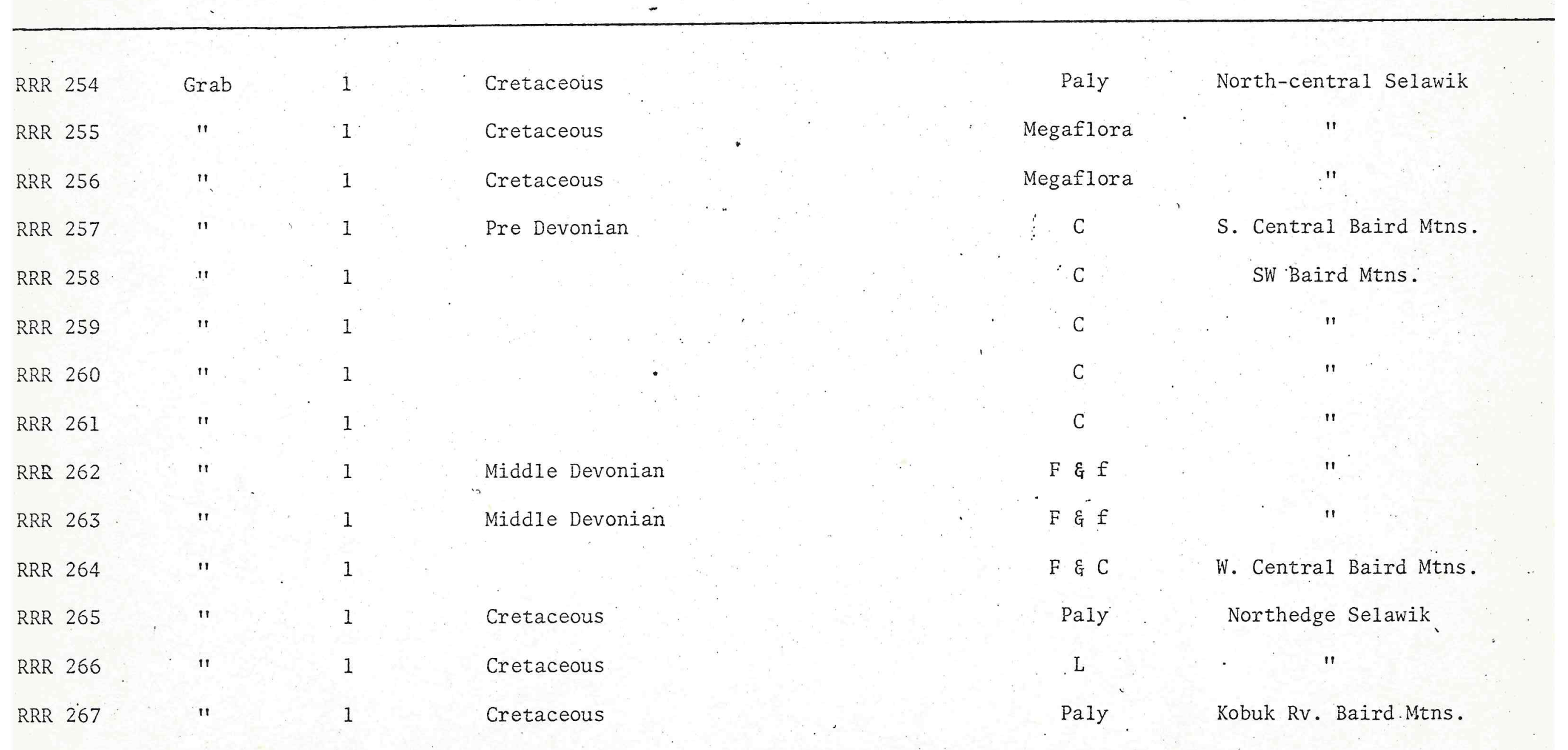




\section{Continued}

\begin{tabular}{|c|c|c|c|c|c|c|c|}
\hline $\begin{array}{l}\text { Sample No } \\
\text { (1) }\end{array}$ & $\begin{array}{l}\text { Type } \\
\text { (2) }\end{array}$ & $\begin{array}{l}\text { Field Book } \\
\text { (3) }\end{array}$ & $\begin{array}{l}\text { Formation } \\
\text { or Age } \\
\text { (4) }\end{array}$ & $\begin{array}{l}\text { Unit } \\
\text { (5) }\end{array}$ & $\begin{array}{c}\text { Footage } \\
(6)\end{array}$ & $\begin{array}{l}\text { Purpose } \\
\text { (7) }\end{array}$ & $\begin{array}{l}\text { Location } \\
\text { (Quad) } \\
\text { (8) }\end{array}$ \\
\hline
\end{tabular}

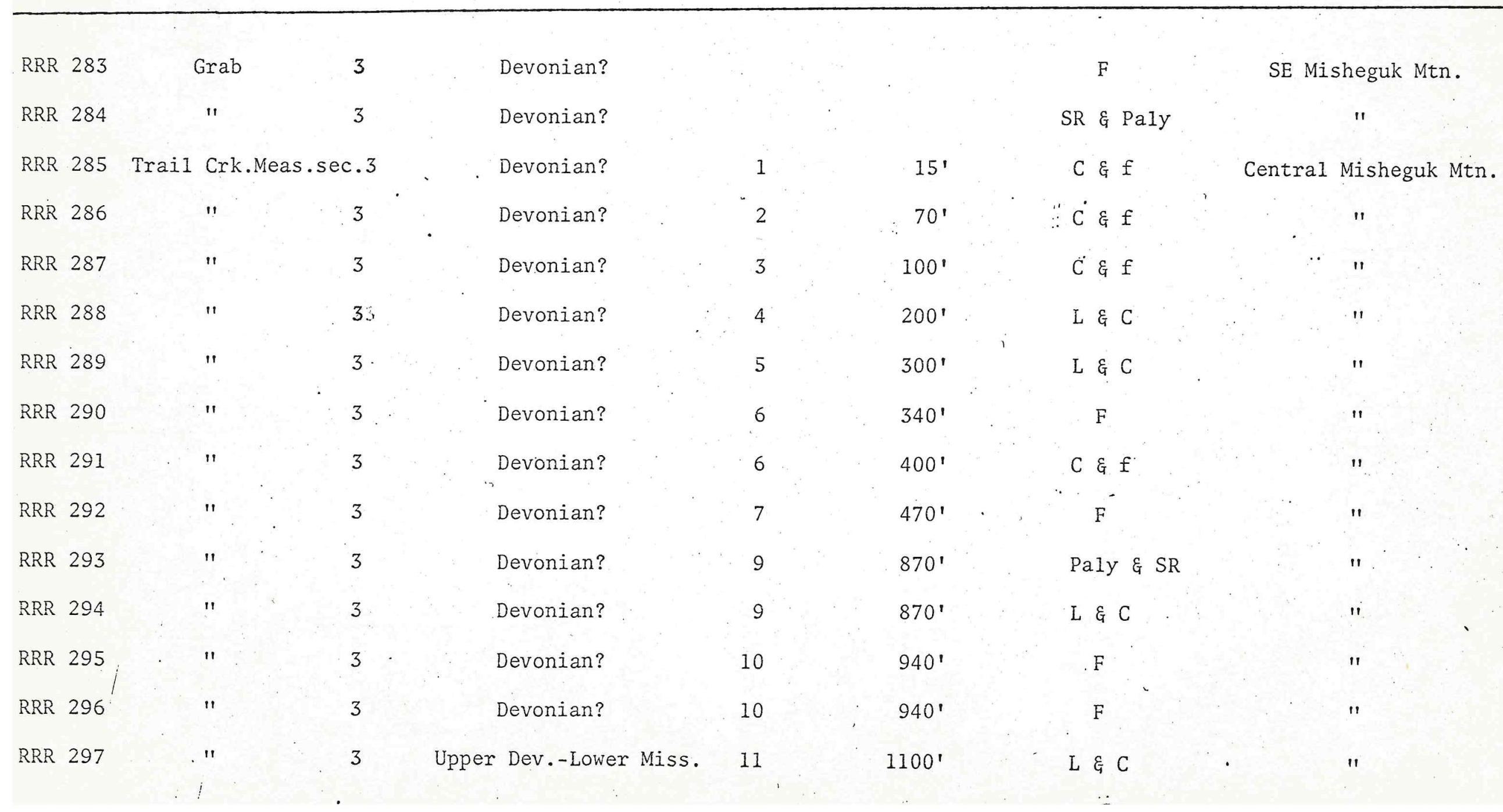


Continued

\begin{tabular}{|c|c|c|c|c|c|c|c|}
\hline $\begin{array}{l}\text { Sample No } \\
\text { (1) }\end{array}$ & $\begin{array}{l}\text { Type } \\
\text { (2) }\end{array}$ & $\begin{array}{l}\text { Field Book } \\
\text { (3) }\end{array}$ & $\begin{array}{c}\text { Formation } \\
\text { or Age } \\
\text { (4) }\end{array}$ & $\begin{array}{l}\text { Unit } \\
(5)\end{array}$ & $\begin{array}{c}\text { Footage } \\
\text { (6) }\end{array}$ & $\begin{array}{l}\text { Purpose } \\
\text { (7) }\end{array}$ & $\begin{array}{l}\text { Location } \\
\text { (Quad) } \\
\text { (8) }\end{array}$ \\
\hline
\end{tabular}

RRR 326

F

SE Misheguk Mtn.

RRR 327

RRR 328

RRR 329

RRR 330

RRR 331

RRR 332

RRR 333

RRR 334

RRR 335

RRR 336

RRR 337

RRR 338

$$
"
$$

Cretaceous

Shublik

Unknown

"

$"$

Cretaceous-Jur.

C (F?)

"

$f \&$ Paly Central Misheguk Mtn.

F

Paly \& SR

Paly \& SR

Paly \& SR

$\mathrm{L}$

Utukok

Cretaceous

F

W.Central Misheguk Mtn.

$f \&$ Paly

NE Misheguk Mtn.

Cretaceous

L \& PaIy

Cretaceous

$f \&$ Paly

Central Misheguk Mtn.

Cretaceous

Paly' \& $S R$

f. \& Paly 
Continued

\begin{tabular}{|c|c|c|c|c|c|c|c|}
\hline $\begin{array}{l}\text { Sample No } \\
\text { (1) }\end{array}$ & $\begin{array}{l}\text { Type } \\
(2)\end{array}$ & $\begin{array}{l}\text { Field Book } \\
\text { (3) }\end{array}$ & $\begin{array}{l}\text { Formation } \\
\text { or Age } \\
\text { (4) }\end{array}$ & $\begin{array}{l}\text { Unit } \\
\text { (5) }\end{array}$ & $\begin{array}{l}\text { Footage } \\
\text { (6) }\end{array}$ & $\begin{array}{c}\text { Purpose } \\
\text { (7) }\end{array}$ & $\begin{array}{l}\text { Location } \\
\text { (Quad) } \\
(8)\end{array}$ \\
\hline
\end{tabular}

RRR 341 Gra

Devonian or older

RRR 342

RRR 343

RRR 344

RRR 345

RRR 346

RRR 347

RRR 348

RRR 349

RRR 350

RRR 351

RRR 352

RRR 353

RRR 354

3

113

11 3

113

!

"

$"$

"

11 3

iा

"1 3

$11 \quad 3$ Devonian or older

Middle Devonian
W.Central Ambler Rv.

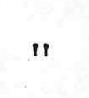

"

C

c

C

NW Ambler Rv.

F

F

$\mathrm{L}$

(2) F

" F

F

$F \& C$

$f \xi C$

L Central Ambler Rv. 
Zontinued

jample No

\section{(1)}

Type Field Book

Formation

Unit

Footage

Purpose

Location

(4)

(5)

(6)

(7)

(8)

\begin{tabular}{|c|c|}
\hline RRR 355 & Grab \\
\hline RRR 356 & $"$ \\
\hline RRR 357 & $"$ \\
\hline RRR 358 & $" 1$ \\
\hline RRR 359 & $"$ \\
\hline RRR 360 & $" 1$ \\
\hline RRR 361 & $"$ \\
\hline RRR 362 & $"$ \\
\hline RRR 363 & $"$ \\
\hline RRR 364 & $"$ \\
\hline RRR 365 & $"$ \\
\hline RRR 366 & $"$ \\
\hline RRR 367 & $"$ \\
\hline RRR 368 & " \\
\hline
\end{tabular}

Devonian or older

C

N.Central Ambler Rv.

3.

3

Huntfork

C

Paly

Huntfork

Kanyut

Pre-Devonian

"

Devonian

$\therefore \mathrm{C}$

. L

Paly \& SR

Paly \& SR

Paly

.

Paly

Unknown

Unknown

Pre-Devonian

$L \& \frac{f}{1}$

$L \notin f$

Paly \& SR

Early Cretaceous

W. Central Survey Pass

East edge Ambler Rv.

NW Survey Pass

".

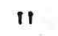

"

iI

SW Survey Pass 
Sontinued

sample No

$$
\text { (I) }
$$

Type Field Book

Formation

Unit

or Age

(5)

Footage

Purpose

Location

(4)

(8)

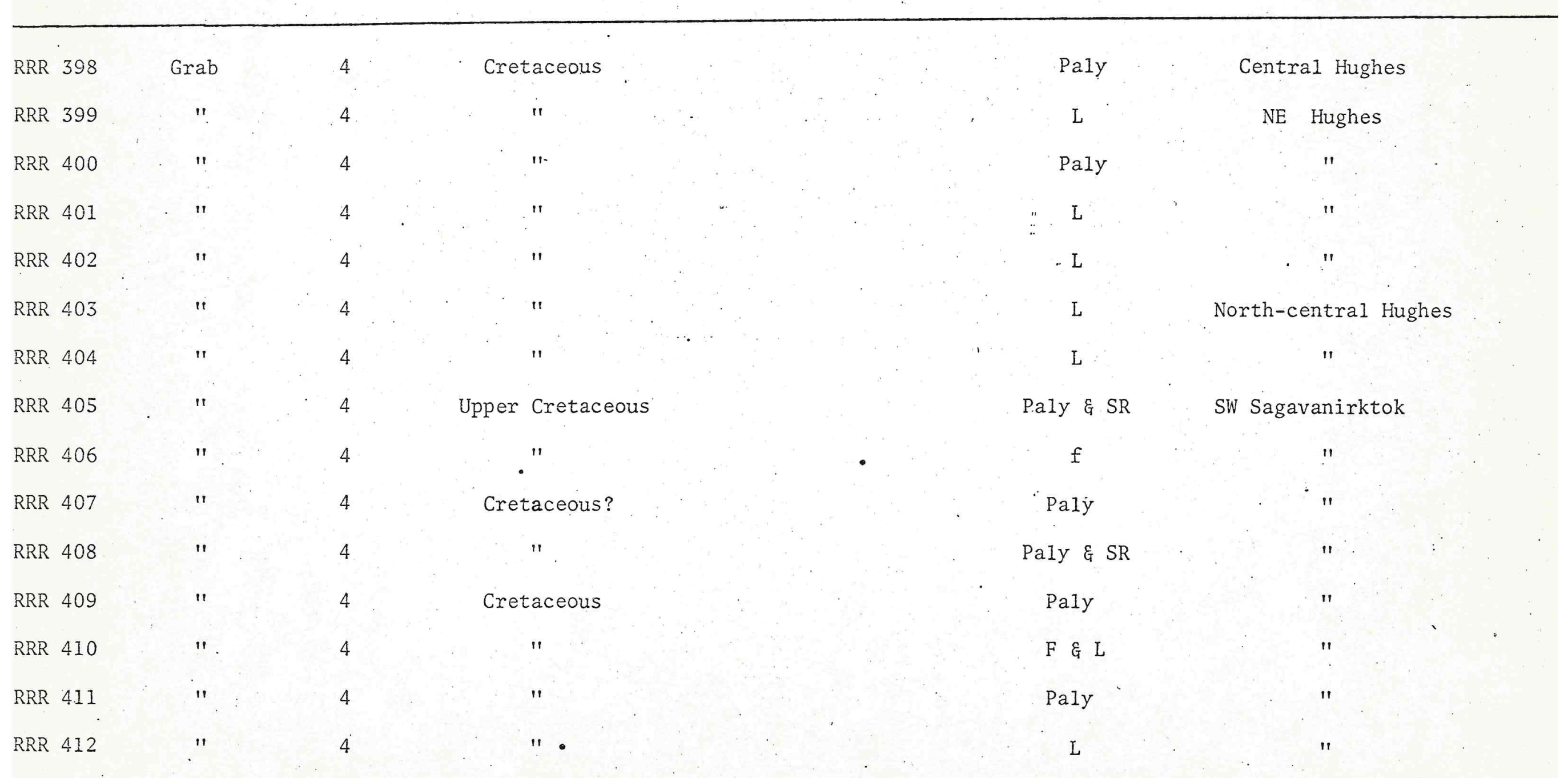


Continued

\begin{tabular}{|c|c|c|c|c|c|c|c|}
\hline $\begin{array}{l}\text { Sample No } \\
\text { (1) }\end{array}$ & $\begin{array}{l}\text { Type } \\
\text { (2) }\end{array}$ & $\begin{array}{l}\text { Field Book } \\
\text { (3) }\end{array}$ & $\begin{array}{c}\text { Formation } \\
\text { or Age } \\
\text { (4) }\end{array}$ & $\begin{array}{l}\text { Unit } \\
\text { (5) }\end{array}$ & $\begin{array}{c}\text { Footage } \\
(6)\end{array}$ & $\begin{array}{l}\text { Purpose } \\
\text { (7) }\end{array}$ & $\begin{array}{l}\text { Location } \\
\text { (Quad) } \\
\text { (8) }\end{array}$ \\
\hline RRR 413 & Grab & 4 & Cretaceous & & & $\mathrm{L}$ & SW Sagavanirktok \\
\hline RRR 414 & " & 4 & $"$ & & & $\mathrm{~L}$ & $"$ \\
\hline RRR 415 & $"$ & 4 & $"$ & & & Paly $\& f$ & S.Central Sagavanirktol \\
\hline RRR 416 & $"$ & 4 & $"$ & - & & $\ddots_{L}$ & $"$ \\
\hline RRR 417 & $"$ & 4 & $"$ & & & Paily \& $f$ & $"$ \\
\hline RRR 418 & $"$ & 4 & $"$ & & & $\mathrm{~L}$ & $"$ \\
\hline RRR 419 & " & 4 & $"$ & & & Paly \& $f$ & $"$ \\
\hline RRR 420 & $"$ & 4 & $"$ & & & Paly $\& f$ & $"$ \\
\hline RRR 421 & $"$ & 4 & " & & & $\mathrm{L}$. & $"$ \\
\hline RRR 422 & $"$ & 4 & $"$ & & & Paly \& $f$ & $"$ \\
\hline RRR 423 & $"$ & 4 & $"$ & & & Paly $\& f$ & $"$ \\
\hline RRR 424 & $"$ & 4 & $"$ & & & $\mathrm{~L}$ & $"$ \\
\hline RRR 425 & $"$ & 4 & $"$ & & & Paly \& $f \& S R$ & $"$ \\
\hline RRR 426 & $"$ & 4 & $"$ & & & $\mathrm{~L}$ & $"$ \\
\hline RRR 427 & $"$ & 4 & $"$ & & & Paly \& $f$ & $"$ \\
\hline
\end{tabular}


Zontinued

jample No

(1)

Typ

Field Book

(3)

Formation

or Age

Unit

(5)

Footage

(6)

Purpose

(7)

Location

(Quad)

(8)

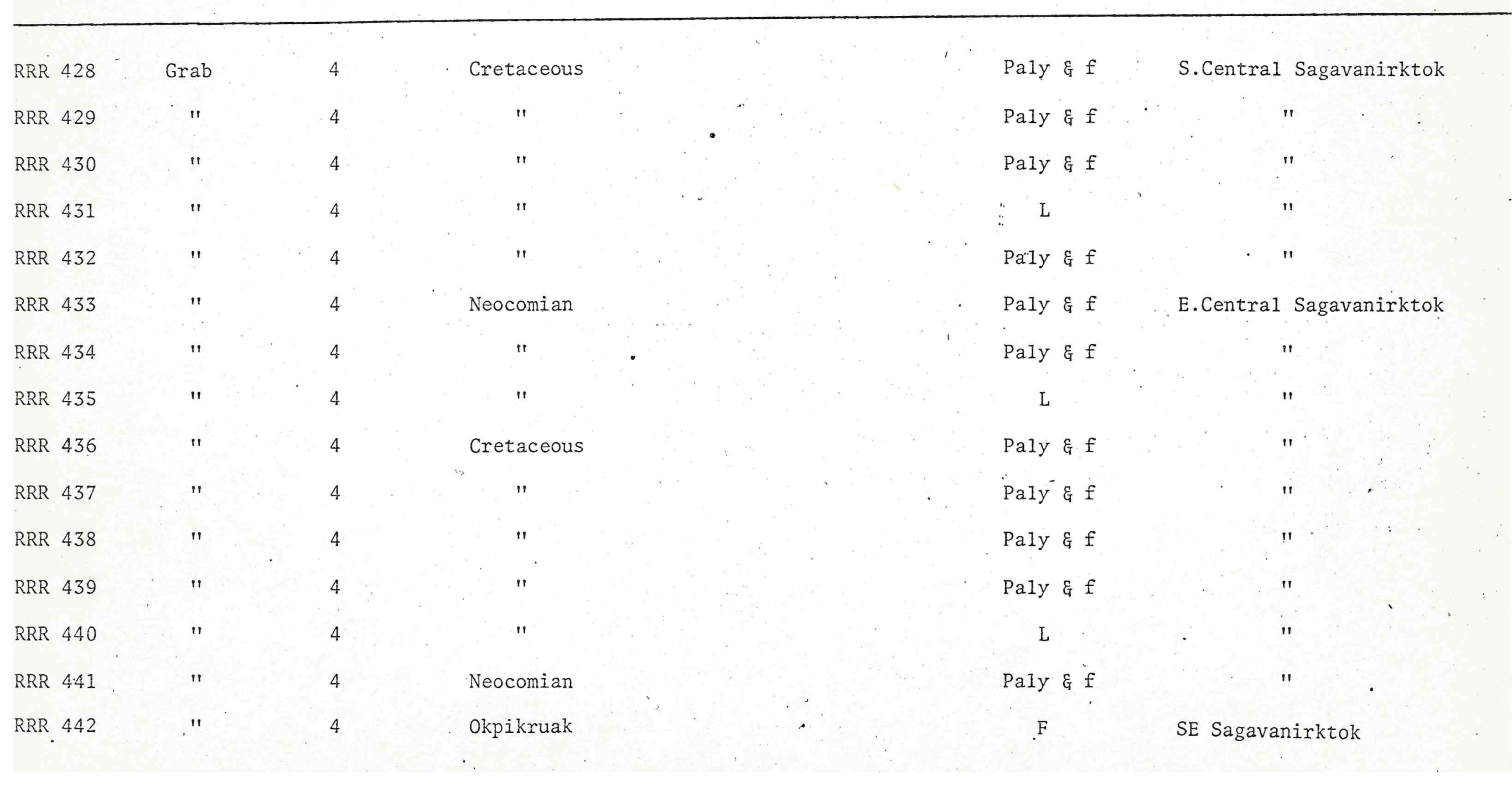


Continued

$\begin{array}{cccccccc}\text { Sample No } & \text { Type } & \text { Field Book } & \text { Formation } & \text { Unit } & \text { Footage } & \text { Purpose } & \text { Location } \\ \text { (1) } & (2) & (3) & \text { or Age } & (5) & (6) & (7) & \text { (Quad) } \\ & & & (4) & & & & \end{array}$

\begin{tabular}{|c|c|c|c|c|c|}
\hline RRR 443 & Grab & 4 & Okpikruak & Paly \& $f$ & SE Sagavanirktok \\
\hline RRR 444 & $"$ & 4 & $"$ & $"$ & $"$ \\
\hline RRR 445 & ". & 4 & $"$ & $"$ & " \\
\hline RRR 446 & $"$ & 4 & $"$ & $"$ & $"$ \\
\hline RRR 44.7 & $"$ & 4 & Tertiary? & Paly & E.Central Sagavanirktok \\
\hline RRR 448 & $"$ & 4 & Tertiary? & L & $"$ \\
\hline
\end{tabular}




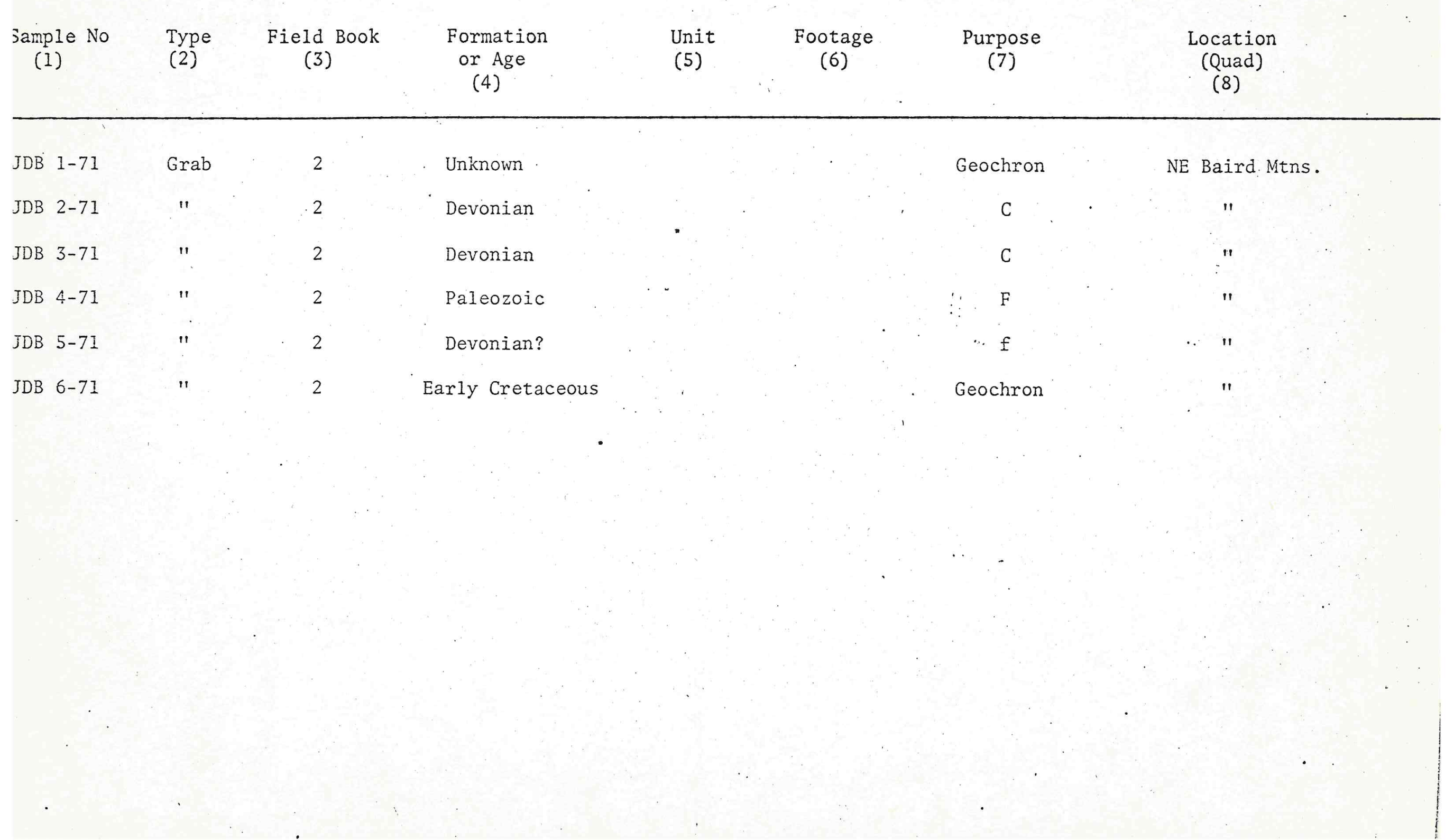





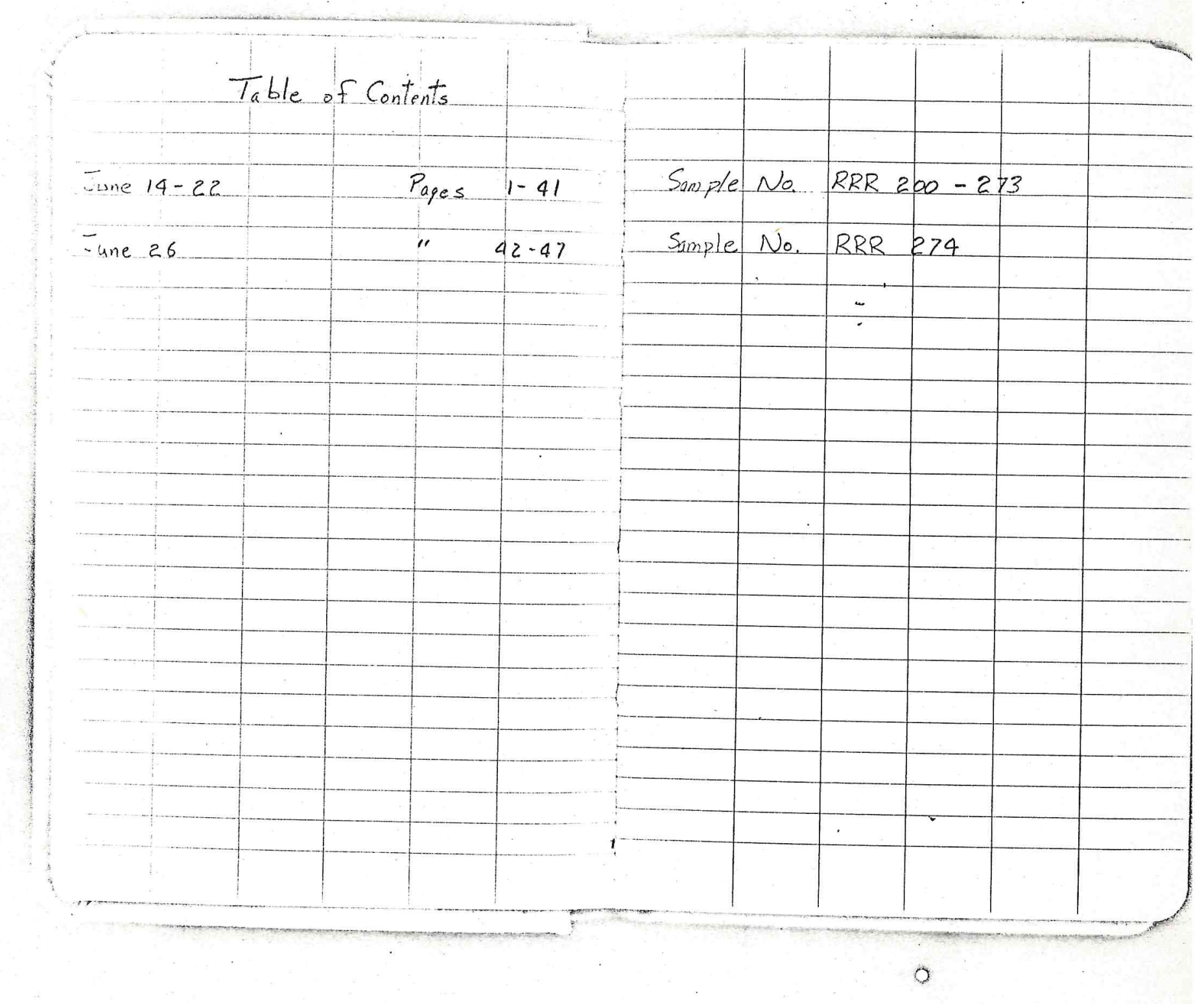




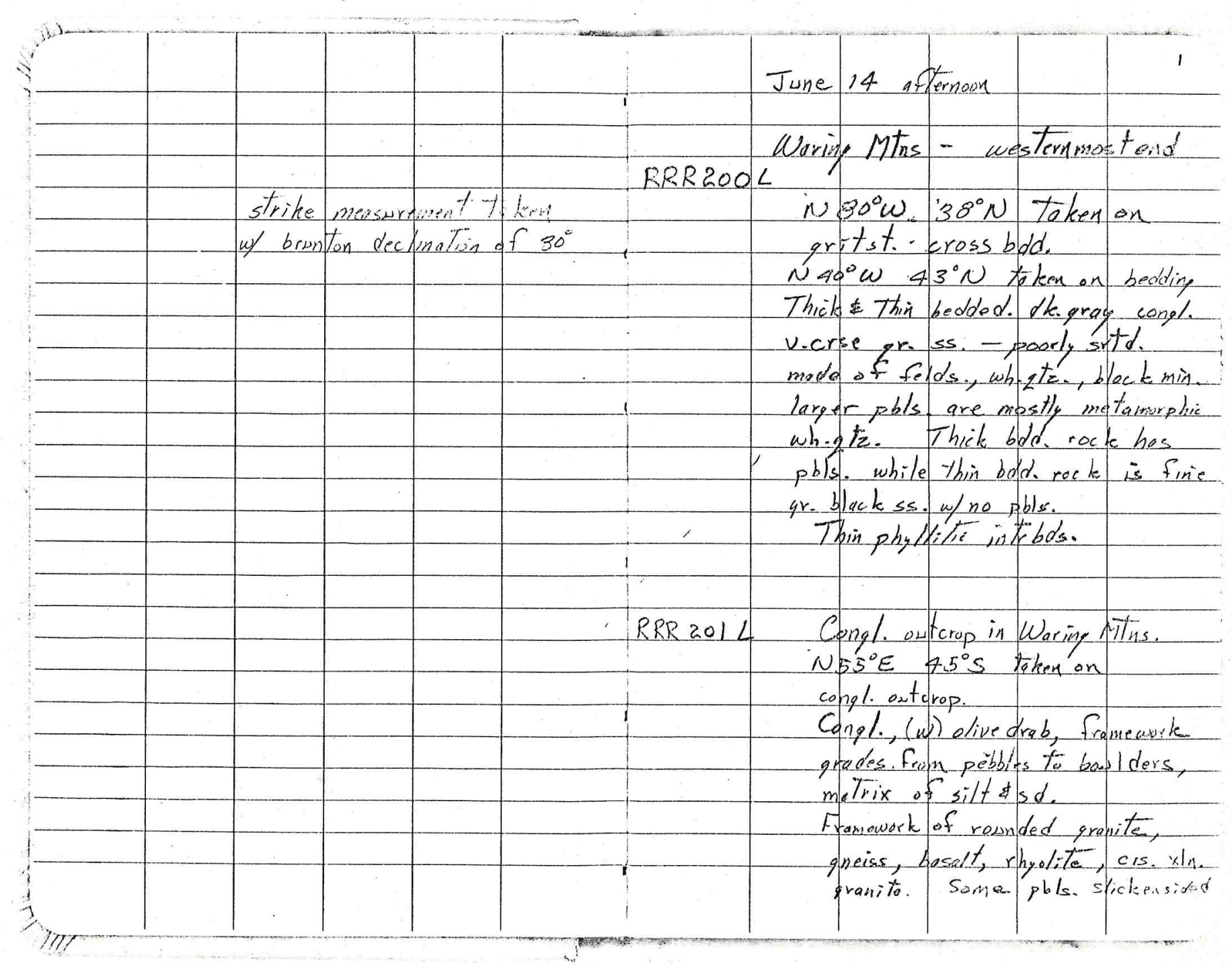




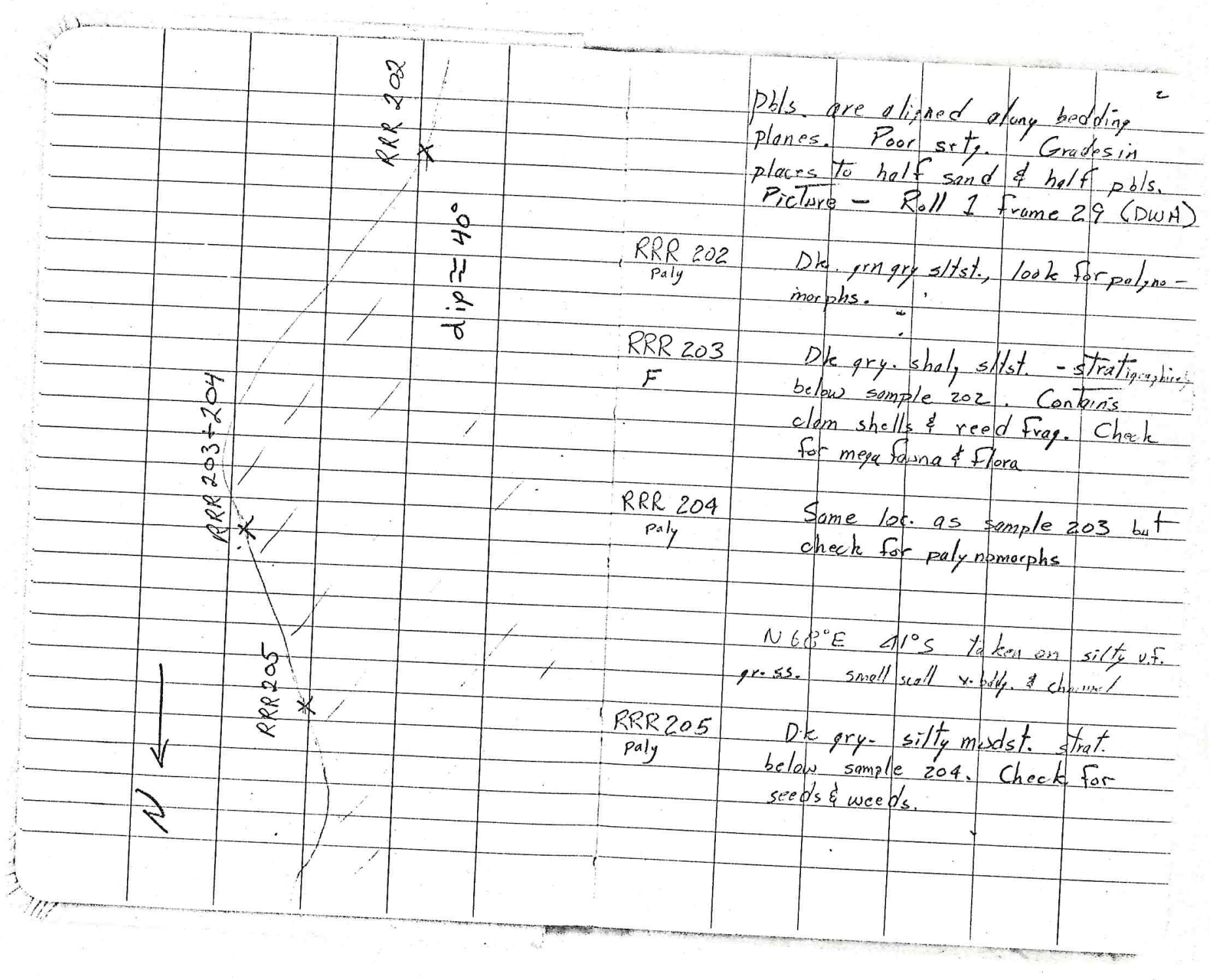




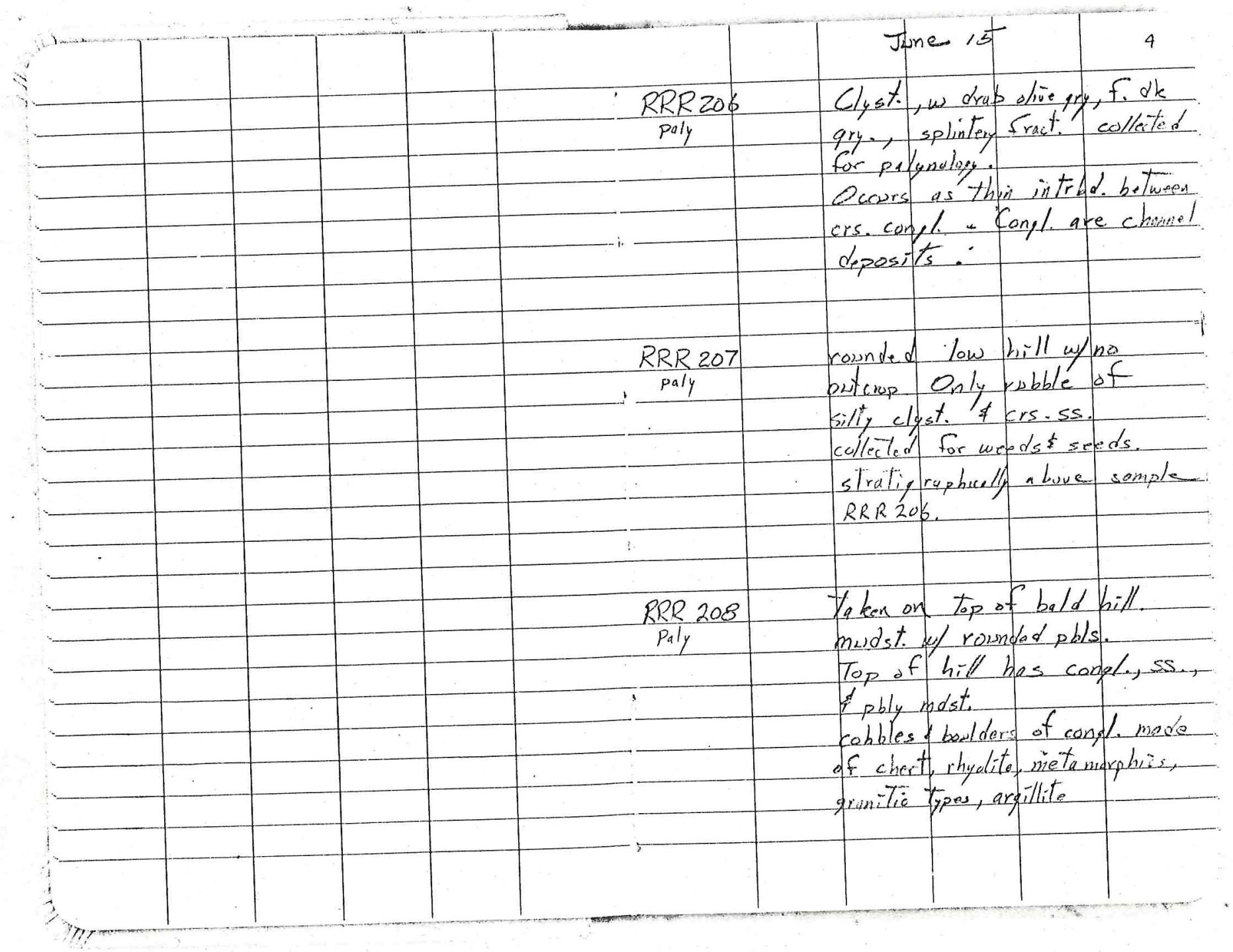




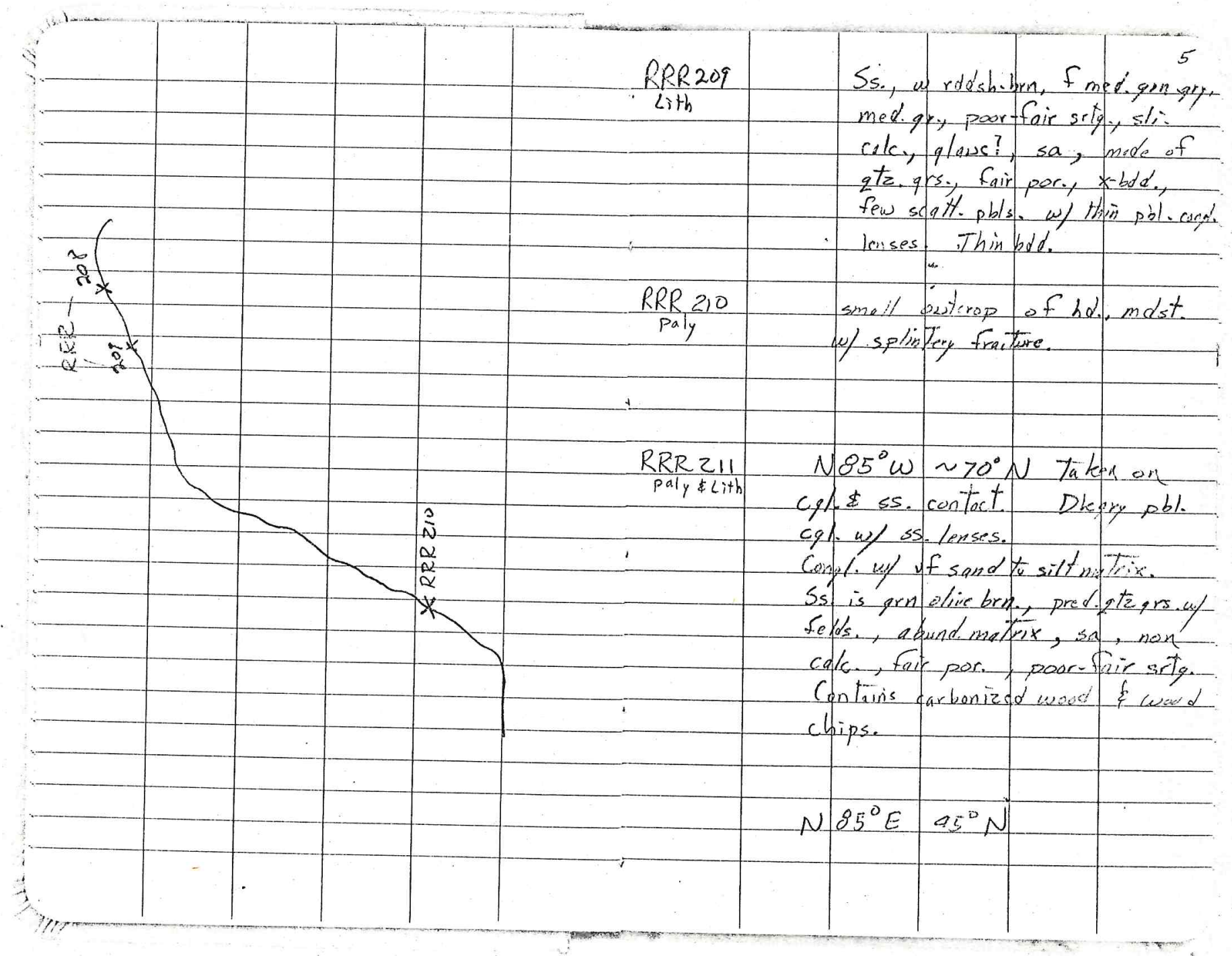




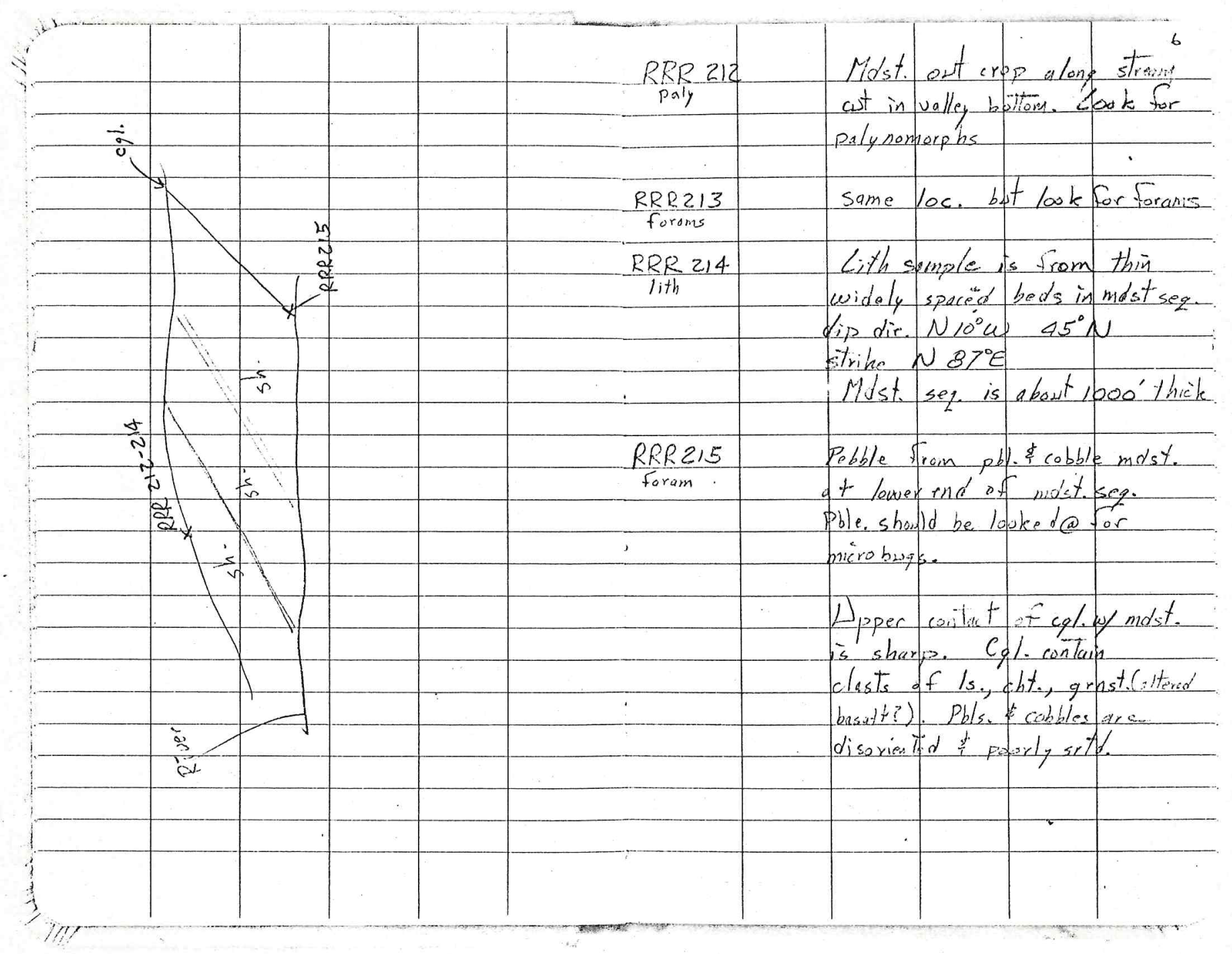




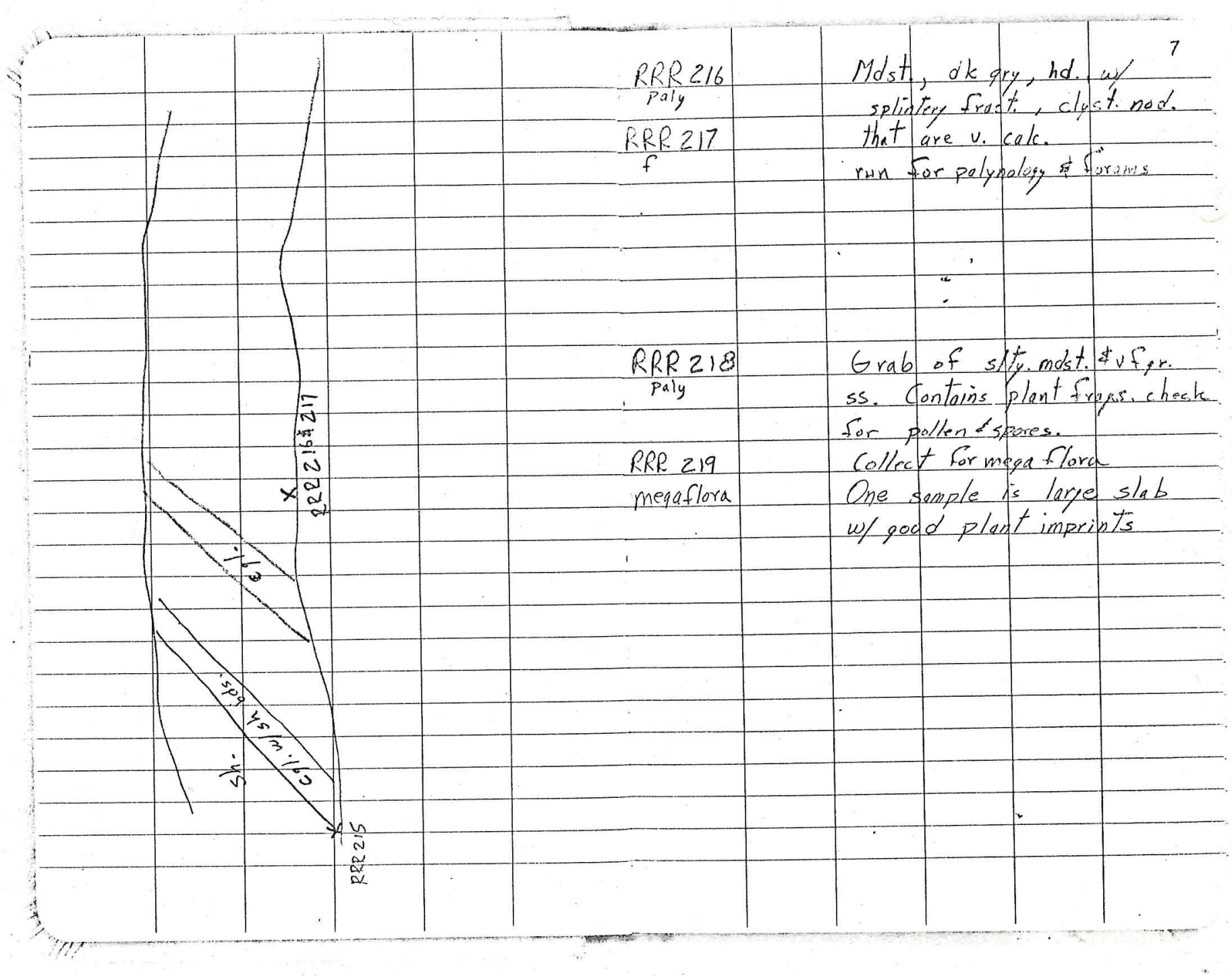




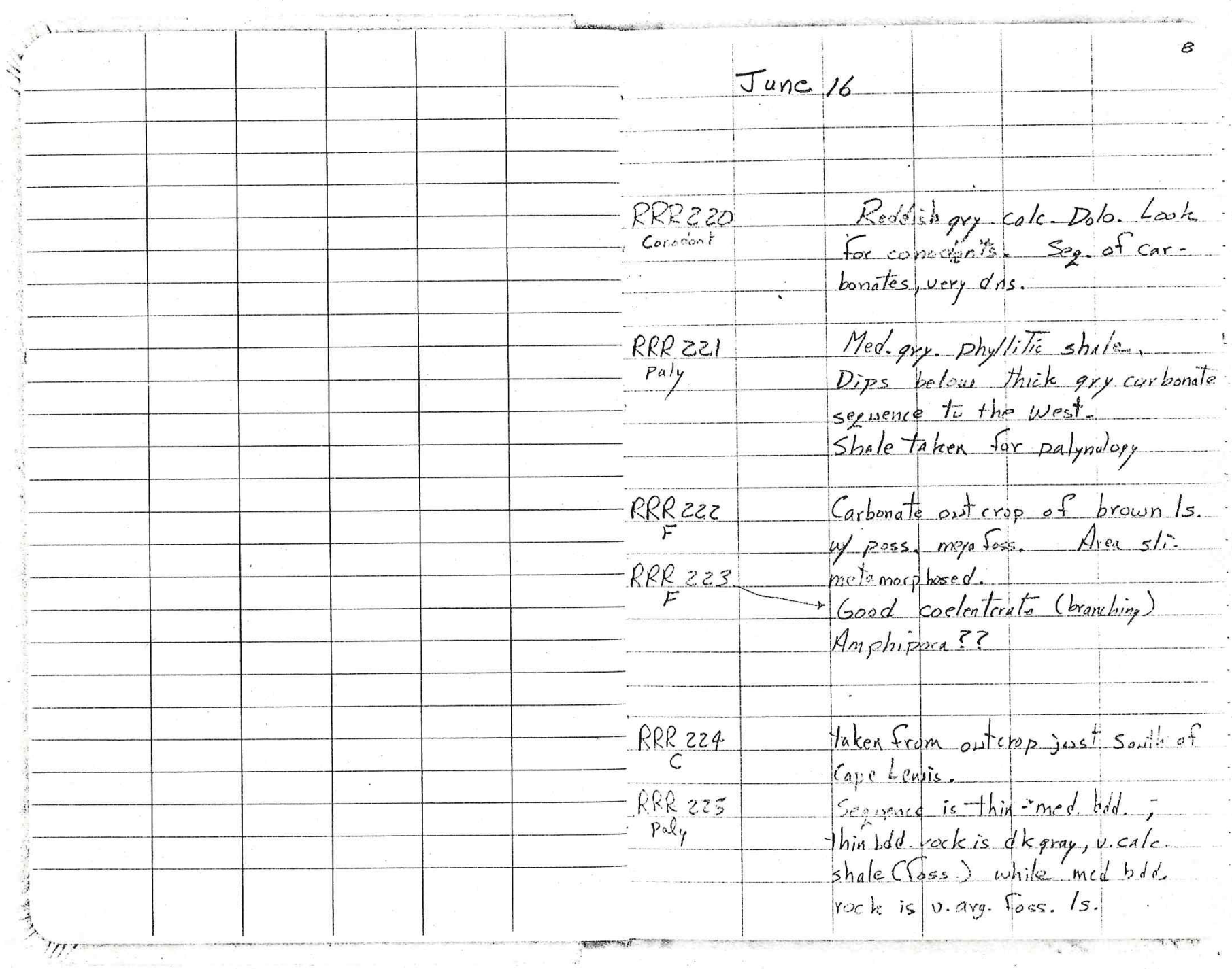




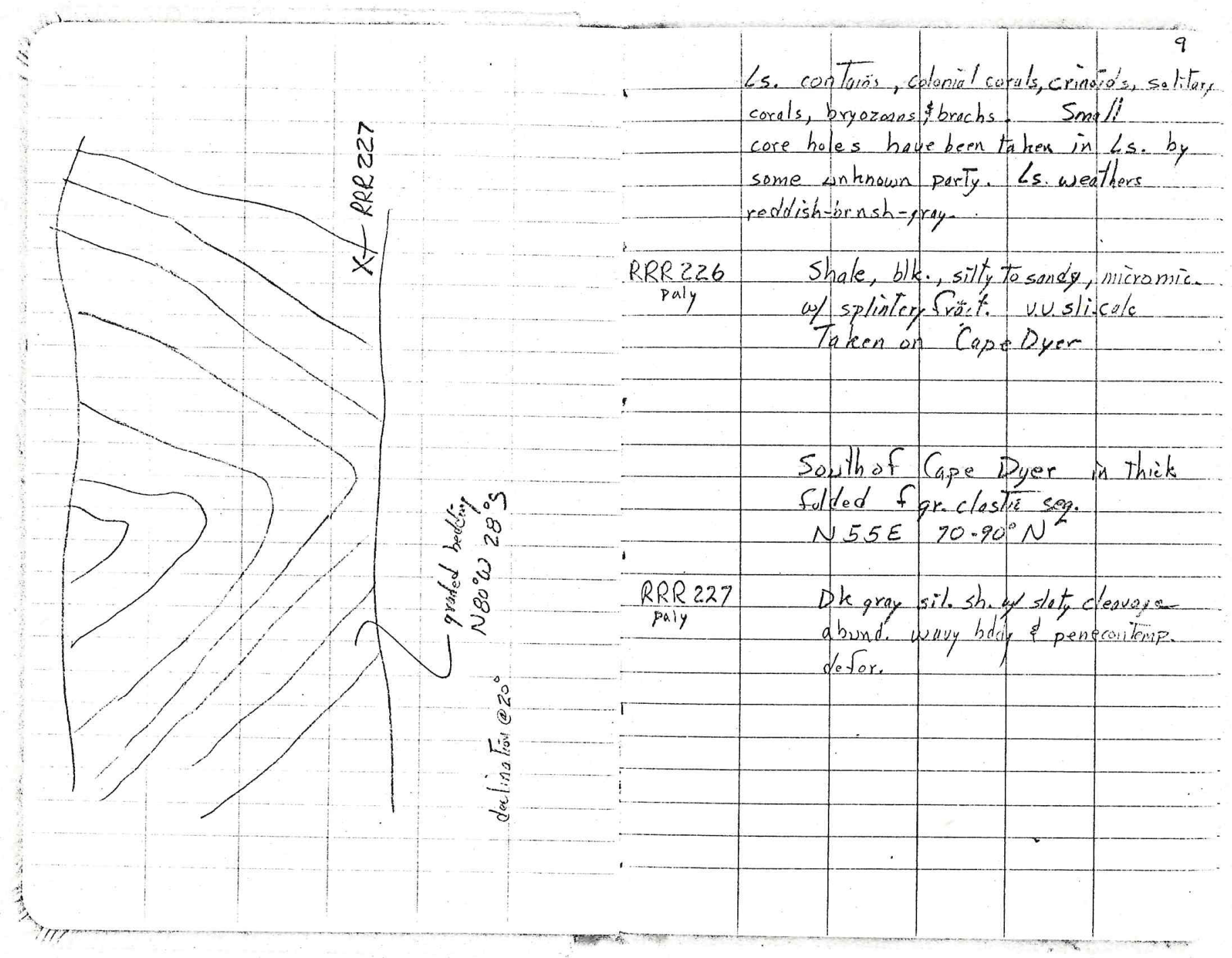




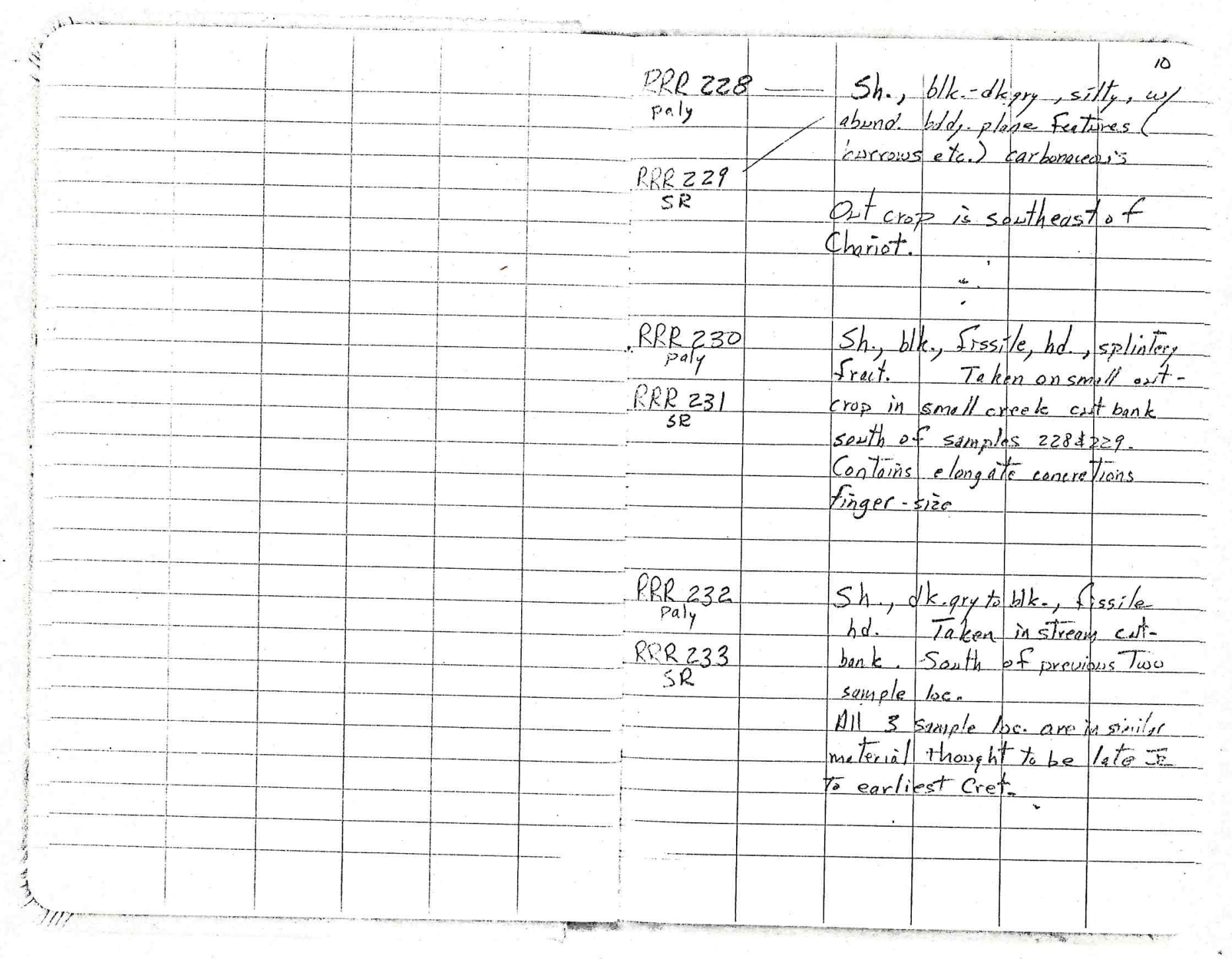




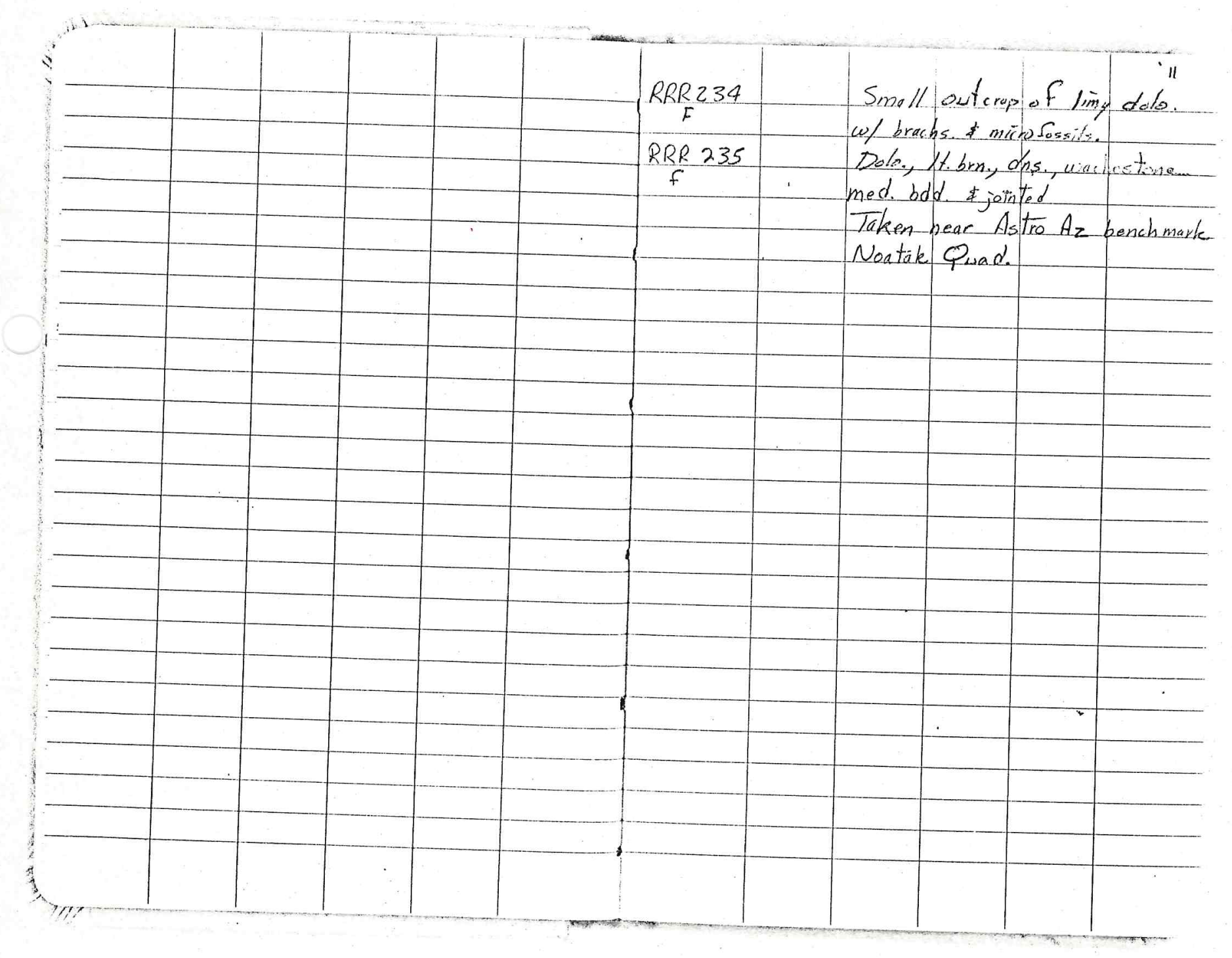




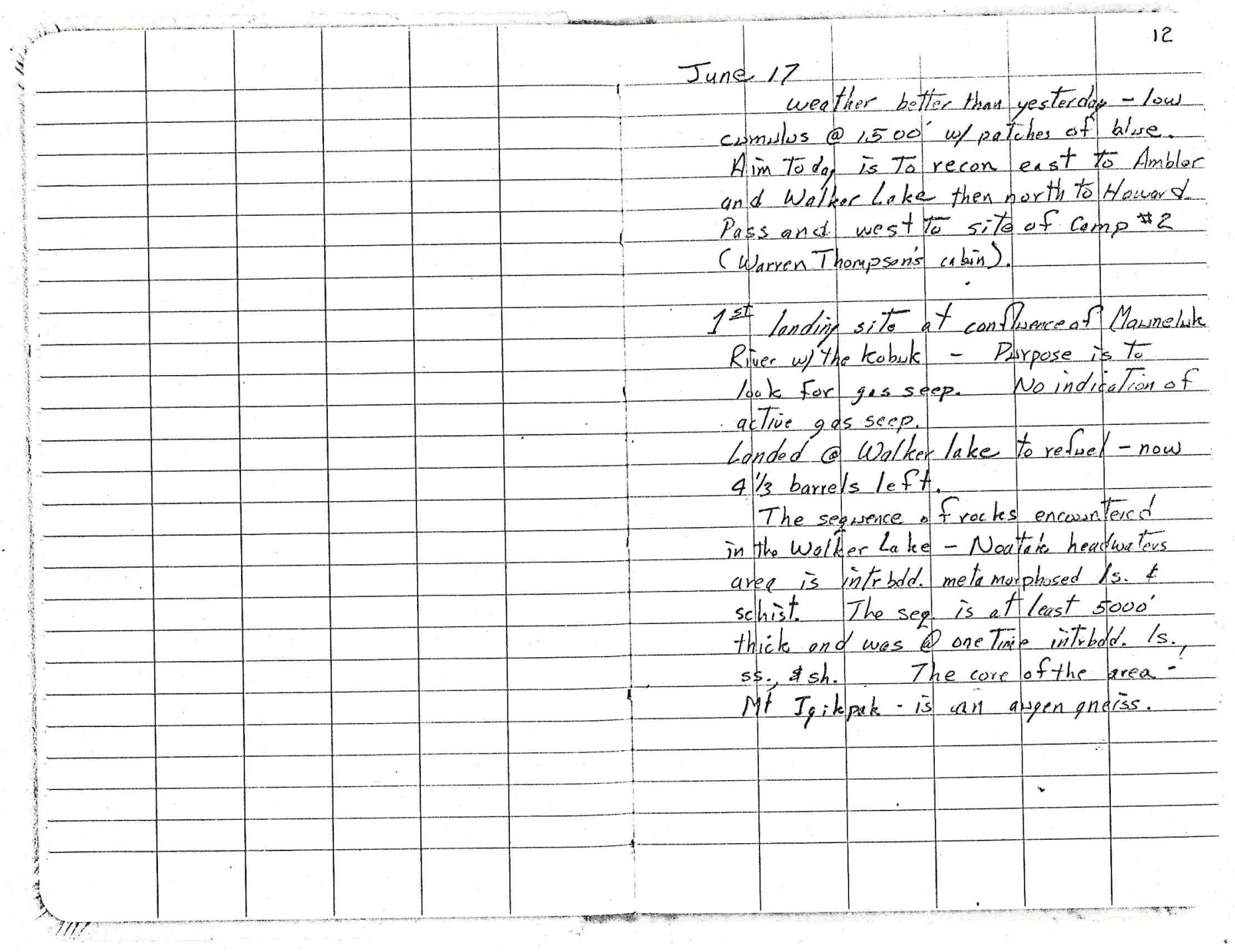




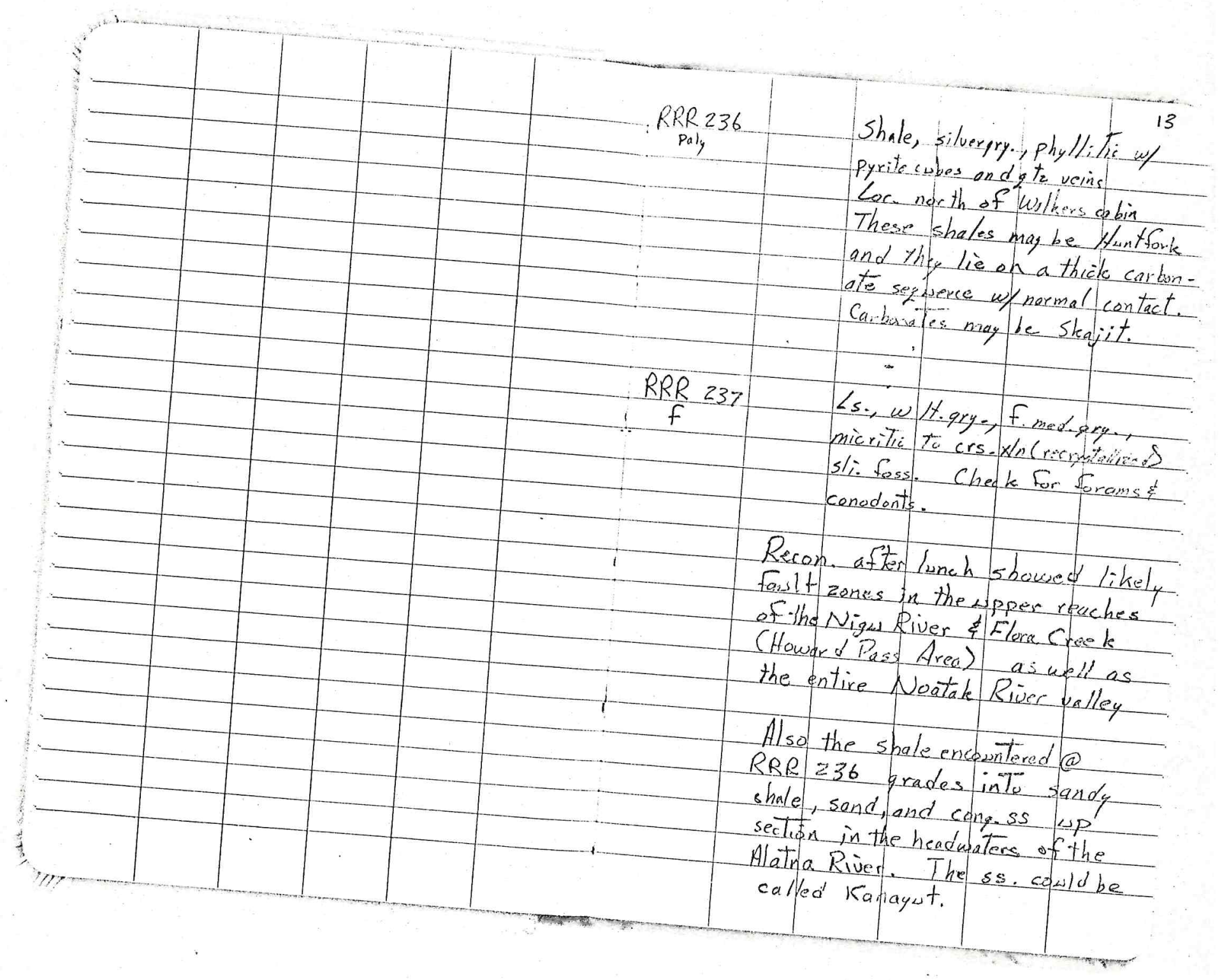




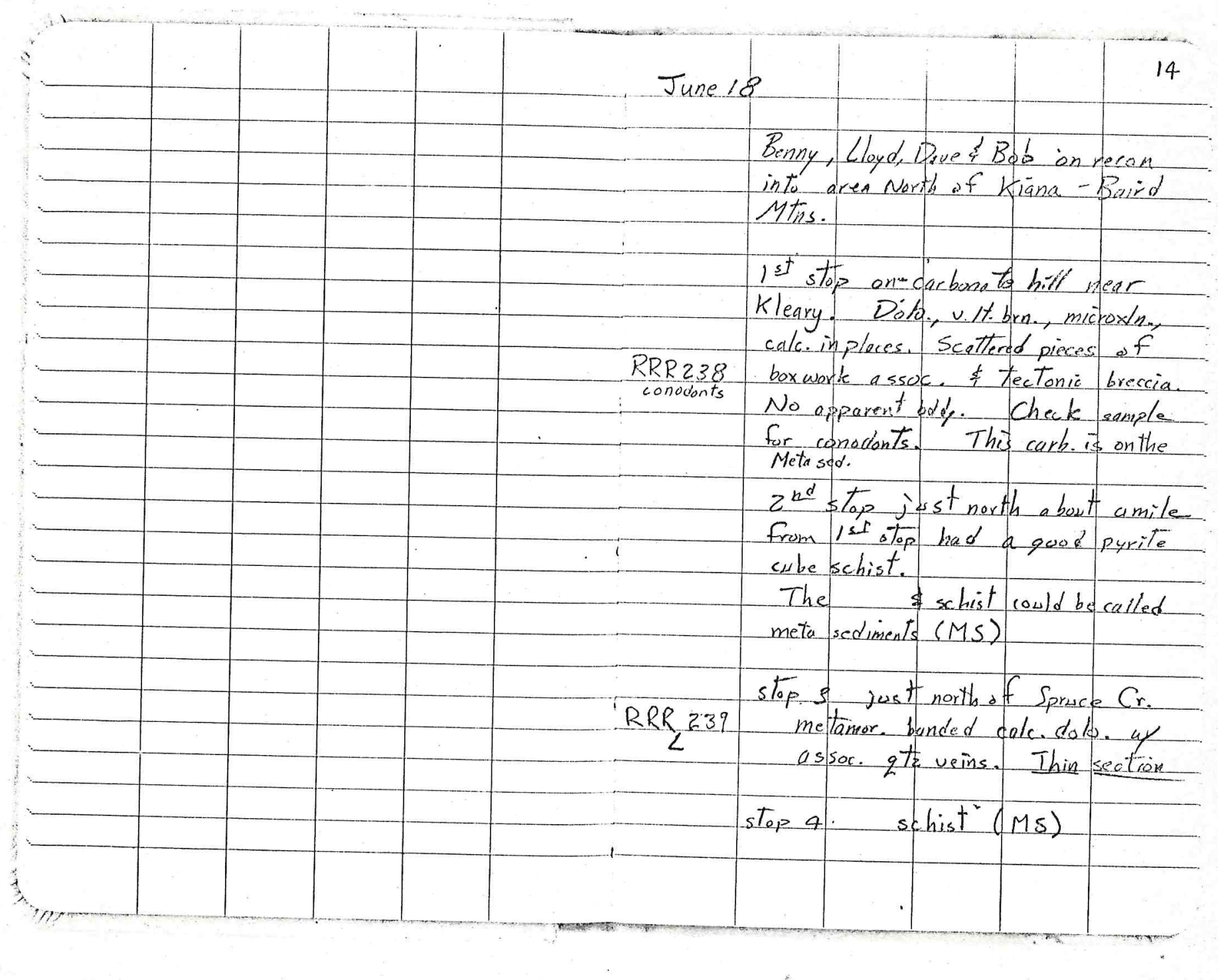




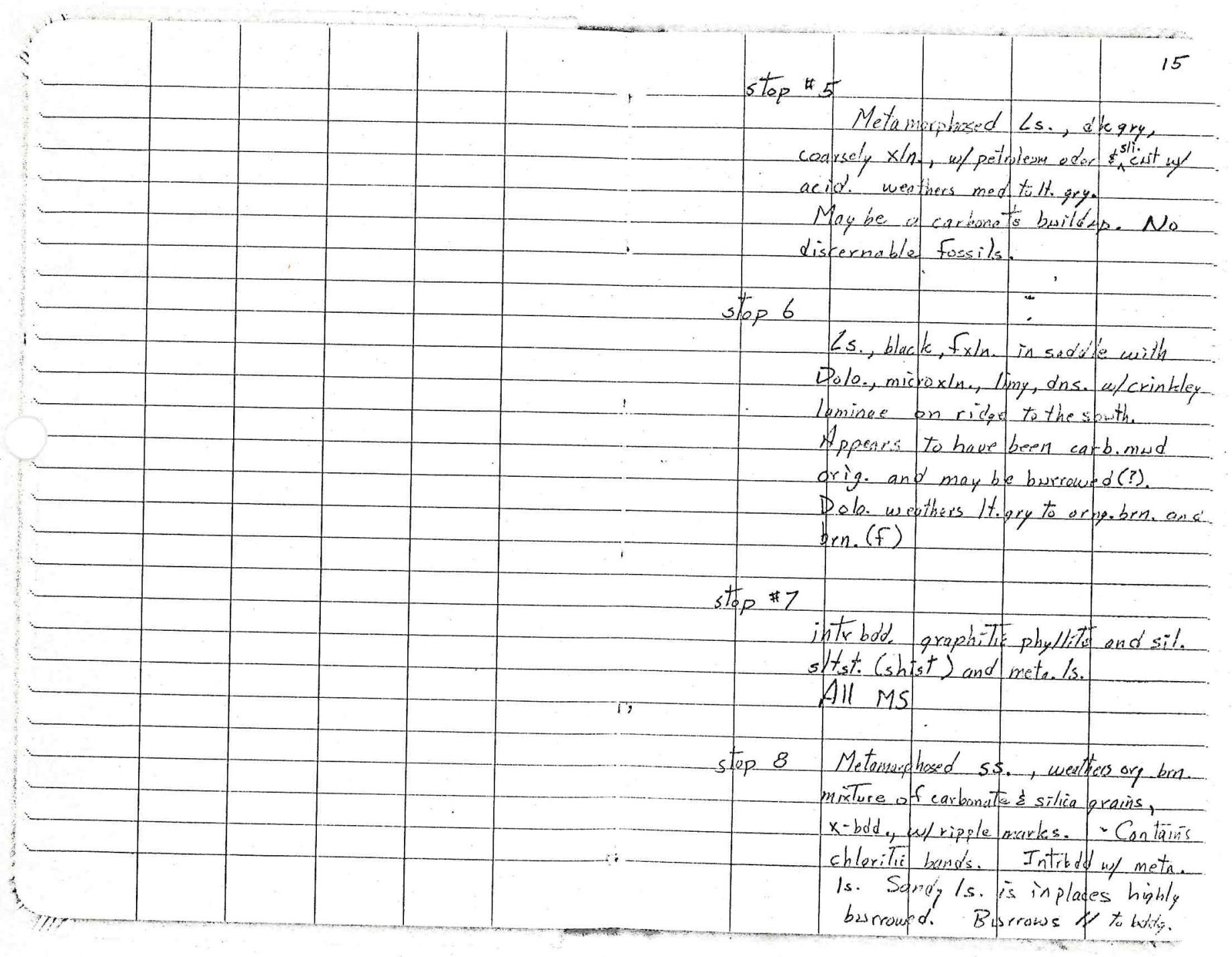




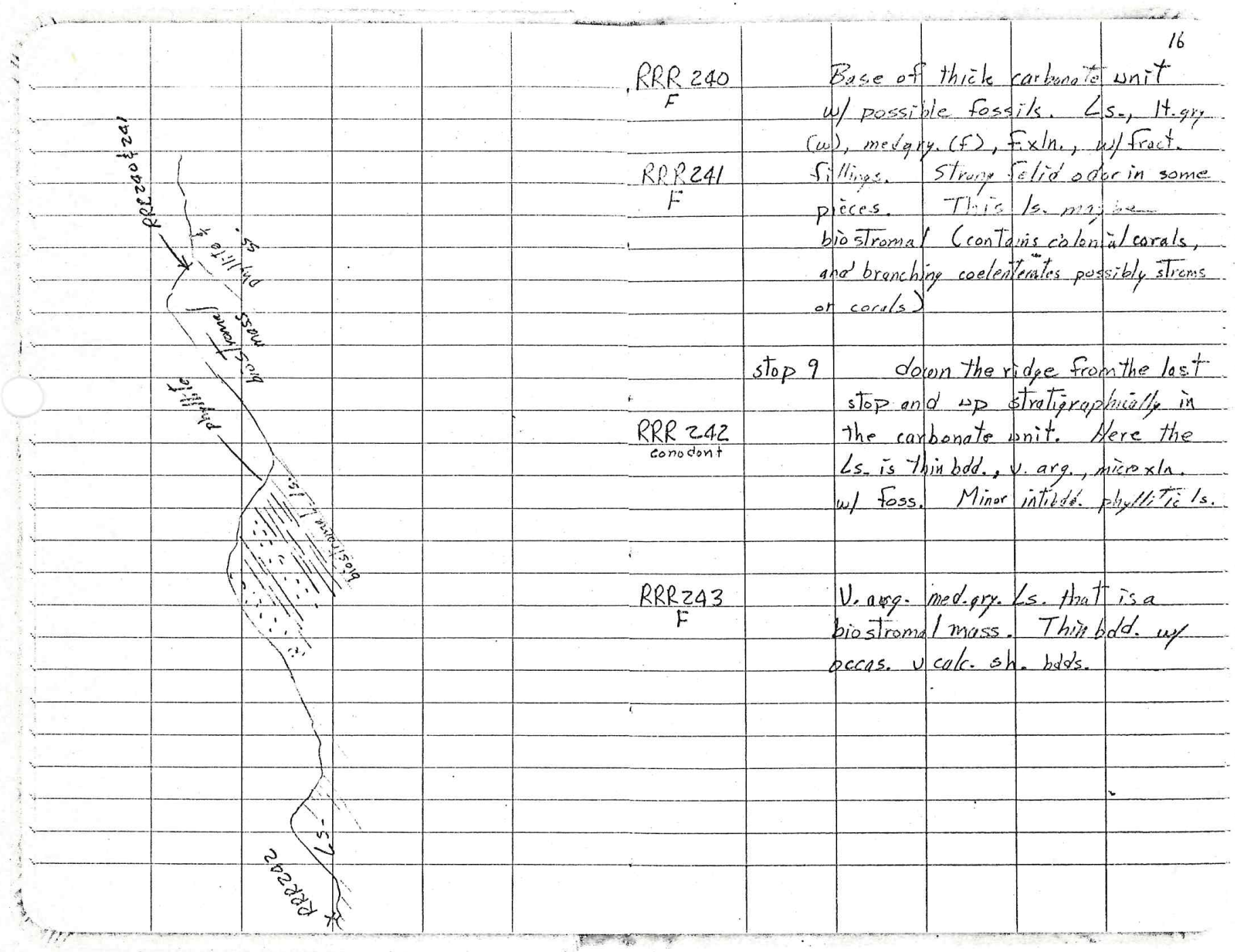




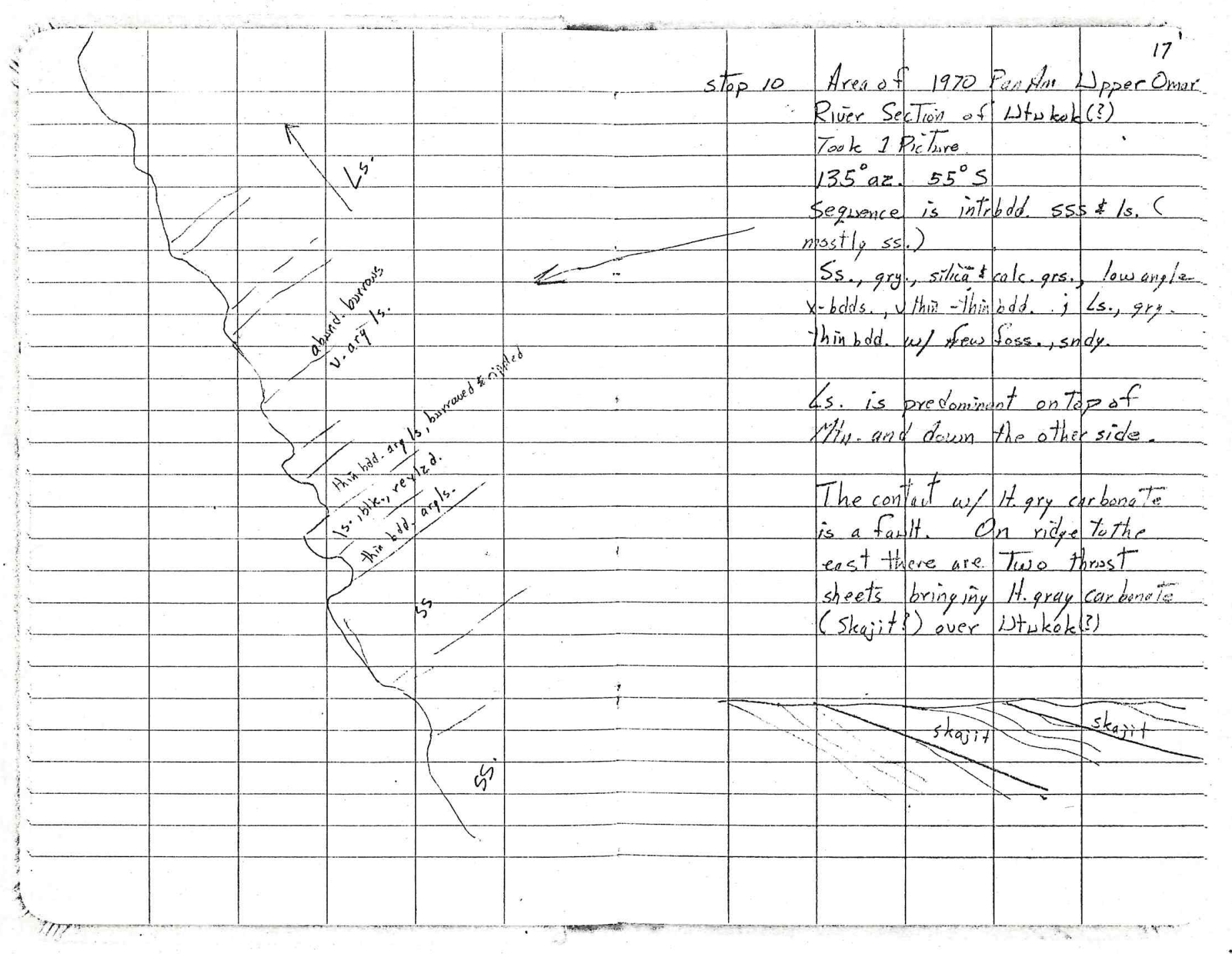




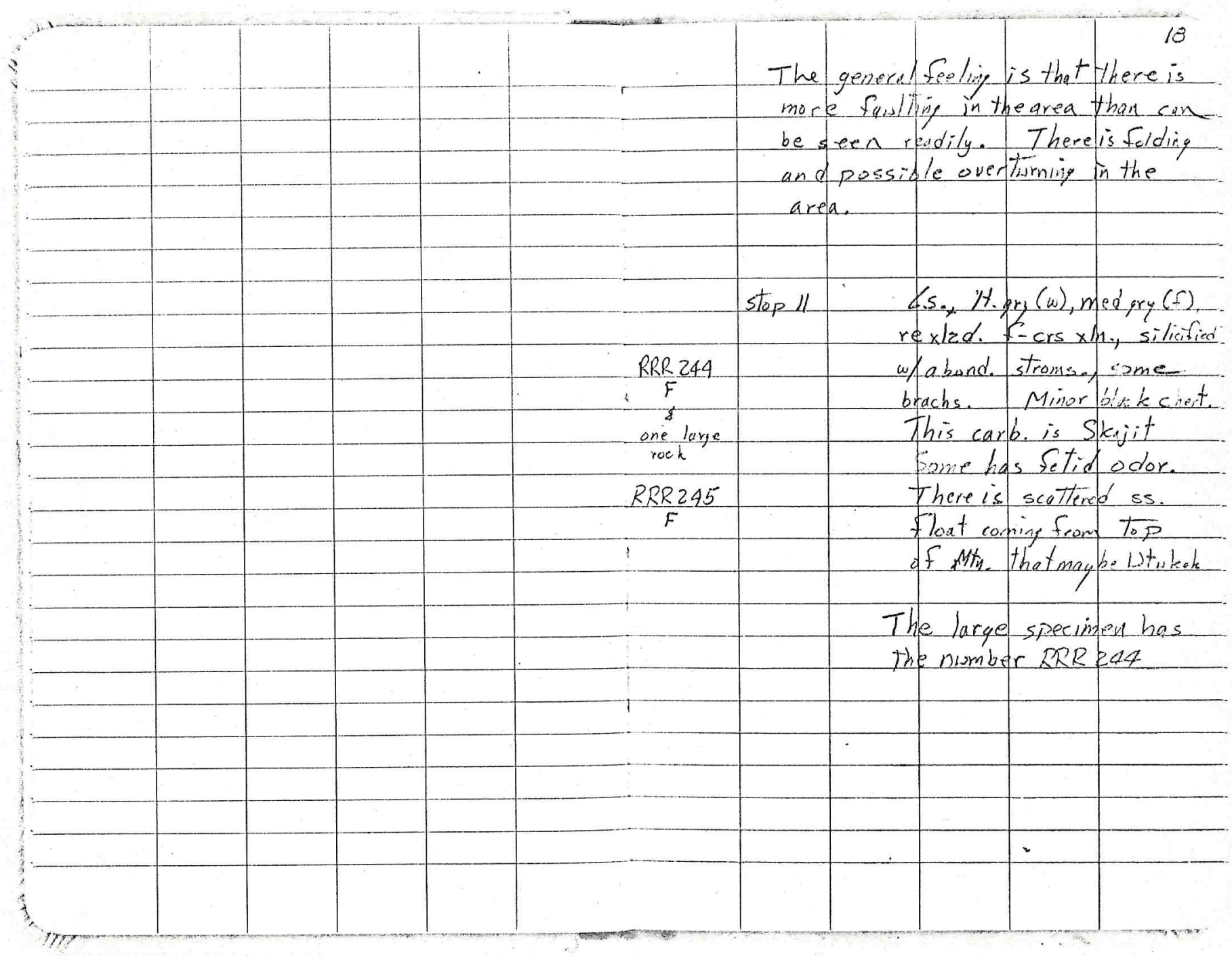




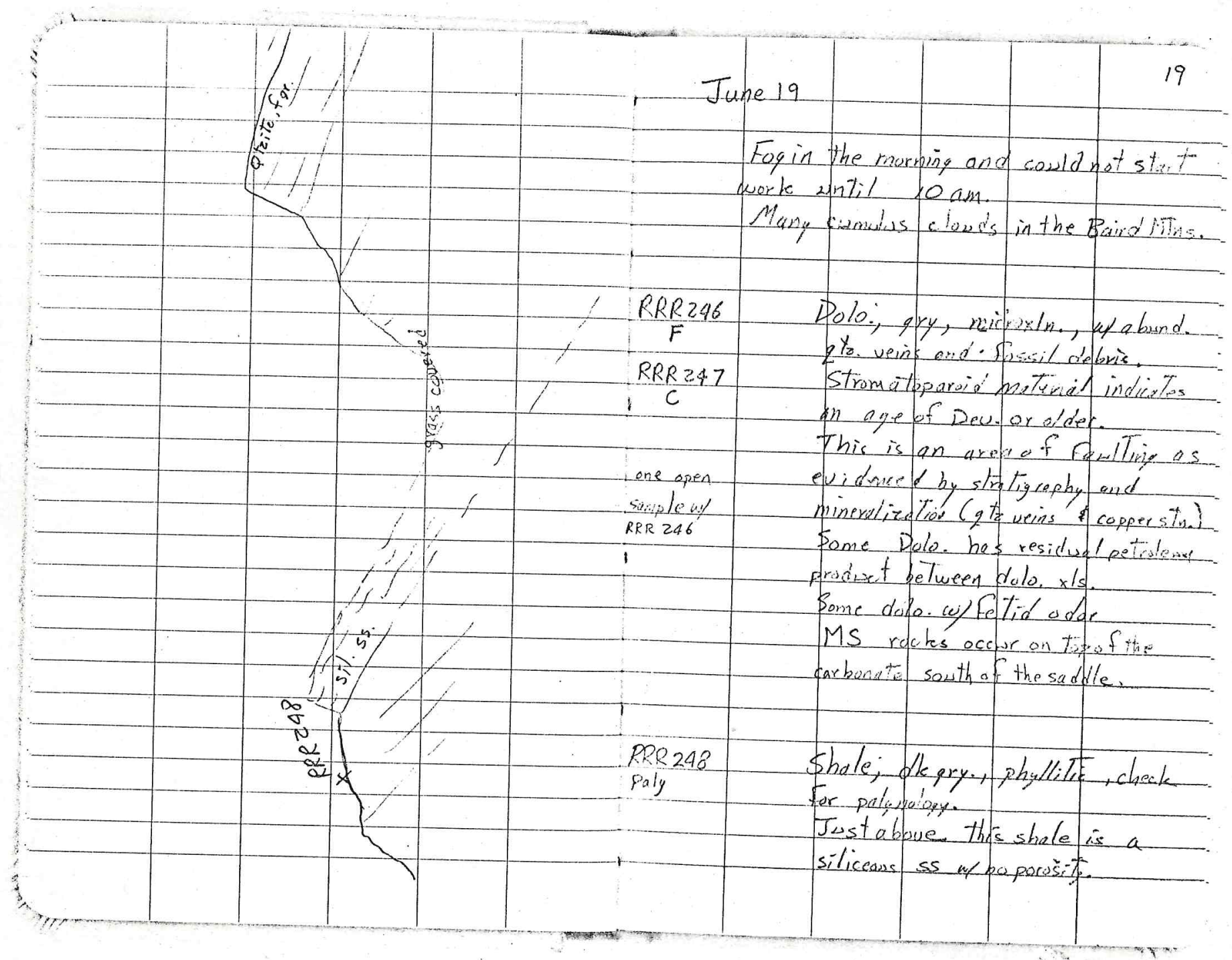




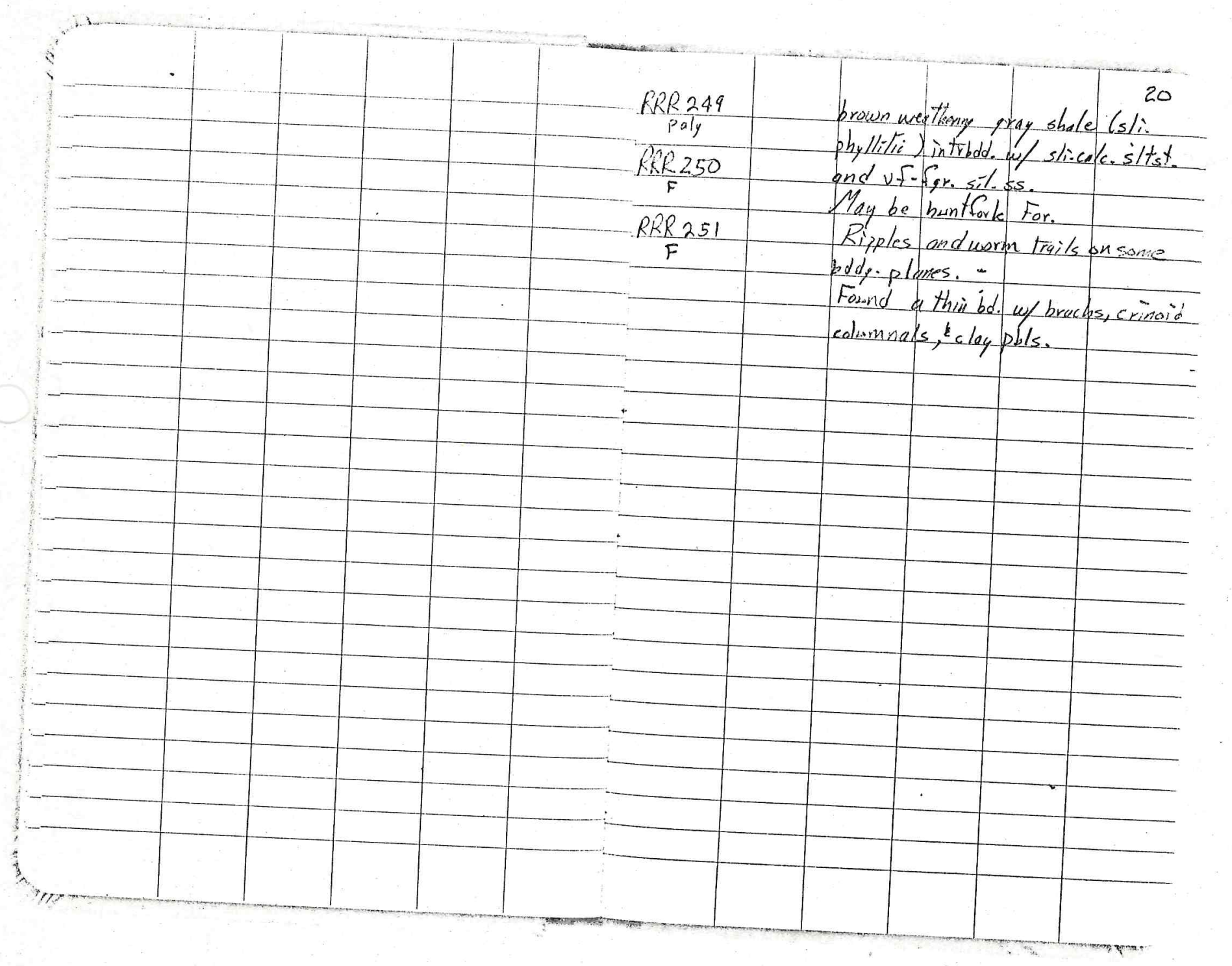




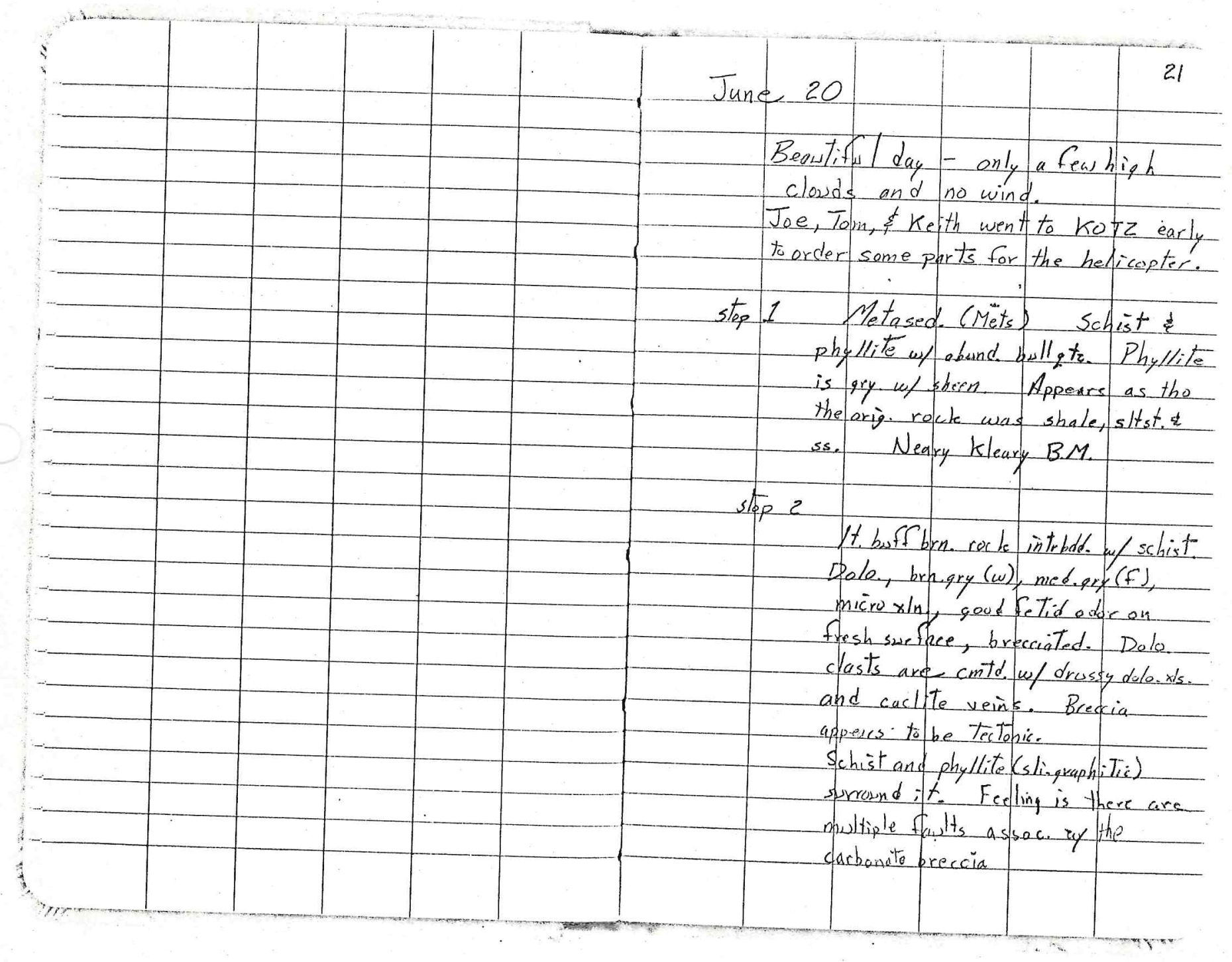




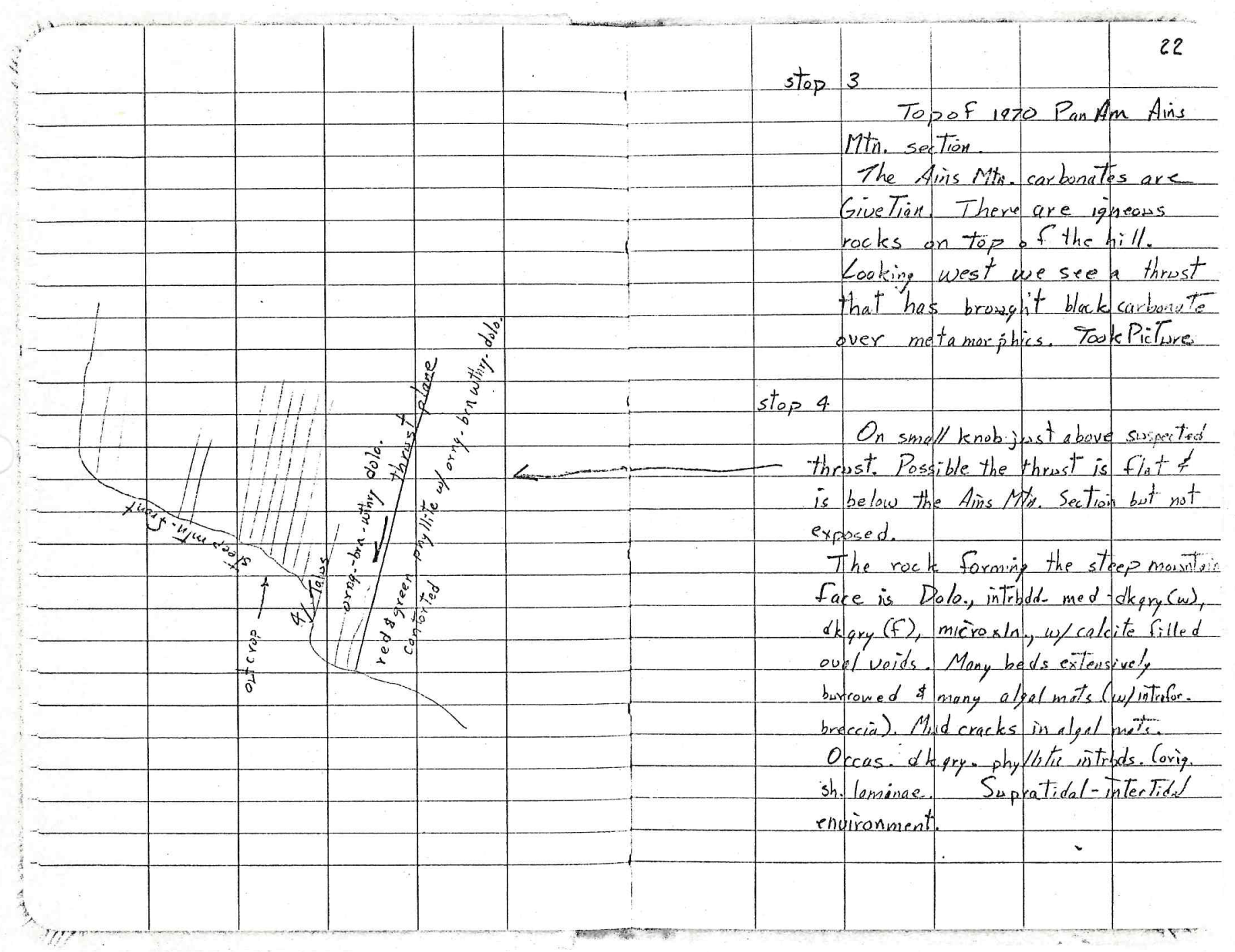




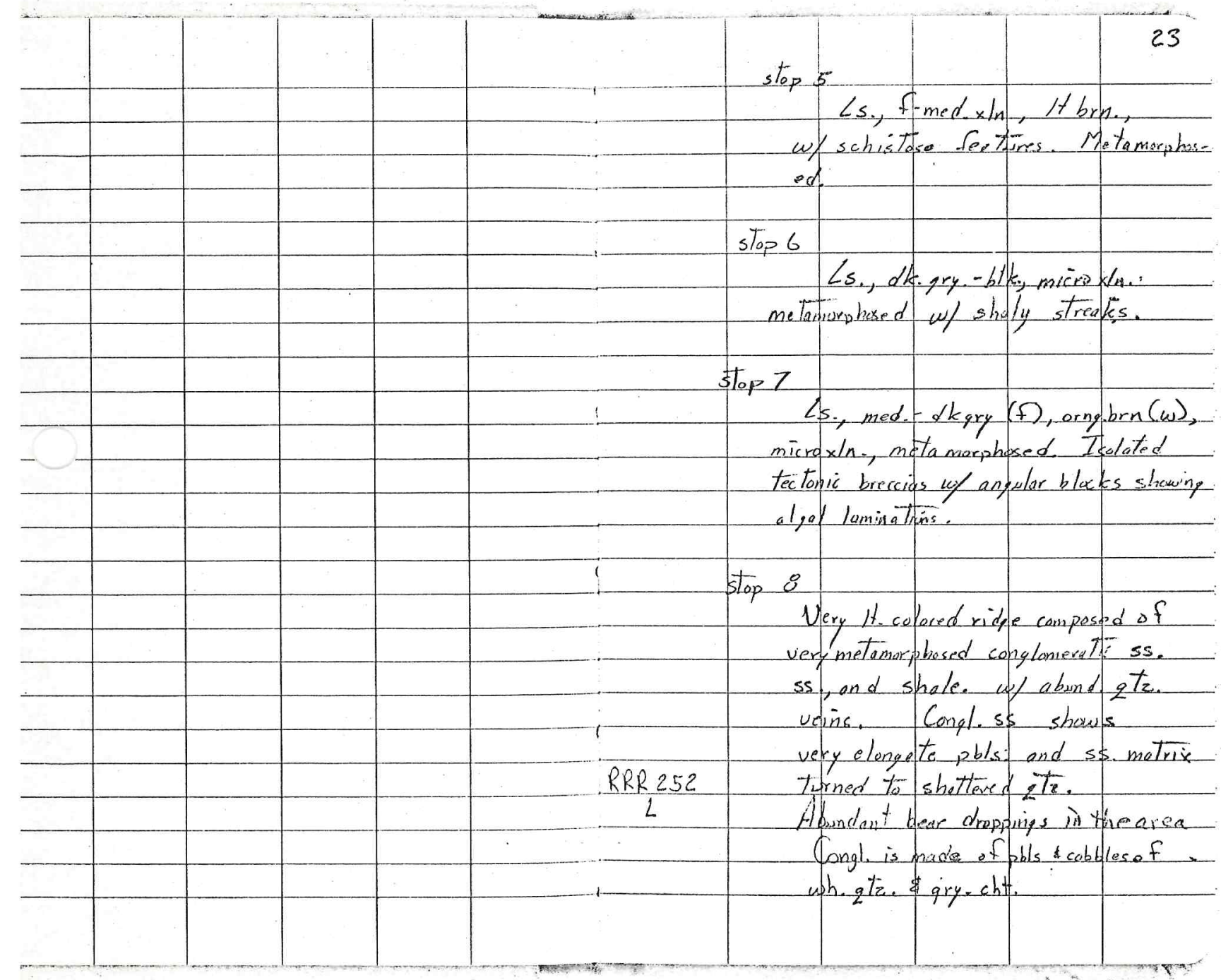




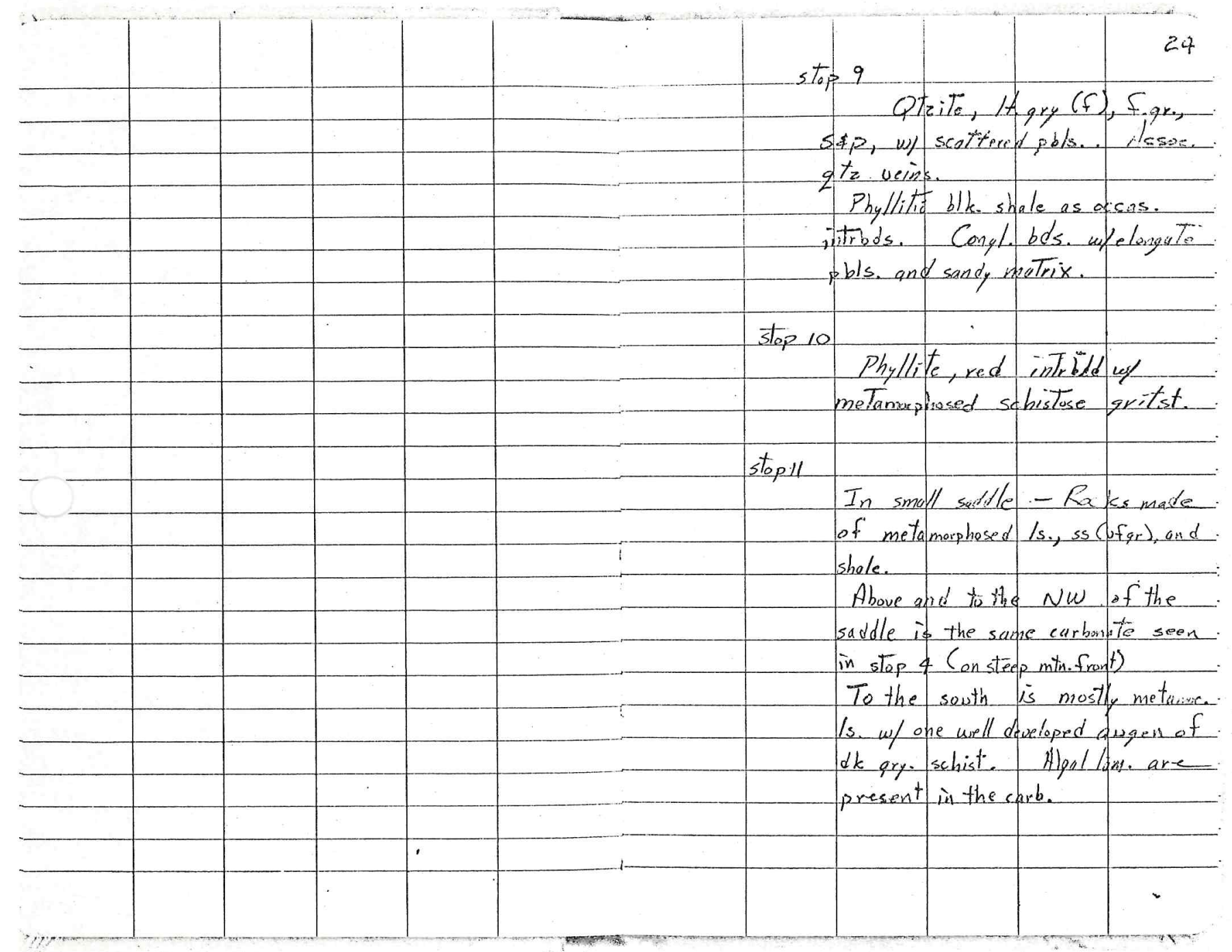




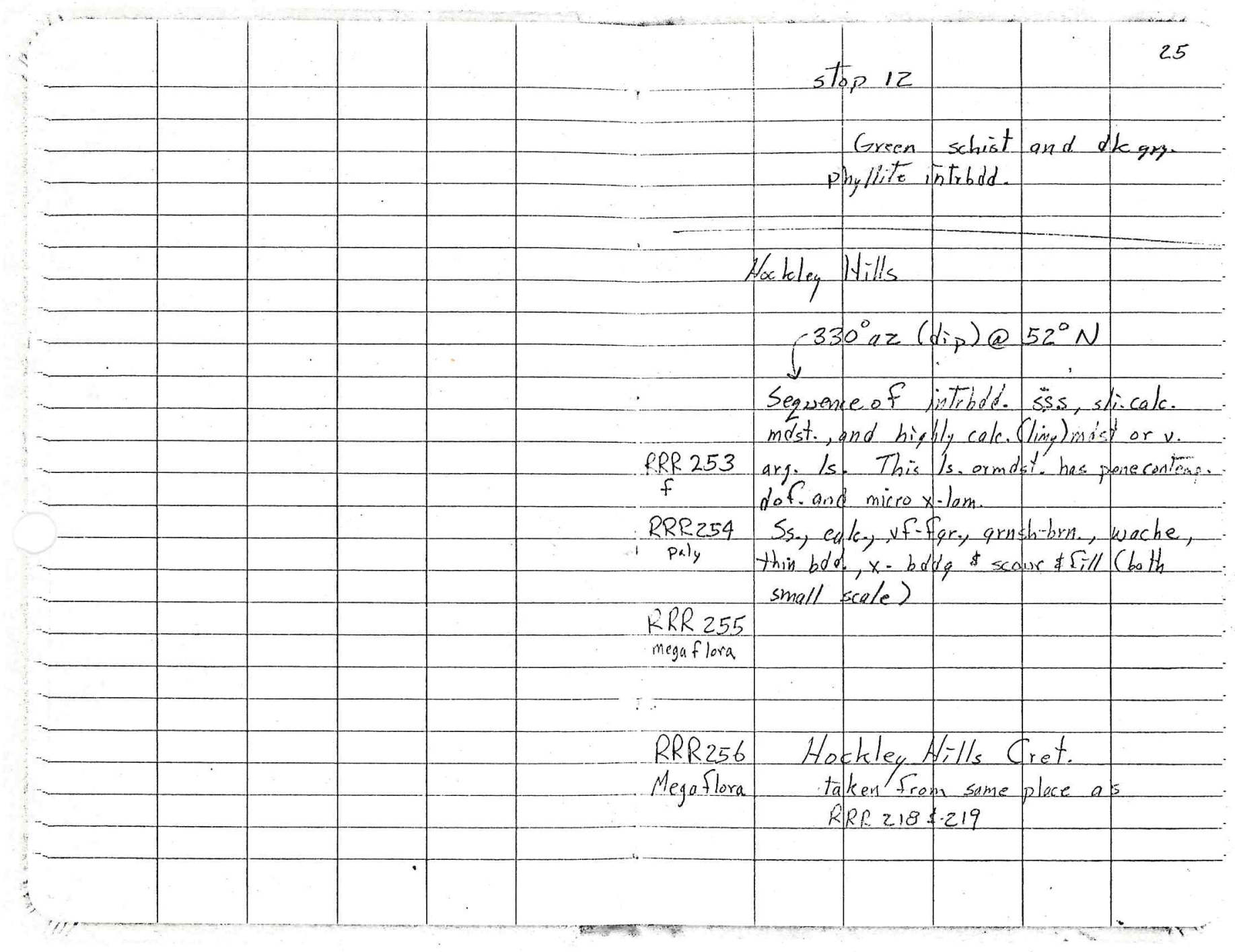




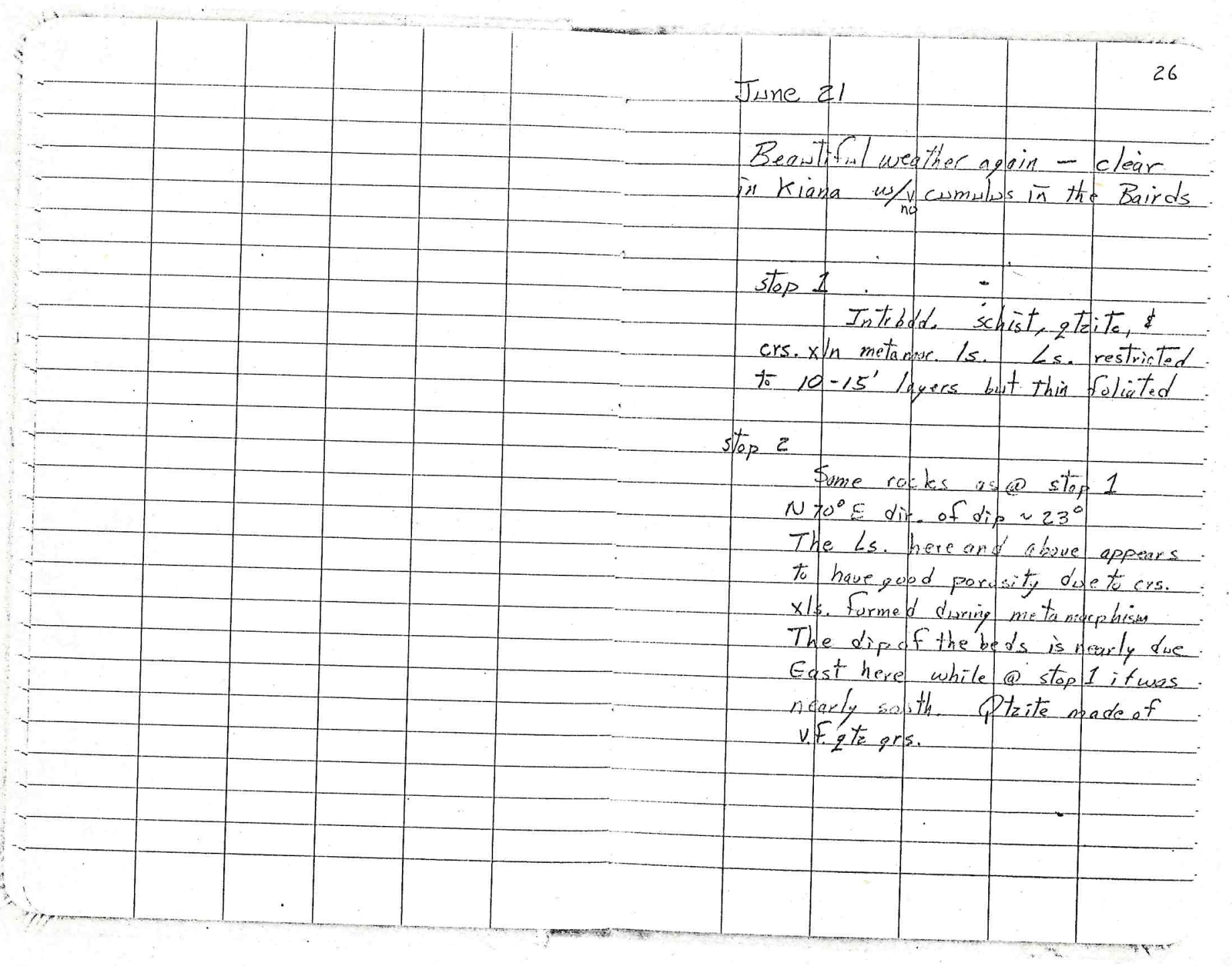




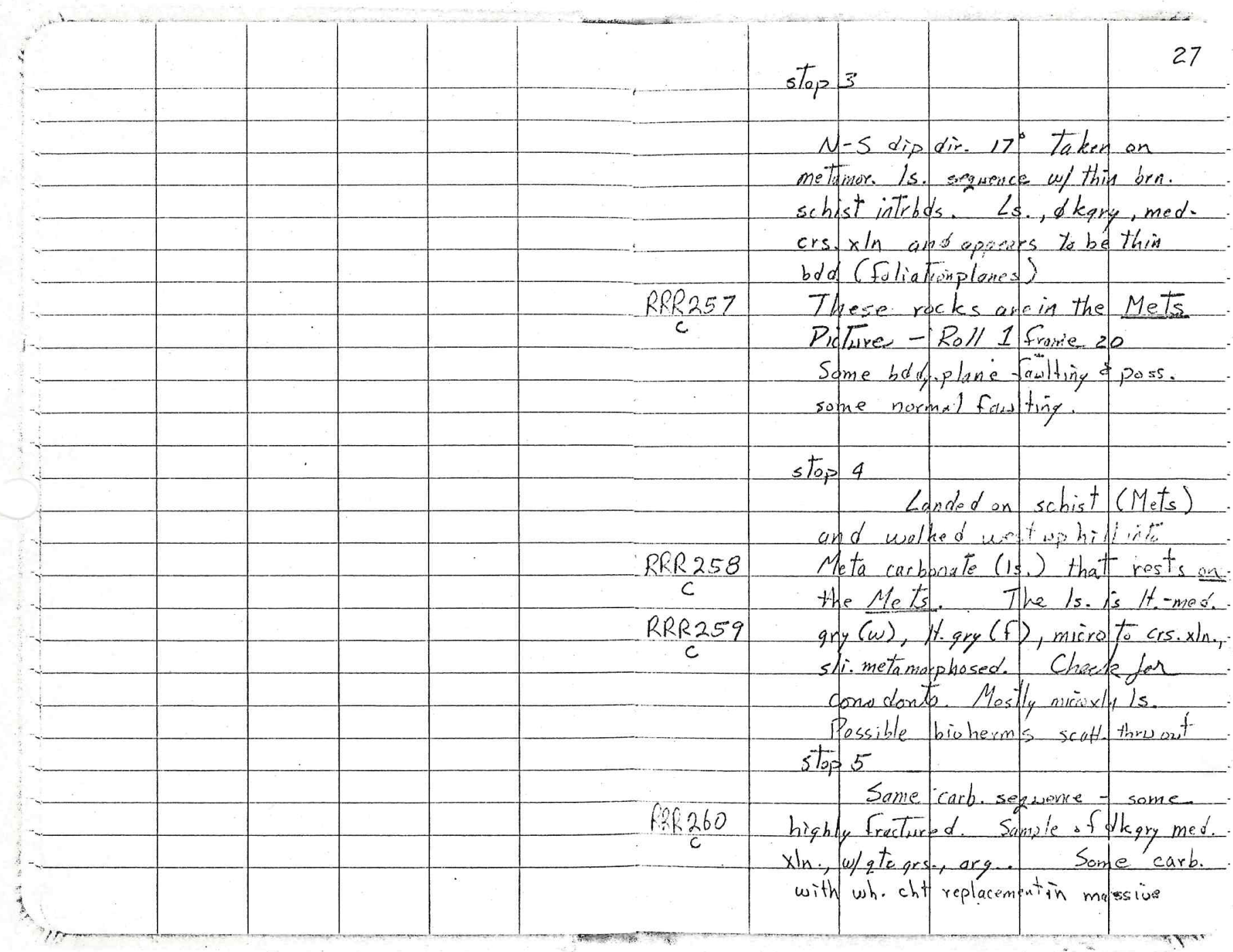




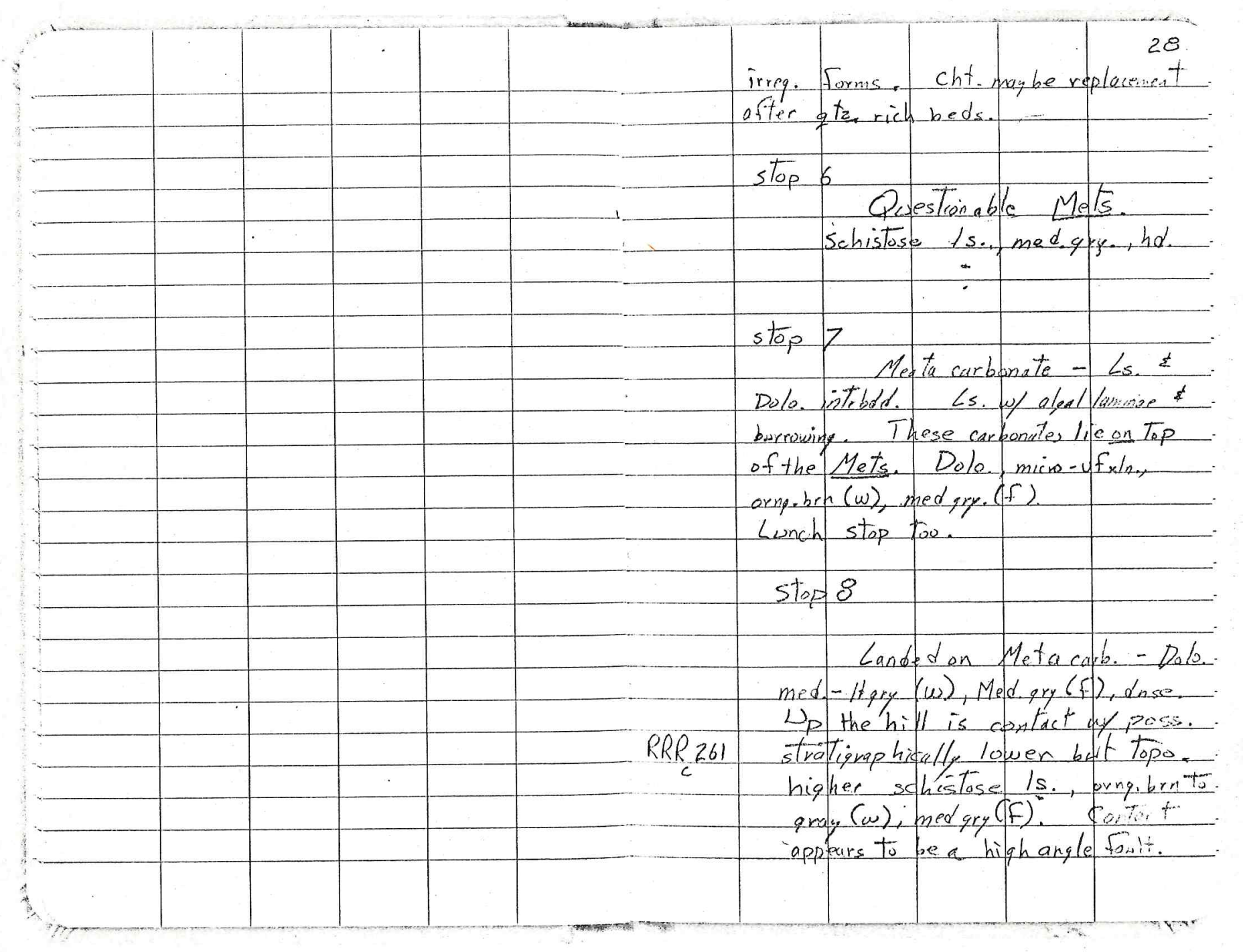




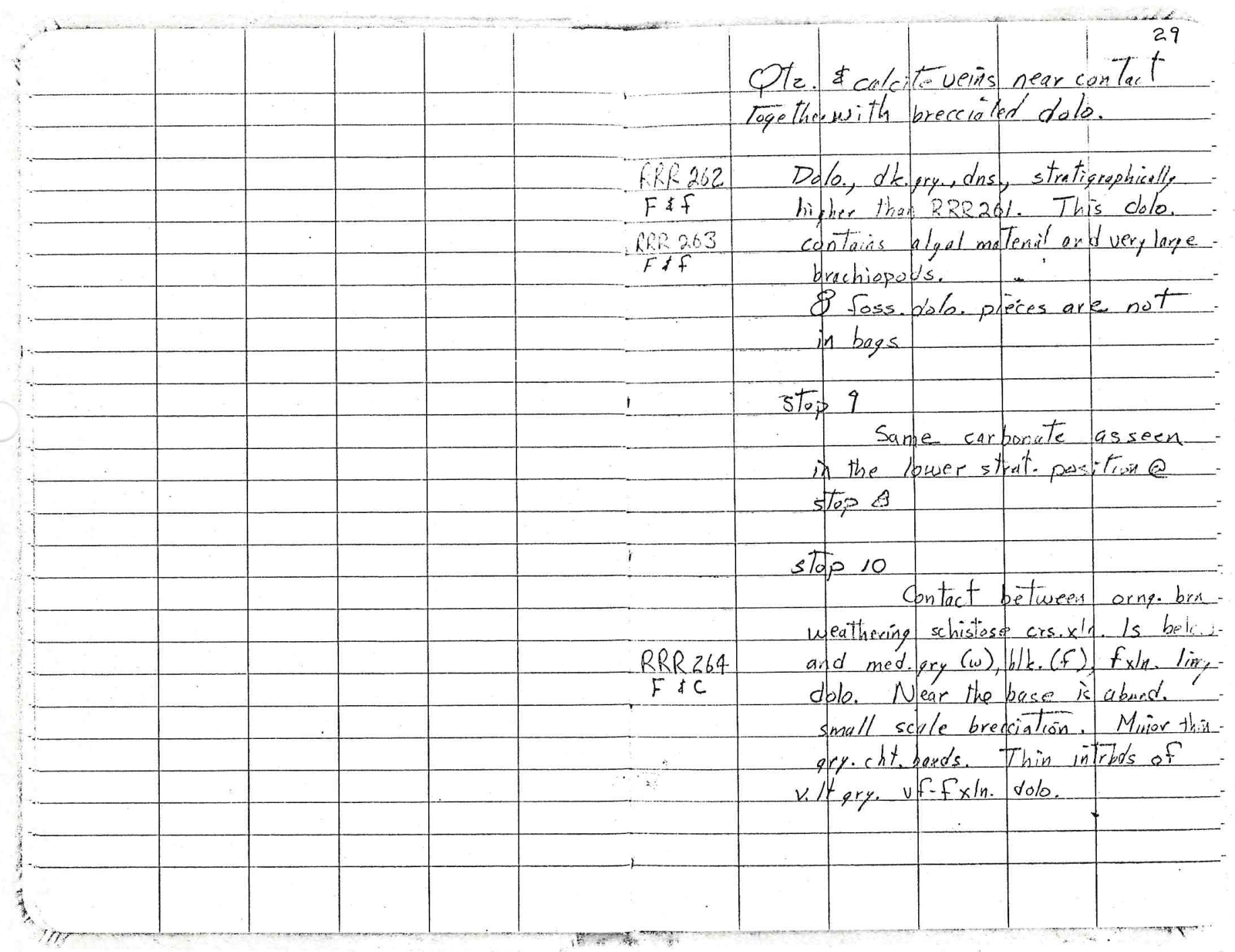




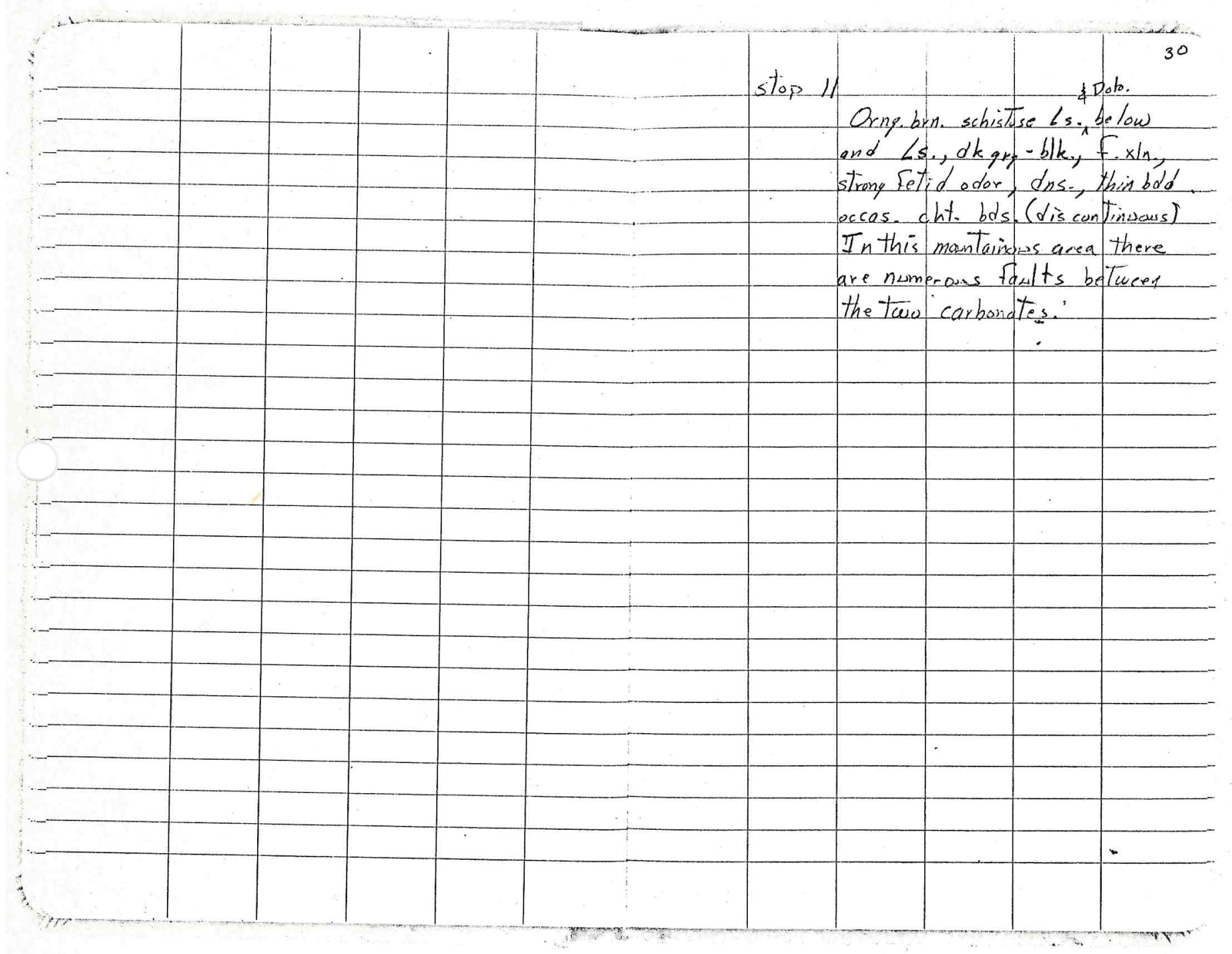




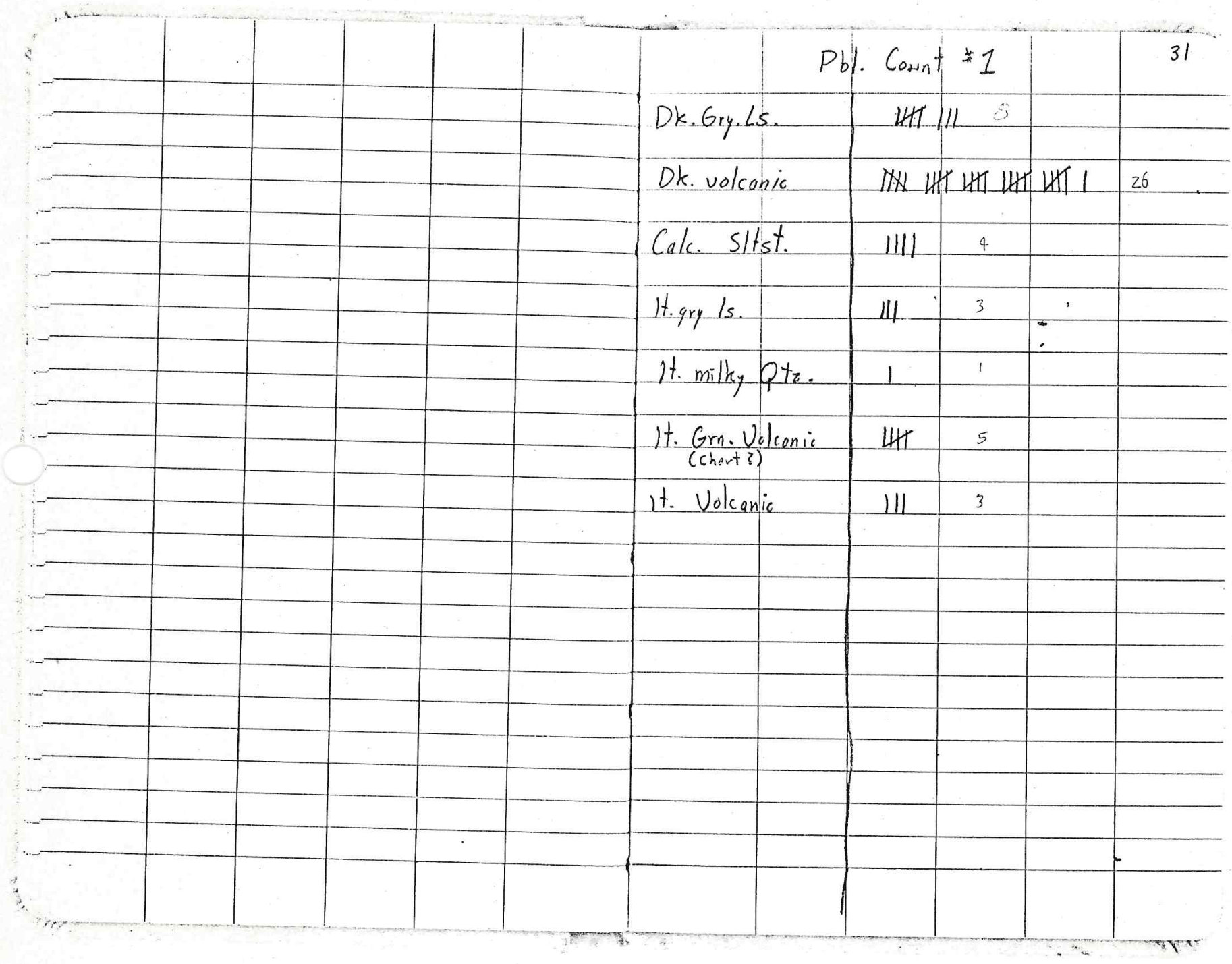




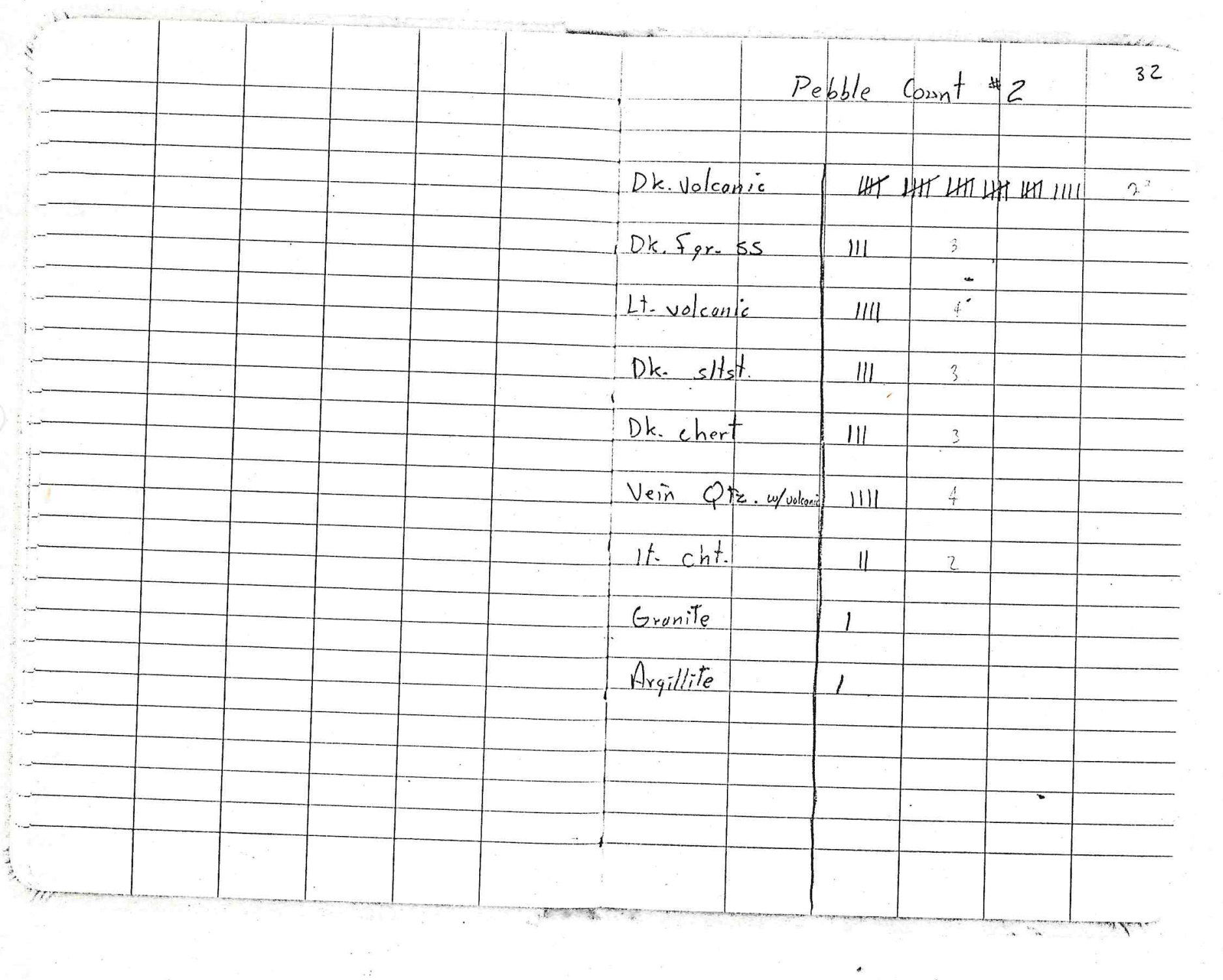




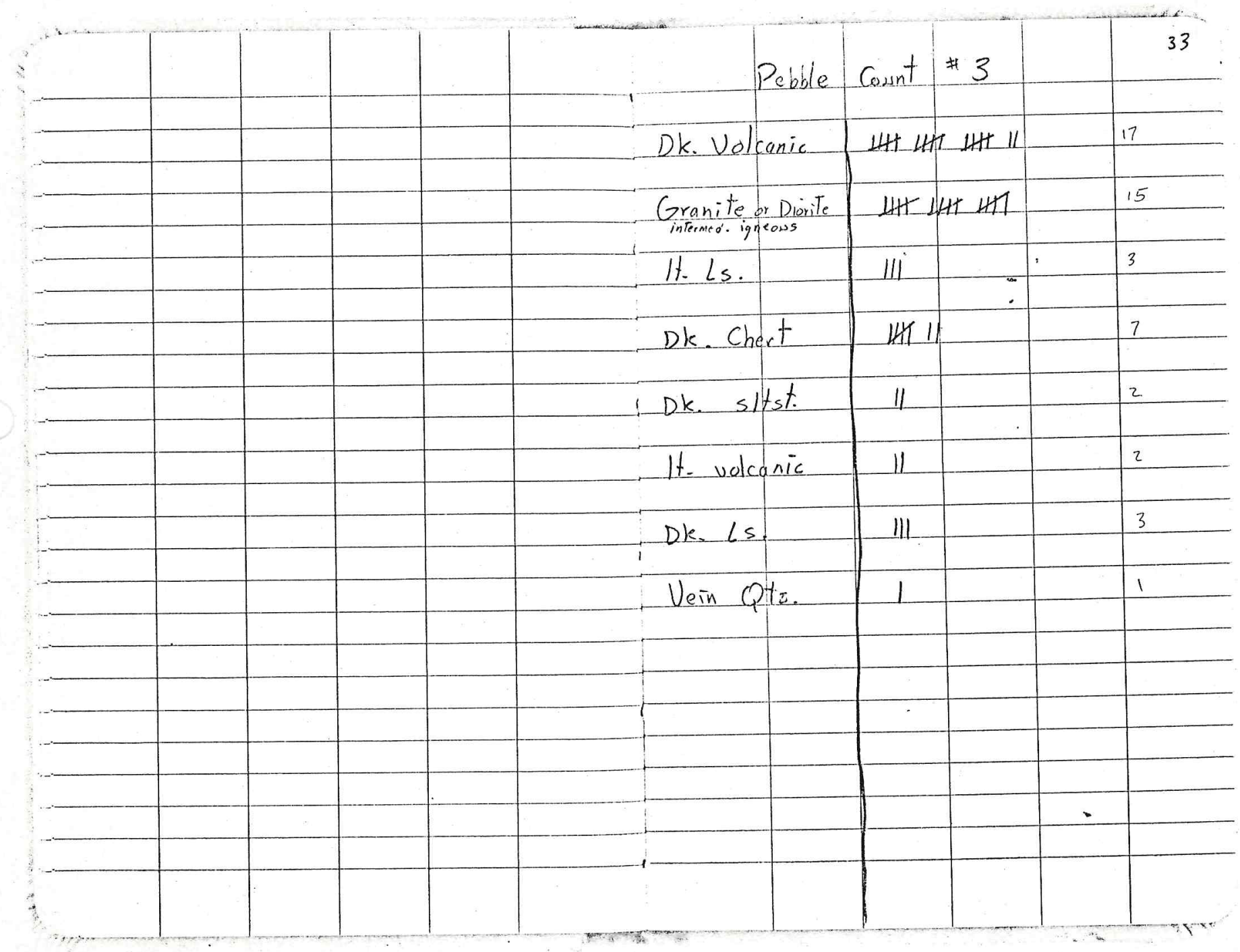




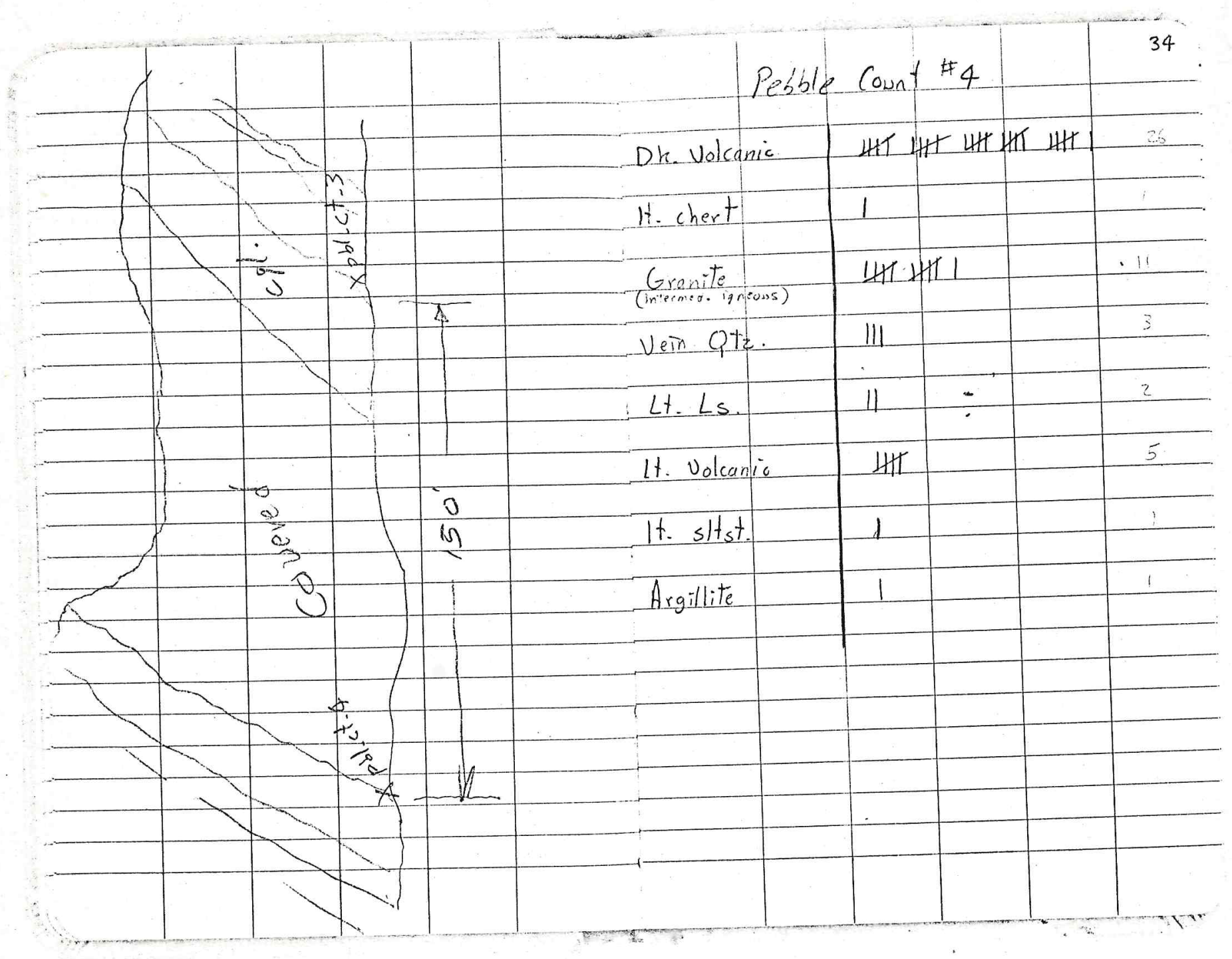




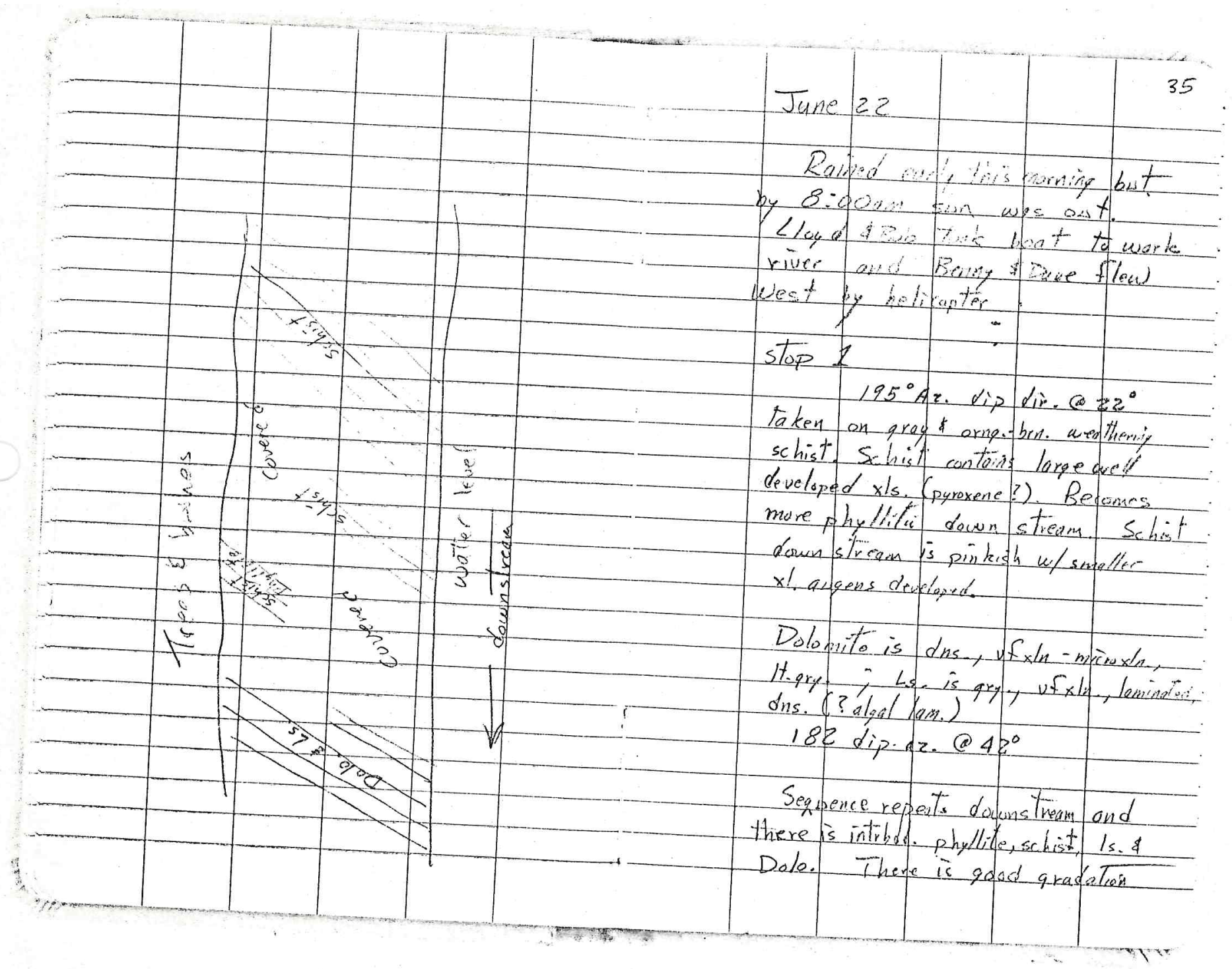




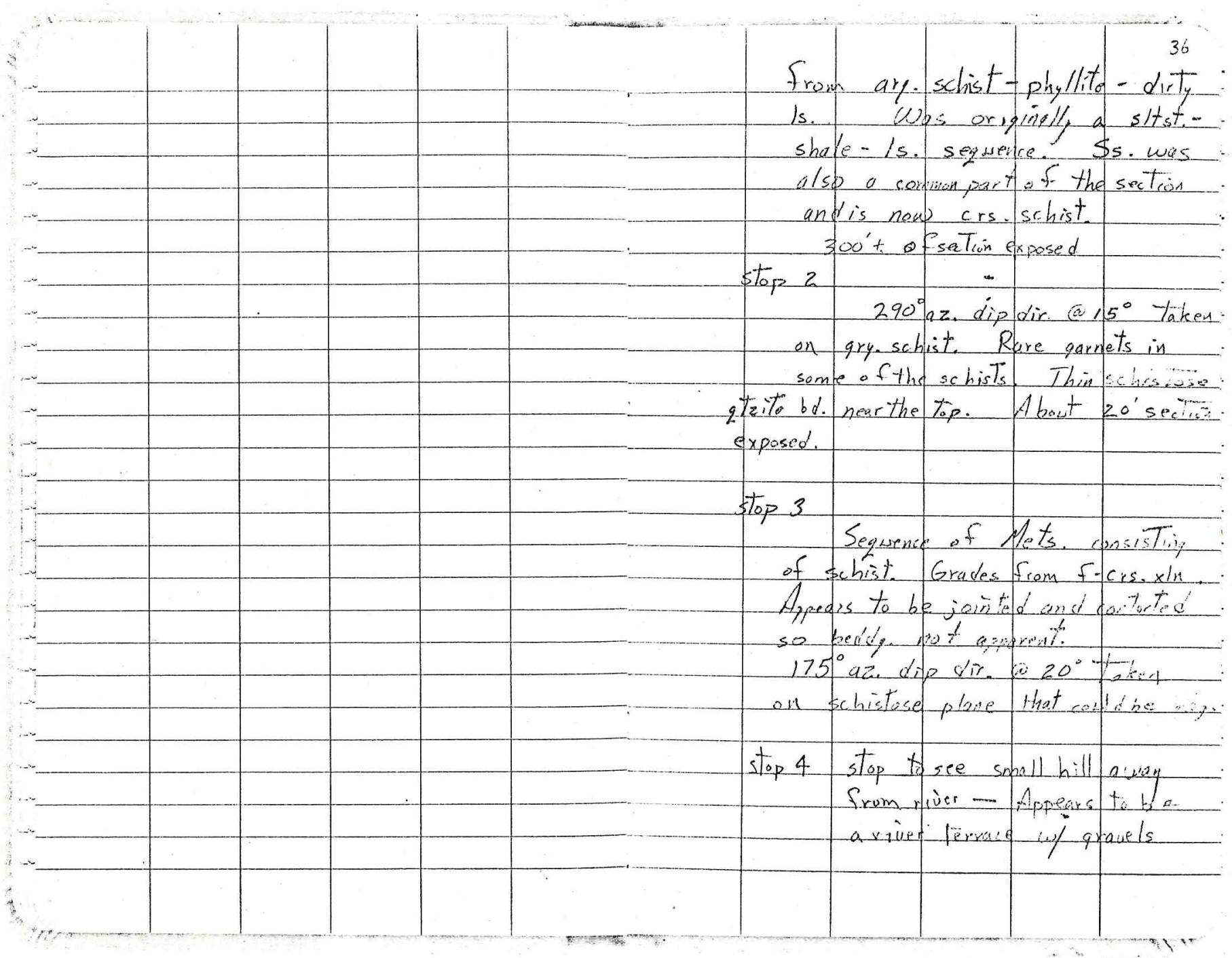




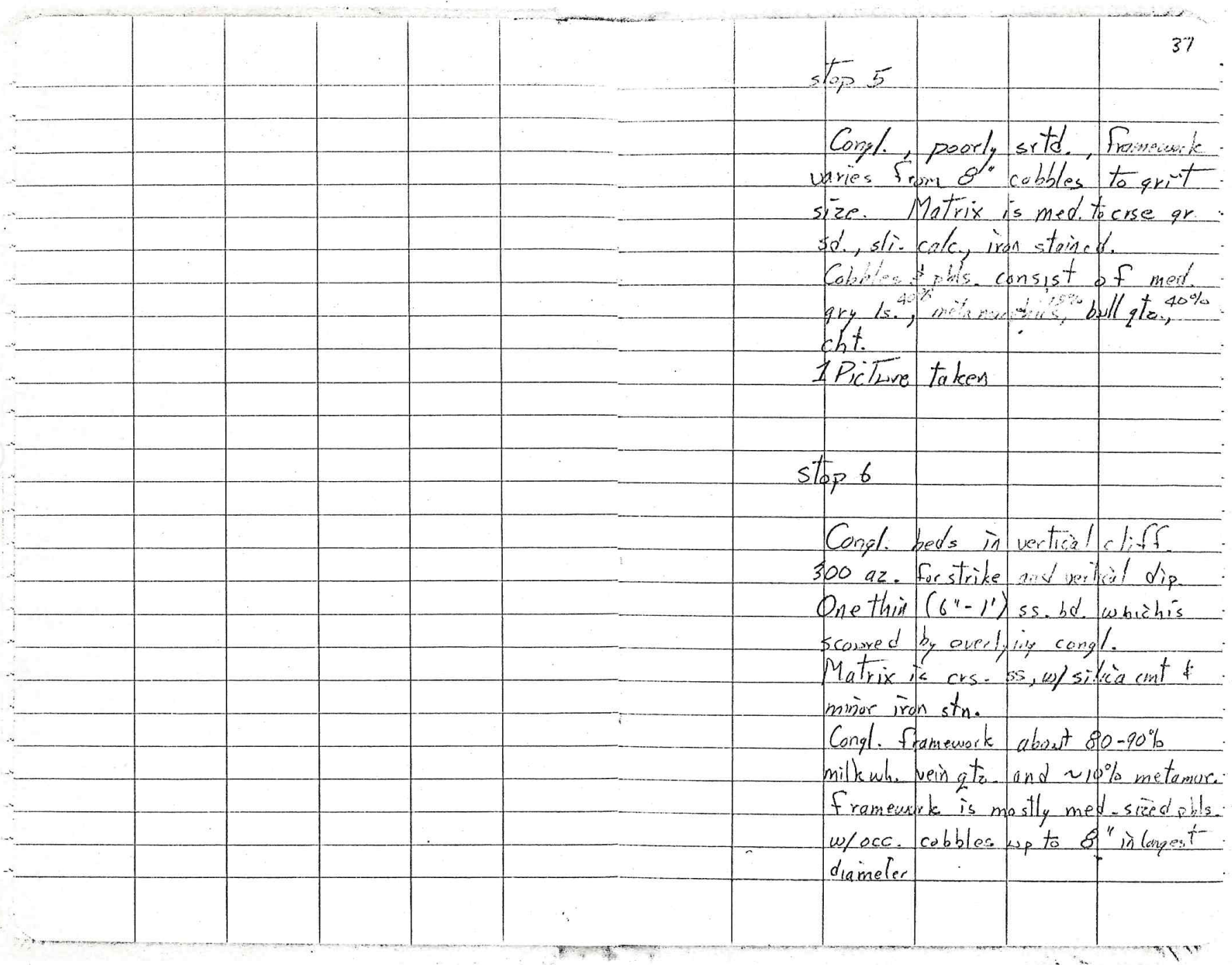




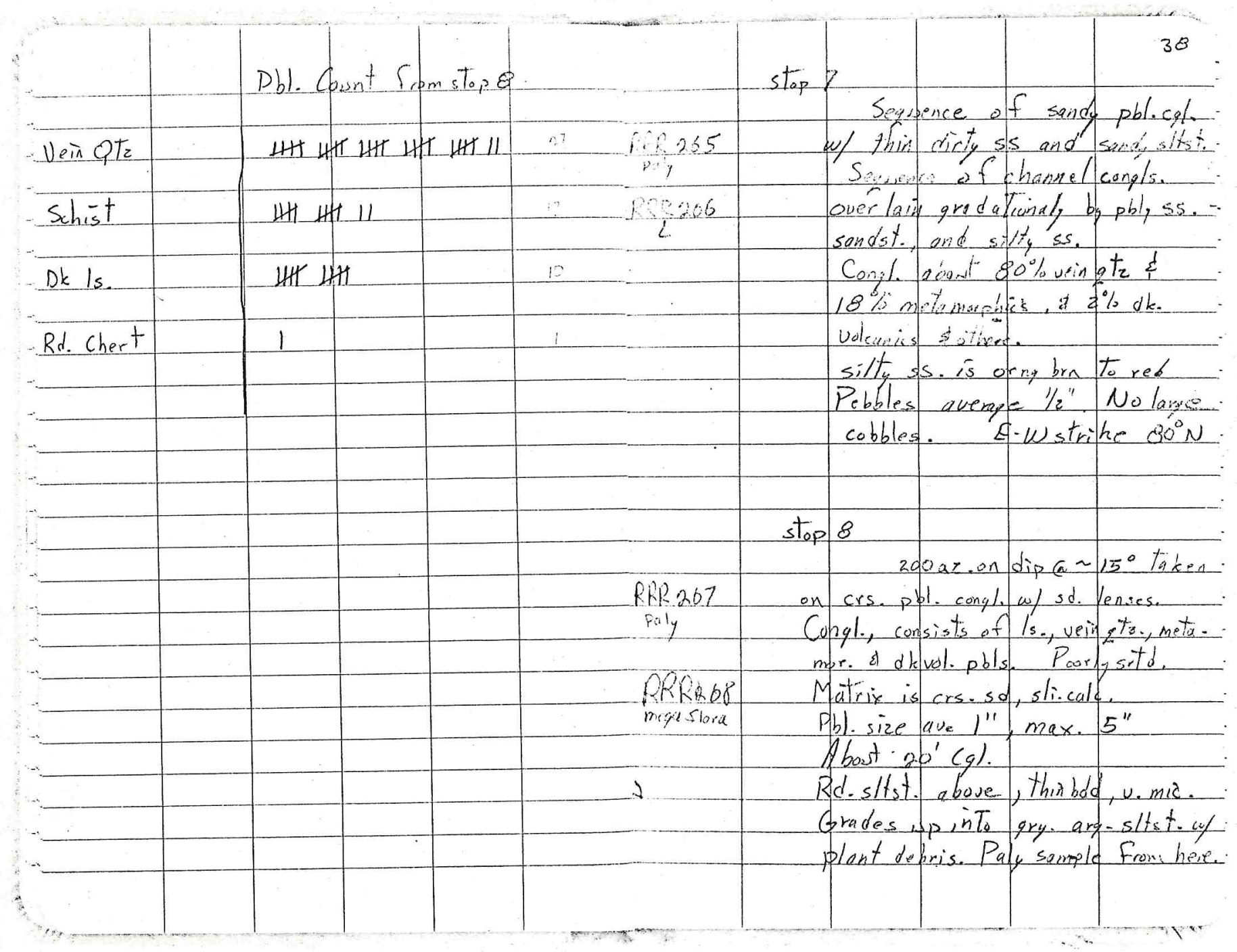




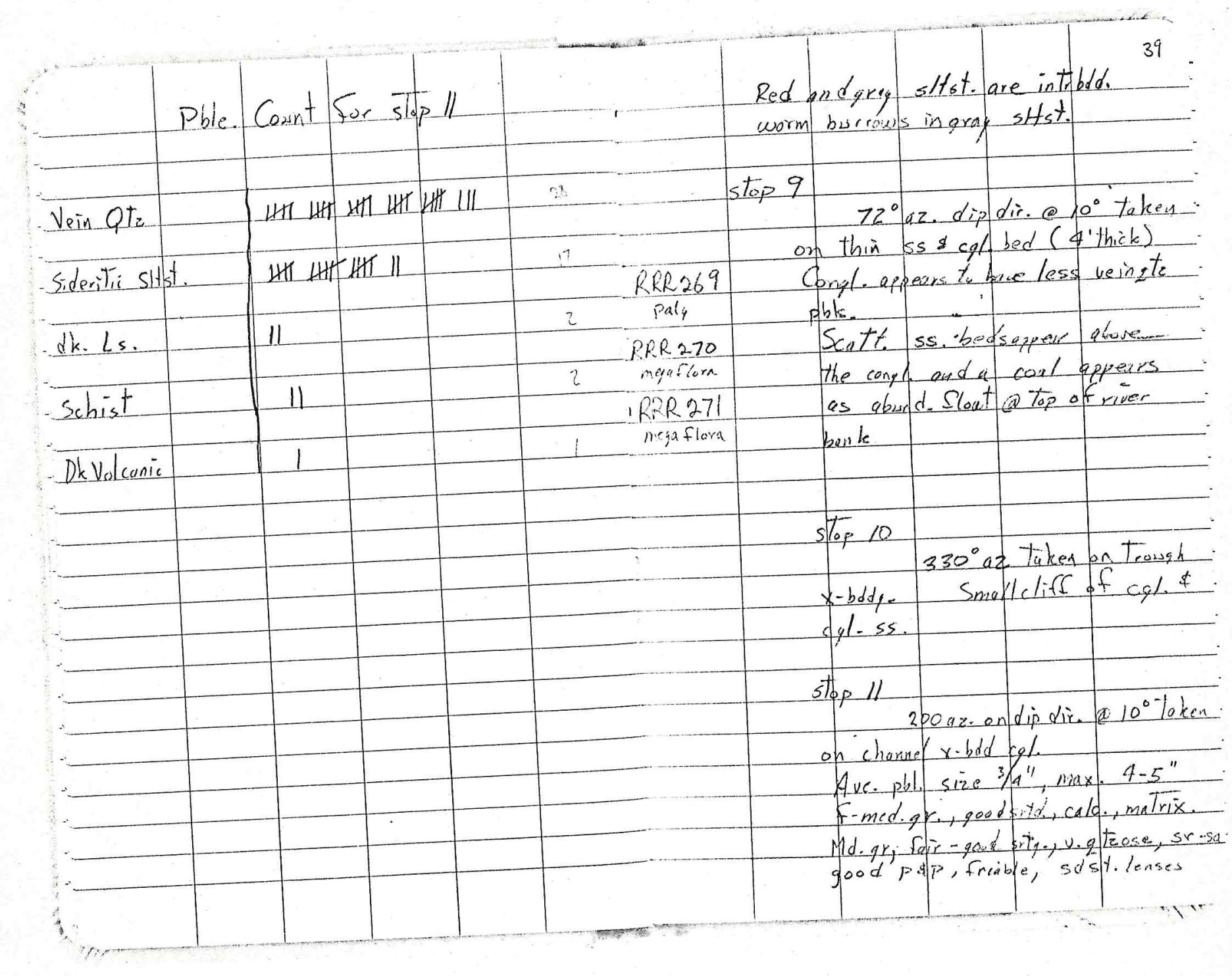




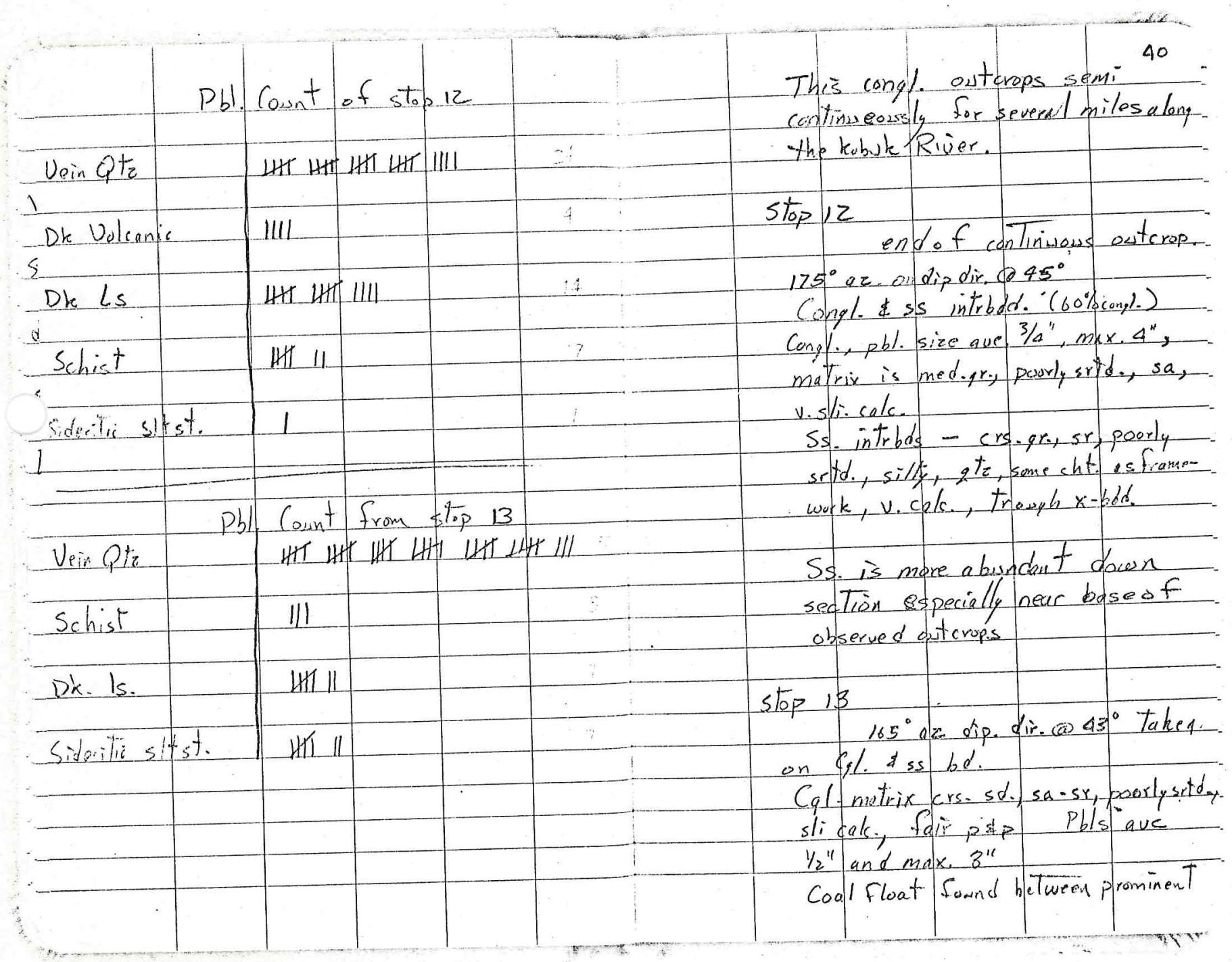




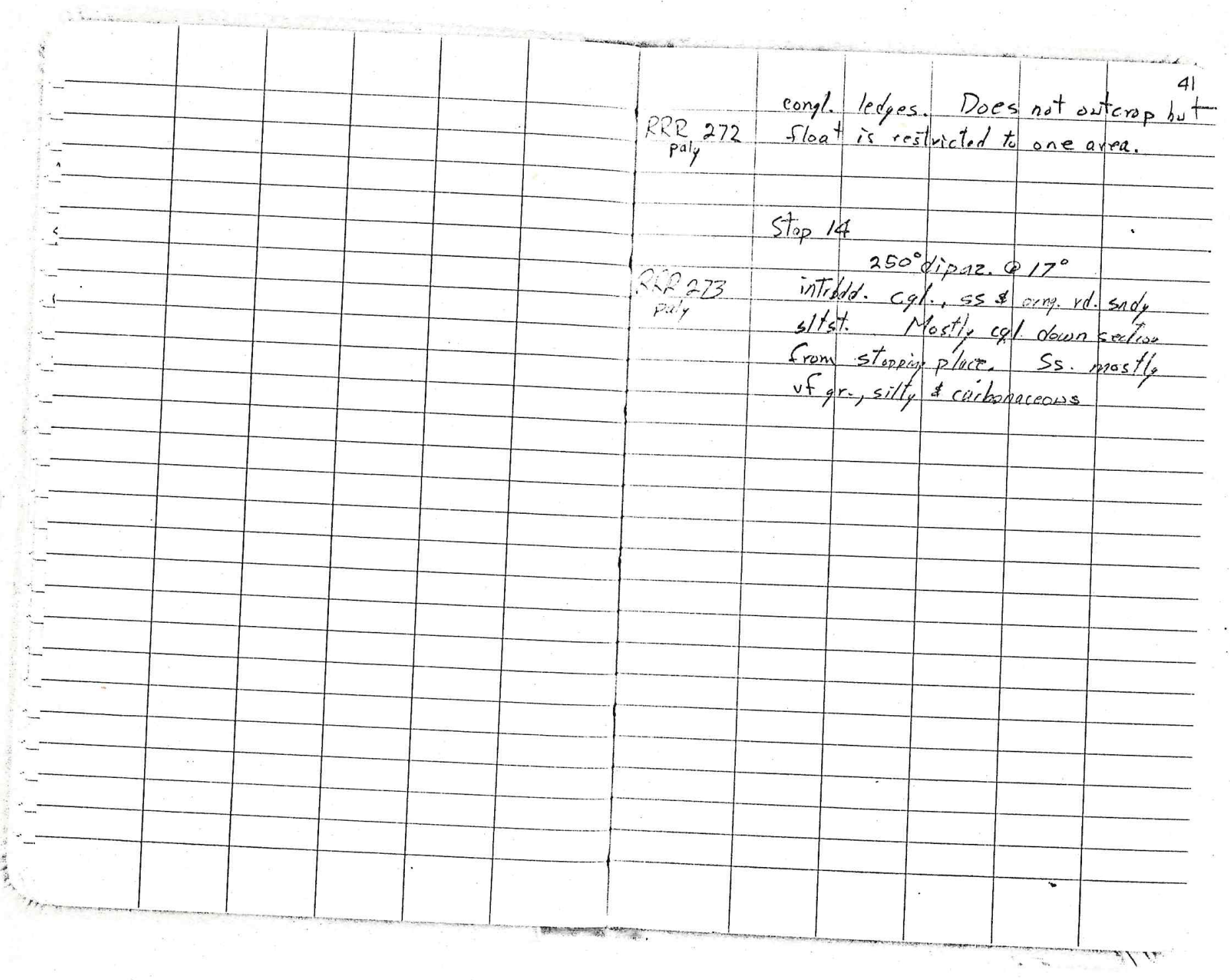




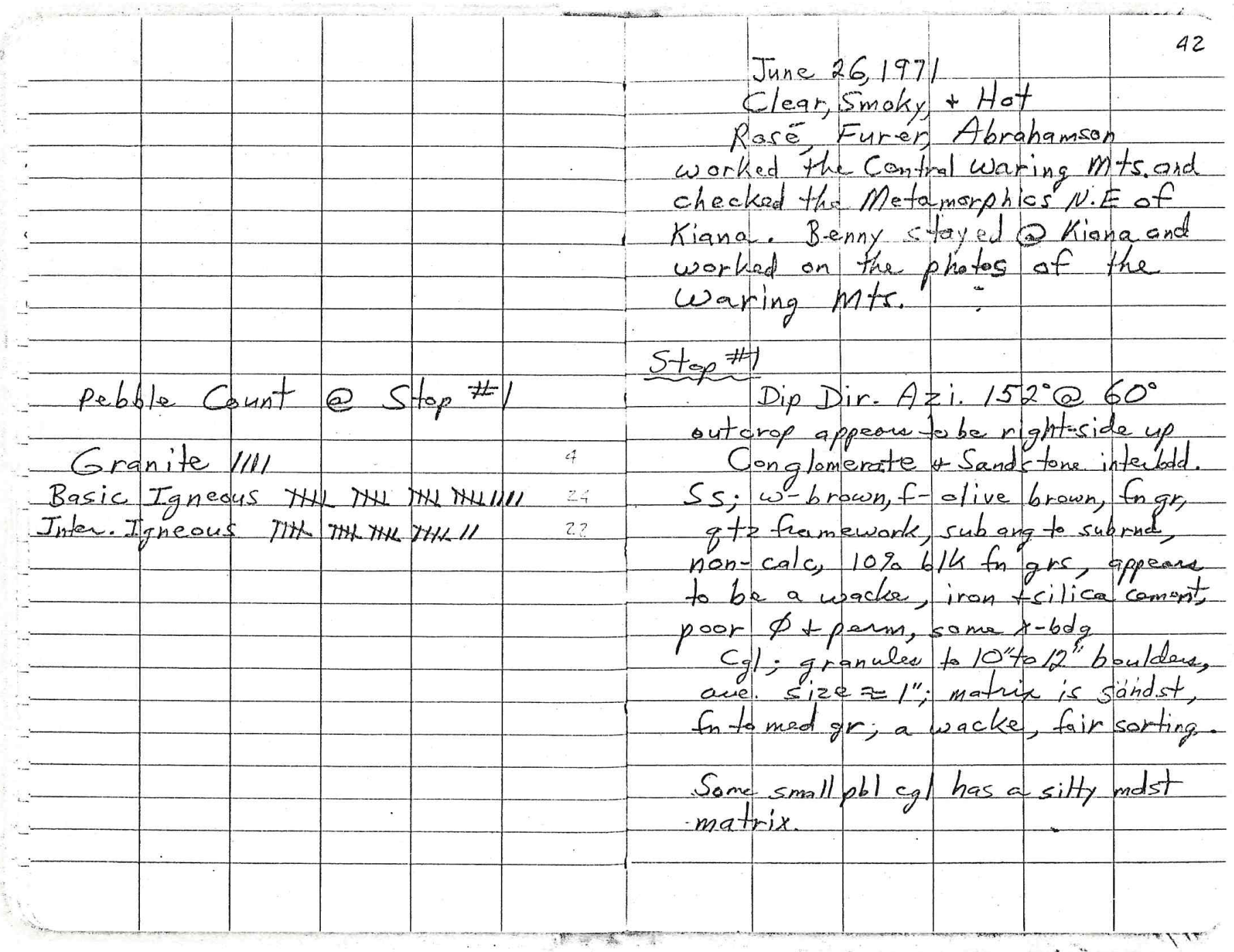




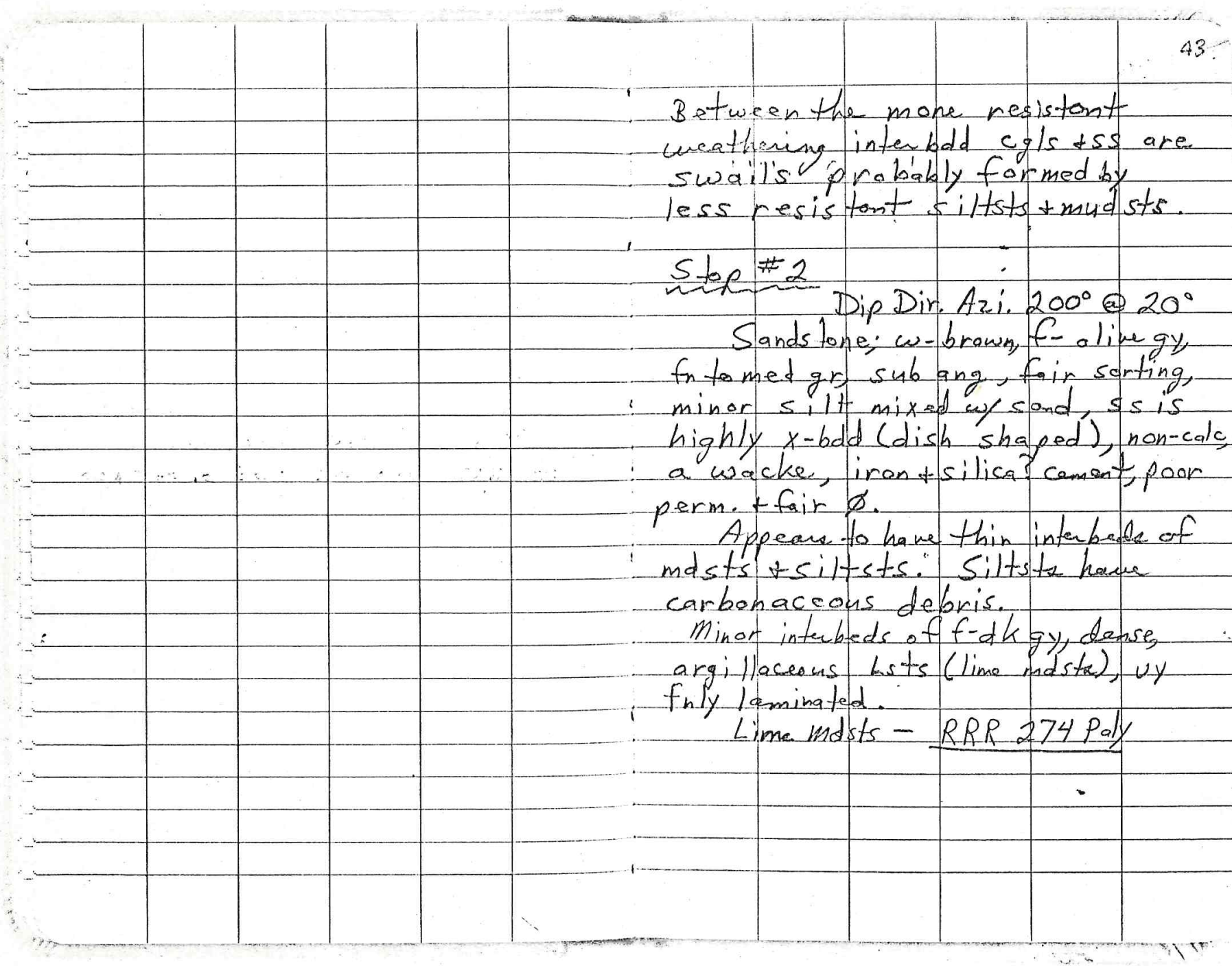

$-10$

Dip Dir. Azi. $200^{\circ} @ 20^{\circ}$

Sandstone; w-brawn, f-aliue $g$ in to med gr subang, fair sorting, minor silt mixed w/s ond, ss is highly x-bdd (dish shaped), non-calc, a wacke, iront silica? coment poor perm. t fair $\varnothing$. siltstz haxe carbonaccous debris.

Minor interbeds of f-dk gy, dense, argillaceous lests (lime indsta), u

\section{Liminated.}




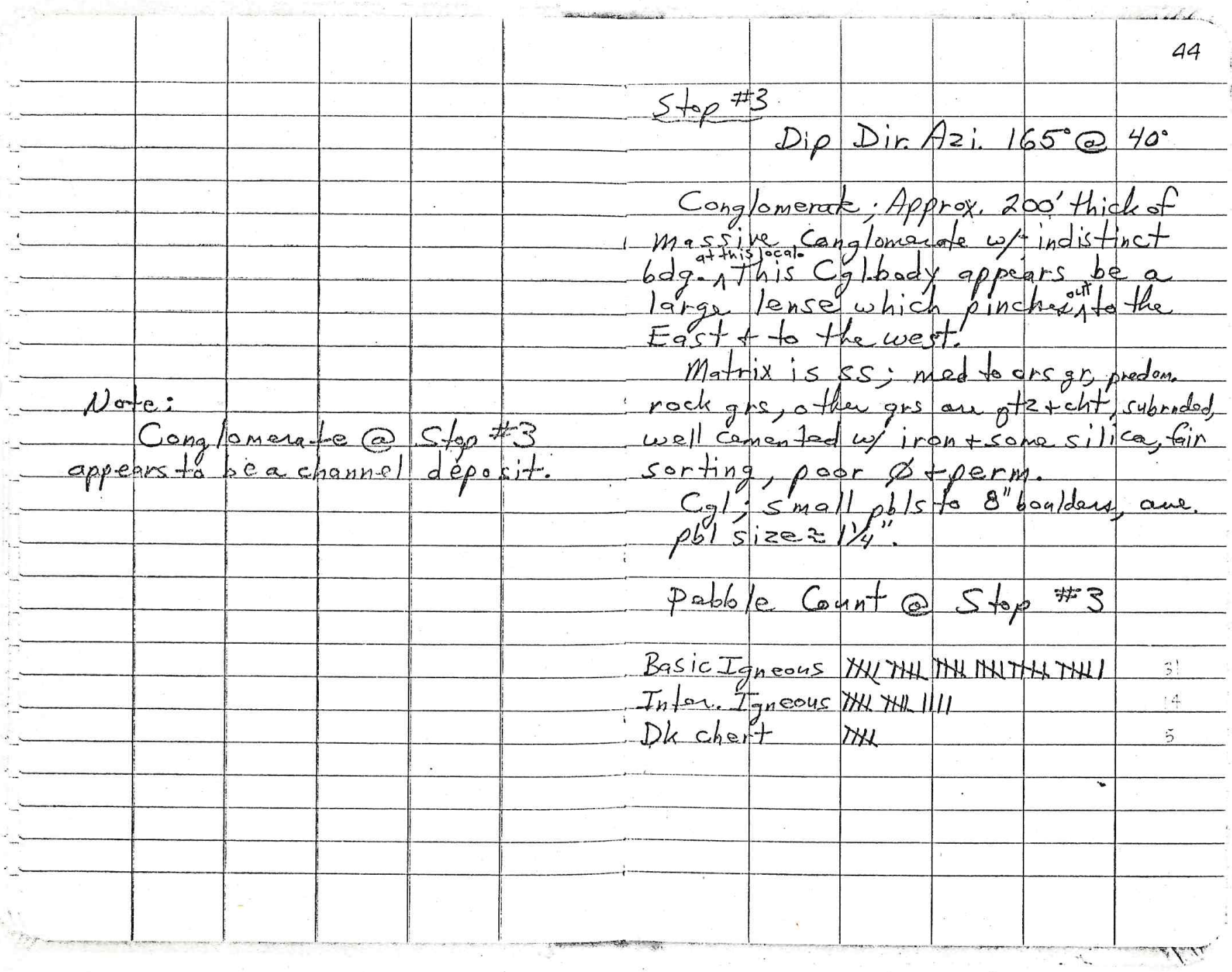




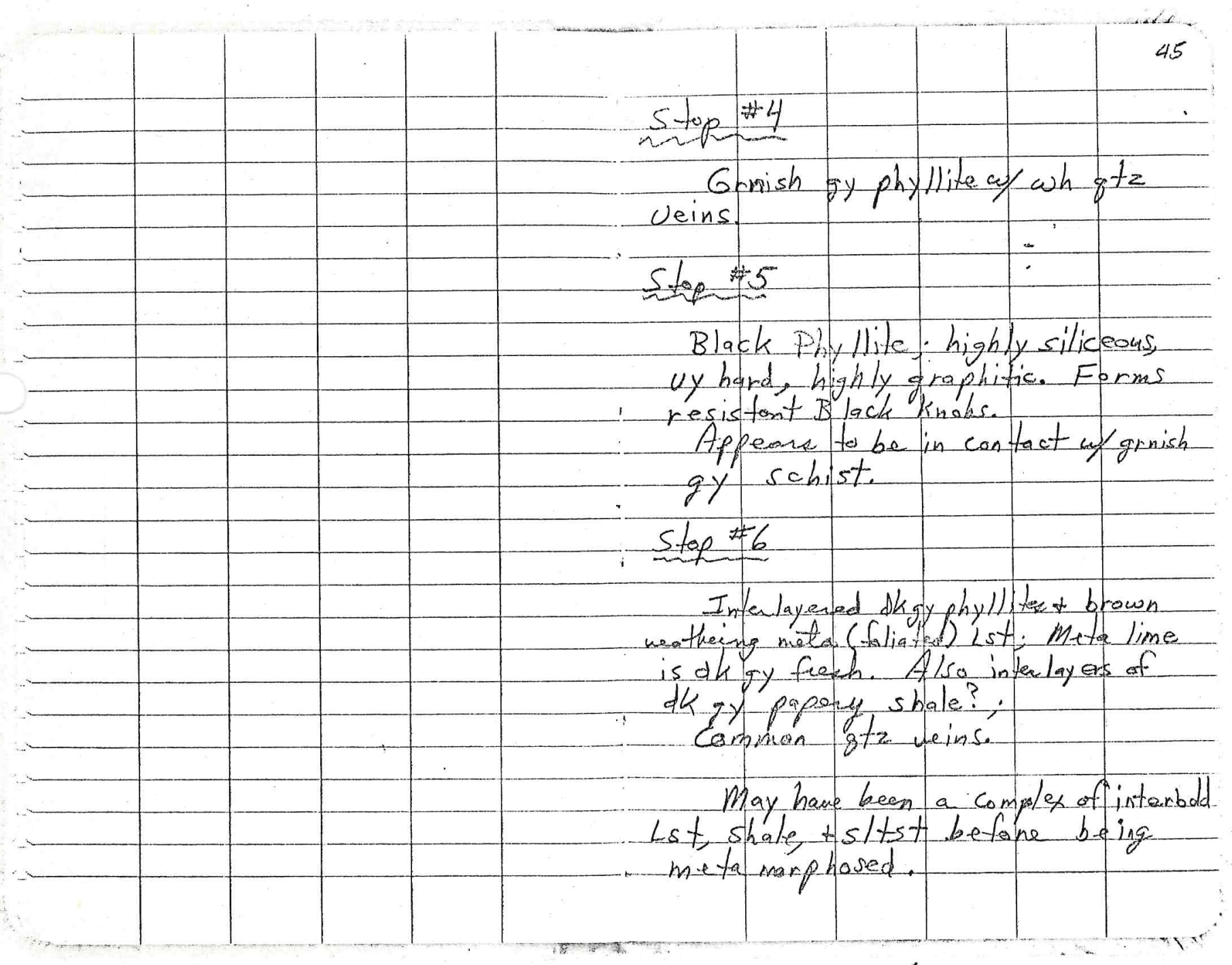




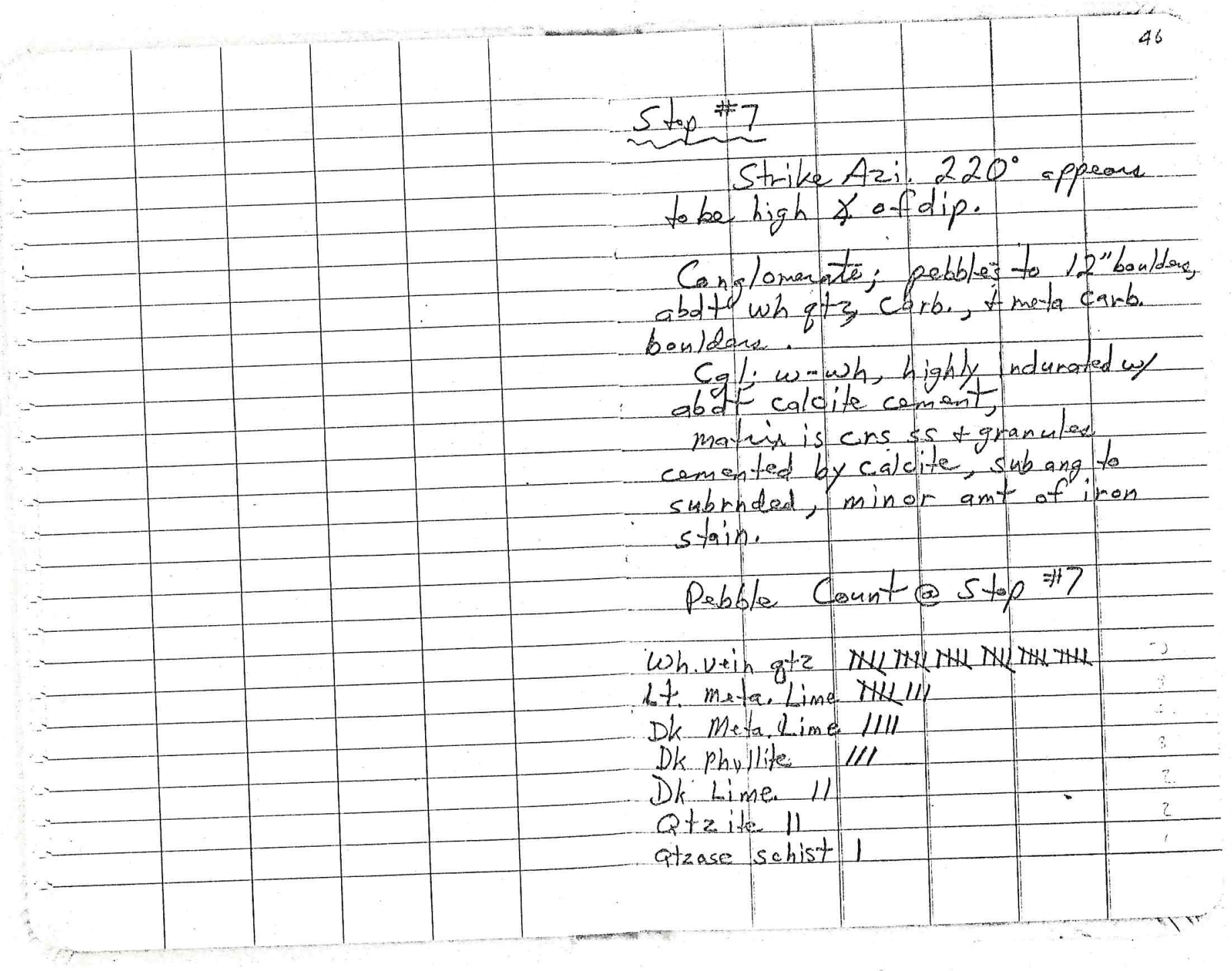




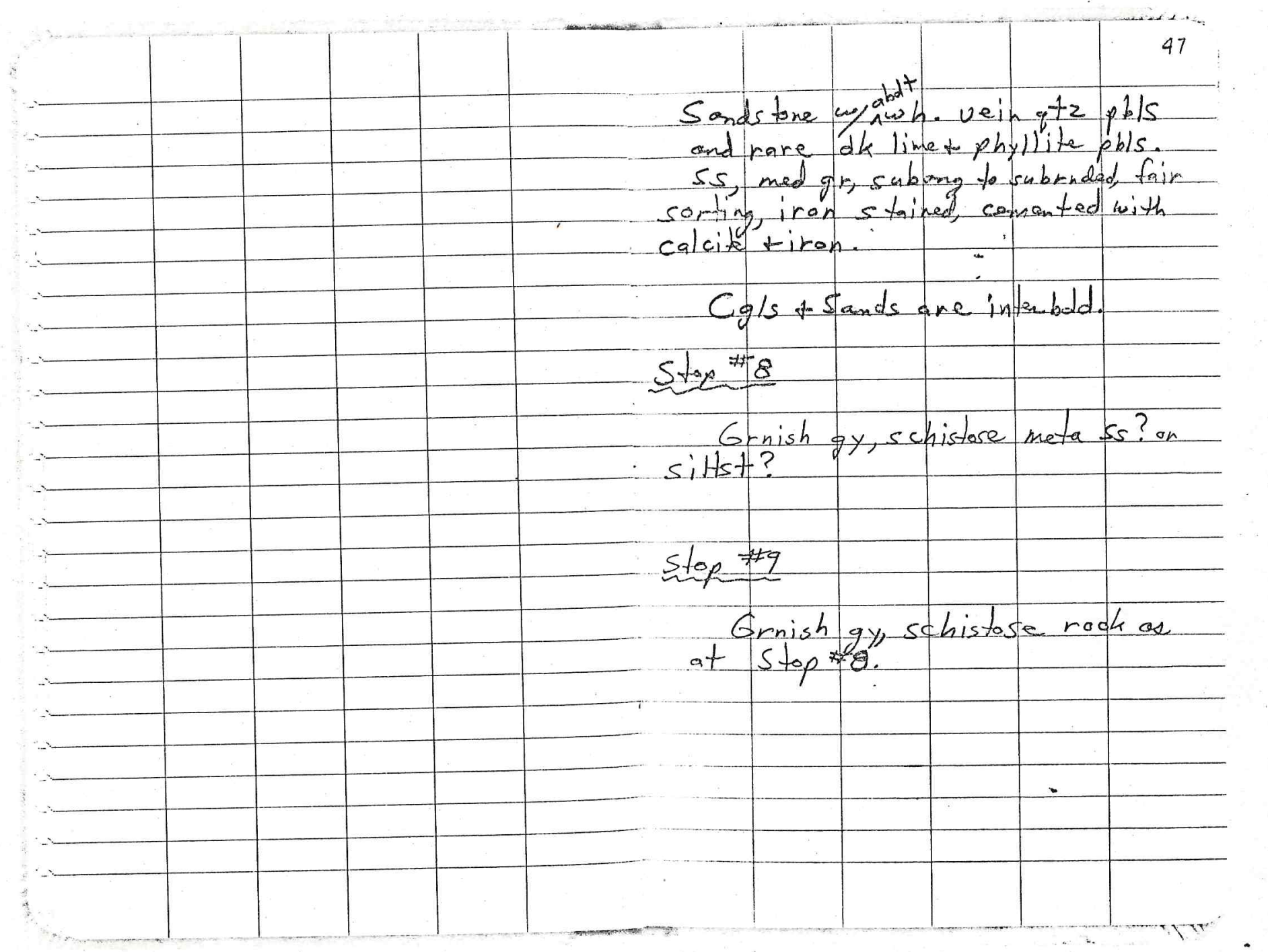





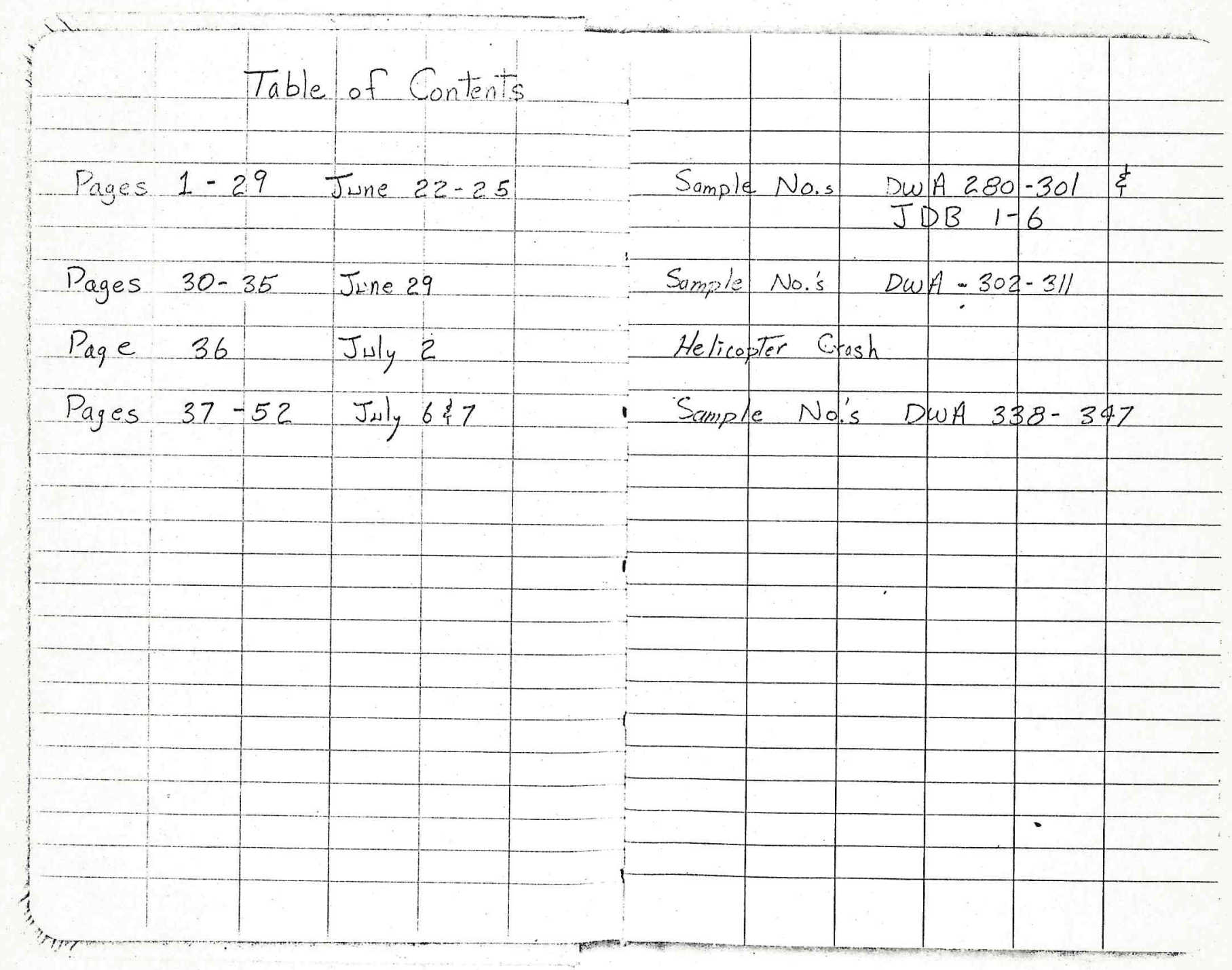




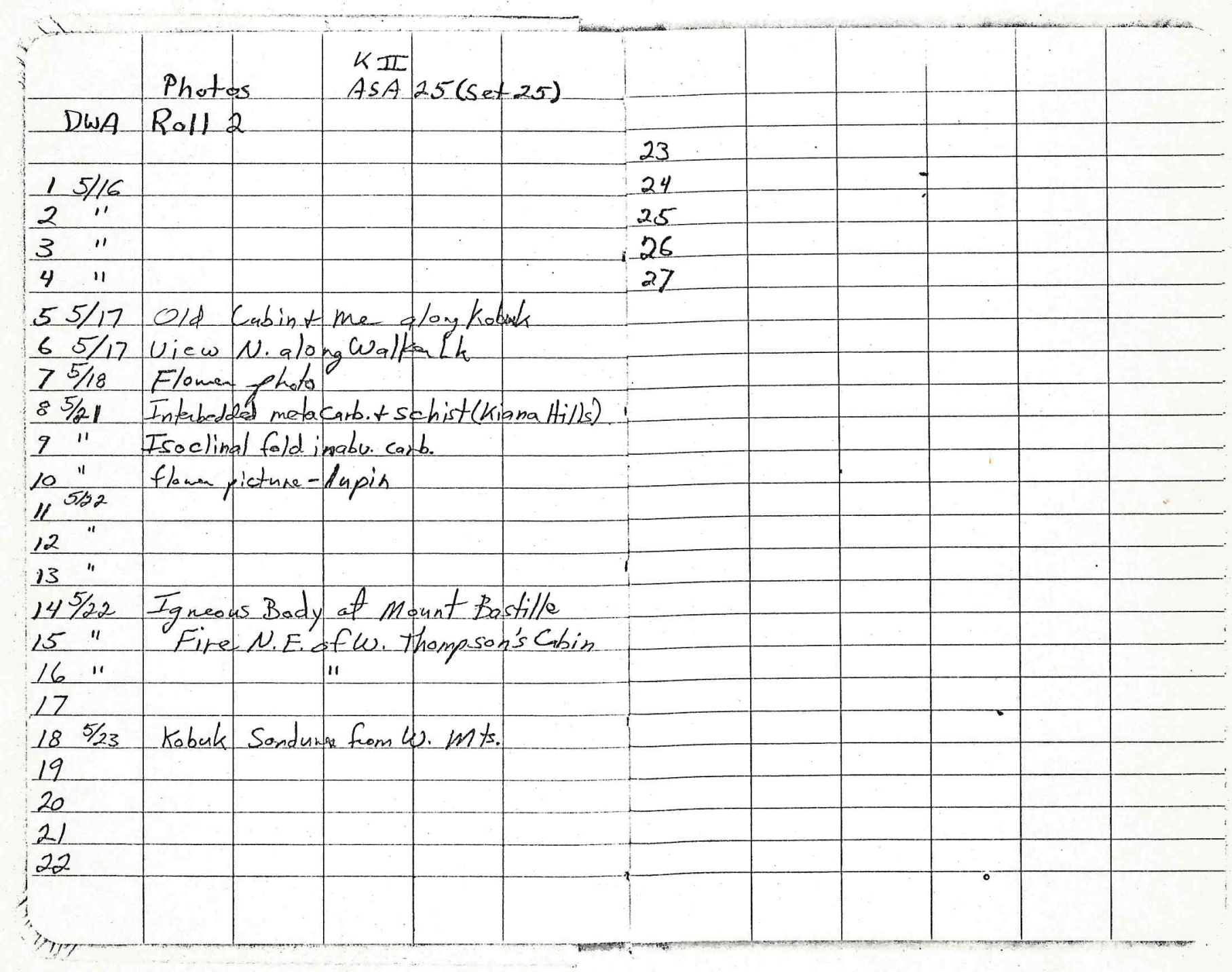




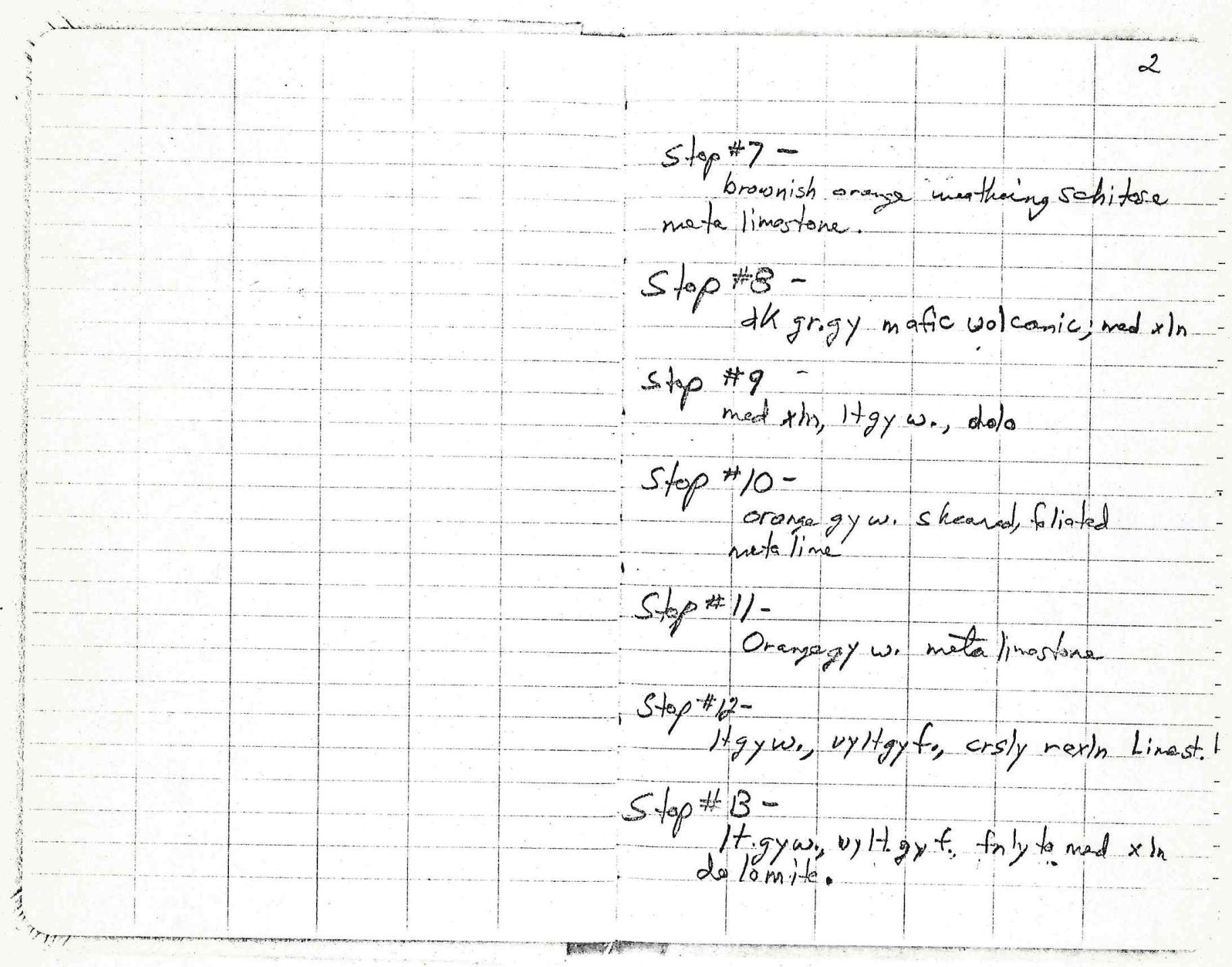




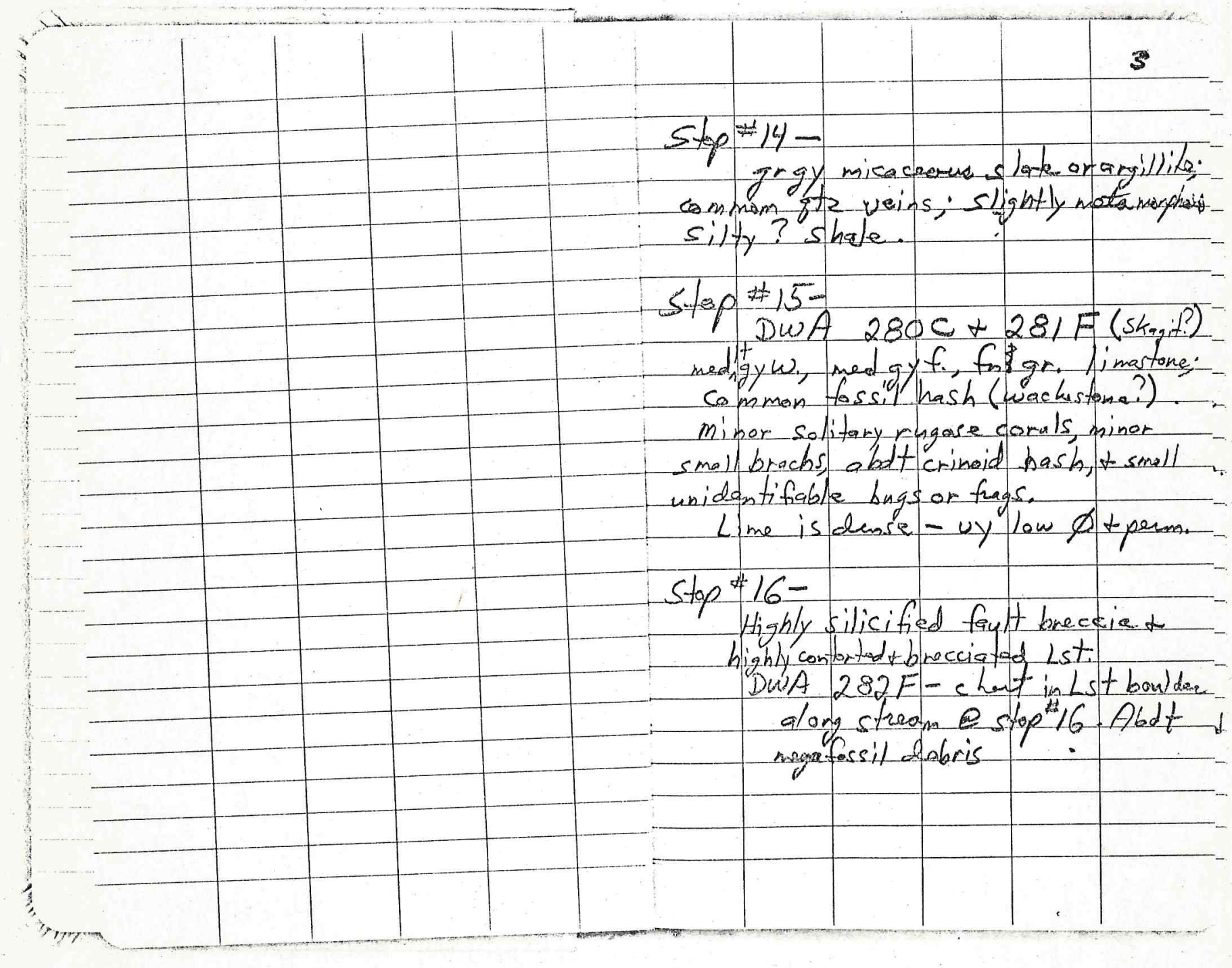




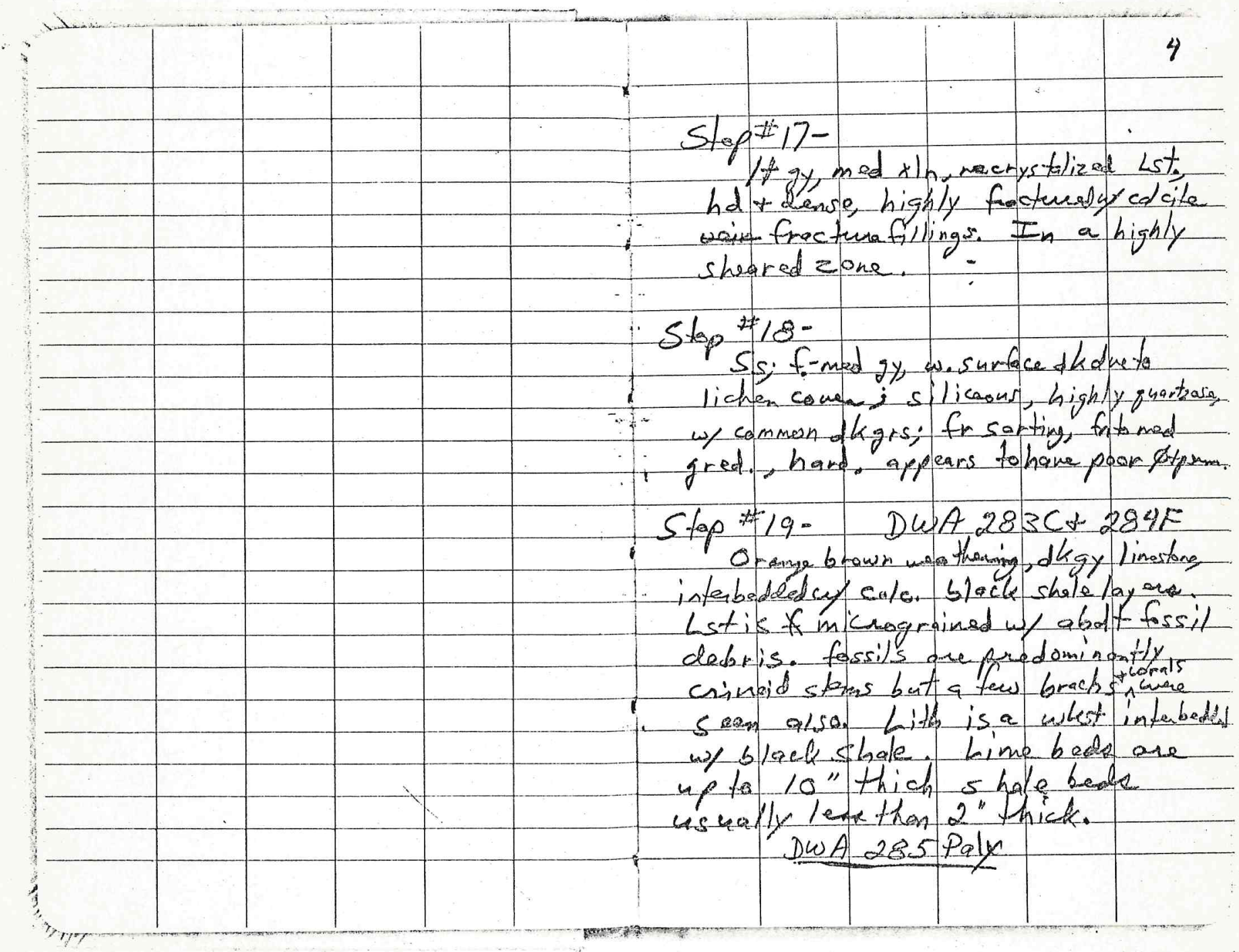




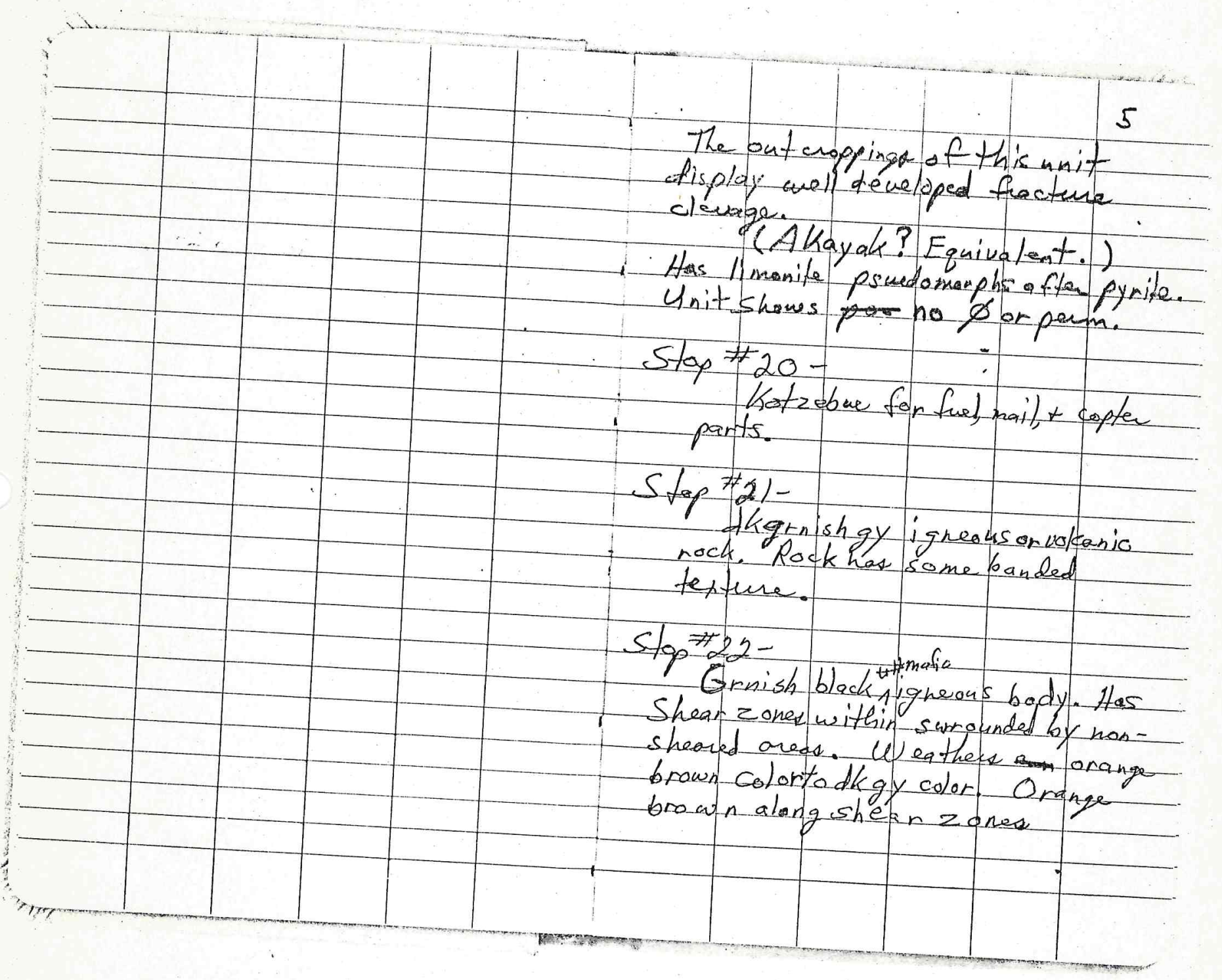




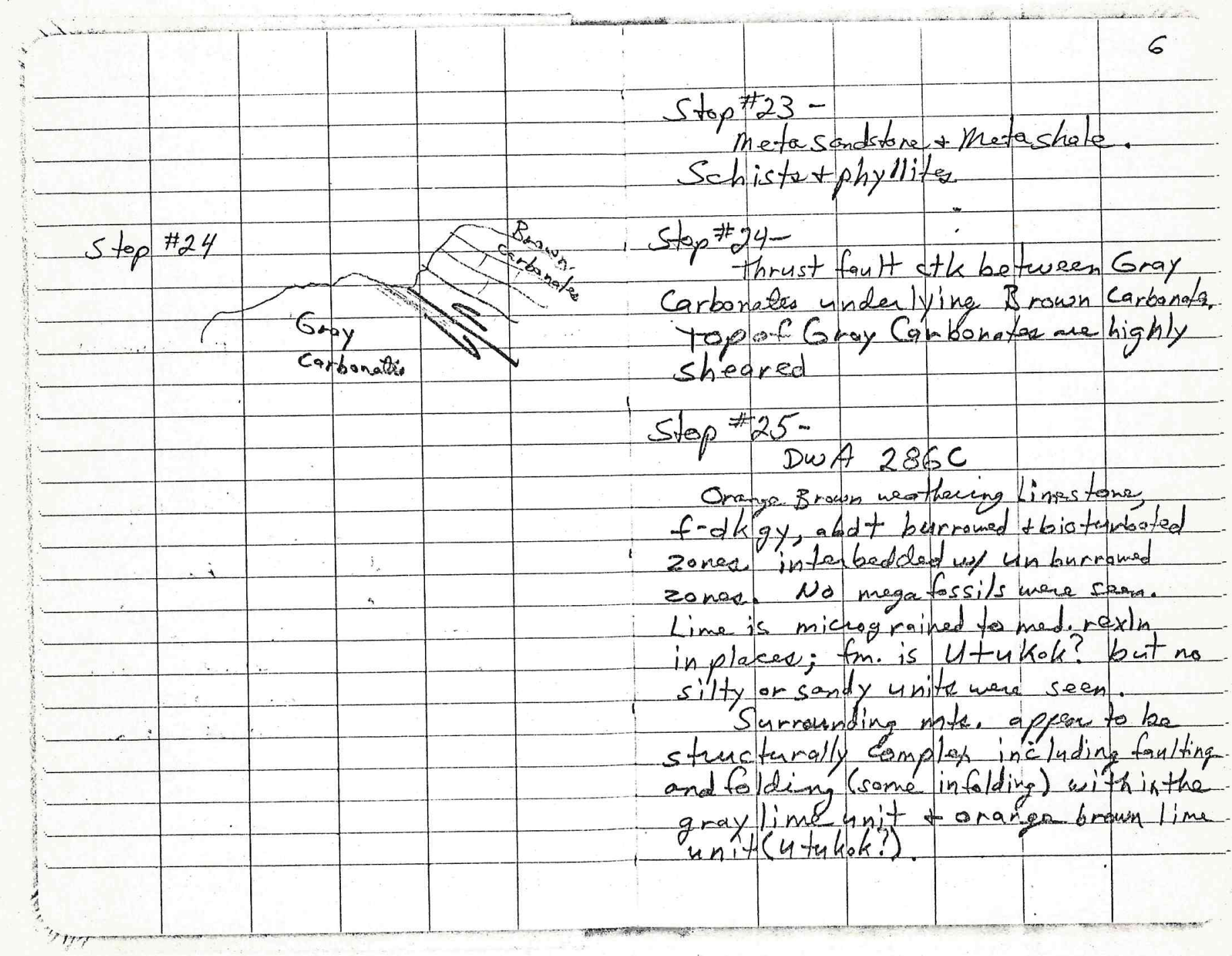




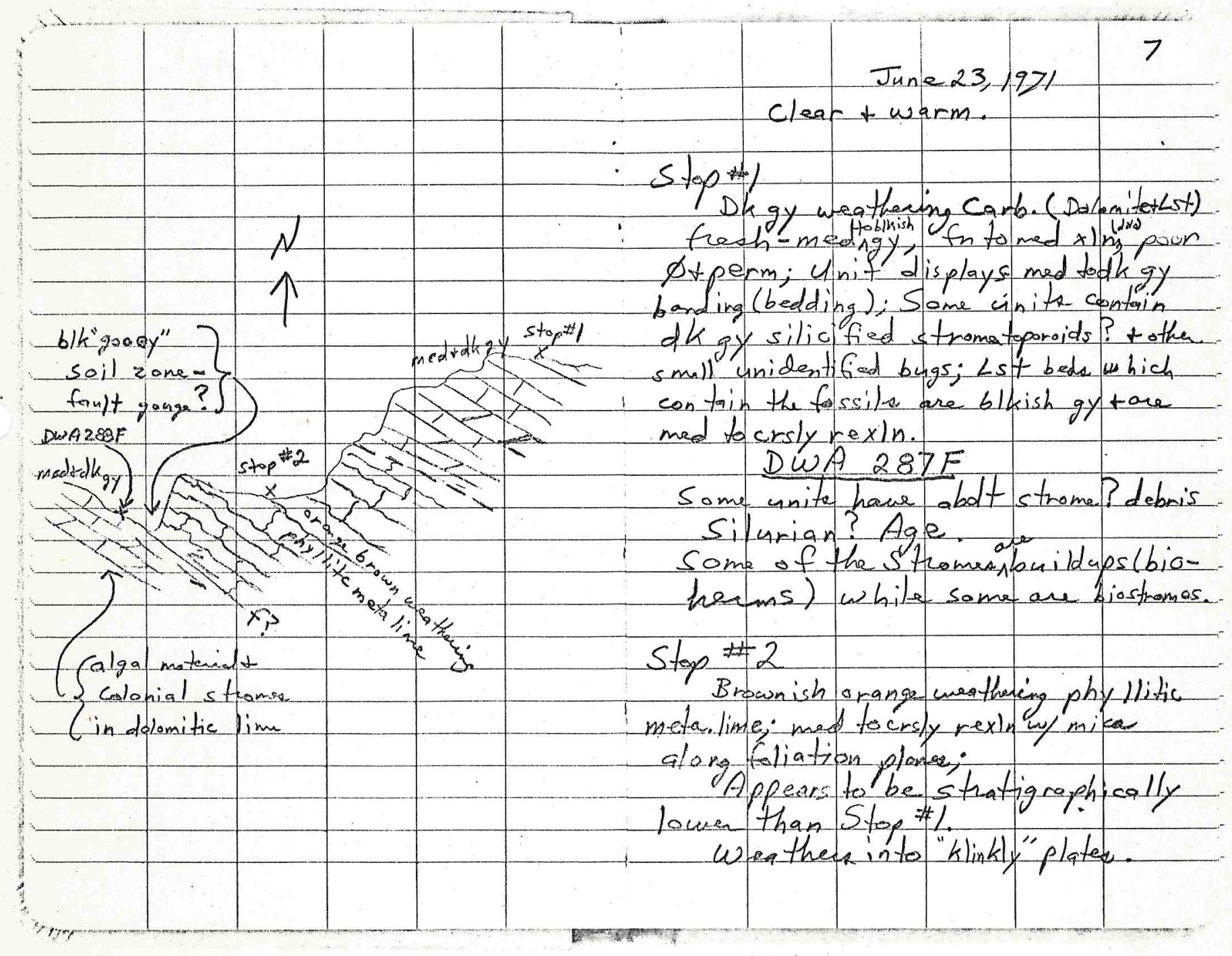




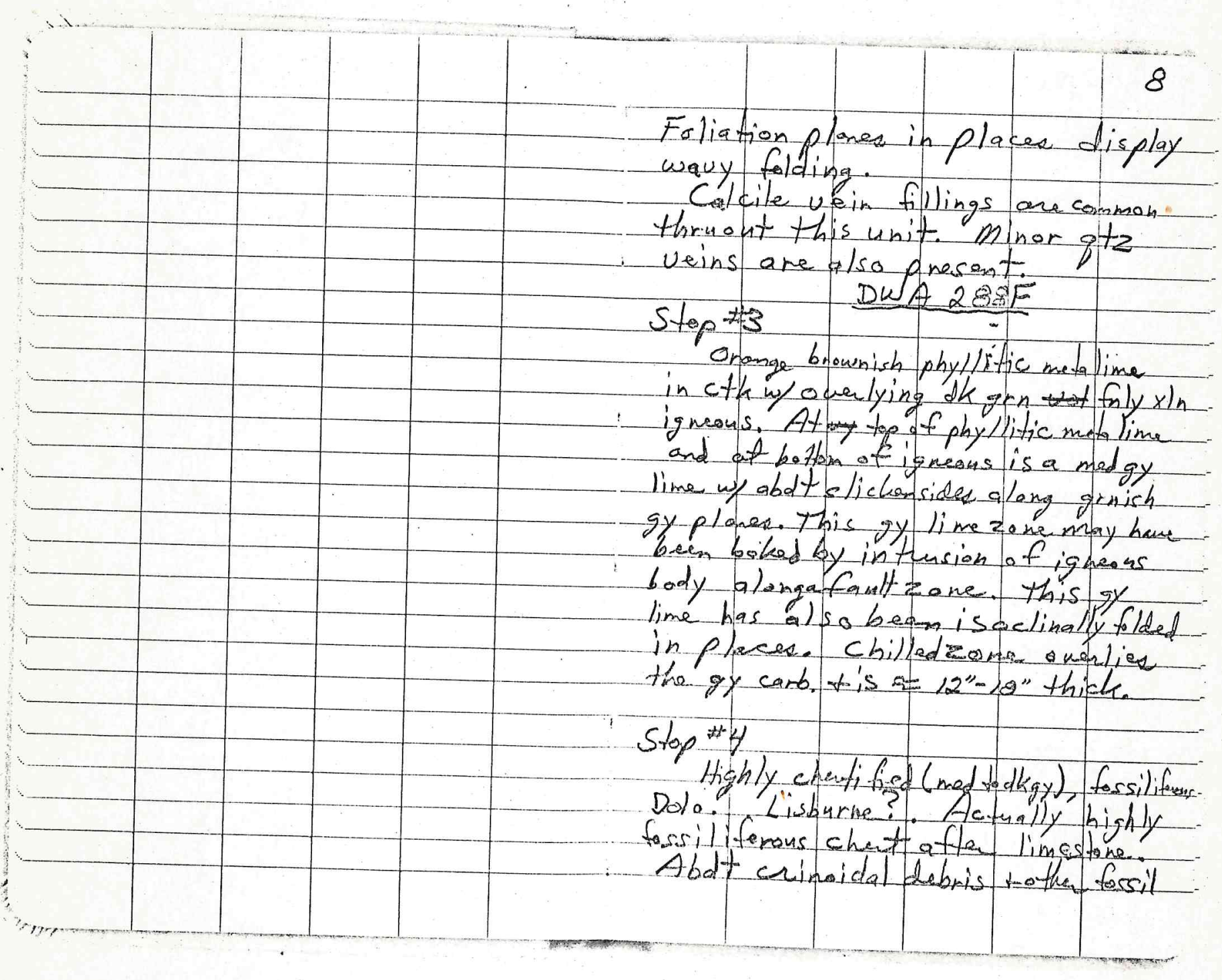




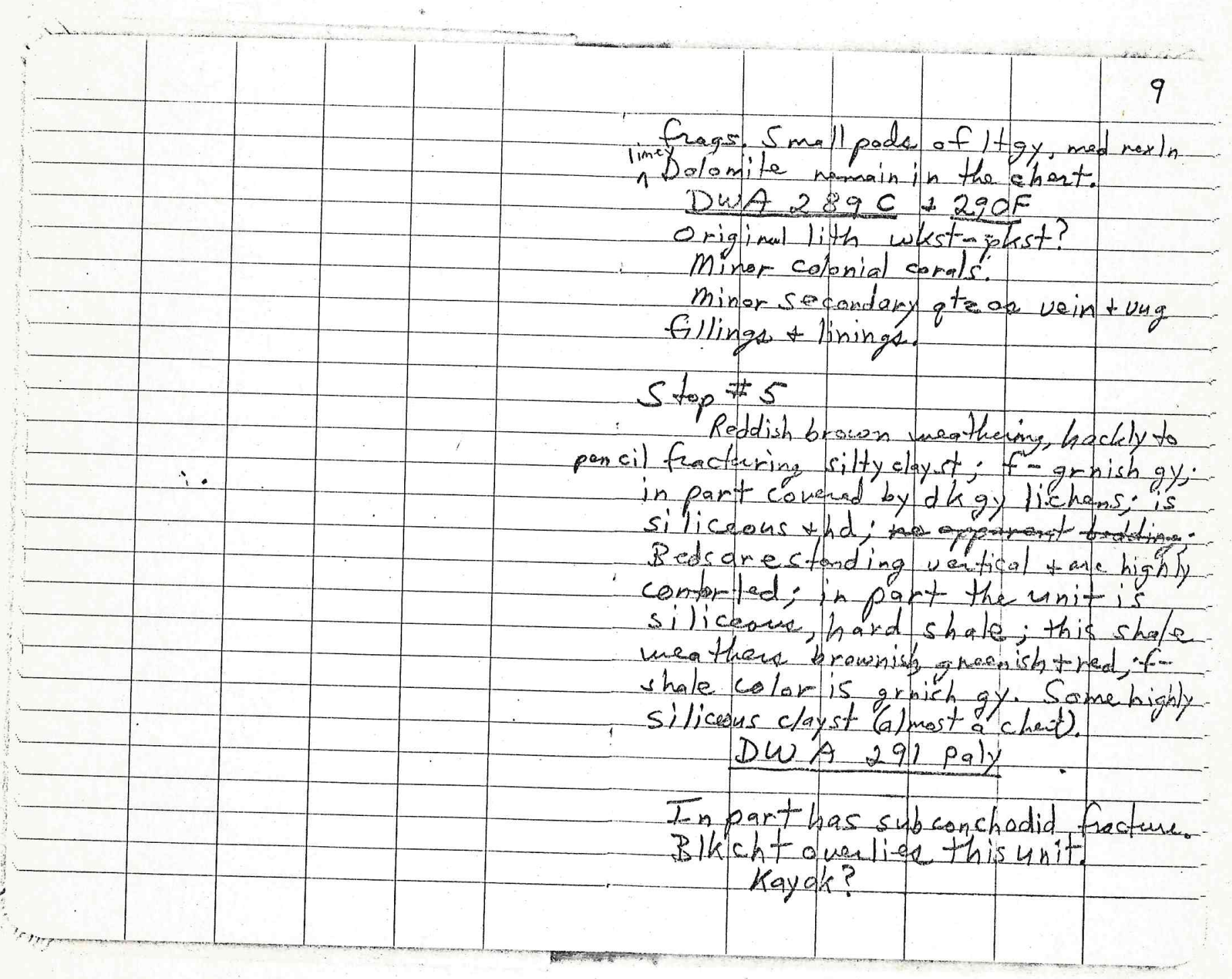




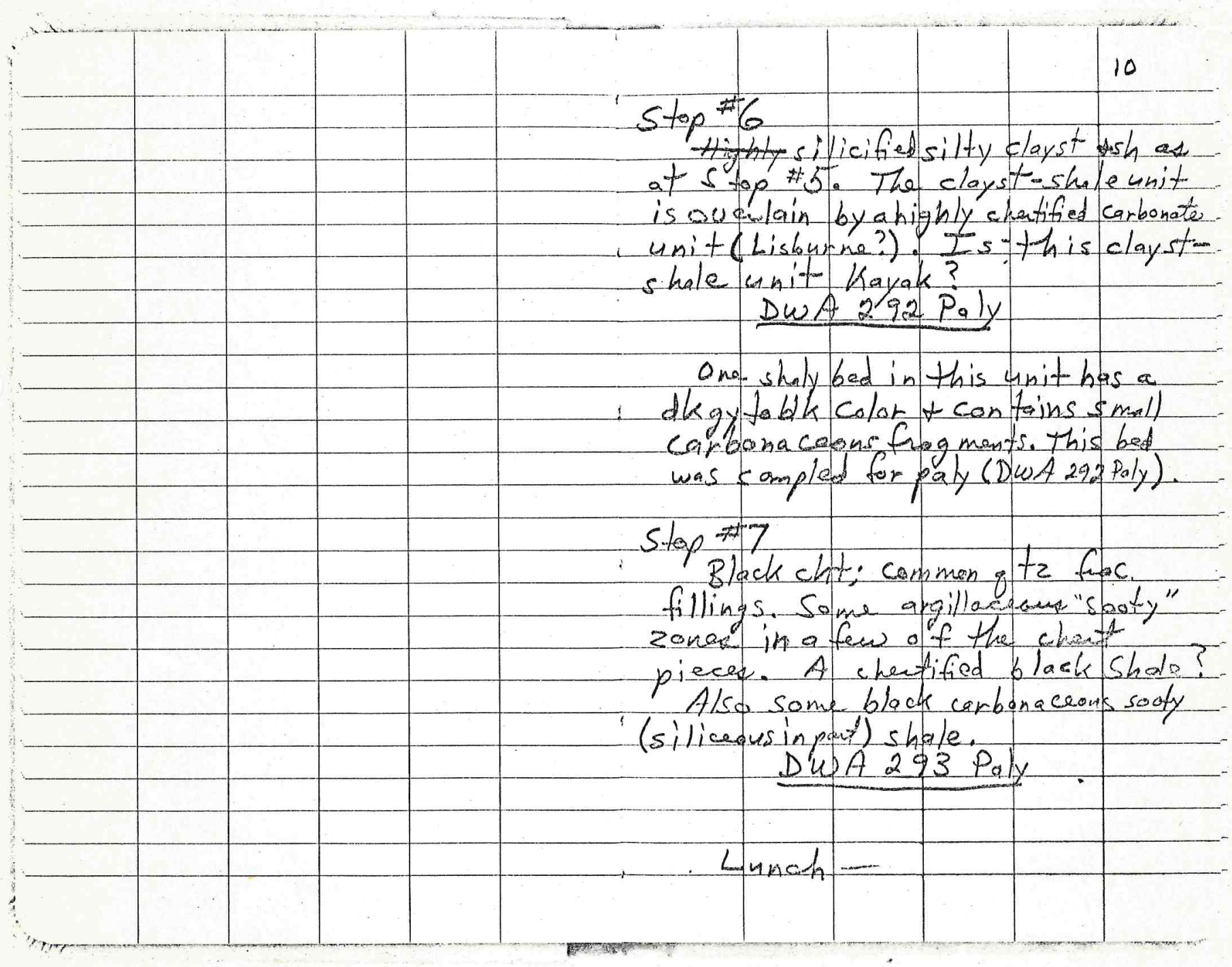




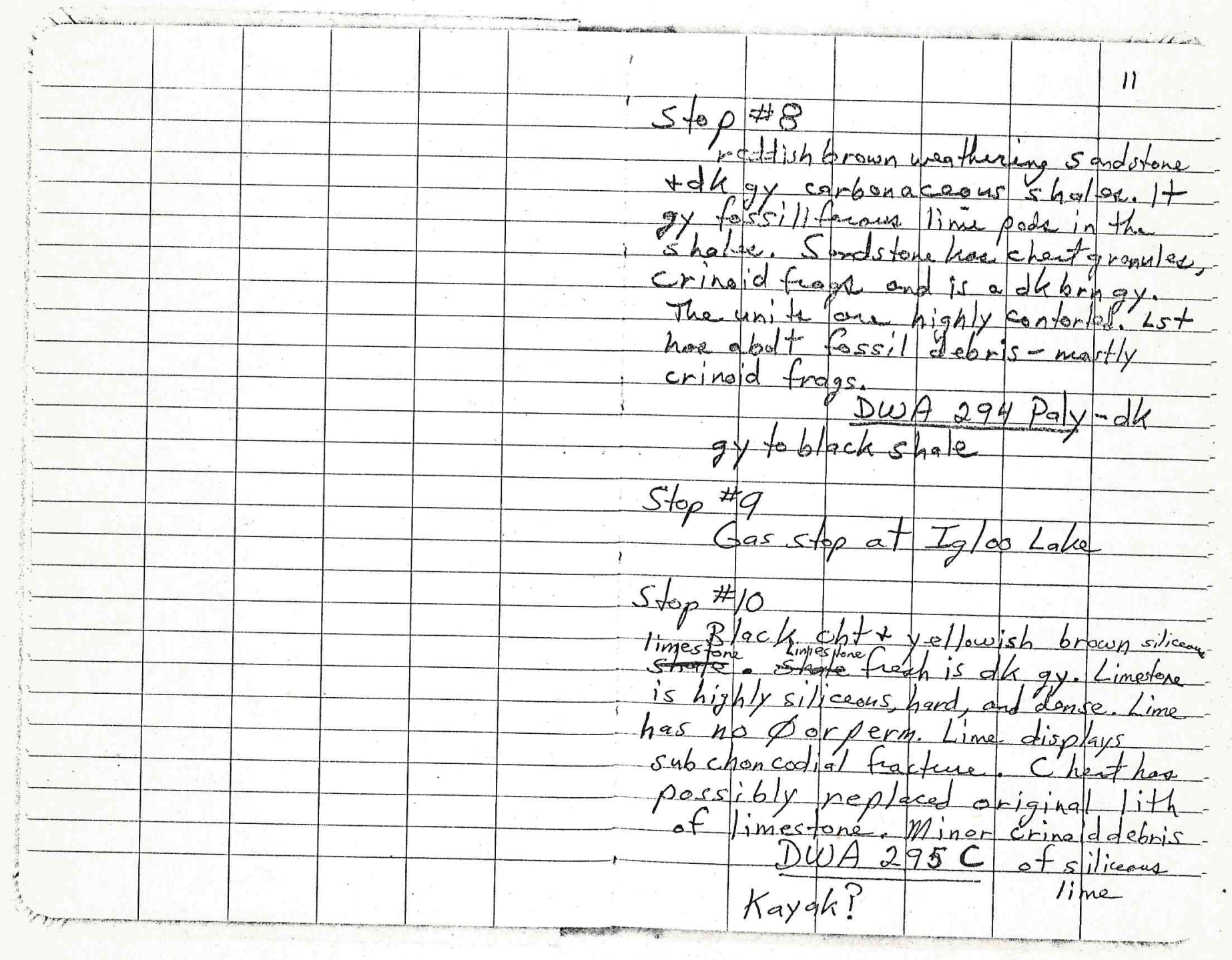




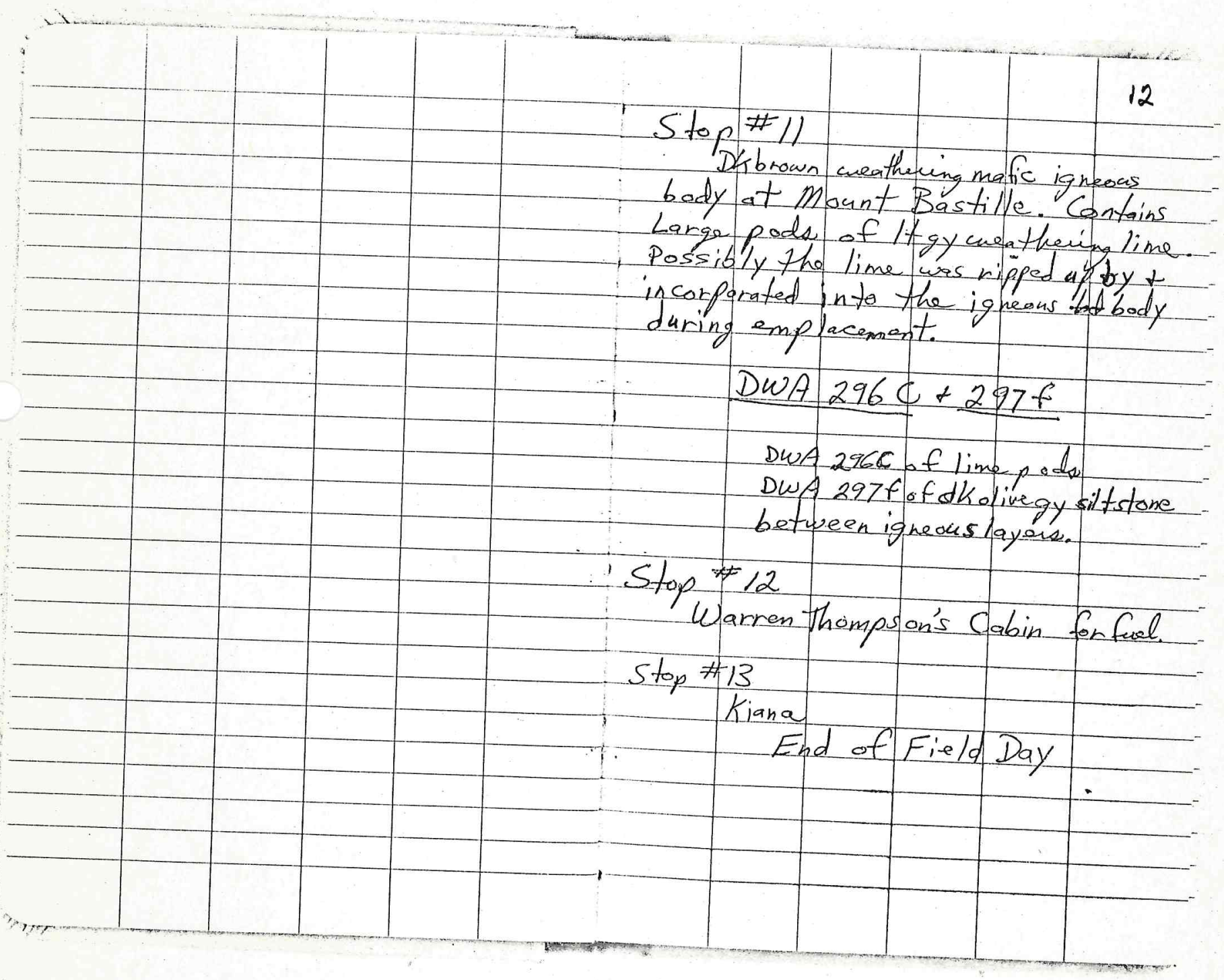




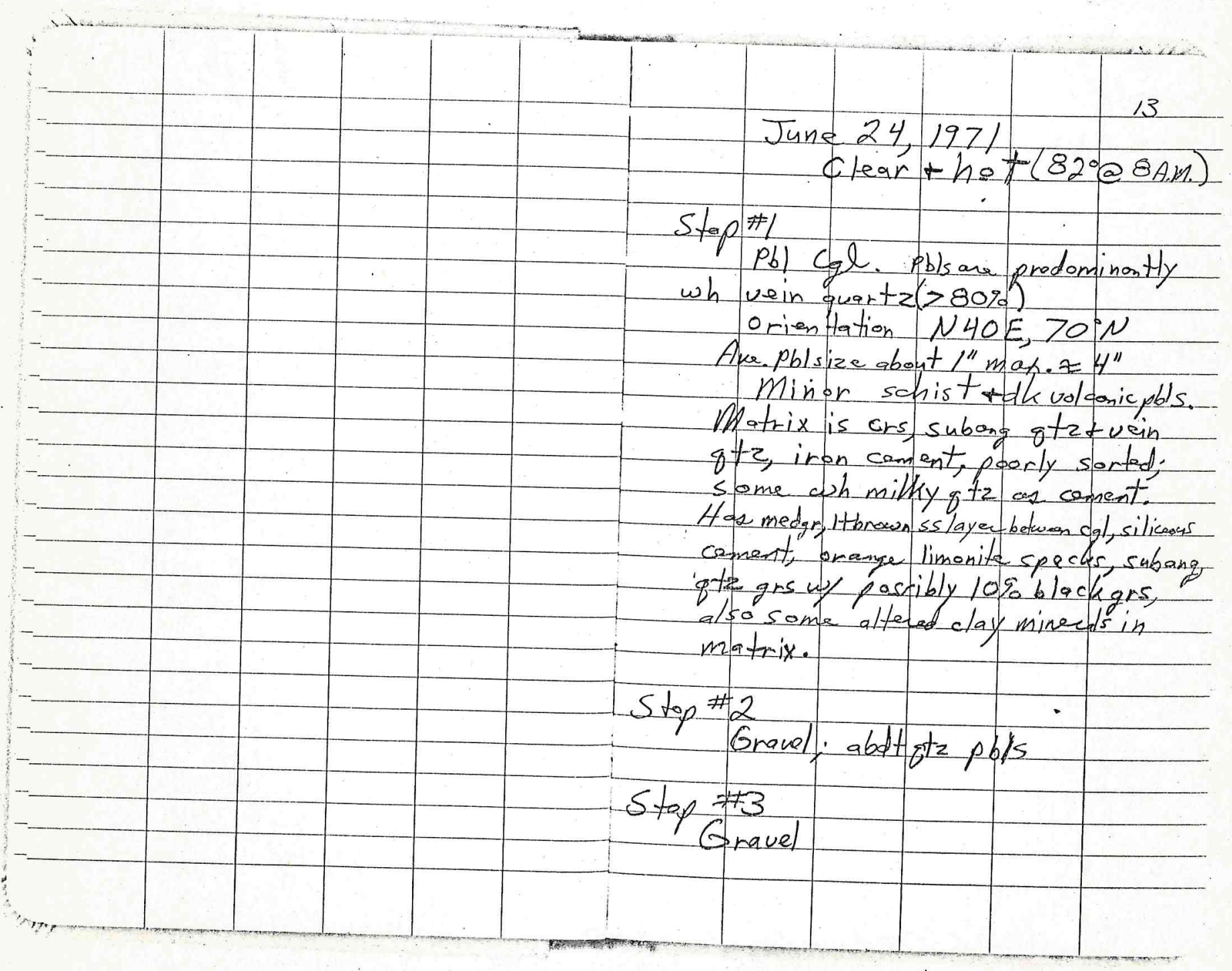




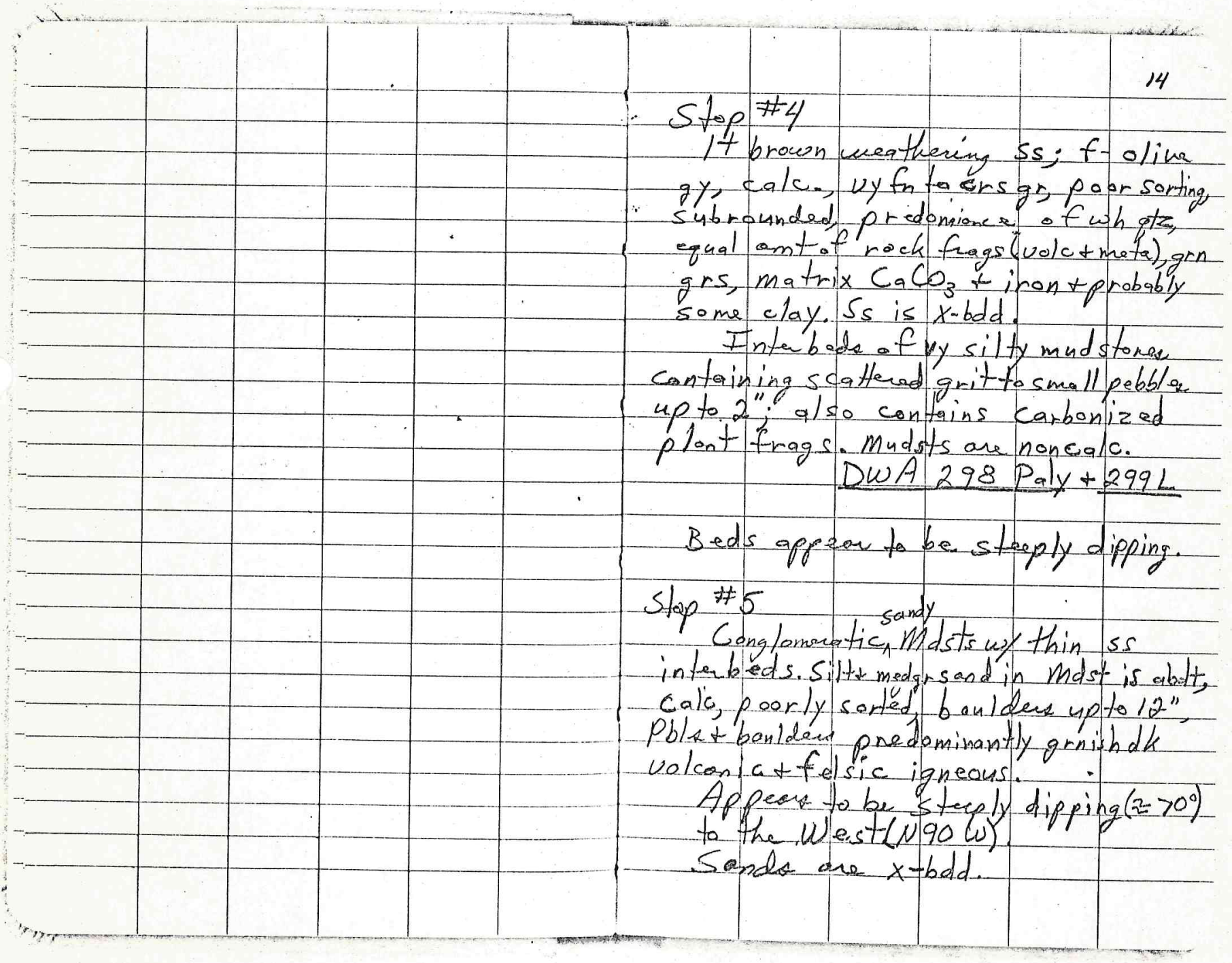




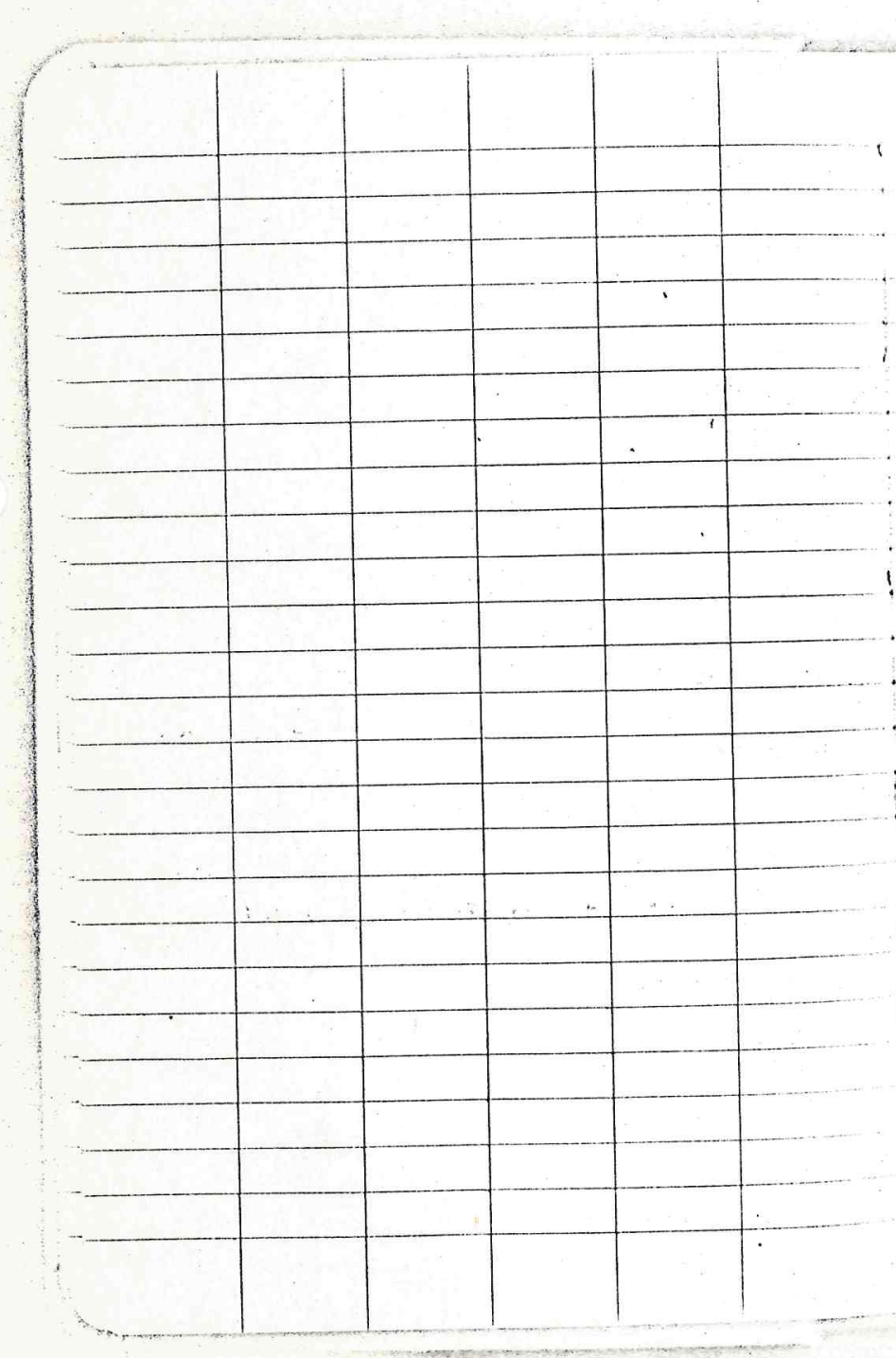

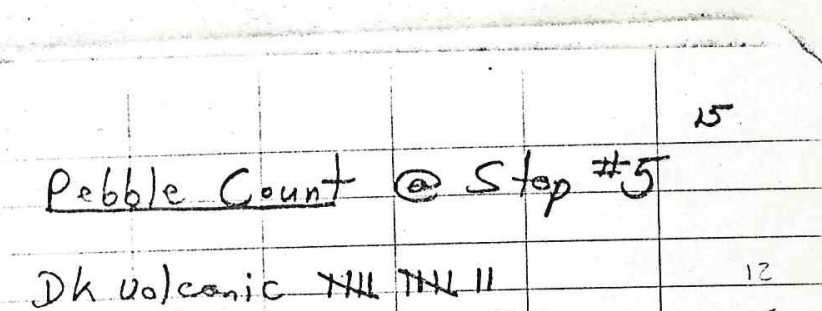

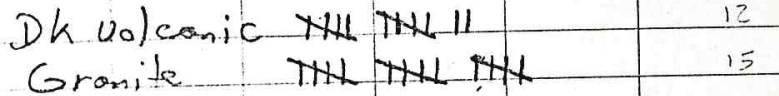

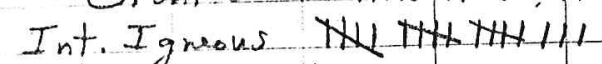
Med gy lime 11

flint

Bull qtz

Basic Ig

Stop $\# 6$

\begin{tabular}{|c|c|c|}
\hline 1 & 2 \\
\hline 1 & & 1 \\
\hline 1 & & \\
\hline & & \\
\hline
\end{tabular}

H gy br we theing ss; finto med grod inter bedted sond, grs are submaded, otat feldsportibuttblackgrs (predom.) t-rock frags: matrix is sift tclay mixture, med. sorting, appears to have poor 申tperm.

Som in tenbeds of gy brown, micacons, sundy, argillacouns siltstene; contains carbonized plant fragments. 


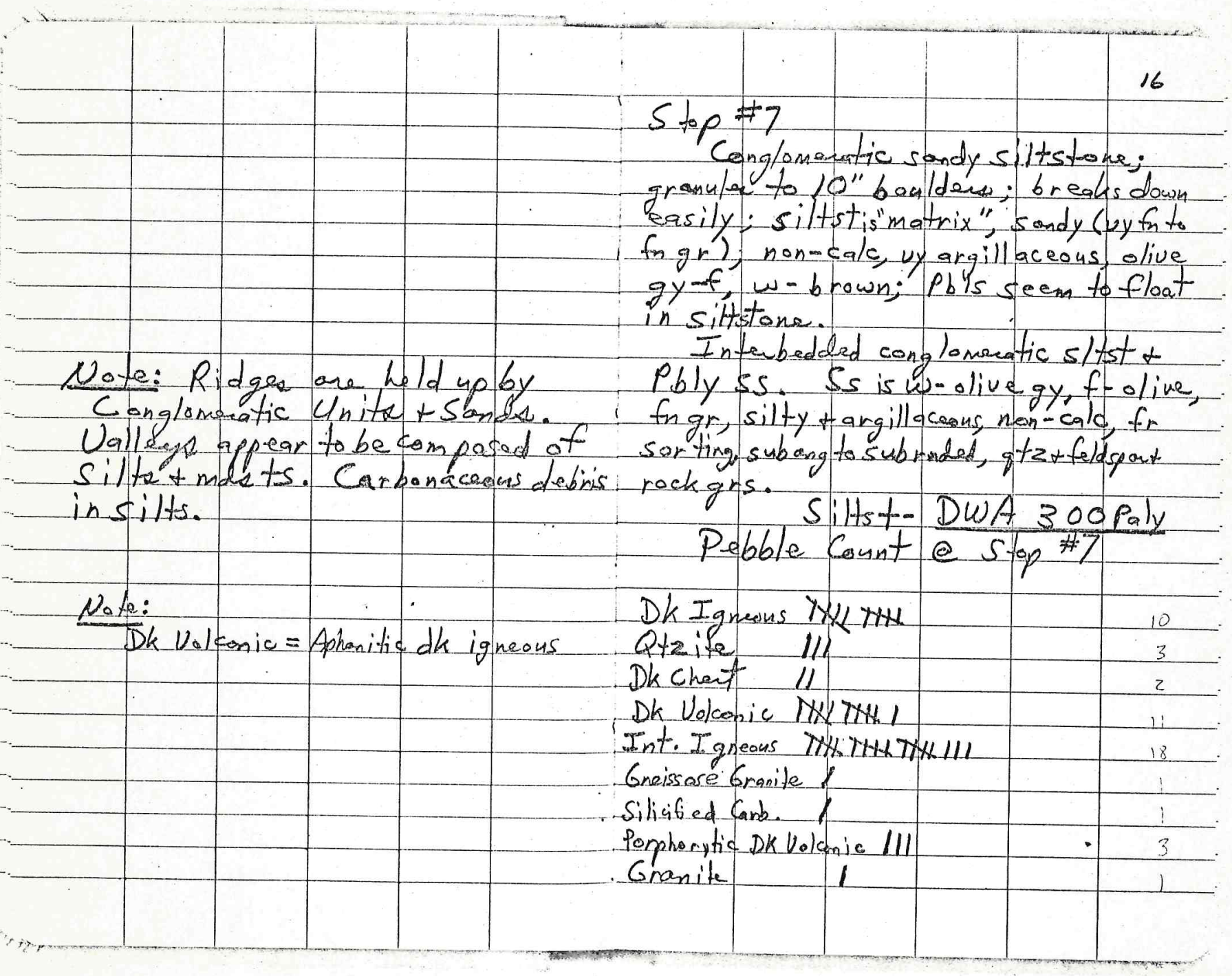




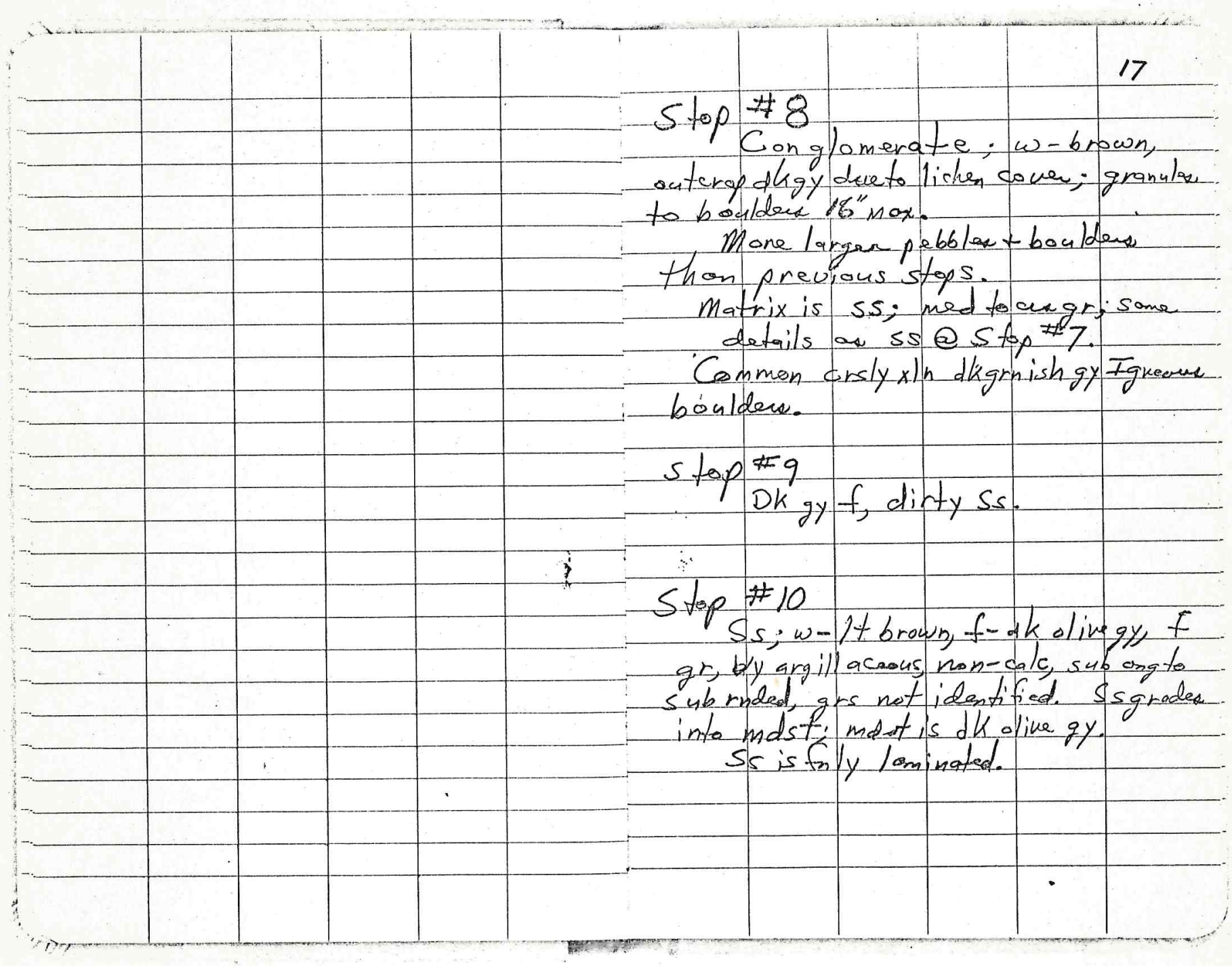




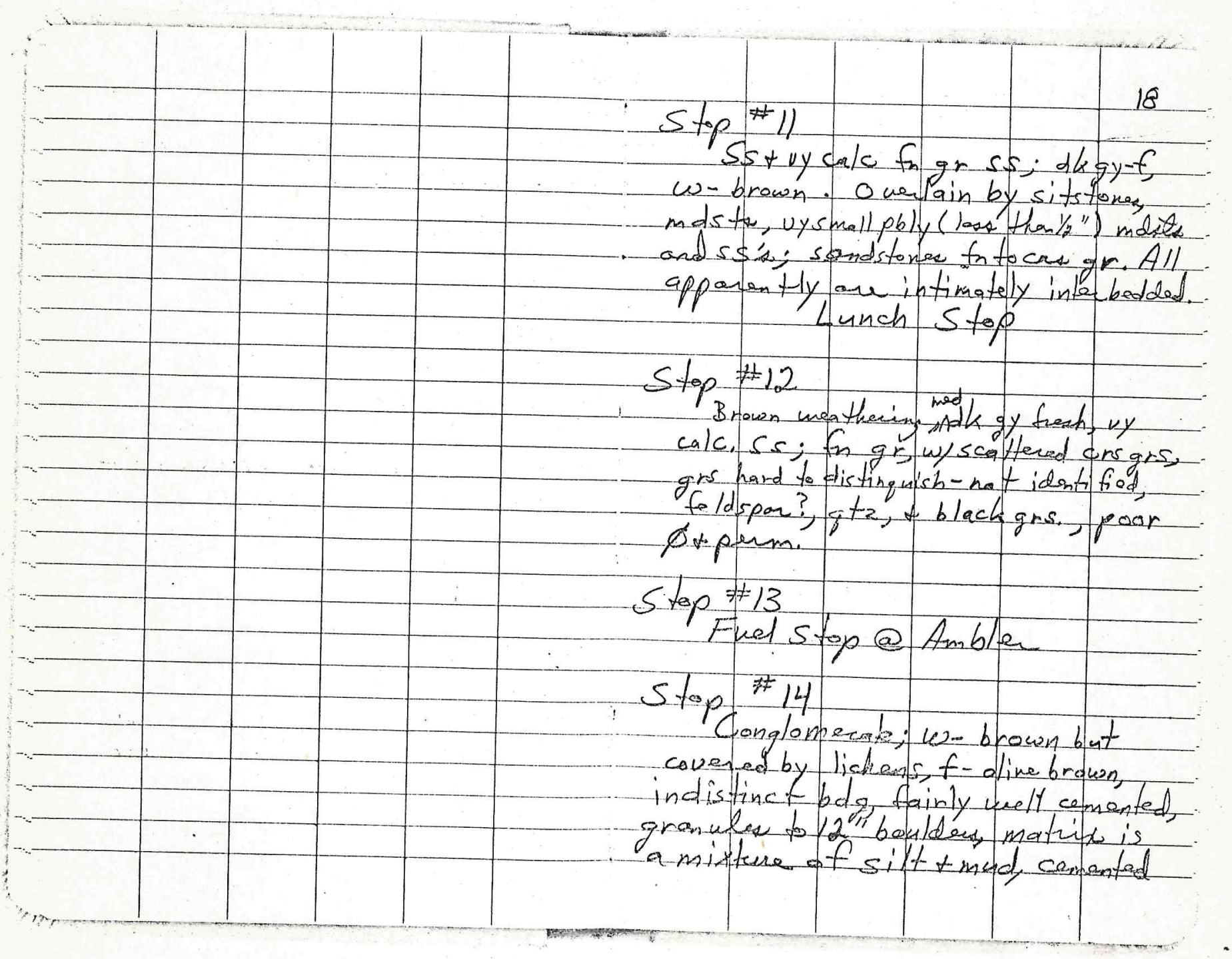




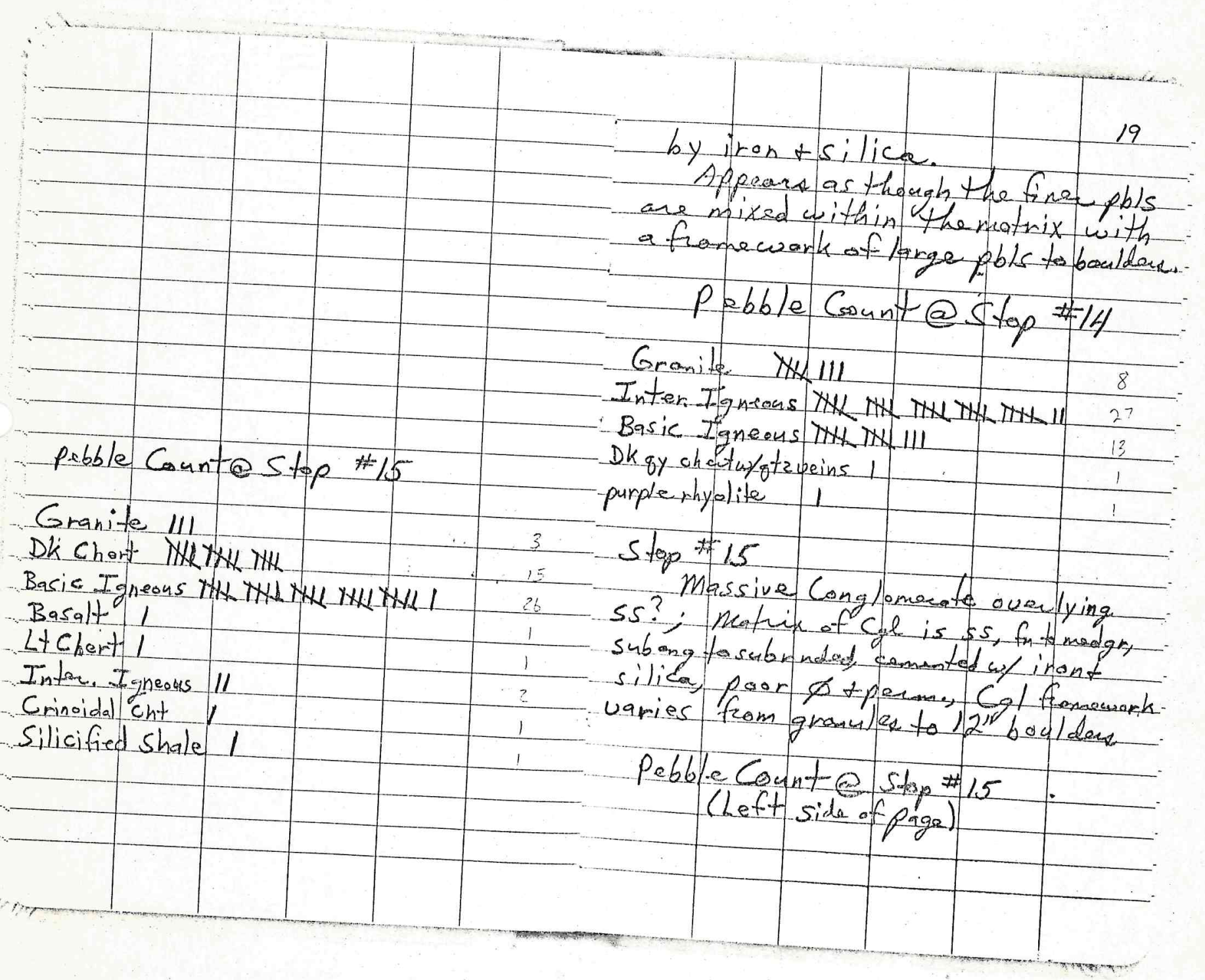




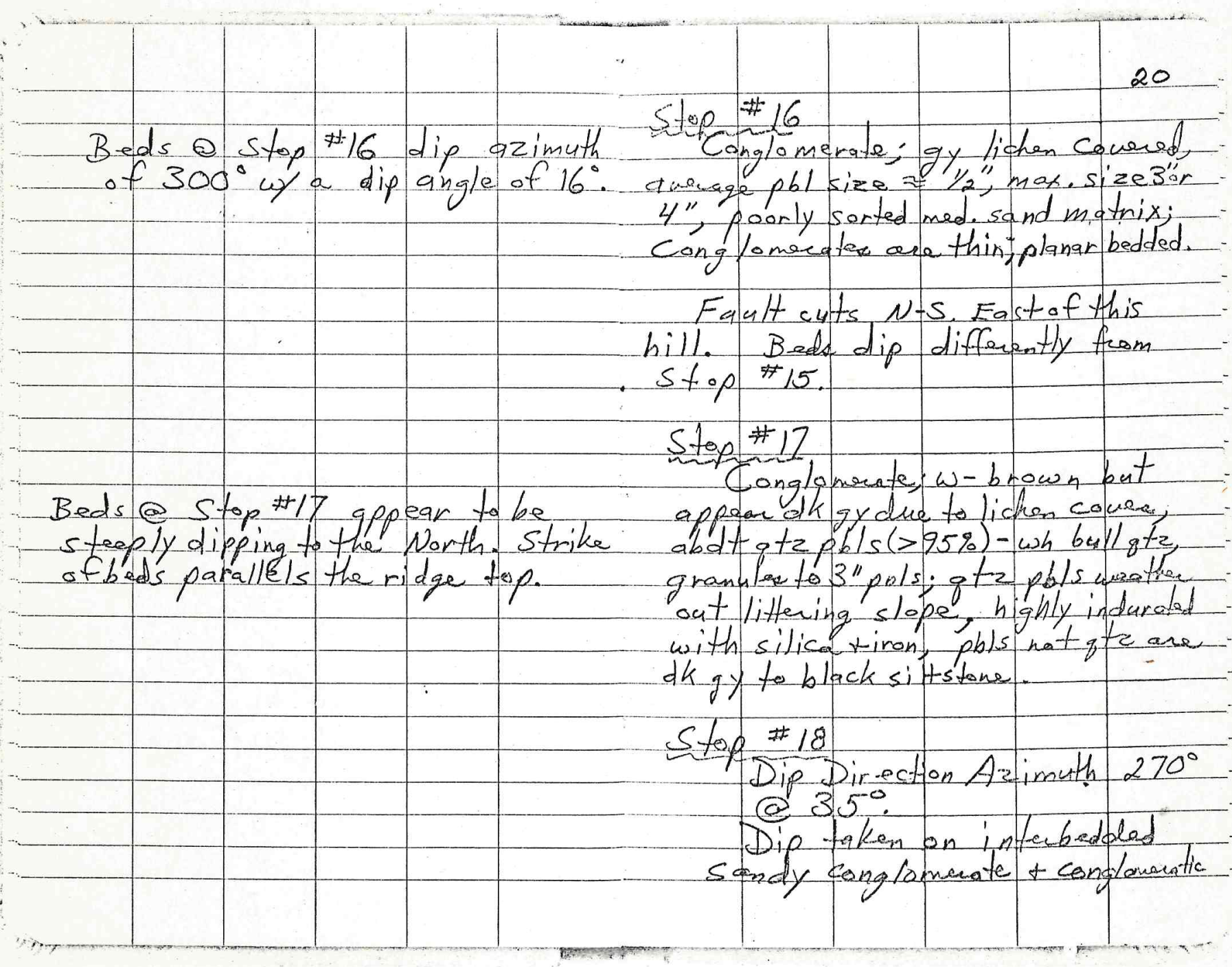




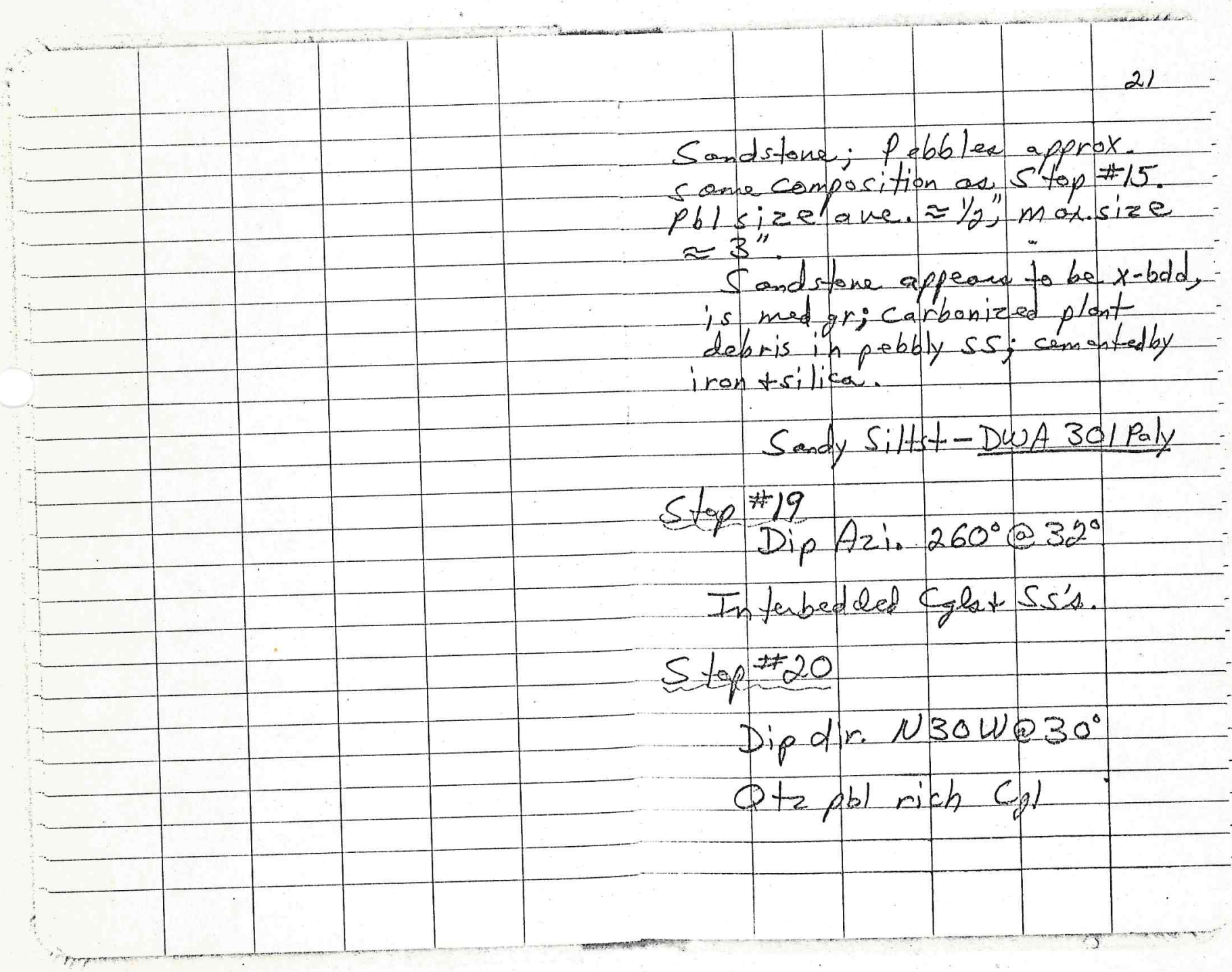




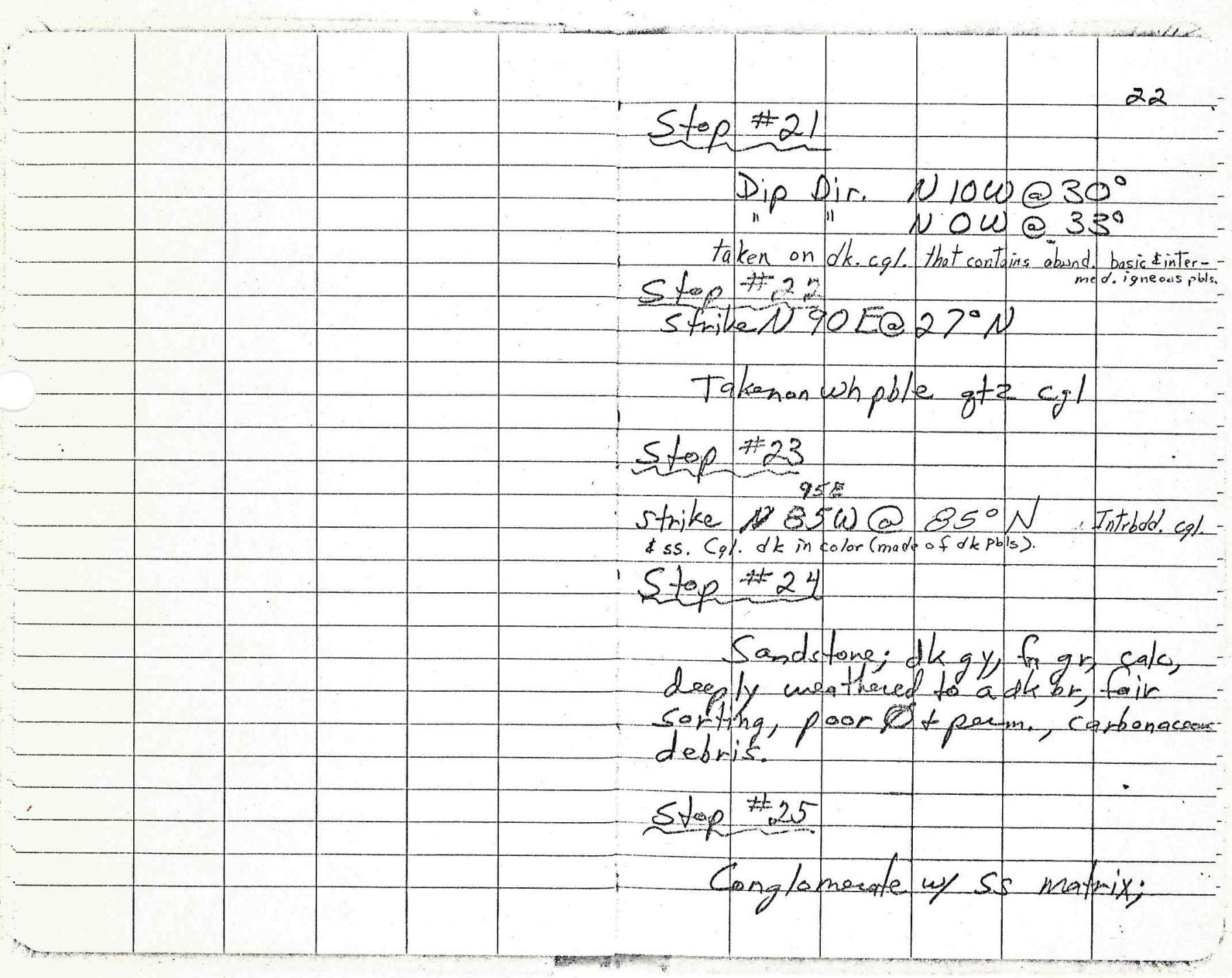




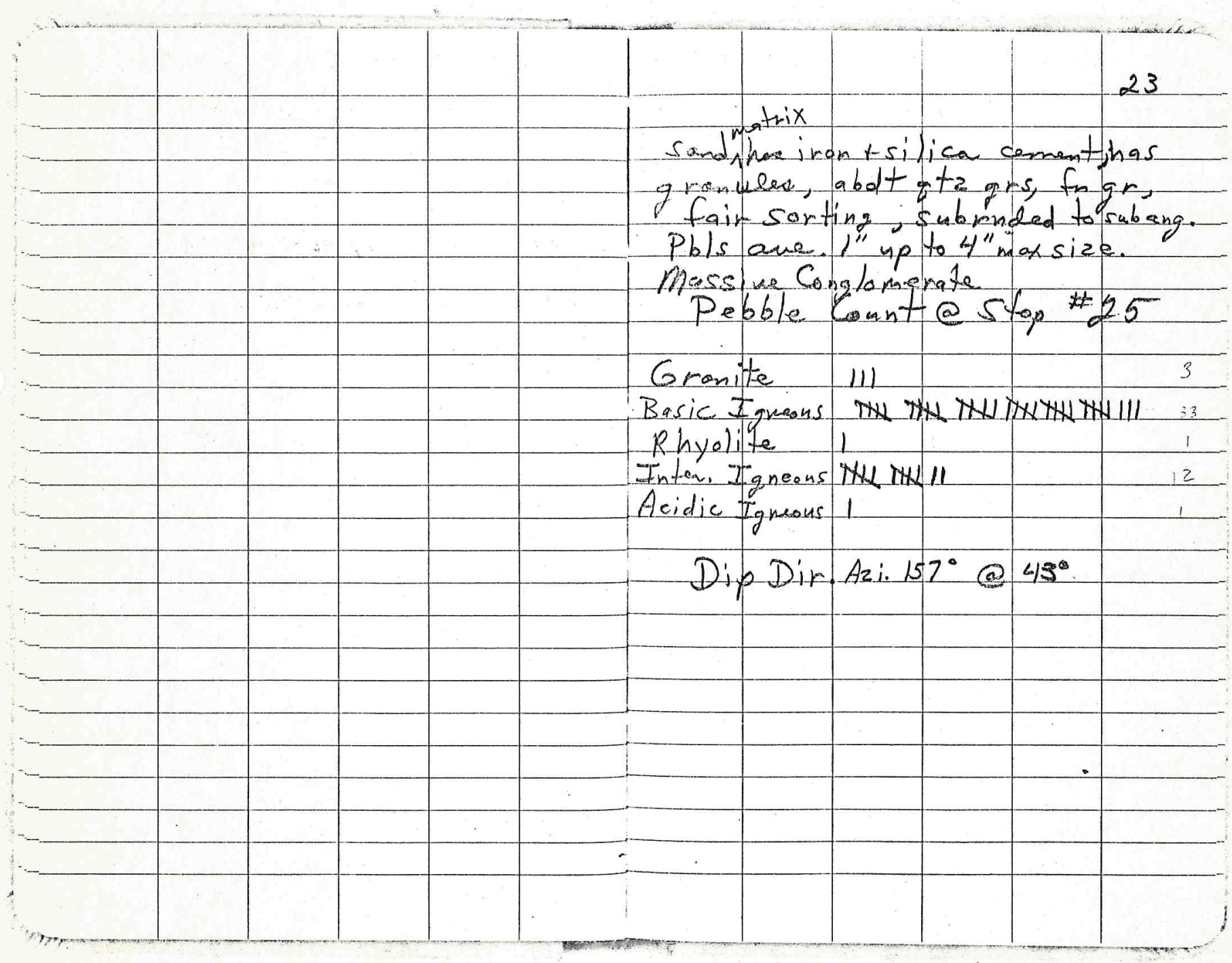




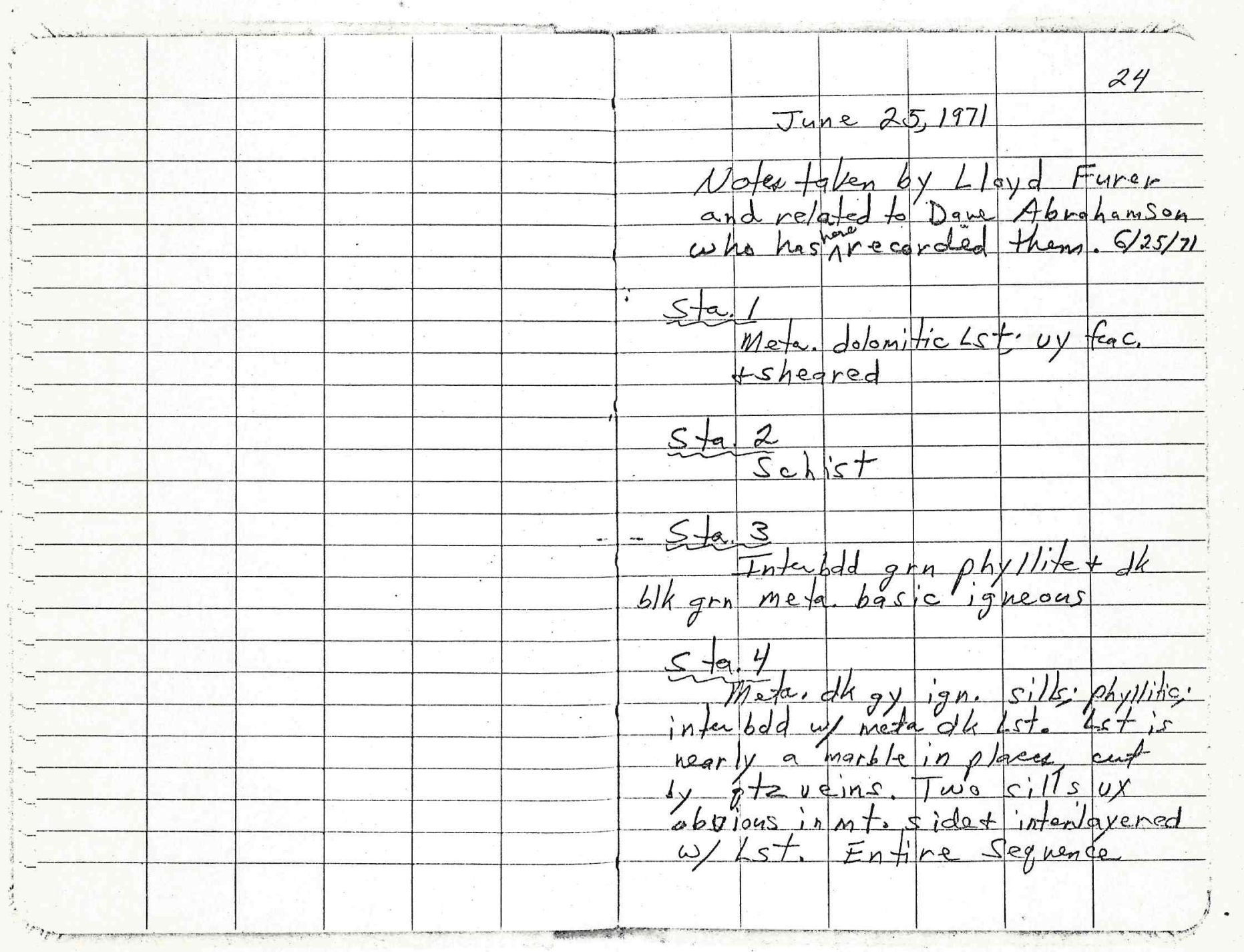




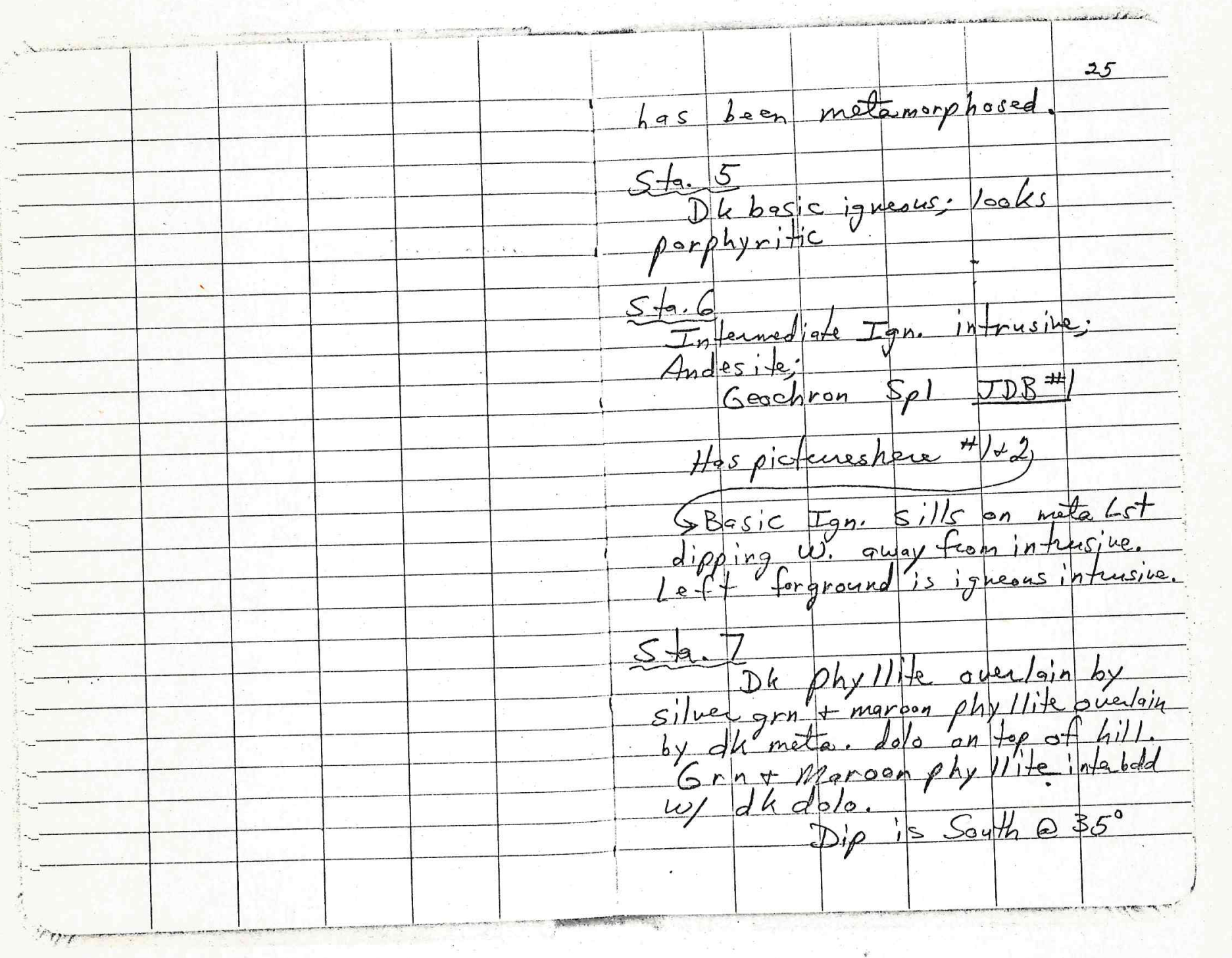




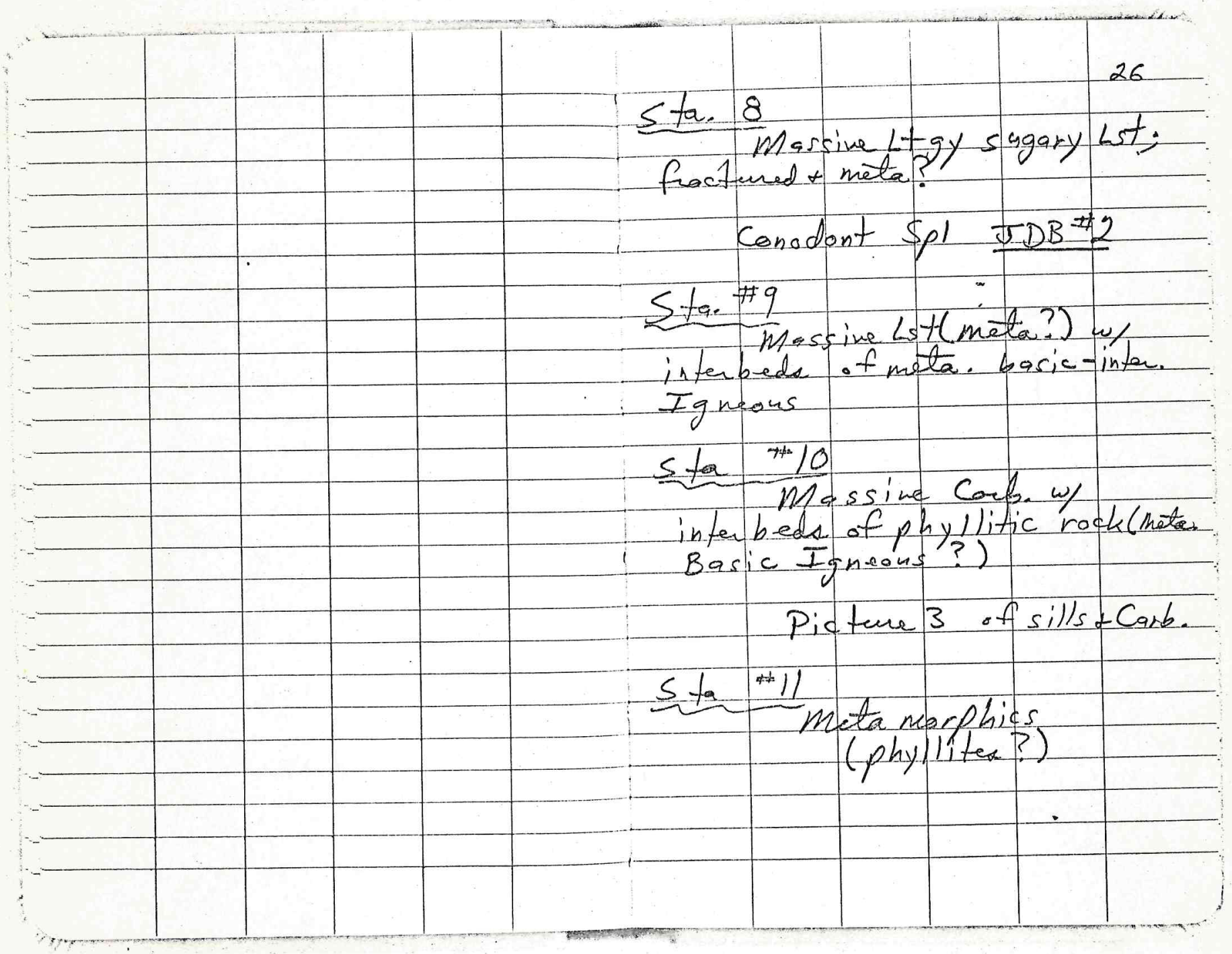




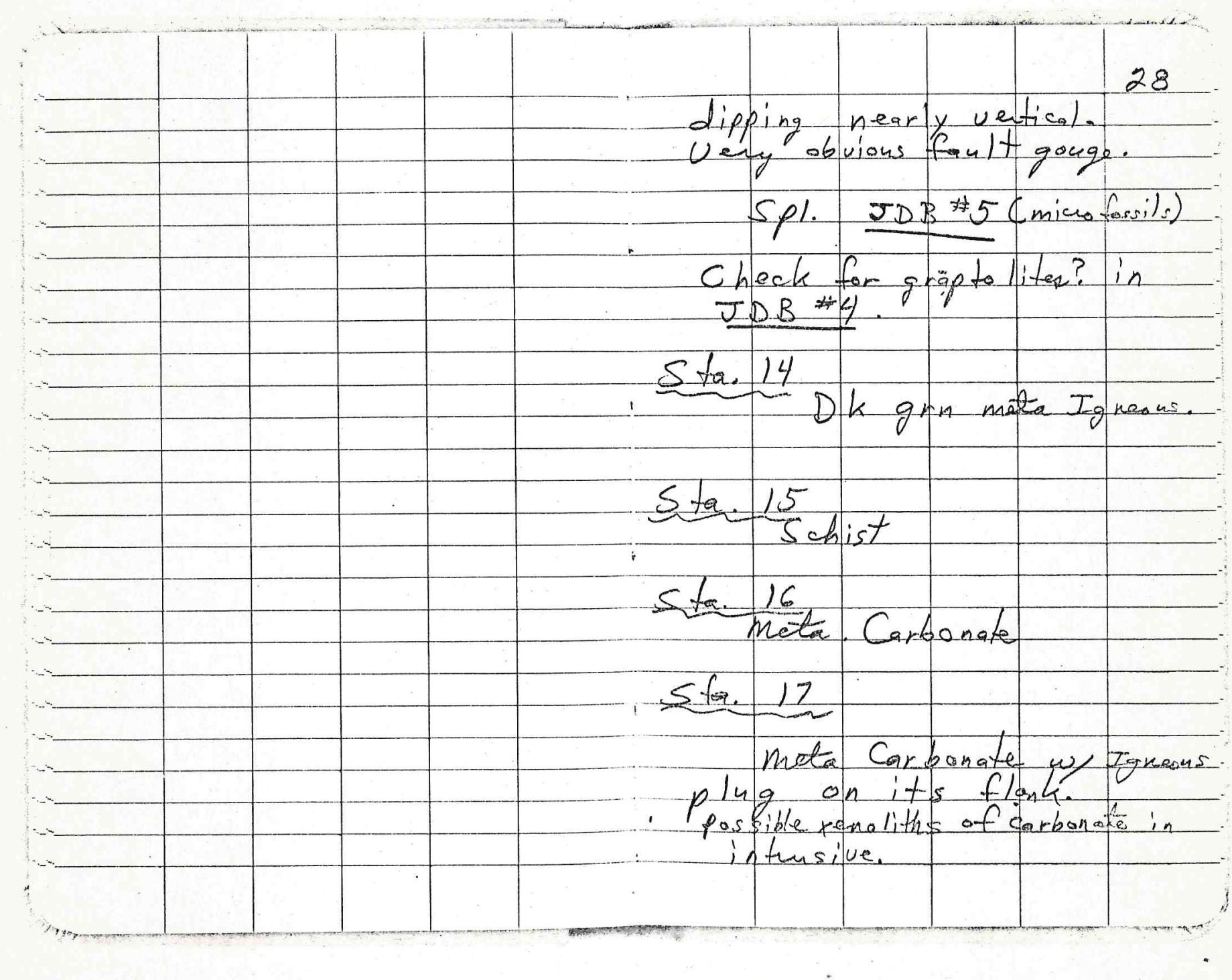




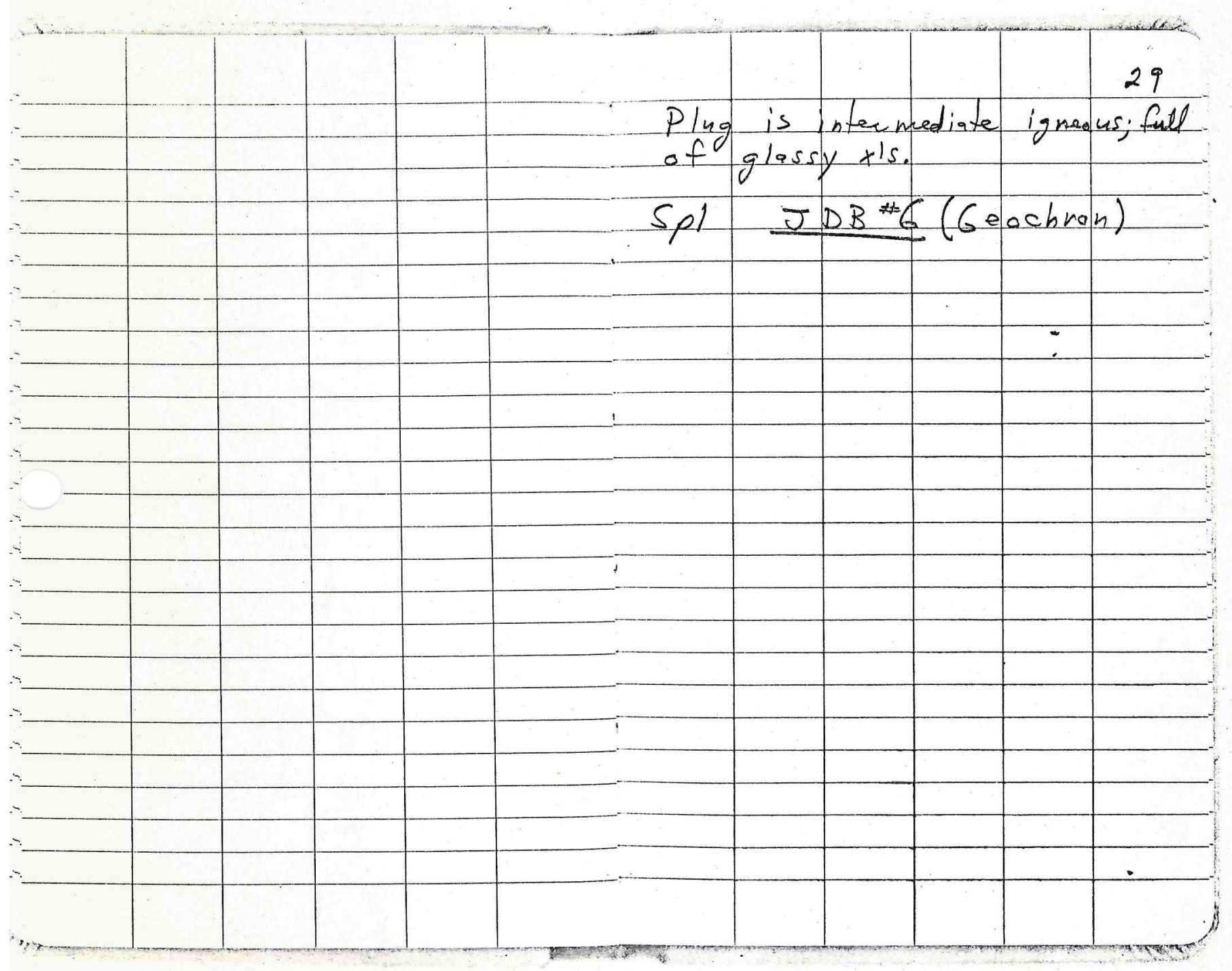




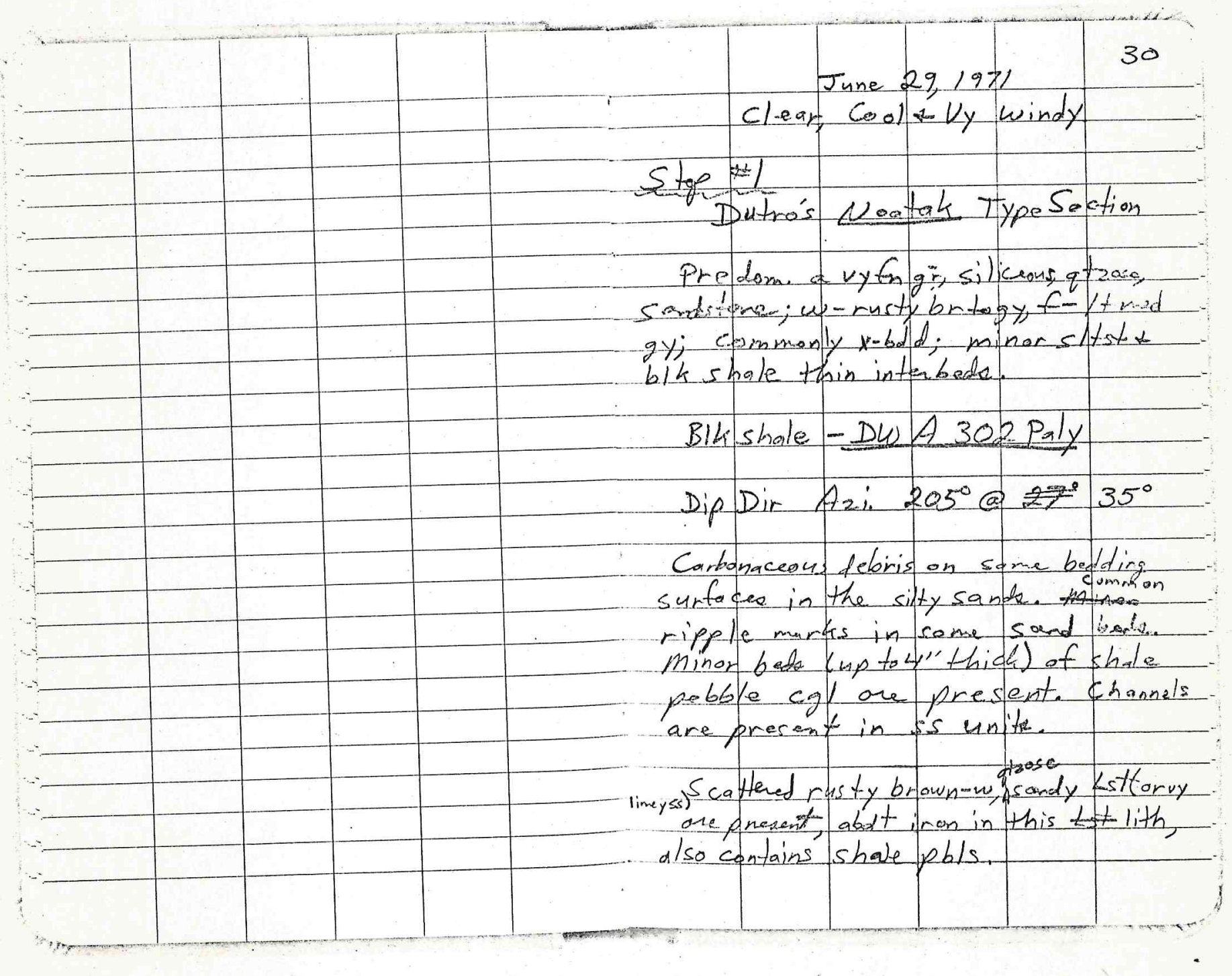




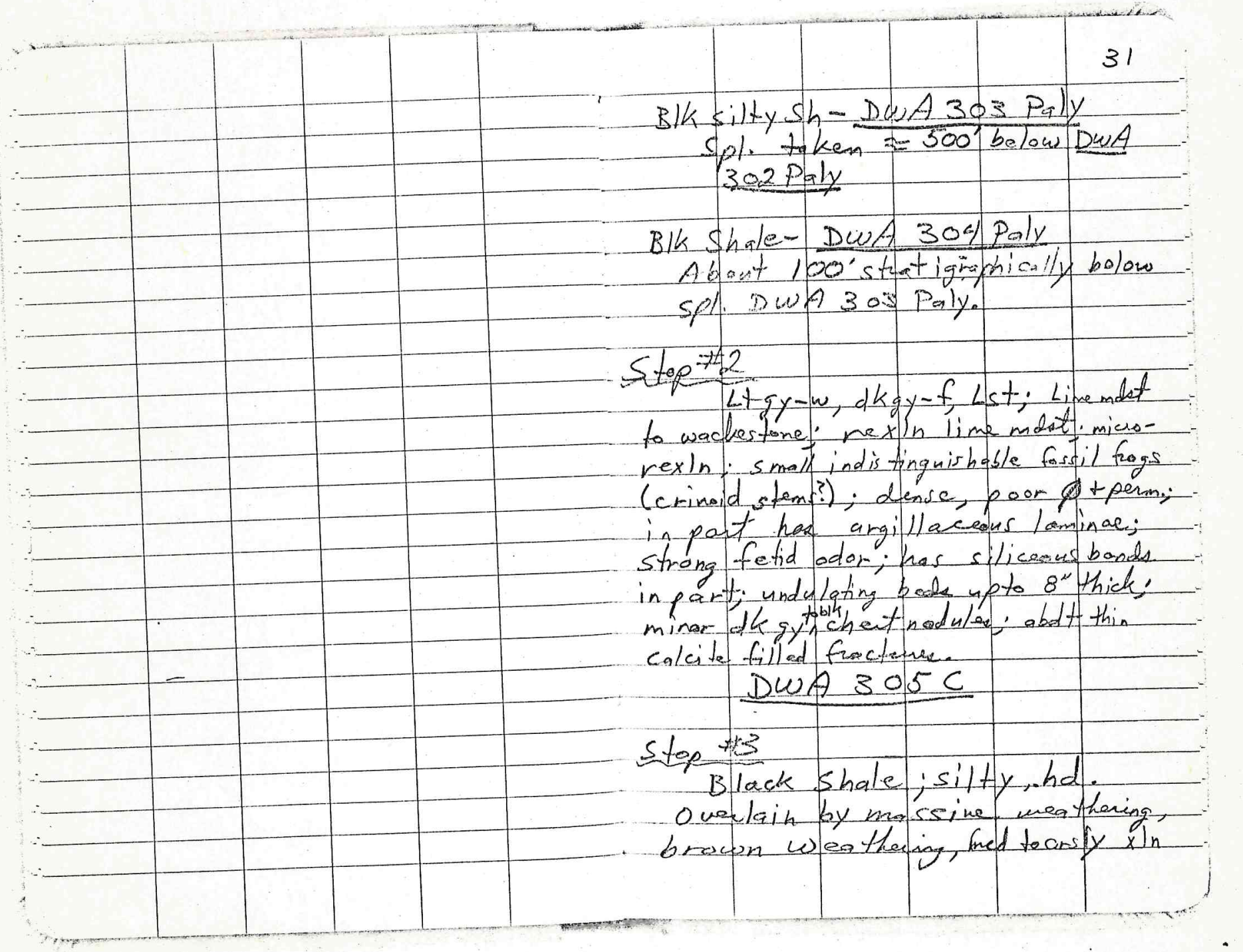




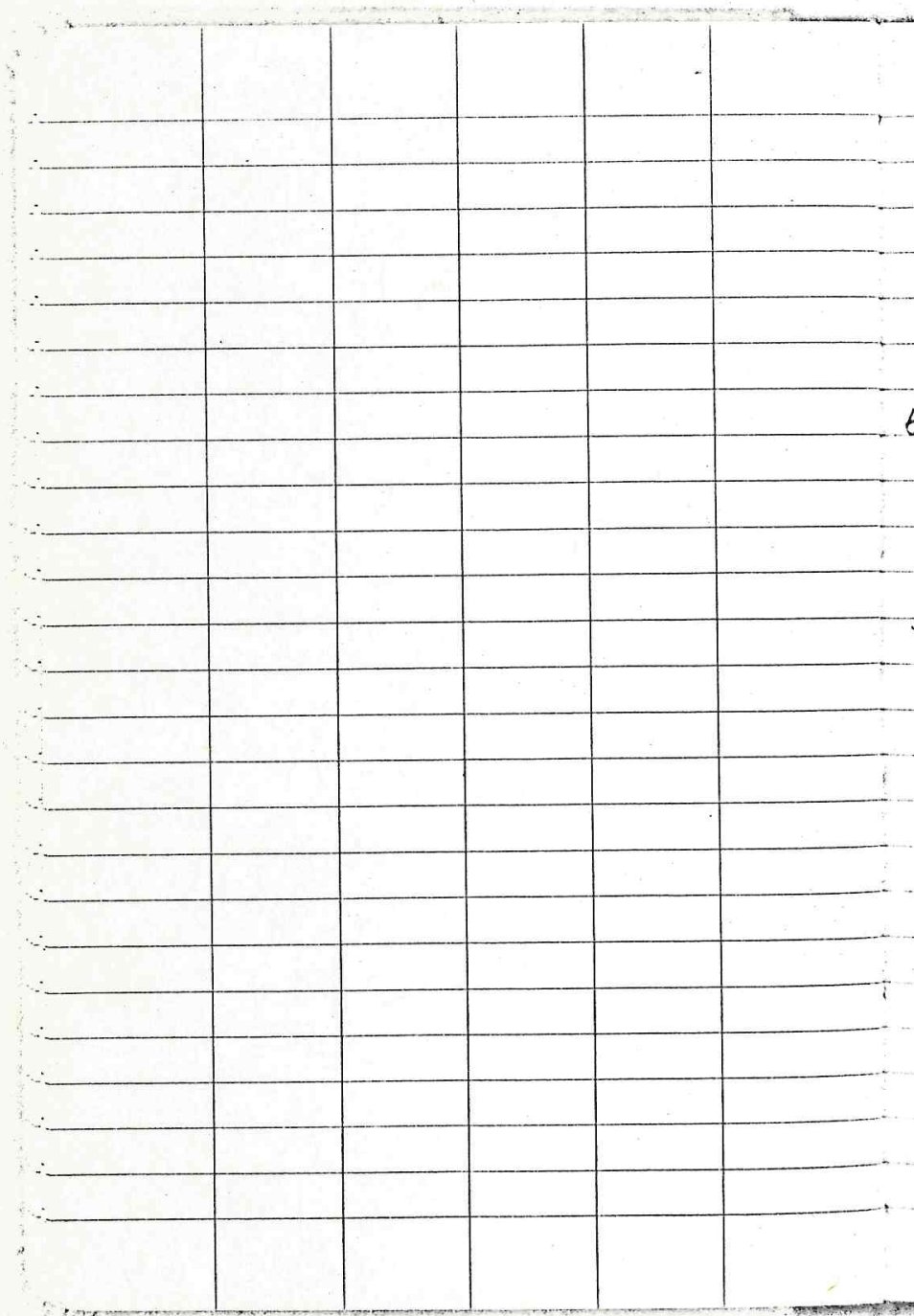

dk-f, basic Igneous. Contact between the two unite is covered but in talus is gnoen chat, baked shale; $L i$ mestore wf abd tsilicans. factore fiflings, and igneous frogmente. $6 k s h-D \omega A 306 P_{a l}$

Bik Shate is Hunt Fork? Stop +4

Lain bybdued topeg probably undeUp the hill is outcrop of $5 / k$ shale w/hd silt intenbede. At top of hill hes thin beddact black cl (Lisburme?). Basic ig noous rock apporently interded between whale $t$ chent. orange-brown uret tharing rock in rounded hills morth of the Luisak Rimen is thowght to be utukek

\begin{tabular}{ll|l|l|}
\hline & & & \\
\hline
\end{tabular}




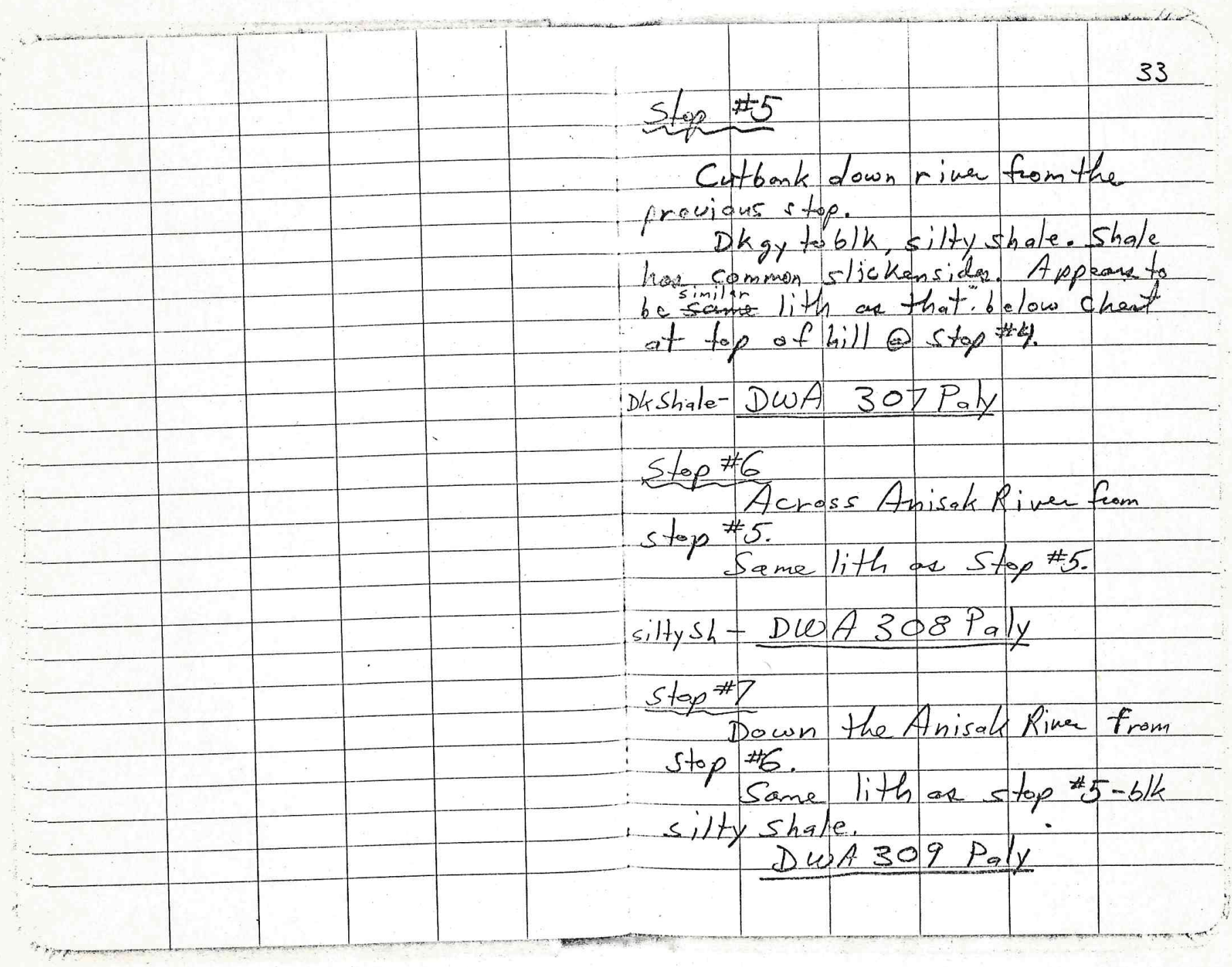




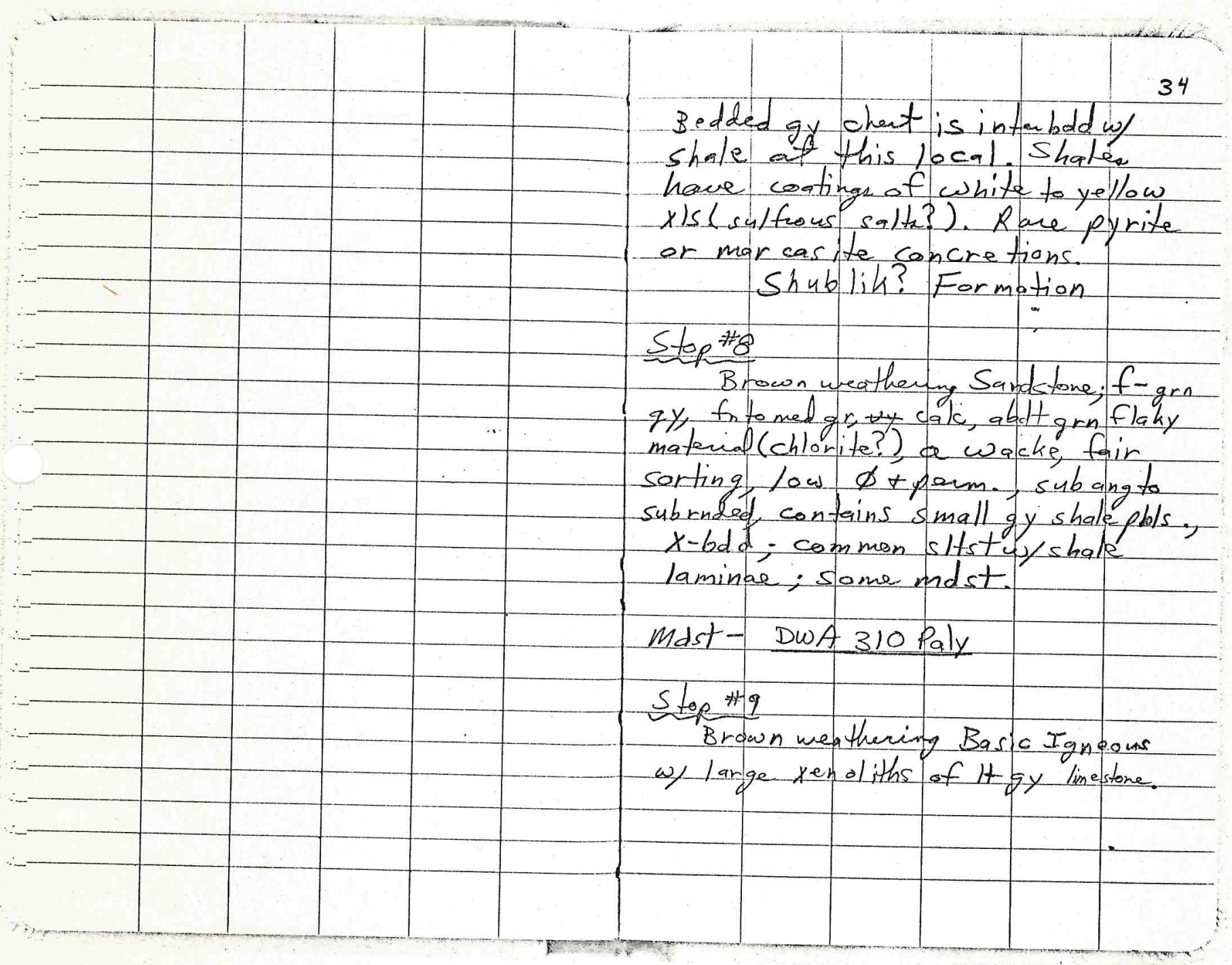




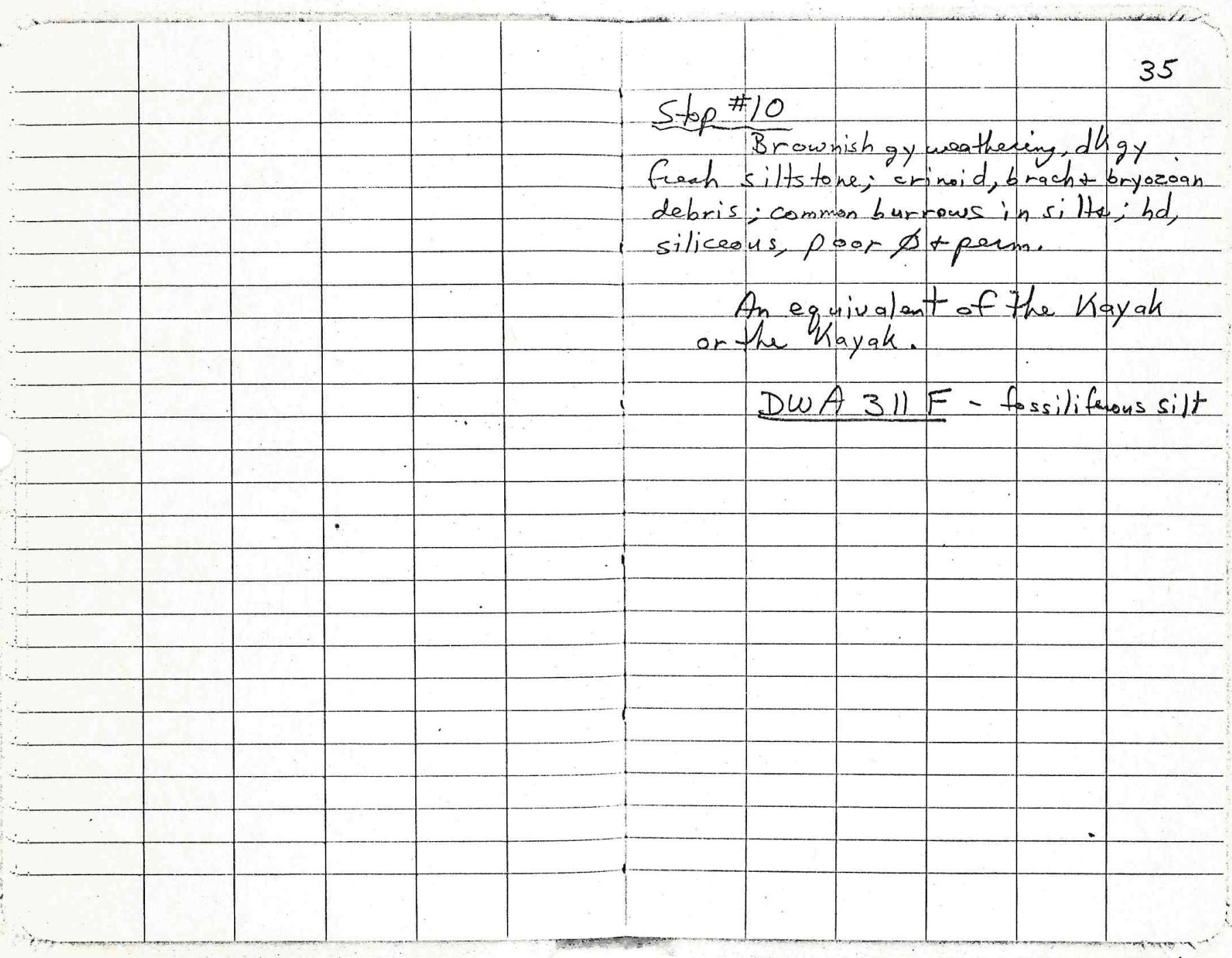




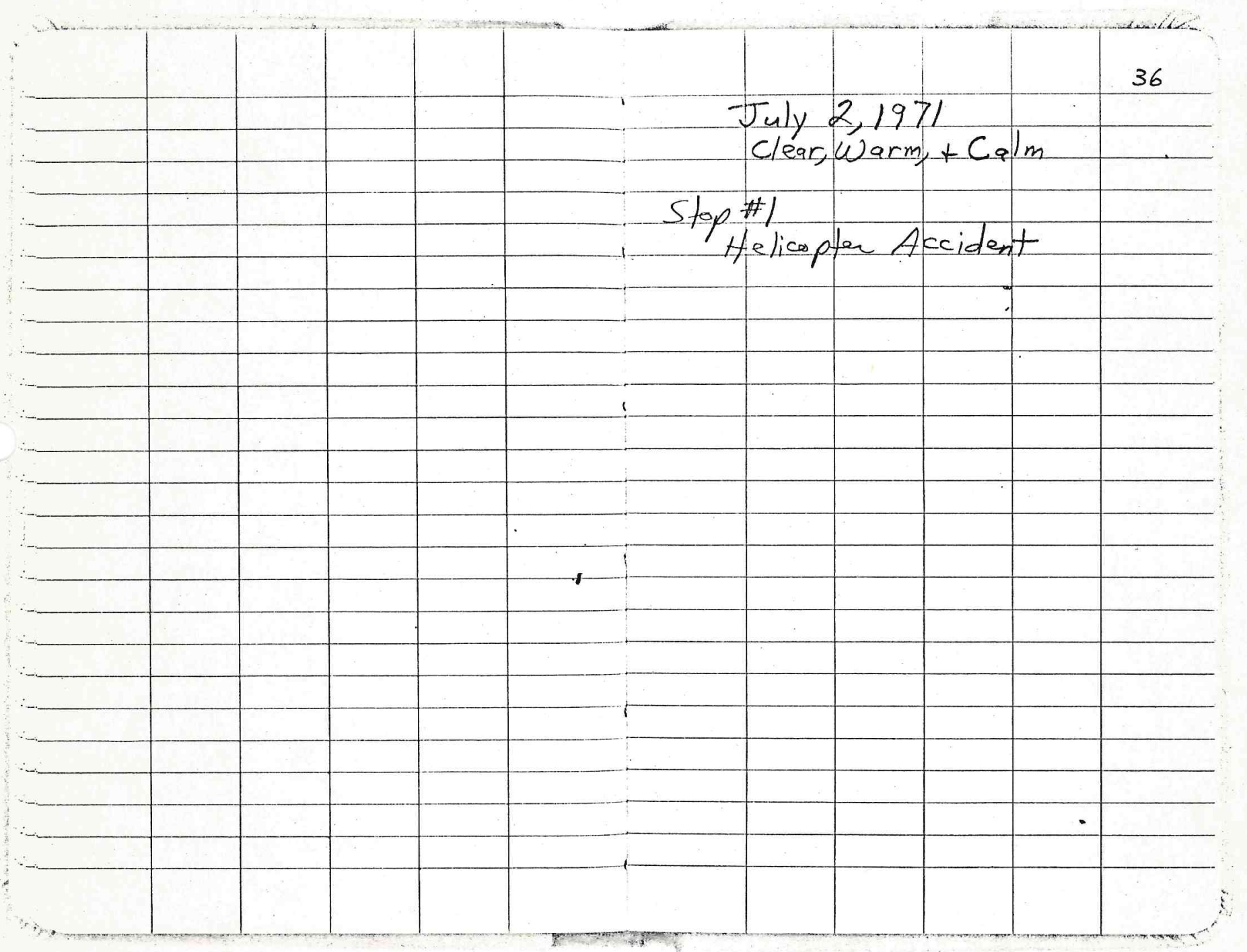


this is Noatak. Noatak overlies Hunt Fork.

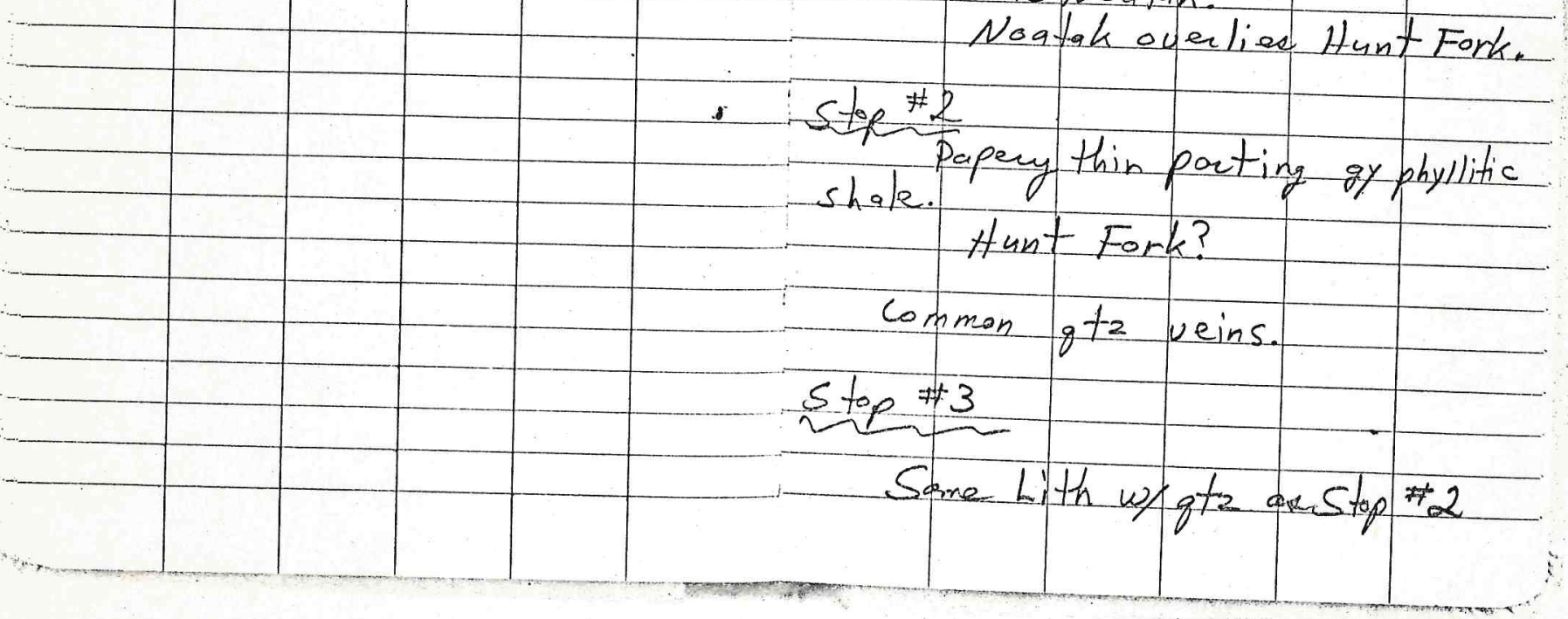




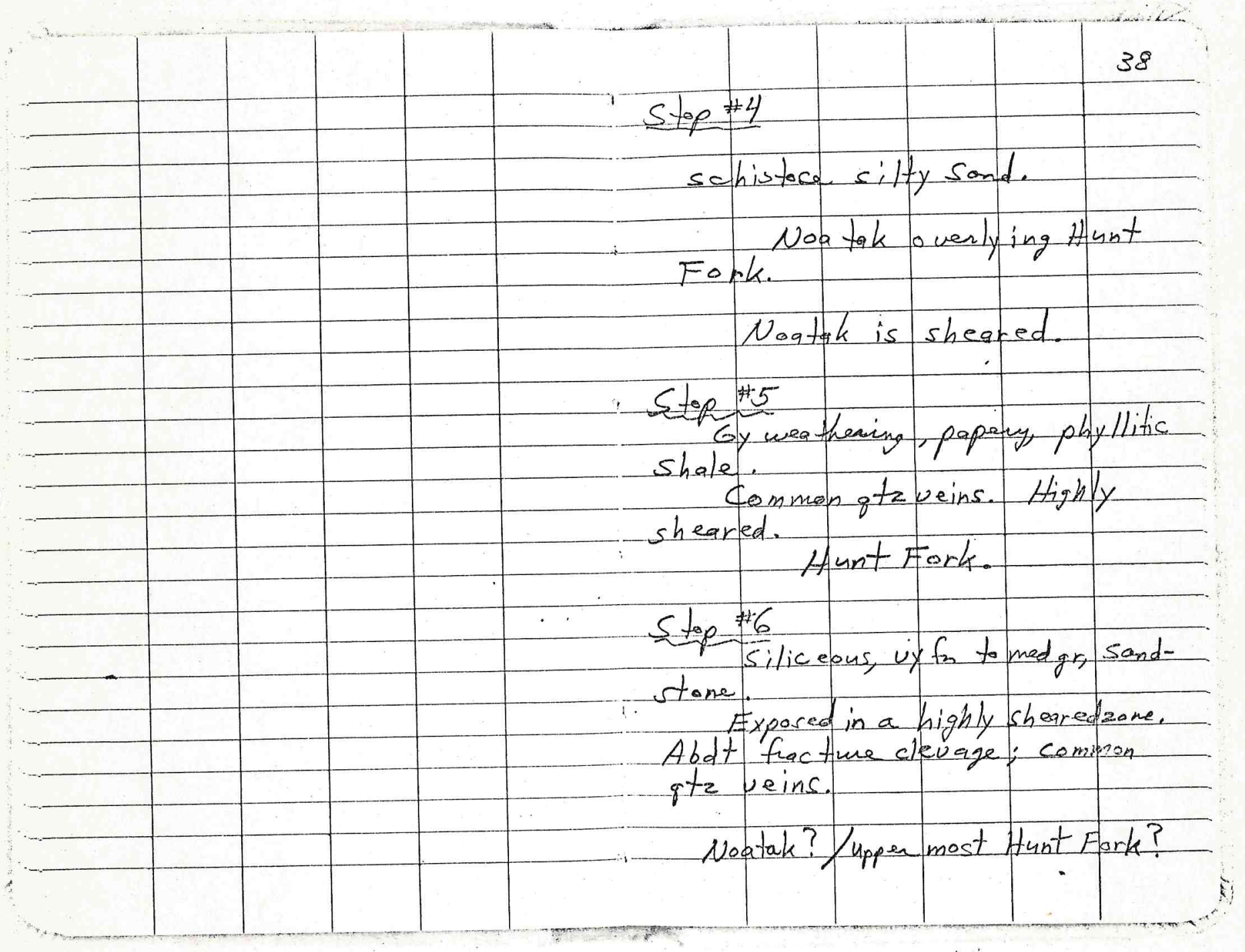




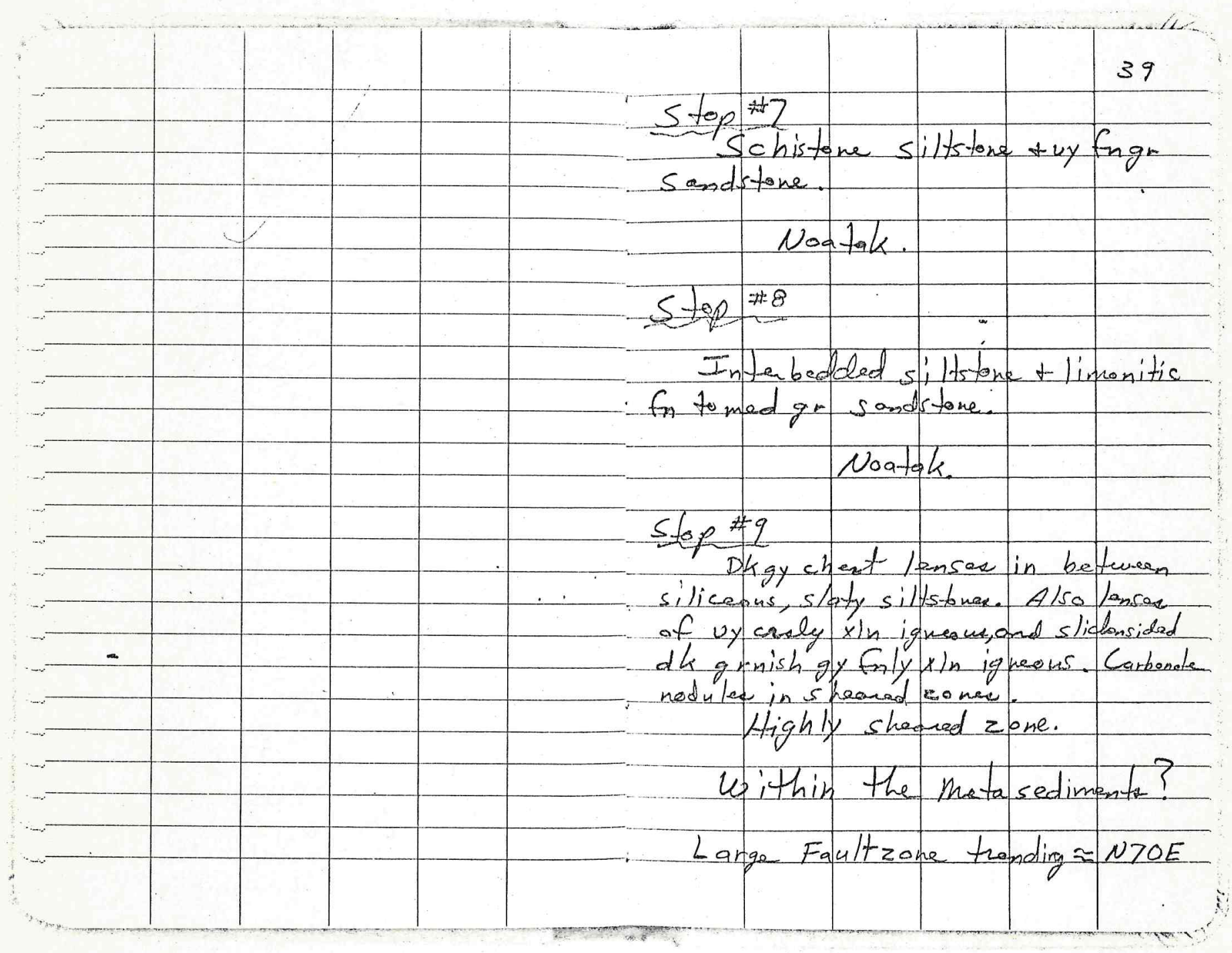




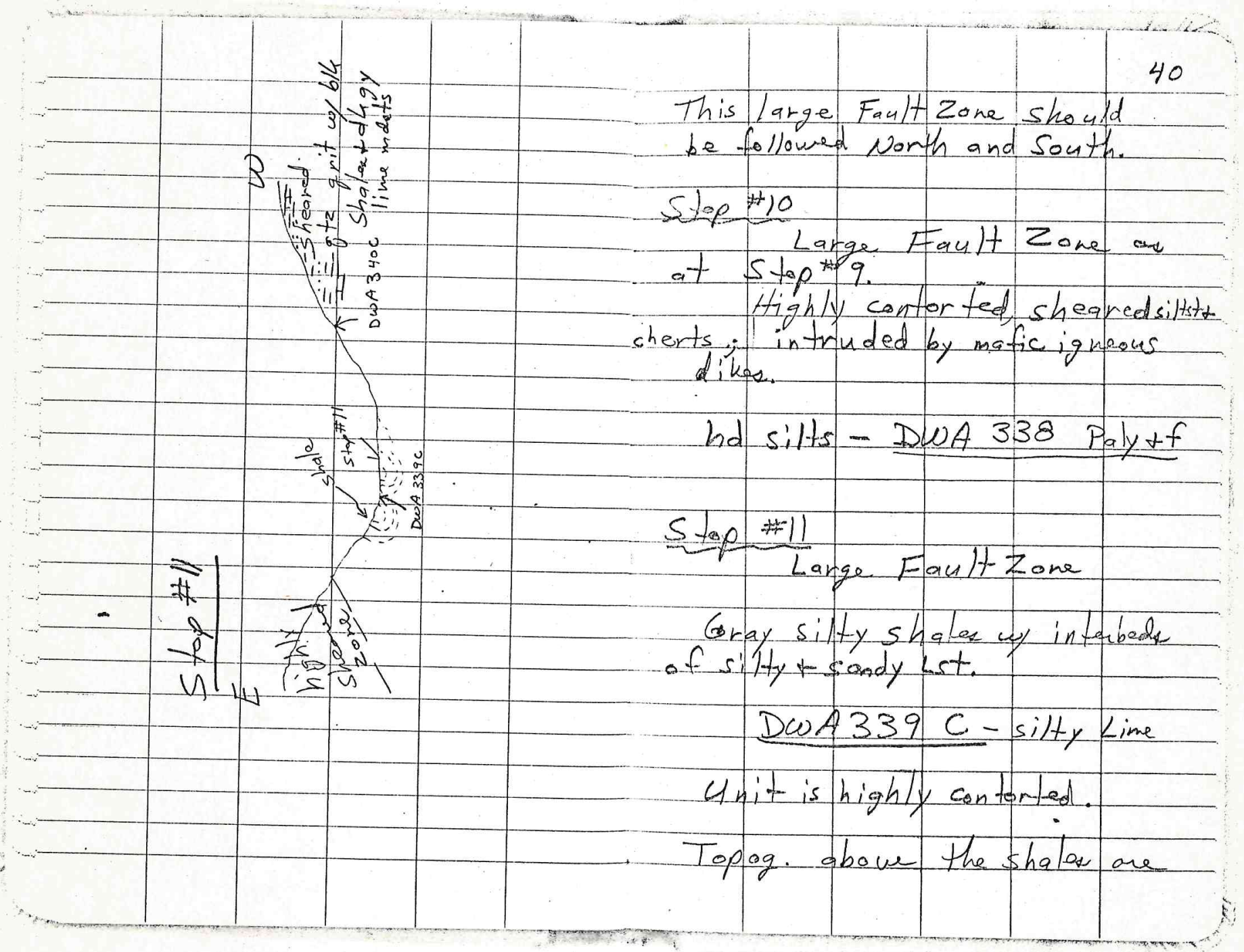




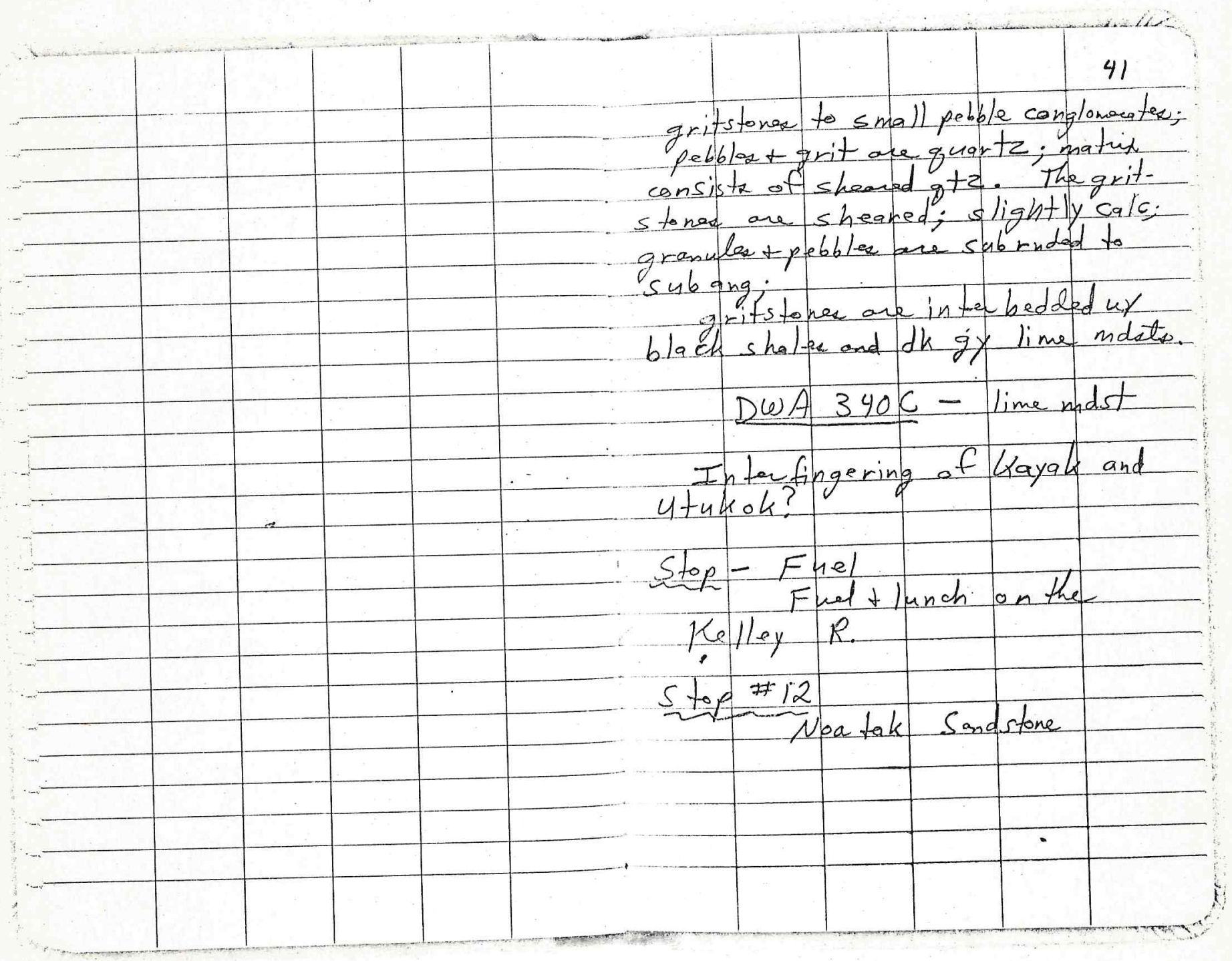




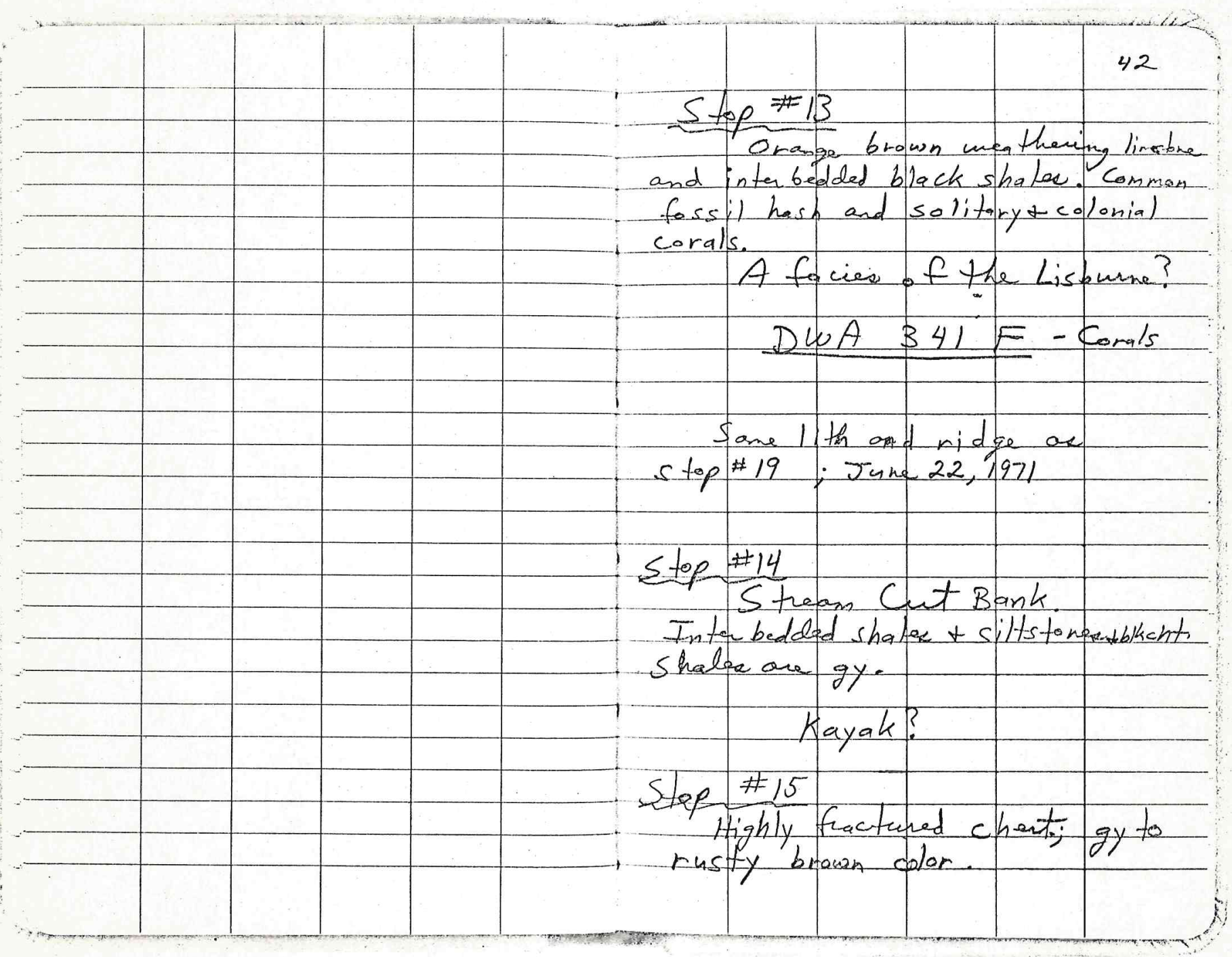


$\frac{2}{2}$ 
Book 3

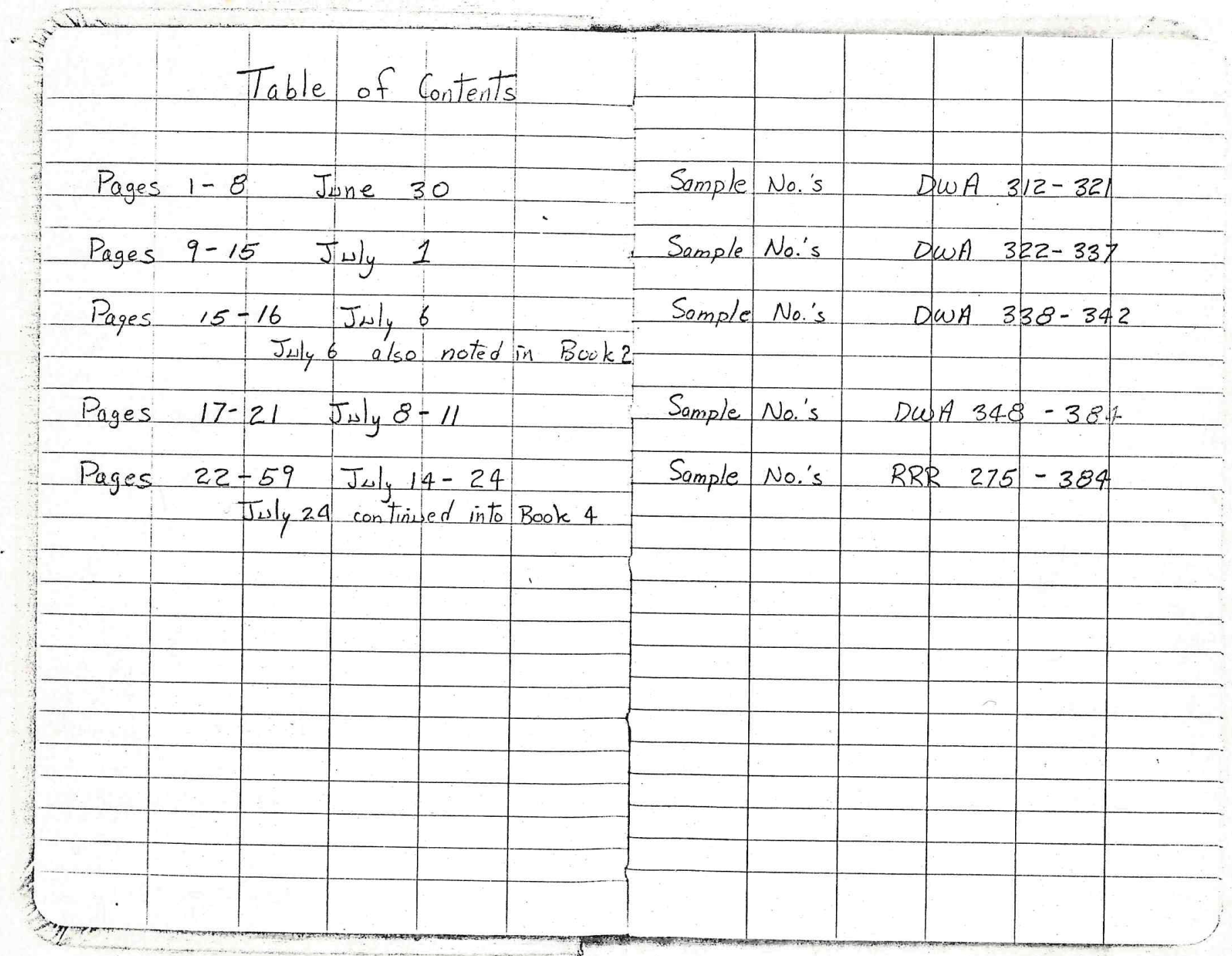




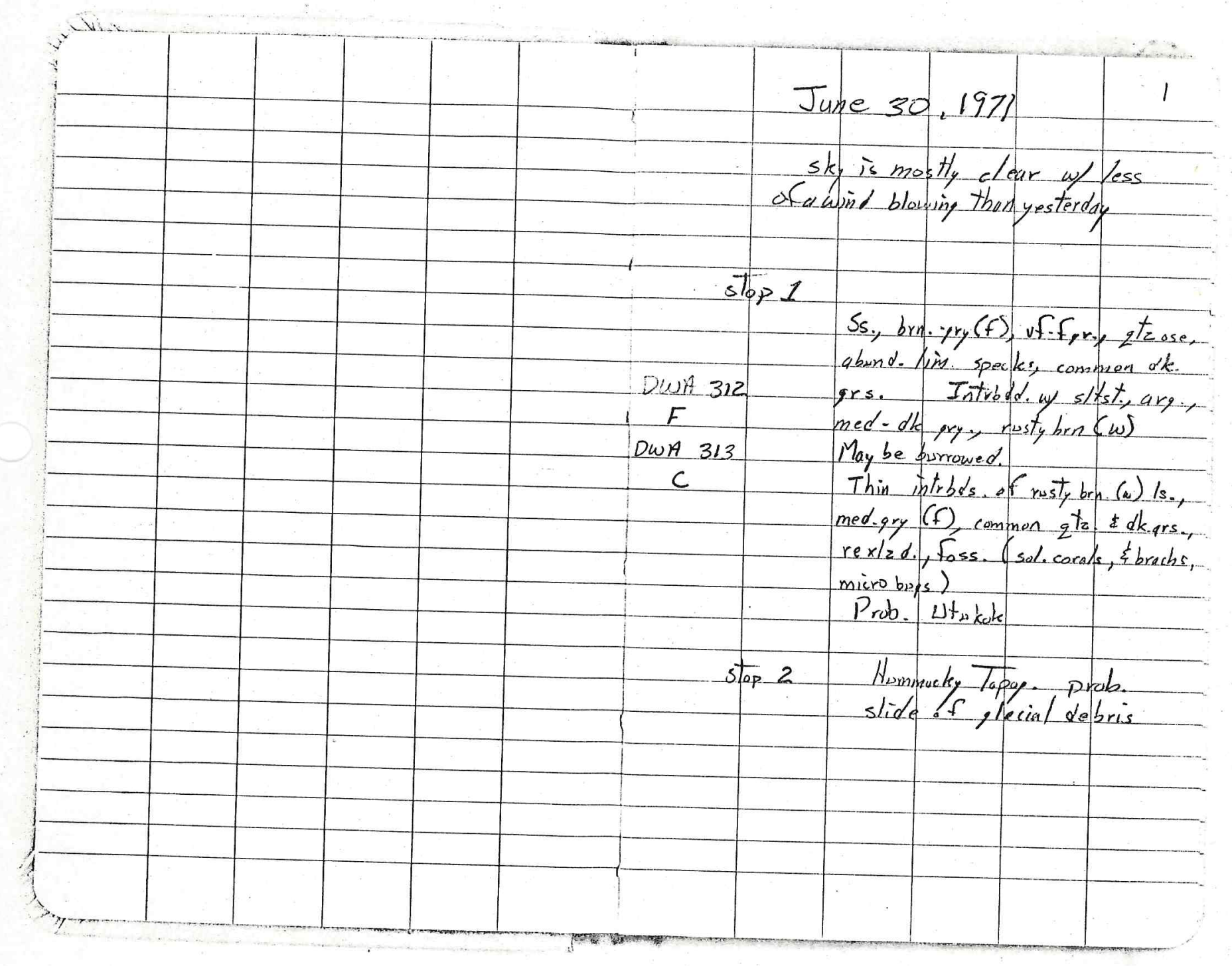




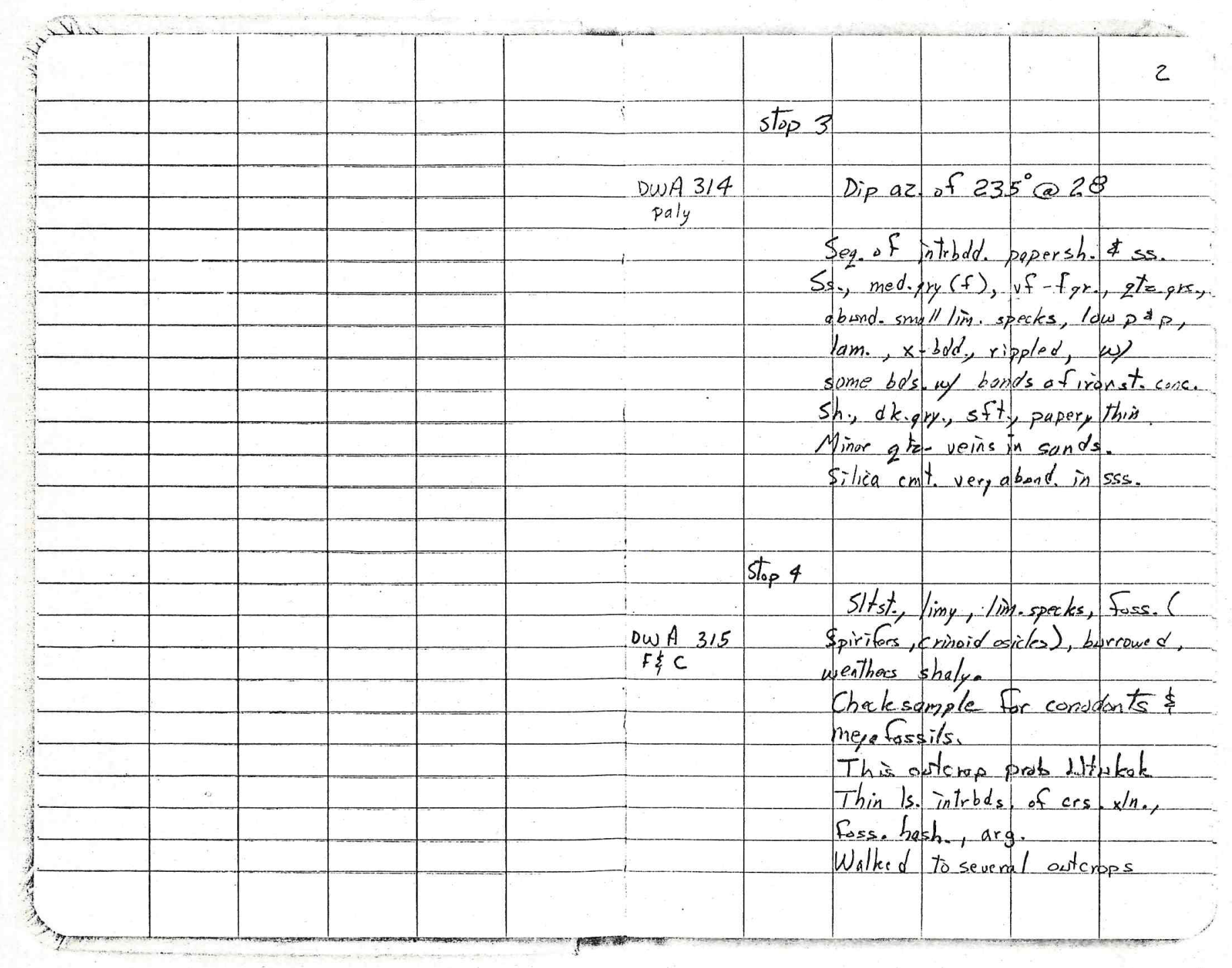




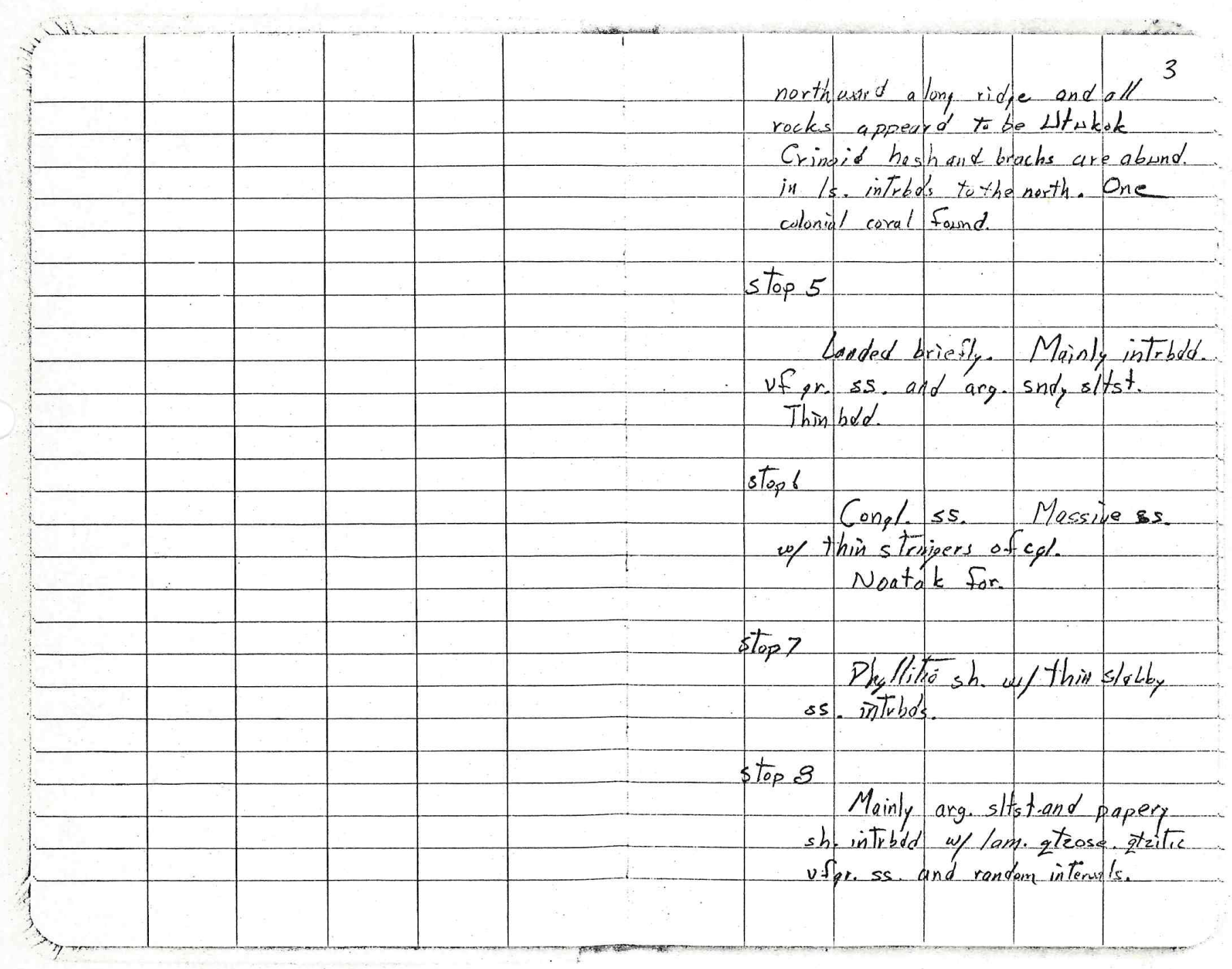




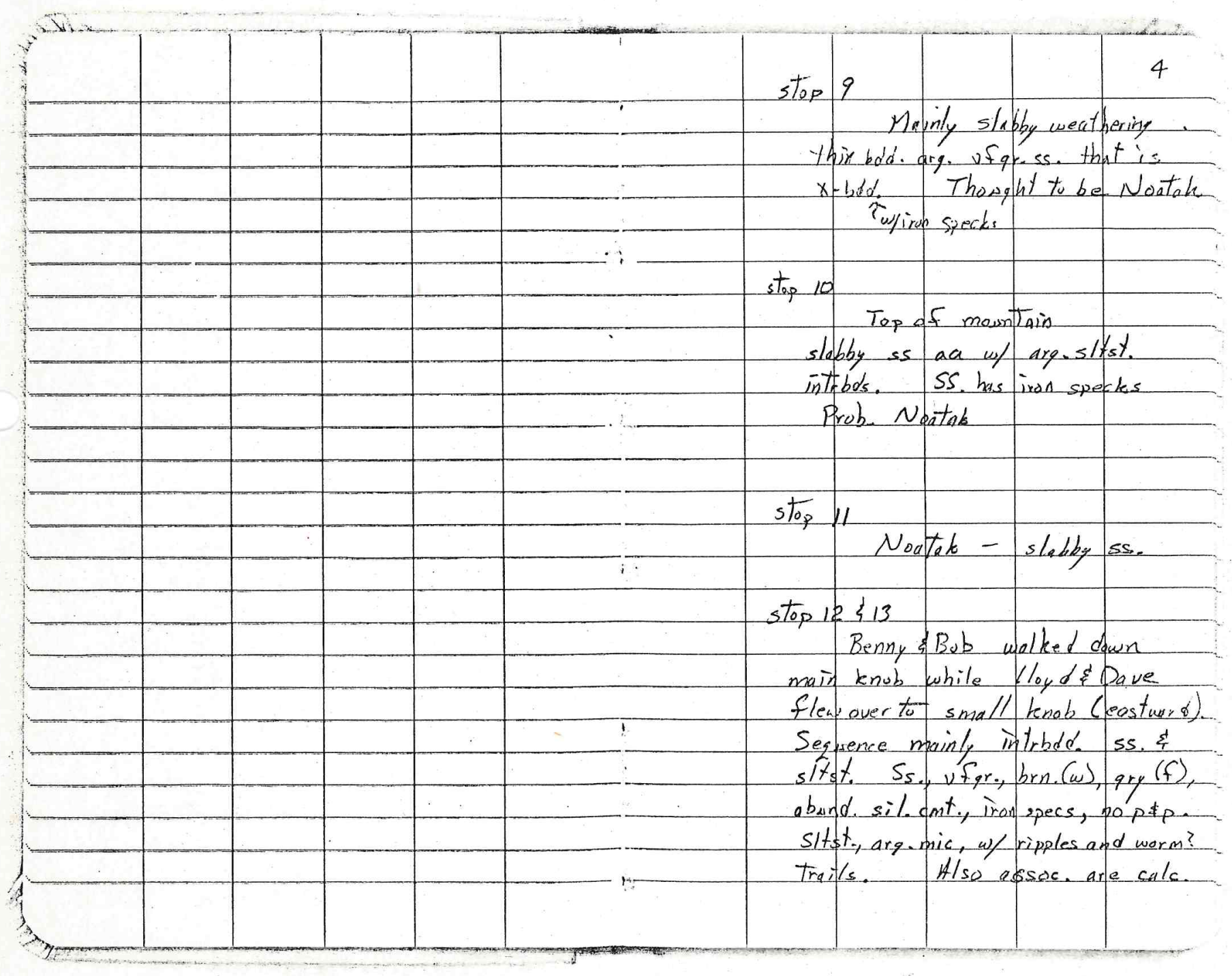




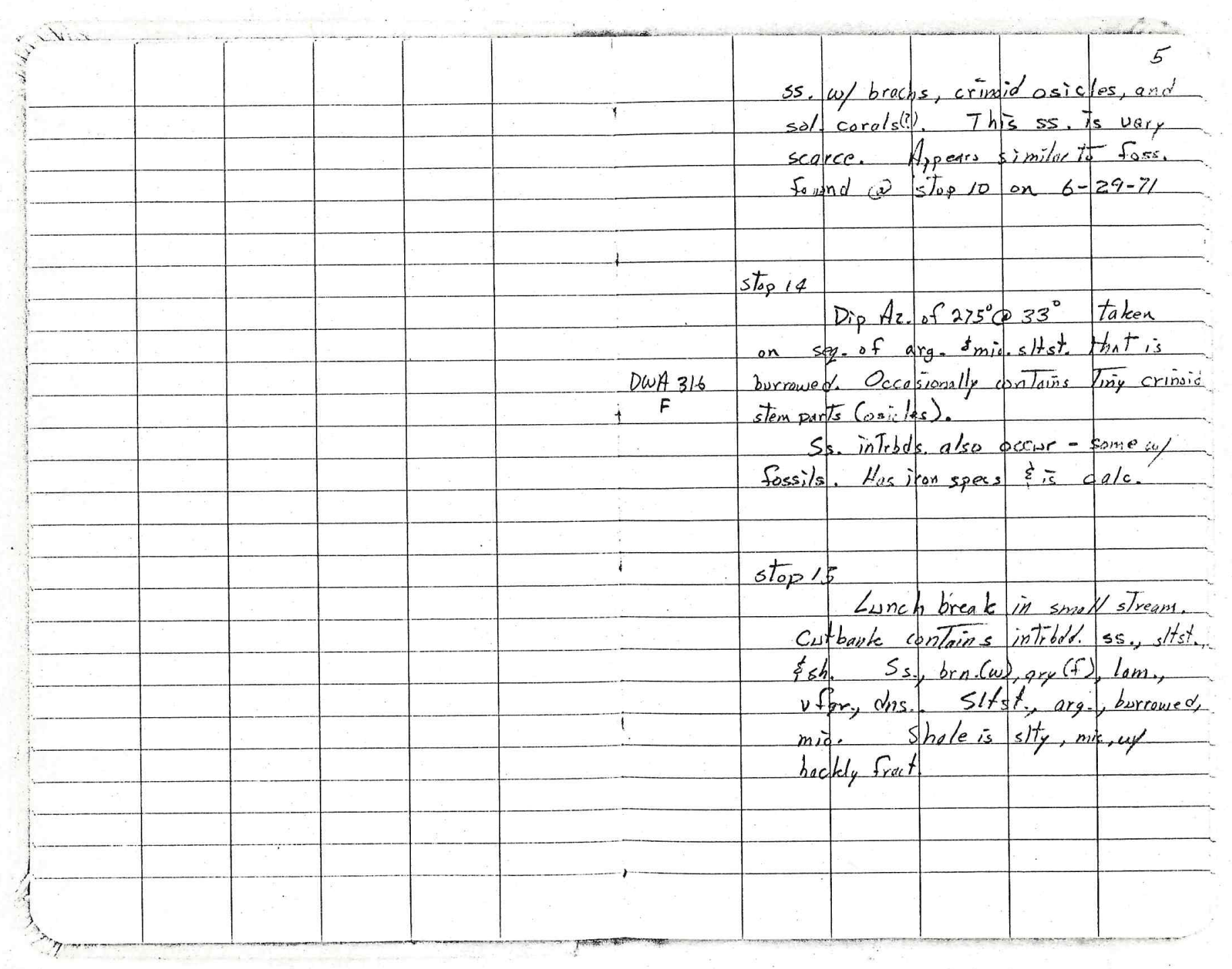




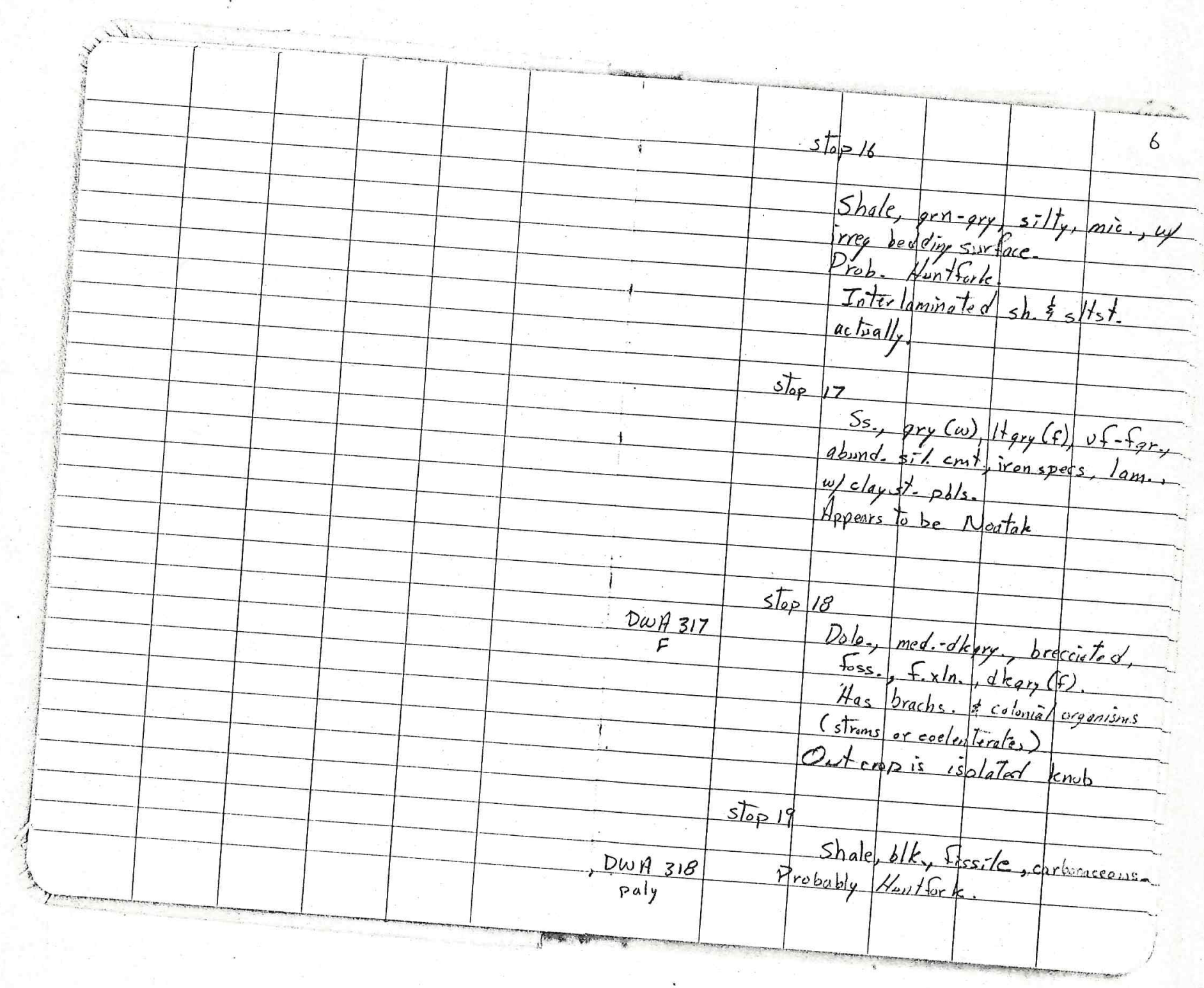




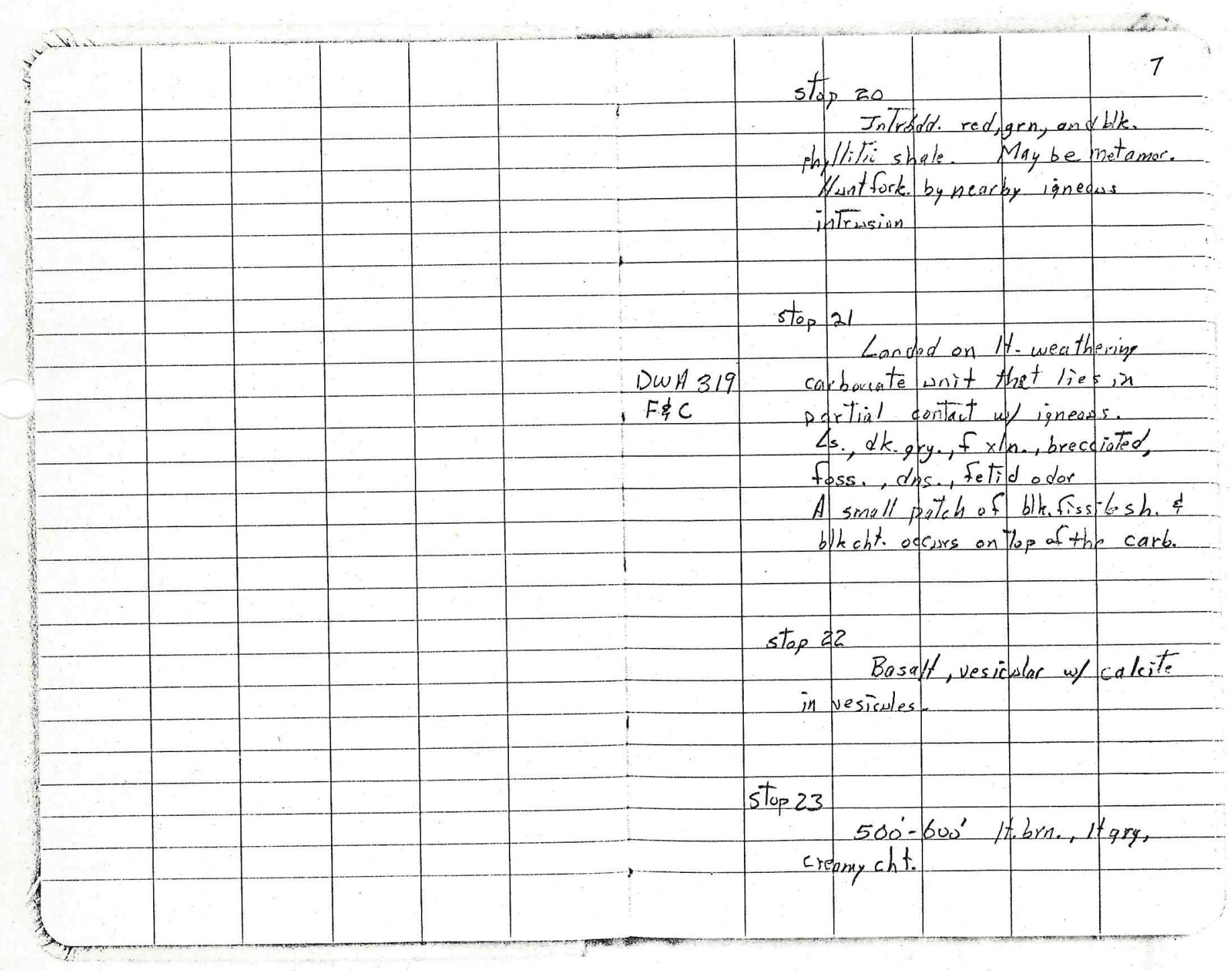




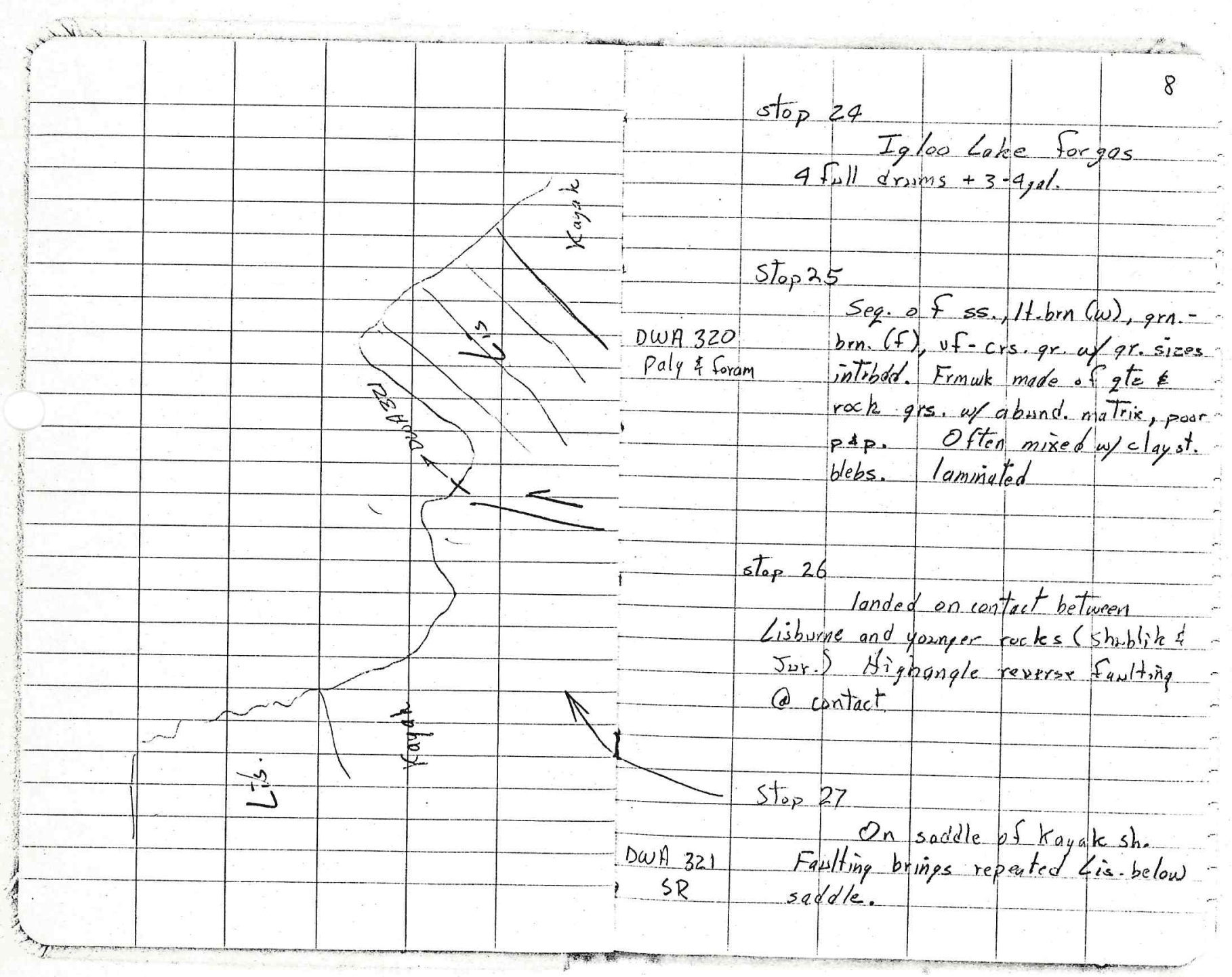




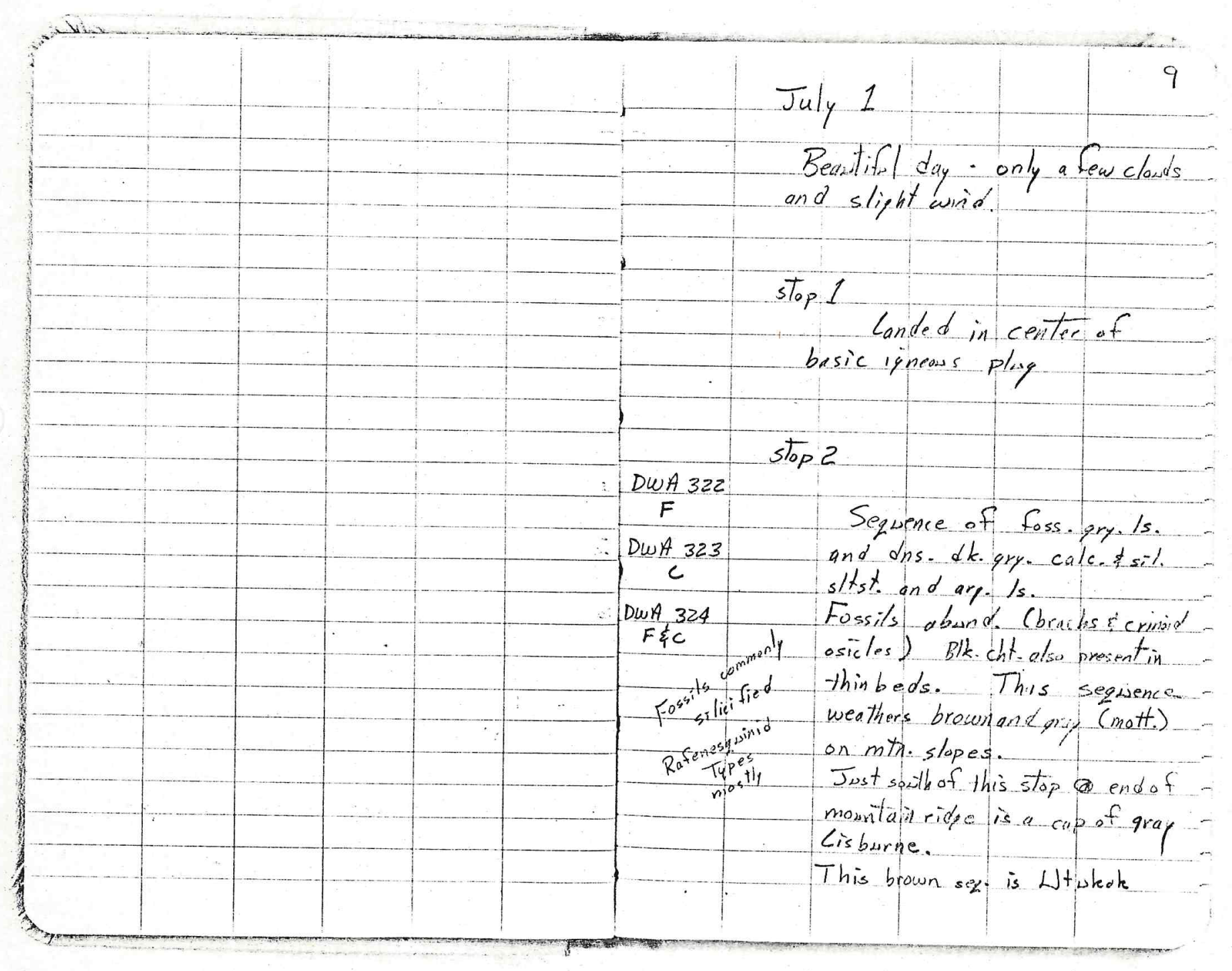




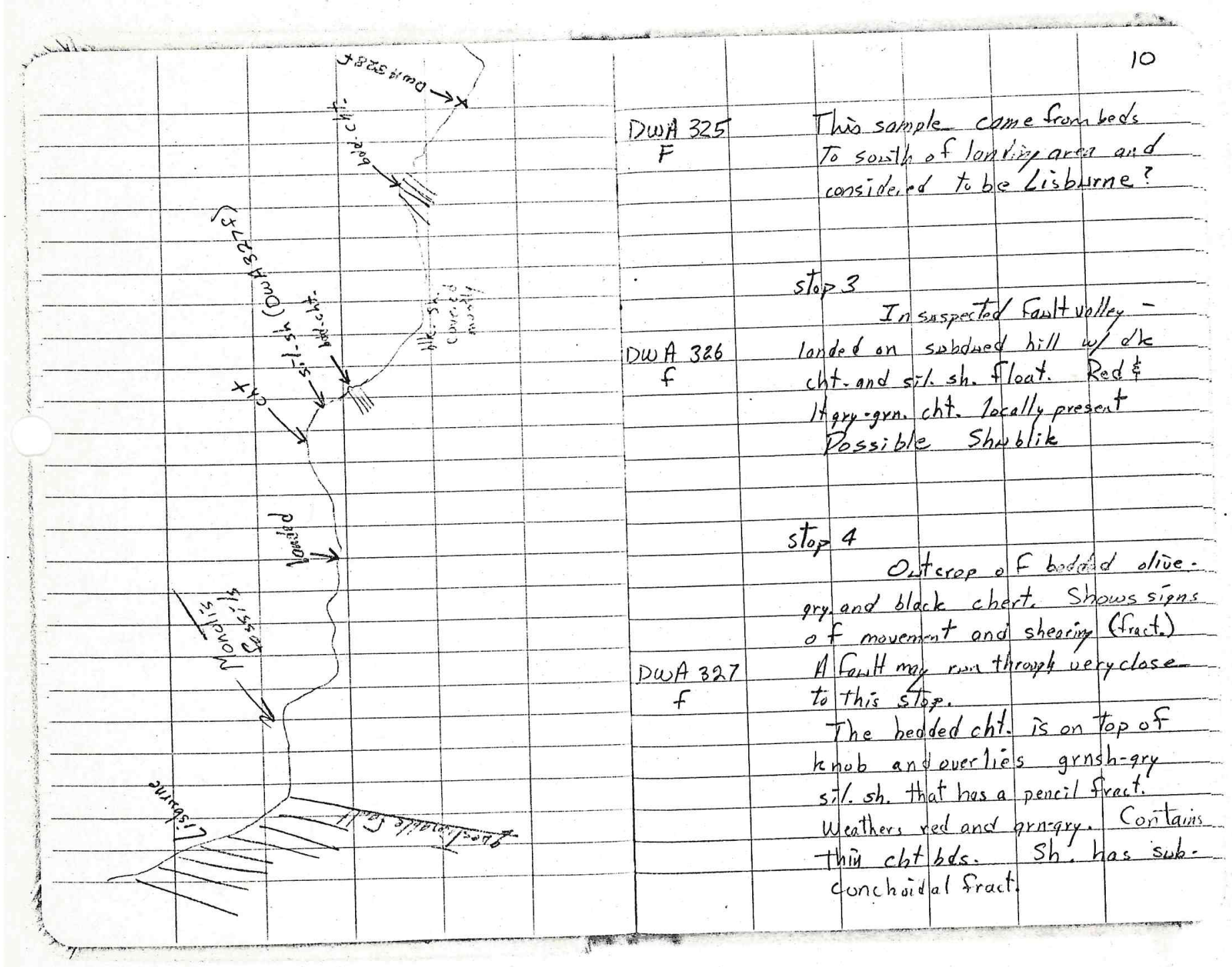




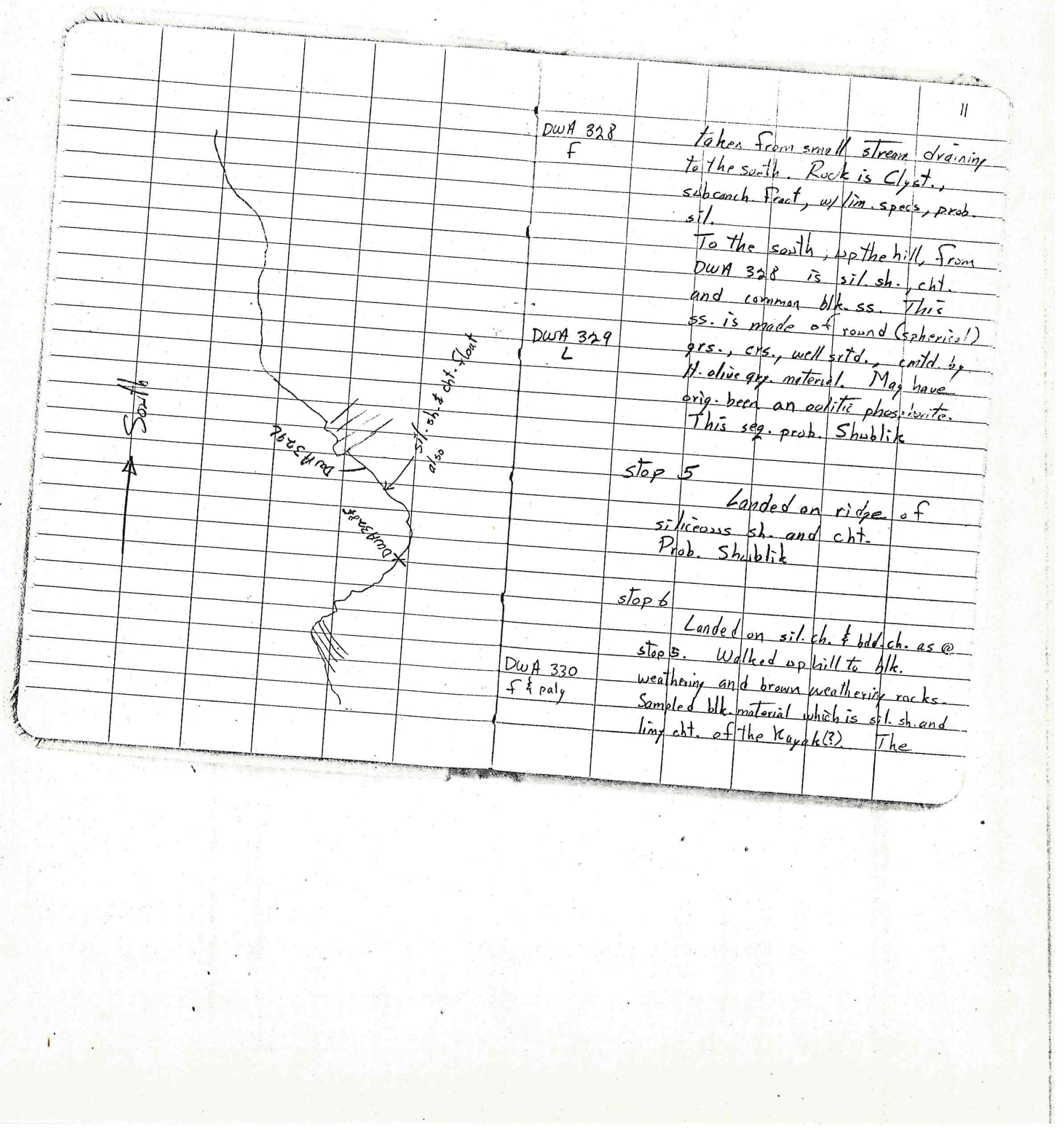




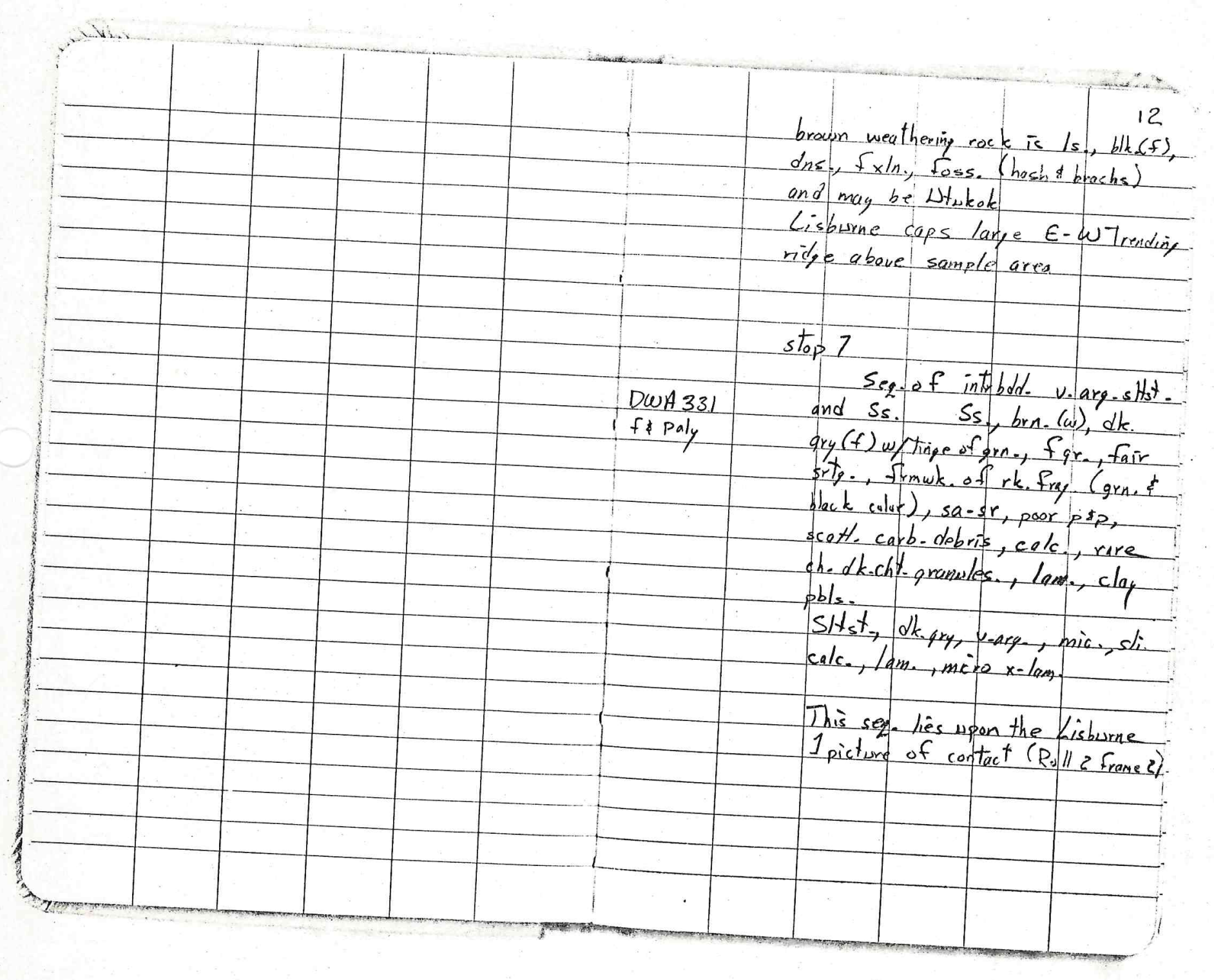




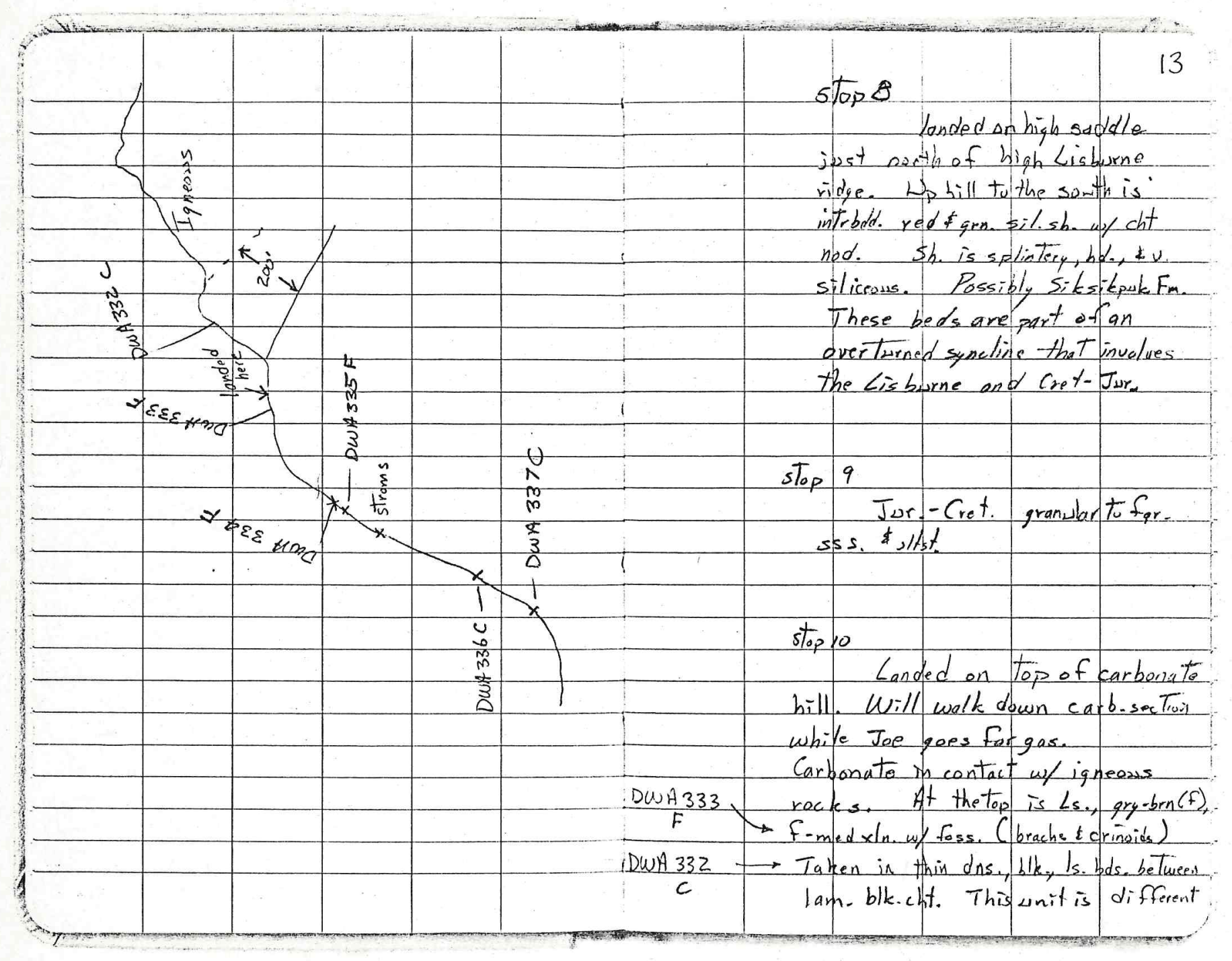




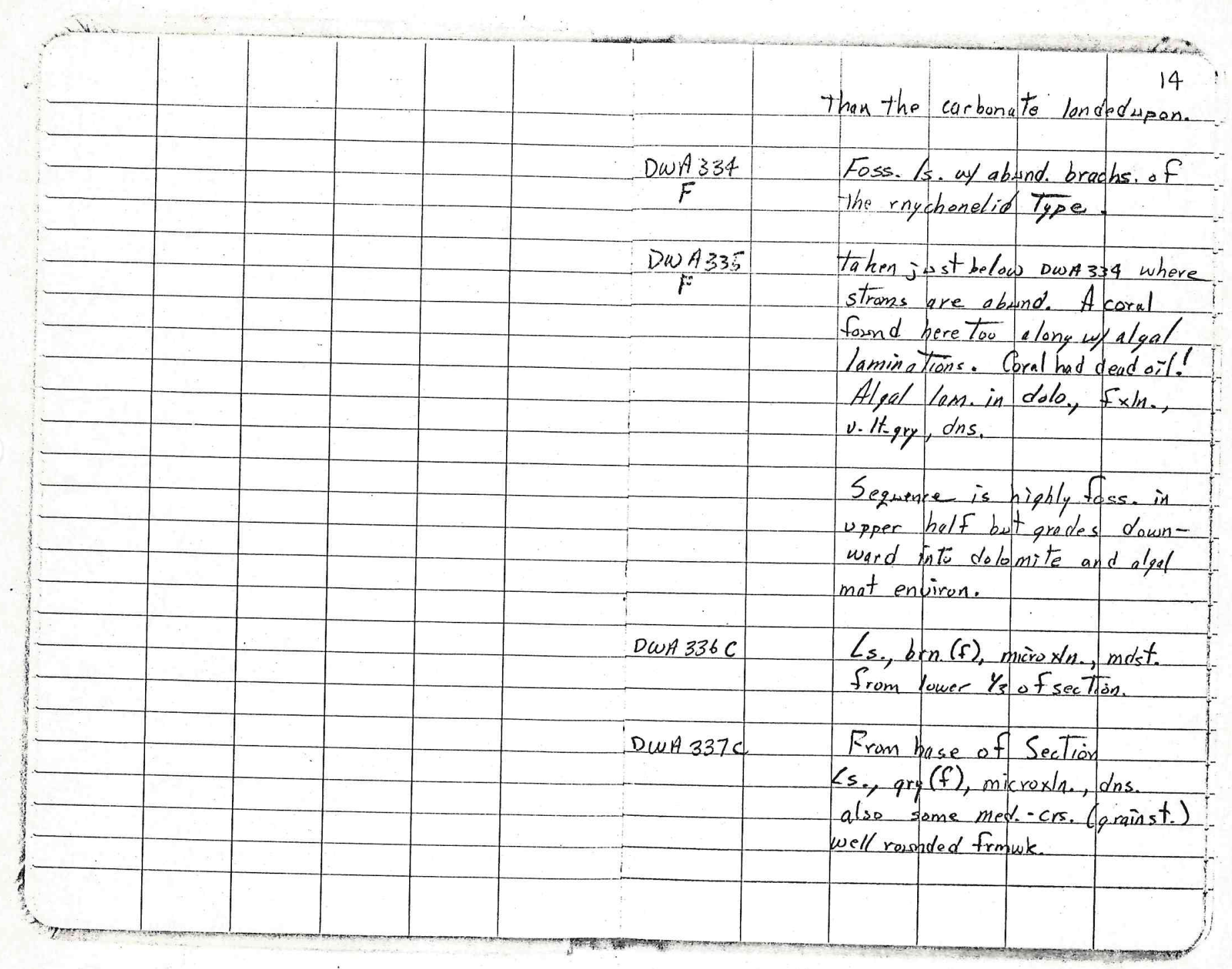




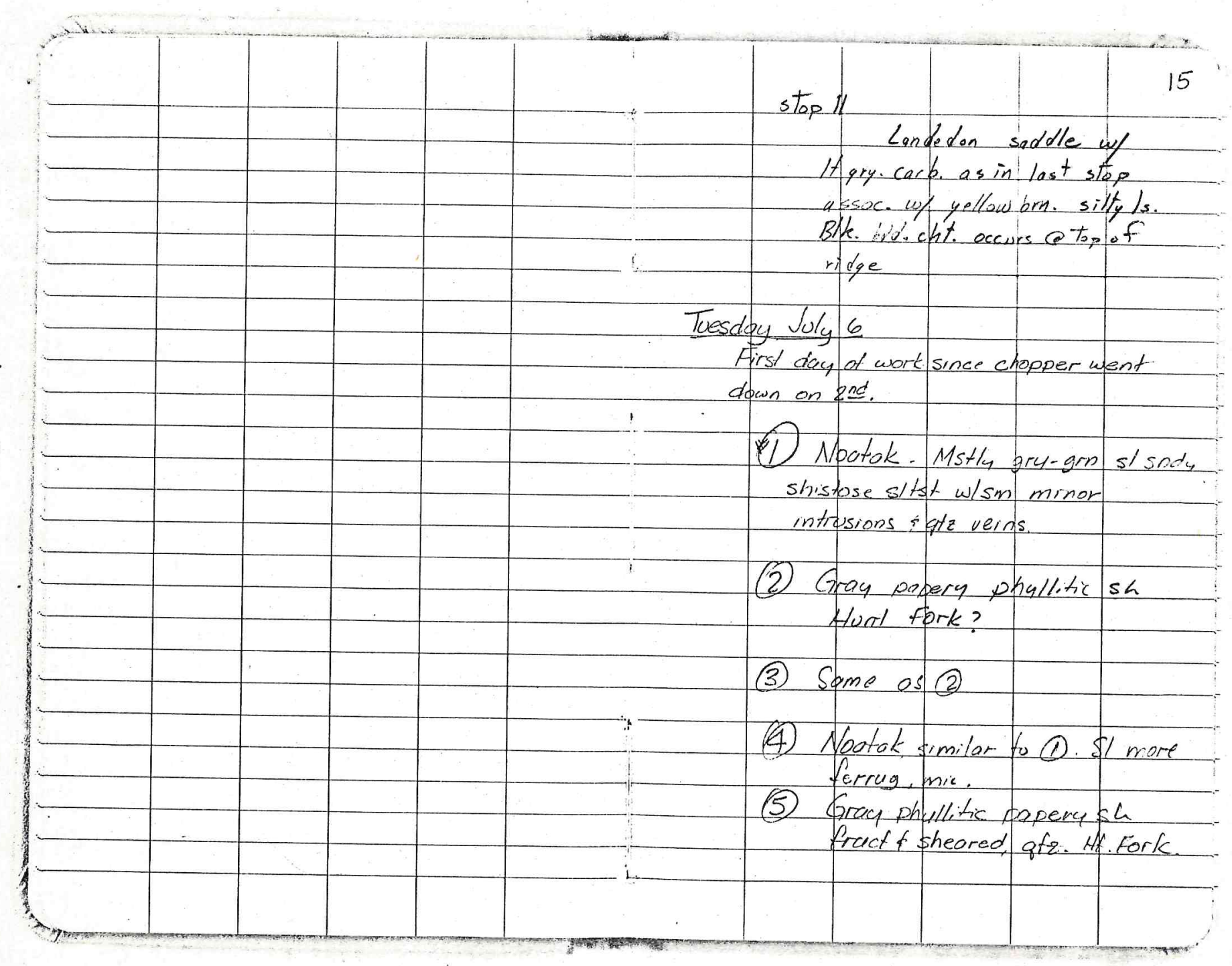




\begin{tabular}{|c|c|c|c|c|c|c|c|c|c|c|}
\hline & (6) & Gray f & Imgr & ss, ferro & & & & & & 16 \\
\hline & & Fract's & sheoree & - Nacta & alc' a & (14) & Shales, & sltst, & Shly sifs & $d$. \\
\hline & & de thont & Fork? & & & & Doss.Ke & gyok?? & & \\
\hline & (7) & $S h=s n$ & $d y$ sifo & $=1 . \quad$ phyll & 11 itic & (15) & Cherts & $k_{s} \cdot \sin$ & of 11/0x] & $b_{f 3}$ \\
\hline & & Shistose & S. Suri & lor toco & & & situibl & K. & & \\
\hline & & & & & & & & & & \\
\hline & (8) & Noatak & k ase & (7) & & (16) & SAOMLII & Dhos. & D. & \\
\hline & & & & & & & & & & \\
\hline & (a) & Meta & Yimestor & as, shato: & bs, chert, & (11) & SAOUB & BLK CA & $k t$ & \\
\hline & & oh pre & tunt Fe & Exe bouen & iment? i & & & & & \\
\hline & & nhighles s & sheared & lgn' dike. & es, serpentinsired. & (18) & SAUB (IN) & Top of & DEAK TO & WORTA \\
\hline & & erge Foul & It zone. & (ev70 $E S$ & & & SAME & & & \\
\hline DWA 338 & (10) & Mets as & s@ & wa fad! & 18 & (19) & $5(s)(\operatorname{shl} 6)$ & 1) shale. & hack's & froot, \\
\hline prf & 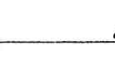 & gontact & $w / s h$ & $4 s i t s t$ & & & & & & \\
\hline & & & & & & (20) & CateReX & Sharsert & ) & \\
\hline DWA $339 \cdot C$ & (11) & Grays: & Wity ura & of tissle & /splintery & & & & & \\
\hline & & shales. & Interbee & fded sith & $d_{y}>L_{s}$ DWA 342 & (21) & Styoszin & $?$ & & \\
\hline & & $S_{m} m / c_{1}$ & or cong & g/ss. & Polu $+f$ & & & & & \\
\hline DNA $300 \times$ & - & DL gra & $1 \mathrm{~s} / \mathrm{m}$ & nente? & & (22) & Gray cht & (Shubl) & k?) & \\
\hline & (12) & Nootod & $W_{0}$ & (stop) & & & & & & \\
\hline & & & & & & & & & & \\
\hline DNA 341-F & (13) & $L_{\text {ISBORN }}$ & $E-C$ & Dests & & & & & & \\
\hline & & & & & -1 & & & & & \\
\hline & & & & & & & & & & \\
\hline
\end{tabular}




\begin{tabular}{|c|c|c|c|c|c|c|c|c|c|c|c|}
\hline & Jula 8 & & & & & ${ }_{4 D W}$ DU $4 \mathrm{~F}$ & 506 & Graes st & phullithe & $\operatorname{csh} \alpha s$ & $\begin{array}{r}17 \\
\text { shastist }\end{array}$ \\
\hline & & & & & & & $\ln$ ter & foeds of & ofger limo & nomitic sf, & $s, S_{m}$ \\
\hline & Stop I & Lt gras & $\Rightarrow$ Dhull A & Ac $-z^{-1}$ & veins & DWA $\Omega 49-F$ & cart & thesred & rerey fors & - Ls. (Bract & acts, gast.) \\
\hline & & Mctase & $(e \pi)$ & & & + & Nose & etak & & & \\
\hline & & & & & & & & & & & \\
\hline & Stop 2 & Grn-sr & ven eriul? & Wite - pd & dpery talc, i & $i$ & Stop? & Durp-gr & $y_{y} s+t_{s} t k$ & to ufgr $\leqslant$ & ss. Si mic. \\
\hline & & mical & $(u f g r)$ & Q $+z$ ve & ins & Down $350-F$ & & $y^{\prime}$ sheored. & Arg, & limonite. & \\
\hline & & (Metas & seds) & & & $351-F, C$ & & heotse & Weathers, & 1.nto Gainten & tularge \\
\hline & & & & & & $\dot{L}$ & & & olates & Foss pack & Kstone w/ \\
\hline & Stop 3 & Aled ores & plary ph & thyllite & few ats. & 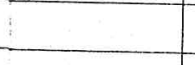 & & & silt $\leqslant$ seds & grms. & \\
\hline & & uns cm & letoseds & $\int \operatorname{Sm} 5 n$ & dy layers. & 1 & & & & & \\
\hline & & & & & & $D W A 352 . F C$ & Stoo 8 & Grau lgr & $n-g r g d o$ & chloritir & phedlete \\
\hline & Stop 4. & For 4 & It oru-to & in limon & itic si & $353-F$ & & sitush als & sitst. Perte. & ke molds. & Sanc'stow. \\
\hline & & silic & w/inter bs & iedded & & & & hagher or & on outeron & sin brr & flucgr \\
\hline & & Noate & slight & thlu meta. & Doss & & & Poss $S_{m}$ & $x-b e d d x d$ & d ss. & \\
\hline & & $x-60$ & coded. & Smmgr & ss, Fairly & & & Hunt to & tork? & & \\
\hline & & $a b d t$ & $f$ afz $u=$ & ins. & & & & & & & \\
\hline & & & & & & & Stop 9 & Ltgra & ufger silic & I ss Gons & $=411 t \sin$ \\
\hline & Stop 5 & Lt gral & fourele & sndy ohl & Wlitic shales & & & bm we & eathing & cht son. & ns atgares \\
\hline & & Sm ssi & s(1) & Meta of & sh more & & & limoma & fie, shear & ed. Sh & interbeds \\
\hline & & intense & than ss. & & & & & $q f-v \in d$ & ins. & & \\
\hline & & (Low & wer Noot & fak-1 Nur & at Fork? & & 5 & & & & \\
\hline & & & & & & DWA 35A.F S & Stop 10 & Lissuru & ue & & \\
\hline & & & & & & $355-f$ & & & & & \\
\hline 2 & & & & & & $356-F$ & & & & & \\
\hline & & & & & & $\begin{array}{l}357-7 \\
358-6\end{array}$ & $e^{\prime}$ y (fiuga & Hasl bo ba & W Lstour & f. 50 akg o & que s d \\
\hline
\end{tabular}




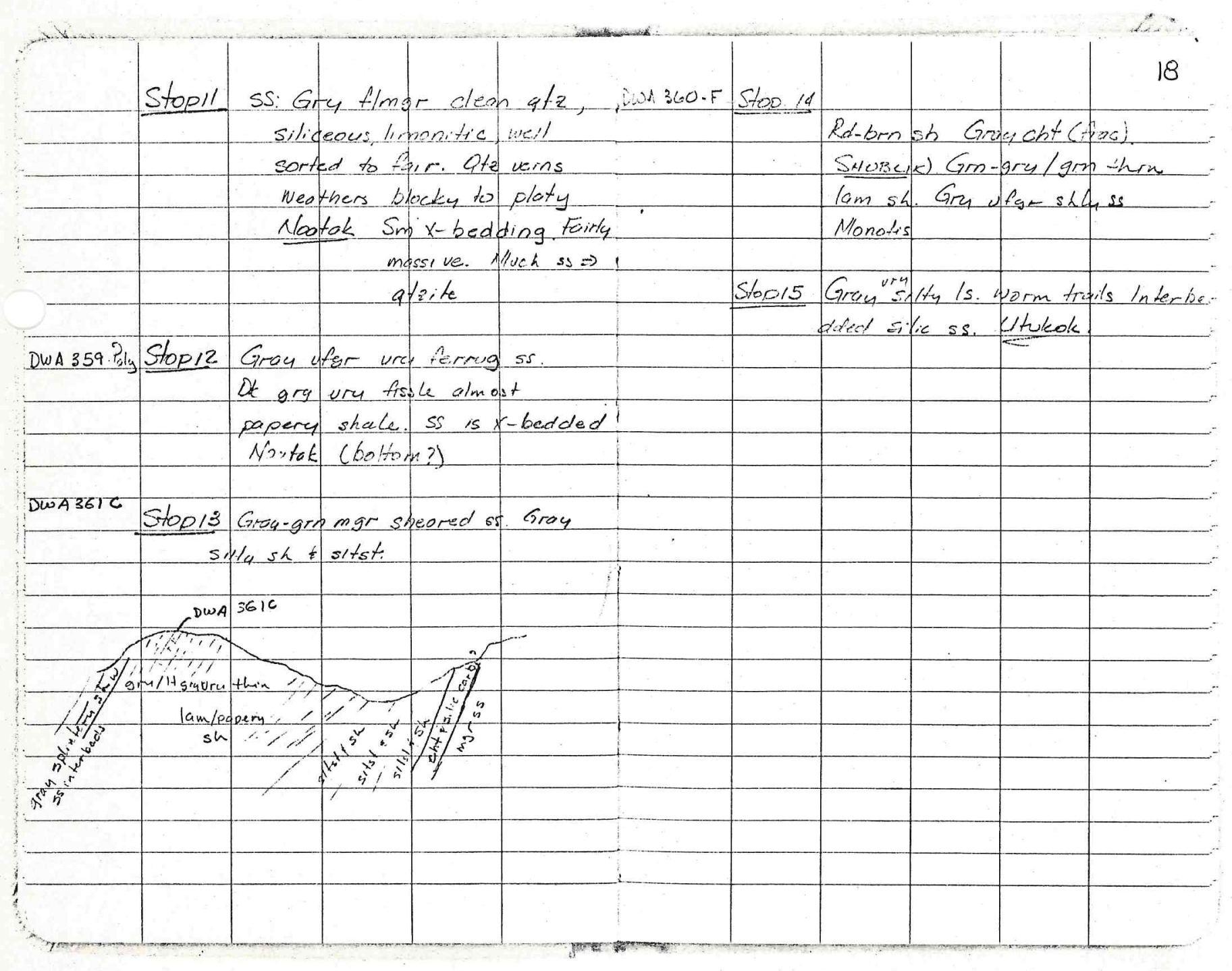




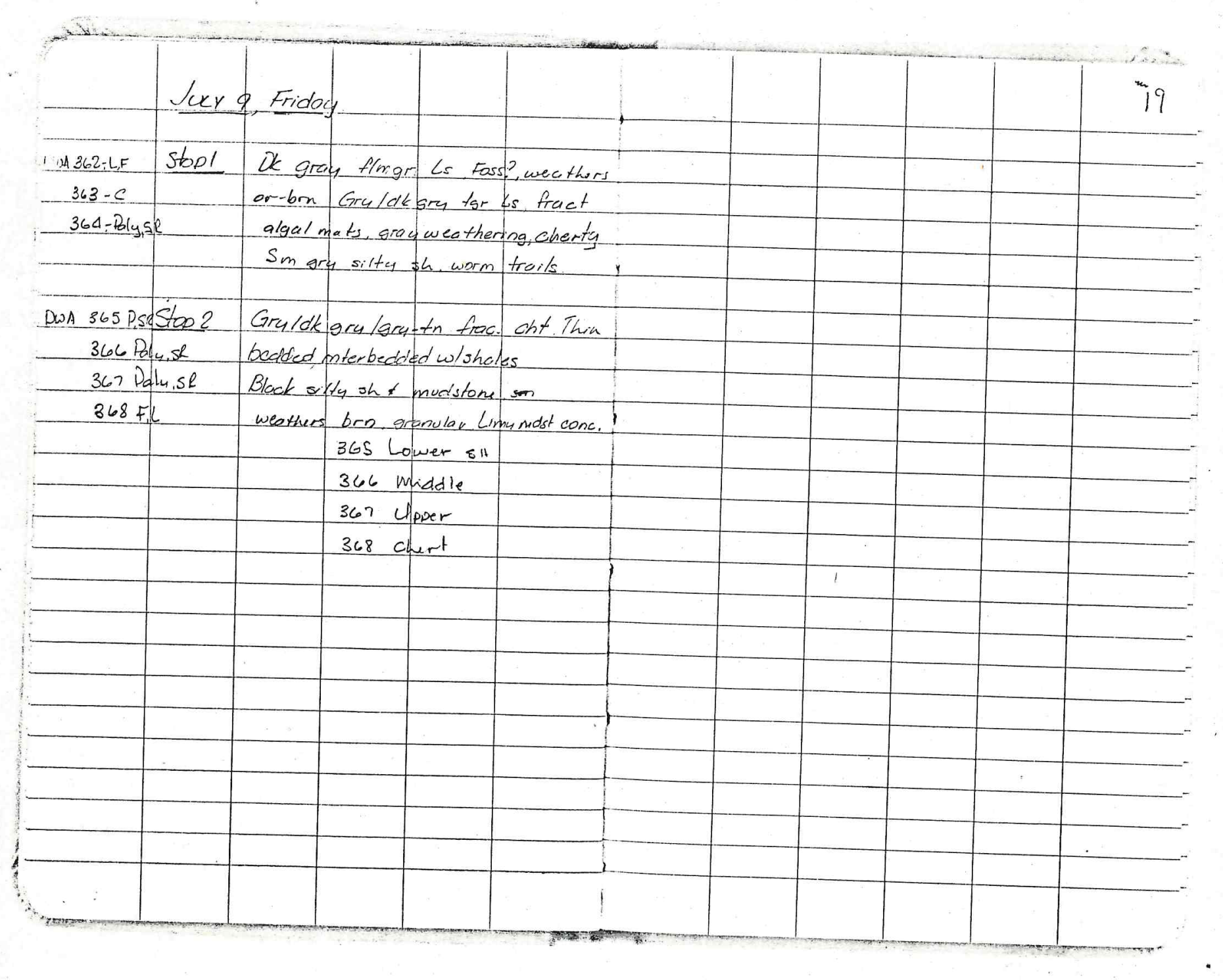




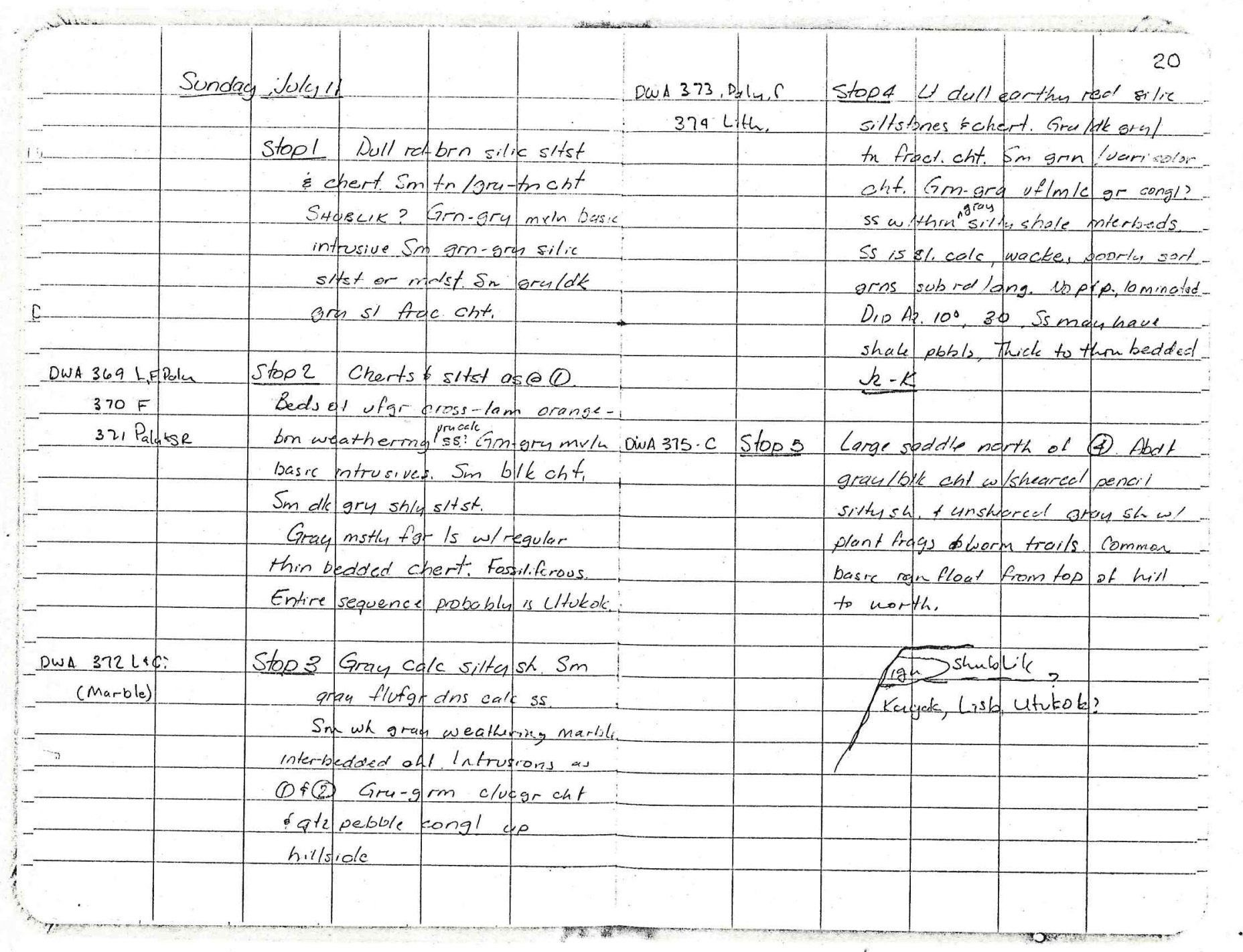




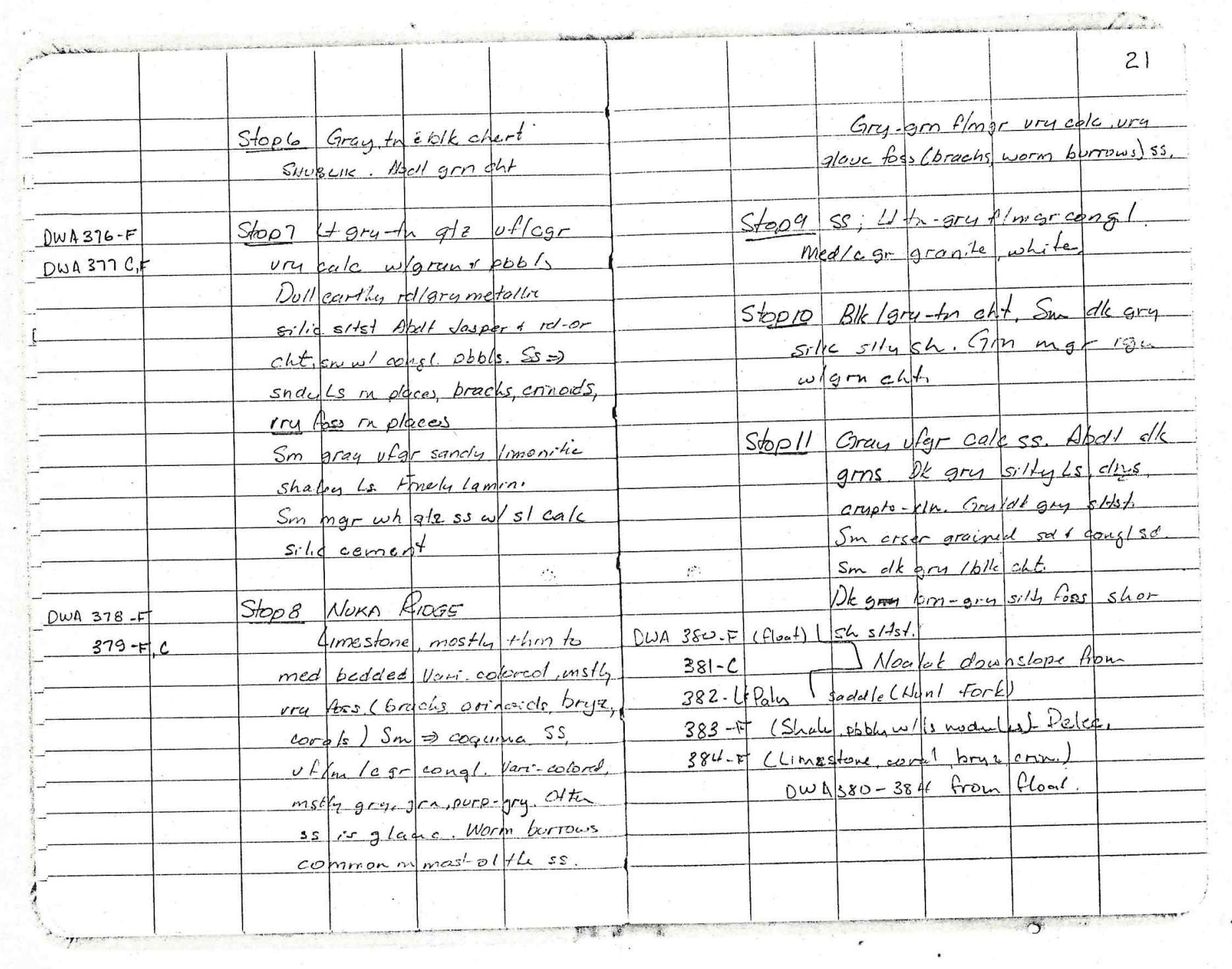




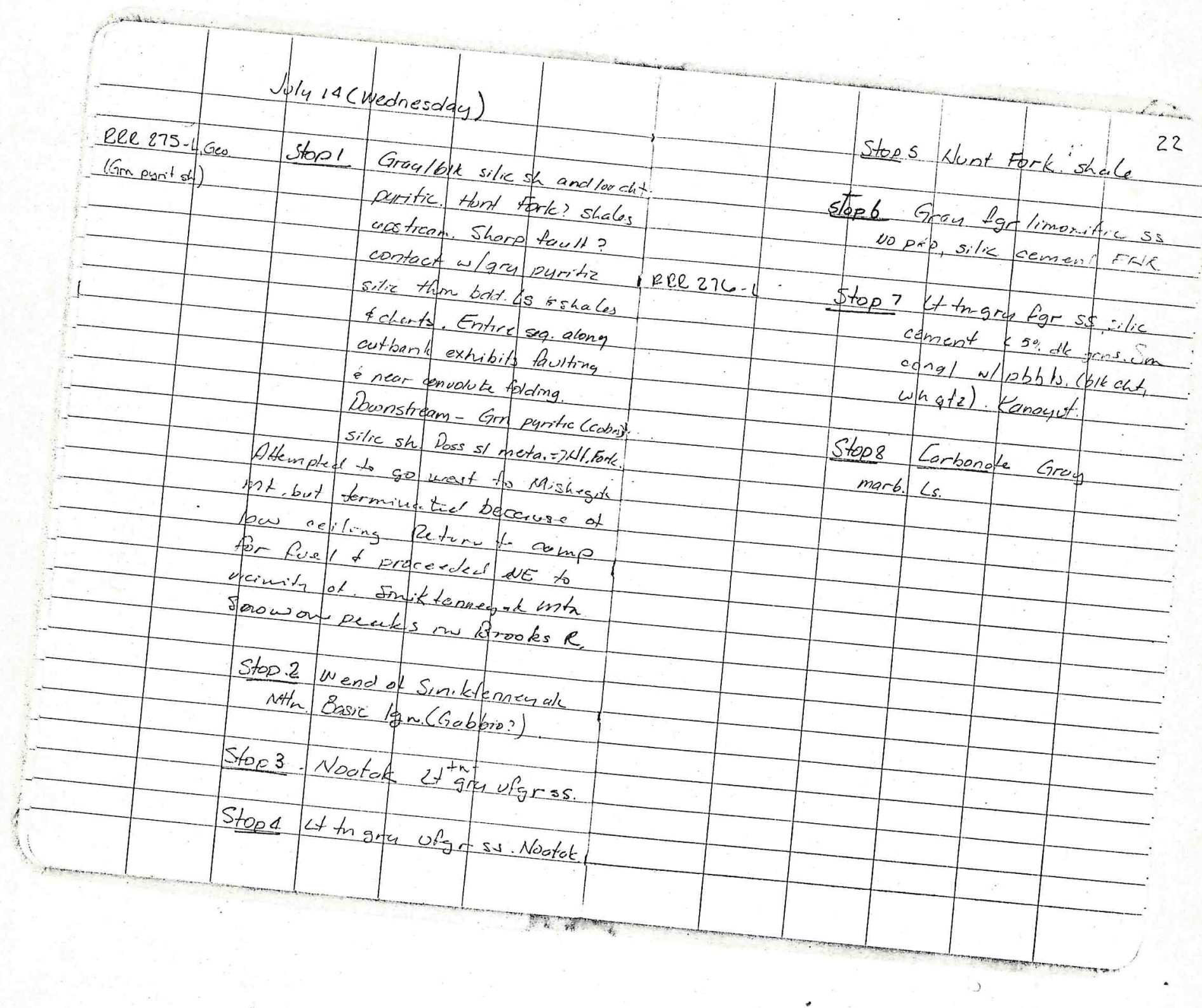




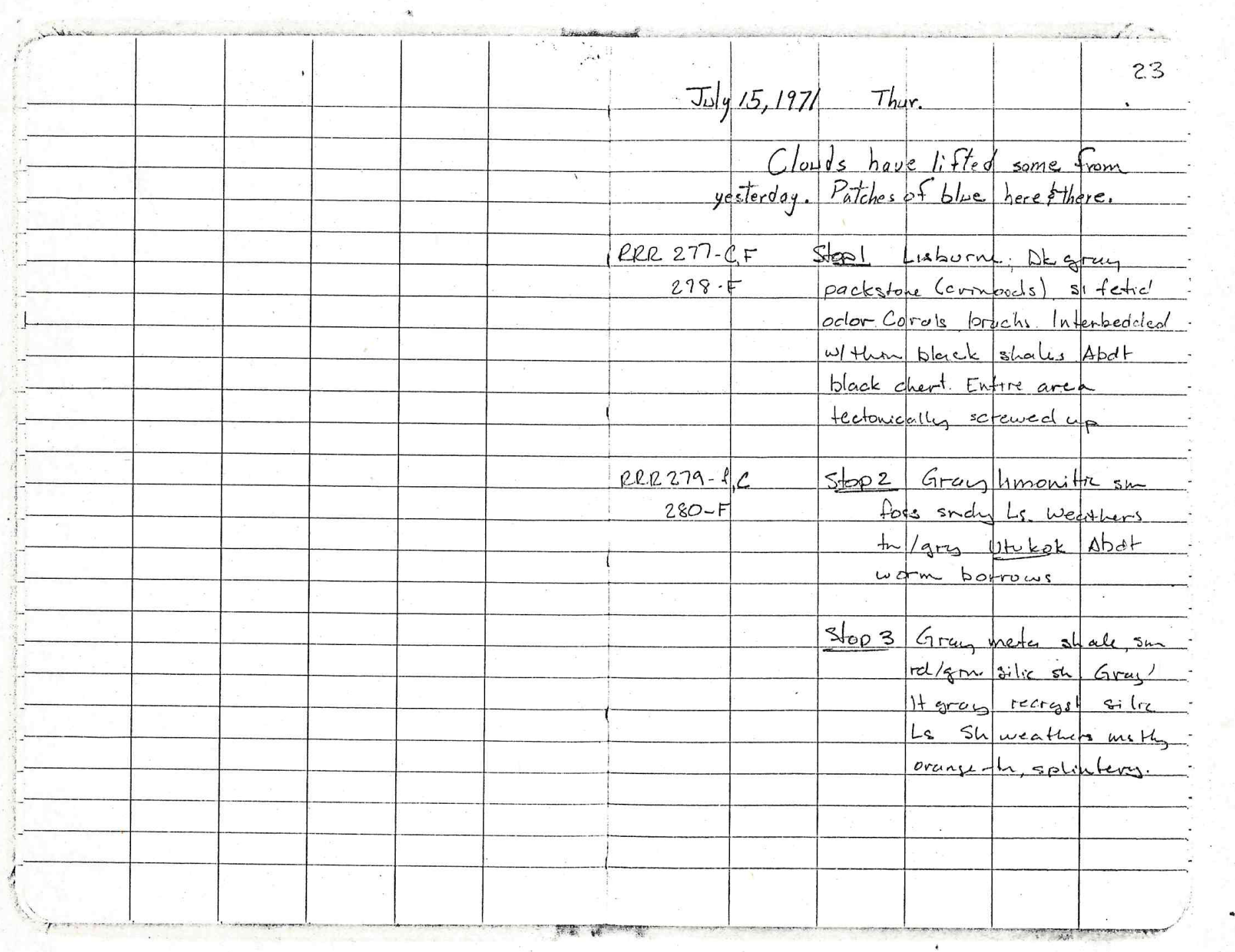




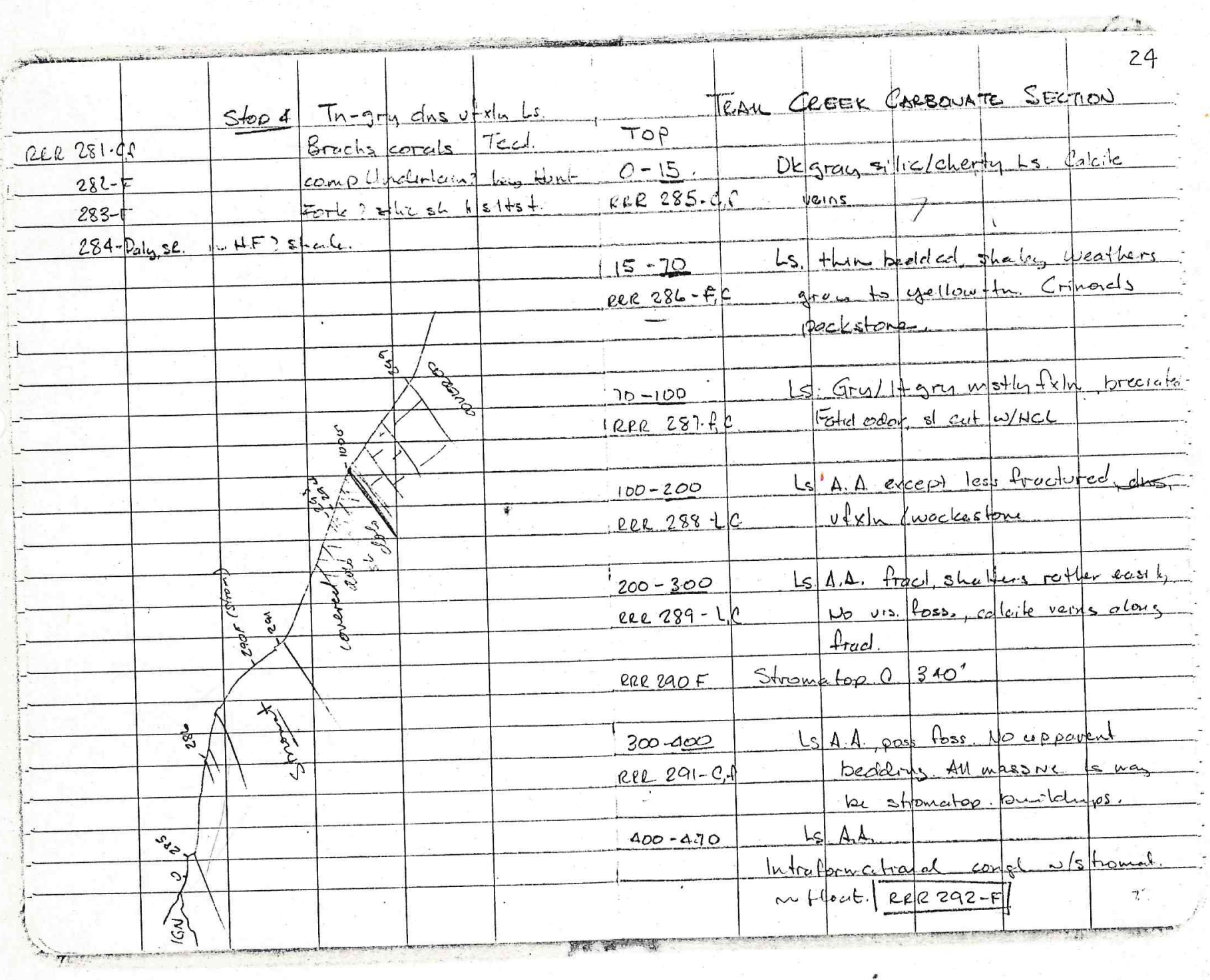




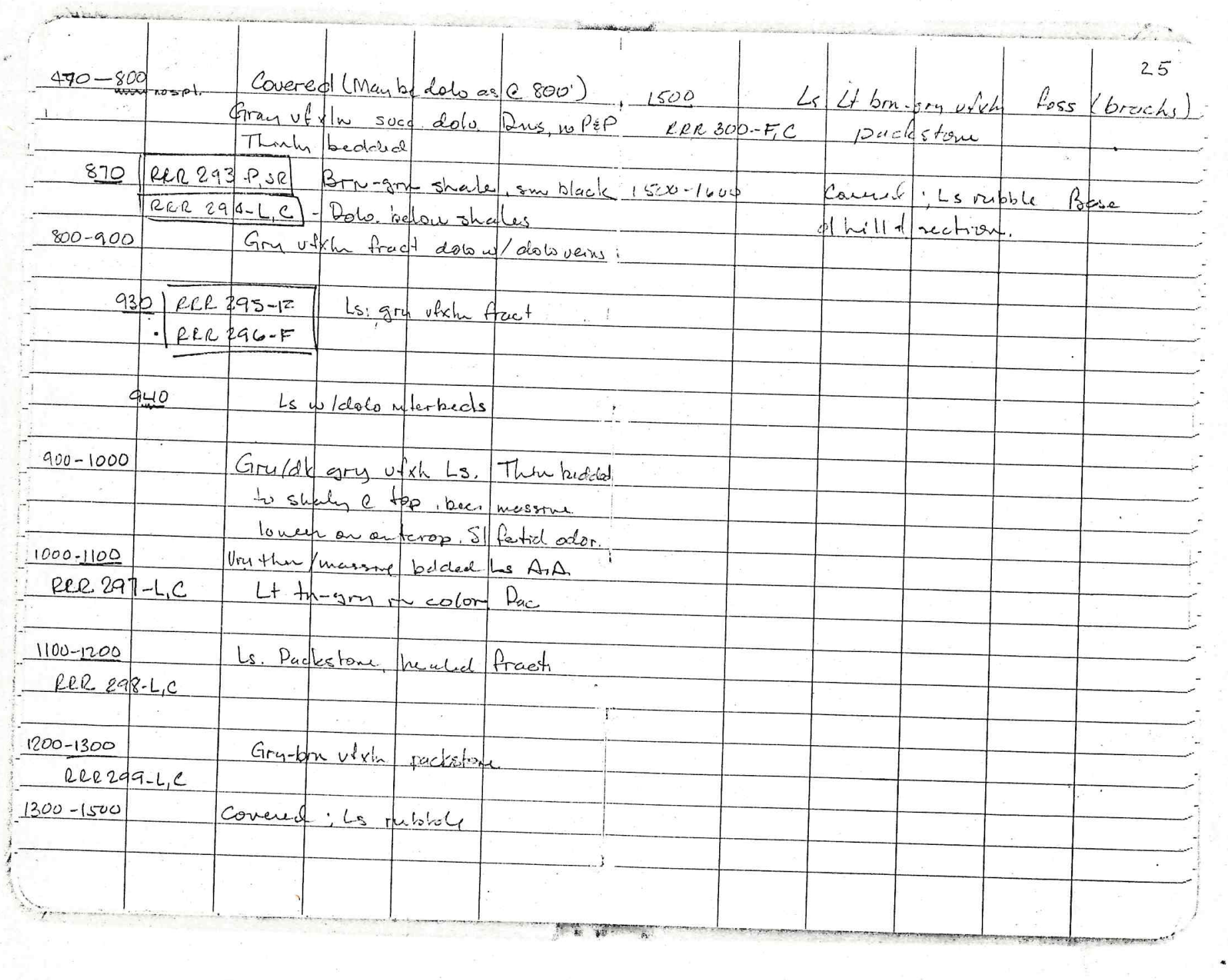




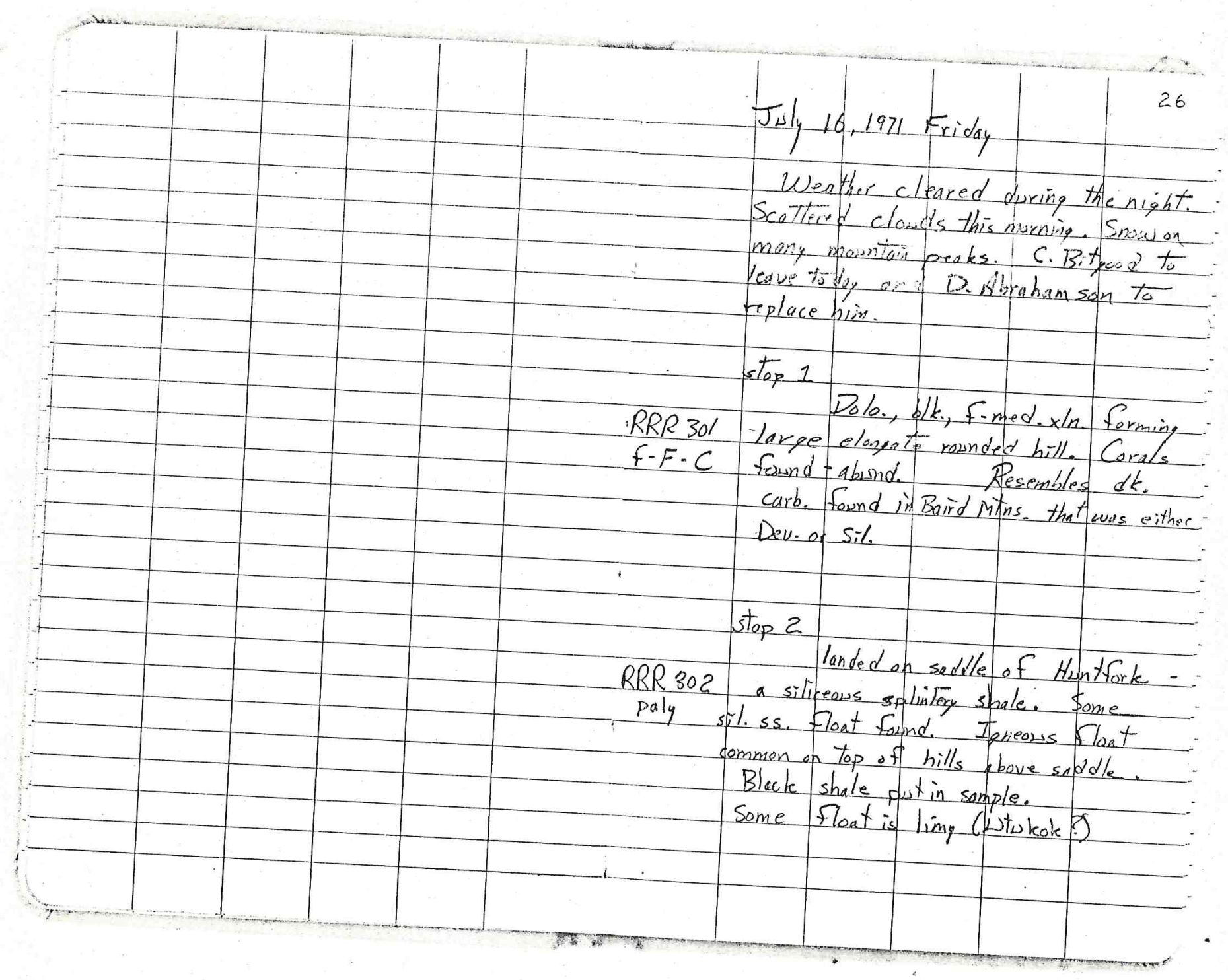




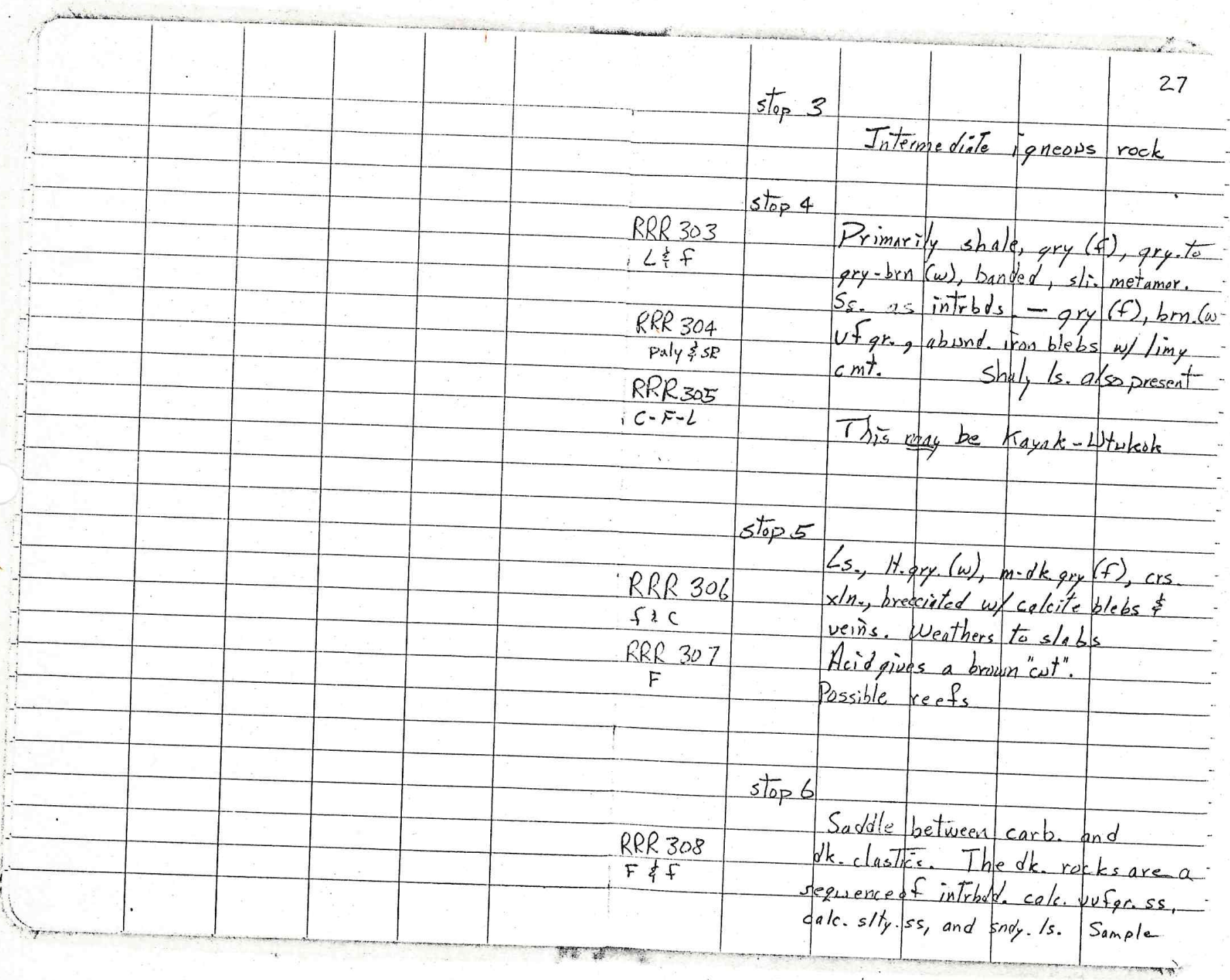




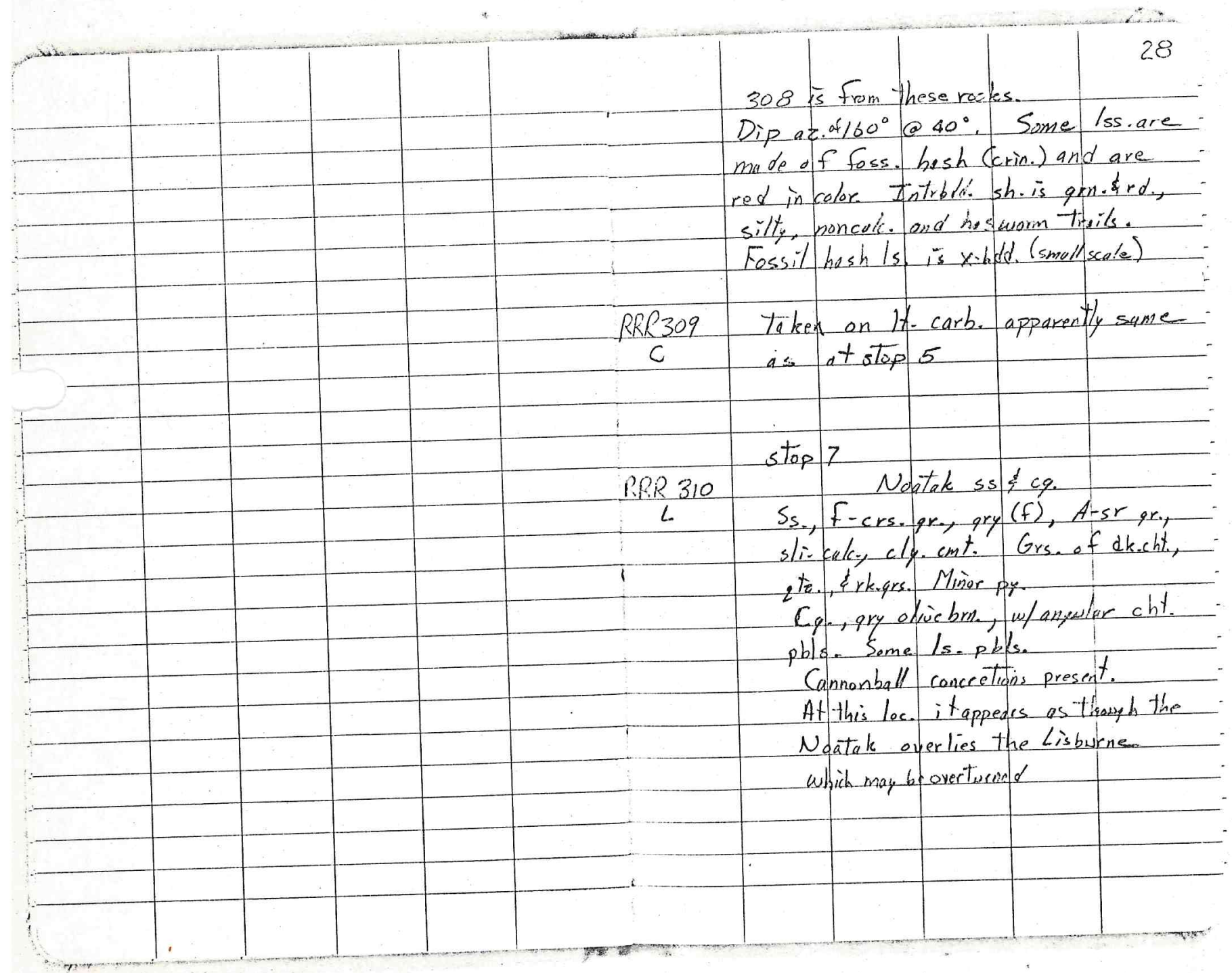




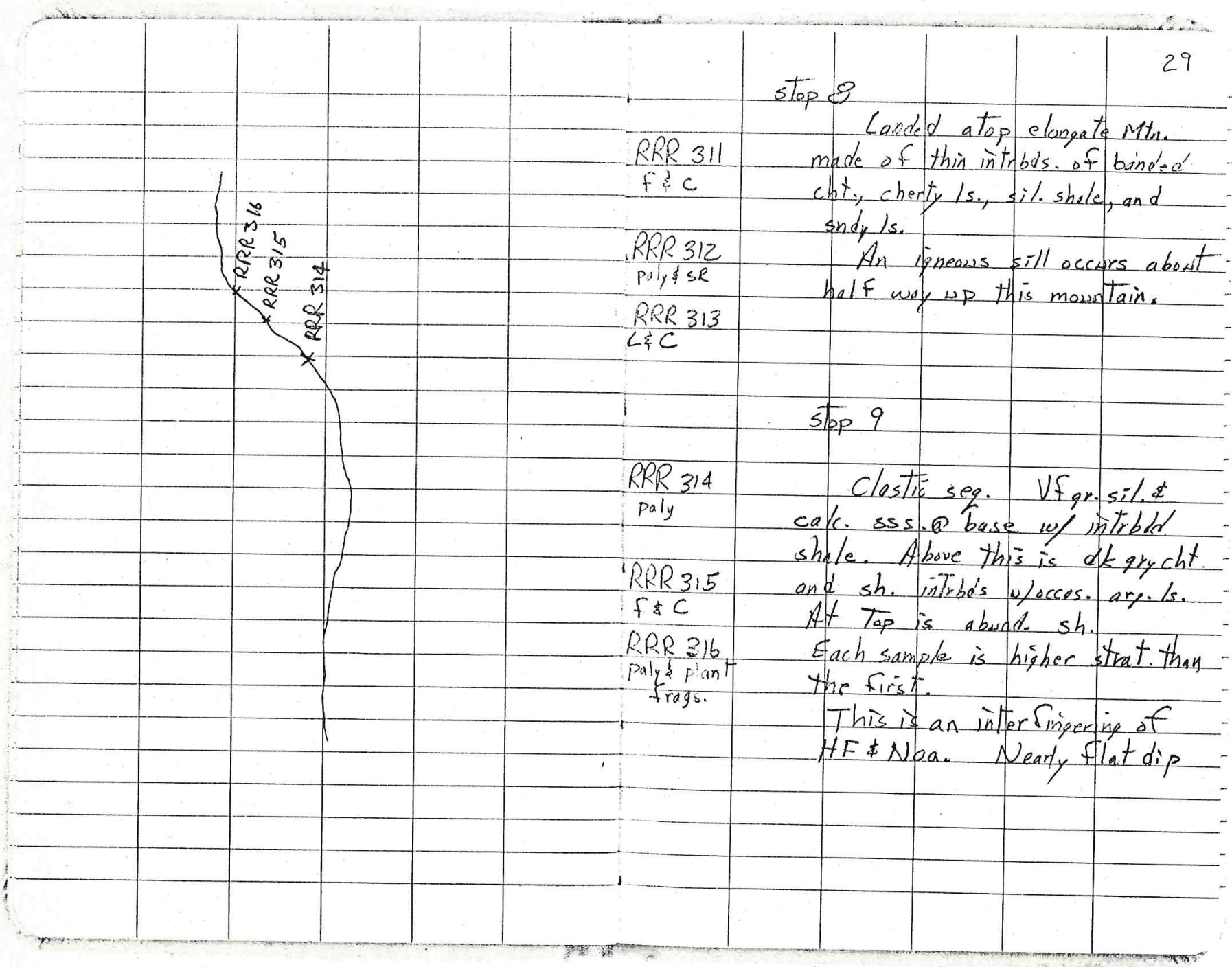




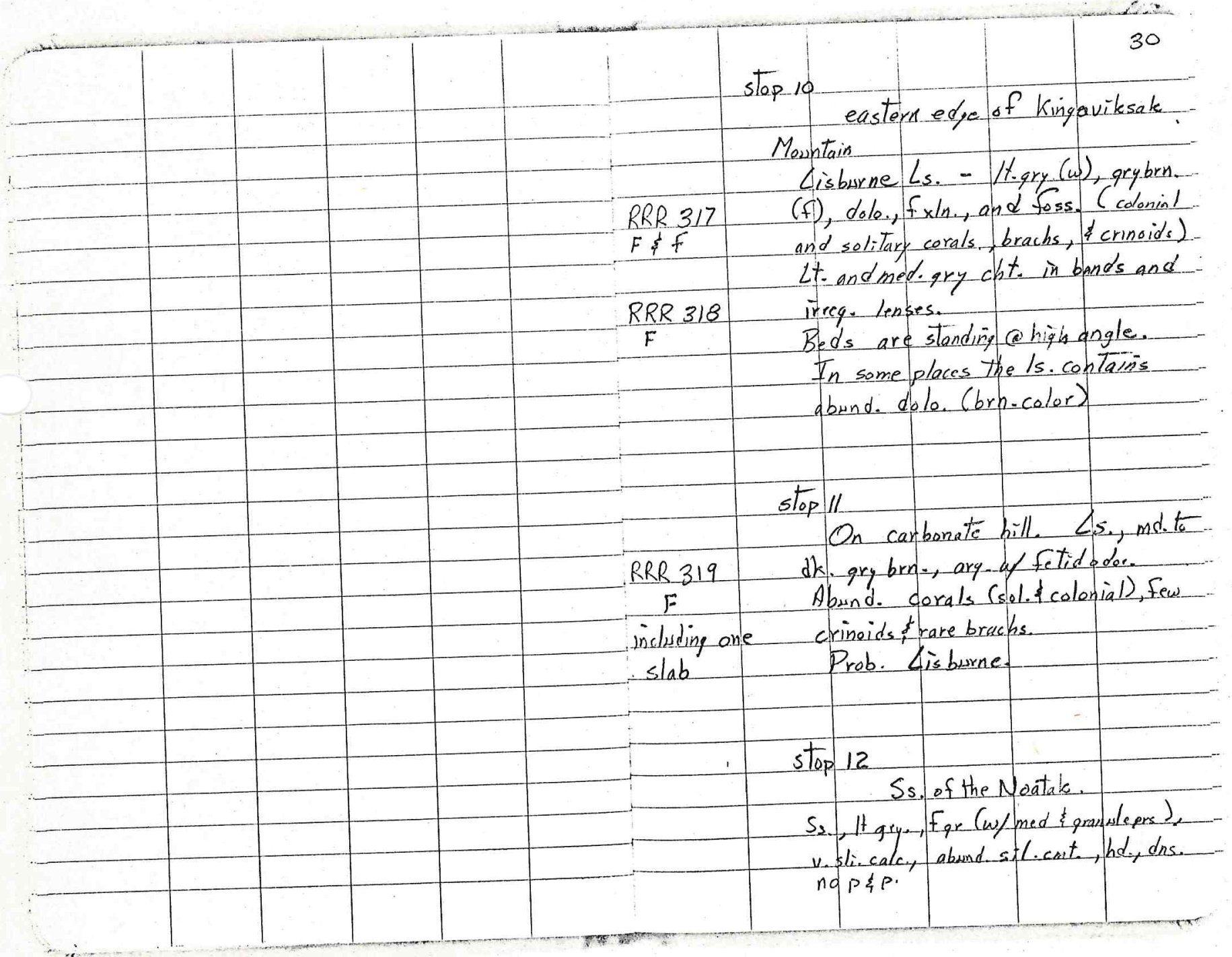




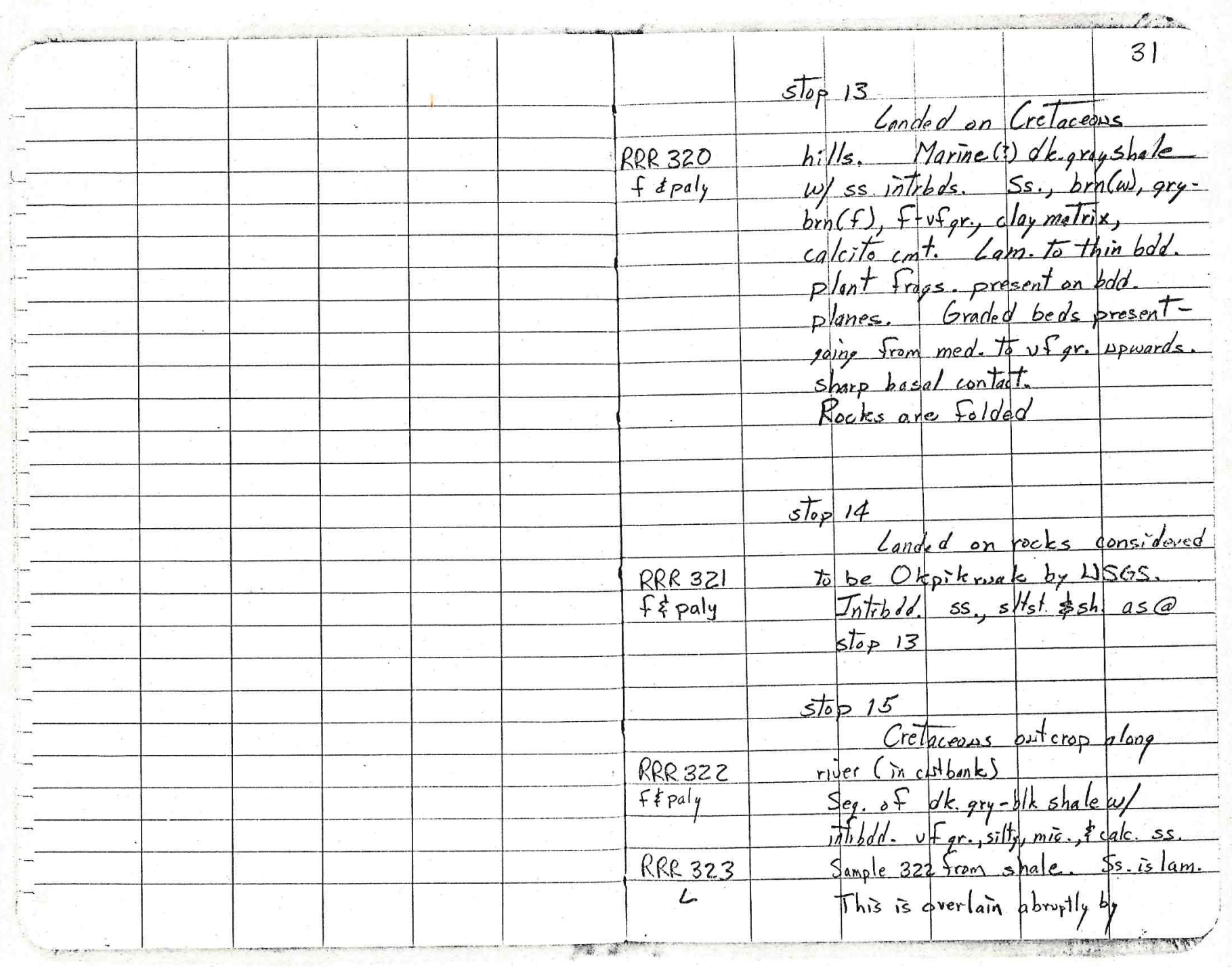




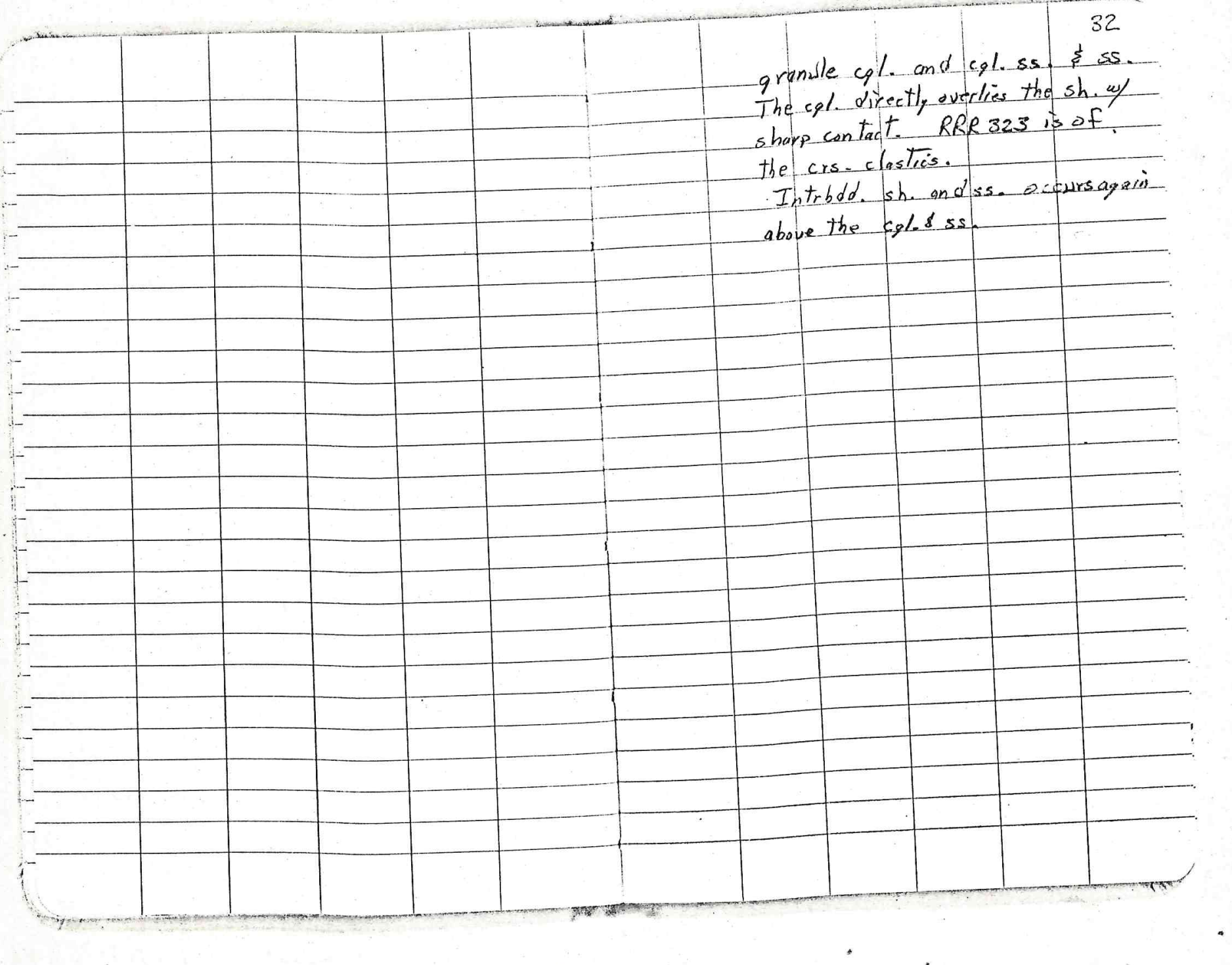




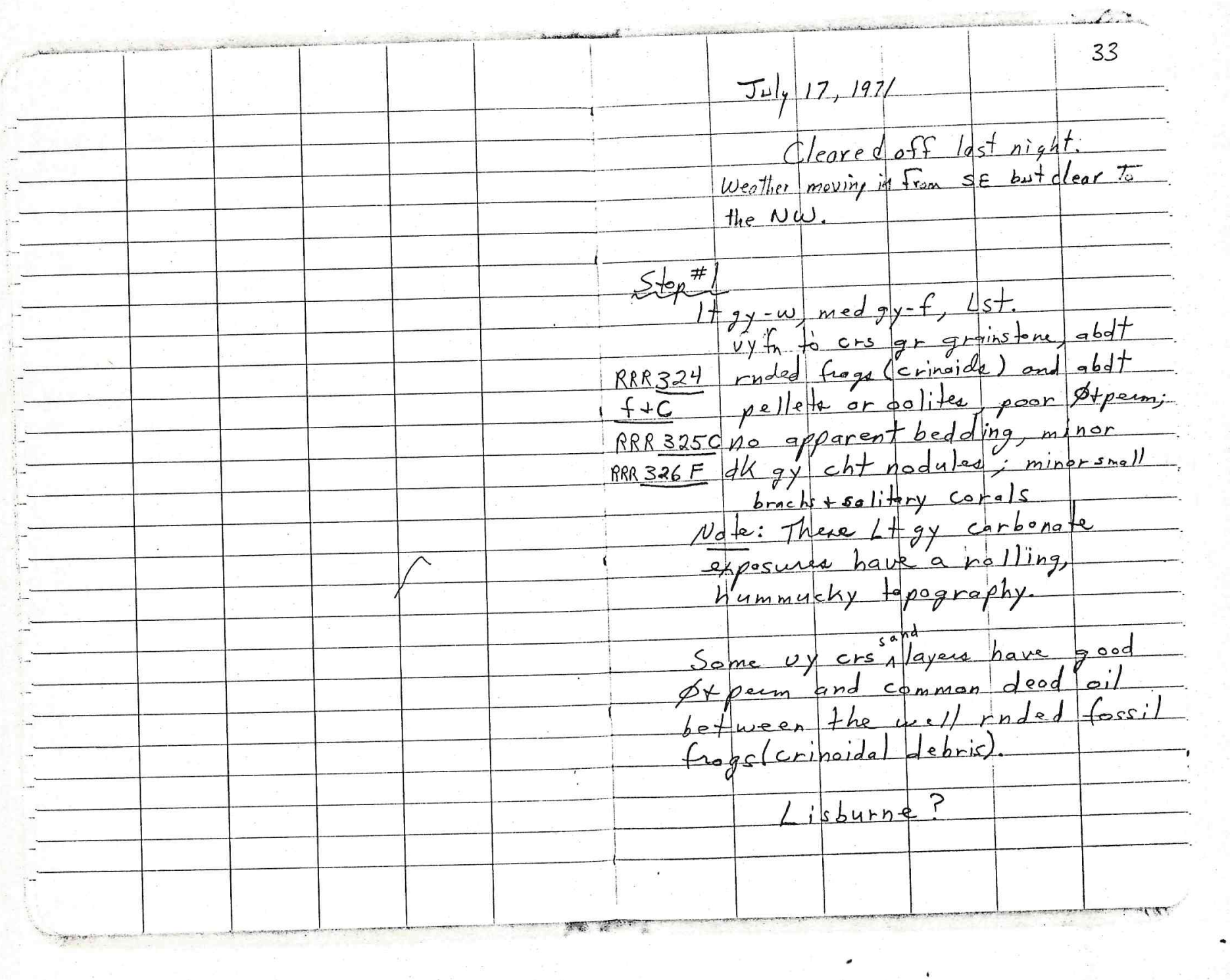




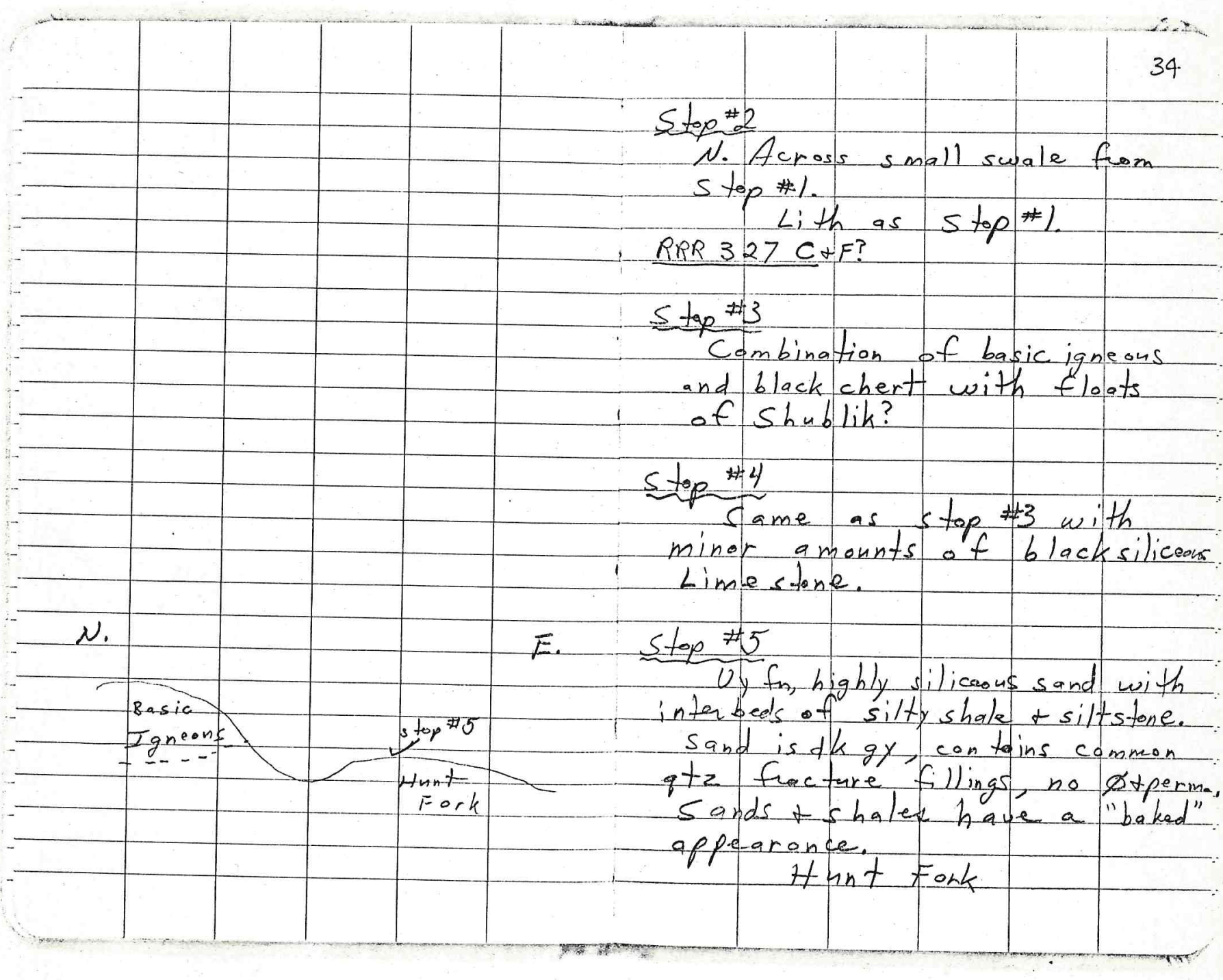




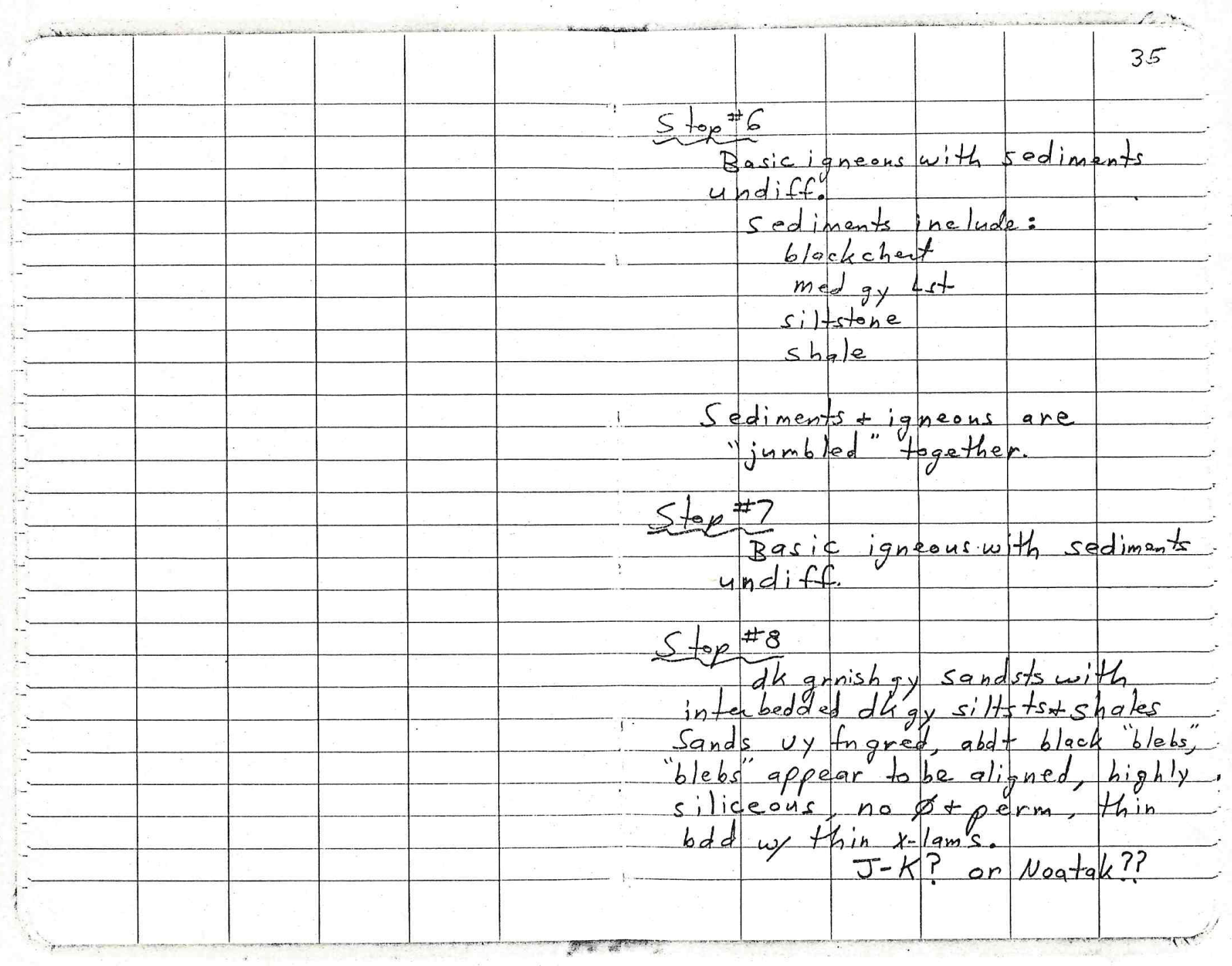




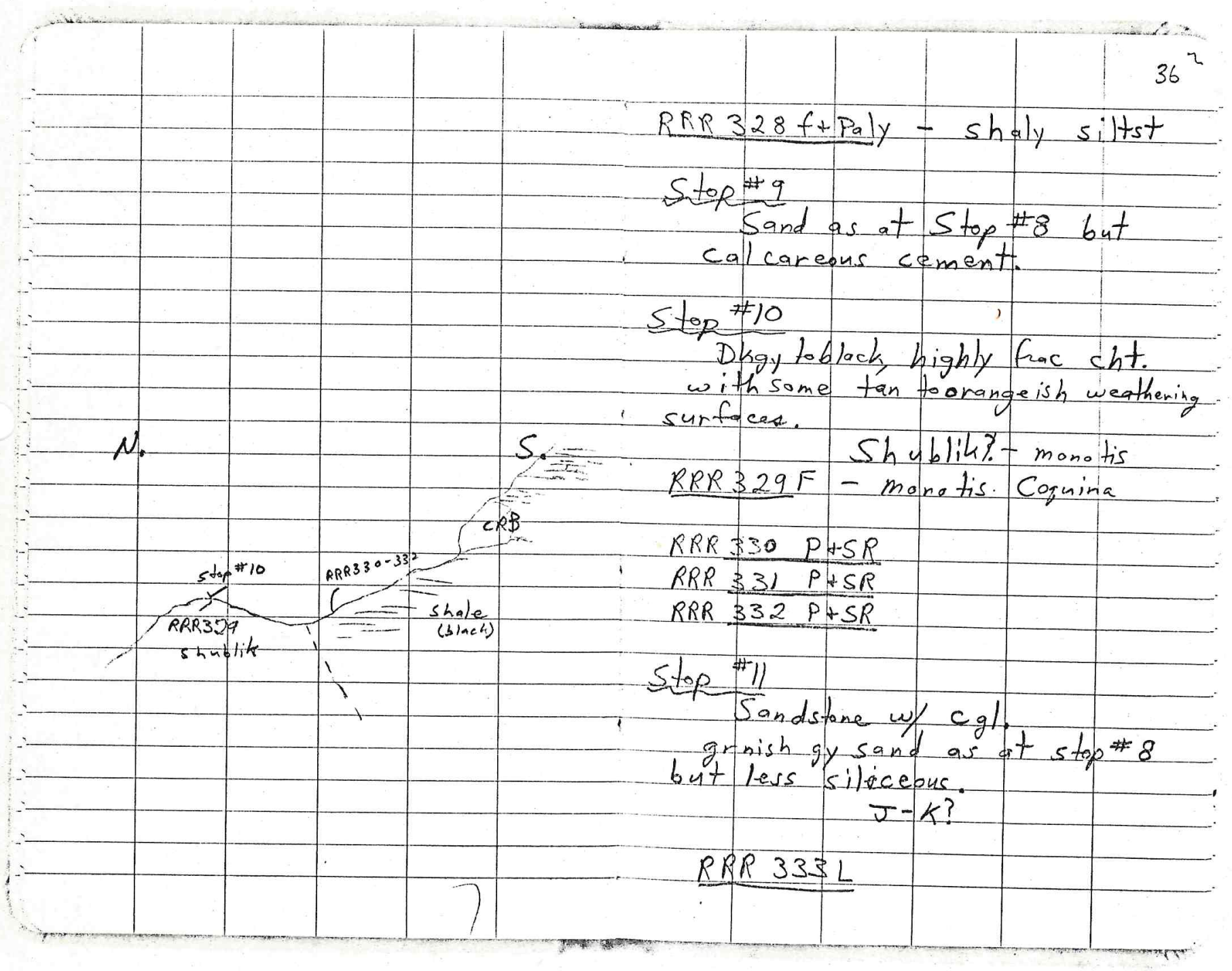




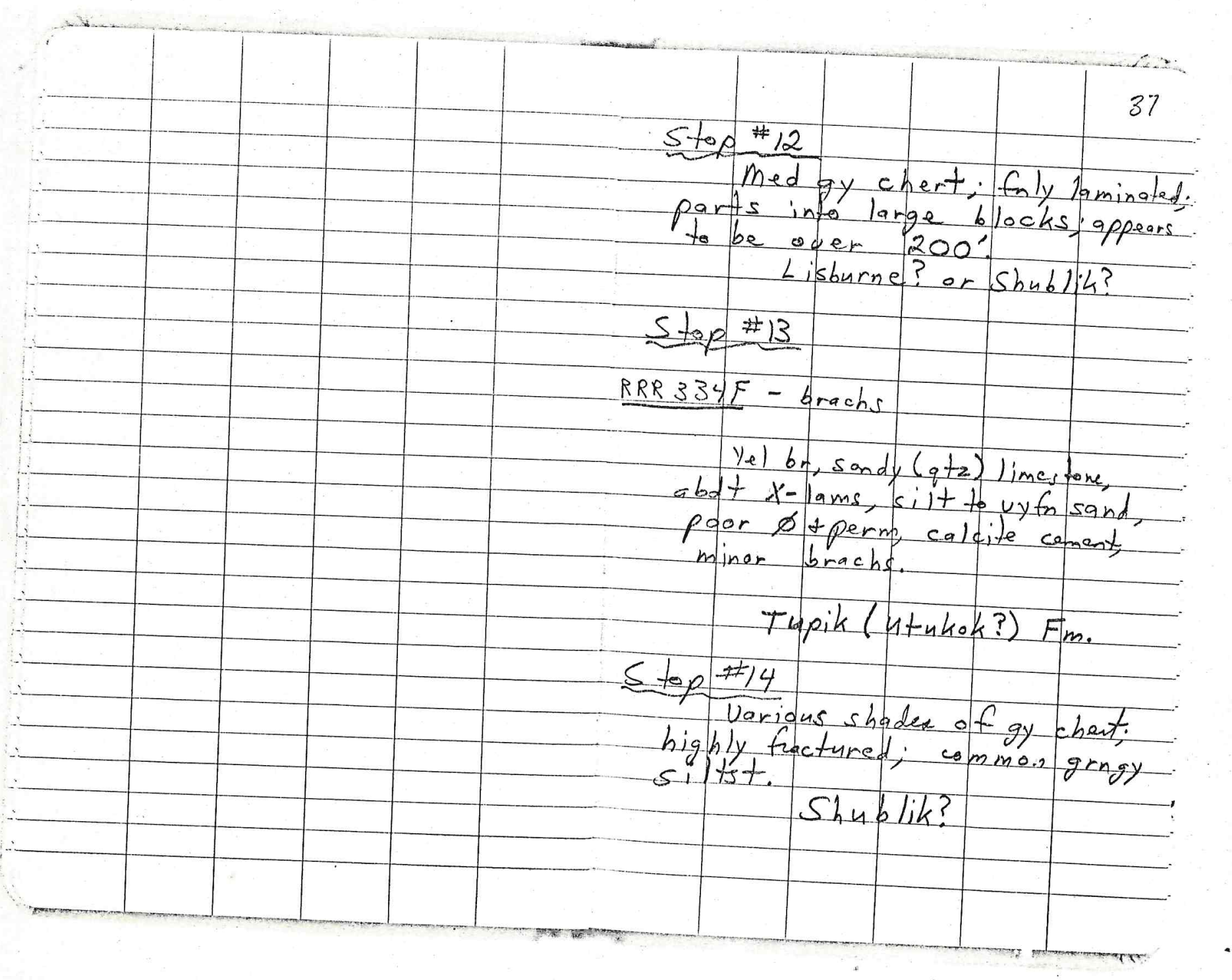




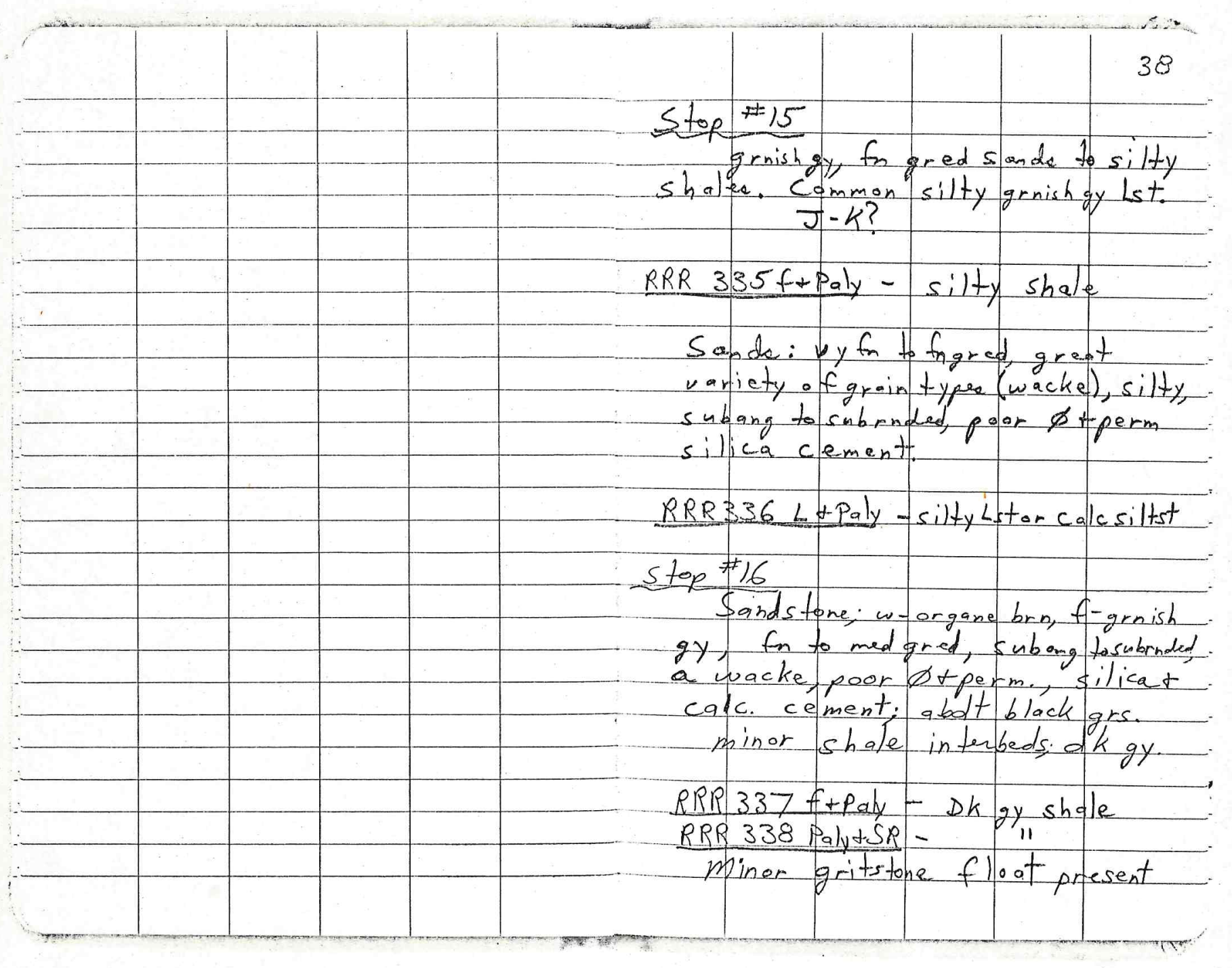




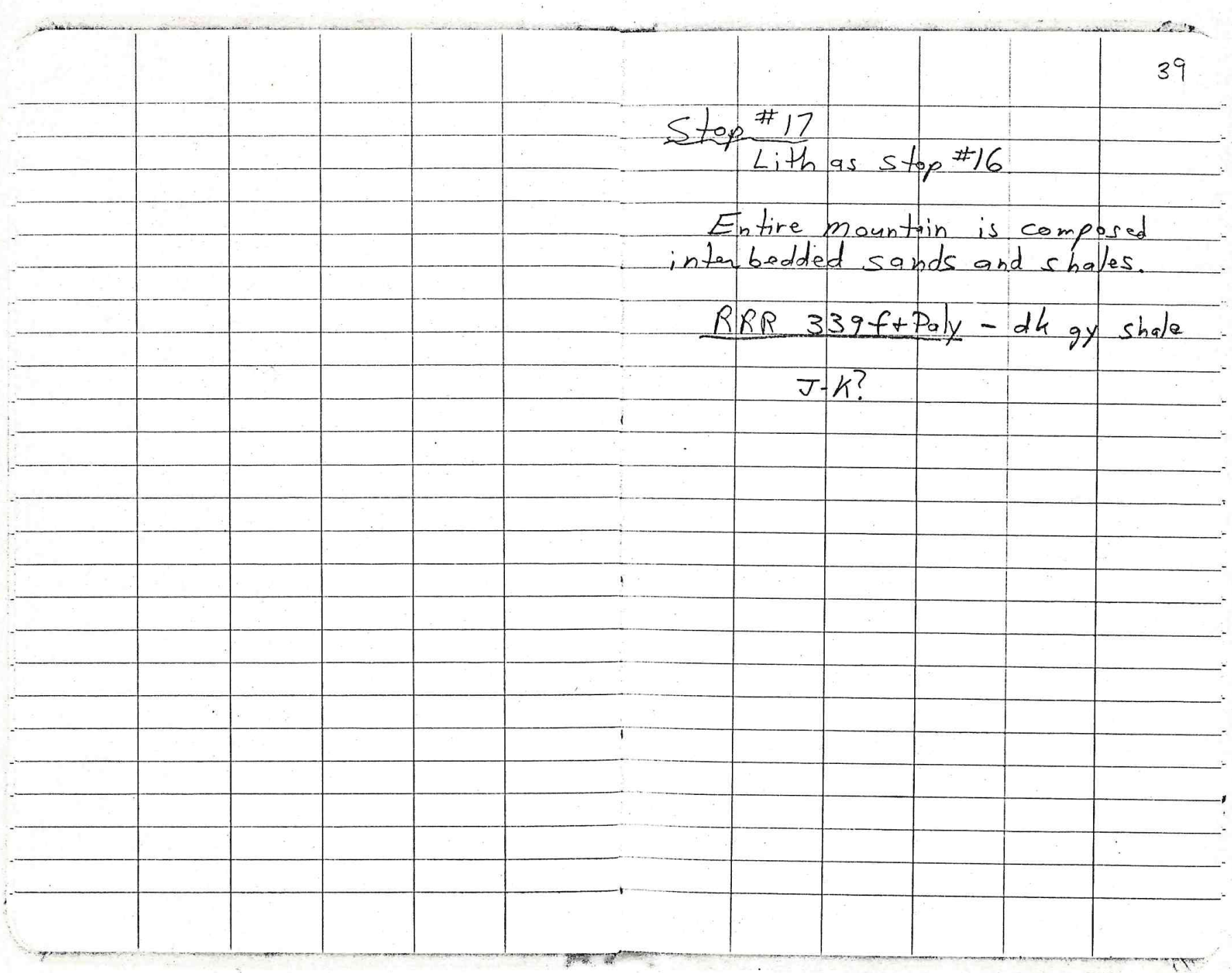




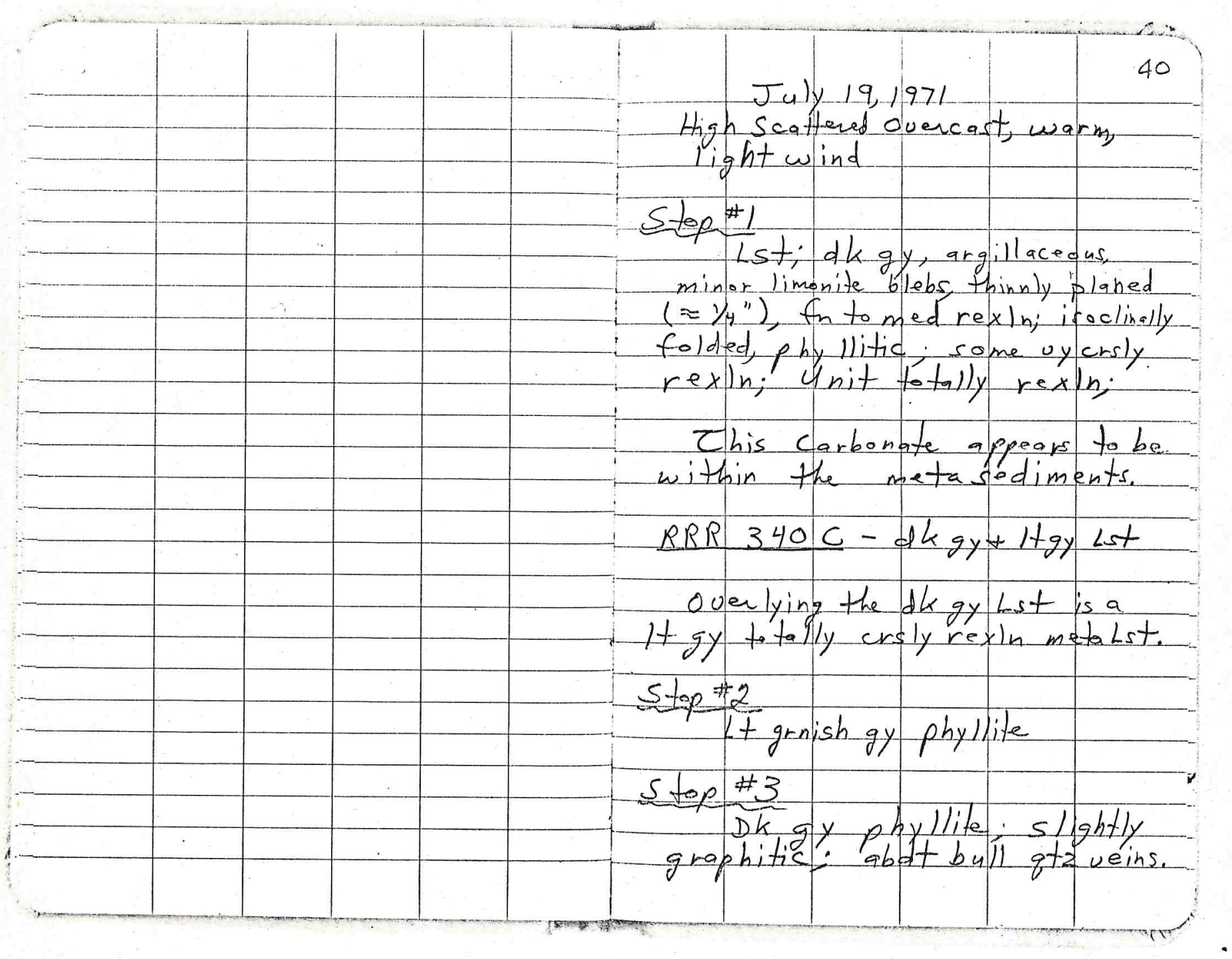




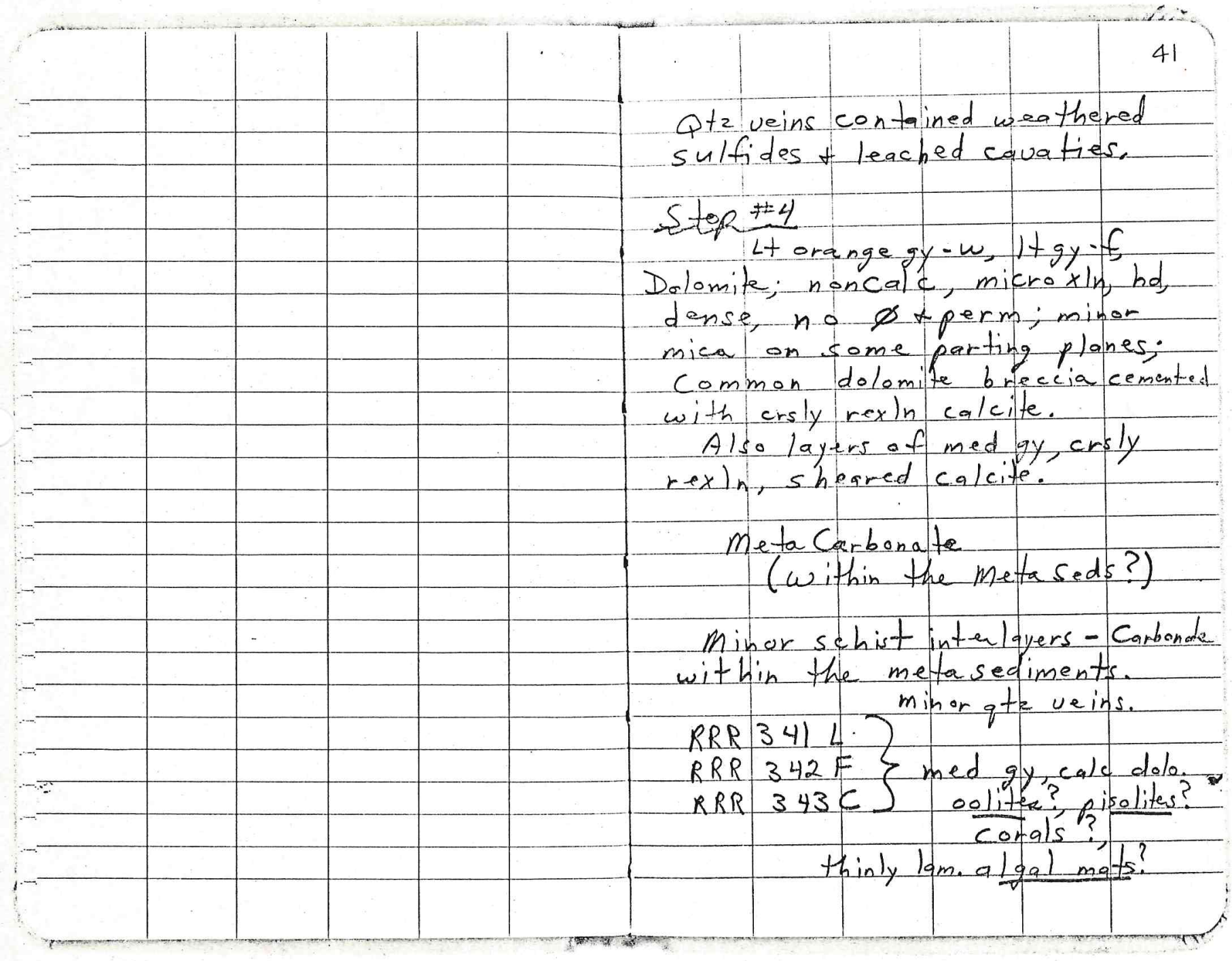


Oolitet pisolite layens are well sorted and inter bedded with algalmats and wavy algal stromatolites.

RRR $344 C$ - med gy crsly rexin Lst Stap $\$ 5$

Tgy, shiny, graphitic phyllite with minor of 2 veins.

Step $\# 6$

limenitic hyllitic schist, highly

Originally a sand?

Stap

metasediments

Lstistrang unidirectional oriantation of calcite crystals 


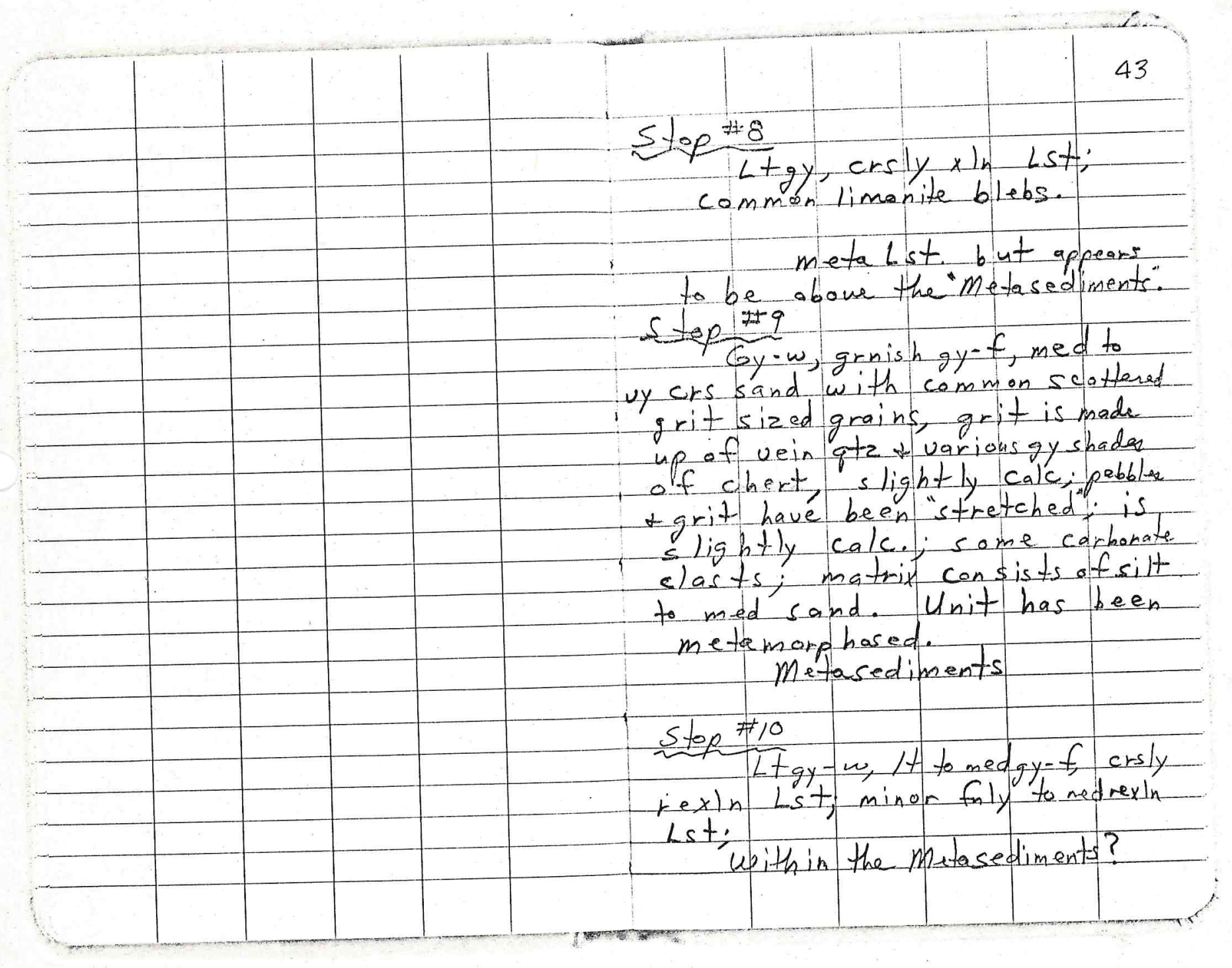




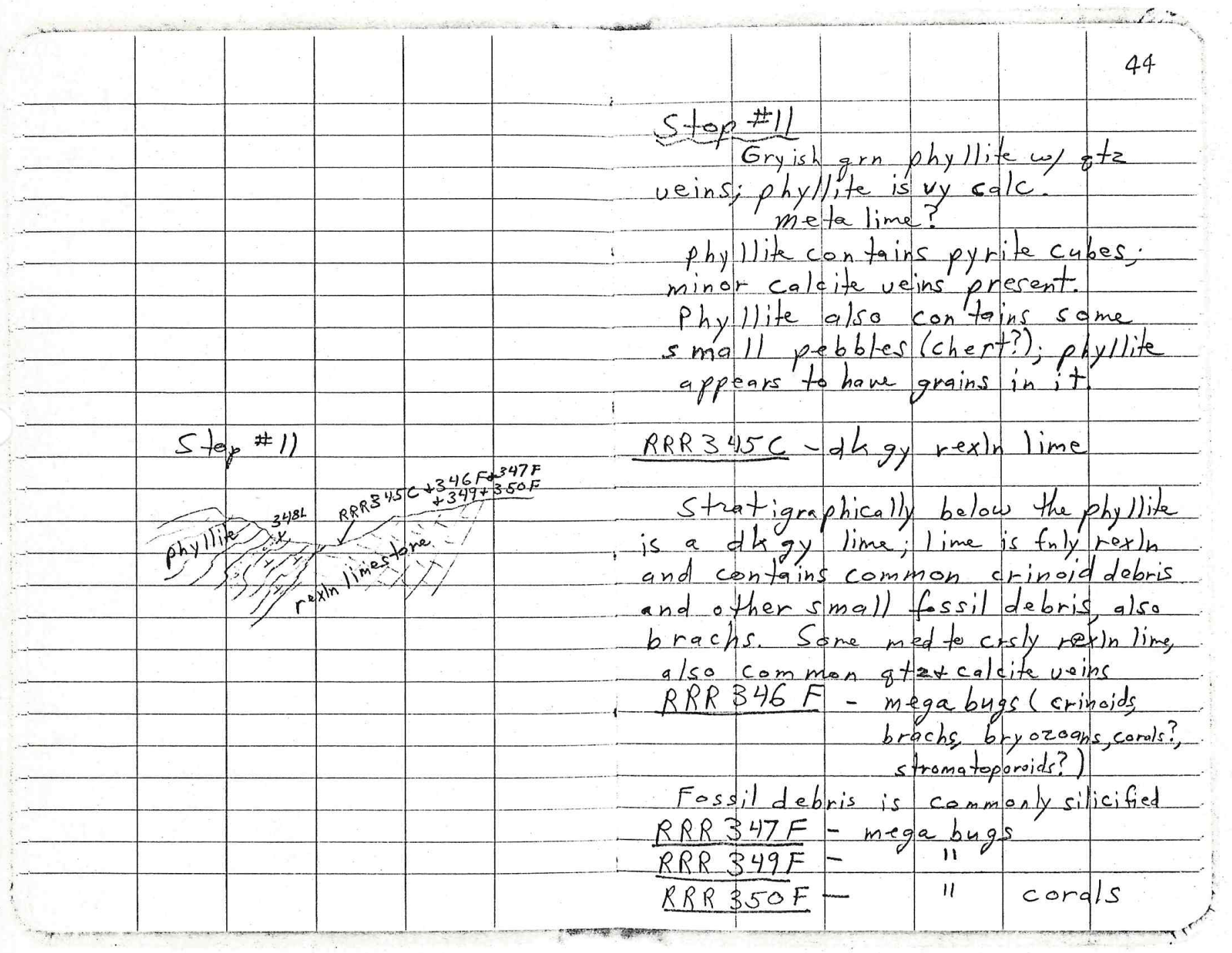




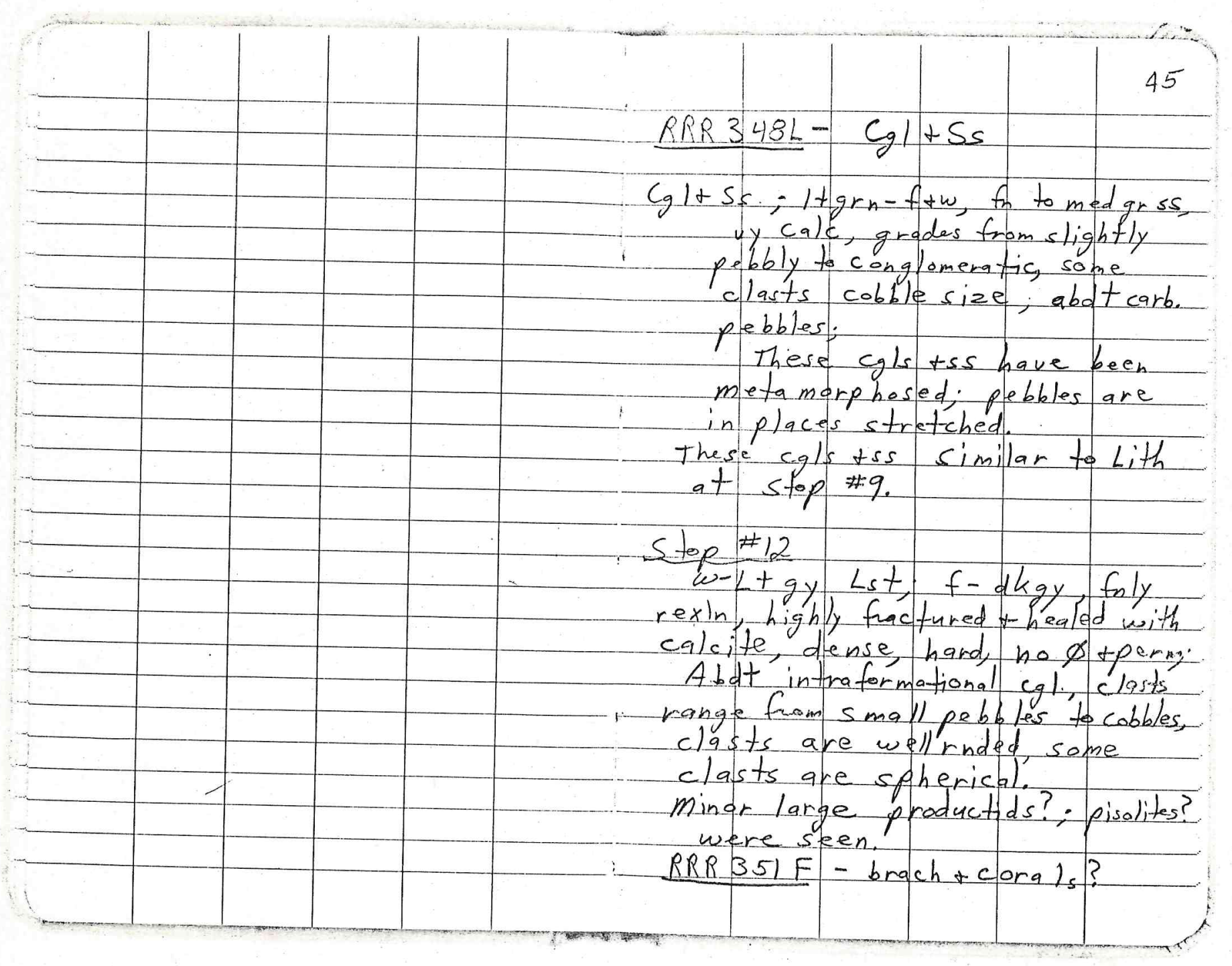




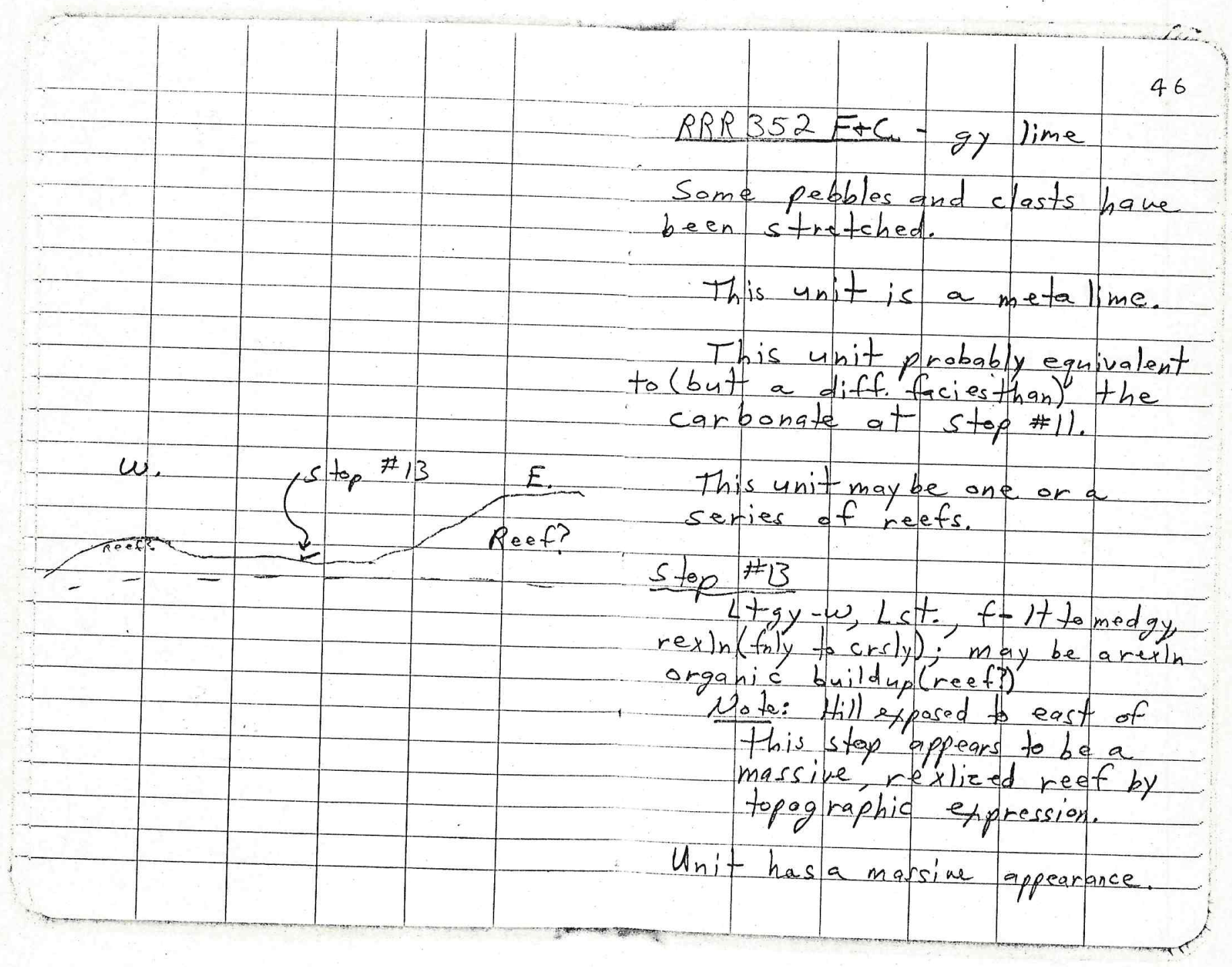




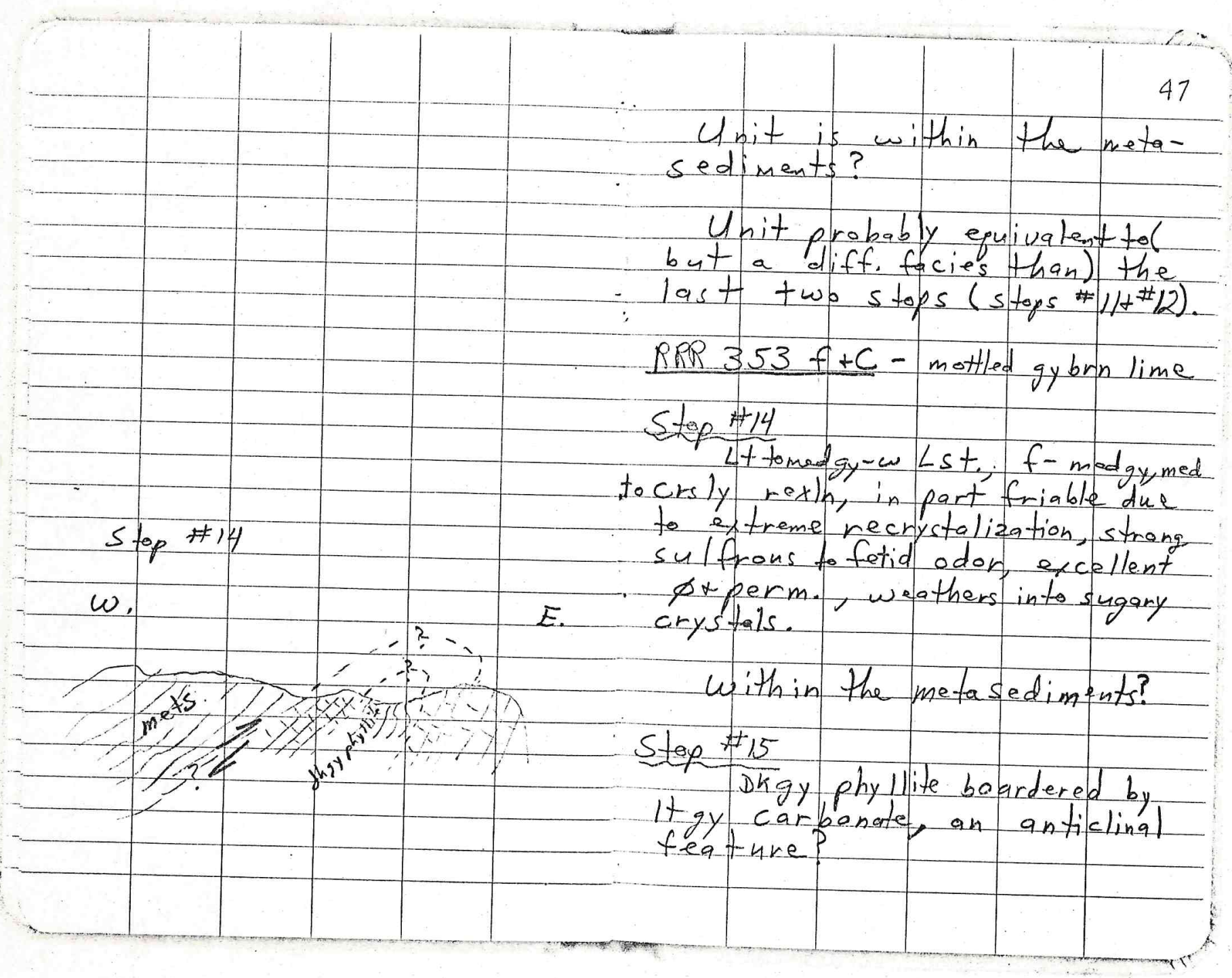




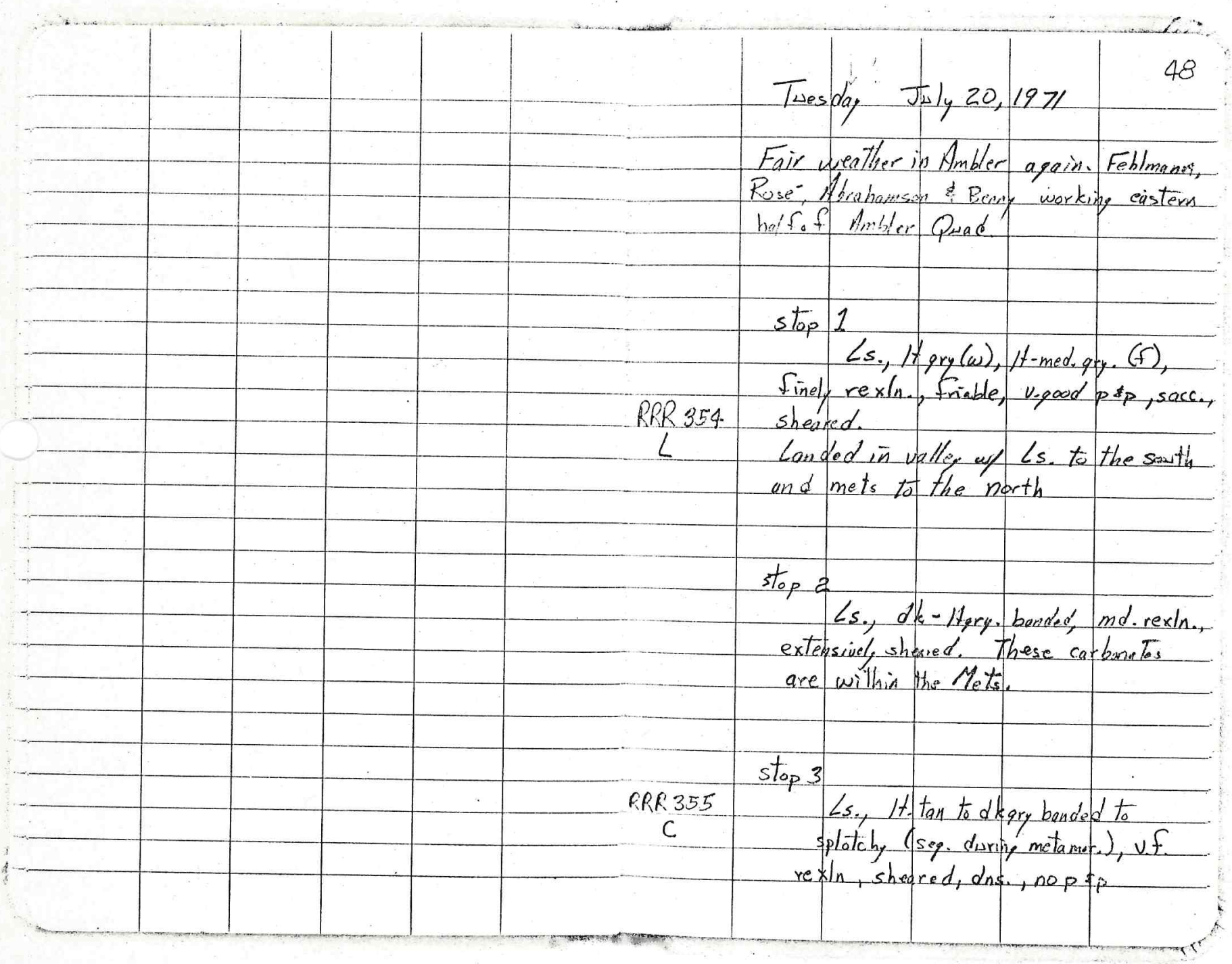




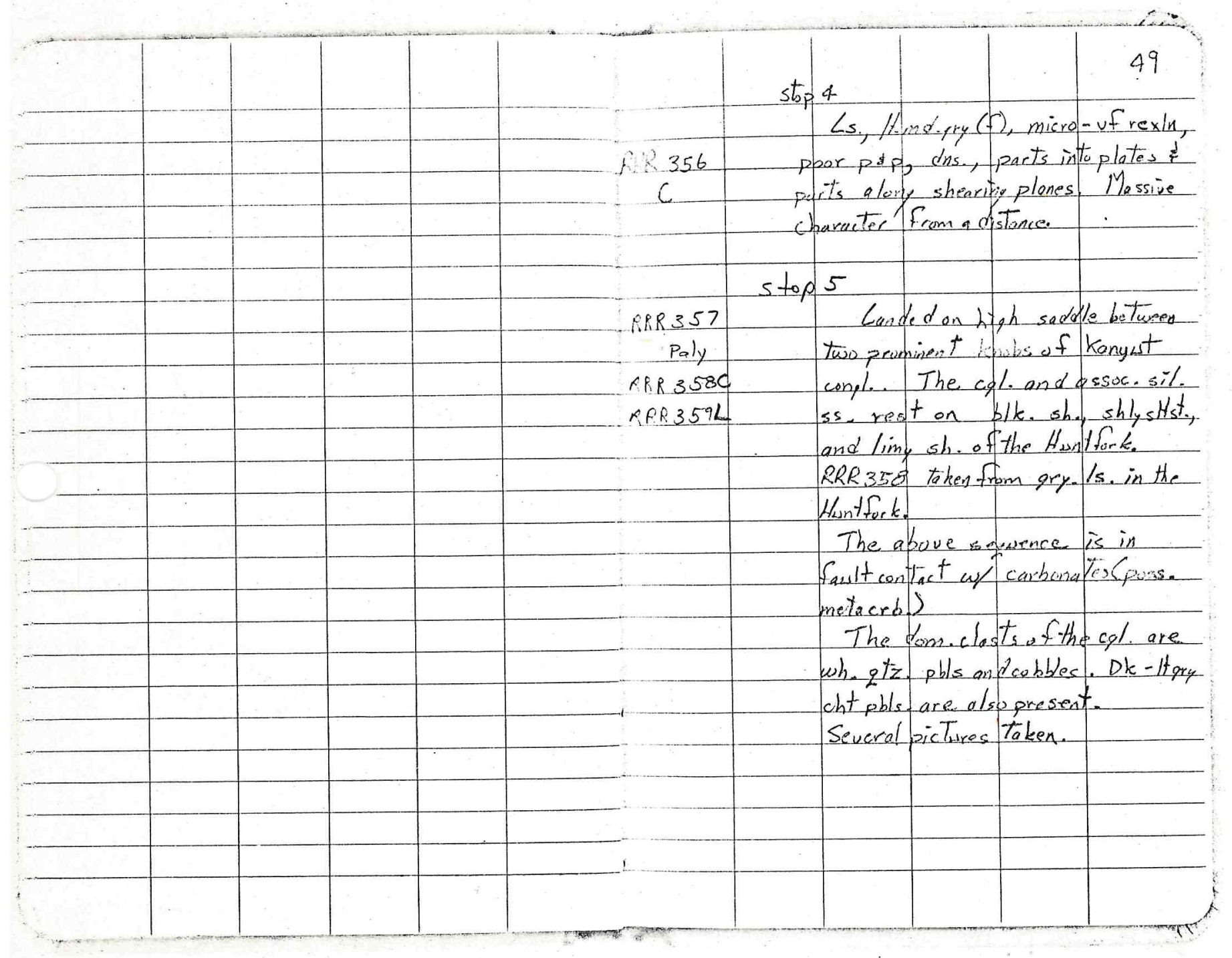




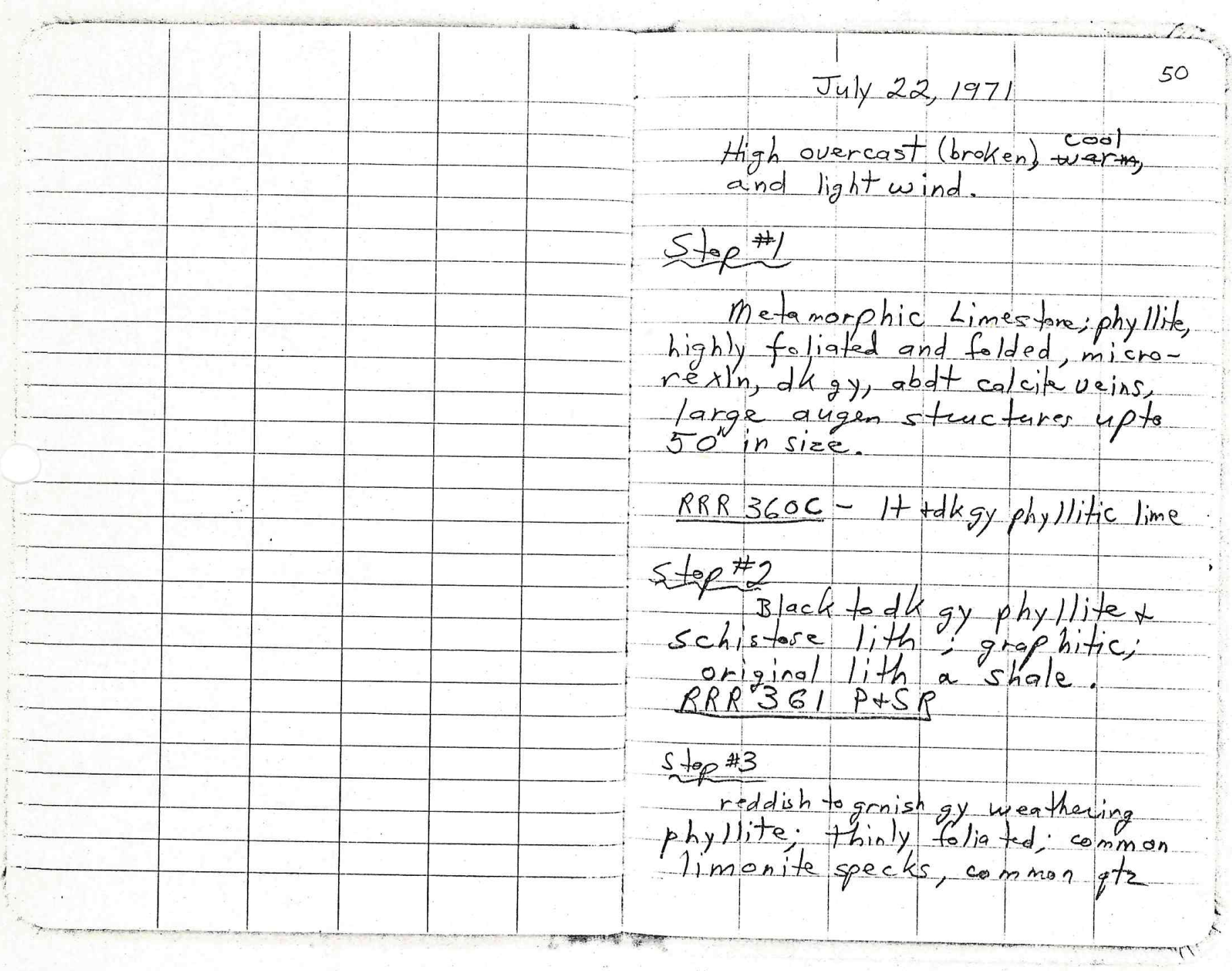




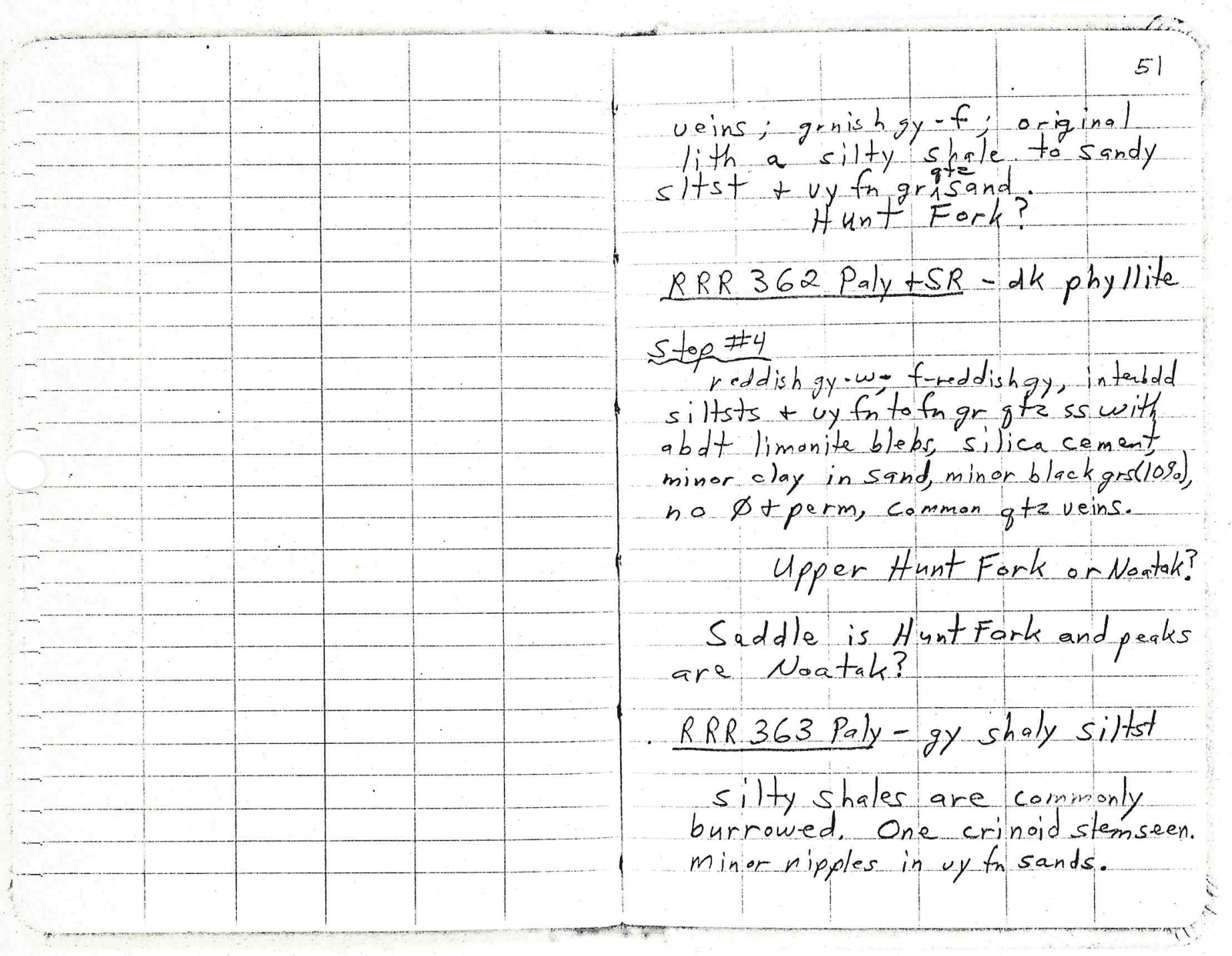




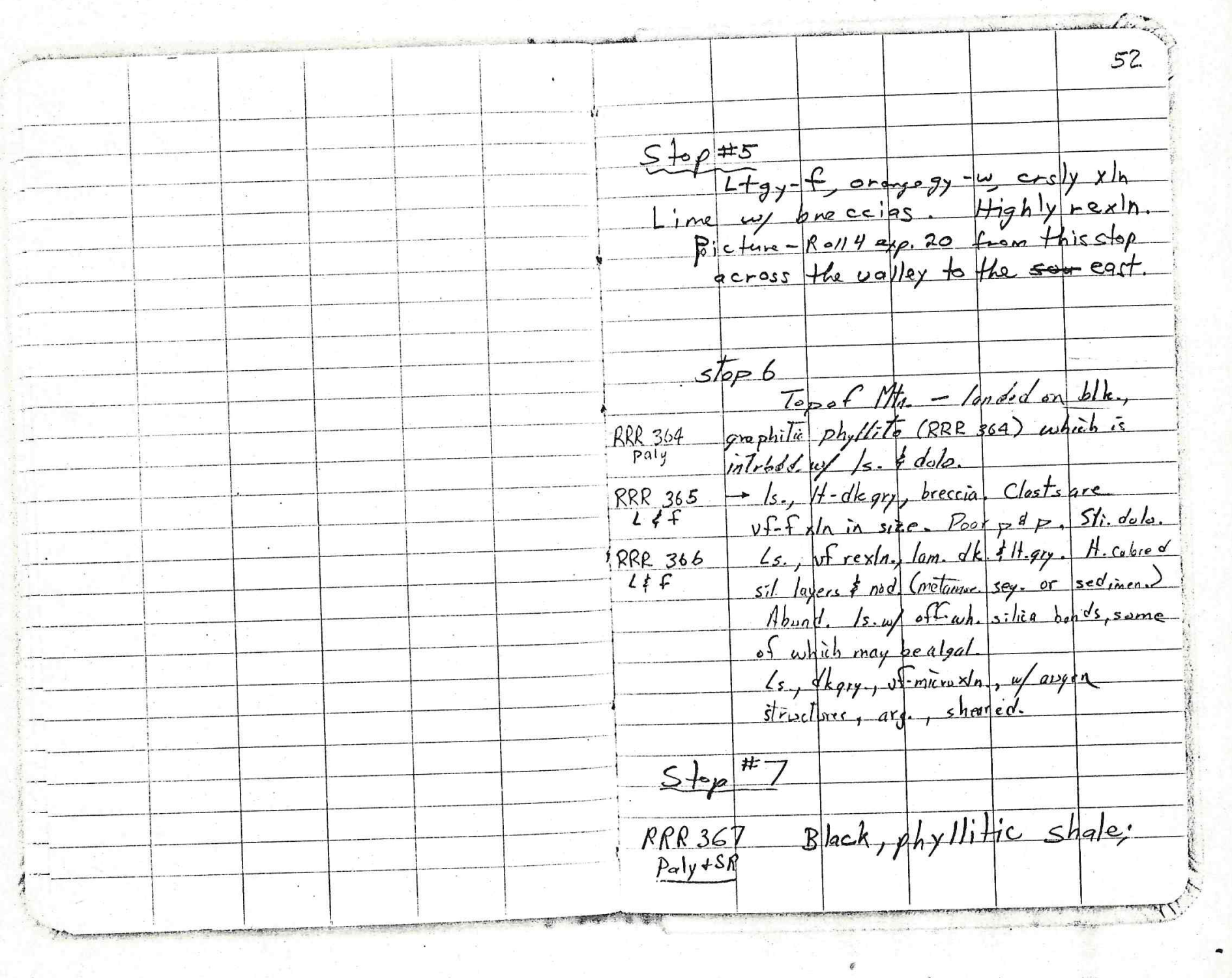




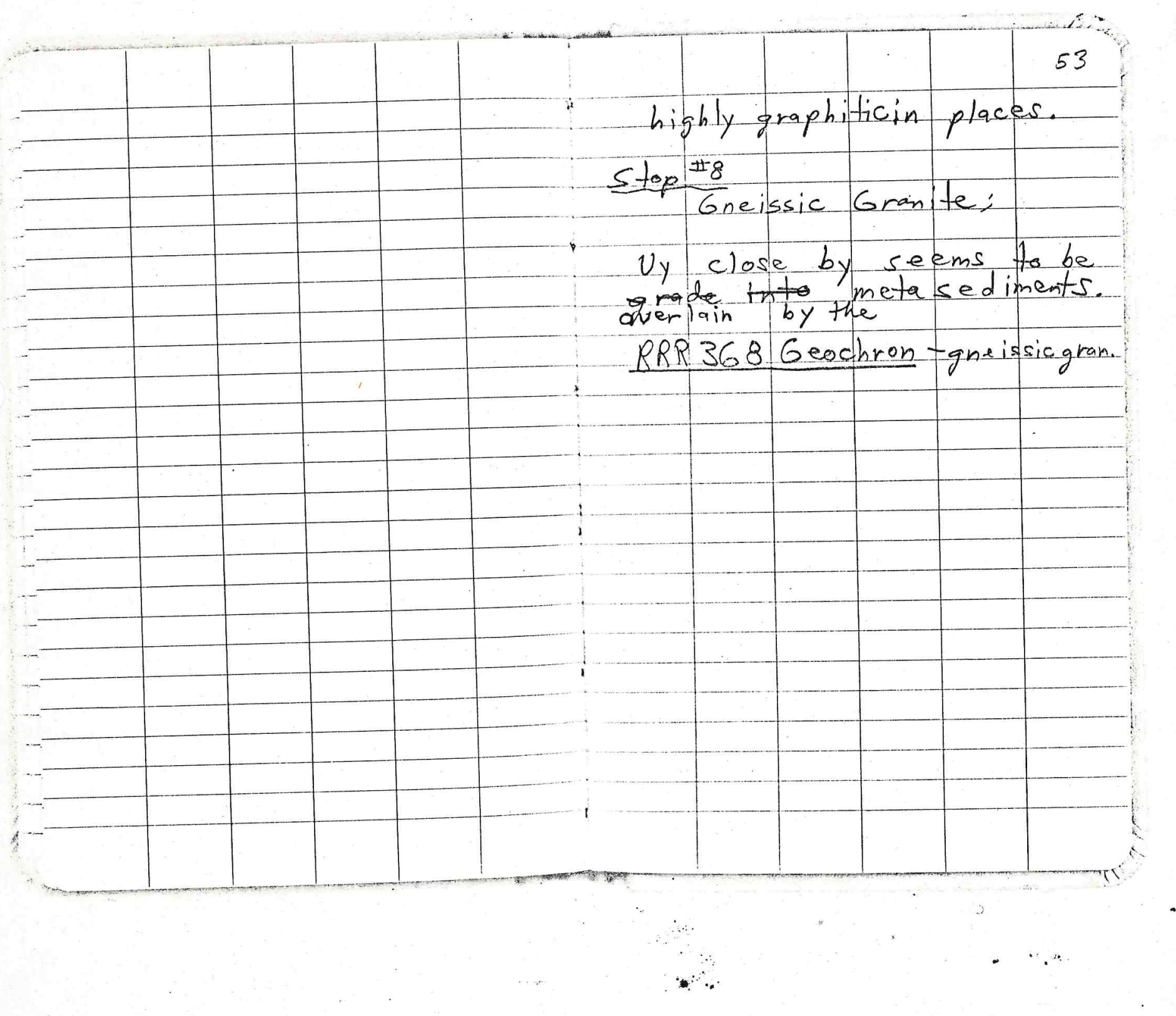




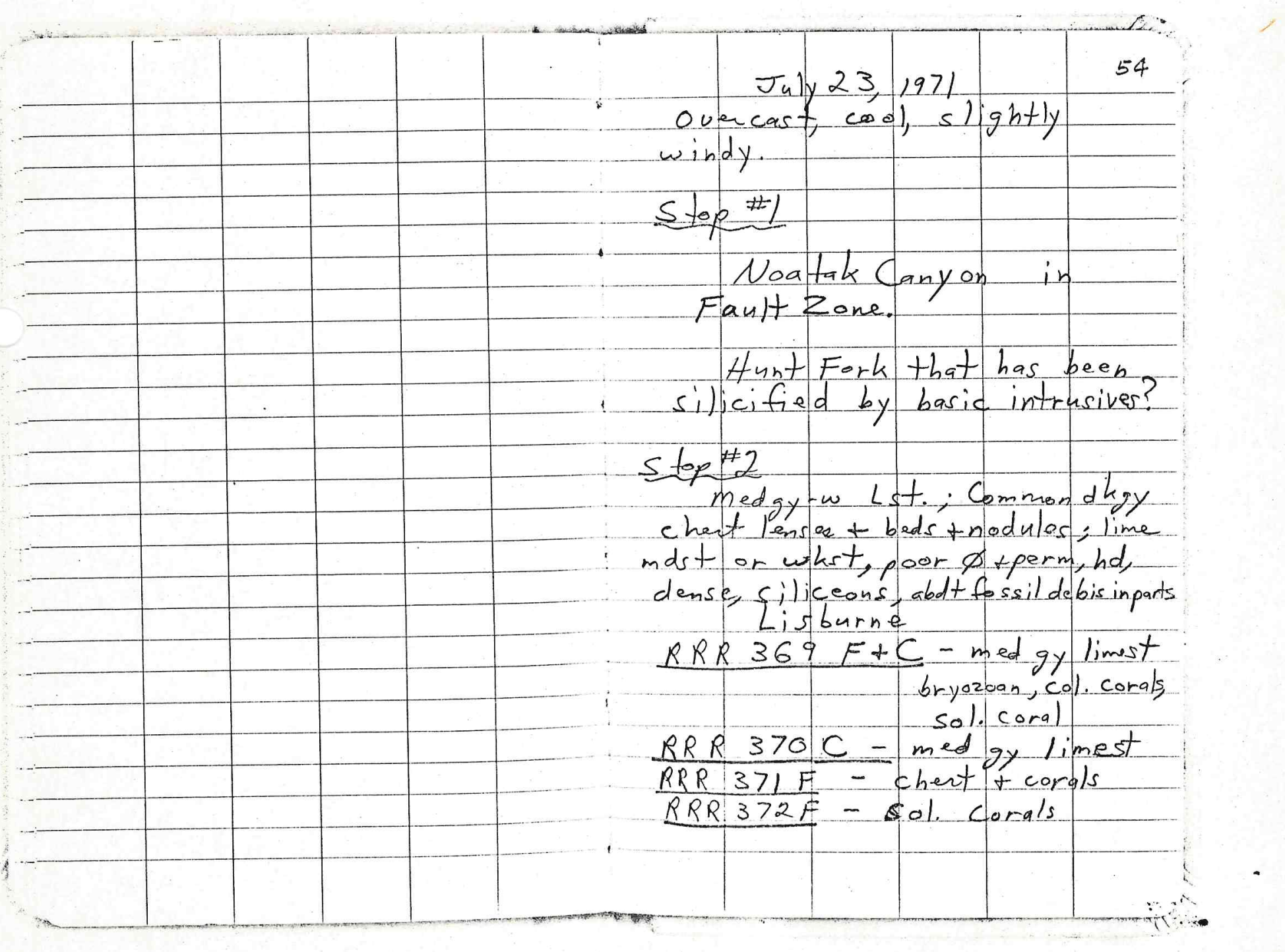




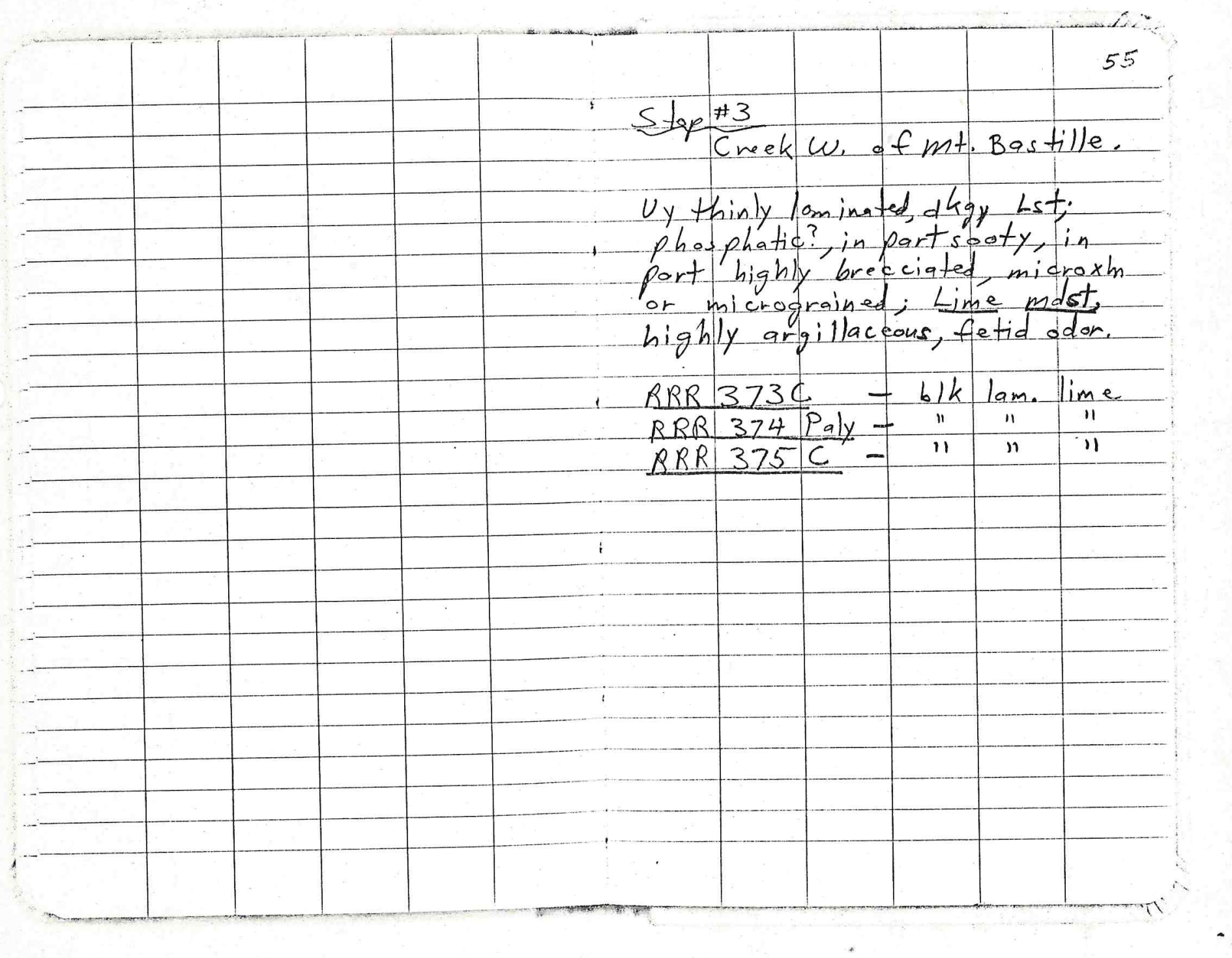




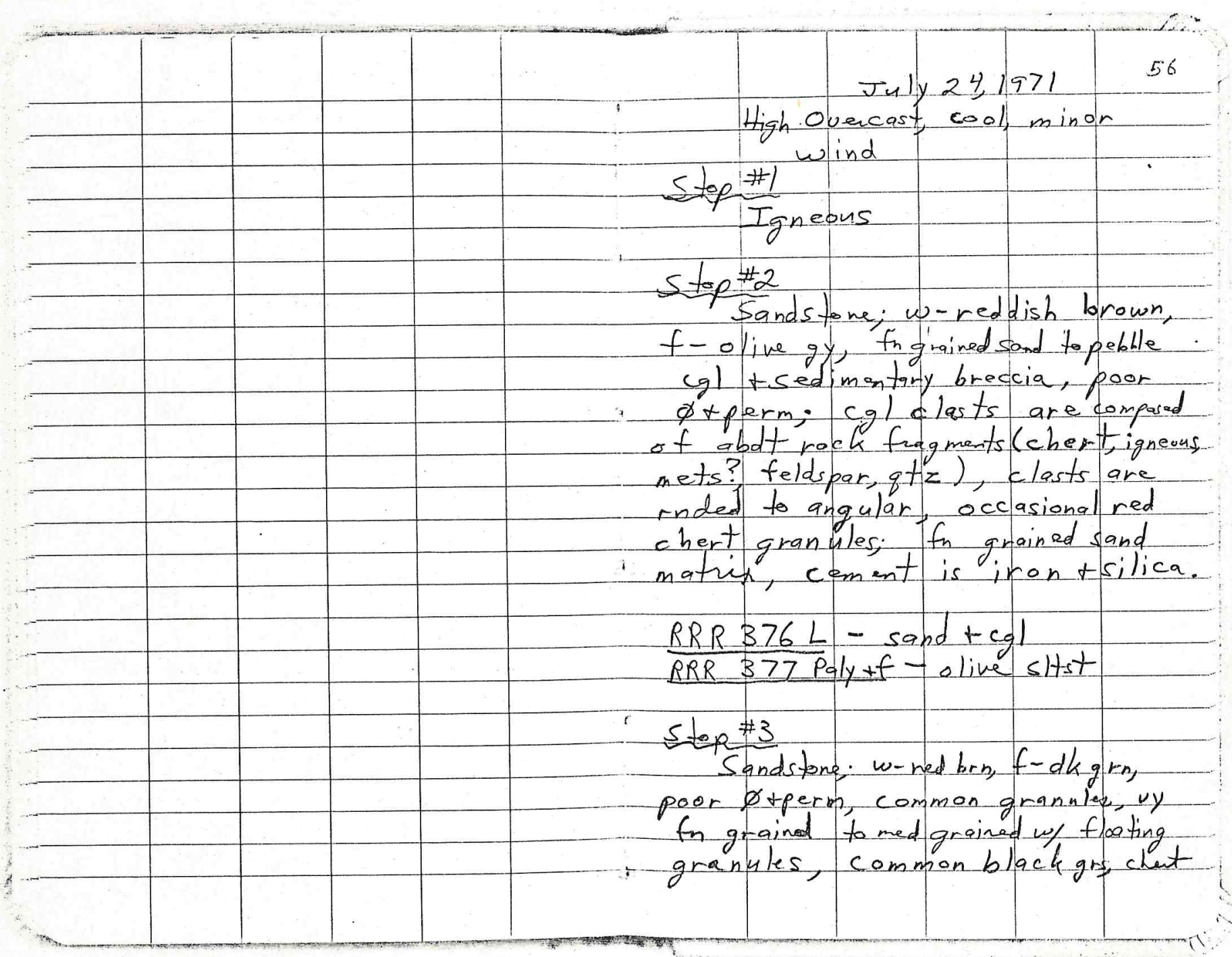




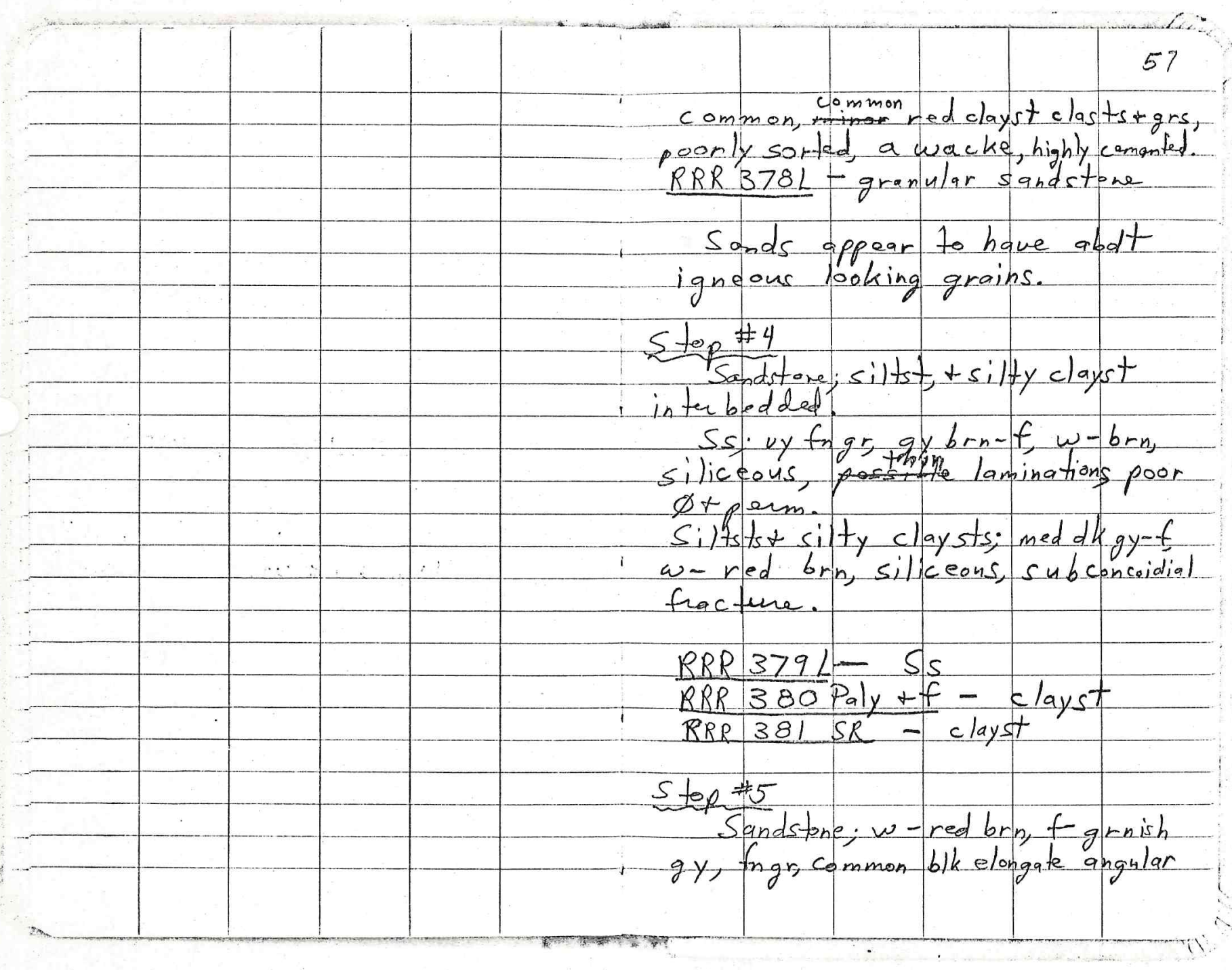




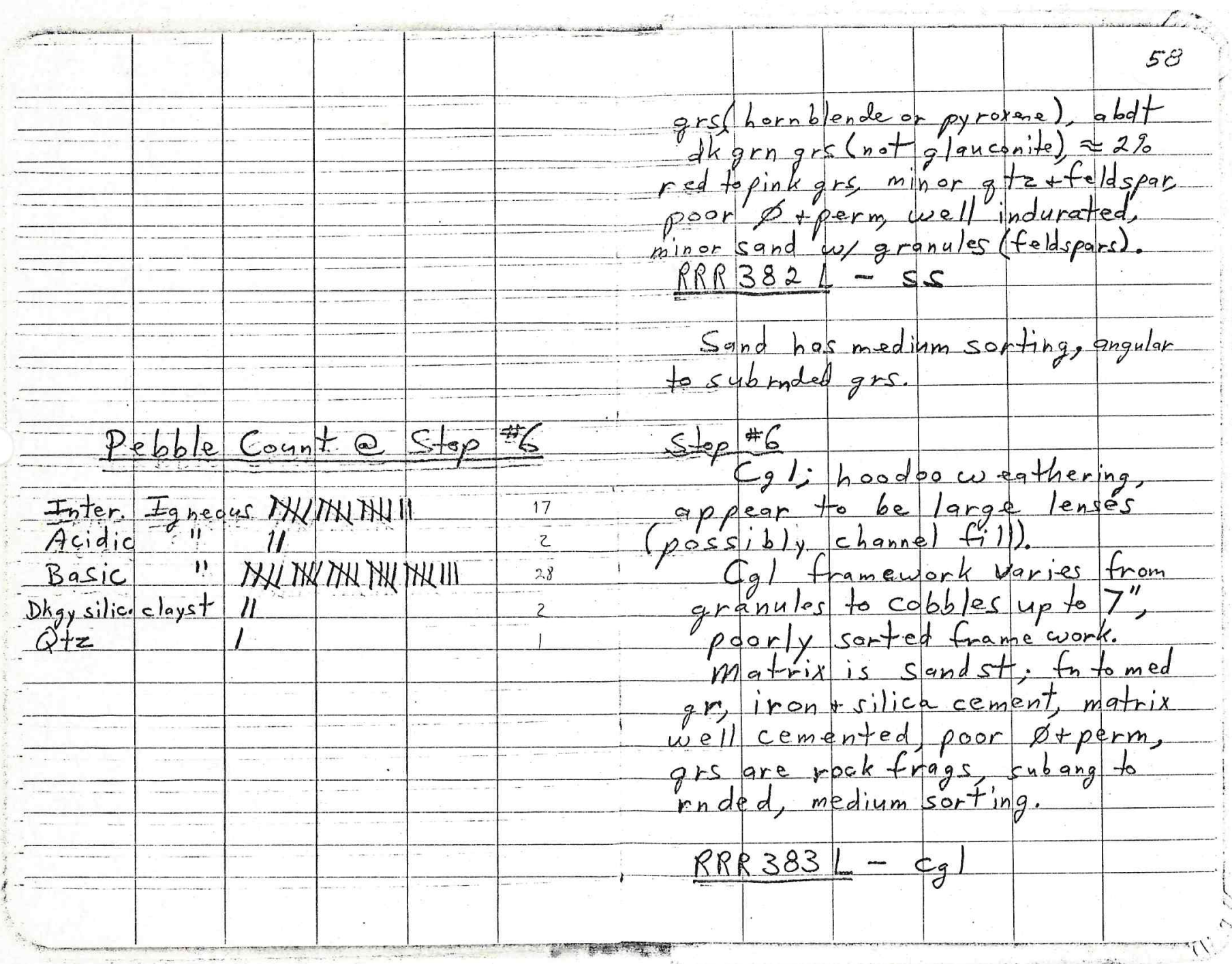




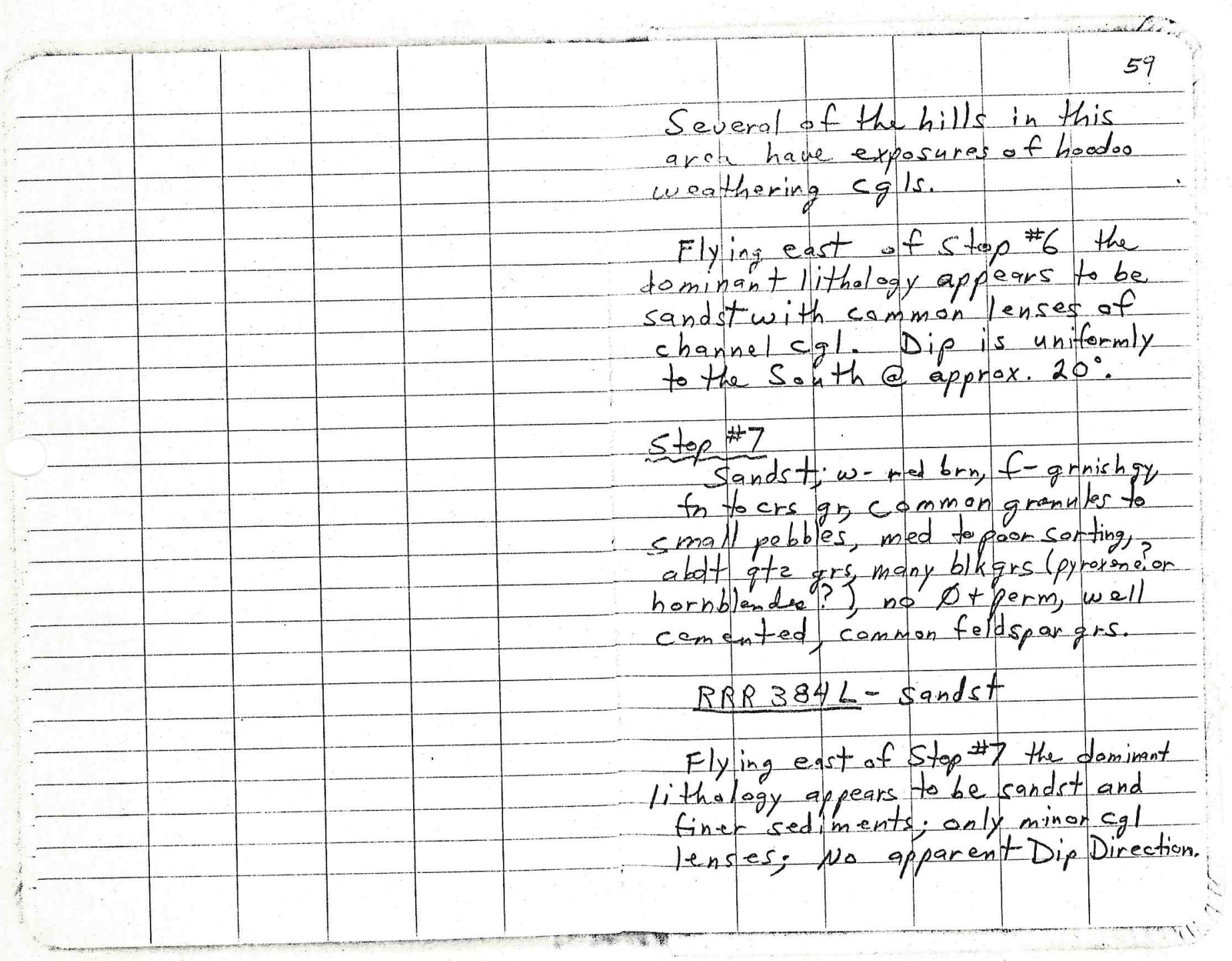




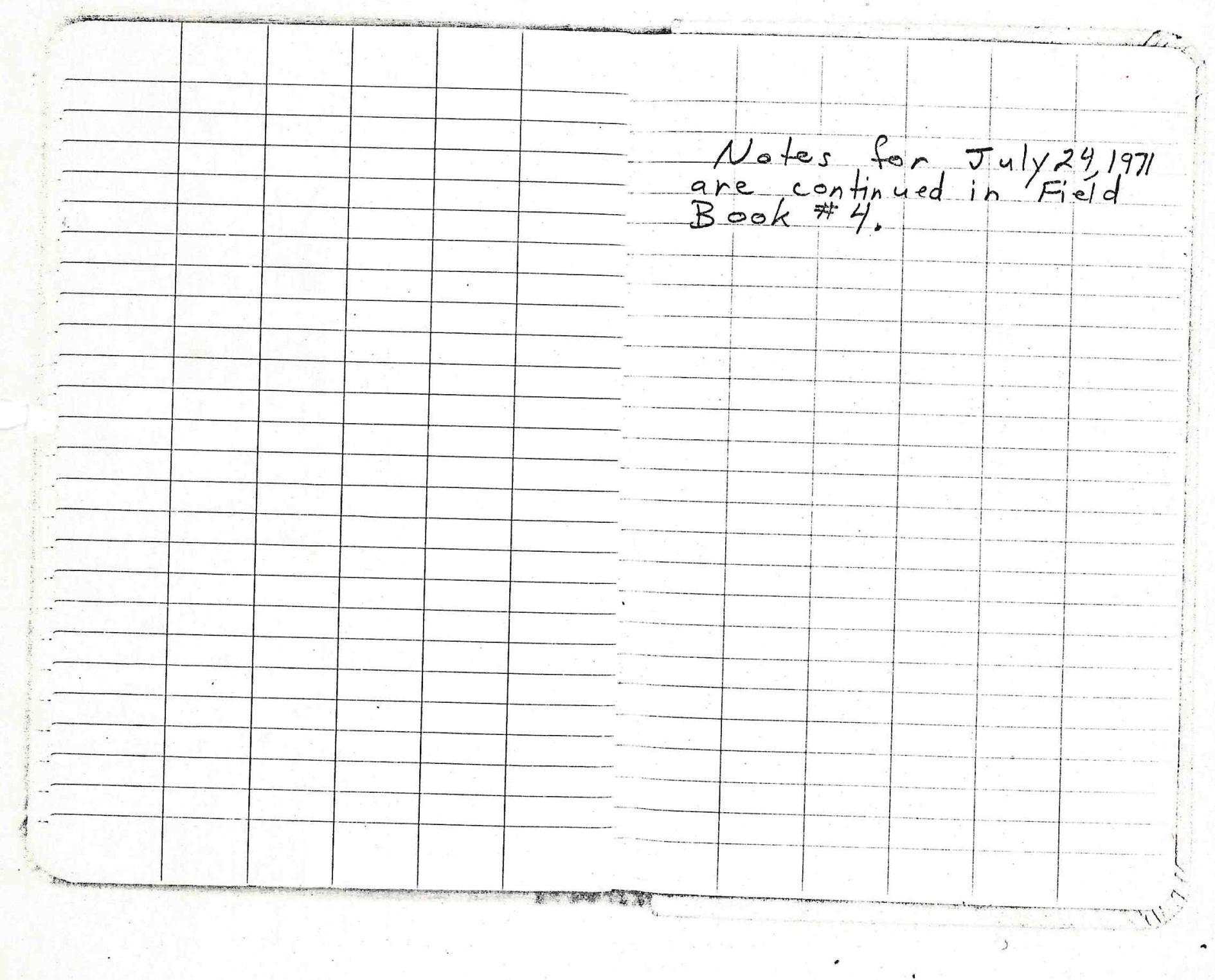



Book 4

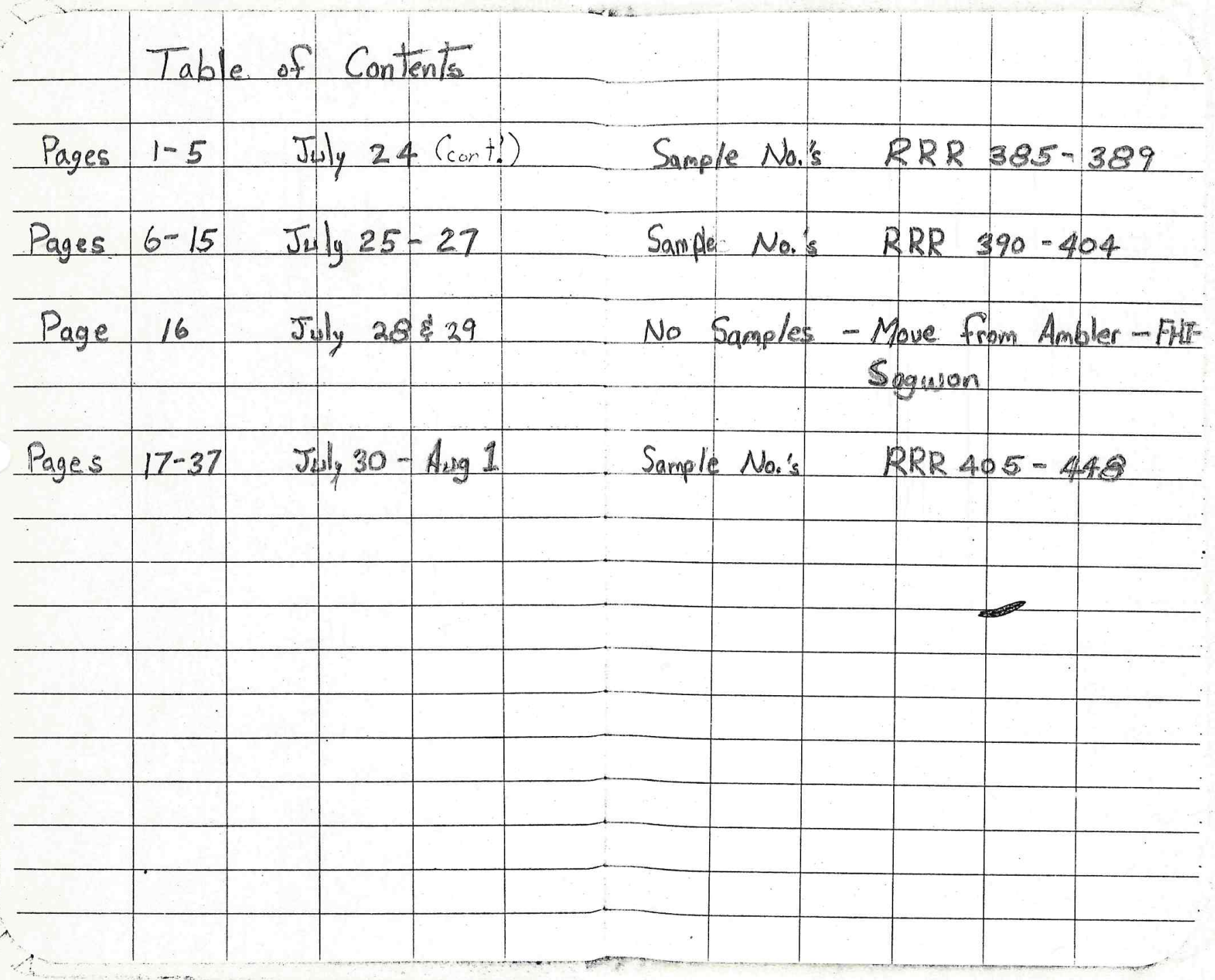




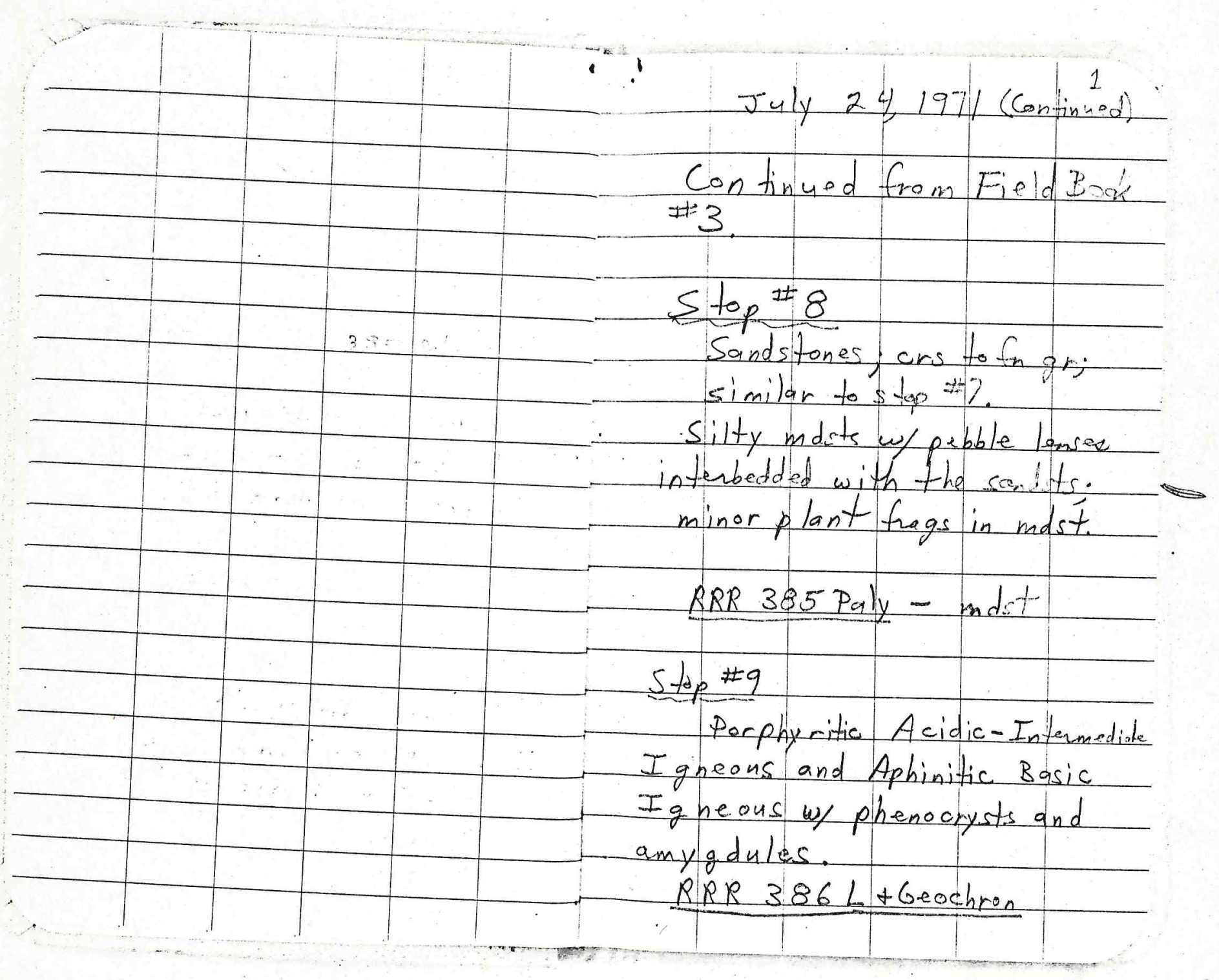




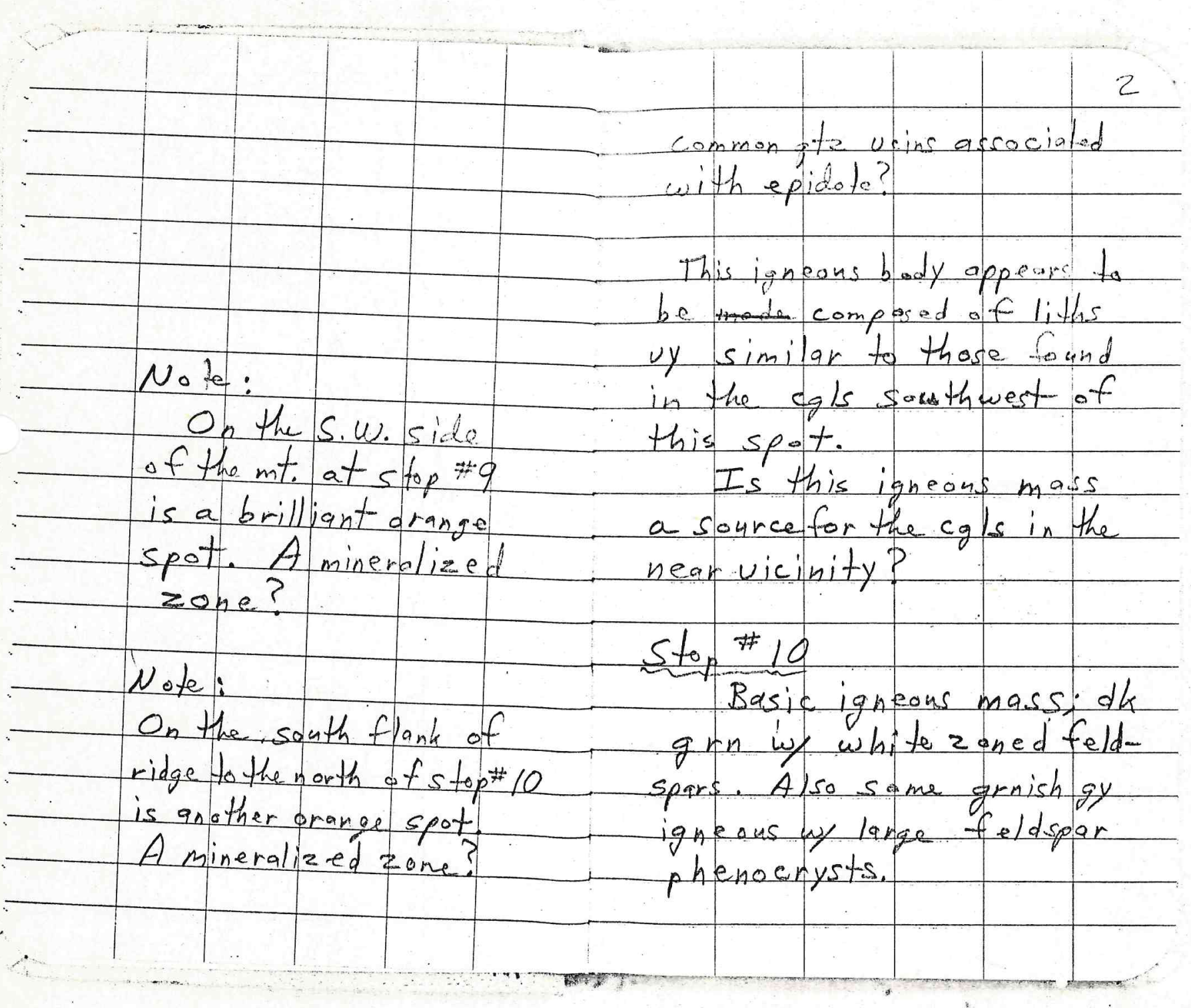


Pebblecount@Stop \#1

phyllite NIINLITW

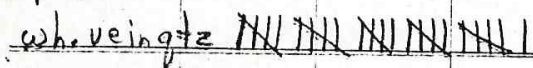
basic igh NNII metar dolo 1

gheiss
Stor
Cg); Cobble to Boulder Carrewark common sandstoms lenses. Cgls are imbricated. Imbrication indicate current direction in the directions of dip.

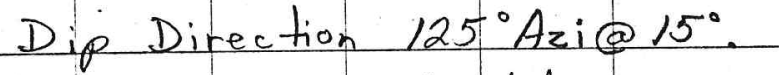
Sands are cross bedded. Note $\mathrm{Cgl}$; small pebbles to boulders Below $\mathrm{cgl}$ ledges at upte at least $16^{\prime \prime}$ in dia, a vee size stop \#II there appeno to be interbedded sandt and siltst. and then more cll and then approx. 5", uy poorly sorted, well rnded. matrix has the appearance of a weathered igneous rock. matrix is a med to crs sand, grs are obdt igneons rock frags and otz, salt + pepper looks abdt ir on cement, fair $\phi$ tperm. Sandst; w-brn, f-bon. minor bon red sitst lensea. 


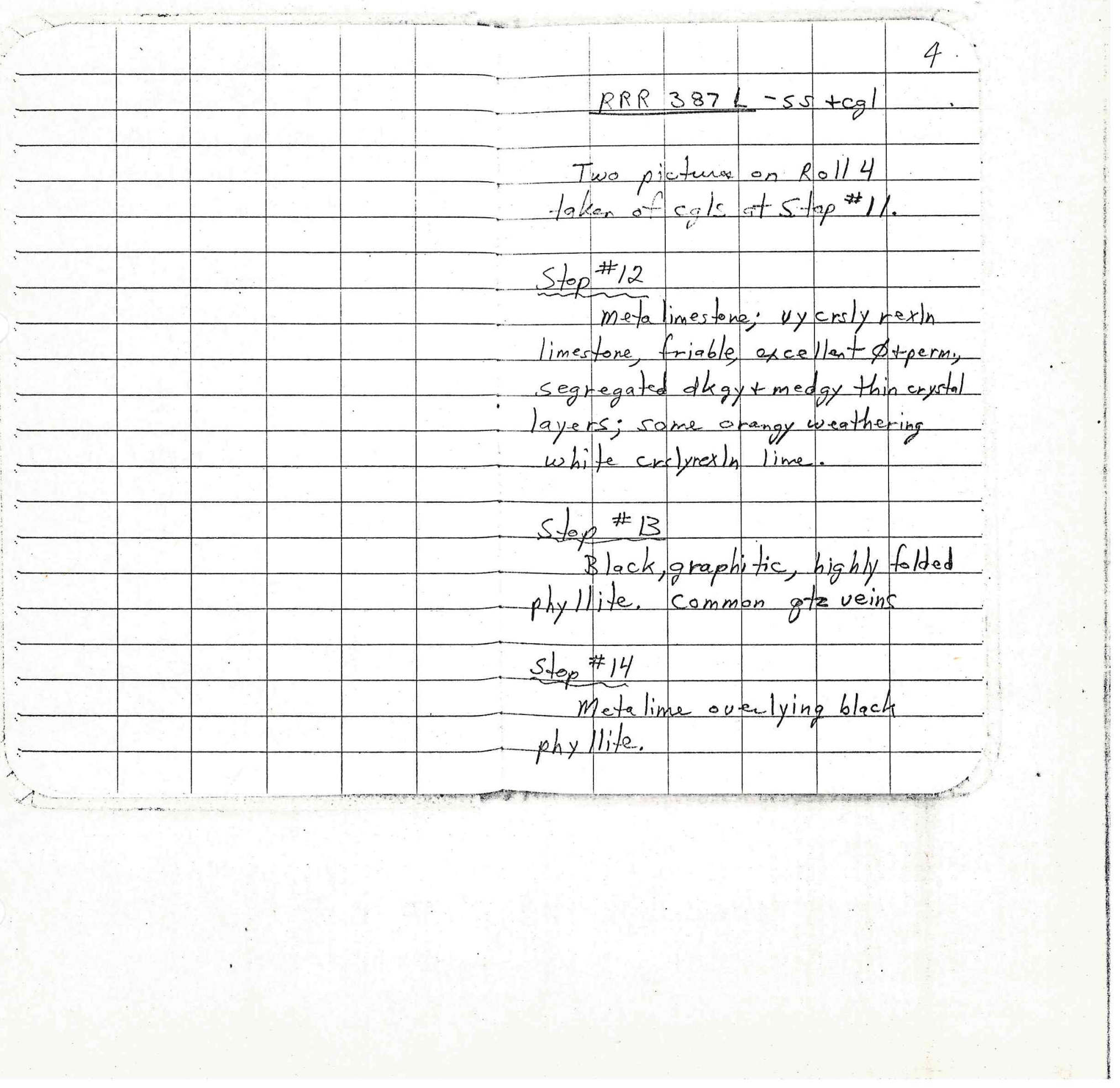


Lst, crsly rexln, segregated intodk + Itgy laminae, hardt dense, no $\phi t$ perm. QRP $3881-$ rexin limest $5 \operatorname{top} \# 15$

Dkgy phy llite w/ thinly interlayered otzite. Quartwite is uy forgrained.

Stop $\# 16$

Cgl: poorly sorted, outorops. in ledges. Abottwit 2 pebbles. cobbles, and boulders upto 12 " in dia. Minor metamarphic pebbles. and cobbles.

$$
\text { RRR } 389 \mathrm{~L}-\mathrm{cg} / \mathrm{ts}
$$




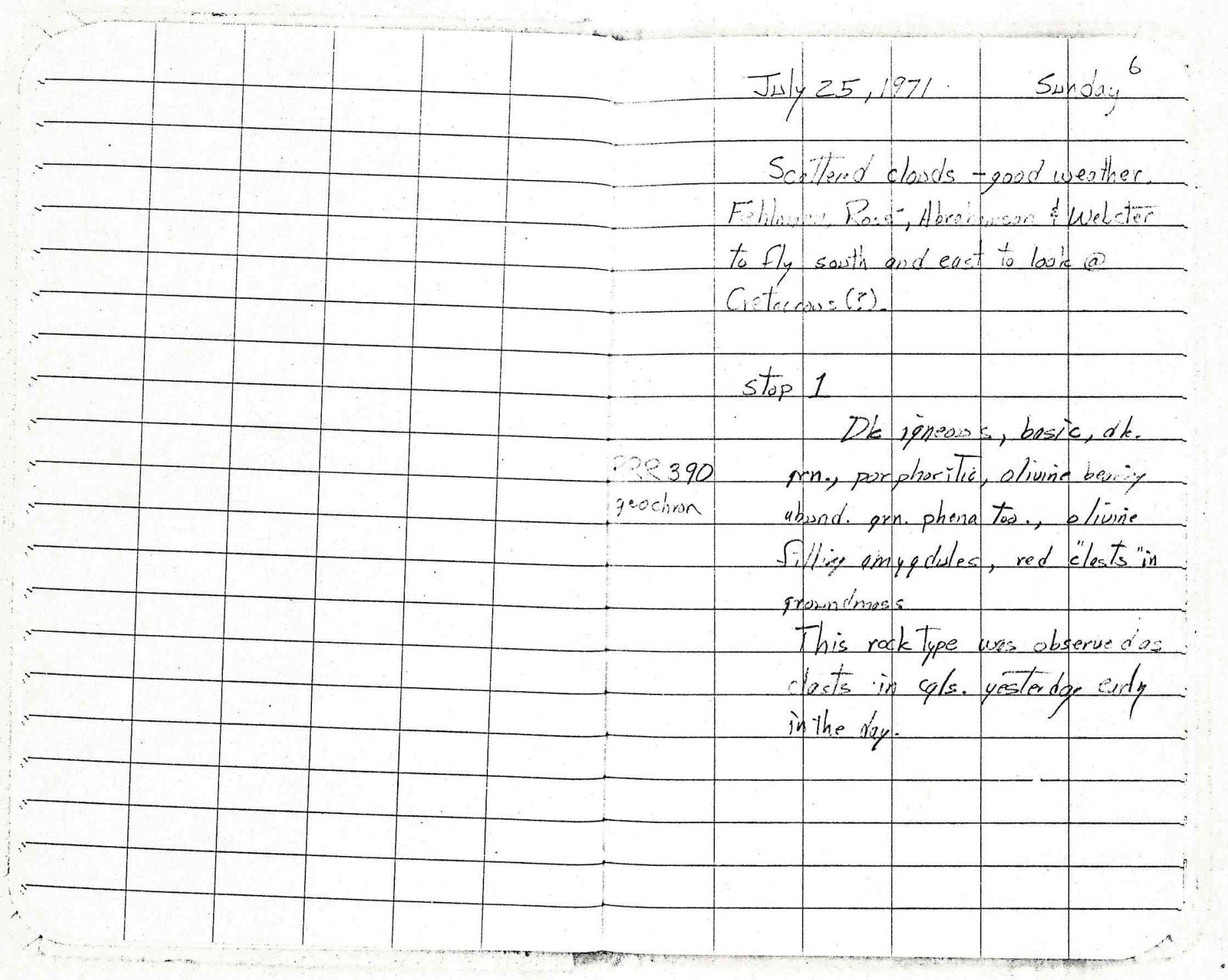




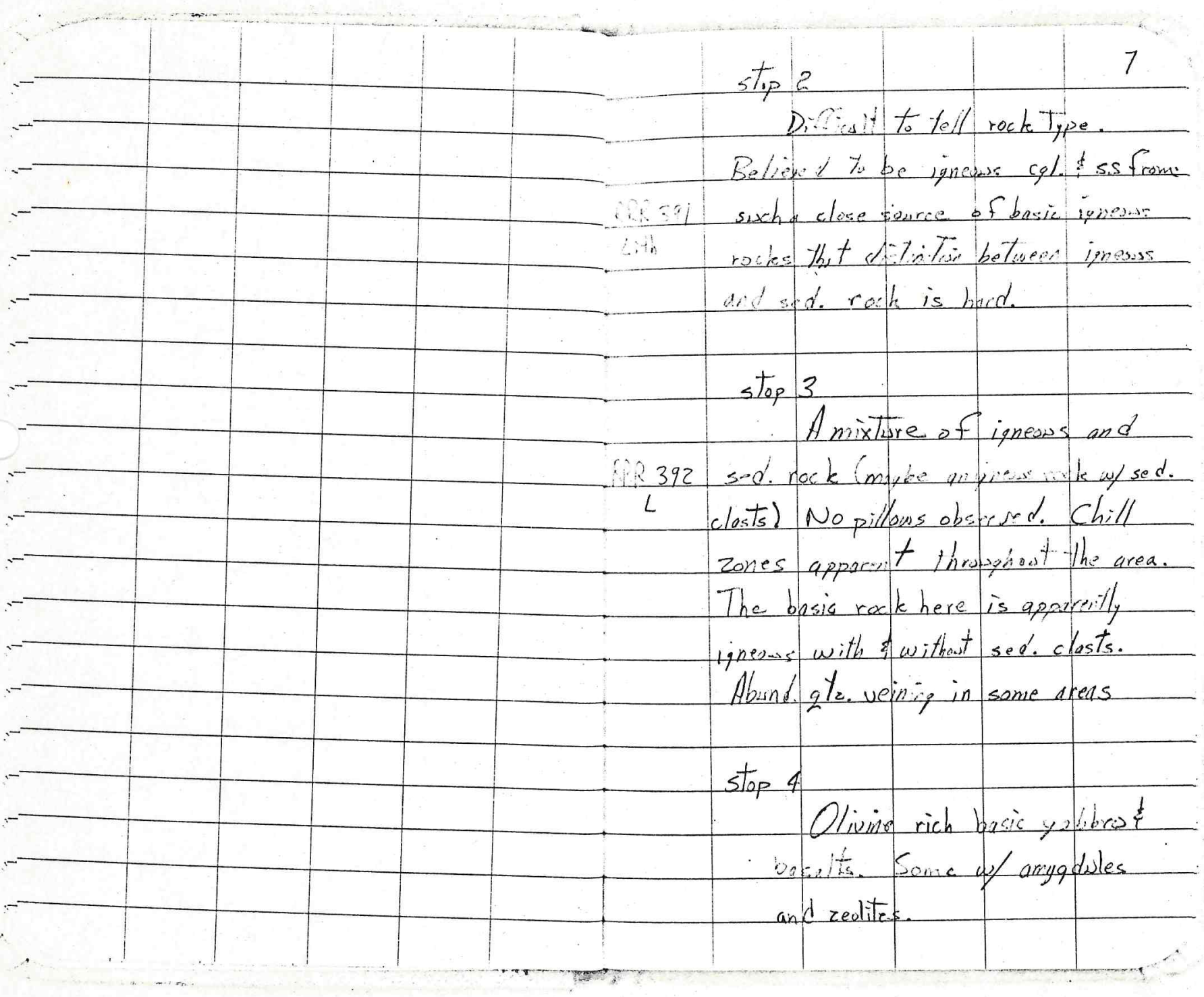




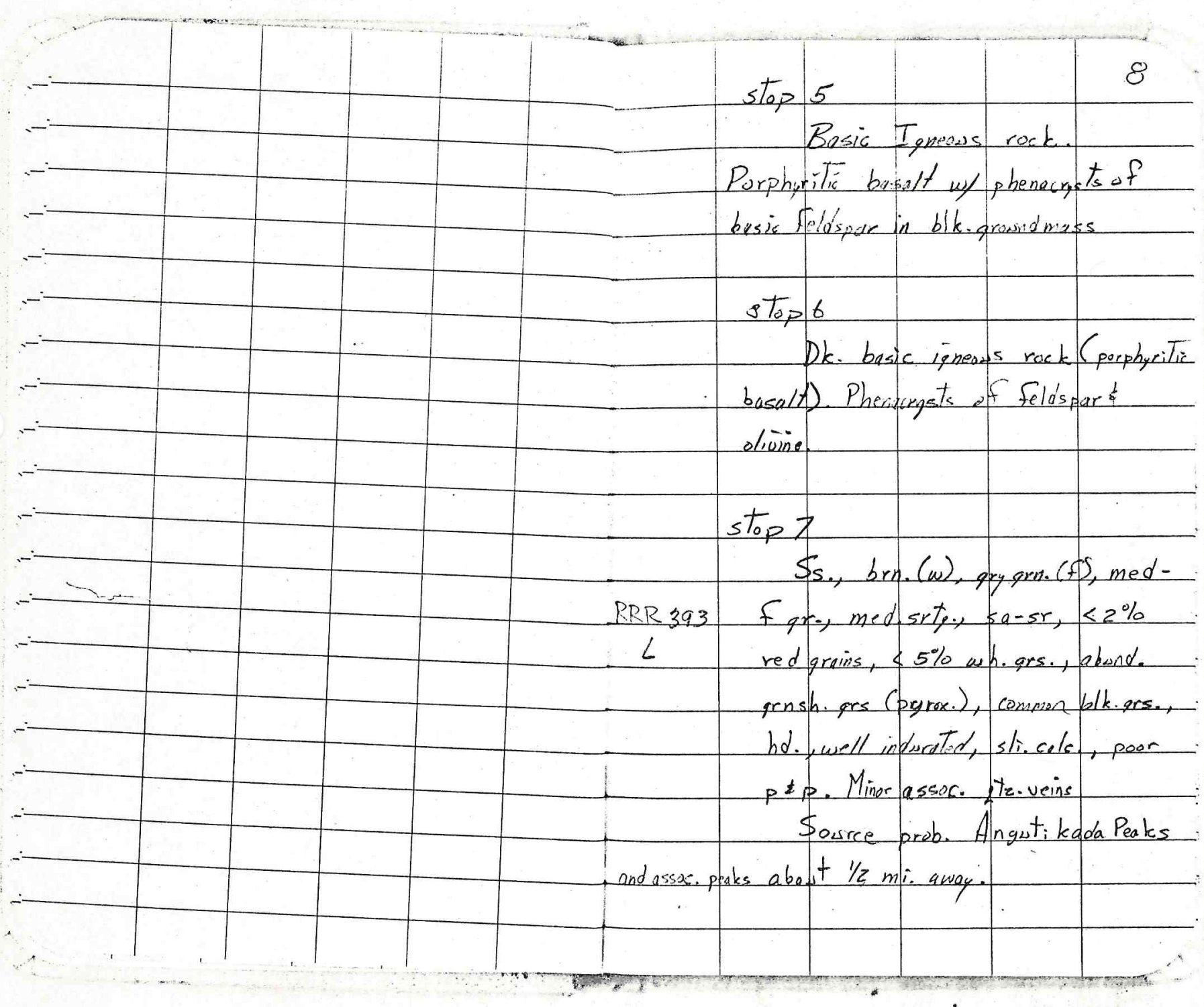




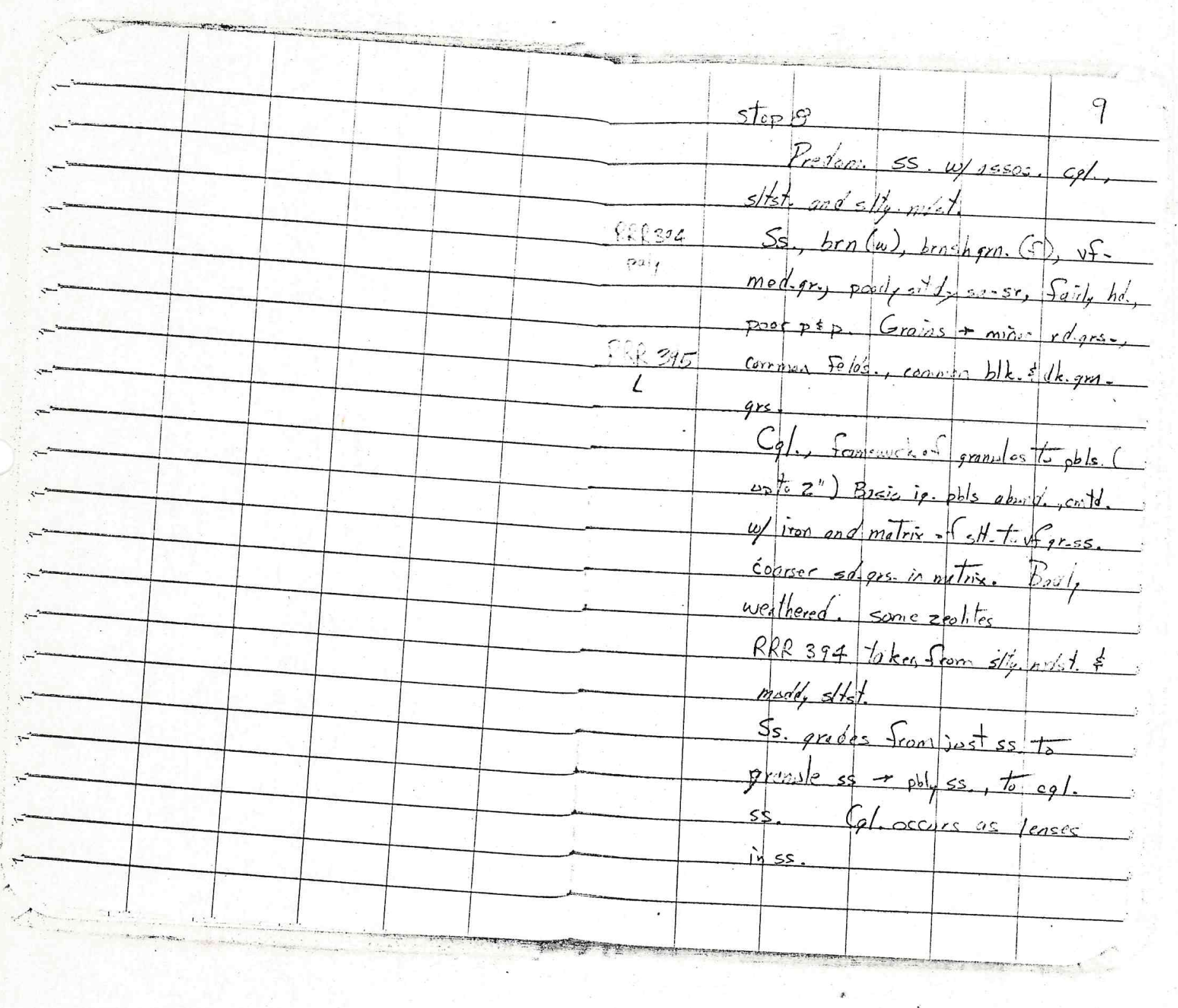




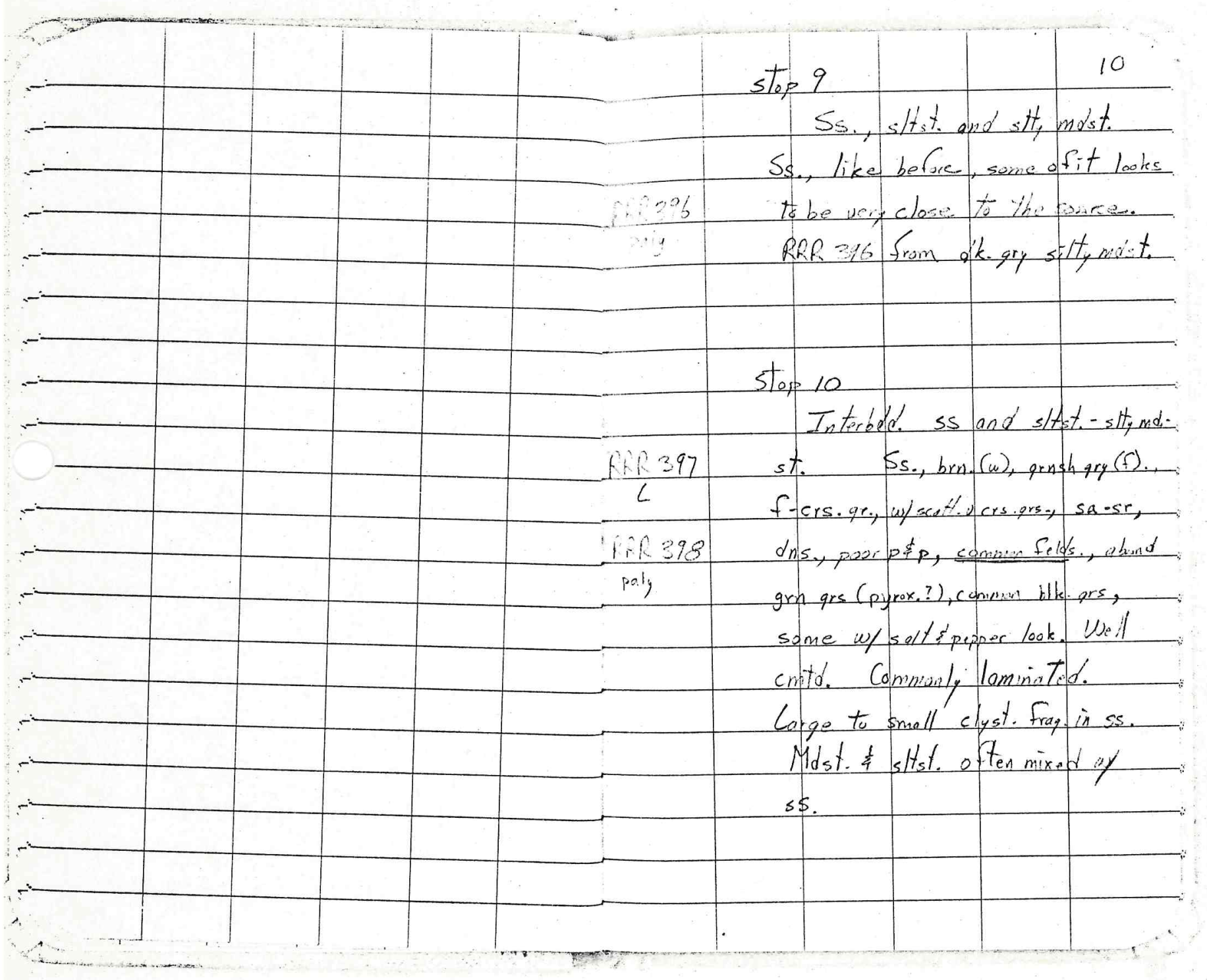




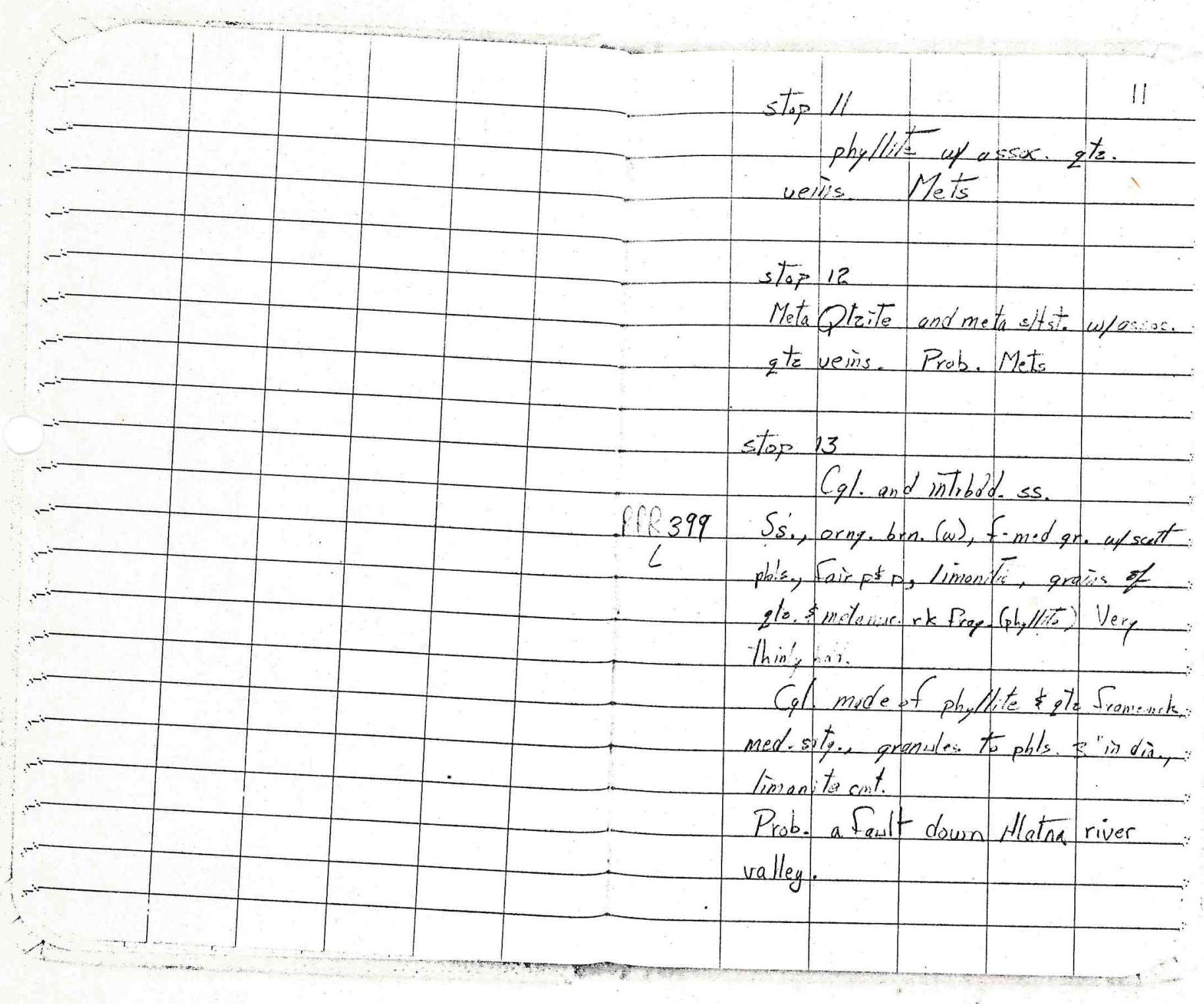




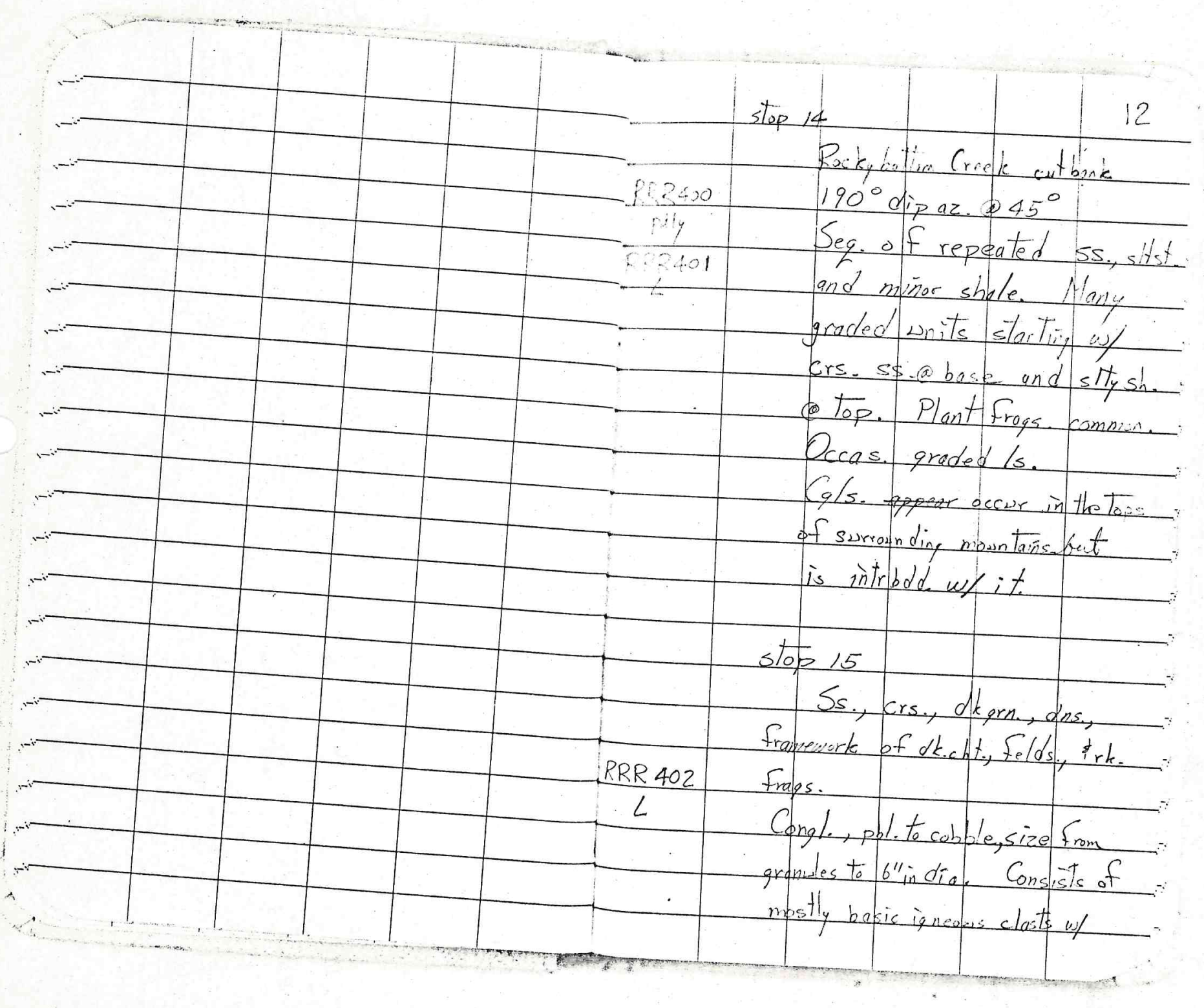




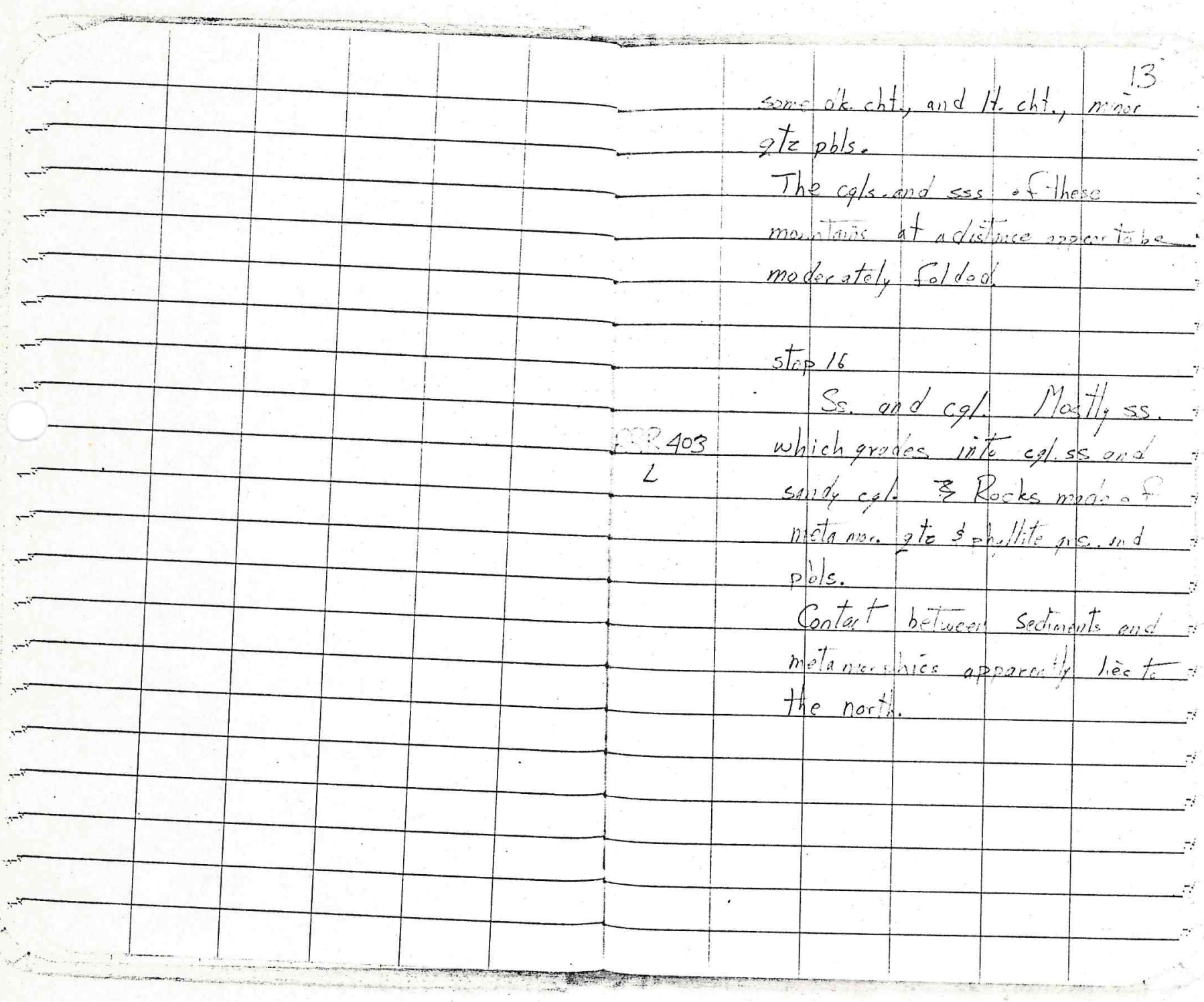




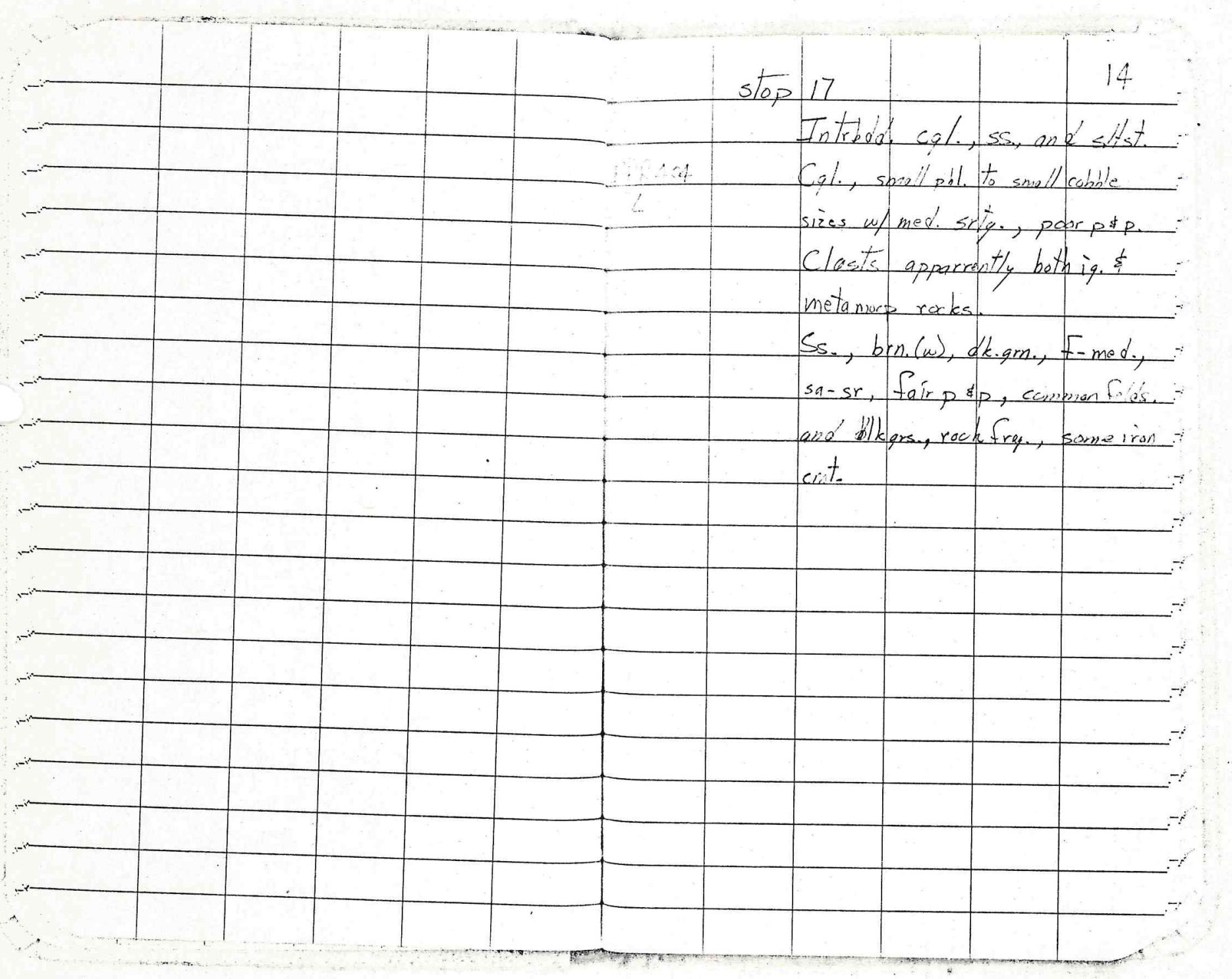




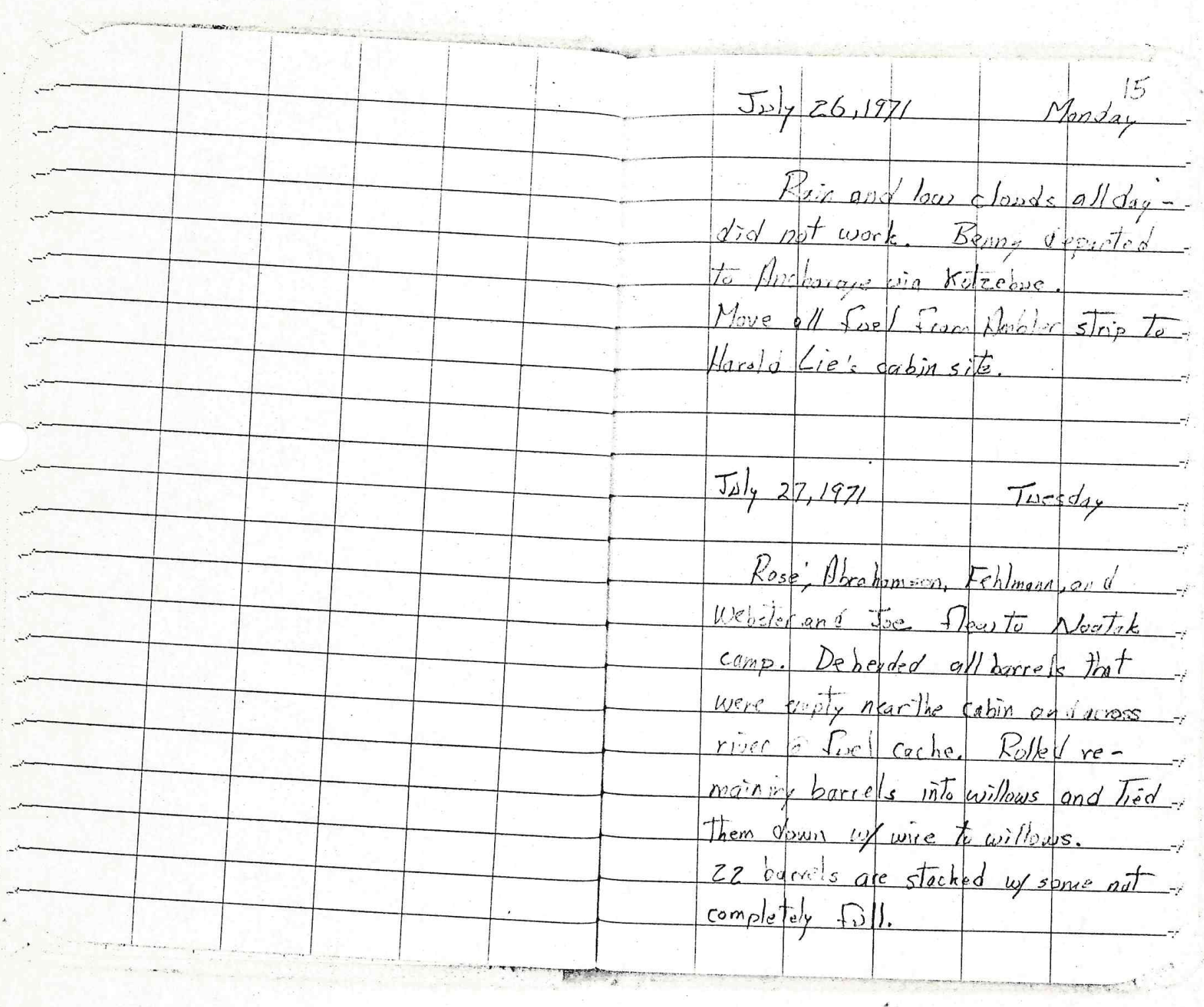




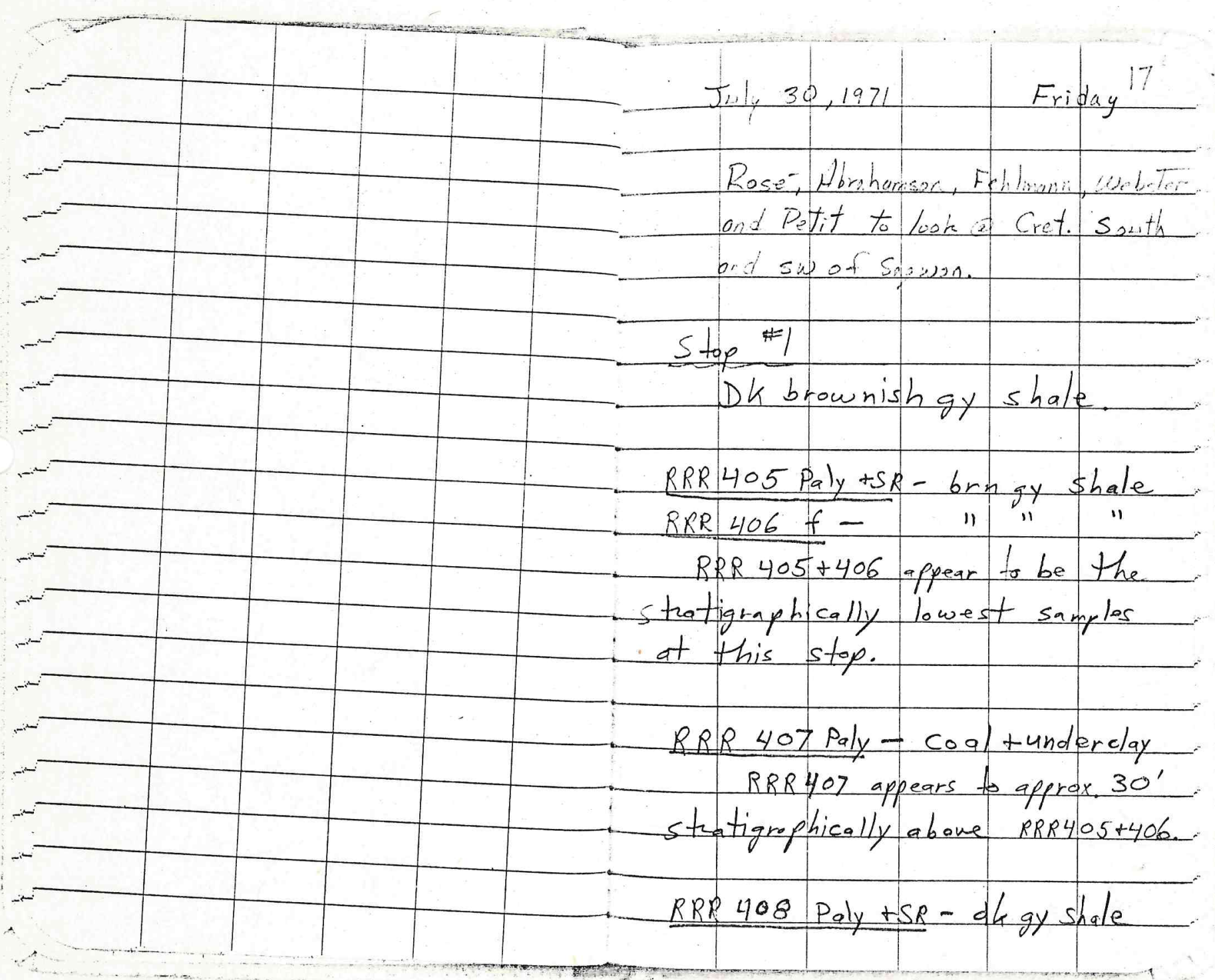




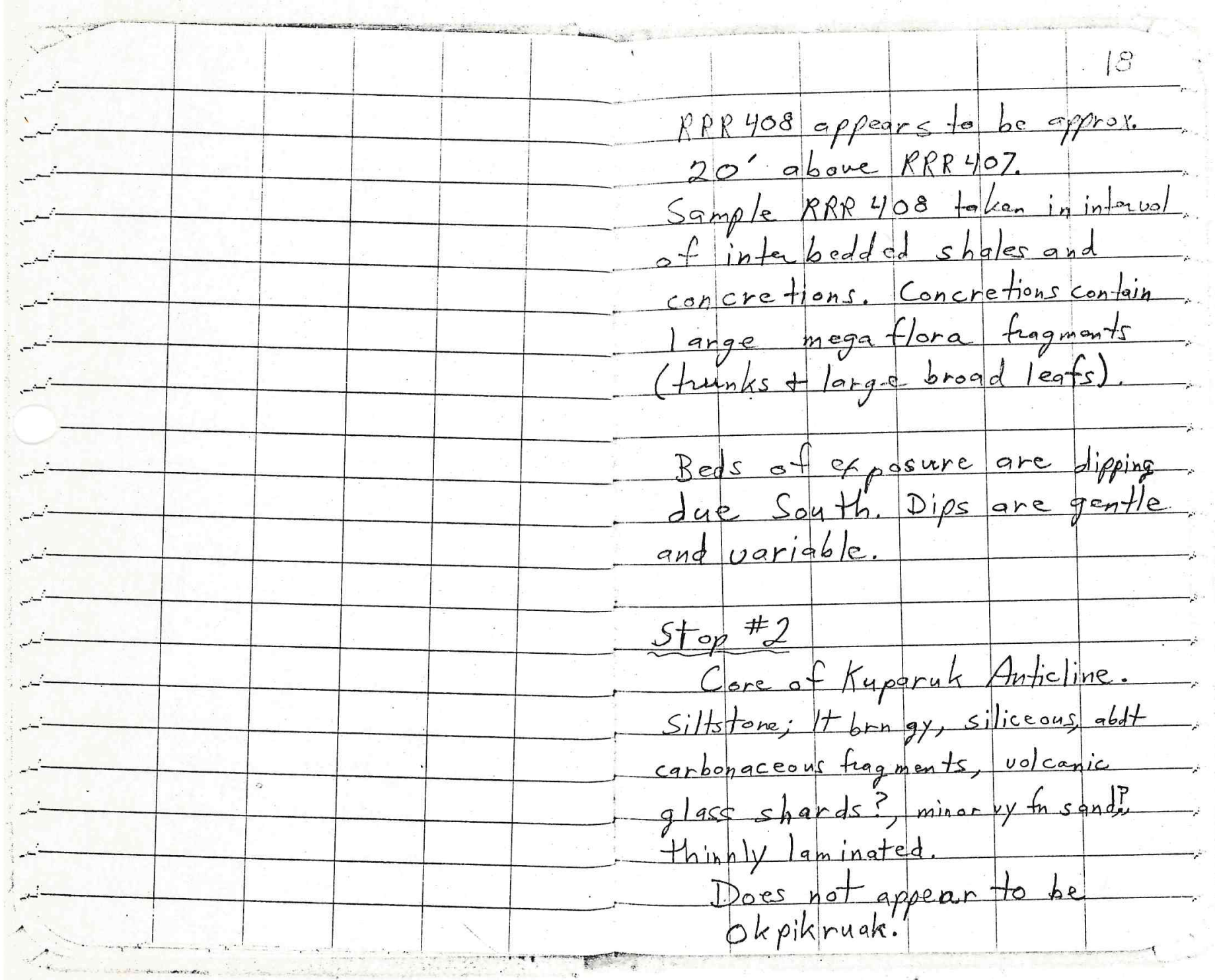




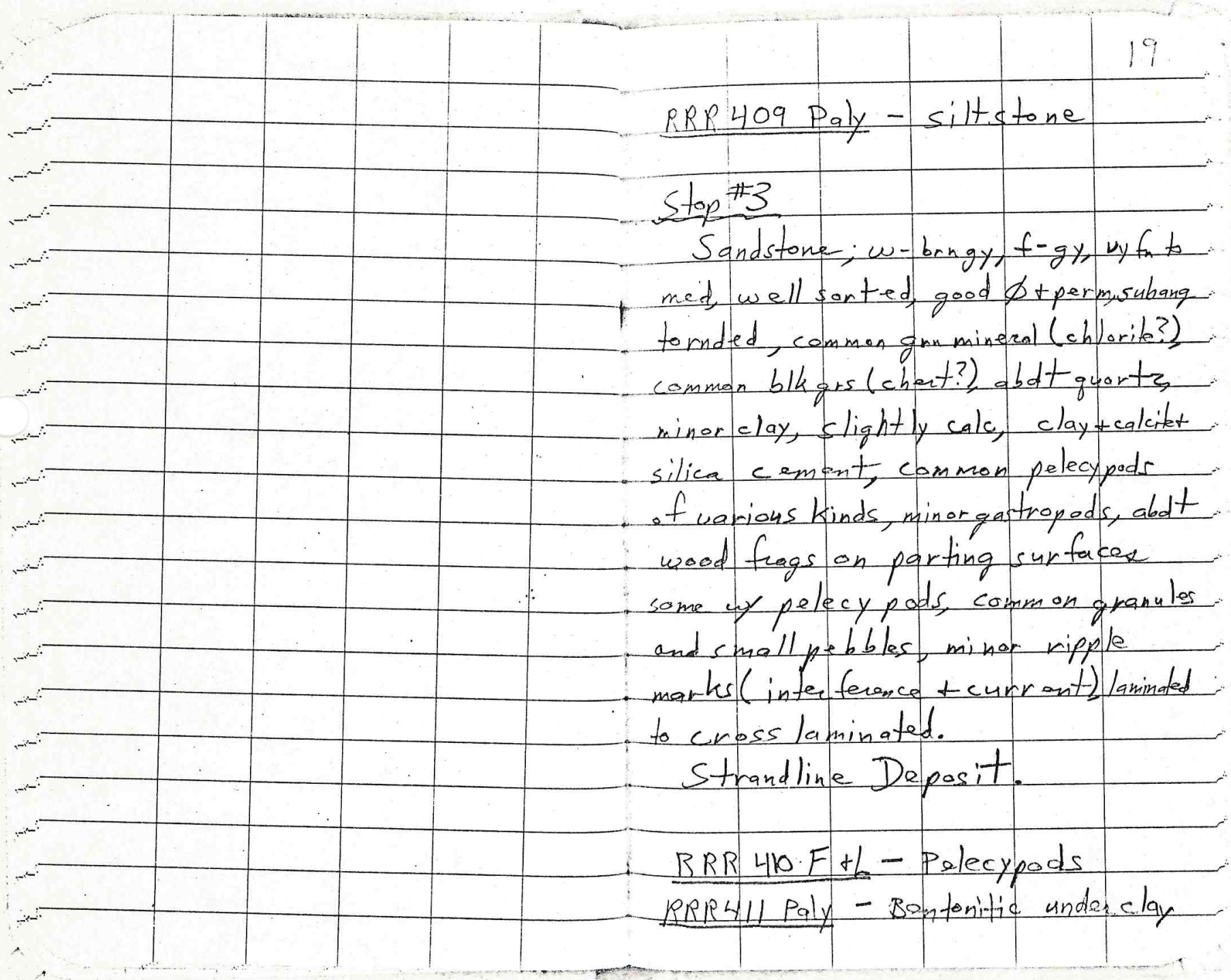




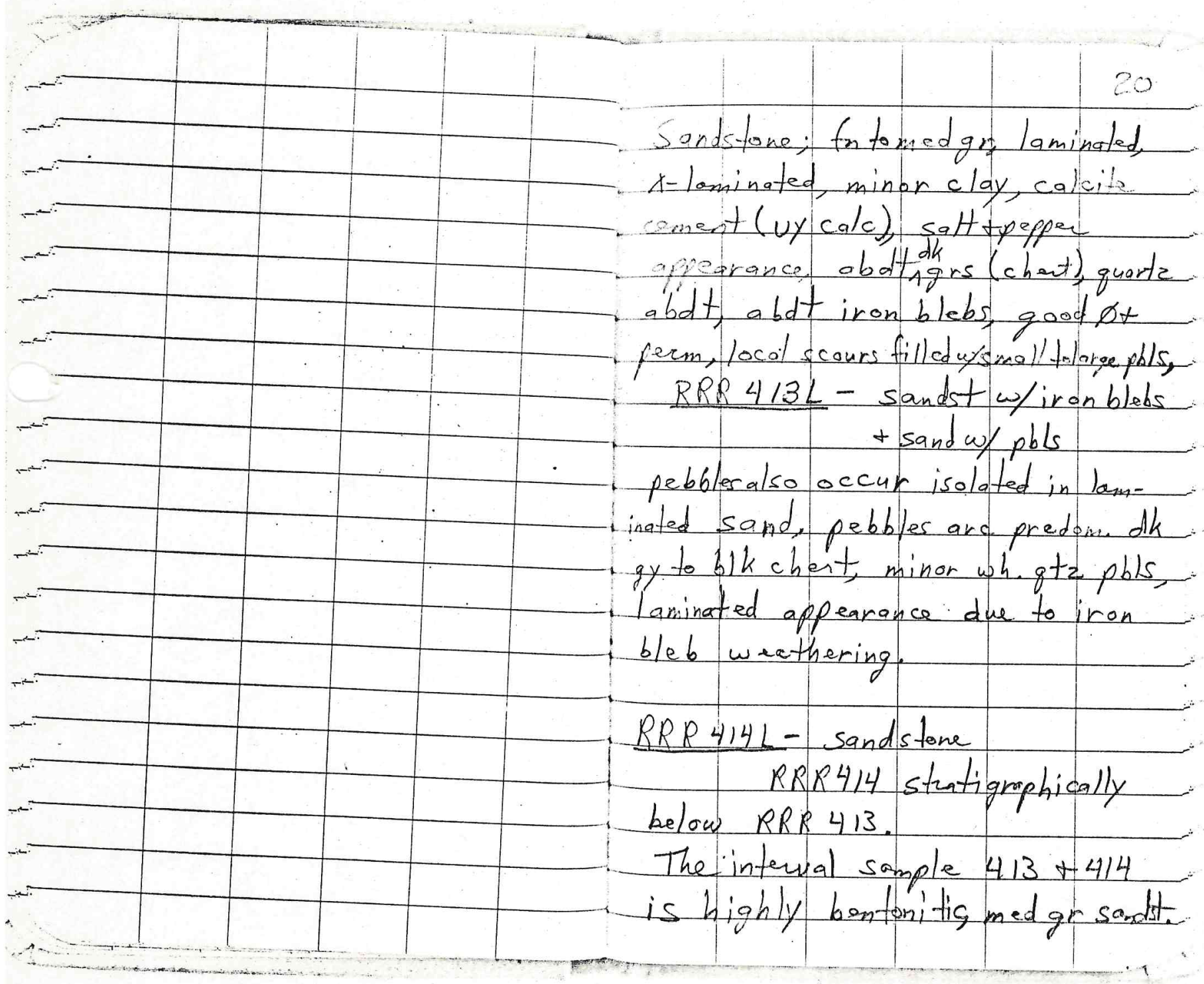




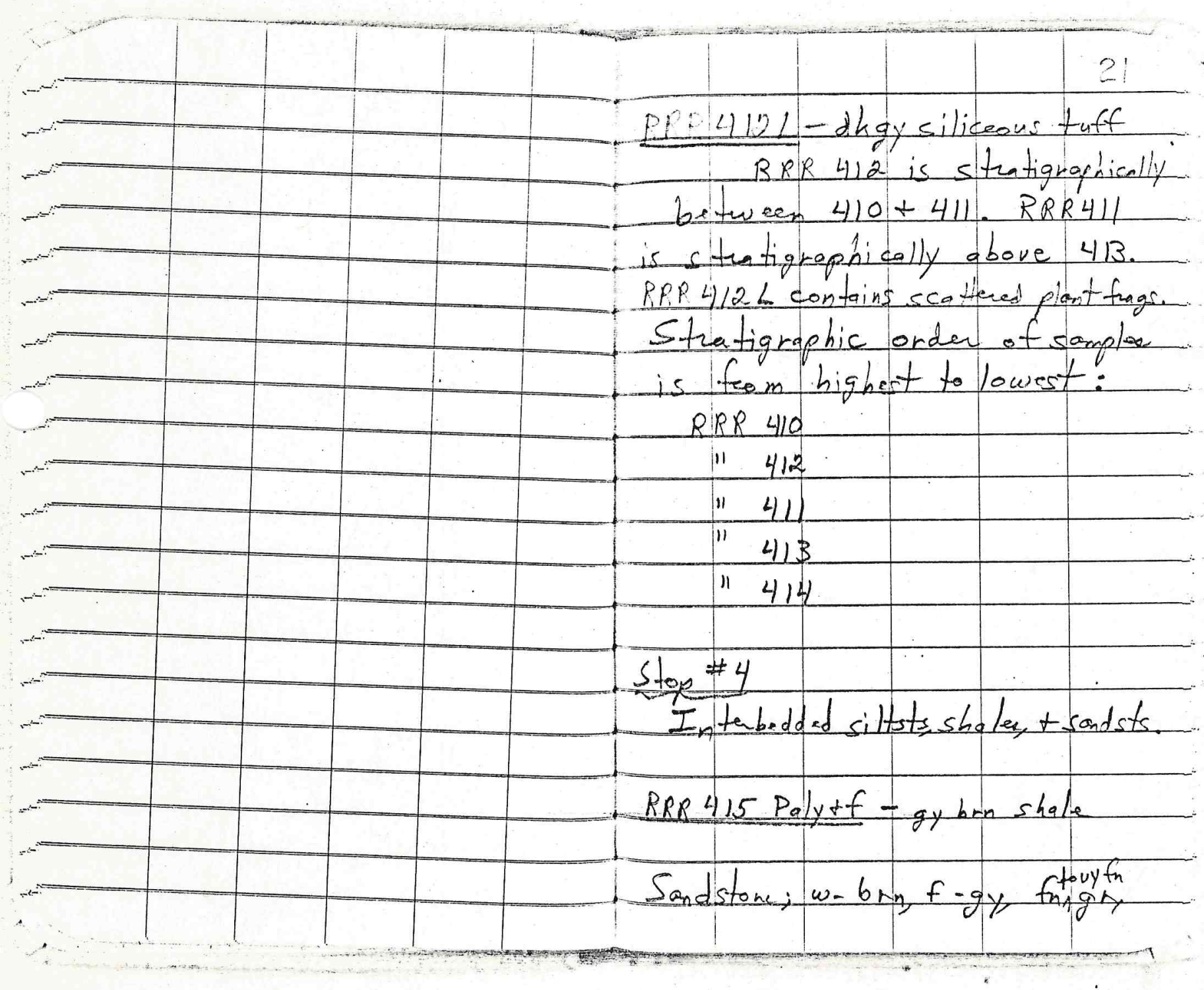




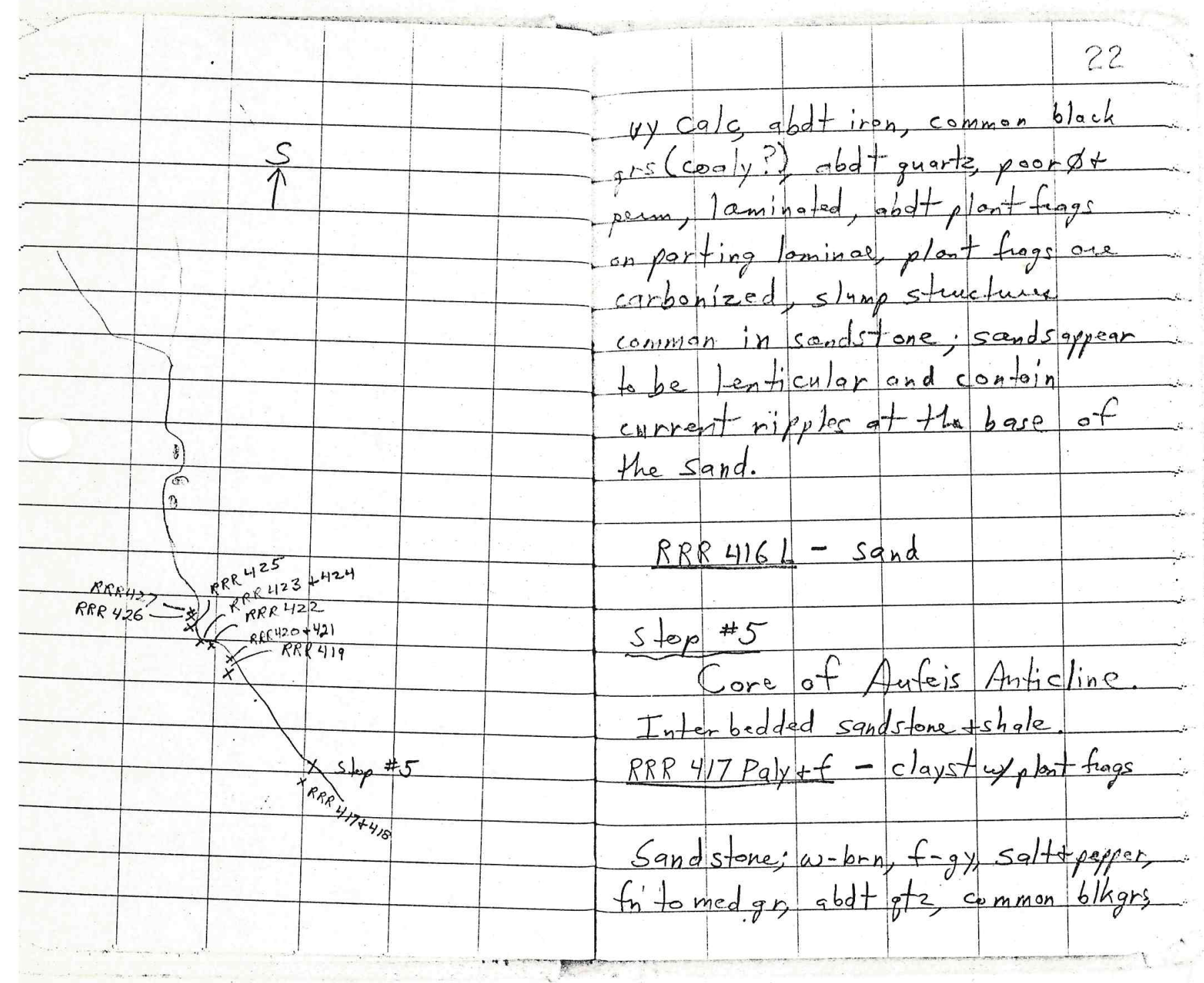




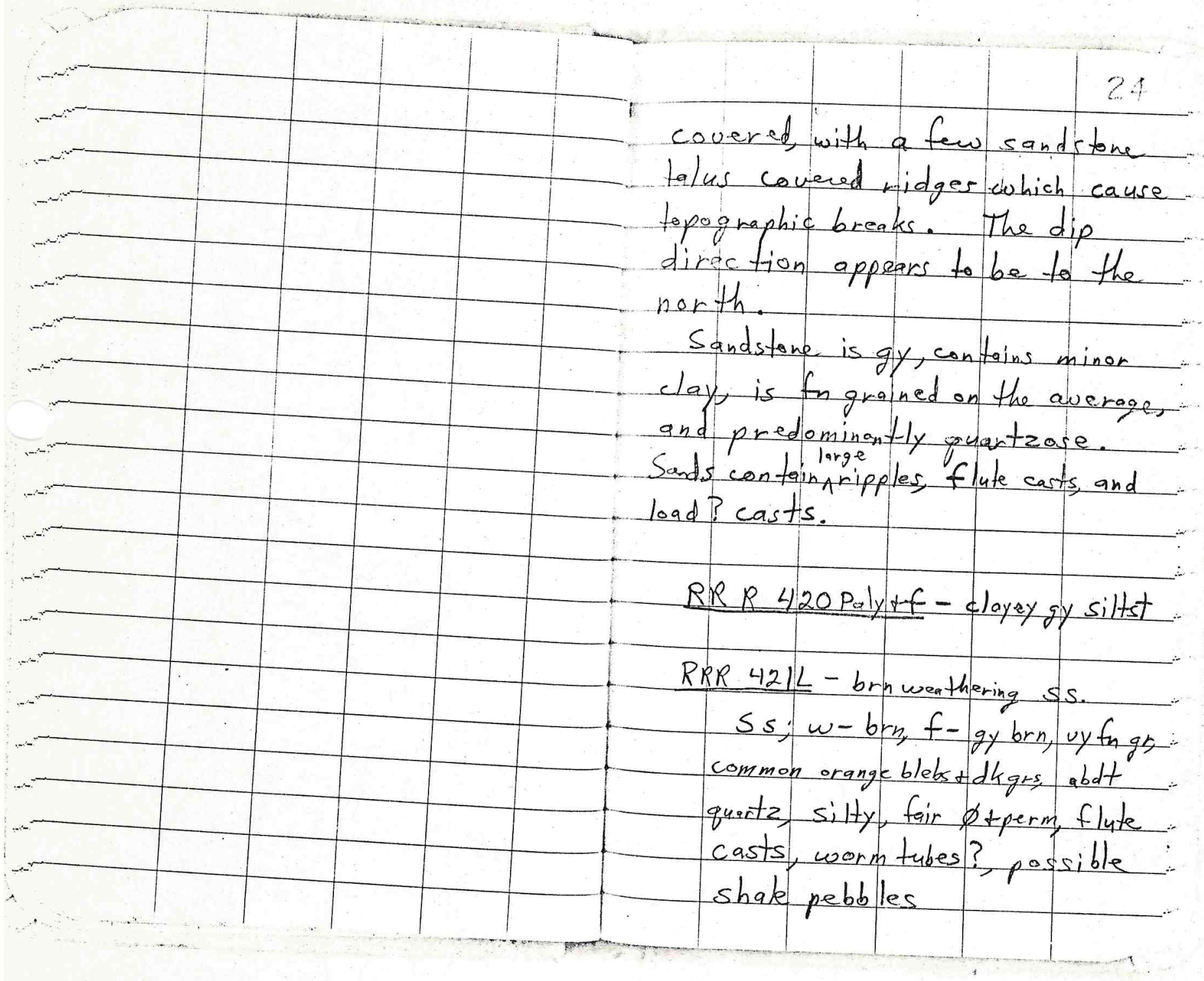




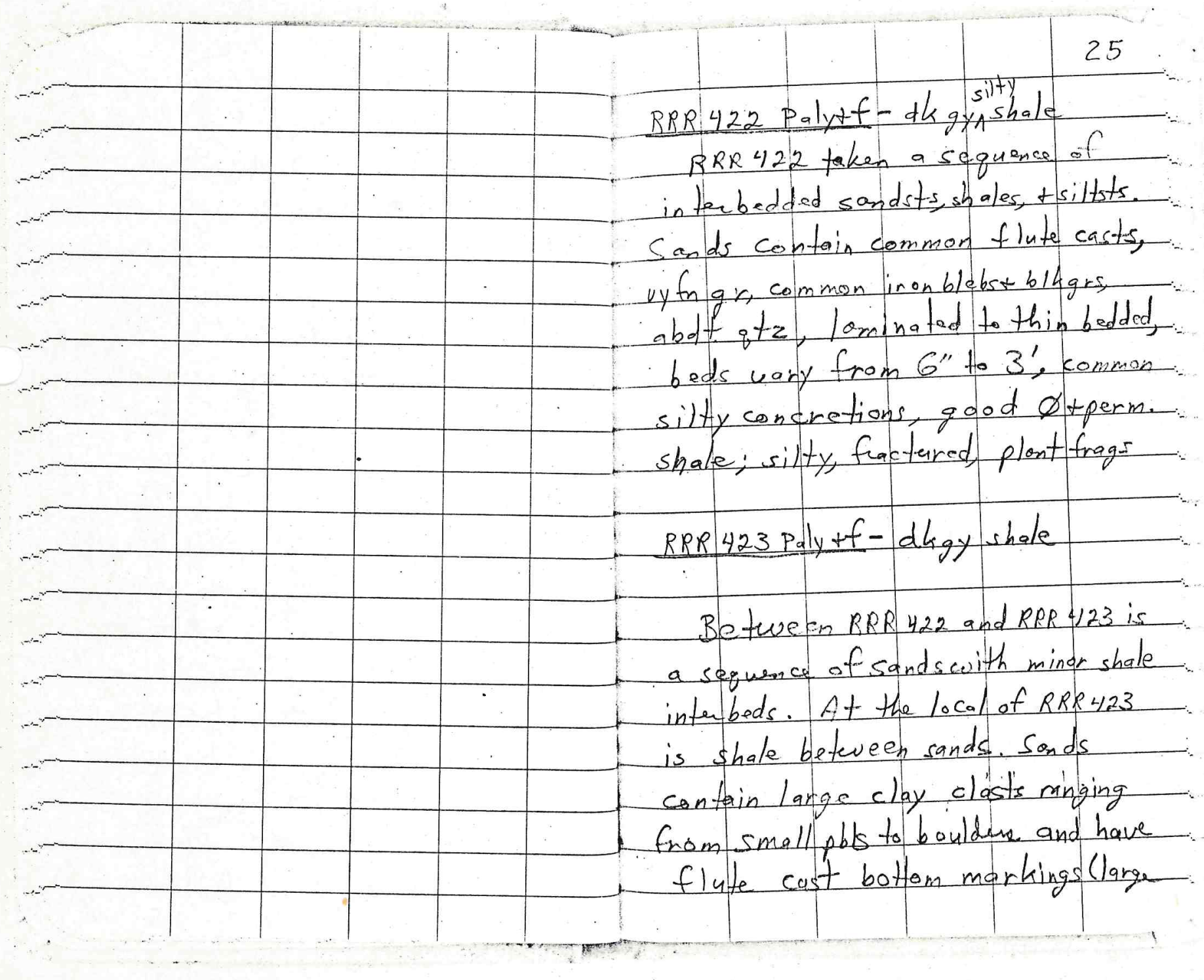




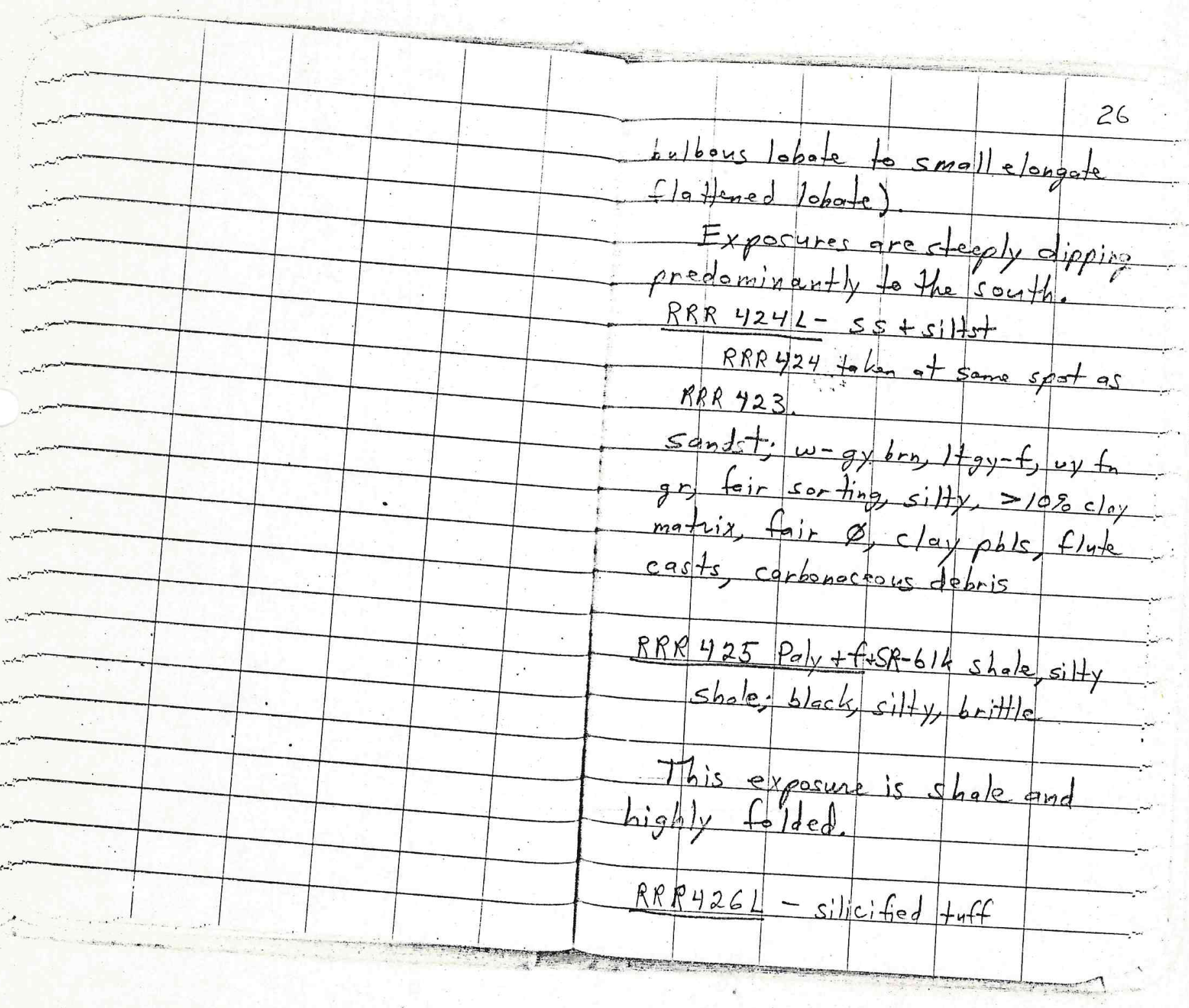


Statigraphically above RRR 425 is a siliceous faffunitw/ bentonitic interbeds QRR LIS7 Paly +f-bentonitic shole. RRR 427 approx. $50^{\prime}$ strat. above RRR 426 .

Dips are to the South-A2i185050: RRR427 is in a sequence of volconic sonds, siltsts, tshales. RRR 428 Paly+f- dh gyshale RRR 428 apyrox. 60 'stuat. above RRR 427. The soquence of samples taken at this locole is through the oxis of the Aufeis Anticline. 


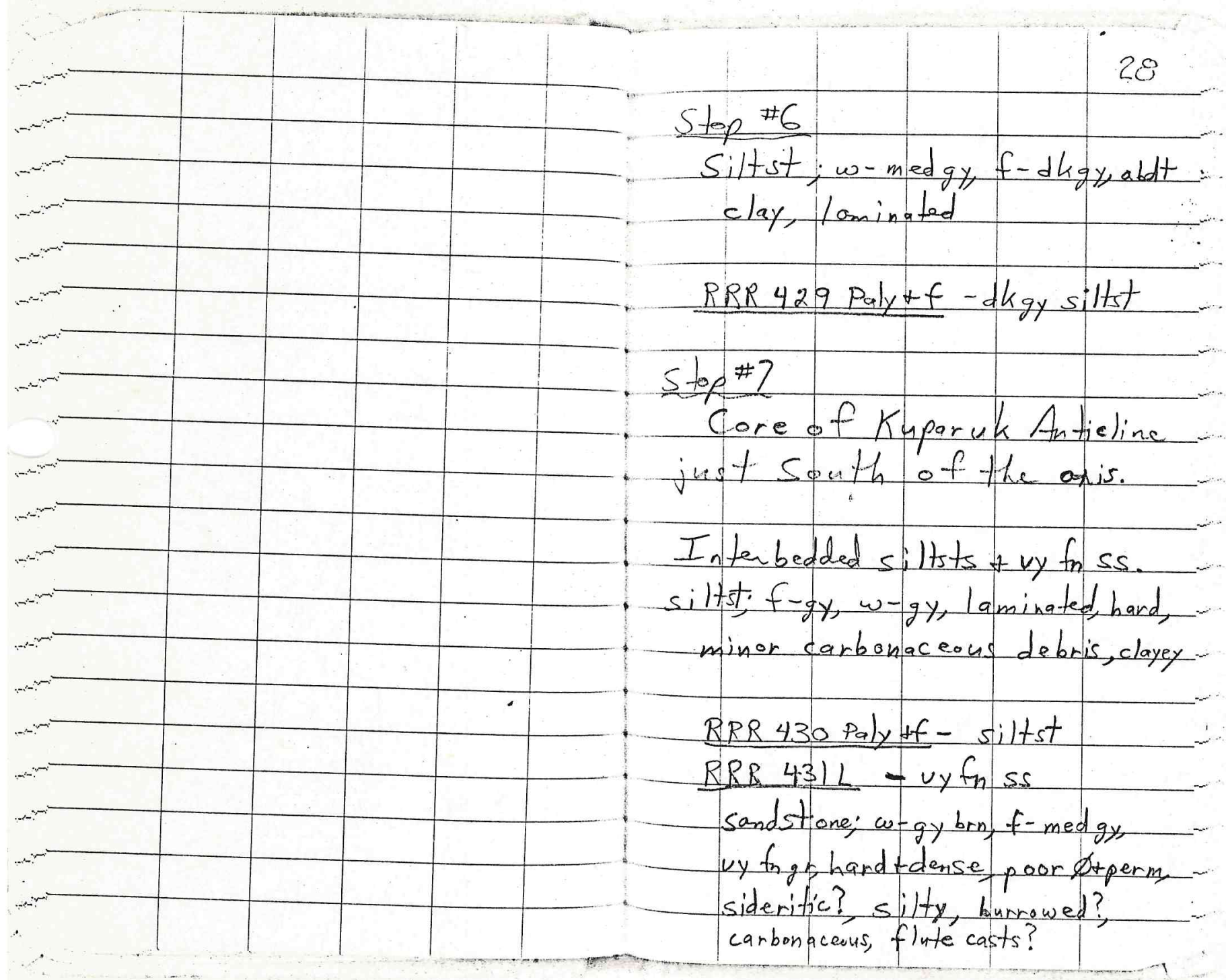




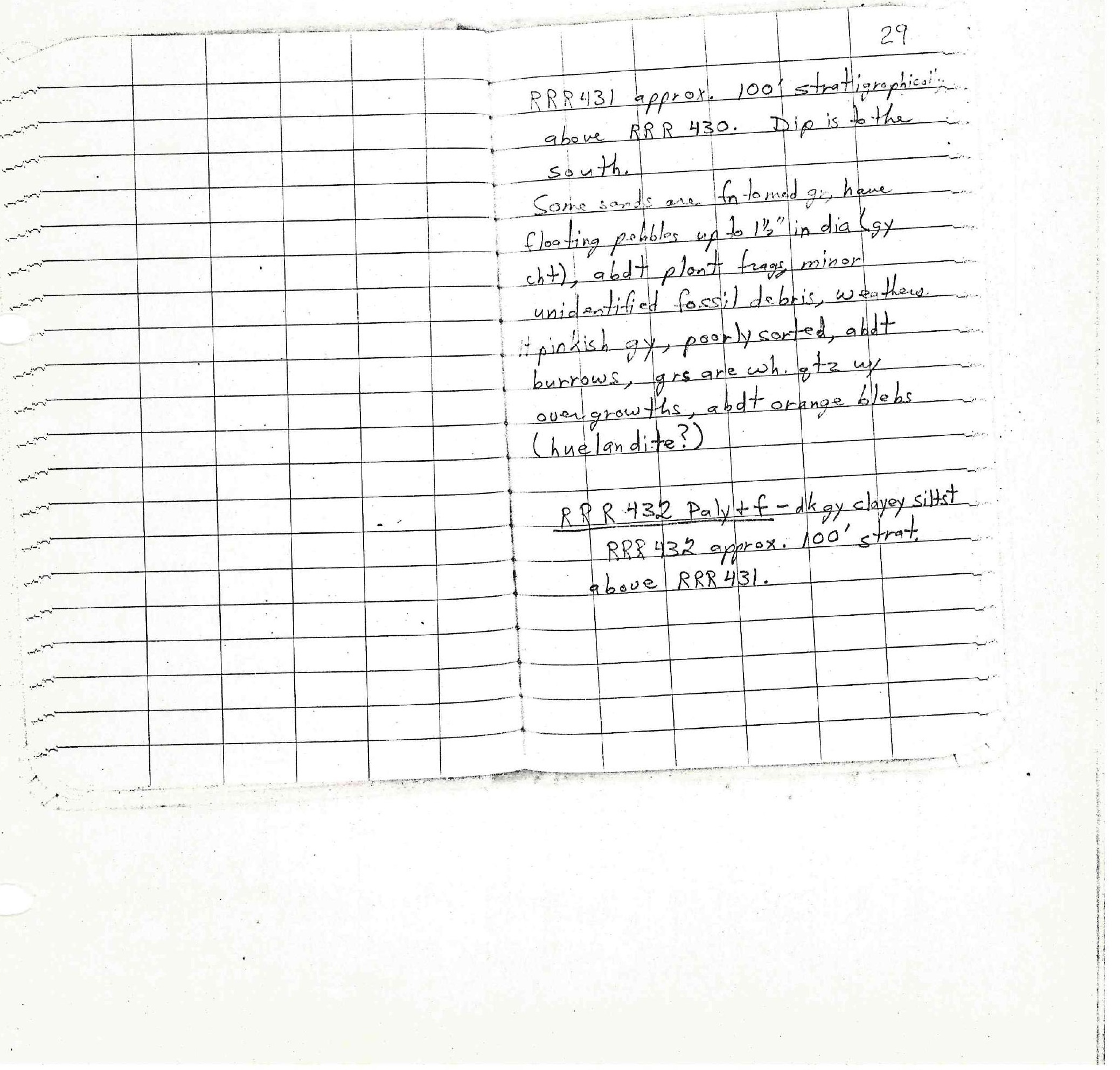



Iuly 31,1971 Saturday 30
Low clouds, cold, snowtrain posē Fehlmann, webster, Abiahan.son, and Petit to look at Cretaceous Ke mik Anticline east of in Kemik Antichine dost of Sogwon. Step ${ }^{\# 1}$ close to core of kamik... Anticline.

RRR 433 Paly ff - blk todk gy sittst No outcrop found took tolus

stop \#2

tundia covert sale talus. RRP 434 Dalyef - dh gy shale RPR 435L-1tgy sandstone 


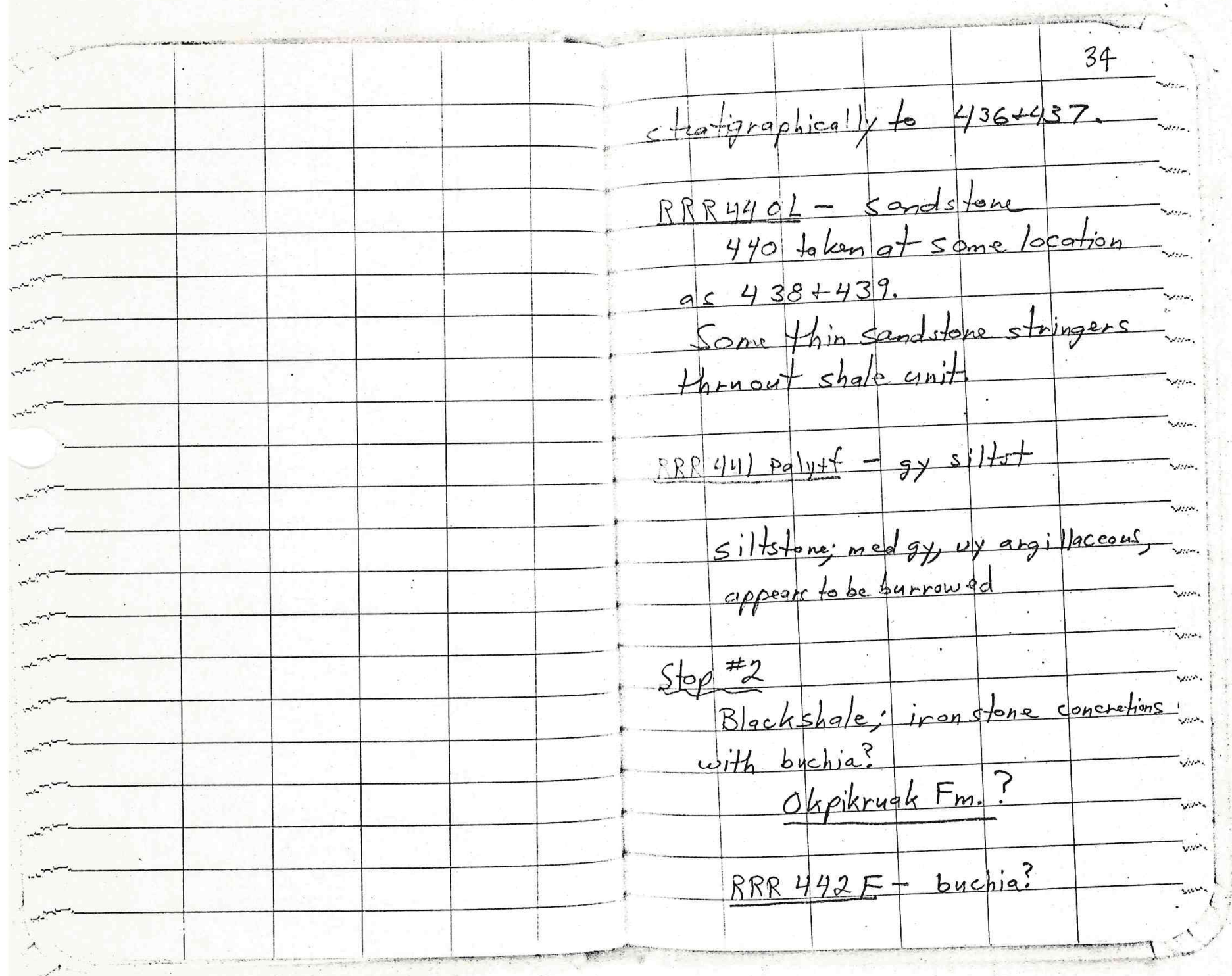




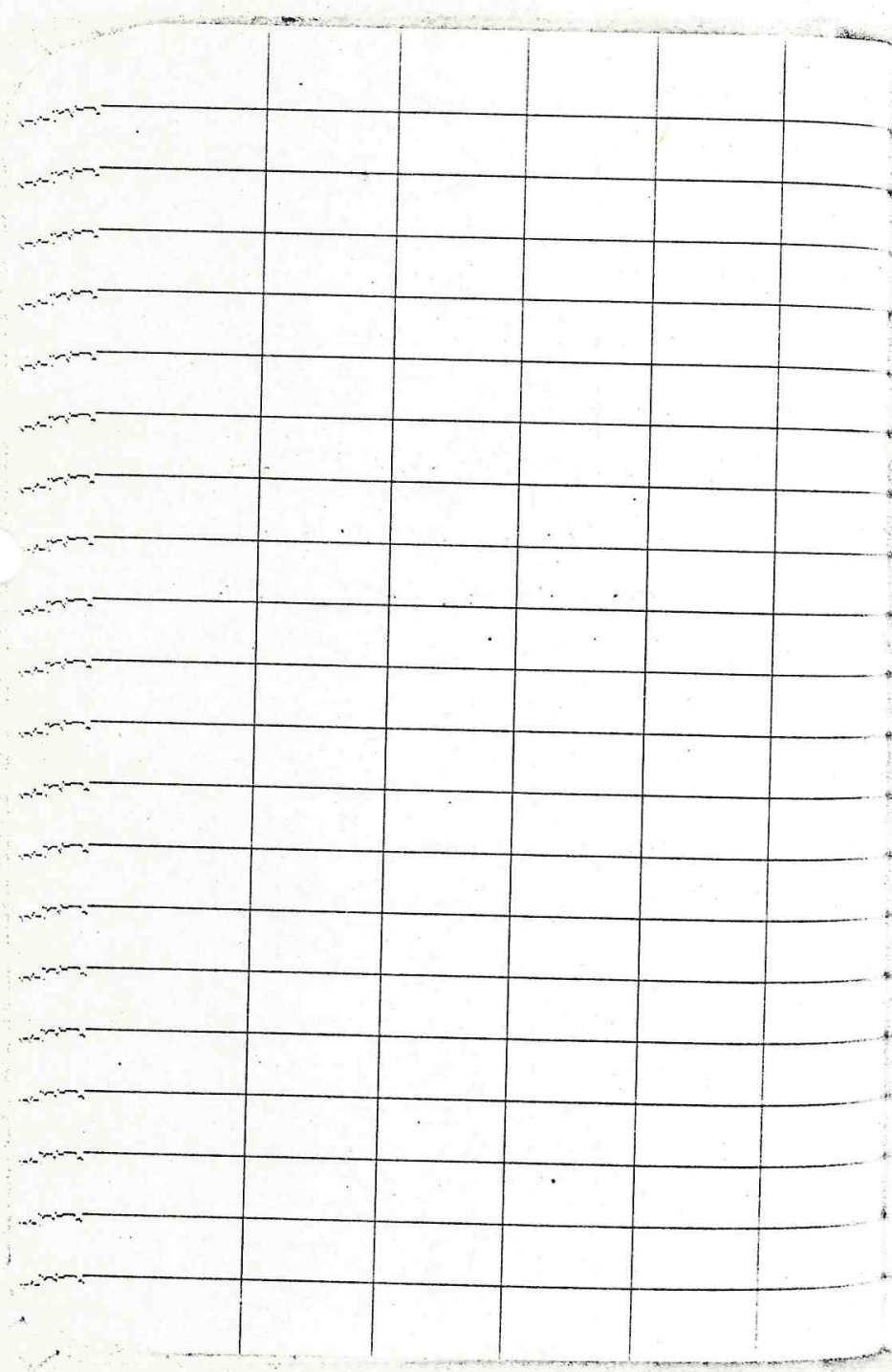

RPR $443 P_{0} l_{y}+f-d k g y$ toblksilty shale

RRR 444 Polyff - akgysilty shale. PRP ind takn approx 100 'stut. below RRR 443 .

Exposure dips steeply to the south. Buchila? is common as impressions + hase commonly been. replaced by pyrite. PRR 445 Paly $+S R-b / k$ silty shale PRR 446 Paly $+f$ $445+446$ token approx. 200' statigraphically below 444 . This exposme gives off an aily This exposwe gives off $a_{n}$ aily slick when dumped into the strom. Agood source rock? 


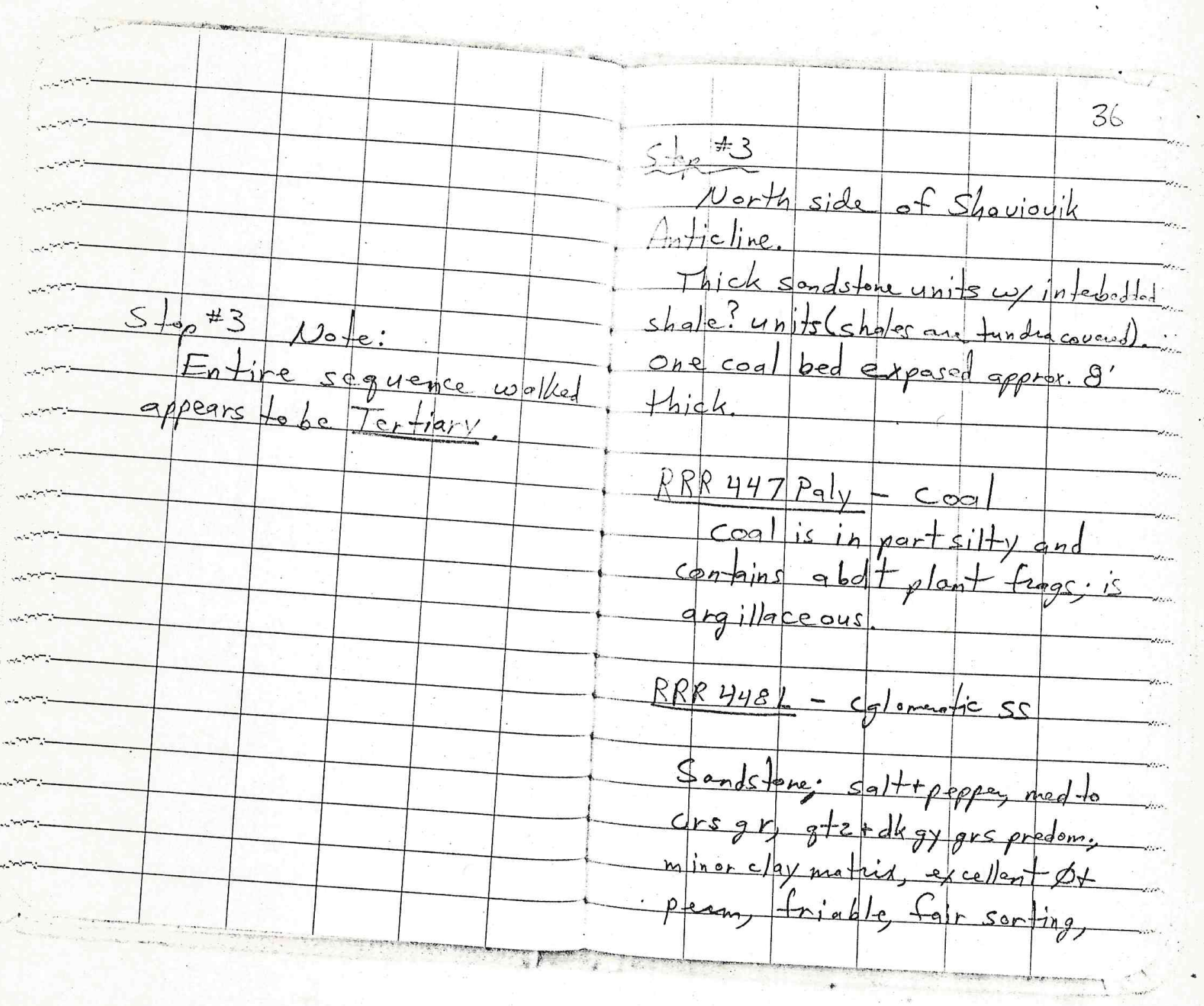




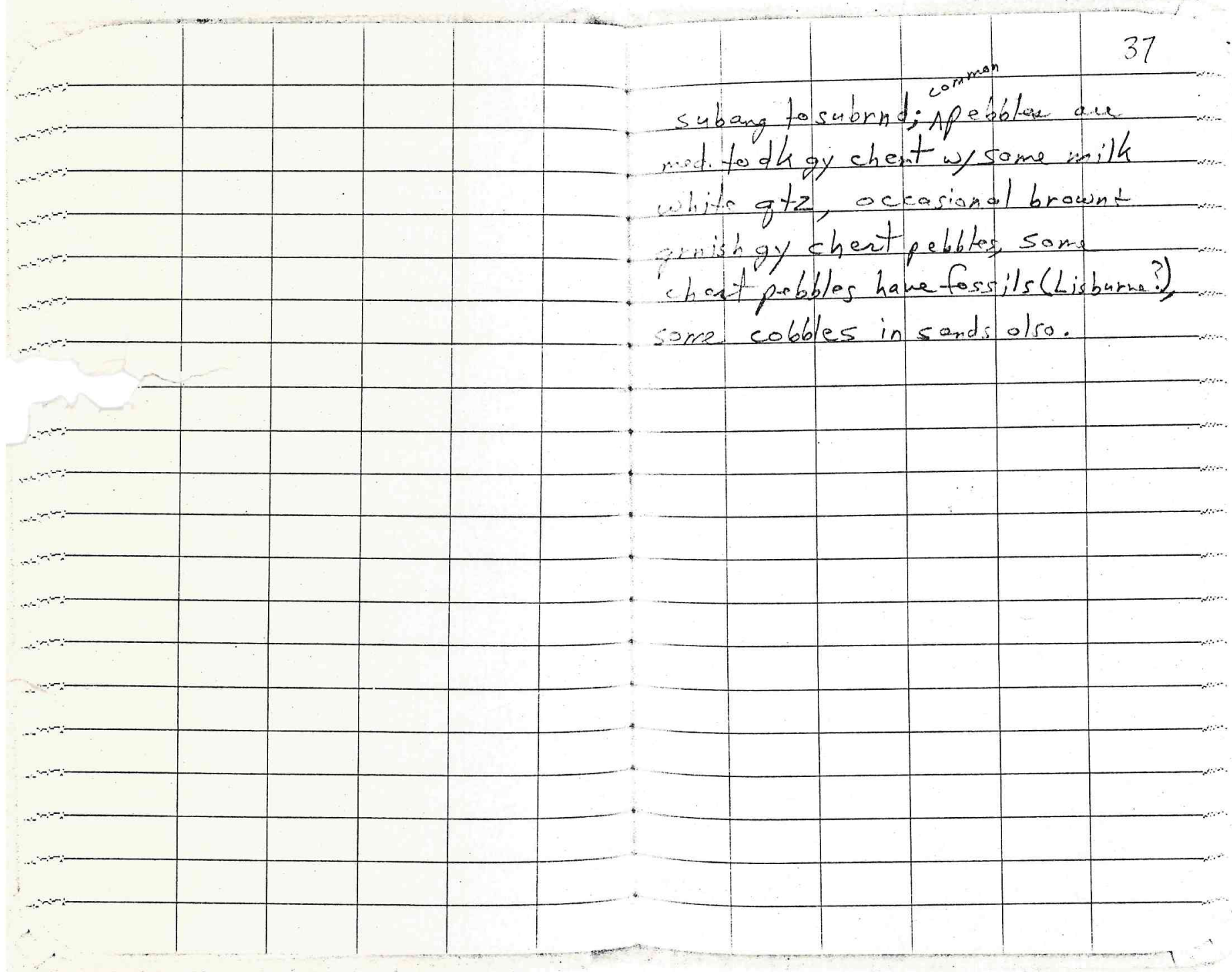

